\title{
Essays on law and economics of state aid
}

Citation for published version (APA):

Nicolaides, P. (2008). Essays on law and economics of state aid. [Doctoral Thesis, Maastricht University]. Maastricht University. https://doi.org/10.26481/dis.20081120pn

Document status and date:

Published: 01/01/2008

DOI:

10.26481/dis.20081120pn

Document Version:

Publisher's PDF, also known as Version of record

\section{Please check the document version of this publication:}

- A submitted manuscript is the version of the article upon submission and before peer-review. There can be important differences between the submitted version and the official published version of record.

People interested in the research are advised to contact the author for the final version of the publication, or visit the DOI to the publisher's website.

- The final author version and the galley proof are versions of the publication after peer review.

- The final published version features the final layout of the paper including the volume, issue and page numbers.

Link to publication

\footnotetext{
General rights rights.

- You may freely distribute the URL identifying the publication in the public portal. please follow below link for the End User Agreement:

www.umlib.nl/taverne-license

Take down policy

If you believe that this document breaches copyright please contact us at:

repository@maastrichtuniversity.nl

providing details and we will investigate your claim.
}

Copyright and moral rights for the publications made accessible in the public portal are retained by the authors and/or other copyright owners and it is a condition of accessing publications that users recognise and abide by the legal requirements associated with these

- Users may download and print one copy of any publication from the public portal for the purpose of private study or research.

- You may not further distribute the material or use it for any profit-making activity or commercial gain

If the publication is distributed under the terms of Article $25 \mathrm{fa}$ of the Dutch Copyright Act, indicated by the "Taverne" license above, 
Essays on Law and Economics of State Aid

\author{
Phedon Nicolaides
}





\title{
Essays on Law and Economics of State Aid
}

\author{
DISSERTATION
}

to obtain the degree of Doctor

at the Maastricht University,

on the authority of the Rector Magnificus,

Prof. dr. G.P.M.F. Mols,

in accordance with the decision of the Board of the Deans,

to be defended in public

on Thursday 20 November 2008, at 16.00 hours

by

Phedon Nicolaides 


\section{Supervisors:}

Prof. dr. Hildegard Schneider

Prof. dr. Wouter Devroe (Catholic University Leuven, Belgium)

\section{Assessment Committee:}

Prof. dr. Peter van den Bossche (Chairman)

Prof. dr. Michael Faure

Prof. dr. Raymond Luja

Prof. dr. Pierre Larouche (Tilburg University, The Netherlands)

Dr. Savvas Papasavvas (Judge, Court of First Instance, Luxembourg) 
To

my parents and my children 



\section{Acknowledgements}

I am very grateful to my two supervisors, Hildegard Schneider and Wouter Devroe, for their guidance and encouragement. Deep thanks should also go to all the members of the Assessment Committee.

This dissertation reflects the work of a decade. Most chapters have been published as articles in journals or chapters in books. Some of them have been co-authored. I am naturally indebted to all my co-authors and especially to Mihalis Kekelekis and Maria Kleis with whom I also carry out the seminars on state aid we organise at the European Institute of Public Administration.

Maria has also helped me with the translation of the summary of the dissertation. Alain Lambert has done excellent work on the final layout of the dissertation. My thanks go to both of them.

It is the EIPA seminars that we have organised in Maastricht and in many member states since 1998 that convinced me that in the field of state aid, you cannot separate law from economics.

Maastricht, 16 September 2008

Phedon Nicolaides 



\section{Table of Contents}

ACKNOWLEDGEMENTS .............................................................................

Chapter 1 - Introduction: The Usefulness of Economics to Competition Law ................ 1

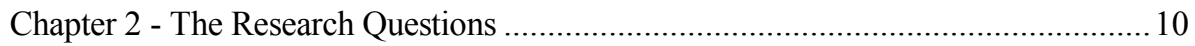

Chapter 3 - Evolving Competition Policy: Reform of Anti-trust and State Aid Rules.. 16

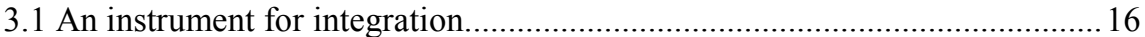

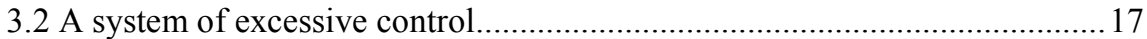

3.3 A complex and wide system, increasingly relying on informal procedures... 18

3.4 Need for reform ................................................................................. 19

3.5 Reform of state aid rules and procedures................................................. 21

3.6 Comparison of reform in anti-trust and state aid .......................................2 23

Annex: Highlights from the State Aid Action Plan ..........................................2 24

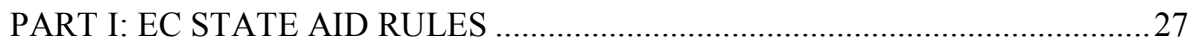

Chapter 4 - The Concept of State Aid ............................................................... 27

4.1 Article 87(1) EC: Aid incompatible with the common market ....................28

4.2 Aid by Member States or through state resources .......................................29

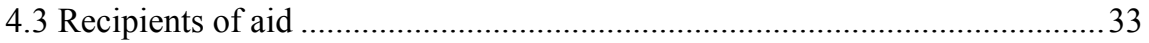

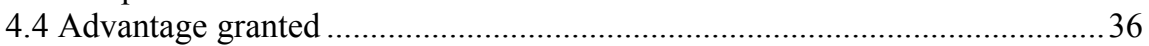

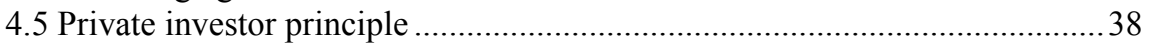

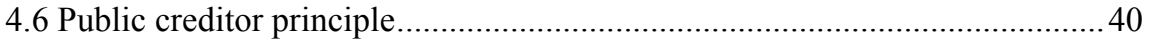

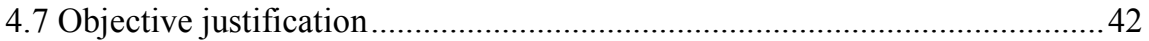

4.8 Selectivity: Specific versus general measures............................................... 44

4.9 Effect on trade and distortion of competition ......................................... 47

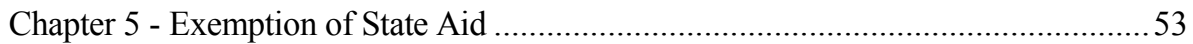

5.1 Aid that is compatible with the common market .......................................53

5.2 Aid that may be compatible with the common market ..............................56

5.3 Criteria and factors in the evaluation of state aid measures ..........................5 59

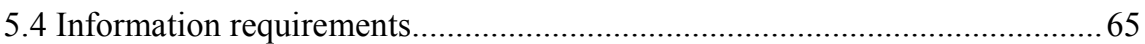

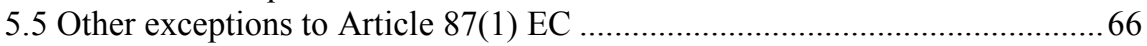

5.6 Services of general economic interest (SGEI) ….....................................6 67

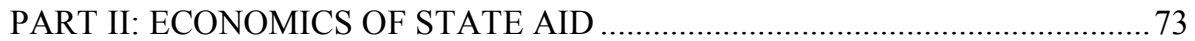

Chapter 6 - State Aid Rules: Do they Promote Efficiency? ........................................ 73 


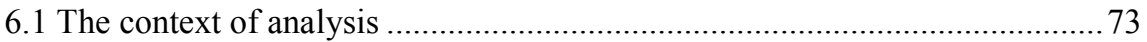

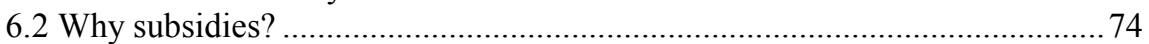

6.3 Why supranational rules on subsidies? .................................................... 75

6.4 Cross-border effects of state aid ............................................................. 78

6.5 European Community state aid policy: The rules .................................... 81

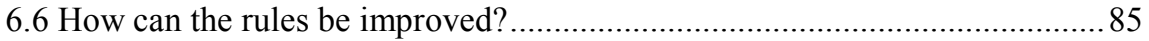

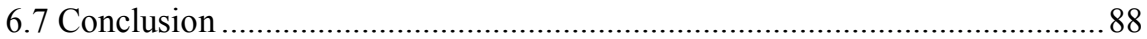

Chapter 7 - The Economics of Granting and Controlling State Aid...........................90

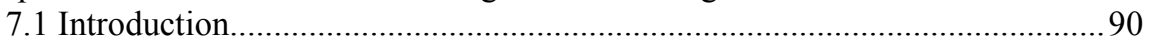

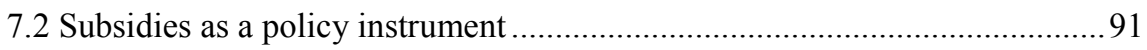

7.3 Why supranational rules on subsidies? ..................................................... 93

7.4 Assessing cross-border effects of state aid: Balancing of effects or coordination of aid? .................................................................................. 96

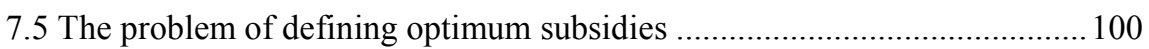

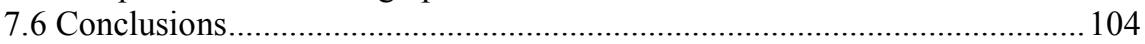

Chapter 8 - Compatibility of State Aid and the Balancing Test: Its Role in the Architecture of the System of State Aid Control........................................................ 106

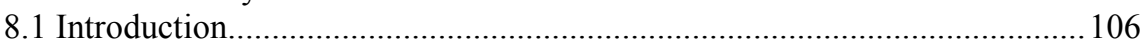

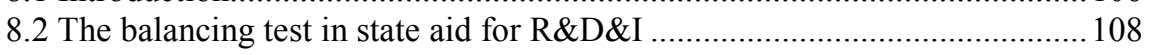

8.3 The balancing test in state aid for Risk Capital........................................ 111

8.4 The balancing test in state aid for environmental protection'..................... 114

8.5 Applications of the balancing test ................................................................ 120

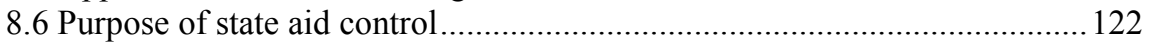

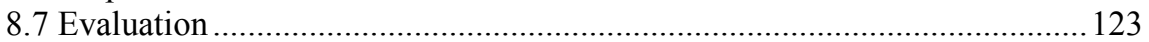

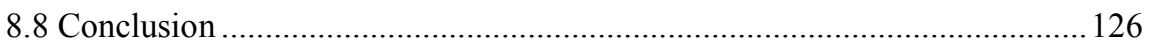

Chapter 9 - The Balancing Test and Incentive Effect: Is State Aid Necessary when

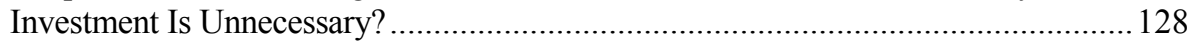

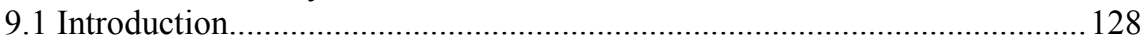

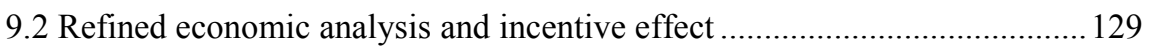

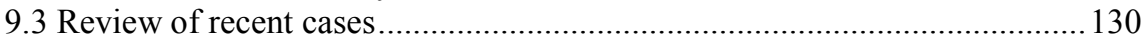

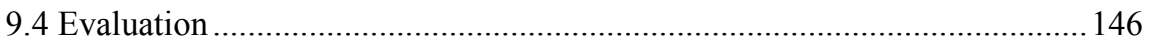

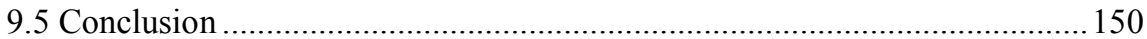

PART III: ASSESSING THE RULES ........................................................... 152

Chapter 10 - The Concept of Undertaking in Education and Public Health Systems . 152

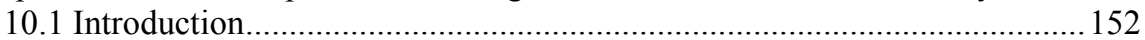

10.2 The concept of an undertaking in the case law of the Court of Justice ...... 153

10.3 The non-economic nature of public education.......................................... 155 


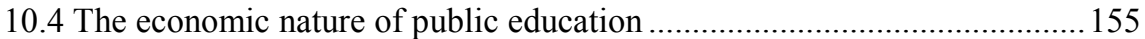

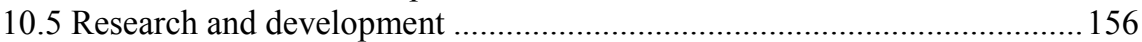

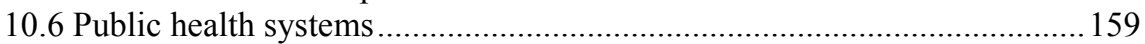

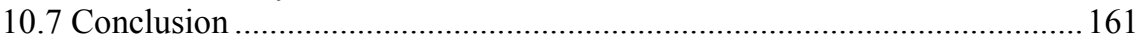

Chapter 11 - Where Is the Advantage? The Case of Public Funding of Infrastructure \& Broadband Networks ...................................................................................... 163

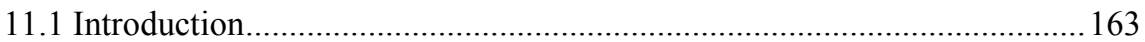

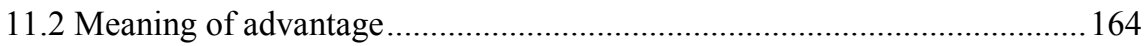

11.3 General v user-specific infrastructure ............................................... 170

11.4 Public infrastructure embedded within private infrastructure ................... 172

11.5 Owner, manager and user of infrastructure ......................................... 173

11.6 Selection of beneficiary through open, transparent and non-discriminatory

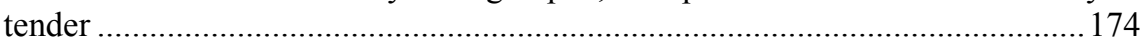

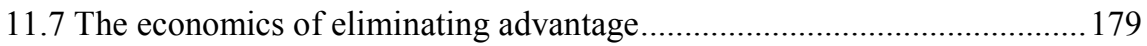

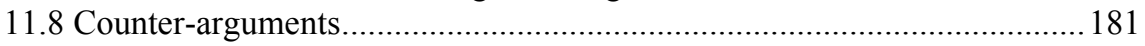

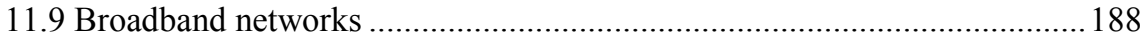

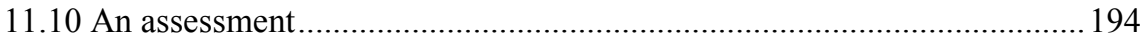

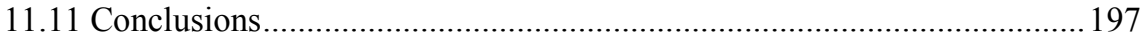

Annex I: Excerpts from the XXXIIIrd Annual Competition Report, 2003........ 198

Annex II: Identification of Advantage in Commission Decisions on Broadband

Chapter 12 - Puzzles of State Aid: Structural Funds, Cumulation and De Minimis ... 209

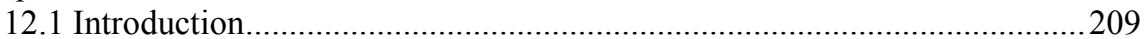

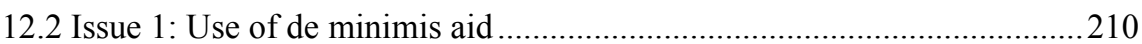

12.3 Issue 2: De minimis aid per legal entity or independent enterprise?..........212

12.4 Issue 3: Status of EC structural funds under state aid rules .......................213

12.5 Issue 4: Inclusion of EC structural funds in the de minimis amount.........219

12.6 Recommendations on procedural simplification ...................................219

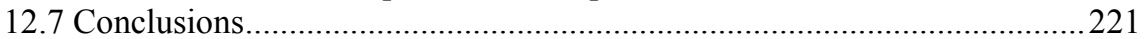

Annex I: Cumulation Rules ................................................................. 222

Chapter 13 - Markets and Words: The Distortive Effect of Government

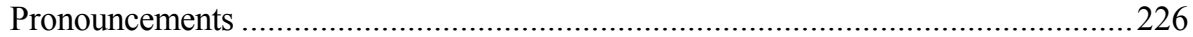

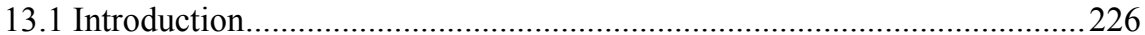

13.2 Investor rationality and public statements..............................................22 227

13.3 A game of market entry and exit with public funds .................................228

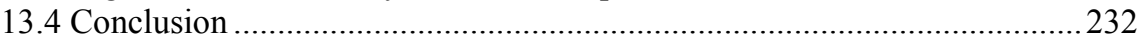

Chapter 14 - Re-introducing the Market in the "Market Economy Investor" Principle 
14.1 A necessary but imperfect principle.

14.2 From market economy investor to private investor ..................................2.233

14.3 The investment horizon and time-frame of analysis ..................................2. 235

14.4 Remedies: Re-introducing the market.....................................................237

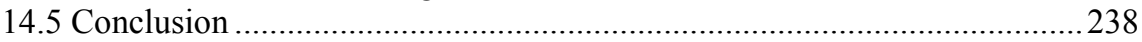

PART IV: THE CHALLENGE OF NATIONAL TAX AUTONOMY ..................240

Chapter 15 - Developments in Fiscal Aid: New Interpretations and New Problems with

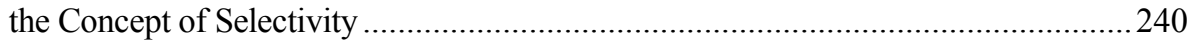

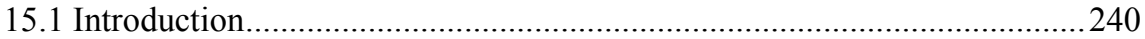

15.2 Portuguese Republic v European Commission, C-88/03: The issue of

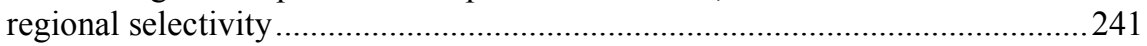

15.3 Laboratoires Boiron v ACOSS, C-526/04 ………………………….....2245

15.4 British Aggregates Association v European Commission, T-210/02 ........249

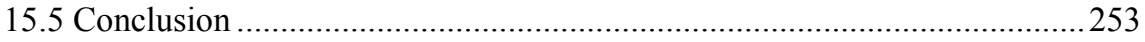

Annex: The Effect of Taxes on Competing Products ………………………....254

Chapter 16 - State Aid and Taxation by Sub-National Authorities ............................258

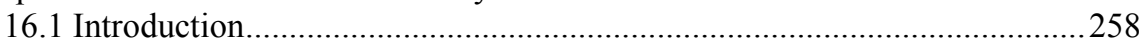

16.2 A review of the main principles that have emerged from recent cases ......260

16.3 Contentious issues: Regional tax measures..............................................2. 265

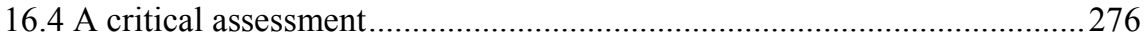

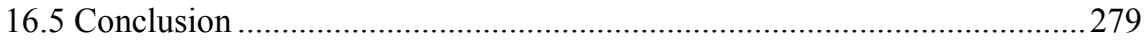

Appendix: Tax autonomy and inter-regional transfers ....................................22

Chapter 17 - The Boundaries of Tax Autonomy: An Assessment of the Opinion of Advocate-General Geelhoed on Case C-88/03, Portuguese Republic v European

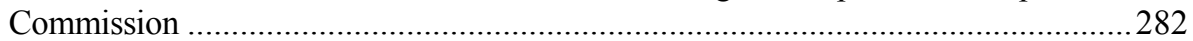

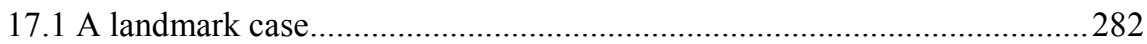

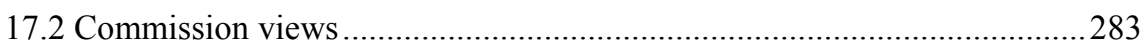

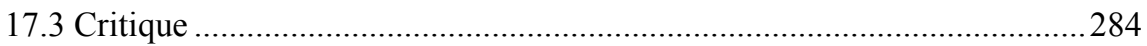

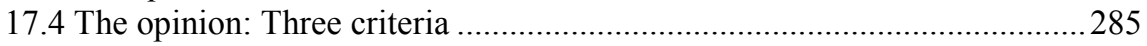

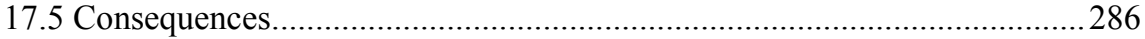

Chapter 18 - Fiscal State Aid in the EU: The Limits of Tax Autonomy .....................288

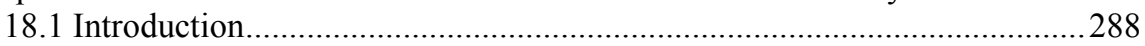

18.2 Applicability of state aid rules to fiscal measures.......................................290

18.3 The economic logic of control of selective measures .................................292

18.4 Selective v general measures ……………………................................2. 295

18.5 Selective v objectively justified tax measures ...........................................29

18.6 A review of recent cases of fiscal state aid ................................................306 
18.7 New criteria: (i) Similar tax burden and (ii) boundaries of fiscal autonomy

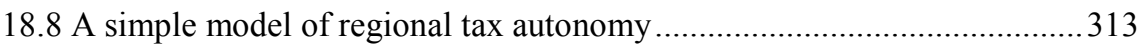

18.9 Assessment of the Azores case ..................................................................319

18.10 Conclusions: New trends in fiscal state aid...............................................327

Chapter 19 - Fiscal Aid in the EC: A Critical Review of Current Practice................... 328

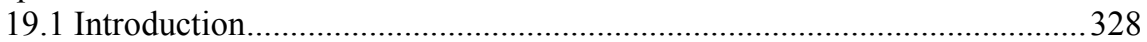

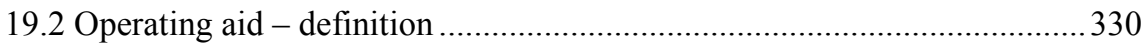

19.3 Exceptions to the general ban on operating aid ..........................................333

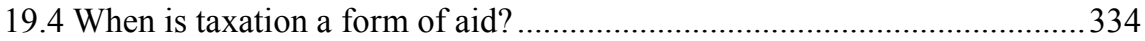

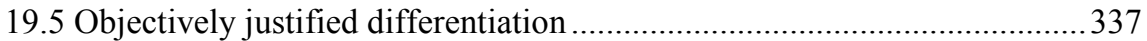

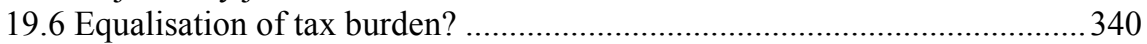

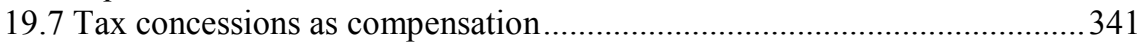

19.8 Tests to distinguish between general and specific tax measures..................343

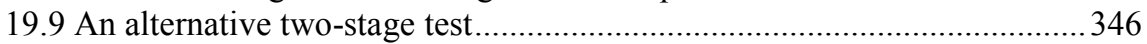

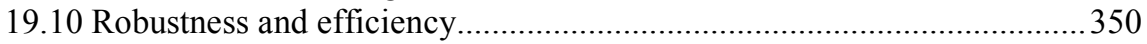

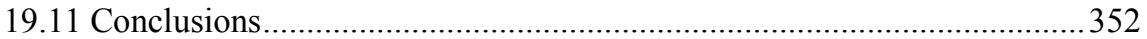

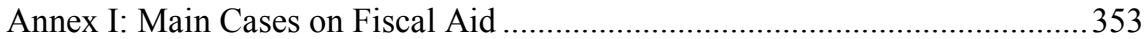

Annex II: Commission Notice on Fiscal Aid....................................................358

PART V: SERVICES OF GENERAL ECONOMIC INTEREST.............................360

Chapter 20 - The Economics of Services of General Economic Interest.....................360

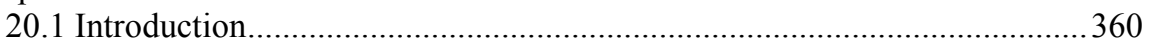

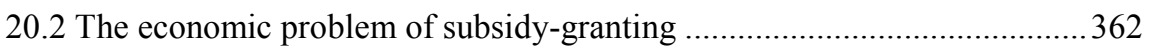

20.3 What costs and how much profit?..............................................................364

20.4 Direct aid to SGEI and the Altmark criteria.............................................368

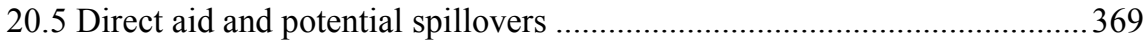

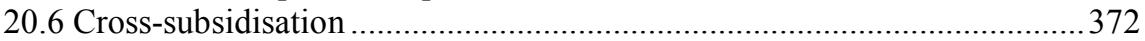

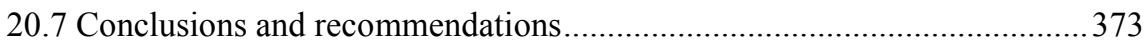

Chapter 21 - Compensation for Public Service Obligations: The Floodgates of State Aid?

21.1 Introduction: Why the floodgates have been flung open?...........................377

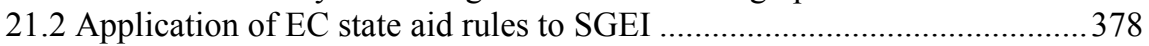

21.3 A critique of the proposed solution of distinguishing between a

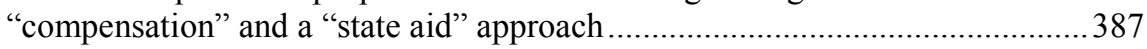

21.4 The distortions to competition caused by compensatory state aid ..............391

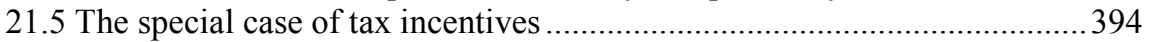

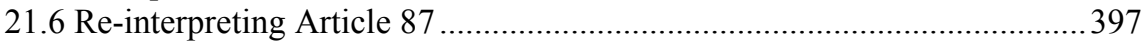

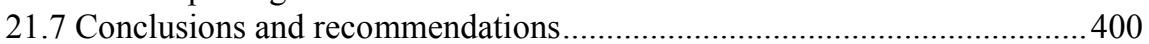


Chapter 22 - Competition and Services of General Economic Interest in the EU:

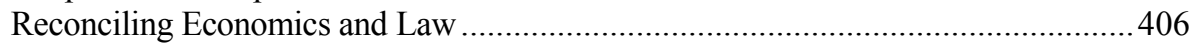

22.1 Introduction: What is the problem? .....................................................406

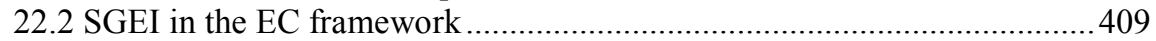

22.3 Application of EC competition rules to SGEI.........................................423

22.4 An assessment of the competition problems caused by the special treatment

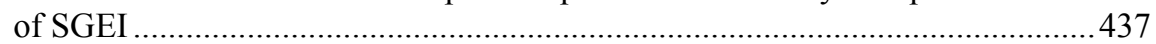

22.5 Removing competition distortions in the provision of SGEI ....................443

Chapter 23 - The Distortive Effects of Compensatory Aid Measures: A Note on the

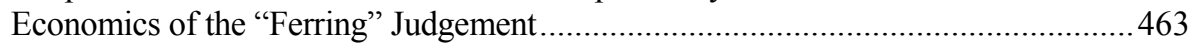

23.1 Introduction...................................................................................... 463

23.2 The concept of state aid and the meaning of derived advantage under EC law 464

23.3 The virtual impossibility of ensuring proportionality and necessity ..........465

23.4 The inherent advantage conferred by compensatory aid..........................468

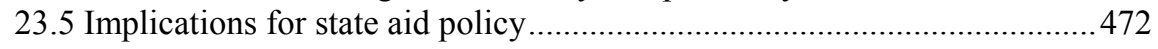

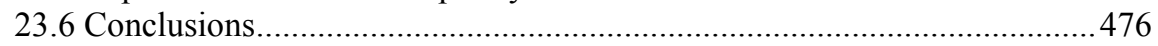

\section{PART VI: GUIDELINES ON AID FOR RESCUE \& RESTRUCTURING AND} REGIONAL DEVELOPMENT .................................................................... 477

Chapter 24 - When Do "Firms in Trouble" Escape from State Aid Rules?................477

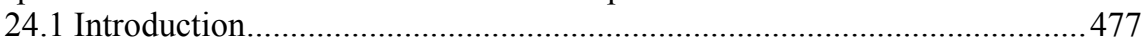

24.2 Rescue and restructuring of firms in difficulty ......................................478

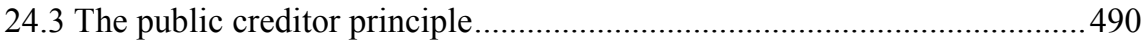

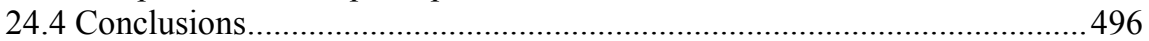

Chapter 25 - An Assessment of EC State Aid Policy on Rescue and Restructuring of

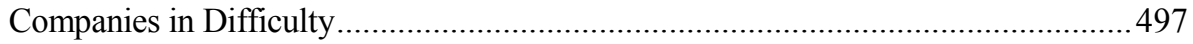

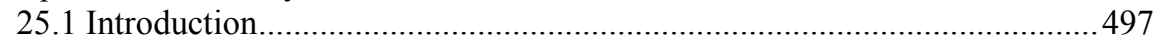

25.2 The main features of the guidelines on rescue and restructuring ...............498

25.3 Commission concerns ........................................................................50 500

25.4 Additional weaknesses and defects.........................................................502

25.5 An assessment of the draft new guidelines on rescue and restructuring and

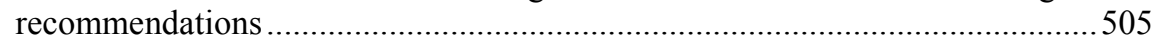

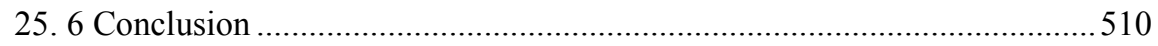

Chapter 26 - Regional State Aid: An Assessment of Community Rules and National 


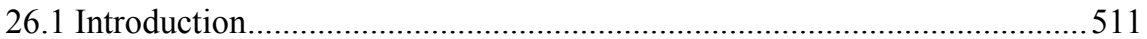

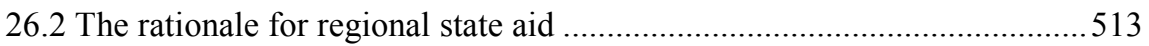

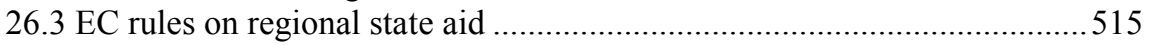

26.4 The Multisectoral Framework................................................................519

26.5 Workability of the regional aid Guidelines .........................................5. 520

26.6 Assessment of national state aid measures...........................................523

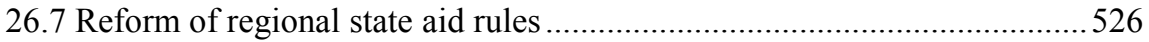

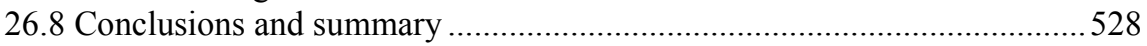

Chapter 27 - State Aid for Maritime Transport......................................................531

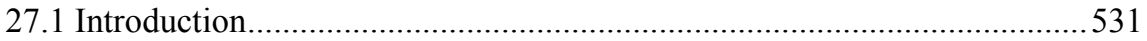

27.2. When do fiscal measures constitute state aid? ........................................532

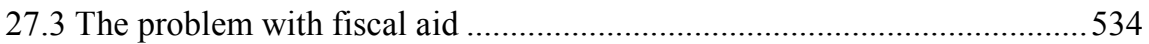

27.4 Fiscal aid measures permitted by the Maritime Transport Guidelines........536

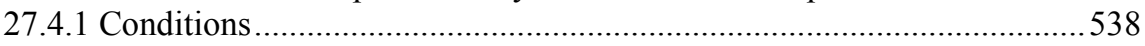

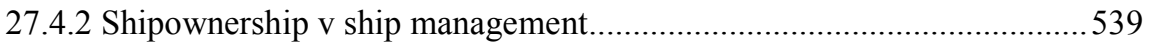

27.5 Problematic issues in the Guidelines ..................................................540

27.5.1 Ring-fencing [preventing non-maritime activities from deriving benefits

from fiscal aid granted to maritime activities]: .............................................540

27.5.2 Non-eligible maritime activities: ......................................................541

27.5.3 The link between maritime transport and other maritime activities:.......544

27.5.4 Taxation of companies $v$ taxation of persons:......................................546

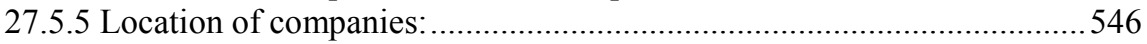

27.5.6 Deduction of social security contributions from tonnage tax liability ....547

27.5.7 All-or-nothing option for tonnage tax for ten years ..............................547

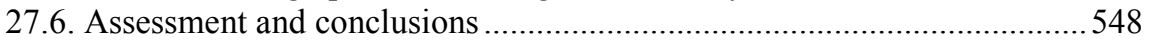

PART VII: THE SYSTEM OF STATE AID CONTROL.....................................552

Chapter 28 - Decentralised State Aid Control in an Enlarged European Union: Feasible,

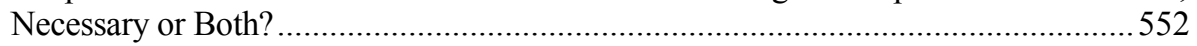

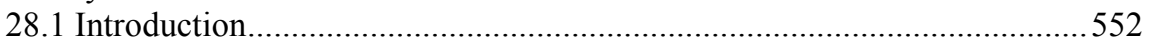

28.2 A model of international cooperation and prevention of non-compliance. 554

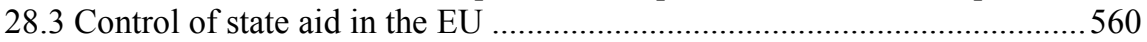

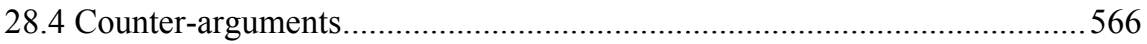

28.5 Conclusions: Options for a decentralised system of state aid control in the

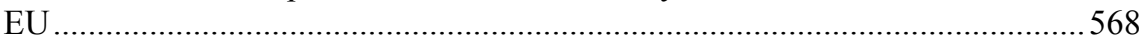

Chapter 29 - Control of State Aid in the European Union: Compliance, Sanctions and

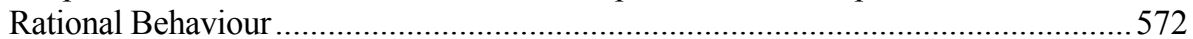

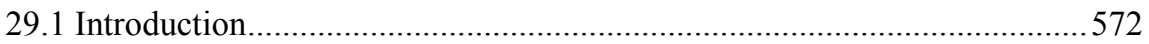


29.2 How does the European Union seek to discourage the granting of unlawful aid?

29.3 "Rational" illicit activities and efficient enforcement...............................578

29.4 Optimum state aid control in the European Union......................................58

29.5 Strengthening control of state aid .......................................................58

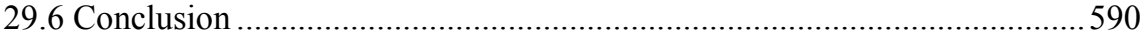

Chapter 30 - Assessment and Conclusions: Will the on-going Reform of State Aid

Policy Contribute towards more Efficient Allocation of Resources?

REFERENCES 600

SAMENVATTING (IN HET NEDERLANDS) 608

CURRICULUM VITAE 612 


\section{Original Sources}

Chapters 4 to 29 have been published in the following journals or edited volumes:

Chapter 4: The Concept of State Aid, in P. Nicolaides, M. Kekelekis, P. Buyskes, $\underline{\text { State }}$

Aid Policy in the European Community, (Kluwer, 2005), chapter 2.

Chapter 5: Exemption of State Aid, P. Nicolaides, M. Kekelekis, P. Buyskes, State Aid Policy in the European Community, (Kluwer, 2005), chapter 3.

Chapter 6: State Aid Rules: Do they Promote Efficiency? in P. Nicolaides and S. Bilal (eds), Understanding State Aid Policy in the European Community, (Kluwer Publishers, 1999), chapter 2.

Chapter 7: The Economics of Granting and Controlling State Aid, in L. Hancher, T. Ottervanger and P.-J. Slot (eds), EC State Aid, (Sweet \& Maxwell, 2006).

Chapter 8: Compatibility of State Aid and the Balancing Test: Its Role in the Architecture of the System of State Aid Control, in J. Derenne \& M. Merola (eds), Economic Analysis of State Aid Rules, forthcoming 2007.

Chapter 9: The Balancing Test and Incentive Effect: Is State Aid Necessary when Investment is Unnecessary? European State Aid Law Quarterly, 2008.

Chapter 10: The Concept of Undertaking in Education and Public Health Systems [with M. Kleis], European State Aid Law Quarterly, 2006.

Chapter 11: Where is the Advantage? The Case of Infrastructure [with M. Kleis], European State Aid Law Quarterly, 2007.

Chapter 12: Puzzles of State Aid: Structural Funds, Cumulation and De Minimis, European State Aid Law Quarterly, 2005.

Chapter 13: Markets and Words: The Distortive Effect of Government Pronouncements, European Competition Law Review, 2005.

Chapter 14: Re-Introducing the Market in the "Market Economy Investor" Principle, European State Aid Law Quarterly, 2003.

Chapter 15: Developments in Fiscal Aid: New Interpretations and New Problems with the Concept of Selectivity, European State Aid Law Quarterly, 2007.

Chapter 16: State Aid and Sub-national Taxation, European State Aid Law Quarterly, 2005.

Chapter 17: The Boundaries of Tax Autonomy: Comments on the Opinion of A-G Geelhoed on Case C-88/03, Portugal v European Commission, European State Aid Law Quarterly, 2006. 
Chapter 18: Fiscal State Aid in the EU: The Boundaries of Tax Autonomy, World Competition, 2004.

Chapter 19: Operating Aid and Fiscal Aid in the EC: A Critical Review of Current Practice, World Competition, 2001.

Chapter 20: The Economics of Services of General Economic Interest, in M. Sánchez Rydelski (ed), State Aid Law, (Cameron May, 2006).

Chapter 21: Compensation for Public Service Obligations: The Floodgates of State Aid? European Competition Law Review, 2003.

Chapter 22: Competition and Services of General Economic Interest in the EU: Reconciling Economics and Law, European State Aid Law Quarterly, 2003.

Chapter 23: The Distortive Effects of Compensatory Aid Measures: A Note on the Economics of the "Ferring" Judgement, European Competition Law Review, 2002.

Chapter 24: When Do Firms in Trouble Escape from State Aid Rules? [with M. Kekelekis], European State Aid Law Quarterly, 2005.

Chapter 25: An Assessment of EC State Aid Policy on Rescue and Restructuring of Companies in Difficulty [with M. Kekelekis], European Competition Law Review, 2004.

Chapter 26: Regional State Aid: An Assessment of Community Rules and National Measures, European State Aid Law Quarterly, 2003.

Chapter 27: State Aid for Maritime Transport, published in A. Antapassis, L. Athanassiou \& E. Røsæg (eds), Competition and Regulation in Shipping and Shipping Related Industries, (Leiden: Martinus Nijhoff, 2008).

Chapter 28: Decentralised State Aid Control in an Enlarged European Union: Feasible, Necessary or Both? World Competition, 2003.

Chapter 29: Control of State Aid in the EU: Compliance, Sanctions and Rational Behaviour, World Competition, 2002. 


\section{List of Cases}

\section{European Court of Justice}

C-30/59, Steenkolenmijen v High Authority [1961] ECR 00001.

C-11/69, Commission v France, [1969] ECR 00523.

C-6/69, France $v$ Commission.

C-10/71, Ministere public luxembourgeois v Muller [1971] ECR 00723.

C-70/72, Commission v Germany [1973] 00813.

C-173/73, Italy v Commission, [1974] ECR 00709.

C-127/73, BelgischeRadio en Televisie v SV SABAM and NV Fonior [1974] ECR 00313.

C-155/73, Sacchi [1974] ECR 00409.

C-27/76, United Brands [1976] ECR 00207.

C-85/76, Hoffmann-La Roche [1979] ECR 00467

C-730/79, Philip Morris v Commission [1980] ECR 25671.

C-61/79, Amministrazione delle Finance dello Stato v Denkavit Italiana, [1980] ECR 01205.

C-266/81, SIOT [1983] ECR 00731.

C-213/81, Norddeutsches Vieh- und Fleischkontor [1982] ECR 03583.

C-323/82 Intermills $v$ Commission [1984] ECR 03809.

C-203/82, Commission v Italy [1983] ECR 02525.

C-7/82, GVL v Commission [1983] ECR 00483.

C-96/82, IAZ International Belgium v Commission [1983] ECR 03069.

C-41/83, Italy v Commission [1985] 00873.

C-270/83, Commission v France [1986] ECR 000273.

C-130/83, Commission v Italy [1984] ECR 02849.

C-240/83, Procureur de la République v ADBHU, [1985] ECR 00531.

C-290/83, Commission v France, [1985] ECR 00043.

C-250/83, Finsider v Commission [1982] ECR 00131.

C-234/84, Belgium v Commission, [1986] ECR 02263.

C-248/84, Germany v Commission [1986] ECR 00685.

C-118/85, Commission v Italy [1987] ECR, I-02599.

C-227/85, Commission v Belgium [1988] ECR 00001.

C-40/85, Belgium v Commission [1986] ECR 02321.

C-67/85, 68/85 and 70/85 Van der Kooy v Commission, [1988 ]ECR 00219.

C-57/86, Greece v Commission, [1988] ECR 02855.

C-263/86, Humbel and Edel, [1988] ECR, I-05365.

C-30/87, Corinne Bodson v SA Pompes funèbres des régions libérées, [1988] ECR 02479. 
C-380/87, Balsamo [1989] ECR 02491.

C-62/87, Wallonia v Commission [1988] ECR 01573.

C-142/87, Belgium v Commission, [1990] ECR I-00959.

C-102/87, France v Commission, [1988] ECR 04067.

C-301/87, France v Commission, [990]ECR I-00307.

C-303/88, Italy v Commission, [1991] ECR I-01433.

C-103/88, Costanzo [1989] ECR 01839.

C-305/89, Italy v Commission [1991] ECR I-01603.

C-33/90, Commission v Italy [1991] ECR I-05987.

C-179/90, Porto di Genova [1991] ECR I-05889.

C-313/90, CIRFS and Others $v$ Commission, [1993] ECR I-01125.

C-41/90, Klaus Höfner and Fritz Elser v Macrotron GmbH, [1991] ECR I01979 .

C-159/91, Christian Poucet v Assurances Generales de France and Caisse Mutuelle Regionaledu Languedoc - Roussillon, [1993] ECR I-00637.

C-320/91, Paul Corbeau, [1993] ECR I-2533.

C-72-73/91, Sloman Neptun Schiffahrts AG v Seebetriebsrat Bodo Ziesemer, [1993] ECR I-00887.

C-159/91, Poucet v Assurances Générales de France [1993] ECR I-00637.

C-278/92, Spain v Commission, [1994] ECR I-04103.

C-387/92, Banco Exterior de España [1994] ECR I-00877.

C-393/92, Municipality of Almelo and others $v$ NV Energiebedrijf Ijsslmij, [1994] ECR I-01477.

C-364/92, Eurocontrol, [1994] ECR, I-0043.

C-279/93, Finanzamt Köln Altstadt v Schumacker [1995] ECR I-00225.

C-96/94, Centro Servizi Spediporto, [1995] ECR, I-02883.

C-159/94, France v Commission, [1997] ECR I-05815.

C-39/94, SFEI v La Poste, [1996] ECR I-03547.

C-241/94, France v Commission [1996] ECR I-04551.

C-353/95P, Tierce Ladbroke v Commission, [1997] ECR I-07007.

C-242/95, GT-Link [1997] ECR I-00449.

C-343/95, Diego Cali \& Figli Srl v Servizi ecologici porto di Genova SpA, [1997] ECR I-01547.

C-67/96, Albany International BV v Stichting Bedrijfspensioenfonds Textielindustrie [1998] ECR I-08033.

C-266/96 Corsica Ferries [1998] ECR I-03949.

C-55/96, Job Centre coop. arl., [1997] ECR I-07119.

C-342/96, Spain v Commission (Tucacex), [1999] ECR I-02459.

C-301/96, Germany v Commission, [2003] ECR I-0000. 
C-35/96, Commission v Italy, [1998] ECR, I-03851.

C-6/97, Italy v Commission, [1999] ECR I-02981.

C-256/97, DM Transport, [1999] ECR I-03913.

C-302/97, Konle v Austria [1999] ECR I-03099.

C-400/97 to 402/97, Administración General del Estado v Juntas Generales

de Guipúzcoa and Diputación Foral de Guipúzcoa [2000] ECR I-01073

C-75/97, Belgium v Commission [1999] ECR I-03671.

C-400/97, Guipúzcoa [2000] ECR I-01073.

C-200/97, Ecotrade v AFS [1998] ECR I-07907.

C-351/98, Spain v Commission, [2002] ECR I-08031.

C-64/98P, Odette Nicos Petrides Co. Inc. v Commission [1999] ECR I05187

C-180/98 to C-184/98, Pavel Pavlov and Others, [2000] ECR, I-06451

C-379/98, Preussen Elektra AG v Schleswag AG, [2001] ECR I-02099.

C-368/98, Abdon Vanbraekel, [2001] ECR, I-05363.

C-390/98, Banks [2001] ECR I-06117.

C-156/98, Germany v Commission [2000] ECR I-06857.

C-83/98P, France v Ladbroke and Commission [2000] ECR I-03271.

C-482/99 French Republic v Commission, [2002] ECR I-04397.

C-157/99, B.S.M. Geraets-Smits v Stichting Ziekenfonds VGZ and H.T.M.

Peerbooms v Stichting CZ Groep Zorgverzekeringen [2001] ECR, I-05473.

C-475/99, Ambulanz Glöckner, [2001] ECR, I-09089.

C-203/99, Veedfald, [2001] ECR, I-03569.

C-382/99, Netherlands v Commission [2002] ECR I-01563.

C-334/99, Germany v Commission [2003] ECR I-01139.

C-143/99, Adria-Wien [2001] ECR I-08365.

C-340/99, TNT Traco SpA v Poste Italiane SpA [2001] I-04109.

C-53/00, Ferring SA v Agence centrale des organismes de securite sociale, [2001] ECR I-09067.

C-242/00, Germany v Commission, [2002] ECR I-05603.

C-57/00 and C-61/00, Freistaat \& Volkswagen v Commission, [2003] ECR I-09975.

C-278/00, Greece v Commission, [2004] ECR I-03997.

C-280/00, Altmark Trans, [2003] ECR I-7747

C-118/00, Larsy v INASTI [2001] ECR I-05063.

C-409/00, Spain v Commission [2003] ECR I-01487.

C-218/00, Cisal di Battistello Venanzio v INAIL [2002] ECR I-00691.

C-34/01 to C-38/01, Enirisorse SpA v Ministero delle Finanze [2003] ECR I14243 . 
C-5/01, Belgium v Commission, [2002] ECR I-11991.

C-83/01 P, C-93/01 P and C-94/01 P, Chronopost $v$ Ufex and Others, [2003] ECR I-06993.

C-126/01 Ministere de l'Economie, des Finances et de l'Industire v GEMOSA, [2003] I-13769.

C-261/01, Van Calster [2003] ECR I-12249.

C-308/01, GIL Insurance ltd v Commissioners of Customs and Excise [2004] ECR I-04777.

C-276/02, Spain v. Commission, [2004] ECR I-08091.

C-345/02, Pearl BV and Others v. Hoofdbedrijfschap Ambachten, [2004] ECR I-07139.

C-174/02, Streekgewest Westelijk Noord Brabant [2005] ECR I-00085.

C-110/03, Belgium v Commission [2005] ECR I-02801.

C-205/03 P, FENIN, [2006] ECR I-06295.

C-209/03, Dany Bidar v London Borough of Ealing and Secretary of State for Education and Skills [2005] ECR I-02119.

C-346/03, Atzeni and Others, [2006] ECR I-01875.

C-88/03, Portuguese Republic (Azores) v European Commission [2006] ECR I-07115.

C-172/03, Heiser v Finanzambt Innsbruck [2005] ECR I-01627.

C-71/04, Xunta de Galicia, [2005] ECR I-07419.

C-148/04, Unicredito Italiano, [2005] ECR I-11137.

C-222/04, Ministero dell'Economia e delle Finanze v Cassa di Risparmio di Firenze SpA, Fondazione Cassa di Risparmio di San Miniato and Cassa di Risparmio di San Miniato SpA, [2006] ECR I-00289.

C-237/04, Enirisorse [2006] ECR I-02843.

C-526/04, Laboratoires Boiron v ACOSS [2006] ECR 07529.

C-393/04, Air Liquide [2006] ECR I-05293.

\section{Court of First Instance}

T-447 \& 449/93, AITEC v Commission, [1995] ECR II-01971.

T-67/94, Ladbroke v Commission [1958] ECR II-00001.

T-358/94, Air France v Commission [1996] ECR II-02109.

T-260/94, Air Inter SA v Commission [1997] ECR II-00997.

T-229/94, Deutsche Bahn v Commission [1997] ECR II-01689.

T-214/95, Het Vlaamse Gewest v Commission [1998] ECR II-00717.

T-106/95, FFSA v Commission, [1997] ECR II-00229.

T-14/96, BAI v Commission [1999] ECR II-00139.

T-46/97, SIC v Commission [2000] ECR II-02125. 
T-288/97, Regione Autonoma Friuli Venezia Giulia v Commission, [2001] ECR II-01169.

T-613/97 Ufex and Others $v$ Commission, [2000] ECR II-04055

T-296/97, Alitalia v Commission 2000 ECR II-03871.

T-155/98, SIDE v Commission [2002] ECR II-01179.

T-128/98, Aeroports de Paris [2000] ECR II-03929.

T-127/99, Daewoo v Commission [2002] ECR II-01275.

T-319/99, FENIN, [2003] ECR II-00357.

T-36/99, Lenzing, [2004] ECR II-03597.

T-55/99, Confederación Española de Transporte de Mercancias (CETM) $v$ Commission, [2000] ECR II-03207.

T-152/99, HAMSA v Commission, [2002] ECR II-03049.

T-228/99, WestLB v Commission [2003] ECR II-00435.

T-346/99, Alava, Guipuzcoa, Vizcaya Commission [2002] ECR II-04259.

T-269/99 to 272/99, Guipuzcoa, Alava, Vizcaya v Commission [2002] ECR II-04217.

T-127/99, Diputación Foral de Álava v Commission [2002] ECR II-01275.

T-92/00, Territorio Histórico de Álava - Diputación Foral de Álava v Commission [2002] ECR II-01385.

T-98/00, Linde [2002] ECR II-03961.

T-195/01 and T-207/01, Gibraltar v Commission [2002] ECR II-02809.

T-116/01, $P \& O v$ Commission [2003] ECR II-029757.

T-157/01, Danske Busvognmoend v Commission, [2004] ECR II-00917.

T-351/02, Deutsche Bahn, [2006] ECR II-01047.

T-212/02 British Aggregates v Commission case [2006] ECR II-02789. 



\section{Chapter 1}

\section{Introduction: The Usefulness of Economics to Competition Law}

The competition policy of the European Community has undergone extensive reform during the past decade. The rules have been modernised and simplified and enforcement has been decentralised. The most significant aspect of modernisation has been the introduction of more rigorous economic analysis, both in the areas of anti-trust and state aid. ${ }^{1}$ Indeed, it has been described as the "cornerstone of the modernisation process".

It is now impossible to carry out an analysis or enforcement of competition law without having to appraise the economic facts of competition cases. The Courts of the European Community have shown an increasing tendency to annul Commission decisions on the grounds that they are based on unsound economic analysis.

The reform of competition policy started with Articles 81 and 82. It was later extended to the field of state aid with the announcement of the Commission's State Aid Action Plan in the Spring of 2005.

The Action Plan outlined a so-called "refined economic approach" which in practice has been embodied in the "balancing test" of the positive and negative effects of state aid. There is now a small number of Commission decisions that apply this refined economic approach and the balancing test. But even before the Action Plan, the Courts in quite a few judgements critically examined the Commission's economic assessment of state aid especially in relation to the so-called "market economy investor principle". According to this principle, financial injections by public authorities do not confer a gratuitous advantage to recipient undertakings when the injections

\footnotetext{
${ }^{1}$ L. Hencher, Towards an economic analysis of State aids, European State Aid law Quarterly, Volume 4 No. 32005.

${ }_{2}^{2}$ J. Langer, Tying and Bundling as a Leveraging Concern under EC Competition Law, Alphen aan den Rijn: Kluwer Law International, 2007, p. xvii.
} 


\section{Chapter 1}

are done on terms similar to those available in financial markets. Therefore, in these cases it is necessary to determine the economic conditions under which public authorities make their investments and establish whether they generate an adequate rate of profitability.

The papers collected in this dissertation seek to gain a deeper understanding of the various aspects of the Community's state aid rules and system of state aid control by using economic reasoning. They examine, for example, whether the state aid rules and procedures promote efficient allocation of resources or whether national administrations are given strong enough incentives to comply with the requirements of the Community's state aid regime.

Law, at its most basic form, is a rule that has to be complied with. Compliance is not voluntary and non-compliance normally incurs penalties. If a person or a company chooses to flout the law, it does so at the risk of sanction.

Economics is the study of how people and organisations respond to incentives. It has a methodological foundation that shapes its analysis. Economics, therefore, offers a natural perspective from which to examine how the law is applied and what effects it may have on the behaviour of both market operators and public authorities that enforce it.

In the case of competition law in particular, economics enriches our understanding of how companies act in the market. This is because economics also studies how companies formulate and pursue their strategies.

In addition, economics provides a variety of tools ranging from the measurement of demand elasticity to the measurement of market concentration.

Therefore, economics is useful to competition law because it offers a methodological perspective for assessing the effectiveness of the law, a framework for explaining the behaviour of market participants and tools for measuring the various market parameters. 
There are, however, significant differences between law and economics. The most importance difference is the fact that economics places at the centre of its analysis the pursuit of efficiency - the maximisation of personal and collective welfare. This criterion may diverge from those defined in law. For example, price discrimination, as other forms of discrimination, may be abominable in the eyes of the law but to economics it is a legitimate practice as long as it improves efficiency.

The emphasis on efficiency also implies that rules and procedures are judged by economics according to their effects rather than form or intention. Law and in particular competition law may have other criteria such as the ease of enforcement or the degree of legal certainty and whether a particular piece of legislation is congruent with higher legal principles.

It is now accepted that economics has the capacity to enrich our understanding of the effects of law and that it provides tools that are indispensable to the enforcement of competition law. Economics can also provide indispensable input to the design of "good" laws. In this context, a law is "good" in two different ways. It aims to promote the welfare of society and its citizens and it is capable of achieving the objectives it sets for itself. Naturally, economics can give an answer or two to the question whether a particular competition rule can raise welfare. And, of course, it can indicate whether companies or public authorities will have strong enough incentives to comply with or apply that rule.

It must not be forgotten, however, that economics does not always function in unison with law. Economics is a separate discipline with distinct concerns. Inevitably, there are fundamental and irreconcilable differences between the two disciplines. For example, the form of a public measure or corporate practice matters to law. It is largely irrelevant to economics. This has long been a matter of discord between the two disciplines.

Despite the fact that it is now widely acknowledged that proper application of competition rules requires a good understanding of the underlying economic principles, very little has been done by economists in the field of state aid. Most economic analysis of public subsidies has been confined to either macroeconomic theoretical and empirical models of fiscal policy or their microeconomic counterparts on market failure and optimum 


\section{Chapter 1}

government intervention. ${ }^{3}$ Only few economists who specialise in competition issues have studied systematically the particular aspects of state aid. ${ }^{4}$ This is shown by the fact that some of the most widely used economic textbooks in competition courses are virtually silent on the issue of state aid. ${ }^{5}$

Since economic analysis of state aid is rare, it is certainly needed. This is the reason why for the past decade I have been examining the state aid law and practice of the European Community from an economic perspective.

The papers collected in this dissertation do not expound new theories of state aid law based on economics. Rather they use economic reasoning and economic tools to do the following: (i) they investigate the effects of the state aid rules of the European Community and (ii) consider how the rules should be designed to minimise distortions of competition and achieve stricter compliance.

Given that the papers have been written over a period of about eight years, their particular objectives vary, reflecting the evolution of policy concerns during the period from 1999 to 2008. Nonetheless, their economic perspective in seeking to evaluate essentially legal rules provides a common thread.

The most frequent conclusion of the papers is that state aid rules could be further improved by making them stricter. The Community system of state aid control still allows amounts and types of aid that may be excessive and too generous, respectively. However, the reform of state aid policy

\footnotetext{
${ }^{3}$ See the classic textbook of R. and P. Musgrave, Public Finance in Theory and Practice, New York: McGraw-Hill, 1973.

${ }^{4}$ An exception is T. Beasley and P. Seabright, The Effects and Policy Implications of State Aids to Industry: An Economic Analysis, Economic Policy, 1999, vol. 28, pp. $15-53$.

${ }^{5}$ See, for example, R. van den Bergh and P. Camesasca, European Competition Law and Economics, Antwerpen: Intersentia, 2001; S. Bishop and M. Walker, The Economics of EC Competition Law, London: Sweet and Maxwell, 2002; D. Hildebrand, The Role of Economic Analysis in the EC Competition Rules $\left(2{ }^{\text {nd }}\right.$ ed.), The Hague: Kluwer Law International, 2002; M. Motta, Competition Policy: Theory and Practice, Cambridge: CUP, 2004; K. Viscusi, and J. Harrington, Economics of Regulation and Antitrust, 3rd ed. Cambridge, MA: MIT Press, 2001.
} 
announced by the State Aid Action Plan may succeed to reduce state aid amounts in line with the overall Lisbon objectives.

The application of the "refined economic approach" of the Action Plan has not generated policy uncertainty, as many commentators had feared. Admittedly it is still too early to reach a definitive conclusion on its effects and application. But the handful of negative decisions by the Commission suggest that it will largely use it to prohibit poorly designed aid measures that grant public money to large companies without any apparent need for public support.

On the whole the Action Plan is a step in the right direction. Unfortunately, however, it does not address one of the weakest points in the system of state aid control: the propensity of certain member states to grant aid without prior notification to and authorisation by the Commission. The Spring 2007 edition of the Commission's Scoreboard was devoted to illegal aid and recovery of aid that had been found to be incompatible with the common market. It showed that the majority of illegal aid was granted by a handful of countries. At present the Community system of state aid control has no means of penalising those member states that repeatedly grant illegal aid.

With the exception of chapters 1 (introduction), 2 (research questions), 3 (the evolution of EC competition policy) and 30 (assessment and conclusions), all the other papers in this dissertation have been published in scientific journals, books or edited volumes. They have been grouped in seven parts. Part I reviews the concept of state aid and its interpretation in the case law. It also explains the system for notification, authorisation, prohibition or recovery of aid. It seeks to make the state aid concept and procedures more accessible to the reader and for this reason it develops several "decisionmaking trees" for determining, for example, when a public measure transfers state resources or confers an advantage to the recipients or is selective.

Part II considers why a regional bloc like the EC would need state aid rules and what such rules should aim to do. Chapters 6 and 7 examine the economic effects of state aid and how it should be assessed. The state aid rules of the EC promote to a large extent economic efficiency and prohibit egregious types of state aid but correction of market failure is not their only or primary objective. They also allow aid to be granted for other purposes 


\section{Chapter 1}

that may fall within the Community's wider objectives. Chapter 8 evaluates the new "refined economic approach" and the related "balancing test". It argues that in principle the test should use more explicit market and trade share thresholds to identify cases capable of appreciably affecting crossborder competition. It also examines the record of the Commission and concludes that on the basis of the few negative decisions that have been taken so far the test does not appear to seek to quantify the positive and negative effects of aid. Rather it develops a screening process for identifying cases of aid with objectionable features. In this sense it is not a fully-fledged economic cost-benefit analysis. The balancing test and the concepts of the necessity and incentive effect of state aid are also examined in chapter 9 which reviews all the cases in which they had been applied as of November 2007. The difference between chapter 8 and 9 is that the former evaluates the methodology of the balancing test, while the latter analyses how it has been applied. That analysis had to come at the end because its findings are linked to the concluding chapter that appraises the overall direction and results of the reform of state aid policy initiated by the State Aid Action Plan.

Part III addresses a number of distinct issues concerning the interpretation of the various aspects of state aid. Chapter 10 analyses the concept of undertaking and the meaning of economic activity. Chapter 11 investigates numerous Commission decisions concerning public funding of infrastructure and broadband networks and how such funding may confer an advantage to infrastructure or network operators. Chapter 12 is primarily concerned with the classification of Community funds as state aid and the conditions related to cumulation of de minimis aid. Chapter 13 argues that government statements that appear to sway the market in favour of particular firms should not be regarded as state aid that is incompatible with the common market because rational economic operators would not believe that a government would be able to offer aid in breach of EC rules. Chapter 14 in general supports the market economy investor principle but suggests that it would be disingenuous to believe that governments exercise the same vigilance in pursuing profit possibilities as private investors. For this reason it is unlikely that they exert the same discipline over the companies in which they invest.

Part IV focuses on the evolution of the case law with regard to state aid hidden in tax exemptions and special tax treatment. On the whole the five 
chapters in that section are in favour of the efforts of the Commission and the Courts to apply vigorously Article 87 to tax measures. The chapters develop several tests to determine whether a particular tax or tax exemption may confer state aid. In most cases the problem of dealing with tax measures is to determine whether they are selective or not and whether they follow from the logic of the underlying tax system. However, the analysis developed there is also critical of certain Court judgements and Commission decisions for stretching the concept of selectivity to cover also measures adopted by regional or local authorities. This is because the economic effect of this kind of measures may on the whole be positive.

Part V considers the problem of how public authorities may support providers of services of general economic interest. Under certain conditions, regulation and obligations imposed by law can be more efficient policy instruments than public subsidies. The four chapters in that section express three criticisms of current practice. First, at present there is no requirement for public authorities to demonstrate that the market cannot provide the service in question without the imposition of a public service obligation. This means that providers may obtain compensation for things they would do anyway. Second, aid granted as a means of compensation for public service obligations may allow recipients to gain a competitive advantage over their rivals in related markets. This can be avoided through auctioning of service contracts. Third, the exemption in Article 86(2) is too lax because it allows the granting of aid to inefficient providers. It is suggested that aid to an inefficient provider is "contrary to the interests of the Community" because a smaller subsidy to a more efficient provider would result in a commensurately smaller distortion of trade and competition.

Part VI turns its attention to sectoral issues and the rules contained in three guidelines: those on aid for rescue and restructuring of companies in difficulty, those on aid for regional development and those that apply to maritime transport. The chapters on rescue and restructuring criticise past and current rules for being too accommodating. Chapters 24 and 25 argue that, although more recent rules on rescue and restructuring aid are definitely stricter, the current regime does not ask important questions such as what is the benefit to society from preventing the collapse of a company. Had it asked such a question it would follow that allowable aid ought not to exceed the quantifiable amount of such benefits. Chapter 26 shows that regional aid 


\section{Chapter 1}

rules also omit to ask vital questions such as what is the magnitude of the regional "handicap" that has to be offset by public incentives to induce investment in backward regions. It does not follow automatically that the regional handicap is the same for every sector or industry and that it is equivalent to the ceiling of aid allowed by the Commission. That chapter also provides original statistical evidence of the inability of regional aid to close the income gap between rich and poor regions and the apparent direction of aid to middle-income rather than the very poor regions. Chapter 27 turns its attention to recent problems in the enforcement of the maritime guidelines. These are some of the most favourable rules for any sector because they allow fiscal aid up to $100 \%$ of tax liability. The problems that are analysed in that chapter emanate from the fact that the distinction between eligible and non-eligible activities does not correspond to the commercial realities of the truly globalised maritime industry. A simplified approach would solve many of those problems.

Part VII assesses the overall system of state aid control in the Community. Chapter 28 examines an "unthinkable" proposition: the decentralisation of state aid control and the delegation of certain tasks to national authorities. This is an "unthinkable" proposition is the sense that the powers of the Commission in the field of state aid are granted directly by the EC Treaty. This is a unique feature of the supranational Community system and one that the Commission holds very dear and guards carefully. However, since one of the main reasons for reform of competition policy has been to relieve the Commission from the administrative burden of routine cases, it can also achieve the same relief with regard to state aid by empowering national authorities to carry out certain tasks. In order to safeguard the integrity of the Community system of state aid control, such national authorities would only be allowed to review routine cases involving small amounts of aid. For other cases they would be allowed to prohibit them but not authorise them. That would be the task of the Commission. Chapter 29 argues that the integrity of the system is weakened by member states that grant illegal aid with apparent impunity. They suffer no other penalty apart from having to recover the aid after it is discovered and found to be incompatible with the common market - a process that may take several years. That chapter explains that compliance with state aid rules would improve if member states would also suffer a penalty where they repeatedly grant aid without prior notification to the Commission and where the European Court of Justice finds that there 
should not have been any doubt that the measures in question contained state aid.

Lastly, chapter 9 reviews the most recent cases where the new refined economic approach of the State Aid Action Plan is applied. This review is culminated in chapter 30 which provides an overall assessment of the ongoing reform of the state aid rules and procedures. The rules are now wider, affording national authorities more possibilities for granting state aid, but at the same time the refined economic approach and the balancing test impose stricter criteria, especially, concerning the necessity of aid to large companies. 


\section{Chapter 2}

\section{The Research Questions}

Article $3(\mathrm{~g})$ of the EC Treaty requires that the European Community establishes a system to ensure that "competition in the internal market is not distorted". In the landmark Metro I case [C-26/76], the European Court of Justice explained that no distortion of competition implies "the existence of workable competition that ensures achievement of the economic objectives of Treaty", i.e. "the creation of a single market with conditions similar to those of the domestic market". This interpretation suggests that the purpose of the Community's competition policy is to be an instrument for achieving the common market or the internal market, as later defined by the Treaty on the European Union or the single market, as was mentioned by the Court in its judgements.

This explanation of the purpose of competition policy was provided by the Court in a judgement concerning the application of the anti-trust rules of competition policy. Similar judgements have been delivered in relation to the purpose of state aid rules. In its earliest judgement on the concept of state aid [Steenkolenmijen v High Authority, C-30/59], the ECJ said "subsidies or aids granted by the States are incompatible with the common market because they constitute an obstacle to one of its essential aims." That obstacle was the "most rational distribution of production at the highest possible level of productivity". The ECJ, in the same judgement, also found that state aid "obstructs the establishment of normal competitive conditions."

That this is the purpose of the state aid rules is reinforced by the fact that the Court has declared in numerous judgements that a measure is classified as state aid not by its aims or intentions but by its effects [see, for example, Steenkolenmijen v High Authority, C-30/59; Italy v Commission, C-173/73]. Among those effects is whether aid distorts competition. 


\section{The Research Questions}

So, the state aid rules of the EC Treaty, in common with the anti-trust rules, seek to further the achievement of a common market with normal competition. Like Articles 81(1) and 82 that prohibit restrictive agreements and abusive practices, Article 87(1) also prohibits state aid that distorts competition by declaring it incompatible with the common market.

But if state aid rules aim to prevent distortions to competition, why then is some state aid exempted from the prohibition that is contained in Article 87(1)? There are two answers to this question. First, just as in the case of exempted restrictive agreements that generate economic benefits as provided in Article 81(3), some state aid also generates net benefits for society. The principal legal basis for exempting this kind of aid is Article 87(3)(c) that under certain conditions allows aid which can promote the development of certain economic areas or activities.

As economic theory acknowledges, markets do not function perfectly all the time. A typical cause of market failure is the existence of either positive or negative externalities. Since externality means that either the full costs or the full benefits are not internalised within firms, the market tends to produce too much of the good that generates negative externalities [because producers do not bear the full costs] and too little of the good that generates positive externalities [because producers do not capture all the benefits]. In these circumstances, government intervention may correct the failure by imposing taxes on the production of negative externalities (e.g. pollution) or by granting subsidies to the production of positive externalities (e.g. education, research). ${ }^{6}$ An absolute ban on state aid would condemn the EC to suffer the results of market failure. That would undermine the objective of encouraging the efficient allocation of resources through the creation of a common market without barriers to trade and investment.

The second answer to the question why some state aid is exempted is simply because the Treaty says so. Here subsidies are seen an effective policy tool for pursuing objectives other than the efficient allocation of resources and undistorted competition. Such other policy objectives are laid down in

\footnotetext{
${ }^{6}$ For references to the literature, especially in a European context, see R. Baldwin and C. Wyplosz, The Economics of European Integration, (London: McGraw-Hill, 2004), ch. 6; J. Pelkmans, European Integration: Methods and Economic Analysis, (Heerlen: Open University, 1997), ch. 12.
} 


\section{Chapter 2}

Article 73 on public transport, Article 86(2) on services of general economic interest, Article 87(2) on aid to individuals and aid to remedy the effects of natural disasters and the effects of the division of Germany and Article 87(3) on aid to regional development, important European projects and culture and heritage.

Therefore, in the context of the EC Treaty, subsidies or, more broadly state aid, have both economic and non-economic goals. Correspondingly, the state aid rules of the EC accommodate both economic and non-economic concerns. This understanding of the purpose of state aid rules provides a reasonable basis for formulating a primary and subsidiary research question from an economic perspective.

Primary question: How important is the efficient allocation of resources for the state aid that is authorised by the Commission?

Subsidiary question: Is authorised aid the least distortionary for the policy purpose for which it is granted?

The papers that are collected in this dissertation argue that until recently, economic efficiency was not an important policy objective. Practice diverged significantly from rhetoric and policy pronouncements. Although the European Commission would pay lip service to the need for efficient allocation of resources, with a few exceptions, most aid that was authorised was not subject to any rigorous test to determine its impact on competition, market structure, incentives to market operators and efficiency. The most notable exception was aid for rescue and restructuring but even in this case much aid was allowed simply because it fulfilled the requirements laid down in the relevant guidelines. Given the fact that efficiency was not a major concern, it is not surprising that the authorised aid was not necessarily the least distortionary.

In response to the 2005 State Aid Action Plan, the UK Office of Fair Trading, one of the most reputable competition authorities in the European Union, carried out a review of the Community system of state aid control and its substantive rules. Its findings are both illuminating and disconcerting.

The OFT stated that it "is strongly of the view that a more economic approach is required when considering distortions to competition. The 


\section{The Research Questions}

current approach is inadequate; it permits some aid that distorts competition significantly, and prohibits other aid that only has minor competition effects."7

It went on to explain that "specifically, the OFT considers the problem ... may arise because of the failure of state aids controls to apply a consistent economic assessment of distortion to competition. That is, aids falling within Article 87(3), but within a Commission guideline, may be permitted notwithstanding that they create a certain level of competition distortion. However, in the absence of transparent economic criteria for their assessment, aids falling within Article 87(3), but outside a guideline, may be prohibited even though they only create a similar level of distortion or, more particularly, where they create only a very low level of distortion to competition." [paragraph 2.9]

More damningly the OFT concluded that "more generally, existing state aid controls generate these perverse outcomes because approval of aid is not based on an economic view of distortion to competition. Current guidelines set ceilings on the amount of aid that can be given relative to the amount of investment being undertaken. While this prevents company expansion or development being entirely state funded, to the detriment of competitors, it does not take into account the fact that the subsidy may allow the recipient to compete on an unequal footing. Hence ceilings are only a very rough approximation of the potential for subsidies to distort a market." [paragraph 2.11]

The OFT's assessment correctly reflects actual practice and is borne out by the findings in the papers collected in this dissertation. Part of the problem lies with how the law has been understood and applied.

In the Philip Morris case, the Court of Justice ruled that Article 87(3) [then 92(3)] did not allow member states to "make payments which would improve the financial situation of the recipient undertaking although they were not necessary for the attainment of the objectives specified in Article [87(3)].".8

${ }^{7}$ OFT Response to the European Commission's Action Plan on State Aid Reform, September 2005, paragraph 2.2, OFT 820.

${ }^{8}$ Philip Morris v Commission, C-730/79, ECR 1980, p. 2671, paragraph 17. 


\section{Chapter 2}

This is a step in the right direction but not a sufficient requirement for limiting aid to the least distortionary amount. More recently, for example, the Court of First Instance ruled that "the Commission is entitled to refuse the grant of aid where that aid did not induce the beneficiary undertakings to adopt conduct likely to assist attainment of one of the objectives mentioned in Article [87(3)] of the EC Treaty."

Both judgements in fact lay down an important principle: that state aid must be necessary. If aid is unnecessary, it is a waste of public resources because it merely reduces the costs of beneficiary undertakings. They would have acted in the same way even without aid.

The papers in the various chapters below explain why establishing the need for aid is a necessary but not sufficient condition either for correcting market failure or for granting the least distortionary amount of aid for the achievement of other policy objectives.

The EC Treaty and the case law do not represent insurmountable obstacles towards more efficient state aid. As both the ECJ and the CFI have ruled many times, they only determine whether the Commission makes manifest error in its assessment and whether it has followed the proper procedures. The Commission is the only authority in the EU that has discretion to determine the compatibility of state aid with the common market.

As recently put very succinctly by the CFI in its judgement on SIDE $\mathrm{v}$ Commission, T-348/04, "by virtue of Article 87(3) EC, the Commission has a wide discretion the exercise of which involves complex economic and social assessments which must be made in a Community context. Judicial review of the manner in which that discretion is exercised is confined to establishing that the rules of procedure and the rules relating to the duty to give reasons have been complied with and to verifying the accuracy of the facts relied on and that there has been no error of law, manifest error in the assessment of the facts or misuse of powers. In particular, it is not for the Community court to substitute its economic assessment for that made by the institution which adopted the decision.” [paragraph 96]

\footnotetext{
${ }^{9}$ Graphischer Maschinenbau v Commission, T-126/99, paragraph 34.
} 


\section{The Research Questions}

More importantly, "in exercising its discretion, the Commission has to ensure that the aims of free competition and those of the derogation are reconciled, whilst complying with the principle of proportionality." [paragraph 98]

These quotes indicate that when the Commission uses the powers conferred to it directly by the Treaty it can require that state aid which is in principle allowed by the Treaty is still confined to the minimum possible to achieve the particular policy objective. In this way the distortion of competition is limited.

Indeed since the launch of the State Aid Action Plan in 2005, the Commission is moving towards that direction and the situation has improved considerably. This is the result of the application of a "more refined economic approach" to the assessment of state aid and in particular the elaboration of the so-called "balancing test". This test seeks, first, to identify the positive and negative effects of state aid and to ensure that the positive ones outweigh the negative.

The majority of the chapters in this dissertation examine the various state aid rules and explain whether they are capable of allowing aid that remedies market failure without distorting competition to an undue or disproportionate extent. Chapters 8 and 9 review the preliminary evidence from the application of the balancing test. The final chapter considers whether the criticism of state aid policy in the papers that appear in other chapters and which were written some years ago is still valid today. 


\section{Chapter 3}

\section{Evolving Competition Policy: Reform of Anti-trust and State Aid Rules}

\subsection{An instrument for integration}

Article 2 of the European Community Treaty identifies the fundamental tasks of the Community. These tasks are to be carried out through the establishment of a common market and an economic and monetary union and through the implementation of common policies and activities. Article 3 requires that, for the purposes set out in Article 2, the activities of the Community shall include, among other things, "a system ensuring that competition in the internal market is not distorted" [3(g)].

The specific rules on competition in the Treaty are contained in Articles 8189. They comprise Article 81 that prohibits collusive agreements and practices, Article 82 that prohibits abuse of dominant market position, Article 86 that applies the rules of competition to public enterprises and enterprises with special or exclusive rights, and Article 87 that declares all forms of state aid to be incompatible with the common market. Articles 83, $84,85,88$ and 89 define either transitional provisions or decision-making procedures.

Because Articles $3(\mathrm{~g}), 81,82$ and 87 refer to the common market where trade is free, the competition policy of the EC is understood to have as its primary objective the facilitation of the establishment of that market. It is an instrument for integration and for removing any anti-competitive practices that segment the common market along national or regional lines. This is also the reason why no agreement or practice that eliminates the possibility of cross-border trade has ever been found to be compatible with EC competition rules.

But the objective of competition policy as such is to ensure non-distortion of competition or the maintenance of "effective competition". The Treaty does 
not define the meaning of effective competition. It is a concept that has emerged by necessity in the case law because the Court of Justice had to have a benchmark against which to identify "distortion", "prevention", or "restriction" of competition.

The two main goals of EC competition policy - integration and effective competition - are not always compatible with each other or free of contradictions. For example, as has long been noted in economics, the granting of absolute territorial protection to distributors of a product may give them a stronger incentive to market that product more aggressively and under certain market configurations (as, for instance, when there is sufficient inter-brand competition) competition may actually intensify. Moreover, what appears in the short-term to be a market-segmenting strategy, may prove in the longer term to be market-integrating (as new firms are able to establish themselves successfully in new markets).

\subsection{A system of excessive control}

When the Treaty was being drafted in 1956-57, there was discussion about the nature of the system that had to be established then to prevent distortions to competition. The options were either an authorisation system whereby agreements are void unless expressly exempted or a system of directly applicable exceptions whereby certain agreements are exempted automatically. In the end the authorisation system was chosen.

That choice was prompted by a desire to achieve "effective supervision" and "simplified administration" (mentioned in Article 83(2)). However, forty years later it was realised that because the system actually created a complex administration, the effectiveness of the supervision was seriously compromised.

Nonetheless, it was felt at that time that the authorisation system was inevitable because:

- Prospective member states either had no competition laws or they were very different, which could lead to diverse interpretations of competition principles. There was a need for legal uniformity. 


\section{Chapter 3}

- There was a need to avoid jurisdictional problems among the various national authorities.

- There was little experience in the member states with competition policy and no effective enforcement of such policy.

- The Commission had no knowledge of the underlying market structures and conditions. The Commission also needed to be informed about market developments.

- Finally, business needed to have a climate of legal certainty in which to conduct its affairs. They had to be given an incentive to notify their agreements and from that derive the certainty they needed.

The resulting system was based on ex ante control by the Commission. Through Regulation 17/62, the Commission was given the sole power to grant exemptions. Member states were not allowed to grant exemptions, even though they could enforce the prohibitions contained in Articles 81(1) and 82. Moreover, member states had to stay their proceedings when the Commission opened its own investigation in the same case.

The exception provision contained in Article 81(3) was inapplicable without prior notification. As a result, the Commission was inundated every year with several hundred requests for exemption, most of which were innocuous to competition and hardly deserved any attention by the Commission.

\subsection{A complex and wide system, increasingly relying on informal procedures}

The formal procedures laid down in Regulation 17/62 were complex and cumbersome. The initiation of an investigation had to be notified through publication in the Official Journal (OJ) of the European Communities and now the European Union. All interested parties had to be afforded the possibility to present their views. The Commission before issuing its decision had to consult an advisory committee made up of representatives of member states. Lastly, any decision had to be published in the Official Journal in all official languages of the EU.

The system of ex ante control had some unexpected consequences while it did not actually achieve completely its aims. At the beginning there was a 
flood of notifications reaching 37,500 by 1967 . This stretched the Commission's limited resources and afterwards the annual influx of several hundred notifications diverted the Commission from its main target of busting cartels and stopping abuses of dominance.

Because Commission services had to find ways to cope with the initial thousands of notifications, they turned to informal procedures which proliferated. The Commission relied heavily on "comfort letters" to assure undertakings of the presumed legality of their actions or to warn them about their suspected illegality. Although informal procedures were quick, they were not transparent, nor did they provide legal certainty. Those letters, unlike formal decisions, were not binding on member states and the national courts.

The system was not only complex and opaque. It was also too wide and caught too many business practices even when they had negligible impact on competition. Almost any agreement between companies was thought to restrict competition. The EC created a system of competition whereby everything was practically prohibited unless notified to and explicitly authorised by the Commission.

The Commission did not recognise that agreements that reduced or eliminated competition between the parties, did not necessarily weaken competition on the market. The Commission appeared to regard competition on the market as equivalent to competition between the parties to an agreement. Economic theory and some Court judgements slowly revealed the fallacy in regarding them as equivalent.

\subsection{Need for reform}

By the end of the 1990s a consensus emerged that the system needed reform. The enlargement of the EU would increase the workload of the Commission and dilute further its control. Enlargement would also increase the number of official languages and complicate procedures further. The gradual dilution of the Commission's effective overseeing of the competition conditions in the EU was indicated by the fact that only about $10-15 \%$ of all the cases (400500 cases per year) were opened by the Commission's own initiative. By contrast, member states were better placed to deal with additional cases. 


\section{Chapter 3}

Member states had about 1,200 competition officials as compared to only 150 officials at the time in DG Competition (excluding those working on state aid, concentrations and public undertakings).

Perhaps more important in this context was the fact that the system was not transparent. Only about $5-7 \%$ of all cases were formally closed. Formal closure that resulted in published decisions would elaborate competition principles and therefore would contribute to a better understanding of how the policy was applied.

There was also the view that the system of prior notification did not contribute to the prevention of distortions of competition. It did not catch the most serious anti-competitive practices. Between 1965 and 1998 only about ten (10) notifications had resulted in a prohibition! By contrast, the system caught practices that would otherwise be exempted under Article 81(3). It was also costly on undertakings that have to prepare elaborate documents to submit to the Commission.

To remedy the weaknesses of the system, the Commission initiated a public discussion with the publication of a White Paper in March 1999 [OJ C 132, 12/5/1999]. The Paper proposed the following:

- end of notification and authorisation system;

- wider use of indicators of market power (market shares);

- decentralised enforcement;

- Article 81(1) to be applied together with Article 81(3);

- member state authorities may withdraw the benefits of block exemptions for agreements that concern exclusively their markets;

- more guidelines to be issued by the Commission;

- member states to inform the Commission more extensively;

- intensified ex post control by the Commission;

- strengthened enquiry powers for Commission;

- higher fines for non-compliance with information requests.

These proposals were eventually codified in Regulation 1/2003 which came into force on 1 May 2004, coinciding with the largest ever enlargement of the EU. 
The Commission also set up the European Competition Network which comprises all the national competition authorities. The purpose of the ECN is primarily to determine case allocation and identify best practices to prevent uneven enforcement leading to forum shopping by undertakings and jurisdictional conflicts between national authorities.

The process of reform in the field of anti-trust has not ended. In 2005 the Commission published a Discussion Paper and launched a series of public consultations on Article 82. The Commission has not yet made any formal proposals. However, it has become clear that practices that were formalistically regarded as abusive will no longer be prohibited. In this connection, the Commission is belatedly responding to extensive developments in economic theory which show that not every instance of price differentiation or discount or product tying has a negative impact on market competition even when practiced by a dominant undertaking. Community Courts have been less activist with respect to Article 82 so it is not possible to predict what the Commission will eventually propose.

\subsection{Reform of state aid rules and procedures}

The EC Treaty confers unique powers to the European Commission in the field of state aid. It has the sole right to assess and authorise state aid. Member states are obliged to inform the Commission of any national measure that may contain state aid. The Commission can prohibit a national measure for granting aid that is incompatible with the common market without having to ask for confirmation from the European Court of Justice. Such extensive powers are non-existent in other policy fields.

Understandably, the Commission has always been very vigilant in protecting those rights and, consequently, it was reluctant to make any proposal to the Council which could be exploited by member states to circumscribe its wide policy discretion. By the late 1990s, however, it became obvious that the rules and procedures concerning state aid that had developed in an ad-hoc manner through every day practice needed to be simplified and codified.

Initially, the Commission proposed to the Council to empower it to issue block exemption regulations as was the practice for a long time in the field of anti-trust. This was achieved through the "enabling" Council Regulation 


\section{Chapter 3}

994/98. This resulted in three block exemption regulations (on aid to SMEs, training aid and employment aid) and a regulation on de minimis aid.

Next came the codification of notification and investigation procedures with Council Regulation 659/99. Not only did it codify the then practice, but it also incorporated principles from landmark Court judgments, developed new rules such as those concerning the time limits of investigations and compulsory recovery of incompatible aid and conferred new powers to the Commission such as those concerning information injunctions and on-site investigations.

In the Spring of 2005, the Commission announced the State Aid Action Plan (SAAP). Its aim, like the reform of anti-trust rules, was to simplify, consolidate and modernise state aid rules. Simplification was to be achieved by abolition of rules and procedures that were no longer necessary. Consolidation was to be pursued through the merging of the various block exemption regulations into a single document. Modernisation was conceived in terms of more thorough economic analysis of state aid. Member states were expected not merely to argue in principle but also to provide tangible evidence that the beneficial effects of state aid outweighed its negative effects.

The SAAP introduced the concept of "refined" economic analysis that is embodied in a so-called "balancing test" which has been subsequently elaborated in the R\&D\&I Framework, the Guidelines on Risk Capital for SMEs and the draft Environmental Guidelines. The balancing test consists of three stages which pose the following questions:

1. Is the aid measure aimed at a well-defined objective of common interest? For state aid to be exempted it must pursue one of the policy objectives which are defined in Article 87(3) [or (2)].

2. Is the aid well designed to deliver the objective of common interest; i.e. does the proposed aid address the market failure or other objective? This in turn is broken down into three subsidiary questions:

i. Is state aid an appropriate policy instrument? There may be other instruments that do not involve subsidies and which are equally good or even better at achieving the desired policy objectives. 
ii. Is there an incentive effect; i.e. does the aid change the behaviour of firms? For aid to be exempted it must be capable of inducing firms to do things they would not otherwise do without government intervention.

iii. Is the aid measure proportional; i.e. could the same change in behaviour be obtained with less aid?

3. Are the distortions of competition and effect on trade limited, so that the overall balance is positive? Even if the aid is appropriate and proportional, it may still generate significant distortions of competition that may harm other member states. These harmful effects have to be taken into account.

Economic analysis is now an integral part of all aspects of the EC's competition policy.

\subsection{Comparison of reform in anti-trust and state aid}

The reform of anti-trust and state aid rules and procedures has followed similar paths and pursued similar objectives. In both cases, the impending enlargement of the European Union acted as a catalyst. The Commission could not cope with the work load generated by the hundreds of notifications. In both cases, self-enforcement has been the solution to reducing unnecessary notifications. Self-enforcement has been effected through greater use of block exemption regulations, co-current application of Article $81(1)$ and $81(3)$ and greater involvement of national competition authorities and national courts.

The enlargement of the EU was also the used by the Commission to justify its request for greater enforcement powers so as to ensure that the rules are applied uniformly across the EU. The Commission now has more extensive powers of investigation in both anti-trust [inspection of private premises] and state aid [on-site inspection].

In both areas of competition the rules have been consolidated, simplified and updated. However, here there is the most significant difference between antitrust and state aid. In the field of anti-trust, the introduction of more rigorous economic analysis has led to a relaxation of the rules. Practices that were considered to be anti-competitive are no longer thought to have an appreciable effect on market competition. This is the case, for example, with 


\section{Chapter 3}

certain forms of cooperation between companies (e.g. in R\&D) or certain types of mergers.

By contrast, in the field of state aid the use of more rigorous economic analysis has led to tightening of the rules. Aid that used to be treated in a formalistic manner is now subject to more intense scrutiny and its positive and negative effects are more carefully quantified and appraised. This is the case, for example, with aid measures that are assessed directly on the basis of Article 87(3)(c).

The trend towards more thorough economic assessment of corporate practises and aid measures has meant that as markets become more integrated the power of any individual company to distort competition declines while the distortion caused by public measures worsens. These markets changes do justify the differences in the enforcement of anti-trust and state aid rules.

\section{Annex: Highlights from the State Aid Action Plan}

Need for state aid policy

“... State aid may be declared compatible with the Treaty provided it fulfils clearly defined objectives of common interest and does not distort intracommunity competition and trade to an extent contrary to the common interest. State aid measures can sometimes be effective tools for achieving objectives of common interest. They can correct market failures, thereby improving the functioning of markets and enhancing European competitiveness. They can also help promote e.g. social and regional cohesion, sustainable development and cultural diversity, irrespective of the correction of market failures." [p. 10]

"However, state aid should only be used when it is an appropriate instrument for meeting a well defined objective, when it creates the right incentives, is proportionate and when it distorts competition to the least possible extent. For that reason, appreciating the compatibility of state aid is fundamentally about balancing the negative effects of aid on competition with its positive effects in terms of common interest." [p. 11]

New challenges 
"... there is a need for renewed impetus to the so-called Lisbon Strategy." [p. $13]$

"The European Council of March 2005 has called on 'Member States to continue working towards a reduction in the general level of State aid, while making allowance for any market failures. This movement must be accompanied by a redeployment of aid in favour of support for certain horizontal objectives such as research and innovation and the optimisation of human capital. The reform of regional aid should also foster a high level of investment and ensure a reduction in disparities in accordance with the Lisbon objectives."' [p. 14]

"The enlargement ... underlines the need ... for better governance to ensure an effective control in the enlarged Union." [p. 16]

"The increasing complexity and number of documents ... have created a need to streamline state aid policy, focus attention on the most distortive types of aid and make state aid control more predictable and user-friendly, thereby minimising legal uncertainty and administrative burden ... There is also a need to strengthen the commitment of Member States to their obligation to enforce state aid rules. Finally, there is a need to increase transparency and advocacy ... and act against unlawful aid, in particular before national judges." [p. 17]

How to face the new challenges?

"To face the new challenges requires a thorough modification of the existing state aid rules, as regards both substance and procedures ... The aim is to present a comprehensive and consistent reform package based on the following elements:

- less and better targeted state aid;

- a refined economic approach;

- more effective procedures, better enforcement, higher predictability and enhanced transparency;

- a shared responsibility between the Commission and Member States.” [p. 18]

"The Commission will continue to develop criteria to fulfil its assessment of aid compatibility ... In general, the positive impact of an aid depends on: 


\section{Chapter 3}

i) how accurately the accepted objective of common interest (whether social, regional, economic or cultural) has been identified,

ii) whether state aid is an appropriate instrument for dealing with the problem as opposed to other policy instruments and

iii) whether the aid creates the needed incentives and is proportionate.

On the other hand, the level of distortion created by an aid generally depends on:

i) the procedure for selecting beneficiaries and the conditions attached to the aid,

ii) characteristics of the market and of the beneficiary and

iii) the amount and type of aid. For example, restructuring aid or investment aid to large companies should be carefully monitored to clearly address an objective of common interest, since the impact of such measures on competition and trade will normally be significant." [p. 20]

"To best contribute to the re-launched Lisbon Strategy for growth and jobs, the Commission will, when relevant, strengthen its economic approach to State aid analysis ... This approach can also help investigate the reasons why the market by itself does not deliver the desired objectives ... One key element in that respect is the analysis of market failures ... Identifying the market failure at stake will help evaluate better whether state aid could be justified and acceptable, would represent the most appropriate solution, and how it should be implemented to achieve the desired objective without distorting competition and trade ..." [pp. 21-23]

"However, it is not enough for state aid to target a market failure. Before resorting to State aid, which is in general only the 'second best' option to achieve optimal allocation of resources, it should be verified whether other less distortive measures could remedy the market failure. State aid should be the appropriate policy instrument and should be designed so that it effectively solves the market failure, by creating an incentive effect and being proportionate. In addition, state aid should not distort competition to an

$$
\text { extent }
$$$$
\text { contrary }
$$

to the common interest." 


\title{
Part I: EC State Aid Rules
}

\author{
Chapter 4 \\ The Concept of State Aid
}

The further we progress towards full market integration the more harmful are distortions of competition. The beneficial effects of liberalisation may be undermined by state intervention which weakens effective competition and prevents the achievement of integration. ${ }^{10}$ State aid is thus considered to be in principle incompatible with the common market.

Article 87(1) EC declares any aid which distorts competition and affects trade between Member States to be incompatible with the common market, unless the Treaty dictates otherwise. This qualification implies that certain exceptions are possible to this general prohibition of state aid. In this respect, the second and third paragraphs of Article 87 define certain categories of aid that are either compatible or may be declared compatible with the common market. It is the exclusive responsibility of the Commission to examine the compatibility of state aid with the common market. ${ }^{11}$

Article 88 EC defines the procedure on the basis of which Member States are required to notify all new state aid (in schemes or individual awards) or amendments to existing state aid schemes to the Commission for assessment. State aid cannot be granted or put into effect unless it has been approved or deemed to have been approved by the Commission. The procedure of Article 88 EC has been extended and elaborated by Council Regulation 659/99 laying down detailed rules for the application of Article 93 EC (now Article $88)$.

\footnotetext{
${ }^{10}$ Eleventh Report on Competition Policy (1981), at p. 179.

${ }^{11}$ Connor Quigley \& Anthony M. Collins, EC State Aid Law and Policy, 2003, Hart Publishing, at p. 2.
} 


\section{Chapter 4}

\subsection{Article 87(1) EC: Aid incompatible with the common market}

The primary objective of state aid policy in the European Community is laid down in Article 87(1) EC, which provides that:

"Save as otherwise in this Treaty, any aid granted by a Member State or through state resources in any form whatsoever which distorts or threatens to distort competition by favouring certain undertakings or the production of certain goods shall, in so far as it affects trade between Member States, be incompatible with the common market."

This wording indicates that state aid is in principle prohibited within the common market. Article 87(1) EC does not present a concrete definition of the concept of state aid by reference to its cause or objective but rather defines it by reference to its effect. ${ }^{12}$ The meaning of aid is derived from the interpretation of Article $87 \mathrm{EC}$ in the rulings of the Community Courts and the decisions of the Commission. Thus, a measure of public support is classified as state aid only if the conditions defined in that paragraph are all satisfied. Alternatively, not all measures of public support, even those that may involve public subsidies, are necessarily classified as state aid, as long as at least one of those conditions does not hold.

The five conditions that must all hold are the following:

(a) aid must be granted by the state or through state resources;

(b) this aid must confer an advantage to the recipients;

(c) the advantage must favour certain (selected) undertakings or economic activities;

(d) aid must affect trade between Member States; and

(e) aid must distort competition in the common market.

However, there are at least three situations, as the Advocate-General commented in the case Italy $\mathrm{v}$ Commission, where despite the presence of the aforementioned factors, the intervention does not constitute state aid in the strict sense of the term, namely:

"(a) where the state conducts itself like a private commercial operator, ${ }^{13}$

(b) where the state is discharging obligations of a civil nature such as the obligation to make reparation for loss and damage or to pay back sums unduly required; ${ }^{14}$ and

\footnotetext{
${ }^{12}$ Case 30/59, Steenkolenmijnen v High Authority, 1961 ECR 1, at p. 19.

${ }^{13}$ Case C-301/87, France v Commission, 1990 ECR I-307, at para. 39.
} 


\section{The Concept of State Aid}

(c) where the exceptional measure forms part of a general system - of taxation or social security, for example - and is justified by the nature of general scheme of the system."15,

\subsection{Aid by Member States or through state resources}

Article 87(1) EC refers to aid granted "by a Member State or through state resources." "Member States" includes central governments and its ministries or departments, regional and local governments or councils. "State resources," on the other hand, refers to public or private bodies designated or established by the state and which use resources which belong to the state or are controlled by the state. ${ }^{17}$ Any aid given by private entities (e.g. privatelyowned companies) is not considered to be state aid and, thus, fall outside the scope of Article 87 EC. However, a private company, whose board is appointed or otherwise controlled by the state would also be considered as part of the state and would, therefore, fall within the scope of Article 87 EC. ${ }^{18}$

This distinction was thought by some to suggest that the concept of aid was wider than mere transfer of monetary resources and in addition covered advantages of regulatory nature. It is now clear from the case law that only advantages granted directly or indirectly through state resources and which have an impact on public budgets are to be considered as aid within the meaning of Article 87 (1) EC and that the advantages of pure regulatory nature are excluded from that Article. ${ }^{19}$ Article 87(1) EC thus applies to all state aid and covers all transfer of resources without being necessary to make a distinction whether the aid is granted by the agents of the state or enterprises controlled by the state or by the state itself. ${ }^{20}$

\footnotetext{
${ }^{14}$ Case C-61/79, Amministrazione delle Finance dello Stato v Denkavit Italiana, 1980 ECR 1205, at para. 31.

${ }^{15}$ Case C-173/73, Italy v Commission, 1974 ECR 709, at point 13.

${ }^{16}$ Opinion of the A.G. on Case C-6/97, Italy v Commission, 1999 ECR I-2981.

${ }^{17}$ Case C-72-73/91, Sloman Neptun Schiffahrts AG v Seebetriebsrat Bodo Ziesemer, 1993 ECR I-887, at para. 19.

${ }^{18}$ Case C-482/99 French Republic v Commission, 2002 ECR I-4397.

${ }^{19}$ Case C-379/98, Preussen Elektra AG v Schleswag AG, 2001 ECR I-2099, at para. 58.

${ }^{20}$ Case C-290/83, Commission v France, 1985 ECR 439, at para. 14.
} 


\section{Chapter 4}

However, for advantages to be capable of being categorised as aid within the meaning of Article 87(1) EC, they must not only be granted directly or indirectly through state resources but they must also be imputable to the State. ${ }^{21}$

Two questions, thus, need to be answered for applying Article 87(1) EC with regard to the definition of aid granted through state resources:

(a) What are "state resources," and

(b) Is the decision to transfer these state resources "imputable" to the state?

According to the opinion of A.G. Jacobs in the Stardust Marine case, state resources are those resources which are directly or indirectly under the control or in other words at the disposal of the state. ${ }^{22}$ This definition was followed in the judgement of the ECJ, which stated that:

"The state is perfectly capable, by exercising its dominant influence over such undertakings, of directing the use of their resources in order, as occasion arises, to finance specific advantages in favour of other undertakings., ${ }^{23}$

The advantage conferred by the state in order to be counted as aid must be supported by state resources in terms of actual or potential financial liabilities. In other words, aid must have a budgetary consequence for the government. This entails that aid, in the meaning of Article $87 \mathrm{EC}$, may be defined as whatever the government gives from its own resources or fails to receive from what is owed to it.

In a landmark case concerning Germany's international Shipping Register, German rules enabled the contracts of employment concluded with seafarers from non-member countries and having no permanent residence in Germany, to be subjected to less favourable working conditions and lower rates of pay than resident seafarers. Those rules were alleged by the trade unions to be tantamount to illegal aid. However, the ECJ ruled that the system applicable by the ship register did not constitute state aid, as it did not seek to create an advantage that would be an additional budgetary burden to the state. There

${ }^{21}$ Case C-345/02, Pearl BV and Others v. Hoofdbedrijfschap Ambachten, 2004 ECR I-7139, at para.35.

${ }^{22}$ Opinion of A.G. on Case C-482/99 French Republic v Commission, at para. 39.

${ }^{23}$ Case C-482/99 French Republic v Commission, 2002 ECR I-4397, at para. 38. 
was no transfer of state resources and, therefore, the scheme fell outside the scope of Article $87 \mathrm{EC}^{24}$

The same holds when the transfer of resources takes place between private undertakings. In the recent Preussen Elektra case, the ECJ ruled that there was no impact on the public budget and any indirect reduction of tax revenues was an inherent feature of the scheme. ${ }^{25}$

This means that regulatory or administrative measures are not considered to be aid even if they confer a commercial advantage to certain undertakings. Such measures do not normally have a budgetary effect for the state. Even though, for example, relaxation of anti-pollution restrictions could reduce the operating costs of an industry and, therefore, could give it a substantial advantage over its competitors, it is not state aid covered by Article 87 EC. It could, however, infringe other provisions of the Treaty. For instance, it may be contrary to the various environmental directives. In addition, the granting by the state of an advantage to a company in the form of an exclusive right to operate, for example, infrastructural facilities at special financial terms confers an advantage that may infringe Articles 82 and 86 EC and/or Community rules on public procurement.

Other regulatory measures that have been found not to constitute state aid are, for example, the exclusion of certain enterprises from labour regulations (e.g. easier dismissal of workers) and protection of certain type of enterprises from creditors.

Likewise, bye-laws adopted by a trade association governed by public law for the purpose of funding an advertising campaign organised for the benefit of its members and decided on by them, through compulsory earmarked charges to which these members contribute, have been held as not being imputed to the state. The ECJ held that such funding was carried out by

\footnotetext{
${ }^{24}$ Case C-72 \& 73/91, Sloman Neptun Schiffarts AG v Seebetriebsrat Bodo Ziesemer, 1993 ECR I-887.

${ }^{25}$ Case C-379/98, Preussen Elektra $A G v$ Schleswag $A G$ (cited above at no.26). See also Stardust Marine case, where the ECJ stated that "it is also necessary to examine whether the public authorities must be regarded as having been involved, in one way or another, in the adoption of those measures."
} 


\section{Chapter 4}

means of resources which the trade association never had the power to dispose of freely. ${ }^{26}$

State resources can be considered as state aid only if their granting is imputable to the state. Thus, in the Van der Kooy case the ECJ concluded that the measure was attributed to the state because the public undertakings in question had to comply with directives issued by a ministerial committee. ${ }^{27}$ More broadly, the fact that a body cannot decide without taking into account the requirements of public authorities has been held to constitute an indicator of imputability. ${ }^{28}$

A measure is also not imputable to the Member State when it merely constitutes a transposition of Community law into national law. ${ }^{29}$

In summary, the following steps may be followed in determining whether the State is the source of aid:

\section{Table 4.1}

${ }^{26}$ Pearl case, paras 36-37.

${ }^{27}$ Joined Cases C-67/85, 68/85 and 70/85 Van der Kooy v Commission, 1988 ECR 219, at para. 55 .

${ }^{28}$ Ibid. In the Stardust Marine case the ECJ held that the mere fact that a public undertaking is under the control of the state is not sufficient for measures taken by that undertaking to be imputed to the state. It is also necessary, the ECJ continued, to examine the real involvement of the state, in one way or another, in the adoption of those measures. The ECJ thus added a number of other indicators that might, in certain circumstances be relevant in concluding for imputability: "the level of the undertaking's integration into the structures of the public administration; the nature of its activities and the exercise of the latter on the market in normal conditions of competition with private operators; the legal status of the undertaking (...); the intensity of the supervision (...); and any other indicator showing, in the particular case, an involvement by the public authorities in the adoption of a measure or the unlikelihood of their not being involved, having regard also to the compass of the measure, its content or the conditions which it contains" para. 56.

29 In Deutsche Bahn the Court of First Instance found that a provision in the German MinöSTG was not imputable to the German State since the obligation not to levy harmonised excise duty on fuel used for the purpose of commercial air navigation was a transposition of Community law into national law, Case T-351/02, Deutsche Bahn, 2006 ECR II-1047, at para.102. 


\begin{tabular}{|c|l|l|}
\hline Stages & \multicolumn{1}{|c|}{ Questions } & \multicolumn{1}{c|}{ Outcome } \\
\hline I & $\begin{array}{l}\text { Does the measure have an impact } \\
\text { on the budget of a public authority } \\
\text { or does it affect the assets or } \\
\text { liabilities of a public authority? }\end{array}$ & $\begin{array}{l}\text { If the answer is yes, there is transfer of } \\
\text { public resources. } \\
\text { If the answer is no, go to Stage II. }\end{array}$ \\
\hline II & $\begin{array}{l}\text { Does the measure involve transfers } \\
\text { from a fund which is controlled by } \\
\text { a public authority? }\end{array}$ & $\begin{array}{l}\text { If the answer is yes, there is transfer of } \\
\text { public resources. } \\
\text { If the answer is no, go to Stage III. }\end{array}$ \\
\hline III & $\begin{array}{l}\text { Is the measure undertaken by an } \\
\text { agent of the state or an undertaking } \\
\text { controlled directly or indirectly by } \\
\text { the state and can the measure be } \\
\text { attributed to the decision of a } \\
\text { public authority? }\end{array}$ & $\begin{array}{l}\text { If the answer is yes, there is transfer of } \\
\text { public resources. } \\
\text { If the answer is no, there is no transfer of } \\
\text { public resources. Either the resources are } \\
\text { private or the measure is regulatory. }\end{array}$ \\
\hline
\end{tabular}

\subsection{Recipients of aid}

The recipients of aid must be "undertakings" which are natural or legal persons engaging in economic activities. An undertaking for the purposes of Article 87 EC can be a professional self-employed person (such as a lawyer or accountant), a partnership, a private company, a group of companies ${ }^{30}$ or a public company wholly or partially owned or controlled by the state. Article $87 \mathrm{EC}$ also applies to aid granted to undertakings located in another Member State. ${ }^{31}$

The concept of an undertaking is not defined anywhere in the Treaty. It refers broadly to any natural or legal person, regardless of legal status and means of being financed, who carries out economic activities of certain regularity and duration and which could be done for remuneration.

${ }^{30}$ Case C-303/88, Italy $v$ Commission, 1991 ECR I-1433, concerning aid granted to ENI, a state holding company, owning the Lanerossi group of companies. In this case the ECJ stated that the Commission was entitled to regard the funds provided by ENI through Lanerossi to four of its subsidiaries as State aid, without it being necessary to establish that the capital funds received by ENI from the Italian Government were specifically intended to make up losses of the subsidiaries. It was sufficient to observe that in any event the receipt of the capital funds enabled ENI to release other resources to make up for the losses of the subsidiaries (para. 14).

${ }^{31}$ Case C-353/95P, Tierce Ladbroke v Commission, 1997 ECR I-7007 


\section{Chapter 4}

An essential aspect of an undertaking is the ability to make independent economic or commercial decisions. Therefore, groups of related companies that cannot individually pursue an autonomous business strategy are considered to constitute a single undertaking. In the Bodson case the ECJ pointed out that Article $81 \mathrm{EC}$ is not concerned with agreements or concerted practices between firms forming a single economic unit. ${ }^{32}$ Anticompetitive behaviour on the part of an undertaking within an economic unit should therefore be considered in the light of Article 82 EC. This indicates that an economic unit should be regarded as one undertaking falling under Article 81 EC. By implication and as will be explained later on, agents acting on behalf of a principal are not separate undertakings, even though they may have a separate legal personality.

The concept of an undertaking is not restricted by size, means of financing, legal status or possible government ownership. Associations of companies thus and government agencies may also be undertakings for the purposes of competition policy.

Furthermore, there is no need for the companies to always pursue profitable activities, in order to be considered as undertakings. In Höfner ${ }^{33}$ and Job Centre,${ }^{34}$ the ECJ ruled that a public employment agency was an undertaking because employment procurement has always been an economic activity pursued for profit (commercial reasons), even if in that particular case it was not done for the purpose of profit. By contrast, the charging of fees does not turn an entity into an undertaking. An anti-pollution monitoring agency in the port of Genoa was found not to be an undertaking, even though it charged an obligatory fee to vessels, the reason being that its services were not economic but mandated in the context of public policy. ${ }^{35}$

Examples of entities which have been found to be undertakings:

- private and public (quoted on stock exchange) companies;

- professional persons;

\footnotetext{
${ }^{32}$ Case C-30/87, Corinne Bodson v SA Pompes funèbres des régions libérés, 1988 ECR 2479.

${ }^{33}$ Case C-41/90, Klaus Höfner and Fritz Elser v Macrotron GmbH, 1991 ECR I1979.

${ }^{34}$ Case C-55/96, Job Centre coop. arl., 1997 ECR I-7119.

${ }^{35}$ Case C-343/95, Diego Cali \& Figli Srl v Servizi ecologici porto di Genova SpA, 1997 ECR I-1547;
} 


\section{The Concept of State Aid}

- the new money transfer system for the Euro, "Target"; it falls within the scope of Article 81 (1) EC for transactions involving commercial financial institutions but it is outside the scope of Article 81 (1) EC for transactions involving central banks;

- the European Broadcasting Union (which runs Eurovision);

- entities managing pensions based on voluntary contributions;

- Comité Français d'Organisation, which organised the 1998 Football World Cup. $^{36}$

Examples of entities which have been found not to be undertakings:

- public authorities in exercising their regulatory role are not undertakings; e.g. local authorities regulating provision of funeral services by awarding licences to private companies; ${ }^{37}$

- social security bodies administering funds from compulsory contributions based on the principle of national solidarity. ${ }^{38}$

- persons in the employment of a single employer (they do not have commercial decision-making autonomy, they form part of an economic unit, which is the firm employing them), as well as their representatives, i.e. trade unions.

- organisations such as groups promoting culture and art, schools offering compulsory education, and other entities providing services to the general public on a non-commercial basis (e.g. weather information).

In summary, the following steps may be followed in determining whether the recipient entity is an undertaking:

\footnotetext{
${ }^{36}$ Commission Decision 2000/12, OJ L5, 08/01/2000.

${ }^{37}$ Case C-30/87, Corinne Bodson v SA Pompes funèbres des régions libérées, 1988 ECR 2479.

${ }^{38}$ Case C-159/91, Christian Poucet $v$ Assurances Generales de France and Caisse Mutuelle Regionaledu Languedoc - Roussillon, 1993 ECR I-0637.
} 


\section{Chapter 4}

Table 4.2

\begin{tabular}{|c|l|l|}
\hline Stages & \multicolumn{1}{|c|}{ Questions } & \multicolumn{1}{c|}{ Outcome } \\
\hline I & $\begin{array}{l}\text { Is the recipient acting in an official } \\
\text { capacity or as a public authority? }\end{array}$ & $\begin{array}{l}\text { If the answer is yes, the recipient is not an } \\
\text { undertaking. } \\
\text { If the answer is no, go to Stage II. }\end{array}$ \\
\hline II & $\begin{array}{l}\text { Does the recipient offer goods or } \\
\text { services for which there is a market } \\
\text { where parties make offers to others } \\
\text { on remuneration? }\end{array}$ & $\begin{array}{l}\text { If the answer is no, the recipient is not an } \\
\text { undertaking. } \\
\text { If the answer is yes, go to Stage III. }\end{array}$ \\
\hline III & $\begin{array}{l}\text { Do the activities of the recipient } \\
\text { involve transactions of unequal value } \\
\text { between what it offers and what it } \\
\text { receives or are the transactions } \\
\text { mandated by the state? }\end{array}$ & $\begin{array}{l}\text { If the answer is yes, the recipient is not an } \\
\text { undertaking. } \\
\text { If the answer is no, the recipient is an } \\
\text { undertaking? }\end{array}$ \\
\hline
\end{tabular}

\subsection{Advantage granted}

State aid has been interpreted by the Commission and the Community Courts to include any transfer of state resources that favours one or more undertakings, resulting in a competitive advantage that could not have been obtained under normal market conditions, whereas the recipients of the aid do not have to provide anything in return. Aid itself is any relief from the expenses which are normally borne by undertakings in their daily operations. As the CFI stated:

"Article 87(1) EC is aimed merely at prohibiting advantages for certain undertakings and the concept of aid covers only measures which lighten the burdens normally assumed in an undertaking's budget and which are to be regarded as an economic advantage which the recipient undertaking would not have obtained under normal market conditions." 39

Article 87(1) EC applies to aid in any form. The concept of aid is very wide and includes any advantage of monetary nature conferred by the state or the agents of the state, which would not have otherwise been enjoyed by the recipient or otherwise favoured companies or sectors. Such advantages encompass not only grants, subsidies, loans or guarantees actually given by the state, but also anything owed to the state, which the latter fails to collect

${ }^{39}$ Case T-157/01, Danske Busvognmoend v Commission, 2004 ECR II-917, at para. 57. The implication from this case was that lightening of "abnormal" burdens is not aid. Combus, a bus company, was compensated by the Danish government for its extra costs of employing civil servants after it was privatised. 


\section{The Concept of State Aid}

or receive, such as taxes, social security payments, interest on loans and dividends on invested public capital, as well as anything that the state gives up without objective reason such as products and services it sells at excessively low prices and anything the state gives away without objective reason such as products and services it purchases at excessively high prices.

The actual form of the aid or the intentions and the formal objectives of the public policies of the authority granting the aid, are irrelevant for the purposes of Article 87(1) EC. Even if a policy has no formal objective of conferring an advantage or assisting an undertaking, its application may still inadvertently favour certain undertakings over others. Article 87(1) EC bans aid according to its actual or potential effects, rather than the declared intentions of the granting authority. ${ }^{40}$

The Advocate-General in the Italy v Commission case puts it very succinctly: "Since 1961, the Court of Justice has consistently interpreted the concept of aid solely by reference to its effects (e.g. C-30/59): the decisive criterion is not the form that the intervention takes, nor of course, its legal nature or the aim it pursues (e.g. C-173/73) but the result to which it leads. Any intervention which gives rise to an economic advantage, accompanied by a correlative decrease in state resources, and benefits a particular undertaking or sector of production, is in principle state aid for the purposes of Article (87) of the Treaty"41

It follows from the EC definition of state aid that this notion is very wide. It includes a large variety of measures, such as:

- grants;

- loans at below-market rates of interest from the state; interest subsidies;

- guarantees by the state for which the beneficiary does not pay a market fee;

- tax advantages: tax base reductions, tax deferment, tax cancellation, tax rate reduction, tax exemptions;

- reductions of social security contributions;

- provision of goods and services by the state at below-market prices;

- sale of land at below-market price by the state;

- purchase of goods and services by the state at above-market prices;

\footnotetext{
${ }^{40}$ Case C-173/73, Italy v Commission.

${ }^{41}$ Opinion of the A.G. on Case C-6/97, Italy $v$ Commission.
} 


\section{Chapter 4}

- capital injections which are not in conformity with the market economy investor principle (lower expected return than what a private investor would demand at similar market conditions and risk).

However, in Enirisore the ECJ ruled that laws which allowed for an exception to a general law preventing public bodies members to withdraw or redeem their shares by granting a right to members opposing resolution to change the company's objects or legal form to withdraw after paying the unpaid balance on their shares did not fall within the scope of Article 87 (1) EC since neither the members nor the undertaking were offered an advantage. According to the ECJ, the law "merely prevents [the undertaking's] budget from being burdened with a charge which, in a normal situation, would not have existed. Consequently, that law merely regulates the exceptional right to withdraw granted to members of that company (...) and does not seek to reduce a charge which that company would normally have had to bear." 42

There have been lengthy discussions as to whether a public support measure that compensates the recipients for the extra costs of obligations to provide services in the general economic interest imposed by the state can be considered as conferring advantage in the meaning of Article 87(1) EC. This issue however is discussed in detail below [see chapter 5], when considering the exceptions from Article 87(1) EC.

\subsection{Private investor principle}

To be able to assess when the actions of a government indirectly constitute state aid by conferring an advantage to certain undertakings, the Commission has developed the "private investor" principle. In order to establish the existence of aid, the Commission would compare the situation in question under the prevailing market conditions with the behaviour of private investors in similar circumstances. The ECJ has also held in this regard that, in order to determine whether a state measure constitutes aid for the purposes of Article 87(1) EC, it is necessary to establish whether the recipient undertaking receives an economic advantage, which it would not

\footnotetext{
${ }^{42}$ Case C-237/04, Enirisorse, 2006 ECR I-2843, at paras 38-46.
} 


\section{The Concept of State Aid}

have obtained under normal conditions. ${ }^{43}$ According to this principle, public authorities may give loans, guarantees, inject capital and otherwise be involved in commercial ventures, but at the same time they must behave in the same way as a private investor would behave in similar circumstances. So there is aid when, for example, the government invests in a company that has suffered financial losses and which cannot survive without public money. The same applies when a government buys shares in a company and for years it receives no dividend and no return on its capital. On the other hand, repayment agreements with public creditors are considered to fall outside Article 87(1) EC, as mentioned below, if private creditors would have taken the same decision in order to recover the sums due to them. ${ }^{44}$

However, a question can be raised as to what happens when there are no similar circumstances or comparable market conditions? That was the situation in the Chronopost case, where La Poste, a legal monopolist in the ordinary mail sector in France, was found to be in a situation very different from that of a private undertaking acting under normal market conditions, given that it was at the time operating in a market network with substantial infrastructures and resources, which would never had been created by a private undertaking. As a result, in the absence of any possibility of comparing the situation with that of a private group of undertakings not operating in a reserved sector, the ECJ put aside the judgement of the CFI and upheld the Commission's decision excluding the existence of State aid in the provision of logistical and commercial assistance by La Poste to Chronoposte. ${ }^{45}$ In such cases, "normal market conditions", which are necessarily hypothetical, must be assessed by reference to the objective and verifiable elements which are available. ${ }^{46}$ For example, if a sold land had been valued by independent surveyors and the price for which it was sold was higher than that valuation, the sale would not be found to have included aid. If, on the other hand, a public investment in the steel mill is accompanied by substantial investment on the same terms by one or more private investors, then it is unlikely that the injection of capital constitutes aid. The point that needs to be borne in mind is that the Commission always

\footnotetext{
${ }^{43}$ Case C-39/94, SFEI v La Poste, 1996 ECR I-3547, at para. 60.

${ }^{44}$ Case C-342/96, Spain v Commission (Tucacex), 1999 ECR I-2459.

${ }^{45}$ Joined Cases C-83/01 P, C-93/01 P and C-94/01 P, Chronopost $v$ Ufex and Others, 2003 ECR I-6993.

${ }^{46}$ Ibid at para. 38 .
} 


\section{Chapter 4}

seeks to establish whether government action can be justified on objective commercial criteria.

\subsection{Public creditor principle}

The failure or unwillingness of a public authority to demand money owed to it is also a form of state aid. As the Community courts have repeatedly stated, the concept of aid is wider than that of a subsidy because it embraces not only positive benefits, such as the subsidies themselves, but also measures, which in various forms mitigate the normal burdens on the budget of an undertaking. ${ }^{47}$ For example, when a public authority tolerates late payment of money owed to it by undertakings, it mitigates their financial burden and places those undertakings in an advantageous position vis-à-vis their competitors. ${ }^{48}$ Public authorities, therefore, have to pursue their debtors with the same vigour as that of a private creditor. ${ }^{49}$

In practice when the courts assess the application of the public creditor, they resort to the simpler criterion of trying to determine whether the public authority concerned pursued all legally possible options and whether it acted promptly. These issues are illustrated well in the two most recent cases concerning Lenzing v Commission ${ }^{50}$, and Spain v Commission ${ }^{51}$, where the courts annulled the contested Commission Decisions, but on different grounds.

In Spain v Commission, the Court of Justice (ECJ) examined a Commission Decision which had found that the Spanish authorities had not acted as a private creditor. The undertaking concerned had not paid taxes and social security for three years before the Spanish authorities agreed to write-off two thirds of the debt and reschedule repayment of the rest over a ten-year period.

\footnotetext{
${ }^{47}$ See, inter alia, Case 30/59, De Gezamenlijke Steenkolenmijnen Limburg v High Authority (cited above at no. 19); Case C-387/92, Banco Exterior de España 1994 ECR I-877; C-256/97, DM Transport, 1999 ECR I-3913; C-5/01, Belgium v Commission, 2002 ECR I-11991.

${ }^{48}$ See DM Transport, ibid.

${ }^{49}$ See Case C-342/96, Spain v Commission.

${ }^{50}$ Case T-36/99, Lenzing, 2004 ECR II-3597.

${ }^{51}$ Case C-276/02, Spain v. Commission, 2004 ECR I-8091
} 
After that agreement, the undertaking continued to fail to pay what the State owed and a year later the authorities began seizing its property. Eventually, the agreement was suspended a year afterwards.

The ECJ accepted the arguments of Spain that the authorities used all the options that were legally available to them culminating in confiscation of property and eventual closure of the company. There was also some evidence that the authorities tried to seize property earlier. It seems that these draconian measures were sufficient to persuade the ECJ that the authorities acted as a private creditor would have acted in a similar situation, and therefore it annulled the Commission Decision.

In the case Lenzing v Commission, the Spanish authorities were dictated by law to fix only a statutory rate of interest on the outstanding debt. The statutory rate was lower than the market rate, but this difference in itself is not sufficient to prove the existence of state aid. This is because a creditor would not apply the same rate as an investor who seeks to maximise profits. A creditor may accept a lower rate so as to minimise losses. ${ }^{52}$

However, the relevant Spanish law did not stipulate the amount of repayments, the number of instalments or the length of the repayment period. In this case, the Court of First Instance (CFI) did recognise the discretion of the authorities on these matters and concluded that that discretion was sufficient to convert actions dictated by law into a form of state aid. In particular, the CFI explicitly referred to the fact that the Spanish authorities had tolerated non-payment of social security contributions for several years. In fact, the CFI rejected a Spanish argument that there was no state aid because the actions of the authorities were not arbitrary. The CFI made a distinction, significant in this context, between arbitrariness and discretion.

Then the CFI went on to state that "[...] in order for the advantages described above to be capable of being classified as aid for the purposes of Article 87(1) EC, it must still be established that [the undertaking in question] could not have obtained them under normal market conditions [...]. More specifically, the Court must consider whether the Commission made a manifest error in concluding that the Social Security Fund and Fogasa acted in the same way as a hypothetical private creditor in so far as possible, the

${ }^{52}$ Spain v Commission (Tubacex). 


\section{Chapter 4}

same situation vis-à-vis its debtor as those two bodies" ${ }^{53}$ At the end, the CFI found that the Commission had not proven that the Spanish authorities had acted as a private creditor in allowing accumulation of debt in the first place, then in agreeing to reschedule that debt over a ten-year period and finally in allowing again the undertaking not to honour the rescheduling agreement. Consequently, it annulled the Commission Decision that had found that there was no state aid in the actions of those authorities.

\subsection{Objective justification}

What happens when there is no obvious market benchmark against which to compare prices or interest rates in order to detect the existence or not of a hidden subsidy? How can aid be objectively justified by the prevailing market conditions? This was the central point of contention in a celebrated case involving a public gas utility in the Netherlands in the early 1980s. The Commission contended that Gasunie, the gas utility in question, gave aid to undertakings engaged in greenhouse horticulture by lowering the tariffs it charged for supplying gas to them. Gasunie argued that those undertakings were energy-intensive businesses and its tariff structure simply reflected discounts for large purchases and also incentives for them not to convert their heating plants to coal. The Commission also claimed that, irrespective of the Gasunie's motives, the lower tariff for horticulture was state aid because it was not available to other large users of gas in other industries. Eventually, the Commission's decision (85/215) was challenged before the ECJ.

The ruling of the ECJ is instructive. It first found that objective differentiation in the tariff structure among distinct classes of customers on the basis of sound economic reasoning is an acceptable commercial practice. There is no aid, for example, in offering discounts to large users of gas. The ECJ also found acceptable the aim of Gasunie to maintain low tariffs so as to keep its customers from converting to coal. The question at issue was whether Gasunie, "unlike an ordinary economic agent," acted to "confer a pecuniary advantage on energy consumers, forgoing the profit which it could normally realise."

\footnotetext{
${ }^{53}$ Cited above, para. 149.
} 
The ECJ concluded that the level of the tariff charged by Gasunie to greenhouses could not be objectively justified on economic grounds. The difference between the low tariff and the immediately higher was much bigger than the cost of conversion of heating plants to coal and the price of coal. The tariff for gas to horticulture was lower than what was necessary to prevent conversion and retain them as customers of Gasunie. ${ }^{54}$

Hence, there is no element of state aid when (a) price differentials are part of an integral tariff system and can be justified on an objective basis (e.g. large purchases, long-term contracts, payments in cash) and (b) price reductions or discounts are made as a necessary response to commercial pressure (e.g. retaining customer loyalty).

In summary, the following steps may be followed in determining whether a state measure confers an advantage:

${ }^{54}$ Joined cases 67/85, 68/85 and 70/85, Van der Kooy v Commission. 
Table 4.3

\begin{tabular}{|c|l|l|}
\hline Stages & \multicolumn{1}{|c|}{ Questions } & \multicolumn{1}{c|}{ Outcome } \\
\hline The State procures or sells goods and services \\
\hline I & $\begin{array}{l}\text { Are the transactions open and } \\
\text { through competitive processes? }\end{array}$ & $\begin{array}{l}\text { If the answer is yes, there is no advantage. } \\
\text { If the answer is no, go as appropriate to } \\
\text { Stage II or III. }\end{array}$ \\
\hline The State acts as a private investor or private creditor \\
\hline II & $\begin{array}{l}\text { Is the investment or credit granted } \\
\text { at market conditions [ignoring } \\
\text { public policy concerns]? }\end{array}$ & $\begin{array}{l}\text { If the answer is yes, there is no advantage } \\
\text { for beneficiary undertaking. } \\
\text { If the answer is no, there is advantage for } \\
\text { beneficiary undertaking. }\end{array}$ \\
\hline The State acts as a public authority & $\begin{array}{l}\text { Does the measure reduce normal or } \\
\text { inherent costs of recipient? }\end{array}$ & $\begin{array}{l}\text { If the answer is yes, go to Stage IV. } \\
\text { If the answer is no, examine why the costs } \\
\text { are abnormal. If the state has caused the } \\
\text { costs, perhaps through negligence, there is } \\
\text { no advantage for beneficiary undertaking. }\end{array}$ \\
\hline IV & $\begin{array}{l}\text { Is the measure intended to } \\
\text { compensate recipient for costs of } \\
\text { public service obligation? }\end{array}$ & $\begin{array}{l}\text { If the answer is no, there is advantage for } \\
\text { beneficiary undertaking. } \\
\text { If the answer is yes and the Altmark } \\
\text { conditions hold, there is no advantage for } \\
\text { recipient undertaking. } \\
\text { If the answer is yes but the Altmark } \\
\text { conditions do not hold, the measure } \\
\text { constitutes aid which is compatible if the } \\
\text { conditions in Art. 86(2) are respected. }\end{array}$ \\
\hline
\end{tabular}

\subsection{Selectivity: Specific versus general measures}

"General" measures of economic policy are not aid. Article 87(1) EC refers to advantages favouring "certain" undertakings or the production of "certain" goods. This has been interpreted over the years to mean that aid must be "selective" or "specific" rather than general. A measure may be selective even if it is phrased in general terms. As the CFI ruled in CETM case:

"The fact that the aid is not aimed at one or more specific recipients defined in advance, but that is subject to a series of objective criteria pursuant to which it may be granted, within the framework of a predetermined overall budget allocation, to an indefinite number of beneficiaries who are not initially individually identified, cannot suffice to call into question the selective nature of the measure, and, accordingly, its classification as state aid within the meaning of Article 87 (1) of the Treaty. At the very most, that circumstance means that the measure is not an individual aid. It does not, however, 


\section{The Concept of State Aid}

preclude that public measure from having to be regarded as a system of aid constituting a selective, and therefore specific, measure if, owing to the criteria governing its application, it procures an advantage for certain undertakings or the production of certain goods, to the exclusion of others." 55

A general measure must be open to firms from all sectors but it does not have to have the same impact in all sectors. For instance, measures designed to reduce the taxation of labour for all firms have a relatively greater effect on labour-intensive industries than on capital-intensive industries, without necessarily constituting state aid. Similarly, tax incentives for environmental, $\mathrm{R} \& \mathrm{D}$ or training investment favour only the firms which are capable of undertaking such investment, but again do not necessarily constitute selective measures that can be classified as state aid. ${ }^{56}$ Further, measures which apply to persons in accordance with objective criteria without regard to the location, sector or undertaking in which the beneficiary may be employed, are not considered to be state aid. ${ }^{57}$

On the other hand however, general measures which are implemented on a discretionary basis would fall under Article 87(1) EC. A scheme operated by Finland and intended to boost employment by subsidising new jobs was found to be incompatible with the common market because the public authorities had discretion in confirming eligibility and thus in disbursing the subsidies. Hence, for a policy measure to escape Article $87 \mathrm{EC}$, its application must be general, without any discriminatory effect among undertakings and its benefits must be readily or automatically available to any undertaking.

Measures which appear to be general may still be found to favour certain undertakings or certain goods. For example, a general export credit scheme operated by France in respect of all national products which were exported was found to be aid prohibited by Article $87 \mathrm{EC} .^{58}$ The same was found for a

\footnotetext{
${ }^{55}$ Case T-55/99, Confederación Española de Transporte de Mercancias (CETM) $v$ Commission, 2000 ECR II-3207, at para. 40.

${ }^{56}$ Commission Notice on the application of the State aid rules to measures relating to direct business taxation, OJ C384, 10/12/1998, at para. 14 .

${ }^{57}$ Commission Notice on co-operation between national courts and the Commission in the State aid field, OJ C312, 23/11/1995, at para. 7.

${ }^{58}$ Case C-11/69, Commission v France, 1969 ECR 523
} 


\section{Chapter 4}

scheme of interest rate subsidies on all exports from Greece ${ }^{59}$ and for a scheme that exempted all Greek export undertakings from a special single tax on undertakings. ${ }^{60}$

Given the fact that not all undertakings operate under identical conditions, in principle there is no such thing as a general scheme that can apply equally to all undertakings. The Commission and the Court, however, do not attempt to examine the precise ex post effects of a general scheme on company competitiveness. They consider instead whether in principle it applies to all sectors of the economy (i.e. whether it discriminates a priori between sectors) and whether any company may, in theory, be eligible to benefit from it.

These indeed are the reasons why, for example, the Commission banned an Italian scheme to promote employment in the footwear industry and a similar French scheme in the textile industry, while it approved a Belgian scheme which also aimed to stimulate employment. The difference between them was that the Belgian scheme, approved in March 1997, reduced the social security contributions of all firms generating new jobs for manual workers in a transparent and objective manner. ${ }^{61}$ Previous versions of the same Belgian scheme were rejected by the Commission because they were restricted to certain industries which were exposed to international competition. ${ }^{62}$ Nevertheless, the approved scheme does not have the same effect in all sectors of the economy. To the extent that certain sectors employ relatively fewer manual workers (i.e. professional services) or relatively more manual workers (i.e. agriculture) they are bound to enjoy the benefits from the scheme in different proportions.

In Unicredito Italy introduced a law which, inter alia, provided that banks which merged or engaged in similar restructuring would benefit from a tax advantage. Unicredito argued that the measure was not selective since it constituted a measure of general character and that the differentiations were "justified by the nature and general scheme of the tax system". The ECJ did not follow this argumentation. First, the measure was selective since it only applied to the banking sector and only to certain undertakings within this sector. The

\footnotetext{
${ }^{59}$ Case C-57/86, Greece v Commission, 1988 ECR 2855

${ }^{60}$ Commission Decision 89/659, OJ L394, 30/12/1989.

${ }^{61} \mathrm{IP} / 97 / 251$

${ }^{62} \mathrm{IP} / 96 / 1127$
} 
measure was therefore, held, to be "selective in relation to other economic sectors and within the banking sector itself". Therefore it could not be regard as a general measure. Moreover, the "nature and overall structure of the [Italian] tax system did not justify the tax reduction in question. ${ }^{63}$

In summary, the following steps may be followed in determining whether a measure is selective:

\section{Table 4.4}

\begin{tabular}{|c|l|l|}
\hline Stage & \multicolumn{1}{|c|}{ Questions } & \multicolumn{1}{c|}{ Outcome } \\
\hline I & $\begin{array}{l}\text { Does the measure intend to favour } \\
\text { certain firms or class of firms? }\end{array}$ & $\begin{array}{l}\text { If the answer is yes, the measure is } \\
\text { selective. } \\
\text { If the answer is no, go to Stage II. }\end{array}$ \\
\hline II & $\begin{array}{l}\text { Is there administrative discretion in its } \\
\text { application? }\end{array}$ & $\begin{array}{l}\text { If the answer is yes, the measure is } \\
\text { selective. } \\
\text { If the answer is no, go to Stage III. }\end{array}$ \\
\hline III & $\begin{array}{l}\text { Are the results likely to favour in } \\
\text { practice certain firms or class of } \\
\text { firms? }\end{array}$ & $\begin{array}{l}\text { If the answer is yes, go to Stage IV. } \\
\text { If the answer is no, the measure is not } \\
\text { selective. }\end{array}$ \\
\hline IV & $\begin{array}{l}\text { Is the measure open to all firms } \\
\text { without any discrimination? }\end{array}$ & $\begin{array}{l}\text { If the answer is yes, the measure is not } \\
\text { selective. } \\
\text { If the answer is no, the measure is } \\
\text { selective. }\end{array}$ \\
\hline
\end{tabular}

\subsection{Effect on trade and distortion of competition}

The conditions under which trade between Member States is affected and competition is distorted for the purposes of Article 87(1) EC are as a general rule inextricably linked. For this reason, if aid is found to have an appreciable effect on trade, it is inevitably found to distort or threaten to distort competition. ${ }^{64}$ Confirming its earlier case-law, ${ }^{65}$ the ECJ stated in the Philip Morris $\mathrm{v}$ Commission judgement that when state financial aid

\footnotetext{
${ }^{63}$ Case C-148/04, Unicredito Italiano, 2005 ECR I-11137, at paras 44-54

${ }^{64}$ Case T-288/97, Regione Autonoma Friuli Venezia Giulia v Commission, 2001 ECR II-1169, at paras. 49-50.

${ }^{65}$ Case C-173/73, Commission v Italy.
} 


\section{Chapter 4}

strengthens the position of an undertaking compared with other undertakings competing in intra-Community trade, the latter must be regarded as affected by that aid. ${ }^{66}$

\section{Effect on trade}

There is no definition or quantitative measure of when aid is capable of affecting trade. It is settled case law however, that aid may affect intraCommunity trade even if it is of relatively small amount. ${ }^{67}$ Any aid, in turn, is presumed to affect trade unless:

- it is de minimis, or

- trade is affected only at national level, or

- the situation is wholly outside the EC.

In common with other Treaty provisions, Article 87 EC does not cover situations which are purely domestic or completely outside the EU. For example, subsidies granted to hairdressers would not be considered to be aid in the meaning of Article 87 EC because individuals do not normally buy hairdressing services from other Member States. ${ }^{68}$ Also, a subsidy to a French company, for example, covering part of the costs of constructing a bridge in Kenya would not normally infringe Article 87 EC, provided of course, that no other EC company would be interested in that project.

However, even if aid is received by an undertaking which sells its products exclusively within the domestic market of a member state, intra-Community trade may still be found to be indirectly affected, if it becomes more difficult for similar products from other Member States to enter that market. A situation of this kind may arise in cases of over-capacity in a particular market, as a result of which domestic production may be maintained or increased, with the end-result that undertakings established in other Member

\footnotetext{
${ }^{66}$ Case 730/79, Philip Morris v Commission, 1980 ECR 2671, at para. 11.

${ }^{67}$ Case T-214/95, Het Vlaamse Gewest v Commission, 1998 ECR II-717, at para. 4849 and the case law cited therein.

${ }^{68}$ XXVIth Report on Competition Policy, 1996, at p. 230. The Commission decided to terminate proceedings on aid for firms providing only local passenger transport services in Italy, since the measure was liable to distort competition in that it did not affect trade between Member States.
} 
States have less chance of exporting their products to the market in that member state. ${ }^{69}$

Also, aid which is given to an undertaking that exports exclusively to a nonEU country may still have an indirect impact on intra-EU trade, if it displaces exports by companies in other Member States, which are then redirected towards the internal Community market. ${ }^{70}$ Similarly, in AITEC v Commission the CFI annulled the Commission's decision to approve an aid scheme on the grounds that the latter should have considered the foreseeable effects of the aid on competition and intra-Community trade. ${ }^{71}$

The Commission is not required to define markets or analyse their structures and the ensuing competitive relationships in order to establish a real effect on trade between Member States, which would anyway be impossible if aid is not yet implemented. If new aid has been granted without prior notification having been given, the Commission is not required to establish whether the aid has a real effect on trade and competition. According to well-established case-law, such a requirement would favour Member States which grant aid in breach of the obligation to notify, to the detriment of those which do notify aid at the planning stage. ${ }^{72}$

\section{De minimis aid}

It is settled case law that small amounts of aid to an undertaking may not affect trade between the Member States and are therefore not caught by Article 87(1) EC. ${ }^{73}$ In order to provide clarity as to what amount may or may not affect trade, the Commission has issued notices and regulations that define such de minimis aid. In December 2006 the Commission introduced a new de minimis Regulation. Regulation 1998/2006 increases the amount of aid which may be granted without the aid having an appreciable effect on trade from $€ 100,000$ to $€ 200,000$. Aid which falls below this threshold is, therefore, no state aid and is, thus, exempted from notification.

\footnotetext{
${ }^{69}$ Case 102/87, France v Commission, 1988 ECR 4067, at para. 49.

${ }^{70}$ Case C-142/87, Belgium v Commission, 1990 ECR I-959, at para. 38.

${ }^{71}$ Cases T-447 \& 449/93, AITEC v Commission, 1995 ECR II-1971, at paras. 139140.

${ }^{72}$ Case T-55/99, CETM v Commission at para. 103 and the case law cited therein.

${ }^{73}$ Case C-351/98, Spain v Commission, 2002 ECR I-8031, at para. 51.
} 


\section{Chapter 4}

However, while allowing Member States to grant more de minimis aid, the rules on cumulation have been tightened. Previously, the only thing which mattered was that the aid did not exceed the threshold. As long as this was not the case, de minimis aid could be granted on top of other aid. Now, Article 2(5) of the de minimis Regulation provides that:

"De minimis aid shall not be cumulated with State aid in respect of the same eligible costs if such cumulation would result in an aid intensity exceeding that fixed in the specific circumstances of each case by a block exemption Regulation or Decision adopted by the Commission".

Some sectors previously excluded from the scope of the de minimis rule have now been included in the new Regulation. This, inter alia, concerns the transport, steel and processing and marketing of agricultural products. Also the de minimis rules do not apply to export aid, aid in the fields of primary agricultural production and fisheries, the coal sector and undertakings in financial difficulty.

\section{Distortion of competition}

For aid to be caught by Article $87 \mathrm{EC}$, it must also be capable of distorting competition. As mentioned above, the conditions under which trade between Member States is affected and competition is distorted are as a general rule inextricably linked. The test defined by the Commission and the Courts for determining the effect on trade and competition is not strict. Small effects on trade are sufficient to lead to distortion of competition. Similarly, anything that actually disturbs or threatens to disturb the conditions of competition between undertakings from different Member States is sufficient for Article 87(1) EC to apply.

In order to establish whether competition is affected for the purposes of Article 87(1) EC, it is necessary first to define the market for the products or services concerned. The market is defined by distinguishing the service or the good in question by virtue of particular characteristics that differentiate it from other services or other goods which are only to a small degree interchangeable with that particular service or good. In that context, the degree of interchangeability between products or services must be assessed in terms of their objective characteristics, as well as the structure of supply and demand on the market, and competitive conditions. ${ }^{74}$

\footnotetext{
${ }^{74}$ Case T-229/94, Deutsche Bahn v Commission, 1997 ECR II-1689, at para. 54, and the case-law cited therein.
} 
In the SIDE v Commission case concerning export aid in the book sector, the CFI criticised the Commission as having committed a manifest error of assessment as regards the definition of the relevant product market. It annulled, thus, the Commission's decision on the grounds that it should have examined the effects of the contested aid on competition and trade between the other operators carrying on the same activity as that for which the aid was granted, in this case the handling of small orders of French-language books. The Commission, thus, should have defined the market as that of agency export rather than that of the export of French-language books in general. ${ }^{75}$

Competition is distorted, if the aid in question strengthens the competitive position of the recipient, say by reducing its operating or investment costs, in relation to its rivals. ${ }^{76}$ Always the relevant question is what would be the competitive position of the recipient in the absence of aid? If this would be worse in relation to its rivals, then aid distorts competition.

Article 87(1) EC is not confined to large amounts of aid, significant distortions of competition or substantial disturbance to trade. Given that Article 87(1) EC requires no quantitative tests, it applies both to direct or indirect effects and actual or potential effects and provided that it focuses on effects rather than the intentions of public policies, it is very difficult for an aid scheme to escape being caught by it, even if it appears to be of a modest amount. It is settled case-law that even aid of a relatively small amount is liable to affect trade between Member States and strengthen the position of the recipient as compared to its competitors ${ }^{77}$

${ }^{75}$ Case T-155/98, SIDE v Commission, 2002 ECR II-1179, at para. 71.

${ }^{76}$ Case 234/84, Belgium v Commission, 1986 ECR 2263, at para. 22. See also, Case C-148/04, Unicredito Italiano, 2005 ECR I-11137 and, C-71/04, Xunta de Galicia, 2005 ECR I-7419.

${ }^{77}$ Case T-214/95, Vlaams Gewest v Commission, 1998 ECR II-717, at para. 49. Further reading on this chapter: C. Arhold, The case law of the European Court of Justice and the Court of First Instance on State Aids in 2004/2005, European State Aid law - Quarterly, Volume 4 No. 2 2005, C. Arhold, The case law of the European Court of Justice and the Court of First Instance on State Aids in 2005/2006 (Part 1), European State Aid law - Quarterly, Volume 5 No. 2 2006, C. Arhold, The case law of the European Court of Justice and the Court of First Instance on State Aids in 2005/2006 (Part 2), European State Aid law-Quarterly, 


\section{Chapter 4}

The argument often advanced by Member States that aid aims to offset alleged competitive disadvantage of the recipient undertakings has never been accepted as such by the Courts or the Commission.

In addition, the fact that a member state seeks to approximate, by unilateral measures, conditions of competition in a particular sector of the economy to those prevailing in other Member States cannot deprive the measures in question of their character as distorting competition. It follows that aid cannot be justified either by the existence of more favourable conditions for undertakings in other Member States or by the competition from those undertakings.

Volume 5 No. 3 2006, C. Arhold, The case law of the European Court of Justice and the Court of First Instance on state aids in 2006/2007 (part 1), European State Aid law-Quarterly, Volume 6 No. 2 2007, E. Kutenicova, Community rules on State aid - a practical handbook, Competition policy newsletter: $n r .2$ 2007. Further reading on this chapter: A. Matthias-Werner, Reform of procedural rules for state aid cases, Competition policy newsletter: nr. 32004. 


\section{Chapter 5}

\section{Exemption of State Aid}

Article 87(1) EC provides that state aid is considered incompatible with the common market and thus prohibited, "save as otherwise provided in this Treaty." In this context, Article 87(2) EC provides that certain aid is automatically compatible with the common market. Secondly, Article 87(3) EC enables the Commission to consider the compatibility of certain aid with the common market on the basis of a number of objectives to be attained. Finally, according to Article 87(3)(e) EC the Council, acting by qualified majority on a proposal from the Commission, may decide in exceptional instances that certain aid may also be considered compatible with the common market.

State aid is in principle considered incompatible with the common market as long as the Member States are not able to explain nor has the Commission found any grounds for establishing that the aid concerned meets the conditions for exception laid down in Article 87(3) EC. ${ }^{78}$

\subsection{Aid that is compatible with the common market}

The second paragraph of Article $87 \mathrm{EC}$ defines three instances in which state aid is automatically compatible with the common market. In practice, very few cases of aid are authorised every year under Article 87(2) EC. In particular, Article 87(2) EC provides that:

" 2 . The following shall be compatible with the common market:

(a) aid having a social character, granted to individual consumers, provided that such aid is granted without discrimination related to the origin of the products concerned;

(b) aid to make good the damage caused by natural disasters or exceptional occurrences;

(c) aid granted to the economy of certain areas of the Federal Republic of Germany affected by the division of Germany, in so far as such aid is required in order to compensate for the economic disadvantages caused by that division."

\footnotetext{
${ }^{78}$ Case 730/79, Philip Morris v Commission, 1980 ECR 2671, at para. 18.
} 


\section{Chapter 5}

Aid to individuals must not be linked to their employer. Any such link will be considered as conferring an indirect advantage to certain firms and therefore will have to be examined in the context of the exceptions allowed by Article 87(3) EC. Taken that the basic characteristic of this category is the social character of the aid, the beneficiaries are normally lower income groups, which need financial contribution, such as elderly people, children and handicapped persons.

A particular example is the aviation sector. Article 87(2)(a) EC, which up to now has only rarely been used, may be of certain relevance in the case of direct operational subsidisation of air routes, provided that aid is effectively for the benefit of final consumers. The aid must have a social character, i.e. it must, in principle, only cover specific categories of passengers travelling on a route (e.g. children, handicapped people, low income people). However, in case the route concerned links an underprivileged region, mainly islands, the aid could cover the entire population of this region. The aid has to be granted without discrimination as to the origin of the services, that is to say whatever EEA air carriers operating the services. This also implies the absence of any barrier to entry on the route concerned for all Community air carriers. $^{79}$

The natural disasters or exceptional occurrences for which aid may be given must be out of the ordinary, substantial and unpredictable. Thus, for example, rainfall below normal rates that has a negative effect on agricultural production is not considered to be a natural disaster. By the same token, above normal rainfall that ruins a holiday season is also not considered to be natural disaster for tourist operators. Natural disasters include droughts, tornadoes, forest fires, earthquakes, volcanic eruptions and diseases of plant and animals of catastrophic proportions. ${ }^{80}$ Also, as has the Commission stated in its guidelines on state aid to agriculture sector, adverse weather conditions such as frost, hail, ice, rain or drought may be assimilated to natural disasters once the level of damage reaches a certain threshold, which has been fixed at $20 \%$ of normal production in the less-favoured areas and

\footnotetext{
${ }^{79}$ Application of Articles 92 and 93 (now 87 and 88) of the EC Treaty and Article 61 of the EEA agreement to State aids in the aviation sector, OJ C350, 10/12/1994, at section III.3. See also case N 26/2003.

${ }^{80}$ VIIIth Report on Competition Policy, 1978, at p. 164.
} 


\section{Exemption of State Aid}

$30 \%$ in other areas. ${ }^{81}$ Exceptional occurrences include war, internal disturbances or strikes, and with certain reservations and depending on their extent, major nuclear or industrial accidents and fires which result in widespread loss. They do not include high interest rates or a crisis in the market since those "are the expression of the market forces which must be faced by any business."

In any case, the ECJ has held on several instances that their must be a direct link between the natural disaster or exceptional occurrence and the economic disadvantage which calls for the aid in question. ${ }^{83}$ In this sense, a the scope of provision under a Greek law which allowed the Greek State to assume and settle certain debts by agricultural cooperatives provided that they related to social purposes was, according to the ECJ to broad to "be regarded as aid to make good the damage caused by natural disasters or exceptional occurrences." $\$ 4$

Most notably, during the past couple of years, Article 87(2)(b) EC has been the basis for the authorisation of aid to businesses affected by flooding of rivers and by marine pollution caused by the sinking of oil tankers and to airlines to compensate them for the losses suffered as a result of the closure of US airspace and the increase in insurance premia in the aftermath of the terrorist attacks on New York in September 2001.

Aid in relation to the division in Germany has not been authorised during the past decade. ${ }^{85}$ It used to be authorised before German re-unification, when the objective of aid was to offset the effects of the physical division of the country, not the overall effects of the communist economic system in East Germany. In practice, approved aid in the past concerned issues such as extra transport costs, poorer communications, etc.

Needless to mention that the mere fact that state aid is always compatible with the common market in the above mentioned instances does not relieve

\footnotetext{
${ }^{81}$ OJ C28, 01/02/2000.

${ }^{82}$ Case C-346/03, Atzeni and Others, 2006 ECR I-1875, at para.80.

${ }^{83}$ Case C-301/96, Germany v Commission, 2003 ECR I-0000, at para. 66;

${ }^{84}$ Case C-278/00, Greece v Commission, 2004 ECR I-3997, at Paras. 82-85.

${ }^{85}$ See Joined cases C-57/00 and C-61/00, Freistaat \& Volkswagen v Commission, 2003 ECR I-9975.
} 


\section{Chapter 5}

Member States from their obligation to notify. Following notification, the Commission decides whether Article 87(2) EC applies to the notified aid or scheme, and only if it does must the Commission rule on the compatibility of the aid in question with the common market.

\subsection{Aid that may be compatible with the common market}

Article 87(3) EC defines five instances in which state aid "may be" compatible with the common market. In this regard state aid is not automatically exempted. The Commission has wide discretion to decide on the compatibility of individual aid or aid scheme with the common market. Responsibility for making that determination rests exclusively with the Commission. This is the reason why Article 88 EC and Regulation 659/99 define a procedure whereby Member States must first notify to the Commission their proposed aid schemes and obtain its authorisation before they implement them. Provided it acts within existing guidelines, the Commission is free to authorise outright, demand changes or reject completely a notified aid scheme. Even if a member state disagrees with the Commission's decision and believes it is mistaken, it may not go ahead with the scheme. It can only challenge that decision before the Court or apply to the Council, if the Commission has not yet completed its investigation. The latter possibility is rarely utilised.

Whenever the Commission examines aid schemes notified by the Member States, it is bound by EC law to authorise only those schemes which fall within the categories defined in Article 87(3) EC. Any other kind of aid must be rejected. This principle is well established in the case law by the ruling in the land-mark case concerning Dutch aid granted to Philip Morris in the late 1970 s. ${ }^{86}$

Article 87(3) EC provides that:

" 3 . The following may be considered to be compatible with the common market:

(a) aid to promote the economic development of areas where the standard of living is abnormally low or where there is serious underemployment;

(b) aid to promote the execution of an important project of common European interest or to remedy a serious disturbance in the economy of a Member State;

${ }^{86}$ Case 730/79, Philip Morris v Commission, 1980 ECR 2671, at para. 18. 


\section{Exemption of State Aid}

(c) aid to facilitate the development of certain economic activities or of certain economic areas, where such aid does not adversely affect trading conditions to an extent contrary to the common interest;

(d) aid to promote culture and heritage conservation where such aid does not affect trading conditions and competition in the Community to an extent that is contrary to the common interest;

(e) such other categories of aid as may be specified by decision of the Council acting by a qualified majority on a proposal from the Commission."

The categories of aid that are of major interest are the first and the third. The provisions on aid for common European projects and for cultural purposes are not utilised very infrequently. With respect to other categories of aid defined by the Council, since the inception of the Community in 1958, the Council has used that provision only twice to define common rules on subsidies to the shipbuilding industry (replaced by a Commission framework in 2003) and to coal-mining (Regulation 1407/2002).

Article 87(3)(a) EC refers to regional aid and is applicable to regions that are disadvantaged compared to the Community average. According to the Commission guidelines on regional aid, ${ }^{87}$ Article 87(3)(a) EC applies to regions having a per capita GDP of less than $75 \%$ of the Community average. The guidelines further indicate that the Article 87(3)(a) EC exemption may be normally granted only for multi-sectoral aid schemes, open to all firms in the sectors concerned, whereas ad-hoc aid to individual undertakings would in general fall outside the scope of that Article, since it is not regarded as capable to boost the economy of the region as a whole. ${ }^{88}$ However, the Commission does assess ad-hoc aid in the context of the guidelines.

Aid under Article 87(3)(b) EC is mostly used to support large research and developments projects with common European interest such as projects which aim to strengthen the European electronics industry by creating knowhow and research networks throughout Europe in which scientists, producers of components and system-users work together in order to ensure an independent European position on basic microelectronics technology. ${ }^{89}$

\footnotetext{
${ }^{87}$ OJ C 54, 04/03/06, p.13

${ }^{88}$ Case T-152/99, HAMSA v Commission, 2002 ECR II-3049, at paras. 201-209.

${ }^{89}$ XXVth Report on Competition Policy, 1995, at p. 238.
} 


\section{Chapter 5}

Aid under this Article is also permissible, if it remedies a serious disturbance in the economy of a member state, such as the aid granted to Greece in the context of privatisation of hundreds of Greek firms and public-sector banks as part of a national economic recovery plan. The decisive factor was the particularly serious economic situation in Greece at the time. ${ }^{90}$

Article 87(3)(c) EC covers regional aid and gives Member States the possibility to assist regions which are disadvantaged compared to the national average. The list of regions qualifying for this exemption is decided by the Commission on a proposal by the member state concerned. Aid is also given to facilitate the development of certain economic activities, such as aid for environmental protection, or for the promotion of research, or aid for the rescue and restructuring of firms in difficulty.

To clarify the kinds of aid that may be compatible with the common market and in order to ensure that its discretion is exercised properly and that the authorities and businesses are clear about their legal position, the Commission has over the years issued a number of notices, communications, guidelines and frameworks which are published in the Official Journal. The Commission also sends letters to member states, which are also published eventually.

The guidelines set out the Commission's views on the meaning of aid for various purposes (e.g. regional development, training, employment, R\&D, environmental protection, rescue and restructuring of companies, etc.), the methods by which aid is calculated, the eligible recipients and the total amount of aid that may be granted. These guidelines, therefore, are indispensable in understanding how the Commission is likely to assess the eligibility or not of an aid measure.

Indeed, the guidelines are intended to assist national, regional and local governments to design aid packages which can be approved by the Commission. This is good practice since there would be considerable waste of public resources if the Commission rejected aid measures which took months to design simply because the officials responsible were not aware of the criteria that would be used by the Commission to evaluate them.

${ }^{90}$ XXIst Report on Competition Policy, 1991, at p. 251. 
It should be noted, however, that the legality of these guidelines is a point of contention among legal experts. Since the guidelines are issued by the Commission, they are binding on the latter. The ECJ, has also affirmed that member states are bound by them if they have agreed to their content. ${ }^{91}$ In Germany v Commission, the ECJ stated:

"It should be noted at the outset that, in the exercise of the powers conferred on it by Articles $87 \mathrm{EC}$ and $88 \mathrm{EC}$, the Commission may adopt guidelines designed to indicate how it intends, under those articles, to exercise its discretion in regard to new aid or in regard to existing systems of aid. When they are based on Article 88(1) EC, those guidelines constitute one element of the regular and periodic cooperation under which the Commission, in conjunction with the Member States, must keep under constant review existing systems of aid and propose to them any appropriate measures required by the progressive development or by the functioning of the common market. In so far as these proposals for appropriate measures are accepted by a Member State, they are binding on that Member State." ${ }^{92}$

In this respect Article 19 of Regulation 659/99 states that: "Where a Member State concerned accepts the proposed measures and informs the Commission thereof, the Commission shall record that finding and inform the Member State thereof. The Member State shall be bound by its acceptance to implement the appropriate measures." Therefore, it can be concluded from the above that the wording of Article 19 must be interpreted as also covering guidelines directed to all the Member States.

\subsection{Criteria and factors in the evaluation of state aid measures}

The criteria used by the Commission to evaluate aid measures reveal a clear policy goal: to increase the effect of market forces. Its aim is to control aid so as to eliminate distortions to competition in the internal market. So, even if aid falls within the scope of the exceptions provided by Article 87(3) EC, the Commission will not authorise it if it confers an unnecessary advantage to certain undertakings. For aid to be permitted under Article 87(3) EC, it must seek to remedy some market failure or aim to induce undertakings to do something they would not otherwise do under normal market conditions. Aid must be necessary to offset a certain commercial, structural or regional handicap and must, therefore, be objectively justified.

${ }^{91}$ Case C-313/90, CIRFS and Others v Commission, 1993 ECR I-1125.
${ }^{92}$ Case C-242/00, Germany v Commission, 2002 ECR I-5603, at paras. 27-28. 


\section{Chapter 5}

For example, the Commission approves certain forms and amounts of aid for the promotion of research which may not be readily undertaken by private companies, if such research has no immediate commercial applications or if its results cannot be appropriated by the company that undertakes it. The reason for subsidising such research is that the market under-provides it even if society as whole gains from it.

\section{Necessity}

The example above suggests that if, in the absence of state aid, undertakings could do on their own what the aid seeks to induce them to do, the Commission would withhold approval of that aid. Therefore, the first criterion used in the Commission's evaluation of notified aid is whether it is necessary to promote the objectives in Article 87(3)(a) to 87(3)(e) EC.

Most cases of notified aid are designed to comply with the various Commission guidelines, frameworks and notices. Once member states satisfy all the criteria specified in the guidelines etc. they do not need to prove the necessity of aid. That is assumed to hold. For example, the regional guidelines define the areas which suffer from regional handicaps and are, therefore, eligible to receive that kind of aid. Member states do not have to prove further the necessity of aid granted in conformity with those guidelines.

However, some guidelines still require member states to provide evidence of necessity of aid to induce recipients to do something they would not otherwise do under normal market conditions. This is required by the guidelines on aid for $R \& D$ and Innovation and for promotion of risk capital for SMEs.

\section{Proportionality}

The second criterion is whether aid is proportional to the aim it pursues. That is, aid should never exceed the minimum amount necessary to induce recipients to undertake, for example, more research, more investment or hire more people. As most forms of state aid do, irrespective of their objectives, distort competition, proportionality has the important task of trying to achieve a balance between the distortion of competition and the achievement of Community objectives through state aid. 


\section{Exemption of State Aid}

In determining the proportionality of aid, the Commission calculates the "extra costs" borne by the recipients of aid. For example, when the Commission approved an aid scheme for transport in the northern regions of Sweden it allowed the Swedish government to reimburse part of the costs borne by businesses for road or rail transport on a scale rising with the distance covered. In the areas with the highest levels of aid, the reimbursement rates ranged from $5 \%$ to $45 \%$. The Commission recognised that the northern Scandinavian regions differed from others in the EC because they "suffer specific handicaps in terms of distance and transport costs. ${ }^{.93}$ A similar scheme was also approved for Finland. ${ }^{94}$

\section{Aid intensity}

Aid intensity is the amount of aid in relation to the costs of production or the costs of investment of the company or project that receives the aid. If, for example, the cost of an investment in an Article 87(3)(a) EC region is $€ 500,000$ and the company that undertakes the investment receives a subsidy of $€ 100,000$, the gross aid intensity is $20 \%$. This intensity falls below the lowest ceiling of permissible aid for such region, which is fixed by the regional guidelines at $30 \%$. It is important to note, however, that the guidelines indicate maximum ceilings. The actual ceiling that applies to each Community region is defined by the Commission in the Regional Aid Map for each member state.

In case of a loan, the Commission calculates the subsidy-equivalent amount. Assume that a government grants a three-year loan of $€ 3,000,000$ at an interest rate of $6 \%$ instead of the going market rate of $8 \%$. The loan is to be repaid in linear instalments plus interest, starting at the end of the first year. To determine the aid intensity of this scheme, it is first necessary to measure the amount of subsidy, or grant equivalent, which is included in the subsidised loan.

The subsidy amount for the first year is the principal sum multiplied by the difference in interest rates $(2 \%)$ and then discounted to the beginning of the year when that aid is given:

i.e. $€ 3,000,000 \times(0.02 / 1.08)=€ 55,557$

\footnotetext{
${ }^{93} \mathrm{IP} / 97 / 91$.

${ }^{94} \mathrm{IP} / 96 / 1131$.
} 


\section{Chapter 5}

(The derived amount means that if you pay $€ 55,557$ in a bank (long-term account) at $8 \%$ and leave it for a year, at the end of the year it will grow to 60,000 which is equal to $3,000,000 \times 2 \%$ ).

The subsidy for the second year, discounted back to the first year, is:

$€ 2,000,000 \times(0.02 / 1.08)^{2}=€ 34,293$

The subsidy for the third year is:

$€ 1,000,000 \times(0.02 / 1.08)^{3}=€ 15,877$

The total amount of the subsidy discounted back to the year it is granted is $€ 105,725$. The total amount of (discounted) interest that the company would have paid at $8 \%$ is $€ 422,903$. This means that the aid intensity is just over $25 \%$. Whether this aid intensity is permissible depends on where the investment takes place. If it is an Article 87(3)(a) EC region, there is no over-compensation. If, by contrast, it is an Article 87(3)(c) EC region, there is over-compensation as the aid exceeds the normal ceiling of $15 \%$.

If, instead of a subsidised loan, the government in question offers a loan guarantee, there may still be an element of state aid involved. The cash-grant equivalent (CGE) of such aid is the difference between the outstanding loan sum guaranteed, adjusted by the probability of default, and any premium paid by the beneficiary, i.e. CGE = (outstanding sum $\mathrm{x}$ risk) - premium. The risk factor is derived from the record of default on loans in similar circumstances. ${ }^{95}$

\section{Cumulation of aid}

To ensure proportionality, the Commission has devised rules for assessing the "cumulation" of aid from different sources. The various guidelines and frameworks contain the same basic rules on cumulation. No aid from two or more sources may be received for the same underlying costs or expenditure. In addition, the sum of aid from all sources, both national and Community, must remain below the relevant intensity ceilings.

\section{Operating aid and export aid}

The Courts and the Commission have always taken a very negative position on operating aid. This is defined as aid, which relieves an enterprise of the expenses it would normally have to bear in its day-to-day management or its usual activities. Such aid is not linked to a specific purpose and has no

\footnotetext{
${ }^{95}$ For further examples, see the Regional Aid Guidelines (cited above at).
} 
incentive effect on enterprises. It is considered to be very distorting while the distortion is normally not justified by a Community objective. Therefore, operating aid can only be exceptionally authorised. Under current rules, operating aid may be authorised under certain conditions in Article 87(3)(a) EC regions provided that it is justified in terms of its contribution to regional development and that its level is proportional to the handicaps it seeks to alleviate (e.g. relief of extra transport costs in outermost regions and of environmental taxes). ${ }^{96}$

Operating aid is also exceptionally allowed to relieve environmental taxes and to be granted to ship-owning companies in the context of the policy on maritime transport. ${ }^{97}$

Export aid is already forbidden under the WTO rules and therefore it is not allowed by the EC. An exception is made for certain types of "soft aid", which may very indirectly be linked to export, e.g. aid to participate in international trade. $^{98}$

\section{Temporary and degressive aid}

Eventually, any publicly aided project should be able to survive on its own without continuous assistance from the government. The reason is that government action should not permanently replace normal market mechanisms. Once, for example, a certain market imperfection is corrected, state aid must be withdrawn. The Commission, therefore, examines carefully the duration of aid schemes and considers whether the means by which aid is given are temporary or permanent. Aid given for an indefinite period of time is unlikely to be approved by the Commission. Approvals are normally granted for specific time periods and for the duration of the relevant guidelines in force.

In the context of authorising large packages of aid to airlines (e.g. Air France, Iberia, Alitalia, Sabena, Olympic), the Commission has pronounced that it will not authorise aid for industries that have on several occasions in the past received hand-outs from the state. It has put forth the principle of aid "one

\footnotetext{
${ }^{96}$ Regional Aid Guidelines (cited above).

${ }^{97}$ See the guidelines on Environmental aid and on Maritime Transport.

${ }^{98}$ See Commission Regulation (EC) No 70/2001 on the application of Articles 87 and 88 of the EC Treaty to State aid to small and medium-sized enterprises.
} 


\section{Chapter 5}

time, last time." 99 This principle has been restated in the recently revised guidelines on aid to rescue and restructuring of firms in difficulty. In practice, "one time, last time" means that the same firm may not receive aid more than once in ten years.

\section{Conditional approval}

Aid falling under Article 87(1) EC, even if it promotes the aims of Article 87(3) EC and is proportional to its objectives, may still distort competition and affect trade in the common market. For this reason, the Commission often attaches particular conditions to its approval of state aid schemes. These conditions seek to minimise the disruption to competition and trade in the internal market and reduce the ability of the assisted company or companies to use the aid they receive for other purposes, such as strengthening their market position in other member states.

Hence, in the context of restructuring aid the Commission often asks for compensatory actions which relate to measures intended to safeguard competition in the sector where aid is granted. For example, as a condition for approving a very large injection of public capital into Air France, the Commission imposed the condition that Air France would give up certain routes in which it had a dominant position and that a number of its landing slots at Orly airport would be made available to other airlines. ${ }^{100}$

\section{Promoting international competitiveness}

While the Commission is anxious to protect the integrity of the common market, it is equally concerned about the deteriorating competitive position of EC companies in international markets. As a result, it has approved a number of state aid schemes whose aim is to promote European companies and help them compete in international markets. For example, it has authorised Danish and Dutch schemes exempting energy-intensive industries from a carbon dioxide/energy tax introduced in those countries a few years ago. $^{101}$

Aid in the form of tax concessions has been approved for the shipping sectors of EC member states on the grounds that shipping companies could

\footnotetext{
${ }^{99}$ XXXth Report on Competition Policy, 2000, at p. 340.

${ }^{100}$ Commission Decision 653/94, OJ L254, 31/12/1994.

${ }^{101} \mathrm{IP} / 94 / 881$ and IP/95/1446.
} 
not otherwise compete in the global markets for maritime transport services. Although the Commission has not imposed any time limitations, it will not allow unlimited amounts of aid for the purpose of improving international competitiveness. It will still want to know whether aid is necessary and proportional to the aim it pursues. ${ }^{102}$

\subsection{Information requirements}

A good indication of the factors that the Commission takes into account in its state aid decisions is provided by the questionnaire that member states answer when notifying proposed aid measures. This questionnaire has been devised by the Commission and is intended to "dissect" proposed measures and make them transparent and amenable to quantitative analysis. ${ }^{103}$

The main questions in the questionnaire concern the following:

- agency granting the aid

- aim of aid scheme

- eligible regions or sectors

- eligible costs to be offset by aid (e.g. land, equipment, training, etc.)

- aid instruments (the following are mentioned: direct grant, soft loan, interest subsidy, tax relief, guarantee, other)

- duration of aid

- estimated total amount of aid (e.g. estimated revenue losses due to tax concessions)

- estimated number of recipients

- justification of the compatibility of the scheme with the Treaty.

It is obvious from the above questions that the Commission is unlikely to authorise aid schemes which are not well designed or argued by the Member States.

${ }^{102}$ Community guidelines on State aid to maritime sector, OJ C13, 17/01/2004.

${ }^{103}$ See the forms attached to Regulation 794/2004. See also the reporting forms attached to the Regional Aid Guidelines and the reporting requirements in the three Regulations of 2001 concerning de minimis aid, training aid and aid for SMEs and the 2002 Regulation on employment aid. 


\section{Chapter 5}

Finally, it should be well understood that the Commission has considerable discretion in calculating the amount of aid involved in public assistance schemes and in measuring the magnitude of the economic handicap facing the beneficiary companies. Moreover, the discretion is wider in cases involving assessment of complex economic and financial data. ${ }^{104}$

\subsection{Other exceptions to Article 87(1) EC}

State aid is in principle considered incompatible with the common market and thus prohibited under Article 87(1) EC, "save as otherwise provided" in the Treaty.

There are four possibilities of exceptions in the Treaty. First, Article 36 EC limits the application of the rules on competition to the extent that it is necessary for the operation of the common agricultural policy. The Council decided in Regulation 26/62 that the rules of competition would indeed apply to agriculture, but the particular forms and amounts of aid that are allowed are determined in the regulations on the common market organisation of each agricultural products.

Second, Article 73 EC considers as compatible with the Treaty aid which meets the need of coordination of public transport services or represents a reimbursement for the discharge of certain obligations inherent in the concept of public service.

Third, Article 86 EC exempts from the rules of competition, undertakings providing services of general economic interest insofar as compliance with competition rules would prevent them from fulfilling the obligations imposed on them by law. The application of Article 86 EC is reviewed in more detail below.

${ }^{104}$ Case T-106/95, FFSA v Commission, 1997 ECR II-229. 


\subsection{Services of general economic interest (SGEI)}

The exception of Article 86(2) EC applies only to providers of SGEI. The Treaty does not define SGEI. SGEI fall within the scope of EC competition rules precisely because they are economic in nature. Member states are free to designate services as being in the general economic interest and this designation may vary across member states. Member states have the right to turn into economic certain services, which may not be economic in other member states (e.g. provision of supplementary pensions). However, the ECJ has identified certain characteristics that justify a service to be regarded as being in the general economic interest. Such services:

- must be important to consumers,

- must be open to all consumers,

- must be provided at uniform terms and predetermined quantity, price and regularity. ${ }^{105}$

Where providers of SGEI cannot generate sufficient revenue, public authorities may grant them state aid. This kind of aid may, under certain conditions, be compatible on the basis of the second paragraph of Article 86 EC. The application of Article 86(2) EC is conditional on the following. The member state concerned must define the content of the obligations and duties it imposes. These obligations must be specific to the particular undertaking and its business which must be linked to the subject-matter of the SGEI in question. The SGEI must be designed in such a way as to make a direct contribution to satisfying the general interest. ${ }^{106}$

In addition, the exception in Article 86(2) EC applies only when restrictions to competition are necessary and proportional to the intended result. Two conditions need to be satisfied in order to prove necessity and proportionality:

The execution of the tasks of SGEI cannot be carried out without restricting competition; this also means that there is no alternative, less restrictive, option for the designated operator to supply the market. The restriction is the minimum or smallest possible.

${ }^{105}$ Case C-393/92, Municipality of Almelo and others v NV Energiebedrijf Ijsslmij, 1994 ECR I-1477, at para. 48.

${ }^{106}$ Case C-159/94, France v Commission, 1997 ECR I-5815, at para. 68. 


\section{Chapter 5}

The Commission must also check whether the restriction is not contrary to the common European interest by obstructing intra-Community trade to an unwarranted degree.

Much of the case law that has clarified how Article 86(2) EC may be enforced refers to utilities such as telecommunications, postal services, electricity distribution, etc. In this connection, the ECJ has acknowledged that the exception of Article 86(2) EC may be invoked for the purpose of maintaining the "economic equilibrium" of the undertakings entrusted with the supply of SGEI. ${ }^{107}$

Since under Article $87 \mathrm{EC}$ a state measure must be judged on the basis of its effects on competition, the question that arises is whether a provider of SGEI, who incurs higher costs than otherwise, may be compensated by the public authority that imposes the SGEI obligation. In one of its earliest pronouncements on the issue of compensation of providers of SGEI, the ECJ veered away from examining compensation in terms of its effects. In a ruling handed down in 1985 in the ADBHU case which concerned the extra costs generated by the obligation imposed by France on certain undertakings to dispose of waste oils, the ECJ stated that those:

"indemnities do not constitute aid within the meaning of Articles $87 \mathrm{EC}$, but rather consideration for the services performed by the collection or disposal undertakings.",108

Public authorities in France paid to the collecting companies indemnities not exceeding their actual annual costs as a form of compensation.

In line with the ADBHU ruling, the Commission held for a long time the view that financial benefits granted by member states to compensate for the additional burden of extra public service duties do not constitute state aid. For example, in the previous Community guidelines on state aid to maritime transport, ${ }^{109}$ it was stated that "the Commission's practice in assessing contracts relating to PSOs (public service obligations) is generally to consider that reimbursement of operating losses incurred as a direct result of

107 Case C-320/91, Paul Corbeau, 1993 ECR I-2533, at para. 21. See also Municipality of Almelo and others $v$ NV Energiebedrijf Ijsslmij at para. 49.

${ }^{108}$ Case 240/83, Procureur de la République v ADBHU, 1985 ECR 531, at para. 18. ${ }^{109}$ OJ C20, 05/07/1997. 
fulfilling certain public service obligations is not state aid within the meaning of Article 87(1) of the Treaty."

But this understanding of compensation not being state aid came to an end, first, in the ruling of the CFI in the FFSA case which concerned a Commission decision that certain tax concessions granted to the French postal service in order to offset its public service obligations were not state aid. In that judgement the CFI took the opposite approach to the Commission and concluded that the measures in question did constitute state aid, even though they could be deemed compatible with the common market under Article 86(2) EC. ${ }^{110}$

Then, the ECJ presented its judgement in the Ferring case and reversed the case law generated by the CFI and which until that moment held that compensation for extra costs was state aid. That case concerned the preferential tax treatment of wholesale distributors of medicines in France. France argued that the preferential tax treatment in the form of tax exemptions was justified on the grounds that public service obligations imposed extra costs on the wholesalers. State aid compensated them for being obliged to deliver medicines within 24 hours of receiving a request and for maintaining a full range of stocks.

The ECJ upheld the above argument stating that a tax advantage enjoyed by undertakings entrusted with the operation of a public service did not constitute an economic advantage and could not, thus, be interpreted as state aid, in so far as that advantage did not exceed the additional costs of performing the public service. The reason being that the recipients would obtain no advantage over competitors for as long as the aid received from the state would not exceed the amount of those extra costs. ${ }^{111}$

The above question was also the main issue the rulings of the ECJ in Altmark and Chronopost. ${ }^{112}$ The principle enunciated in Ferring was

\footnotetext{
${ }^{110}$ Case T-106/95, FFSA v Commission, 1997 ECR II-229, at para. 178; upheld on appeal at Case C-174/97P, FFSA v Commission, 1998 ECR I-1303.

${ }^{111}$ Case C-53/00, Ferring SA v Agence centrale des organismes de securite sociale, 2001 ECR I-9067, at para. 33.

112 Case C-280/00, Altmark Trans, 2003 ECR I-7747 and Joined Appeal Cases C83/01 P, C- 93/01 P and C-94/01 P Chronopost $v$ Ufex and Others, 2003 ECR I-
} 


\section{Chapter 5}

confirmed and elaborated by the ECJ in Altmark. The ECJ laid down four conditions in order for compensation for public service obligation not to constitute state aid:

"First, the recipient undertaking must actually have public service obligations to discharge, and the obligations must be clearly defined.

Second, the parameters on the basis of which the compensation is calculated must be established in advance in an objective and transparent manner.

Third, the compensation cannot exceed what is necessary to cover all or part of the costs incurred in the discharge of public service obligations, taking into account the relevant receipts and a reasonable profit for discharging those obligations.

Fourth, where the undertaking which is to discharge public service obligations is not chosen pursuant to a public procurement procedure which would allow for the selection of the tenderer capable of providing those services at the least cost to the community, the level of compensation needed must be determined on the basis of an analysis of the costs which a typical undertaking, well run and adequately provided with means of transport so as to be able to meet the necessary public service requirements, would have incurred in discharging those obligations, taking into account the relevant receipts and a reasonable profit for discharging the obligations." 113

In the Chronopost judgement the ECJ went further to limit the scope of the above Almark fourth condition. The ECJ annulled the decision of the CFI, which had also put aside the previous Commission decision, ${ }^{114}$ insofar as it found that the logistical and commercial assistance provided by La Poste, the French postal administration, to its affiliate company SFMI-Chronoposte, which is active in the market of express courier services, constituted state aid within the meaning of Article 87(1) EC. The CFI in reaching its decision indicated that the remuneration received by La Poste in return for the provision of logistical and commercial assistance was not sufficient to exclude any aid element as La Poste, by virtue of its position as the sole public undertaking operating in a reserved sector, had been able to provide that assistance at lower costs that a private operator not enjoying the same rights would have been able to do so. It went also further to stress that the Commission should at least have checked that the payment received in return by La Poste was comparable to that demanded by a private holding company or a private group of undertakings not operating in a reserved sector,

6993. See also the earlier ruling of the CFI Case T-613/97 Ufex and Others $v$ Commission, 2000 ECR II-4055 and Joined Cases C-34/01 to 38/01, Enirisorse Spa, 2003 , not yet reported.

${ }^{113} \mathrm{Ibid}$, at paras 88-93.

${ }^{114}$ SFMI-Chronopost, Commission Decision 98/365, OJ L164, 09/06/1998. 
pursuing a structural policy, whether general or sectoral - and guided by long-term prospects. ${ }^{115}$

The ECJ took the view that the CFI erred in making the above assessment without taking into account the fact that an undertaking such as La Poste was in a situation very different from that of a private undertaking acting under normal market conditions. La Poste was at the time operating in a market network with substantial infrastructures and resources, which would never had been created by a private undertaking. As a result, in the absence of any possibility of comparing the situation with that of a private group of undertakings not operating in a reserved sector, the ECJ put aside the judgement of the CFI and upheld the Commission's decision excluding the existence of state aid in the provision of logistical and commercial assistance by La Poste to Chronopost. ${ }^{116}$

Following the recent case law, where public service compensation (PSC) is held not to constitute state aid within the meaning of Article 87(1) EC, if certain conditions are met, the Commission has adopted three new measures to clarify the conditions under which a public service compensation can be compatible with the common market in accordance with Article 86(2)EC:

- Commission Directive 2005/81 amending Directive 80/723 on the transparency of financial relations between member states and public undertakings;

- Commission Decision 2005/842 on the application of Article 86EC to state aid that compensates for public service obligations; and

- Community Framework for state aid in the form of public service compensation.

The Decision applies to all undertakings in all sectors that have an annual turnover less than EUR 100 million and to hospitals, social housing undertakings and certain air amd retime links to islands and ports and airports below a certain threshold, with the condition that they provide SGEI. In so far as it constitutes state aid, PSC is compatible with the common market and need not be notified provided that the public service obligations

\footnotetext{
${ }^{115}$ Case T-613/97, Ufex and Others $v$ Commission.

${ }^{116}$ Joined cases C-83/01, C 93/01 and C-94/01 P, Chronopost $v$ Ufex and Others. Further reading on this chapter: E. Kutenicova, Community rules on State aid - a practical handbook, Competition policy newsletter: $n r$. 2, 2007.
} 


\section{Chapter 5}

are precisely defined and officially assigned and the PSC should not exceed the costs of the public service obligations, taking into account revenues and reasonable profit. Profit must not normally exceed the average rate in the sector concerned and must be adjusted to the risk incurred by the undertakings by virtue of the intervention of the Member State.

The Framework applies to all sectors except transport and public service broadcasting. According to the Framework, where the criteria laid down in Altmark are not met, PSC may be compatible pursuant to Article 86(2), if the SGEI are clearly and officially assigned, the PSC does not exceed the costs of the public service obligations, taking into account revenues and reasonable profit, the method of calculation is specified and recoupment of over-compensation is possible. 


\title{
Part II: Economics of State Aid
}

\author{
Chapter 6 \\ State Aid Rules: Do they Promote Efficiency?
}

\subsection{The context of analysis}

The policy of the European Community on state aid control is in a process of evolution. New rules are being proposed by the Commission, which has recently expressed its concern at the large amounts of aid still being offered by central and regional governments in the Member States. This is an opportune moment to take stock of Community practice and evaluate Community rules. The purpose of this Chapter is to attempt to make such an evaluation by asking whether the rules promote economic efficiency.

To assess whether EC state aid rules promote economic efficiency, we first have to define the context in which we are making that assessment. An issue that has to be clarified at the outset is whether governments should grant state aid and whether the EC needs to have any rules at all on state aid. To put it differently, before we even examine the efficiency of the existing rules, we have to know why governments grant aid and why a regional grouping like the EC needs to constrain what its members do.

Once we have established whether subsidies should be granted at all, and whether groupings of countries should regulate the kind and amount of subsidies given by their members, we can address the issue of whether existing EC rules conform with what theory prescribes. To the extent that practice deviates from theoretical prescription, we need to identify the causes and effects of that discrepancy. If the EC has objectives other than the pursuit of economic efficiency, are the prevailing rules and procedures the least distortionary means of achieving those objectives? 


\section{Chapter 6}

\subsection{Why subsidies?}

There is a large amount of literature on whether, when and how governments should aid their companies or industries. By and large, this literature concludes that, on efficiency grounds, aid may be justified when it is intended to correct market failure. The typical reasons cited for market failure are externalities (plus public goods), economies of scale and asymmetric information. Because of these reasons, it is thought necessary for a government to intervene and subsidise training, undertake part of the cost of research and other knowledge-generating activities, offer incentives for investment in environmentally friendly machinery and production processes, regulate entry into the utilities sector and define the obligations of producers towards consumers.

Note that market failure is a necessary but not a sufficient condition for providing public support to industry. The "first-best" policy would be to address market failure directly, instead of granting state aid to compensate for it. Only when direct measures are not feasible should aid be considered, as a "second-best" option. However, the appropriate amount and method of aid may still be too difficult to determine. Not only may the government have to rely on incomplete information about the state of the economy, but it may also suffer from asymmetric information. The private sector seeking to benefit from state aid possesses information not directly available to the government, which thus runs the risk of being misled when designing and implementing its aid policy. Besides, the aid-giving agency may be in danger of being "captured" by special interest groups. The "politicisation" of state aid is one of the major problems facing aid-granting agencies. Hence, the cost of getting the policy wrong may outweigh the benefits of intervention to correct market failure.

When should such intervention be classified as state aid? Here we follow the convention according to which a public measure is regarded as state aid if (i) it favours a particular firm or industry (i.e. it is a "specific" measure instead of a "general" one) and (ii) it results in financial cost to the government or its agencies (i.e. regulatory measures, even when they favour particular firms, are not considered to be state aid). 
In the EC, much of the legal analysis in state aid cases focuses on whether a given state aid measure is specific or general. This legal issue has its economic counterpart. A specific measure would change the relative prices of goods and services nationally, while a general measure would leave them unchanged. Note, however, that this kind of neutrality prevails only under certain assumptions, which are unlikely to hold in practice. For example, a general measure such as an employment subsidy given to all sectors of the economy would still have a more pronounced impact on labour intensive sectors in labour-rich countries.

Given that countries trade goods for which they have a comparative advantage in their production, it is very doubtful whether there can be a general measure that has the same effect on all sectors of the economy. This does not mean that it is impossible to design measures that have a neutral impact. It only means that such measures are both difficult to design and unlikely to conform with what are normally presumed to be general measures (i.e. aid which is given on the basis of non-discriminatory criteria and through procedures which are automatically and unconditionally open to all sectors on the same terms). These are legal criteria which may not take into account the particularities of the various sectors of the economy.

A question that arises is whether general measures can also be efficient policy instruments. This is an interesting question in the context of this Chapter because a basic tenet of economic policy is that intervention should be as specific as possible to avoid unwanted side effects. We will return to this issue later on.

\subsection{Why supranational rules on subsidies?}

As argued above, measures that are not of a general nature have, by definition, an impact on relative prices and therefore on the allocation of resources among sectors. In an open economy, this implies that the terms of trade are affected. If the effect is significant enough it may shift the comparative advantage of the country. While this results in welfare losses when resources are reallocated to inefficient sectors, it may raise national welfare when aid policies are intended to correct market failures so as to shift resources to sectors where the true comparative advantage of a country 


\section{Chapter 6}

lies. Note, once more, that for aid to be welfare improving, the efficiency gains derived from aid policies must be larger than the (direct and indirect) costs of state aid.

Assuming that state aid compensates for market distortions, we can turn to the question of why a group of countries, each of which is presumed (at least initially) to maximise efficiency, should need or tolerate any supranational constraints on their discretion to disburse subsidies or other forms of state aid? One answer is that rational, welfare-maximising behaviour does not preclude subsidy wars in pursuit of "beggar thy neighbour" objectives. Hence, supranational rules may be voluntarily adopted in order to prevent the emergence of predatory or rent-shifting national policies.

In this context it is worth noting that rent-shifting policies are normally implemented through the selection of "national champions" which have, or are expected to acquire, market power (as reflected in large market shares). Because they seek to be selective, they are, as a result, inherently discriminatory (and to a large extent, arbitrary). Given that the process of selection necessarily entails that (i) certain industries must be left out and (ii) those not favoured are penalised by not having access to public funds, it is not unreasonable to conclude that ultimately the ban on rent-shifting measures, intentionally or unintentionally, prevents governments from discriminating against "unfashionable" economic activities.

Economic policies, especially those that affect traded goods or mobile factors of production, generate cross-border spillovers. To the extent that these spillovers are positive (as, in some instances, with subsidies to an industry using imported goods as inputs), there is no need for supranational rules. Countries benefit from the state aid policy of their partners. In contrast, when a domestic aid policy generates negative spillover effects (i.e. it reduces the welfare of other countries), supranational rules may protect the interests of partner countries as well. Supranational rules may have the purpose of not only eliminating these negative spillovers, but also of introducing greater transparency and predictability in the partner countries' policy making. Greater policy transparency and predictability make it easier for companies to plan their investments and for other governments to formulate and implement their own policies. 
Supranational rules may also prevent tit-for-tat strategies of the type "Since you give aid to your industry, I'll help my industry too". Governments often get caught in such "prisoner's dilemma" situations where domestic aid is granted to restore the "level playing field" with subsidised foreign industries. However, all countries would be better off with a cooperative outcome.

The need for supranational rules is further strengthened as the assumption of efficiency maximisation is relaxed. Such rules constrain the decision-making discretion of national governments and make them less vulnerable to domestic lobbying by special interest groups. This is not a farfetched supposition given the fact that external constraints are often sought for internal political reasons. In this context, supranational rules improve the fairness or objectivity of domestic decision-making. Even when supranational rules do not meet efficiency criteria, they may dilute national preferences for interventionist or discriminatory policies (which generally benefit small but organised, politically influential groups as they have to apply to (and accommodate) a larger number of entities. A national specificinterest group is therefore less likely to influence such rules or their application. Besides, supranational rules and institutions help to shield national decision-makers from domestic pressures as they can shift the blame for unpopular or politically difficult decisions not to support specific sectors (generally the so-called "national champions") to international institutions. The prevention of discriminatory measures or discouraging rentseeking activities is in general welfare improving.

Finally, state aid may also serve non-economic objectives: self-sufficiency, protection of national interests (e.g. the defence sector), etc. In the context of the European Union, the integration of the internal market has been the main objective of Community policies and action. Hence, as discussed in the section on EC rules, state aid is subject to the requirement that it should not distort competition or intra-EU trade, at least in principle. However, the completion of the single market will not necessarily result in efficient (i.e. EU welfare-maximising) policies. It follows that the political objective of market integration may conflict with the economic prescription for efficiency. Supranational rules, however, may serve to clarify and rank these various objectives. 


\section{Chapter 6}

In summary, supranational rules serve several objectives. While we acknowledge this multiplicity of objectives, we are confining our analysis to the question of efficiency. Do EC rules permit only market-correcting intervention? This question has two facets. The first is whether all marketcorrecting interventions are allowed. The second is whether only marketcorrecting interventions are possible. That is, may interventions of a different sort (i.e. with different objectives) be permitted as well? To answer these two questions we have to examine in more detail the meaning and implications of market-correcting intervention.

\subsection{Cross-border effects of state aid}

Economic theory recognises that, in principle, the purpose of state aid is to correct or compensate for market failure, with the ultimate objective of improving economic welfare. Thus, it may seem that there should be no objection and, consequently, no supranational constraints on marketcorrecting measures. However, this may not hold true for at least two reasons.

First, it is well known from the theory of second-best that, in markets with multiple distortions, addressing only one source of distortion by intervening in the market creates its own distortion, which may have the apparently paradoxical effect of reducing welfare. For instance, R\&D subsidies designed to stimulate technical innovation and productivity, if granted to an industry which operates in a protected sector and which causes environmental pollution, may result, respectively, in a greater misallocation of resources (away from the production of goods where the country has a natural comparative advantage) and to higher national negative externalities in terms of pollution, and thus have a negative welfare impact.

Second, as argued above, national policy may generate negative cross-border spillovers. This would happen for instance in the case of predatory or rentshifting policies that are expressly intended to assist national firms in capturing market share from foreign firms. Obviously, rent-shifting policies often result in "negative-sum games" with the potential of making everyone worse off. 
However, it cannot be generally argued that all strategic policies that seek to support particular industries necessarily worsen global welfare. One may wonder, therefore, whether such strategic state aid policies should be prohibited per se or only when the aid-providing government does not have the potential means to compensate for negative effects on third countries. In other words, should state aid which generates larger (domestic) gains than losses (abroad) be allowed? In such "positive-sum games" both national and global (i.e. all countries' aggregated) welfare increase, even if the welfare of some countries may be negatively affected. In this particular case, state aid is potentially Pareto-efficient, although it hurts some countries. EC rules, as they do not directly address the issue of efficiency, remain ambiguous in relation to such policies.

The argument for banning aid to particular industries is not only economic but also procedural. Who would evaluate whether global welfare has increased? There is only one supranational authority with that kind of power, and that is the Commission. Hence, it is not feasible to expect that countries outside the EU have the means to coordinate their actions so that only aid that is globally welfare improving is granted.

Apart from strategic aid to industry, there may be other forms of aid that also generate negative effects for some partner countries even in cases where global welfare increases. It becomes necessary to ask whether there are any market-correcting interventions that can result in cross-border spillovers? In open economies, internal policies virtually always have a direct or indirect external effect. Even intervention in a non-traded sector may have an indirect effect on a traded sector and thus on a foreign economy.

An example will help clarify this issue. Firms may choose to invest in a location where other similar firms already maintain production facilities or have an established business presence. They may make that investment in order to obtain access to raw materials, transport networks, factors of production or to benefit from external economies or agglomeration effects. The government may initiate and speed up the process of agglomeration by offering regional investment incentives. In case the government of another country attempts to follow precisely the same policy, the two countries may end up undermining each other's efforts even though both intend to pursue a first-best policy of basically correcting externalities. Both countries are 


\section{Chapter 6}

trapped in a prisoner's dilemma situation. Should there be rules on investment incentives of this sort? Not only are there cross-border spillovers, but both countries may be better off by agreeing not to pursue those policies. However, if one country could compensate the other, a better option for both of them would be to agree for one to grant the subsidy while the other refrains from doing the same.

Consider a different example. A firm that proposes to build a new lean car engine asks the government for research subsidies. The firm wants to carry out research on new component materials, new fuels and new methods of fuel injection. Again there are extensive externalities and at the same time substantial commercial risks. Should the government subsidise this project? Even if subsidies are a first-best response to a market failure, should this kind of research still receive public support if governments in other countries intend to support similar projects submitted to them. Should they both subsidise or not?

Both examples illustrate a common prisoner's dilemma. All countries would be worse off without government intervention and yet there is a significant risk that public support could lead to too much intervention, with consequent excessive subsidies and waste of resources. Note that in neither example does the government explicitly intend to extract rent from other countries. We conclude that distortion-correcting aid is not necessarily free of negative cross-border effects, especially when it directly induces a shift in the location of production by influencing investment decisions.

When individual decisions lead to a sub-optimal collective outcome, ostensibly there is a need for coordination. The problem is how to define and measure this "collective interest" and how to coordinate national policies. In this context a blanket prohibition, as in the case, for example, of export subsidies, would not be appropriate. There is a need for a supranational mechanism or authority to coordinate national aid decisions. That authority needs to have discretion to judge each case on its own merits. Hence, within the context of a regional grouping like the EC, the pursuit of efficiency necessarily means some form of coordination which, in turn, means the exercise of policy discretion. 
Without attempting to define the meaning of collective interest or other criteria that may guide coordination, on the basis of the discussion above we can derive a number of general but quite robust conclusions about the purpose of supranational rules on state aid. At a minimum state aid rules should ensure that:

(i) aid is given only when the market alone (before government intervention) leads to inefficient or sub-optimal outcome;

(ii) aid is capable of addressing the source of market failure directly (it should be as narrow or as wide as the extent of the failure);

(iii) market-corrective aid does not lead to a collective sub-optimal outcome.

As argued below, in the EC, the source and magnitude of market failure are not always identified and measured.

\subsection{European Community state aid policy: The rules}

Art. 87 declares as incompatible with the common market any form of aid that confers an advantage to a firm or undertaking and distorts intra-EC trade and competition. A few categories of aid, mostly of social character, are pronounced as compatible with the common market while a number of other categories may be found, under certain conditions (notably when it is in the Community interest), to be compatible with the common market. The Commission is, among other things, empowered with the task of establishing when aid falls in the latter categories.

From a legal point of view, the construction and provisions of Art. 87 may be beyond reproach. The same, however, cannot be said from an economic point of view. On the one hand, the prohibition is too wide. It catches virtually all aid schemes because very few are found in practice not to have an actual or potential effect on intra-EC trade and competition. If a support measure is classified as a form of state aid, it is invariably found to affect trade and competition (which are often used interchangeably). On the other hand, the discretion enjoyed by the Commission to authorise aid is not bounded by precise operational criteria.

In determining the relevance of state aid, the Commission should assess the effects of the state aid scheme considered in relation to its presumed 


\section{Chapter 6}

objectives: correction of market failure, social considerations, economic development, common interest, etc. Although the Commission considers the specific instruments and amounts it does not carry out an explicit costbenefit analysis of the impact of state aid, nor does it examine whether the aid scheme represents an optimal (i.e. first-best) economic policy option. Besides, the nature of market failure is often not even clearly identified.

The examination of aid schemes is not normally done by considering what would happen in the absence of government support (although for certain schemes, such as those to support R\&D, the Commission does require that governments show their necessity; i.e. that R\&D would not be undertaken without state assistance). This is surprising because the European Court of Justice established early on in case law that public assistance should not replace market mechanisms. The Commission often asks how firms would behave without receiving state aid but, with a notable and admittedly significant exception, it does not attempt to quantify the magnitude of the distortion.

That exceptions are the permissible aid ceilings (or intensities) defined in the various guidelines with respect to certain aid schemes and industrial sectors. For example the permissible aid ceilings for regional development aid are set according to the perceived regional backwardness which may be assumed to correspond to the degree of market failure (if backwardness is market failure).

However, aid intensities or ceilings are defined more for the purpose of ensuring that aid is proportional to the objective sought. Even though the Commission always insists on proportionality and makes references to economic factors such as "regional handicaps", it does not appear to relate aid to what is necessary to offset underlying market distortions.

While aid intensities may be construed in some loose manner as the Commission's way of relating allowable aid to the magnitude of market failure, it is puzzling why similar reasoning has not been used to evaluate direct involvement of the state in companies through injections of public capital (i.e. situations where the state becomes a shareholder). 
The Commission has pioneered the "private investor" principle according to which governments should behave like any other private investor by expecting to receive a reasonable financial return on their investments. Although the private investor principle can probably be considered as a bold initiative, given that the Treaty does not exclude the state from ownership of factors of production (Art. 295), the Commission should be asking why certain companies have difficulty attracting private capital. Even if the state receives the same return as a private investor would expect to earn, it cannot be considered to be equivalent to a private investor (otherwise, why could a company not attract private capital? Participation by the state should be either presumed to correct an imperfection (and therefore the return can be justifiably lower) or otherwise it should be expected to earn a higher rate of return because of the advantages it carries. This means that under normal conditions, investment by the state should carry a "handicap", rather than be considered as equivalent to investment by private firms.

The absence of sufficient analysis of the need for public support is most obvious in aid schemes for the rescue or restructuring of ailing companies. The main criteria used by the Commission are that aid should be transitory and should make the recipient companies commercially viable again. It is not always clear what kind of imperfection such state aid schemes seek to redress (apart from the imperfections and failures of the management of those firms).

Admittedly, aid is frequently sought in these situations in order to offset charges related to the dismissal of workers and the rationalisation of operations (e.g. compensation, pension liabilities, etc.). It is presumably in the broader national interest to facilitate industrial adjustment. The problem is that aid in cases of rescue and restructuring is not exclusively granted for those purposes.

More puzzling is the fact that aid is approved when it is demonstrated that the beneficiaries will be able to function profitably without it. But if they can live without public handouts, why do they need any at all? Why is private capital not able to bring that kind of change? Why are those companies not able to attract private capital if indeed they can demonstrate the feasibility of their long-term profitability? 


\section{Chapter 6}

The closest that the Commission comes to coordinating national aid schemes is when it defines ceilings for regional aid and imposes "compensatory" conditions on other schemes it approves. This conditional authorisation aims to prevent the recipient of aid from using public handouts to strengthen its commercial position at the expense of firms in other member states. For example, aid to national airlines such as Air France, Alitalia, Olympic, Iberia and Sabena has been approved on condition that these airlines do not attempt to expand their market share by reducing prices or acquiring other airlines. In this context, it would not be inaccurate to say that coordination in practice means prevention of a disturbance of the status quo. Clearly, there is an element of "strategic" policy in this kind of aid schemes, with the difference that the intent is not to capture rents, but rather to defend (i.e. prevent the shifting abroad of) rents. Arguably, such schemes, by maintaining the status quo and existing level of trade and degree of competition in the EU, effectively prevent the competitive effects derived from integration of the internal market from being realised.

If aid is authorised explicitly for the purpose of correcting market failure, it ought not to make any difference that the status quo is disturbed. By definition, the current market conditions are not those that would have prevailed had the distortion not existed. And, after all, economic integration and the removal of obstacles to trade, movement and investment are marketcorrecting schemes on a larger scale.

Under certain conditions, the Treaty in Art. 87(3)(c) enables the Commission to authorise aid intended to promote the development of particular regions or economic activities, provided that it is not contrary to Community interest. Such aid goes beyond what is necessary to offset regional backwardness or severe unemployment and which is already permitted under Art. 87(3)(a). There is no definition of Community interest in the Treaty. Over the years it has been asserted that the interest of the Community has been advanced by aid such as that to attract ships back to EU registries or to provide financial services to Central and East European countries. The Treaty expresses so many different objectives that it is fairly easy for the Member States and the Commission to claim that a certain project is not contrary to the Community interest. 
The Commission admittedly applies stricter criteria and lower ceilings to aid schemes authorised under Art 87(3)(c) than under Art 87(3)(a). But the question is whether it should authorise aid at all, given that it is not clear that the market has failed in those cases.

The EC has a number of non-economic objectives and some of those inevitably creep into the Court's rulings on state aid and into the Commission's evaluations of notified or non-notified schemes. Although certain policy objectives are non-economic, policy makers should still quantify and take into account their costs in terms of forgone efficiency and, therefore, welfare. The fact that those objectives are not explicitly economic does not make them costless. More importantly, policy makers should always favour first-best policies when available. State aid may often prove to be an inefficient instrument to address non-economic objectives.

\subsection{How can the rules be improved?}

It would be completely unrealistic, if not naive, to expect that EC rules could be changed in such a way as to prohibit absolutely any state aid scheme that is not intended to correct market failure. Indeed, if a proposal along these lines were ever discussed, there would be interminable debates on the definition of market failure. It is doubtful that politicians would ever reach a consensus on the meaning of market failure or, even if they did, that they would be able to define it in an operationally meaningful manner that would not be open to creative interpretation and abuse.

Hence, it is unavoidable that the Member States would want to assist particular firms, industries or regions for reasons other than economic ones. In this case the Commission has an important role to play in ensuring that aid does not distort intra-EC trade to an extent unwarranted by the objective sought. It is impossible to define a priori the magnitude of aid that is appropriate for each of those objectives. Despite this inherent difficulty, the Commission should attempt to make explicit the non-economic objectives for which aid may be authorised. That would improve decision-making transparency in an important policy area. 


\section{Chapter 6}

But instead of focusing on what is not possible, it would be more productive to examine what is possible. Can market-correcting aid be meaningfully defined and then exempted all together? That would reduce the workload of the Commission and allow it to concentrate its resources on serious cases of state aid.

As mentioned earlier, a basic tenet of the theory of economic policy is that intervention should go to the heart of the distortion. This is normally understood that corrective measures should be as specific as possible so that they do not generate unwanted side-effects. But going to the heart of the distortion also means that the scope of the corrective measures should cover the (full) extent of the distortion itself, implying that no affected activities or areas are left outside. For example, governments should not grant loans or inject capital to the manufacturing industry at subsidised interest rates in an attempt to offset imperfectly functioning capital markets. It would be more efficient to intervene directly in the capital markets so that the manufacturing industry does not receive more favourable treatment than the service sector.

Also if the government, for example, proposes to give aid to an industry for the training of workers, it should explain why it does not offer similar assistance to other industries with similar training needs. If available resources are limited or if the identified industry is perceived to have more urgent needs, there can be defined objective criteria for selecting the neediest industry or the training programme that generates the highest value or return. Such objective (i.e. non-discriminatory) criteria in effect "generalise" the scope of application of the particular state aid scheme and prevent public assistance from flowing to politically favoured industries.

As already mentioned, alleged market failures can justify government interventions in areas such as training, $\mathrm{R} \& \mathrm{D}$, investment, industrial production, the environment, consumer protection, etc. This is not an exhaustive list of what governments should or actually do. It is rather an indicative list that suggests that market failure is very unlikely to be confined to a single firm or even a single industry. As its name suggests, if the failure of the market is generic, it is likely to be market-wide. That is, when voluntary exchange and transactions do not lead to a socially optimal outcome, it is reasonable to expect that the cause is not confined to a particular firm or industry. 
This is an important conclusion. Market correcting intervention should seek to address particular causes of market failure in all the industries or sectors they appear. Consequently, correcting measures should be of a more general than specific nature. This would conform with EC rules on state aid that allow general aid schemes. Therefore, if governments claim that their schemes seek to correct market failure, the presumption should be that corrective measures are general and that they are automatically exempt from the prohibition of Art. 87.

Carrying the argument to its logical conclusion, suggests, on the other hand, that aid to individual firms or industries is very unlikely to be the optimum method of correcting generic market failure. It should, as a rule, be prohibited even if the granting agencies show that the recipients can eventually operate without aid. The burden of proof should be on governments to show that their proposed schemes deal with a firm-specific or industry-specific failure. Moreover, if they can demonstrate that the recipients can become commercially viable, it is prima facie evidence that the market has not failed. Ironically, this reasoning itself undermines the case for aid.

Indeed, the question why firms cannot attract funds from capital markets should also be raised in cases of public injection of capital and acquisition of private shareholdings. The question should not be whether the state behaves like a private investor. This is a fiction because the state cannot default. The relevant question is why the recipient firms cannot attract $100 \%$ private funding. Where is the market failure that discourages that kind of funding?

The Commission must be more explicit about the criteria it uses to determine when aid is compatible with the common or Community interest. Presumably, the common interest dictates eligible aid schemes when they cause significant cross-border effects so as to induce relocation of production or investment. But how much aid is too much? How much aid is sufficient to correct market distortions and how much should be permitted for each Member State? Concepts of the common interest as they are used at present are incapable of providing answers to these questions, especially when not all Member States would gain if all granted aid. 


\section{Chapter 6}

In conclusion, it is not possible to define in precise detail acceptable and unacceptable categories of state aid (even though the WTO agreement on subsidies attempted to do just that) because a simple prohibition against all schemes that have cross-border effects would be too wide, while a narrower ban on all schemes that do not or cannot improve efficiency would be too vague and politically unacceptable. Member States may want to subsidise particular economic activities and particular regions for social or political reasons. However, current practice as regards this kind of aid could still be improved by stricter application of the requirement that it is not contrary to a well-defined concept of Community interest.

Where aid has an implicit economic objective, the Commission should seek to rigorously establish the nature and magnitude of market failure. Permitted aid should be solely what is necessary to correct that failure. When aid schemes have the potential to shift economic activity from one location to another, then the Commission should also impose additional limits on the amount of aid or other compensatory requirements.

Finally, one may ask whether these suggestions can be implemented under current Treaty provisions on state aid. We do not see any major obstacles here. Art. 87(3) identifies certain policy objectives for which Member States may grant aid in order to attain them. It is up to the Commission to determine the conditions under which aid is compatible with the common market. Such compatibility need not be in conflict with the correction of market failure.

\subsection{Conclusion}

EC state aid rules are both too restrictive and too permissive. They prohibit all forms of aid that may affect intra-EC trade or competition. We argue that, in principle, aid intended to correct market failure should be allowed even if it has cross-border effects. On the other hand, authorised aid schemes are hardly confined to the correction of market failure. They have much broader objectives. The problem is that it is not obvious how much distortion of competition is tolerated in the pursuit of those broader objectives. 
The control of state aid would be improved and aligned to efficiency considerations if the Commission analysed whether market failure is the centrepiece of its evaluation of aid cases and whether the proposed modalities and amount of aid are both necessary and proportional to the task of correcting the failure.

The presumption should be that specific schemes that benefit particular firms or industries are incompatible with the common market because market failure is unlikely to be confined to a single firm or even a single industry. Moreover, the injection of public capital and acquisition of shares by a government should also be presumed to be a form of aid even if the state purports to behave as a private investor. The burden of proof should be on governments to demonstrate the need for their involvement and the reason why private investment is not forthcoming. 


\section{Chapter 7}

\section{The Economics of Granting and Controlling State Aid}

\subsection{Introduction}

The justification for this chapter is given in the State Aid Action Plan of the European Commission: ${ }^{17}$

"Making more use of a refined economic approach is a means to ensure a proper and more transparent evaluation of the distortions to competition and trade associated with state aid measures. This approach can also help investigate the reasons why the market by itself does not deliver the desired objectives of common interest and in consequence evaluate the benefits of state aid measures in reaching these objectives."

Economic analysis of state aid is indispensable. Otherwise, national authorities cannot assess the effects of public assistance they grant to enterprises. At the Community level, economic analysis is required only in a small number of cases such as rescue and restructuring, risk capital and the assessment of private investor principle. Even in these cases, however, the economic analysis that is performed is limited. ${ }^{118}$ It does not attempt to assess, for example, the costs and benefits of proposed aid or the impact on competition.

${ }^{117}$ European Commission, State Aid Action Plan: Less and Better Targeted State Aid, $\operatorname{COM}(2005) 107$ final.

${ }_{118}$ See, for example, the critique in P. Nicolaides, Markets and Words: The Distortive Effect of Government Pronouncements, European Competition Law Review, 2005; P. Nicolaides and M. Kekelekis, An Economic Analysis of EC Guidelines on State Aid for the Rescue and Restructuring of Companies in Difficulty, Intereconomics, 2004; P. Nicolaides, Re-Introducing the Market in the "Market Economy Investor" Principle, European State Aid Law Quarterly, 2003; P. Nicolaides, Competition and Services of General Economic Interest in the EU: Reconciling Economics and Law, European State Aid Law Quarterly, 2003. 
These things may change. The intention of the Commission is to rely more on thorough economic assessment of state aid, as it already does in the field of anti-trust.

This chapter is structured as follows. Section 2 examines the economic rationale for state aid. Section 3 considers why a system of supranational control of aid may be useful in the context of economic integration. Section 4 reviews the possible ways that state aid may be assessed so that it raises joint welfare or promotes the common interest. Finally, section 5 identifies typical problems in designing effective and efficient subsidy policies.

\subsection{Subsidies as a policy instrument}

Governments grant state aid or subsidies for many reasons: economic, social, political, strategic. ${ }^{119}$ Despite their prevalence, public subsidies are almost always a second-best solution for improving the functioning of markets because they introduce their own distortions and because they can be exploited by special-interest groups.

There is a large amount of literature on whether, when and how governments should aid particular economic activities, industries or regions. By and large, this literature concludes that, on efficiency grounds, aid may be justified when it is intended to correct market failure. The typical reasons cited for market failure are externalities (plus public goods), economies of scale and asymmetric information. Because of these reasons, it is thought necessary for governments to intervene and subsidise activities such as training,

${ }^{119}$ On the general problem of granting state aid, see S. Lehner, R. Meiklejohn \& A. Louw, Fair Competition in the Internal Market: Community State Aid Policy, (Luxembourg: OOPEC, 1991); R. Meiklejohn, The Economics of State Aid, European Economy, 1999, no.3, pp. 25-31; D. Neven, The Political Economy of State Aids in the European Community: Some Econometric Evidence, Cahiers de Recherches Économique, 1994, no. 9402, University of Lausanne; P. Nicolaides \& S. Bilal, An Appraisal of the State Aid Rules of the European Community: Do they Promote Efficiency?', Journal of World Trade, 1999, vol. 33(2), pp. 97-124; Public Subsidies, Office of Fair Trading, London, November, 2004; and various speeches by the Chief Economist of DG Competition, European Commission. 


\section{Chapter 7}

research, investment in environmentally friendly processes or backward regions and supply of important services such as electricity or transport.

The Commission, in the State Aid Action Plan, also acknowledges that:

"One key element in that respect is the analysis of market failures ... which may be reasons why the markets do not achieve desired objectives of common interest, in particular if they are of an economic nature. In those cases, identifying the market failure at stake will help evaluate better whether state aid could be justified and acceptable, would represent the most appropriate solution, and how it should be implemented to achieve the desired objective without distorting competition and trade to an extent contrary to the common interest."

Market failure is a necessary but not a sufficient condition for providing public support to industry. The "first-best" policy would be to address market failure directly, instead of granting state aid to compensate for it. Only when direct measures are not feasible should aid be considered, as a "second-best" option.

Again, the State Aid Action Plan also accepts that some market failures "may be solved by regulatory or other means." It goes on to add that "it is not enough for state aid to target a market failure. Before resorting to State aid, which is in general only the second best option to achieve optimal allocation of resources, it should be verified whether other less distortive measures could remedy the market failure. State aid should be the appropriate policy instrument and should be designed so that it effectively solves the market failure, by creating an incentive effect and being proportionate. In addition, state aid should not distort competition to an extent contrary to the common interest."

The appropriate amount and method of aid may still be too difficult to determine. Not only may the government have to rely on incomplete information about the state of the economy, but it may also suffer from asymmetric information. Enterprises seeking to benefit from state aid possess information not directly available to the government which runs the risk of being misled when designing and implementing its aid policy.

The aid-giving agency may be in danger of being "captured" by special interest groups. The "politicisation" of state aid is one of the major problems facing aid-granting agencies. Hence, the cost of getting the policy wrong may in reality outweigh the benefits of intervention to correct market failure. 


\subsection{Why supranational rules on subsidies?}

The State Aid Action Plan justifies control of state aid at the European level in the following terms:

"State aid control comes from the need to maintain a level playing field for all undertakings active in the Single European Market, no matter in which Member State they are established. There is a particular need to be concerned with those state aid measures, which provide unwarranted selective advantages to some firms, preventing or delaying the market forces from rewarding the most competitive firms, thereby decreasing overall European competitiveness. It may also lead to a build-up of market power in the hands of some firms, for instance when companies that do not receive state aid (e.g. non-domestic firms) have to cut down on their market presence, or where state aid is used to erect entry barriers."

Indeed, subsidies that are not of a general nature have, by definition, an impact on relative prices and therefore on the allocation of resources among sectors. In an open economy, this implies that the terms of trade are affected. If the effect is significant enough it may shift the comparative advantage of the country. While this results in welfare losses when resources are reallocated to inefficient sectors, it may raise national welfare when aid policies are intended to correct market failures so as to shift resources to sectors where the true comparative advantage of a country lies. Note, once more, that for aid to be welfare improving, the efficiency gains derived from aid policies must be larger than the (direct and indirect) costs of state aid.

Assuming that state aid compensates for market distortions, we can turn to the question of why a group of countries, each of which is presumed (at least initially) to maximise economic efficiency, should need any supranational constraints on their discretion to disburse subsidies? The typical answer is that rational, welfare-maximising behaviour does not preclude subsidy wars in pursuit of "beggar thy neighbour" objectives. Hence, supranational rules may be voluntarily adopted in order to prevent the emergence of predatory or rent-shifting national policies.

Rent-shifting policies are normally implemented through selection of "national champions" which have, or are expected to acquire, market power (as reflected in large market shares). Because they seek to be selective, they 


\section{Chapter 7}

are, as a result, inherently discriminatory (and to a large extent, arbitrary). Given that the process of selection necessarily entails that (i) certain industries must be left out and (ii) those not favoured are penalised by not having access to public funds. Under these conditions, it is not unreasonable to conclude that ultimately the ban on rent-shifting measures, intentionally or unintentionally, prevents governments from discriminating against "unfashionable" economic activities.

Economic policies, especially those that affect traded goods or mobile factors of production, generate cross-border spillovers. To the extent that these spillovers are positive (as, in some instances, with subsidies to an industry using imported goods as inputs), there is no need for supranational rules. Countries benefit from the state aid policy of their partners. In contrast, when domestic aid policies generate negative spillover effects (i.e. it reduces the welfare of other countries), supranational rules may protect the interests of partner countries as well. Supranational rules may have the purpose of not only eliminating these negative spillovers, but also of introducing greater transparency and predictability in the partner countries' policy processes. Greater policy transparency and predictability make it easier for companies to plan their investments and for other governments to formulate and implement their own policies.

Supranational rules may also prevent tit-for-tat strategies of the type "since you give aid to your industry, I'll help my industry too". Governments often get caught in such "prisoner's dilemma" situations where domestic aid is granted to restore the "level playing field" with subsidised foreign industries. However, all countries would be better off with a cooperative outcome.

The need for supranational rules is further strengthened when the assumption of efficiency maximisation is relaxed. Such rules constrain the decisionmaking discretion of national governments and make them less vulnerable to domestic lobbying by special interest groups. This is not a farfetched supposition given the fact that external constraints are often sought for internal political reasons. In this context, supranational rules improve the fairness or objectivity of domestic decision-making. Even when supranational rules do not meet efficiency criteria, they may constrain domestic tendencies for interventionist or discriminatory policies (which generally benefit small but organised, politically influential groups as they 
have to apply to (and accommodate) a larger number of entities. A national specific-interest group is therefore less likely to influence such rules or their application. Besides, supranational rules and institutions help to shield national decision-makers from domestic pressures as they can shift the blame for unpopular or politically difficult decisions not to support specific sectors (generally the so-called "national champions") to international institutions. The prevention of discriminatory measures or discouraging rentseeking activities is in general welfare improving.

Finally, state aid may also serve non-economic objectives: self-sufficiency, protection of national interests (e.g. the defence sector), etc. In the context of the European Union, the integration of the internal market has been the main objective of Community policies and action. It follows that the political objective of market integration may conflict with the economic prescription for efficiency. Supranational rules, however, may serve to clarify and rank these various objectives.

In summary, the case in favour of supranational control does not exclusively rest on the presence of cross-border externalities. However, such externalities make supranational overview and assessment necessary. Before concluding this section it is worth identifying the typical market conditions under which aid in one country has a significant negative impact on competition in another.

The UK Office of Fair Trading has recently commissioned a study on the question of cross-border distortion of competition. ${ }^{120}$ The study concluded that the magnitude of the competition distortion is determined by:

- The absolute size of the subsidy.

- The relative size of the subsidy in relation to the subsidised costs.

- The degree of selectivity of the subsidy.

- Whether the subsidy affects the recipient's costs directly [i.e. whether it is operating aid].

- Whether the subsidy is provided on a recurring basis.

- The extent of concentration in the market.

- The level of product differentiation.

${ }^{120}$ Public Subsidies, Office of Fair Trading, London, November, 2004. 


\section{Chapter 7}

- The symmetry (or asymmetry) of firm size in the market.

- The presence of barriers to entry.

For example, the larger the distortion of competition, the bigger the subsidy, the more selective it is, and the higher the degree of market concentration.

The OFT study also finds that Community rules allow state aid that may have a very distortionary effect, because it falls within existing guidelines, while they prohibit aid with insignificant effects because it falls outside such guidelines. Although this observation is correct, it is not novel. ${ }^{121}$ The study further recommends that where the distortion of competition is insignificant, Community rules should allow national authorities to implement their policies without much interference by the Commission. Again, this is the right conclusion, but it raises questions as to how Community rules can be adjusted to offer this flexibility without compromising legal certainty. The OFT is currently undertaking further studies on this issue and it may be able to provide more concrete recommendations in the future.

\subsection{Assessing cross-border effects of state aid: Balancing of effects or coordination of aid?}

If we accept that there is a case to be made both for subsidies to correct market failure and for supranational control of such subsidies, the questions that still remain to be answered are how their cross-border effects should be evaluated and whether more extensive coordination of aid may be desirable.

With respect to the first problem the issue is how the distortion-correction in one country should be weighted against the distortion-creation in another due to the impact on competition. The Community state aid policy is based on the premise that "state aid should not distort competition to an extent contrary to the common interest." This is the role of the Commission.

\footnotetext{
${ }^{121}$ See, for example, P. Nicolaides \& S. Bilal, An Appraisal of the State Aid Rules of the European Community: Do they Promote Efficiency?', Journal of World Trade, 1999, vol. 33(2), pp. 97-124.
} 
But the State Aid Action Plan is silent on this very important aspect of state aid policy. It does not explain at all how the "common interest" is to be determined and how the benefits from a market-correcting subsidy in on member state can be assessed against possible losses in other member state. More importantly, the SAAP does not explain whether the amount of permissible subsidies will be allowed to vary from member state to member state according to the magnitude of market failure in different member states. At present the only allowable variation is the case of regional aid. For all the other kinds of state aid and in all the other guidelines and frameworks, the rates of allowable aid are the same for all member states.

In other words, should state aid which generates larger domestic gains than losses abroad be allowed? In such a situation global welfare increases, even if the welfare of some countries may be negatively affected. In this case, state aid is potentially pareto-efficient, although it hurts some countries. EC rules, as they do not directly address the issue of efficiency, remain ambiguous in relation to such policies.

Therefore, in addition to control of rent-shifting subsidies, supranational supervision of aid must also perform some kind of balancing of positive and negative effects across countries. At present, this is only presumed to happen when EU member states comply with Commission regulations and guidelines.

In some of the guidelines, in particular those for regional aid, maritime transport and broadcasting, the Commission also examines whether aid contributes to the problems of industries with overcapacity [regional guidelines] or whether aid recipients engage in predatory pricing [transport and broadcasting guidelines]. Preventing increase in overcapacity or decrease in prices contributes to reducing the distortions of competition. But the remaining regulations and guidelines do not contain similar safeguards.

With respect to the second problem, as is well known from the theory of second-best, intervention to correct one source of distortion in markets with multiple distortions creates its own distortion, which may have the paradoxical effect of actually reducing welfare. For instance, R\&D subsidies designed to stimulate technical innovation and productivity, if granted to an industry which operates in a protected sector and which causes 


\section{Chapter 7}

environmental pollution, may result, respectively, in a greater misallocation of resources (away from the production of goods where the country has a natural comparative advantage) and to higher national negative externalities in terms of pollution, and thus have a negative welfare impact.

In open economies, internal policies virtually always have a direct or indirect external effect. Even intervention in a non-traded sector may have an indirect effect on a traded sector and thus on a foreign economy.

An example will help clarify this issue. Firms may choose to invest in a location where other similar firms already maintain production facilities or have an established business presence. They may make that investment in order to obtain access to raw materials, transport networks, factors of production or to benefit from external economies or agglomeration effects. The government may initiate and speed up the process of agglomeration by offering regional investment incentives. In case the government of another country attempts to follow precisely the same policy, the two countries may end up undermining each other's efforts even though both intend to pursue a first-best policy of basically correcting externalities. Both countries are trapped in a prisoner's dilemma situation. Should there be rules on investment incentives of this sort? Not only are there cross-border spillovers, but both countries may be better off by agreeing not to pursue those policies. However, if one country could compensate the other, a better option for both of them would be to agree for one to grant the subsidy while the other refrains from doing the same.

Consider a different example. A firm that proposes to build a new lean car engine asks the government for research subsidies. The firm wants to carry out research on new component materials, new fuels and new methods of fuel injection. Again there are extensive externalities and at the same time substantial commercial risks. Should the government subsidise this project? Even if subsidies are a first-best response to a market failure, should this kind of research still receive public support if governments in other countries intend to support similar projects submitted to them. Should they both subsidise or not?

Both examples illustrate a common prisoner's dilemma. All countries would be worse off without government intervention and yet there is a significant 
risk that public support could lead to too much intervention, with consequent excessive subsidies and waste of resources. Note that in neither example does the government explicitly intend to extract rent from other countries. The point is that distortion-correcting aid is not necessarily free of negative cross-border effects, especially when it directly induces a shift in the location of production by influencing investment decisions.

When individual decisions lead to a sub-optimal collective outcome, ostensibly there is a need for coordination. The problem is how to define and measure this "collective interest" and how to coordinate national policies. In this context a blanket prohibition, as in the case, for example, of export subsidies, would not be appropriate. There is a need for a supranational mechanism or authority to coordinate national aid decisions. That authority needs to have discretion to judge each case on its own merits. Hence, within the context of a regional grouping like the EC, the pursuit of efficiency necessarily means some form of coordination which, in turn, means the exercise of policy discretion.

It is worth mentioning that the only rules that allow cross-country modulation of the amount of aid that is granted are those concerning regional aid. This means that more aid is allowed in poorer regions because their development handicap is greater than those of richer regions. This is a form of coordination. The question in the context of the SAAP is whether future rules will allow aid intensities to vary according to the degree of market failure experienced in each country.

One way to deal both with the problem of balancing of effects felt in different countries and with the problem of coordination, which is also consistent with the more economic approach espoused in the SAAP, is to modulate permitted subsidies in terms of a percentage in relation to the magnitude of the market failure. This would mean that the amount of subsidies will vary across member states. It would also mean that the extent of the effect on trade would not matter because irrespective of how other member states are affected, it would always be considered to be in the common interest. 


\section{Chapter 7}

\subsection{The problem of defining optimum subsidies}

In the State Aid Action Plan, the Commission makes the following observations:

"It is important to realise that state aid does not come for free. Nor is state aid a miracle solution that can instantly cure all problems. Tax payers in the end have to finance state aid and there are opportunity costs to it. Giving aid to undertakings means taking funding away from other policy areas."

Designing an efficient subsidy policy is very important. An authority that wants to offer subsidies has to address the following problems:

\section{Necessity}

It needs to be determined whether subsidies are necessary to induce firms to do something they would not otherwise do under normal market conditions. This has three aspects. First, the presumed market failure has to be proven. Second, even in the presence of market failure it does not mean that firms will not, for example, invest or hire staff or undertake R\&D. They may only do less than what is socially optimum. This means that the subsidy has to be the minimum necessary - which is the issue of proportionality that is examined below. Third, even in the presence of a general market failure it still does not follow that each firm suffers from that failure. For example, a firm may manufacture a very specialised product so that it faces no risk of imitation by competitors. This firm would not need any public incentive to engage in $R \& D$ or to retain its technological leadership. For the same reason, in industries where $R \& D$ is indispensable for the survival of each firm, subsidies would not be necessary to induce them to undertake research. This is in essence the fundamental problem of every subsidy-granting authority. It can never know what the subsidy recipients truly intended to do in case they would obtain no subsidy.

\section{Proportionality}

Even if the need for subsidies is established in principle, the next problem is to determine the minimum amount necessary. This has two aspects. First, the granting authority has to calculate the amount of subsidy that will induce the recipient firms to carry out the socially-optimum investment, training, $R \& D$, etc. Second, the authority has to identify the true costs of the recipients. Every subsidy recipient has a strong incentive to exaggerate its relevant costs. 
In principle, if each euro of the subsidy fully captures the cost to society for granting that subsidy, ${ }^{122}$ then the subsidy is proportional (and, therefore, at its optimum level) when the last euro granted is equal to the extra benefit derived by society (or the marginal cost of the subsidy is equal its marginal benefit).

\section{Impact on competition in the same and other markets}

But subsidies also create costs in terms of the distortions they cause. This is because subsidy recipients obtain an advantage that is not normally available to their competitors. Even if society obtains some benefits from more investment or $\mathrm{R} \& \mathrm{D}$, it may also experience negative effects by the fact that the recipients capture market share at the expense of potentially more efficient competitors. Not only national authorities do not normally worry about any negative impact on foreign competitors, sometimes they intentionally seek to distort international competition by supporting their national "champions". In any case, consumers lose out from not having access to cheaper or better products. In addition, there is the potential of distortion in adjacent markets. Government subsidies in one market may stimulate demand for inputs from other markets, distorting competition in favour of the suppliers that happen to have access to the subsidy-receiving firms.

\section{Administrative costs}

The granting of subsidies is costly for both the authority that provides them and the firms that obtain them. The former have to maintain the necessary administrative infrastructure to process applications and to ensure compliance with the relevant rules. The latter have to expend resources to apply for subsidies and to report later on how they have used them. It has been estimated that such administrative costs account for about $10 \%$ of

\footnotetext{
${ }^{122}$ That is, the subsidy is neither a pure transfer, so it has zero costs, nor does it generate other costs. Further reading on this chapter: N. Tosics and N. Gaal, Public procurement and State aid control - the issue of economic advantage, Competition policy newsletter: $n r .3$ 2007, P. Nicolaides, Puzzles of State Aid: structural funds, cumulation and state aids, European State Aid law-Quarterly, Volume 4 No. 3 2005, A. Paczkowska - Tomaszewska and K. Winiarski, Monitoring State aid in Poland, European State Aid law - Quarterly, Volume 5 No. 4 2006, C-D. Ehlermann and M. Goyette, The interface between EU state aid control and the WTO disciplines on subsidies, European State Aid law-Quarterly, Volume 5 No. 42006
} 


\section{Chapter 7}

subsidies granted [5\% for the granting authorities and $5 \%$ for the recipient firms]. ${ }^{123}$

\section{Other costs}

Subsidies have to be raised through taxation which is itself an economic distortion. In addition, there is the possibility that subsidies generate spillovers that worsen distortions in other markets or create new distortions in the same market. For example, subsidies to farmers stimulate demand for fertilisers produced through polluting processes in other markets. At the same time overproduction of agricultural products results in excessive use of fertilisers worsening soil degradation of farmland.

It is very doubtful that aid that is compatible with EC rules is strictly necessary and proportional, causes no other distortions and keeps any other costs to the minimum necessary.

\section{A case study: Rescue and restructuring aid}

The purpose of this case study is to show that compliance with existing guidelines does not necessarily guarantee that allowable aid is either necessary or efficient. ${ }^{124}$

Consider the recently revised guidelines on state aid for rescue and restructuring which deal with aid to companies in financial trouble [OJ C244, 1/10/2004]. The new guidelines impose stricter limits on permissible aid and, in common with the old guidelines, exempt aid that remedies the social impact of company closure or prevents the emergence of monopoly or oligopoly due to the exit from the market of the company that is in financial trouble.

A requirement of the guidelines is that the aid is capable of bringing the beneficiary company back to long-term viability. For the owners of the

\footnotetext{
${ }^{123}$ National Audit Office, Regional Grants in England, (London: Stationery Office, 2003).

${ }^{124}$ For a fuller critique of the rescue and restructuring guidelines and practice of the EU see P. Nicolaides and M. Kekelekis, When Do Firms in Trouble Escape from State Aid Rules? (with M. Kekelekis), European State Aid Law Quarterly, 2005; P. Nicolaides and M. Kekelekis, An Economic Analysis of EC Guidelines on State Aid for the Rescue and Restructuring of Companies in Difficulty, Intereconomics, 2004.
} 
company this means that they should be able to make a normal return on their investment. But if that is the condition for granting aid, it immediately raises the question why aid is needed in the first place? Obviously, the answer is that without the aid, the return to the owners/investors would be lower otherwise and would be so low as not to justify any further investment of their own funds. So the question is about the rate of return that the owners of the company should be allowed to make. The guidelines are silent on this point.

Consider the following example. Suppose that the cost of the restructuring plan is 120 . With this expenditure, the firm comes back to viability. Also suppose that once the company is restructured, it will generate income whose net present value for the owners is 100 . This means that they should invest at maximum not more than 100. If they invest more than 100, the return on their investment will fall below the cost of the new capital [i.e. they could earn a higher return by investing elsewhere]. If the government wants to keep this company afloat because its closure will cause significant social upheaval in its area, then it must give aid of at least 20. Indeed, most restructuring cases are based on similar calculations.

Nonetheless, aid may be unnecessary in the following circumstances. Assume that the owners have past obligations towards their workforce. In case of closure they are obliged to pay compensation for laying off workers. In addition, closure may require decommissioning of plants and cleaning up of the sites occupied by the factories of the company. Assume that these closure costs amount to 15 . This implies that since the owners would be 15 worse off if the company would close down, their net costs of investing in keeping the company as a going concern is not 100 , but 85 . Therefore, an aid package of 20 is 15 too much. The owners would be satisfied with aid of just 5. If the closure costs would exceed 20, then no aid would be needed at all to persuade the owners to invest to save the company.

This is just one example that demonstrates that (a) sometimes aid may be unnecessary and that (b) it is difficult to calculate the truly necessary amount of aid because it requires knowledge of how the recipients would behave without aid.

In fact the problem facing the aid granting authority is even more complicated. In the example above it was simply assumed that the purpose 


\section{Chapter 7}

of the aid was to encourage the owners of the company to keep it afloat. But the public authority is not just interested in rescuing companies. It is interested in minimising the social impact from company closure. This social impact presumably can be quantified.

Therefore, the amount of state aid that should be granted is not just what is necessary to induce the owners to make further investments. It should also not exceed the value of the social costs it prevents. Otherwise, it would be better to spend the money directly on the workers who are made unemployed. An example will clarify this point.

As before we assume that the total cost of restructuring is 120 and that the requested aid is 20 . If the social costs from the company closure exceed 20, then the public authority should grant the aid. If the social costs are less than 20 , then the public authority would save money [which presumably can invest more productively elsewhere] by not granting the aid and still compensate unemployed workers. In this situation the aid is inefficient.

\subsection{Conclusions}

The economic justification for state aid is the correction of market failure. However, a number of qualifications have to be made in this respect. First, market failure is a necessary, but not sufficient condition. Second, the costs of government intervention to correct market failure may outweigh any benefits. These costs include the cost of distortion to competition, the cost of taxation for raising subsidies, and the cost of administering the disbursement of subsidies. Third, the aid-granting authorities are always at a disadvantage in relation to aid recipients because they do not know the real costs of the latter and above all cannot know what the recipients would have done in the absence of aid.

An economic approach to assessing state aid also suggests that supranational control of aid is necessary only when such aid affects cross-border competition. Current state aid rules of the EC have a wider reach because of the broad interpretation of the concept of effect of trade. This means that Community resources are "wasted" in controlling cases that have little if any impact on cross-border competition and on firms in other countries. 
But the biggest challenges for supranational control of state aid are, first, to balance the effects of aid in one country against the effects in other countries and, second, to determine the extent to which a supranational institution such as the Commission should coordinate national aid. A more economic approach which would modulate the size of permissible aid according to the degree of market failure would significantly address both of these challenges. $^{125}$

${ }^{125}$ L. Hancher, Towards an economic analysis of State aids, European State Aid law - Quarterly, Volume 4 No. 3 2005, P. Nicolaides, Puzzles of State Aid: structural funds, cumulation and state aids, European State Aid law-Quarterly, Volume 4 No. 32005 . 


\section{Chapter 8}

Compatibility of State Aid and the Balancing Test:

Its Role in the Architecture of the System of State Aid Control

\subsection{Introduction}

One of the objectives of the State Aid Action Plan is to introduce a refined economic analysis of state aid. The purpose of this chapter is to consider how the balancing test fits in the architecture of state aid control.

The "refined economic analysis" of the SAAP is embodied in a so-called "balancing test" which has been elaborated in the draft R\&D\&I Framework and the Guidelines on Risk Capital in SMEs. The balancing test consists of three stages, each answering the following respective questions:

1. Is the aid measure aimed at a well-defined objective of common interest? For state aid to be exempted it must pursue one of the policy objectives which are defined in Article 87(3) [or (2)].

2. Is the aid well designed to deliver the objective of common interest; i.e. does the proposed aid address the market failure or other objective? This in turn is broken down into three subsidiary questions:

i. Is state aid an appropriate policy instrument? There may be other instruments that do not involve subsidies and which are equally good or even better at achieving the desired policy objectives.

ii. Is there an incentive effect; i.e. does the aid change the behaviour of firms? For aid to be exempted it must be capable of inducing firms to do things they would not otherwise do without government intervention.

iii. Is the aid measure proportional; i.e. could the same change in behaviour be obtained with less aid? 
3. Are the distortions of competition and effect on trade limited, so that the overall balance is positive? Even if the aid is appropriate and proportional, it may still generate significant distortions of competition that may harm other member states. These harmful effects have to be taken into account.

The balancing test adopted by the Commission has been criticised for a number of reasons: legal [primarily that Article 87(3) supposedly does not allow for this kind of analysis], economic [primarily that the test is too narrow] and procedural [primarily that the complexity of the test reduces legal certainty].

Addressing the first two criticisms is outside the scope of this chapter. Given that the purpose of this chapter is to appraise the role of the balancing test in the system of state aid control, the third criticism has to be considered at the outset.

Any test that is not applied mechanically is bound to raise uncertainty. This is even more so where the test does not depend on procedural criteria but on an assessment whose results are not known in advance. However, this is not necessarily a negative development. Legal certainty is not the only concern in state aid control, nor the most important one. The most important concern is to prevent distortion of trade and competition. Certainly, it is desirable that prevention of distortion of competition can be achieved with procedures that afford a high level of legal certainty to national authorities and undertakings. At the same time, however, a small reduction of legal certainty for the sake of avoiding misallocation of resources is a trade-off worth making.

The criticism about the complexity of the test is also largely misplaced. Attempting to remedy market failure through state aid is a difficult task. The public authority that grants the aid must somehow be able to predict the behaviour of market players. In essence, it asks how they are likely to behave with and without government intervention. Since these are two alternative states of the world, if one occurs, the other necessarily does not. The alternative state can never be known with absolute certainty. Moreover, there is a degree of endogeneity in government intervention because market players lobby in favour or against it and because they react accordingly. 


\section{Chapter 8}

Refusing to acknowledge these difficulties which are inherent in public policy and criticising the complexity of the balancing test is the policy equivalent of hiding one's head into the sand. If assessing the impact of state aid is as difficult as critics claim, then they must explain why it is legitimate for governments to grant aid without actually knowing what its impact may be and whether it will achieve its objectives. The argument that the economic assessment of state aid is difficult is more of an indictment of the laxity and ineffectiveness of current procedures. However, as is argued in this chapter, there can be improvement in the way that the test is applied so that it fits better in the architecture of the system of state aid control.

The chapter first reviews how the test has been elaborated in the R\&D\&I Framework, the Risk Capital Guidelines and the draft Environmental Guidelines. Indeed it is important to understand how it has been elaborated because it is the only way to form an opinion about how tough or easy the test is likely to be. This is because one of the aims of the SAAP is to "reduce and better target" state aid and because in broader terms an objective of the system of state aid control in the EC is to guide member states to design state aid measures that are likely to be approved by the Commission. After that, the chapter reviews some recent cases where the Commission applied the balancing test. The chapter concludes with an evaluation of its likely contribution to the system of state aid control and how it may be improved so that its role can be strengthened.

\subsection{The balancing test in state aid for $R \& D \& I^{126}$}

Not all aid cases of state aid to R\&D\&I will be subject to the balancing test. It is assumed that for most cases, compliance with the criteria and ceilings laid down in the Framework [and a future block-exemption regulation] will also satisfy the conditions of the test. This means that, in practice, most aid granted to SMEs or for research far removed from the market will not have to undergo the balancing test. Aid will be subject to a more detail assessment only when it exceeds certain thresholds.

\footnotetext{
${ }^{126}$ Accessed at

http://ec.europa.eu/comm/competition/state_aid/others/action_plan/rdi_frame_en.pd f
} 

of the System of State Aid Control

In addition, degree of the Commission's assessment will be proportional to the risk of distortion of competition. This means that the detailed assessment will not necessarily require that all the criteria be verified; the scope of the analysis will depend on the nature of each case.

The starting point of the balancing test is the identification of market failure that hampers R\&D\&I. The Commission expects proof of knowledge spillovers, imperfect and asymmetric information or coordination failures. Member states can illustrate the existence of market failure through benchmarking showing that other regions, markets or sectors experience higher levels of R\&D\&I. To show that state aid is an appropriate instrument, the Commission wants proof of the advantages of using a selective instrument such as state aid over other possible policy responses.

The next important step is to determine whether the aid has an incentive effect. The Commission considers that as a result of aid, R\&D\&I activity should be increased in size, scope, amount spent or speed. Where aid is granted to large firms or when the aid is closer to the market raising more competition concerns, the incentive effect will have to be identified by counterfactual analysis, comparing the levels of intended activity with aid and without aid.

At the same time, aid must be proportional; i.e. even if aid is necessary and has an incentive effect, it must not exceed the minimum amount required to carry out the R\&D in question or it must not result in excessive distortion of competition. The amount of required aid is linked to the degree of market failure.

The essence of the balancing test is that the negative effects of aid (distortion of competition) must be limited. These effects can be categorized in the following:

i. Disruption of the dynamic incentives of undertakings and crowding out of private investment.

ii. Support of inefficient production.

iii. Encouragement of exclusionary practices and enhancement of market power.

iv. Impact on trade flows between member states. 


\section{Chapter 8}

There are three distinct ways in which R\&D\&I aid can distort competition in product markets:

i. R\&D\&I aid can distort the dynamic incentives of market players to invest (crowding out effect). In its analysis, the Commission takes into consideration the following elements:

i. Aid amount. The significance of the aid amount will be measured with reference to total private $R \& D$ expenditure in the sector, and the amount spent by the main players.

ii. Closeness to the market / category of the aid

iii. Open selection process

iv. Exit barriers

v. Incentives to compete for a future market

vi. Product differentiation and intensity of competition.

ii. R\&D\&I aid can create or maintain positions of market power. The Commission is unlikely to identify competition concerns related to market power in markets where each aid beneficiary has a market share below $25 \%$ [still to be confirmed] and in markets having a market concentration with Herfindahl-Hirschman Index (HHI) below 2000 [still to be confirmed]. In its analysis, the Commission takes into consideration the following elements:

i. Market power of aid beneficiary and market structure.

ii. Level of entry barriers.

iii. Buyer power.

iv. Selection process.

iii. R\&D\&I aid can maintain an inefficient market structure. The Commission considers whether the aid is granted in markets featuring overcapacity, in declining industries or in sensitive sectors.

Once the foreseeable positive and negative impacts of the state aid are identified, the final step is to compare them. For this purpose the Commission has said that it will not use the criteria set out above mechanically but will make an overall assessment based on the proportionality principle. It will attach different weights to the different criteria depending on the facts of each case. 

of the System of State Aid Control

\subsection{The balancing test in state aid for Risk Capital ${ }^{127}$}

As in the case of aid to R\&D\&I, the measures that fall below the thresholds defined in the Guidelines are presumed to satisfy the compatibility test. A more detailed compatibility assessment will be necessary for risk capital measures which do not satisfy all the conditions laid down in the Guidelines, notably investments exceeding EUR 1.5 million. The analysis of compatibility of the measures will be based on a number of positive and negative elements. No single element is determinant, nor can any set of elements be regarded as sufficient on its own to ensure compatibility.

The Commission considers that there is no general risk capital market failure in the Community. It does, however, accept that there are market gaps for some types of investments at certain stages of enterprises' development. These gaps result from an imperfect matching of supply and demand of risk capital and can generally be described as an equity gap.

The Commission considers that the main source of market failure relevant to risk capital markets, which particularly affects access to capital by SMEs and companies at the early stages of their development and which may justify public intervention, relates to imperfect or asymmetric information.

Imperfect or asymmetric information may result notably in:

i. Transaction and agency costs: potential investors face more difficulties in gathering reliable information on the business prospects of an SME.

ii. Risk aversion: investors may become more reluctant to provide risk capital to SMEs.

Evidence of market failure must be based on a study showing the level of the equity gap with regard to the enterprises and sectors targeted by the risk capital measure. The relevant information concerns the supply of risk capital and the fundraising capital, as well as the significance of the venture capital industry in the local economy. The evidence could also include the following elements:

\footnotetext{
${ }^{127}$ Accessed at

http://ec.europa.eu/comm/competition/state_aid/others/risk_capital_guidelines_en.p df
} 


\section{Chapter 8}

(a) development of the fundraising over the past five years, also in comparison with the correspondent national and/or European averages;

(b) the current overhang of money;

(c) the share of government aided investment programs in the total venture capital investment over the preceding three to five years;

(d) the percentage of new start-ups receiving venture capital;

(e) the distribution of investments by categories of amount of investment;

(f) a comparison of the number of business plans presented with the number of investments made by segment (amount of investment, sector, round of financing, etc.).

The Commission considers that state aid to risk capital measures may constitute an appropriate instrument within the limits and conditions set out in these guidelines. However, risk capital provision is essentially a commercial activity involving commercial decisions. In this context, more general structural measures not constituting state aid may also contribute to an increase in the provision of risk capital, such as promoting a culture of entrepreneurship, introducing a more neutral taxation of the different forms of SME financing (for example new equity, retained earnings and debt), fostering market integration, and easing regulatory constraints.

Where member states have considered other policy options and the advantages of using a selective instrument such as state aid have been established and submitted to the Commission, the measures concerned are considered to constitute an appropriate instrument.

State aid for risk capital must result in a net increase in the availability of risk capital to SMEs, in particular by leveraging investments by private investors. The lack of incentive effect means that some enterprises funded through publicly supported measures would have obtained finance on the same terms even in the absence of state aid (crowding out). The Commission considers that aid in the form of risk capital satisfying the conditions laid down in these guidelines ensures the presence of an incentive effect. The need to provide incentives depends on the size of the market failure related to the different types of measures and beneficiaries. Therefore different criteria are expressed in terms of size of investment tranches per target enterprise, degree of involvement of private investors, and consideration of notably the size of the company and the business stage financed. 

of the System of State Aid Control

Therefore, the Commission will also take into account the following additional criteria showing the profit-driven character of investment decisions and the commercial management of the measure, where relevant:

i. Commercial management.

ii. Presence of an investment committee.

iii. Size of the measure/fund [the budget for investments into target SMEs should be of a sufficient size to take advantage of economies of scale in administering a fund and the possibility of diversifying risk via a pool of a sufficient number of investments].

iv. Presence of business angels.

The need to provide incentives depends on the size of the market failure related to the different types of measures, beneficiaries and development stage of the SMEs. A risk capital measure is well-designed if the aid is necessary in all its elements to create the incentives to provide equity to SMEs in their seed, start-up and early stages. State aid will be inefficient if it goes beyond what is needed to induce more risk capital provision. In particular, to ensure that aid is limited to the minimum, it is crucial that there is significant private participation and that the investments are profit-driven and are managed on a commercial basis.

The Commission will consider that the following elements positively influence the assessment of proportionality as they represent a best-practice approach:

i. Open tender for managers.

ii. Call for tender or public invitation to investors.

When deciding whether to authorise the grant of public funds for measures designed to promote risk capital, the Commission will seek to limit as far as possible the following categories of risk:

i. The risk of crowding out: The presence of publicly supported measures may discourage other potential investors from providing capital. This could, over the longer term, further discourage private investment in young SMEs and thus end up widening the equity gap, while at the same time creating the need for additional public funding.

ii. The risk that advantages to the investors and/or investment funds create an undue distortion of competition in the venture capital market relative to their competitors that do not receive the same advantages. 


\section{Chapter 8}

iii. The risk that an oversupply of public risk capital for target enterprises not invested according to a commercial logic could help inefficient firms stay afloat and could cause an artificial inflation of their valuations, making it all the less attractive for private investors to supply risk capital to these firms.

\subsection{The balancing test in state aid for environmental protection ${ }^{128,129}$}

The positive effects of environmental aid depend on the following factors.

Existence of a market failure

The Commission will in general not question that there are negative externalities related to environmental protection, but verify whether the State aid measure has a substantial impact on environmental protection.

Appropriate Instrument

In its compatibility analysis, the Commission will in particular take account of any impact assessment of the proposed measure which the Member State may have made, including considerations of using other policy options than State aid, and take account of justifications that the polluter-pays principle (PPP) will be respected.

Incentive effect and necessity of aid

Aid cannot be considered necessary solely because the level of environmental protection is increased. The advantages of new investments or production methods are normally not limited to their environmental effects.

In addition to the calculation of extra costs, the Commission will take account of the following elements in its analysis:

a) Expected change: At least one of the following elements must be demonstrated, taking into account the normal behaviour of an undertaking in the sector concerned:

${ }^{128}$ Draft Community guidelines for State aid for environmental protection - 10 May 2007. Accessed at:

http://ec.europa.eu/competition/state_aid/reform/guidelines_environment_en.pdf

${ }^{129}$ For ease of presentation, I ignore here that part of the explanation of how the balancing test may be applied to tax exemptions. 

of the System of State Aid Control

i) Increase in scope: reduction of a specific type of pollution that would not be reduced without the aid;

ii) Increase in size: reduction of a specific type of pollution to a further extent due to the aid;

iii) Increase in speed: reduction in pollution starting at an earlier point in time due to the aid.

b) Production advantages: If there are other advantages linked to the investment in terms of increased capacity, productivity, cost reductions or quality, the incentive effect is normally lower.

c) Advantages linked to image: Indications that the undertaking or the relevant sector can benefit from advantages linked to a better environmental image will normally reduce the incentive effect.

d) Advantages linked to the labelling of production method: If undertakings in the industry/sector concerned are able to differentiate environmentally friendly products from conventional products and thereby set higher prices for the environmentally friendly products, the incentive effect of aid is normally lower.

e) Possible future mandatory standards: If there are negotiations at Community level to introduce (higher) mandatory standards which the measure concerned would seek to target, the incentive effect of aid is normally lower.

f) Level of risk: If there is a particular risk that the investment will be less productive than expected, the incentive effect of aid will normally be higher.

g) Level of profitability: If the level of profitability of the action pursued is negative over the time horizon by which the investment is fully depreciated or the operating aid is intended to be in force, taking account of all the advantages and risks identified in this point, aid will normally have an incentive effect.

\section{Proportionality of the aid}

The Member State should provide evidence that the aid is necessary, the amount is kept to the minimum and that the selection process is proportional. In its analysis the Commission will consider the following elements:

a) Selection process: the selection process should be conducted in a nondiscriminatory, transparent and open manner, without unnecessarily exclude companies that may compete with projects to address the same environmental objective. The selection process should lead to the selection of beneficiaries that can address the environmental objective using the least amount of aid or in the most cost-effective way. 


\section{Chapter 8}

b) Aid limited to the minimum: Member States shall demonstrate that the aid intensity which is linked to the calculation of extra costs does not lead to an aid amount exceeding the expected lack of profitability when taking into account all the advantages and risks.

Analysis of the distortion of competition and trade

If the aid is proportional, notably if the calculation of the extra investment or operating costs has taken into account all advantages to the undertaking, the negative impact of the aid is likely to be limited. However, a profit-seeking undertaking will normally only increase the level of environmental protection beyond mandatory requirements if it considers that this will result at least marginally in some sort of advantage for the undertaking.

Dynamic incentives/crowding out

State aid for environmental protection may have as a result that aid beneficiaries refrain from investing in environmentally-friendly technologies beyond regulatory standards and simply wait for the State to intervene.

In its analysis, the Commission will consider the following elements:

a) amount of aid: The higher the amount of aid, the more likely it is that part of the aid can be used to distort competition. This is in particular the case if the aid amount is high compared to the size of the general activity of the beneficiary.

b) frequency of aid: If an undertaking receives aid repetitively, it is more likely that this will distort dynamic incentives.

c) duration of the aid: If operating aid is granted for a long period, this is more likely to distort competition.

d) gradual decrease of aid: If operating aid is reduced over time, the undertaking will have an incentive to improve efficiency; therefore, the distortion of dynamic incentives will be reduced over time.

e) readiness to meet future standards: , if the aid will enable the undertaking concerned to meet new Community standards expected to be adopted in the foreseeable future, the aided investment will reduce the costs of investments that the undertaking would have had to make in any event.

f) level of the regulatory standards and/or taxation in relation to the environmental objectives: the lower the level of mandatory requirements, the higher is the risk that aid to go beyond mandatory requirements is not necessary and will crowd out investments or be used in a way that distorts dynamic incentives. 

of the System of State Aid Control

g) risk of cross-subsidisation: Where the undertaking produces a wide range of products or produces the same product using a conventional and an environmentally friendly process, the risk of cross-subsidisation is higher.

h) technological neutrality: Where a measure focuses on one technology only, the risk of distorting dynamic incentives is higher.

Maintaining inefficient firms afloat

State aid for environmental protection may be justified as a transitory mechanism to move towards a full allocation of environmental negative externalities. It should not be used to grant unnecessary support to undertakings, which are unable to adapt to more environmentally friendly standards and technologies because of their low levels of efficiency.

In its analysis, the Commission will consider the following elements:

a) nature and type of beneficiaries: Where the beneficiary has a relatively low level of productivity and is in poor financial health, it is more likely that the aid will contribute to artificially maintaining the undertaking in the market.

b) overcapacity in the sector targeted by the aid: In sectors where there is overcapacity, investment aid risks to sustain the overcapacity and maintain inefficient market structures.

c) normal behaviour in the sector targeted by the aid: If other undertakings in the sector have reached the same level of environmental protection without aid, it is more likely that the aid will serve to maintain inefficient firms in the market.

d) level of mandatory standards: If there are no standards or if the mandatory standards are relatively low compared to the actual level of environmental protection, there is a higher risk that the aid will generate or maintain inefficiencies.

e) duration of the aid: The longer the duration of the aid, the higher is the risk that the aid will serve to maintain inefficient undertakings in the market.

f) investment costs or aid amount in form of tax reduction/exemption in proportion of the beneficiary's turnover: the higher the cost, or the aid amount, compared to the activity of the beneficiary, the more likely it is that the aid will lead to inefficiencies.

Market power/exclusionary behaviour

The Commission will assess the market power of the beneficiary concerned before the aid is granted, and the change in market power which can be 


\section{Chapter 8}

expected as a result of the aid. Aid for environmental protection given to a beneficiary with substantial market power may be used by this beneficiary to strengthen or maintain its market power, by further differentiating its products or excluding rivals. The Commission is unlikely to identify competition concerns related to market power in markets where each aid beneficiary has a market share below $25 \%$ and in markets having a market concentration with Herfindahl-Hirschman Index (HHI) below 2000.

In its analysis, the Commission will consider the following elements:

a) Market power of aid beneficiary and market structure: Where the recipient is already dominant on the affected market, the aid measure may reinforce this dominance by further weakening the competitive constraint that competitors can exert on the recipient undertaking.

b) New entry: where the aid concerns product markets or technologies that compete with products where the aid recipient is an incumbent and has market power, the aid may be used strategically to prevent new entry or substitution towards more environmentally friendly products offered by competitors.

c) Product differentiation and price discrimination: the aid may have as a negative effect to facilitate product differentiation and price discrimination by the aid recipient, to the detriment of consumers.

d) Buyer power: The market power of an undertaking may be limited by the market position of the buyers. The presence of strong buyers can serve to counter a finding of market power if it is likely that the buyers will seek to preserve sufficient competition in the market.

e) Selection process: Aid measures which allow undertakings with market power to influence the selection process, such as by having the right to recommend undertakings in the selection process or influencing the environmental project in a way which disfavours alternative projects on unjustified grounds, are liable to raise the Commission's concern.

f) Conditions of competition in the affected markets and importance of price competition between the various competitors: the more competition is based on price, the greater the risk that it is affected by aid in form of tax reduction/exemptions. If by contrast, products are highly differentiated and competition is not primarily based on price, the impact of the aid in form of tax reduction/exemption is likely to be less important. 

of the System of State Aid Control

Effects on trade and location

State aid for environmental protection may result in some territories benefiting from more favourable production conditions, notably due to comparatively lower production costs as a result of the aid, or due to higher production standards achieved through the aid. This may result in companies re-locating to the aided territories, or to displacement of trade flows towards the aided area.

Balancing and decision

In the light of these positive and negative elements, the Commission will balance the effects of the measure and determines whether the resulting distortions adversely affect trading conditions to an extent contrary to the common interest.

The Commission may raise no objections to the notified aid measure without entering into the formal investigation procedure or, following the formal investigation procedure laid down in Article 6 of Regulation (EC) No 659/1999, decide to close the procedure with a decision according to Article 7 of that regulation. Where it takes a conditional decision within the meaning of Article 7(4) of that regulation, it may for instance consider attaching the following conditions, which must reduce the resulting distortions or effect on trade and be proportionate:

a) Lower aid intensities than the maximum intensities allowed or lower level of tax reduction.

b) Separation of accounts in order to avoid cross-subsidization from one market to another market, when the beneficiary is active in multiple markets.

c) Additional requirements to improve the environmental effect of the agreements concluded as counterpart for tax reduction.

d) No discrimination against other potential beneficiaries (reduce selectivity).

It is worth pointing out that the balancing test in the environmental guidelines, which is the most recent, is significantly more elaborate than the previous applications to $R \& D \& I$ and risk capital. This probably reflects the complaints voiced by member states that the Commission had not given them sufficient guidance on how to comply with the balancing test. 


\section{Chapter 8}

\subsection{Applications of the balancing test}

First of all it is necessary to remark on an apparently ignored aspect of the balancing test. That is the fact that the test is not really new. The Commission has always used a version of the balancing test to assess state aid granted outside any of the regulations and guidelines. It has had to base its assessment directly on Article 87(3)(c). This Article has always required that exempted aid is shown to have incentive effect, that it is proportional and that it is in the common interest. The only difference between the practice of the Commission until 2005 and the practice since the publication of the SAAP in 2005 is that now there are more detailed and explicit criteria which also serve to help member states design aid measures that can be exempted by the Commission.

During the past few years the Commission has systematically applied the balancing test to numerous cases concerning aid to the construction and operation of broadband networks. ${ }^{130}$ In all cases but one it has found aid to be in the common interest [for promoting Lisbon objectives] and necessary [because private operators tend not to supply broadband services in rural areas due to the high costs of building networks in sparsely populated areas]. Given that public contracts for the construction and/or operation of such networks are in most cases awarded following public procurement procedures, the Commission normally finds that competitive tendering minimises the amount of state aid and therefore fulfils the criterion of proportionality. As far as distortion of competition is concerned, the construction of networks in rural areas promotes rather that weakens competition, so the Commission also finds that the distortion of competition is minimal.

In this connection, it is worth noting the differences in the Commission's analysis of the impact on competition in Article 87(1) and Article 87(3)(c). In the view of the Commission, public funding of broadband networks

${ }^{130}$ See Monika Hencsey et al, State Aid Rules and Public Funding of Broadband, Competition Policy Newsletter, 2005, no. 1, pp. 8-15; Lambros Papadias et al, Public Funding for Broadband Networks - Recent Developments, Competition Policy Newsletter, 2006, no. 3, pp. 13-18. 

of the System of State Aid Control

normally constitutes state aid because, among other things, state intervention confers an advantage to the network operators causing a distortion of competition in the meaning of Article 87(1). However, the Commission also finds that in the case of networks in rural areas, the expansion of supply of broadband services strengthens competition so there is no undue distortion in the meaning of Article 87(3)(c).

The one case where the Commission concluded that aid to broadband did not satisfy the criteria of the balancing test and therefore was declared to be incompatible with the common market concerned the Dutch city of Appingedam. In case C 35/2005, the Commission examined municipal funding for the expansion of the town's network. It found that the measure lacked incentive effect because the market already provided significant amount of services. The aid was not necessary and was banned.

Outside the broadband cases, the balancing test resulted in negative decisions in two instances. In the case concerning the introduction of digital terrestrial tv in Berlin-Brandenburg, the Commission concluded in Decision $2006 / 513$ that aid was not an appropriate instrument. The issue was prompt switch from analogue to digital tv and this caused a coordination problem between broadcasters. The Commission's view was that the coordination problem could be better resolved through regulatory measures that would manage both the timing of the switch and the frequency spectrum that would be released. Moreover, given the existence of rife competition between different platforms, the Commission found that aid channelled to certain broadcasters would distort competition in favour of specific technologies without economic or scientific justification. The measure was banned.

Another similar case concerned Italian funding of digital decoders to boost demand for digital tv so that terrestrial broadcasters would switch from analogue to digital signals. In its Decision 2007/374, the Commission prohibited the measure because it failed the balancing test. The aid was not an appropriate instrument because, just like in the Berlin case, regulatory intervention could address more effectively the coordination issue. More importantly, by limiting the beneficiaries to terrestrial broadcasters, the Italian authorities caused undue distortion of competition. Cable and satellite broadcasters were unjustifiably excluded. 


\section{Chapter 8}

In all three cases the Commission reached its negative conclusion without having to carry out a quantitative economic assessment of the costs and benefits of those measures.

\subsection{Purpose of state aid control}

To appreciate the role of the balancing test in the architecture of state aid control in the EC, it is first necessary to define the aims of that control. I believe it has two broad aims. The first is to support the achievement of a truly integrated internal market; i.e. to prevent distortions to trade and competition. It protects the interests of competitors who do not receive state aid. Since neither the Treaty, nor economic theory require an absolute prohibition of state aid, its control has to be selective. Indeed the role of the Commission is to determine the kinds of aid that are compatible with the objectives and criteria laid down in the Treaty.

The second aim of the system of state aid control is to guide member states to design their policies and state aid measures in such a way so that the Commission will be in a position to approve them. The results of this guidance are to afford a reasonable degree of legal certainty both to national authorities and undertakings and to prevent waste of administrative resources.

It has been suggested that the cost of designing and implementing state aid measures for public authorities represents about $5 \%$ of the amount of state aid granted. ${ }^{131}$ Another 5\% is spent by undertakings in applying for state aid and complying with the conditions imposed by the Community and national authorities. These are significant amounts and indicate that the value of that guidance has to be seriously taken into account by any assessment of the system of state aid control.

${ }^{131}$ See the assessment of regional subsidies in the report by the National Audit Office, Regional Grants in England, (London: Stationery Office, 2003). 


\subsection{Evaluation}

The balancing test begins by asking whether aid has a legitimate purpose. This is absolutely correct because if aid is not intended to remedy some kind of market failure or promote some other kind of well-defined policy objective then there is hardly any justification for the government to intervene in the economy. And if the government intervenes without any well-defined purpose, then it is likely that the intervention is motivated by short-term political objectives of doubtful value for the long-term interests of the economy as a whole.

In this connection, it should be noted, however, that the balancing test is quite accommodating. The test uses a broad criterion because it refers to "policy objectives of common interest". The reason is that aid which is exempted under Article 87(3) may serve objectives other than the remedying of market failure. However, in the R\&D\&I Framework and the Risk Capital Guidelines the emphasis is, correctly, on market failure because it is not possible or efficient to attempt to raise R\&D\&I or encourage investment of risk capital in SMEs by giving aid, for example, to employment, and vice versa.

The next step of the balancing test is to ask whether state aid is an appropriate instrument. Although this is a legitimate question it should not necessarily form the second step of the test. Priority should have been given to another question - whether there is a significant impact on competition and cross-border trade. Since state aid control in the EU is intended to protect the uninterrupted functioning of the internal market, the interests of the other member states and those of the Community in general, it makes sense to have a "filter" to identify the most problematic cases for the common interest.

In fact, this consideration could be taken a step further. This kind of filter should operate at the very first stage of economic analysis of state aid. Aid that is granted only to companies with insignificant market share or which are unlikely to engage in cross-border trade, should not be subject to Community scrutiny, irrespective of whether that aid is granted for a legitimate objective or not or whether it constitutes an appropriate policy 


\section{Chapter 8}

instrument or not. If member states waste their public money on ineffectual policy instruments it is their problem as long as they do not cause any negative cross-border spillovers.

There is another, probably more important, reason why I believe that the balancing test should start with well-defined thresholds to determine cases of Community concern. The reason is that markets hardly ever function perfectly. This does not mean that government intervention is always legitimate. On the contrary, it reveals the magnitude of the difficulty of designing intelligent public policies. But the point here is that if member states will have to prove market failure, it will be rather easy for them to do so. In this respect, the balancing test does not really impose any onerous burden on member states, nor will it result in rejections of any significant number of state aid measures.

The same consideration applies to whether state aid is an appropriate instrument and whether it has an incentive effect. The Economic Advisory Group on Competition Policy, in their commentary on the R\&D\&I Framework, observe that there many other things that government can do besides granting aid, such as improving scientific training. ${ }^{132}$ The Commission also identifies a number of alternative policy responses to market failure such as strengthening the culture of entrepreneurship. In principle, these views are valid. But this kind of measures take time to design, implement and gestate. I believe that member states will have little difficulty arguing that the state aid they wish to grant is an appropriate instrument for generating short-term results given its immediate impact on market players.

With respect to the incentive affect, it is clear that aid lacks such an effect whenever it is granted after the project starts or the investment takes place or when it aims to subsidise the every day operations of beneficiary firms, including their normal product development activities. In other cases, applicant firms are unlikely to have difficulty showing that their planned investment cannot be profitable without aid. This is simply because they can

132 EAGCP, Commentary on the European Commission's Draft Community Framework for State Aid for Research, Development and Innovation, 3 July 2006. Accessed at http://ec.europa.eu/comm/dgs/competition/eagcp.pdf 

of the System of State Aid Control

add costs to raise the quality of the product or can add time to the minimum length of time that is needed for a project to be completed or can identify all sorts of risks ranging from competitors' reaction to technological changes.

My conclusion is that proof of market failure, the appropriateness of state aid and incentive effects will be rather easy obstacles for member states to surmount. They will not be decisive in rejecting proposed state aid measures. Therefore, they should be given less significance and should be at a later stage of the test. Again, if member states want to grant poorly designed state aid, it is their problem as long as they do not impose any burden on the rest of the Community. Therefore, more attention should be given at the outset to defining thresholds that identify cases where there is serious Community concern.

After determining the necessity and proportionality of aid, the balancing test seeks to assess the trade and competition impact of aid. They all look at factors such as market shares, the degree of market concentration, the existence of entry barriers, the extent of product differentiation, etc.

The Commission in its balancing test is explicit that the specific weights that will be attached to the various factors will change from case to case. This leaves national authorities with considerable degree of uncertainty as to whether the aid under investigation can be approved or not. This is a different uncertainty than that which emanates from the ex ante unknown outcome of the competition assessment and which depends on market conditions which are external to the assessor, i.e. the Commission. Here the uncertainty is caused by the subjective use of different weights by the assessor. Perhaps it is impossible to define with any precision before hand the relative importance that the Commission will attach to the various factors. But as it has done in the case of Article 81(3), it should provide examples that can illuminate its policy preferences and make its approach more transparent.

It is instructive that the latest elaboration of the balancing test in the draft environmental guidelines is so more detailed about the various factors that will be taken into account in the assessment of aid. This shows that the Commission is responsive to member state requests for more guidance and also that the Commission adds to the test as it gains experience from its use. 


\section{Chapter 8}

This experience, as revealed by the actual Commission decisions, is also instructive. Despite its name, in reality the "refined economic approach" or the "balancing test" does not perform either a fully fledged economic analysis or a weighting of the positive and negative effects of state aid. The three Commission decisions reviewed earlier demonstrate that the Commission follows in state aid the same approach as with Article 81(3). I have argued else where that in reality the enforcement of Article 81(3) is not based on true economic analysis. ${ }^{133}$ Rather the Commission puts the practice under investigation through a "screening" process and if the practice fails specific elements of that process, it declares the practice to fall within the prohibition of Article 81(1).

The same appears to happen with Article 87(3)(c). If a measure fails any of the factors that are deemed to be important, then the measure cannot be exempted. There appears to be no attempt to quantify the positive and negative elements of an aid measure and certainly no attempt to determine whether the net effects are positive or negative.

\subsection{Conclusion}

A more refined economic analysis of state aid is much needed in the system of state aid control of the EU. The Commission has adopted a test that purports to balance out the positive and negative effects of state aid.

This test will contribute to the control of distorting aid not by asking whether state aid is a well-designed policy but by offering guidance to member states on the kinds of aid that are more likely to harm intra-Community

\footnotetext{
${ }^{133}$ P. Nicolaides, The Balancing Myth: The Economics of Article 81(1) \& (3), Legal Issues of Economic Integration, 2005, vol. 32(2), pp. 123-145. Further reading on this chapter: N. Tosics and N. Gaal, Public procurement and State aid control - the issue of economic advantage, Competition policy newsletter: $n r .3$ 2007, P. Nicolaides, Puzzles of State Aid: structural funds, cumulation and state aids, European State Aid law - Quarterly, Volume 4 No. 3 2005, A. Paczkowska Tomaszewska and K. Winiarski, Monitoring State aid in Poland, European State Aid law-Quarterly, Volume 5 No. 4 2006, C-D. Ehlermann and M. Goyette, The interface between EU state aid control and the WTO disciplines on subsidies, European State Aid law-Quarterly, Volume 5 No. 42006
} 
Compatibility of State Aid and the Balancing Test: Its Role in the Architecture of the System of State Aid Control

competition. For this purpose, more explicit thresholds of Community interest should be developed, the assessment of the impact of aid on competition should be elaborated and this assessment should come earlier in the test rather than last.

If the Commission does not elaborate further the procedure that will follow to assess the competition impact of state aid there will be a risk that member states will challenge before the Court of Justice every negative decision of the Commission. Indeed the Court has acknowledged that the Commission enjoys wider discretion in applying Article 87(3) than 87(1). However, the Court has also annulled a significant number of Commission decisions for failure to provide adequate reasoning.

The balancing test must be tough if it is to contribute to achievement of the SAAP aims. But a tough test must be transparent as well. In fact the screening approach that the Commission follows in practice is more transparent than a fully-fledged economic test. 
Chapter 9

\section{Chapter 9}

\section{The Balancing Test and Incentive Effect:}

Is State Aid Necessary when Investment Is Unnecessary?

\subsection{Introduction}

The prohibition of state aid by Article 87(1) is not absolute. State aid may be exempted when it is capable of inducing recipient undertakings to do something they would not normally do under conditions of free competition. In this way, undertakings can be induced to change their practices so that they facilitate the achievement of a particular public policy objective such as more research, training or environmental protection.

Therefore, in order for state aid to be exempted it must be shown to be necessary for the undertakings that receive it. These undertakings have to do something extra with the aid they receive. That "extra" must go beyond their normal practices. In other words, the aid must have an incentive effect.

With some exceptions, the European Commission has always regarded operating aid as lacking incentive effect. Only in poor or remote areas, and then only for finite periods of time, is operating aid considered to be necessary to induce companies to carry out investments or hire workers. ${ }^{134}$ Both the Commission and Community courts have repeatedly declared operating aid to distort competition "in principle" because it keeps companies artificially afloat by covering costs they should be able to cover themselves.

\footnotetext{
${ }^{134}$ An exception to rules that operating aid must be temporary and degressive is aid that is granted to remote regions (as defined in Article 299) and to offset transport costs.
} 


\section{The Balancing Test and Incentive Effect:Is State Aid Necessary when}

Investment Is Unnecessary?

The Commission also questioned the need for aid whenever it examined it directly on the basis of Article 87(3)(b), (c) or (d); i.e. aid granted outside any of the block exemption regulations and guidelines. This approach has been recently made more explicit and systematic in the so-called "balancing test" that was introduced by the State Aid Action Plan of 2005.

The purpose of this paper is twofold. First, it examines the application of that part of the balancing test that concerns the necessity of aid. It reviews the cases where the Commission found that there was no incentive effect and explains the reasons that led the Commission to that conclusion.

Second, it considers the meaning of incentive effect and the situations where it can be meaningfully applied to prevent the granting of unnecessary aid. The paper will argue that whether aid has an incentive effect or not depends on the time frame or context in which it is assessed. The implication of this argument is that the Commission may be implementing a too narrow understanding of incentive effect and therefore it may be overly strict.

The paper examines not just the reasoning directly linked to the incentive effect as defined in the balancing test, but also the factors that are assessed by the Commission in order to determine whether aid is an appropriate policy instrument and whether it addresses genuine market failure.

\subsection{Refined economic analysis and incentive effect}

The State Aid Action Plan has introduced, among other things, a "refined economic analysis" of state aid. This refined economic analysis is embodied in a so-called "balancing test" which has been elaborated in the R\&D\&I Framework, the Guidelines on Risk Capital for SMEs and the draft Environmental Guidelines. Demonstration of the incentive effect or the necessity of state aid is an intrinsic component of the balancing test and the refined economic analysis of state aid.

As put by the Commission in its decision ${ }^{135}$ concerning aid proposed to be granted by Belgium to GM Europe,

${ }^{135}$ Commission Decision 2007/612 on training aid to General Motors, paragraph 24. 


\section{Chapter 9}

“(...) an aid measure can be found compatible with the common market pursuant to Article 87(3)(c) of the EC Treaty only when it is necessary for the beneficiary to undertake the activity in question. The Commission notes that the necessity of the aid is a general compatibility criterion. Where the aid does not lead to additional activities being undertaken by the beneficiary that would have not been achieved by the market forces alone, the aid cannot be authorised. With regard to compatibility on the basis of Article 87(3)(c) of the EC Treaty, the aid does not 'facilitate' the development of economic activities if the company would have undertaken the supported activities in any event, and notably in the absence of aid."

\subsection{Review of recent cases}

The cases reviewed below are divided into three groups: (i) training aid; (ii) aid to stimulate the switch to digital television or the construction and operation of broadband networks; and (iii) R\&D aid. The review also includes references to recently launched investigations which, however, have not been concluded yet. For a summary of the cases, please see the Annex.

\subsubsection{State aid for training}

What makes these cases interesting is how the Commission has reinterpreted the current exemption Regulation 68/2001 on training aid. The Regulation in its various articles does not require that member states demonstrate the incentive effect of state aid. It does not even impose the condition which is found in many other documents that aid may only be granted if work on the aided project has not already started. The Regulation merely stipulates that large amounts of aid that exceed EUR 1 million are not exempted from the notification requirement and that they have to be individually notified to the Commission.

The Commission has recently taken a "tougher" view towards certain cases of training aid, mostly in the automobile sector, because it believes that it lacks incentive effect. It has justified this tougher approach on the basis of recital 10 of the Regulation according to which "in view of the fact that enterprises in the Community generally underinvest in the training of their workers, State aid might help to correct this market imperfection and therefore can be considered under certain conditions to be compatible with 
The Balancing Test and Incentive Effect:Is State Aid Necessary when Investment Is Unnecessary?

the common market". Recital 11 goes on to add that "State aid is limited to the minimum necessary to obtain the Community objective which market forces alone would not make possible."

Therefore, the Commission now interprets the Regulation as stipulating that training aid must aim to remedy a genuine market failure and that it must be limited to what companies themselves are not willing or capable of realising.

\section{Commission Decision 2007/612 on training aid to General Motors (Belgium)}

The Commission initiated the formal investigation procedure because "the aid did not seem to lead to additional activities by the beneficiary" and that it "appeared to have no positive effect, but to be only distortive".

Training linked to the launch of a new model is, according to the Commission, normally incurred by car makers since the launch of a new model is a normal activity in the car market. Even in the absence of aid, the training activities would have been undertaken by GM Europe.

In addition, aid supporting the extension of the press activities lacks incentive effect since "press-related training expenses are necessary for (increasing) the production of car parts, which is a normal activity in the automobile industry. Car parts constitute an important and indispensable input to the assembly plant, and represent a significant part of the cost of the car. Thus, it seems that the market forces alone would suffice to incite the company to incur the corresponding trainings expenses."

With regard to shifting activities to different locations, it appears that in the car industry, manufacturers with several plants assign the production of new models to that plant that can make them at the lowest cost which, ceteris paribus, is the plant that can obtain the largest subsidy. From this it can be inferred that, possibly with the exception of regional aid, transferring an activity from one plant or location to another does not prove that the activity in question is additional or extra to the normal operations of the company that seeks aid. Therefore, such a subsidy is not necessary and lacks incentive effect. 


\section{Chapter 9}

"As regards the verification of the necessity of training aid in the car industry, the Commission observes that, over the last year and a half, it has amassed evidence that some car manufacturers are putting their production plants in different Member States in competition with each other for the production of new models. Car makers compare several plants when they plan to launch a new product, then decide where to locate the production on the basis of total operation costs, which means all types of costs, including government support of any kind, training aid as well. This evolution seems to derive from the facts that large car manufacturers have production capacities in excess of demand and that the production lines have become more flexible. A plant can thereby accommodate the production of additional models more easily. In view of this economic reality, where competition between production plants is more intense, and in view of the resulting risk that certain training aid measures do not contribute to the objective of common interest laid down in recital 10 of Regulation (ECI No 68/2001 but simply constitute distortive operating aid, the Commission has to scrutinise more carefully the need for aid 'in order to ensure that State aid is limited to the minimum necessary to obtain the Community objective which market forces alone would not make possible' (recital 11 of the Regulation). Such assessment is even more justified in view of the current market situation in the motor vehicle sector, characterised by significant over-capacity within the EU, which persists due to the sluggish demand growth and the important productivity gains regularly achieved." (26)

"Since in the present case several plants have been put into competition, and therefore the aid may have been granted for other objectives than inciting the firm to undertake additional training activities, the Commission considers it necessary to verify the necessity of this aid." (28)

"The Commission observes, however, that the objective sought by the training aid Regulation is not - contrary to regional investment aid - to influence the choice of location of economic activities, but to remedy the underinvestment in training in the Community, as mentioned above." (37)

The Commission does not deny that training is necessary. On the contrary, it acknowledges that "the introduction of a new model on a production line can only be achieved successfully after a significant training of the workforce. In other words, important training activities are necessary to produce the new model. ... Consequently, once GM Europe has decided to produce this 
The Balancing Test and Incentive Effect:Is State Aid Necessary when Investment Is Unnecessary?

model, the training expenses become necessary to implement that business decision." (32-33)

Once the training becomes necessary, the aid becomes unnecessary. Furthermore, training expenses which have to be incurred for the launch of new models also constitute operating costs. The Commission concludes that "the corresponding aid does not lead to additional training, but covers normal operating expenses of the company, thereby reducing normal costs." (43) Operating aid in principle distorts competition and cannot be declared compatible with the common market.

Finally, what kind of aid can be deemed to be necessary? The answer is that the aid which is necessary is the aid which supports activities that are not necessary for the beneficiary company! "Not necessary" here means that the activities in question are not essential for the commercial survival or wellbeing of the company.

Training that appears to exceed the needs of the company, "cannot be concluded that it would have been undertaken in the absence of aid. In the absence of further elements proving the opposite, the Commission considers that State aid appears to be necessary for the training in question to be carried out." (47)

\section{Commission Decision 2006/938 on training aid for Ford Genk (Belgium)}

Belgium proposed to offer a grant to Ford Genk amounting to EUR $12,280,000$ for the period 2004-2006. Of this sum, 38\% was aid for general training, and $61 \%$ was for specific training.

The following costs were to be covered during on-the job-training:

- Lean organisation: Cost of the personnel in the team providing training in lean, flexible, and efficient production methods, in line with the new Ford Production System (FPS).

- Off-line personnel costs: Cost of the workforce during classroom training.

- Training enablers: Large, glass-enclosed rooms with areas for reading and socialising, containing notice boards for posting up production and quality information. Only the depreciation of these areas would be an 


\section{Chapter 9}

eligible cost for the period in question as long as they were used for training purposes.

- Personnel costs of the training department: Salaries of the employees in the company's training department who are working for this training programme.

- Cascading: The director of the plant calls a meeting of all the workforce three times a year in order to brief them on the implementation of Ford's 'lean organisation' system (FPS). Cost of the workforce during this meeting.

- Six Sigma: Expenditure arising from the personnel costs of the team providing training using the "DMAIC" method (define-measure-analyseimprove-control).

- Restructuring: In recent years Ford Europe has tried to adapt its production capacity to a stagnating level of demand. To this end, over the period December 2003 to April 2004, Ford Genk reorganised its production and 2,770 employees were laid off or offered early retirement. In order to guarantee continuity in production and quality, 279 experienced employees were asked to stay for some additional weeks or months to train their successors.

- Launch costs: Personnel cost of the "product coaches", i.e., the first workers involved in launching new models. They learn about the new product (construction, use of the new plant, process), and then transfer this knowledge to other workers.

- In addition, consultancy costs (provision of training services by eternal suppliers) were also included in the eligible costs.

The Commission examined the various categories of costs and came to the following conclusions.

Training enablers: The rooms are used for training activities. They are located within the plant and therefore do not constitute buildings. They can be considered as falling within the category of "tools and equipment" laid down in Regulation 68/2001.

Personnel costs of training department: "Large companies are more likely to have their own training department and therefore less prone to require the assistance of external counselling services. Furthermore, in order to be compatible with Article 87(3)(c) of the Treaty, the aid measure must be 


\section{The Balancing Test and Incentive Effect:Is State Aid Necessary when Investment Is Unnecessary?}

proportionate to the objective, and must not distort competition to an extent contrary to the common interest. In view of this, the Commission considers that excluding the costs arising from internal training departments from the scope of Article 4(7)(e) of Regulation 68/2001 would discriminate against the category of large enterprises. The Commission therefore accepts them as eligible expenditure."

The Commission, however, adjusted the aid intensity for aid that aimed to offset the costs of the training department. The Commission considered that guidance and counselling services were of the same nature (general/specific) as the training activities they refer to. Consequently, in order to avoid overcompensation of such guidance and counselling costs, the expenditure of the training department on training classified as "specific" or "general" must be subject to the same maximum aid intensity as the corresponding training activity. The costs of the training department will therefore be classified as "general" or "specific" in the same proportion as the "general" and "specific" training elements of the overall training project. In this case, taking the training activities for which the Commission authorises aid, this will result in $57.8 \%$ for general training and $42.2 \%$ for specific training.

Restructuring costs: When deciding to undertake restructuring, a company compares the present value of the expected reduction in costs in future periods with the costs of the restructuring. The expenditure for training employees who will occupy a new function following the restructuring is a normal and indispensable part of the restructuring costs. Indeed, once the company has decided to lay off a significant part of its staff, temporary training for the employees referred to above is indispensable for ensuring the continuity of production and quality. The company has no choice but to incur such training expenditure for the remaining workforce in order to replace the expertise that will be laid off. Consequently, the aid in question would simply subsidise the company's normally and indispensable restructuring costs, which would have been incurred anyway, even without aid. So this aid does not seem necessary and, in any event, it will not result in additional training.

Launch costs: "Over the last year the Commission has amassed evidence that some car manufacturers are putting their production plants in different Member States in competition with each other for the production of new models. Car makers compare several plants with a view to production of a 


\section{Chapter 9}

new product, then decide where to locate the production on the basis of total operating costs, which means all types of costs, including government support of any kind, training aid as well. In view of this economic reality, and in view of the resulting risk that certain training aid measures do not contribute to the objective of common interest laid down in recital 10 of Regulation 68/2001 but simply constitute distortive operating aid, the Commission has to scrutinise more carefully the need for aid in order to ensure that State aid is limited to the minimum necessary to obtain the Community objective which market forces alone would not make possible. Such assessment is even more justified in view of the current market situation in the motor vehicle sector, characterised by significant overcapacity."

"The Commission observes that in the car industry the production of a new model is necessary to maintain competitiveness. The launch of a new model is therefore a normal and regular feature of the car industry. In order to produce new models, car manufacturers need to train their workforce in the new techniques that will be adopted. The related training costs necessary for launching the new models are therefore normally incurred by car makers on the sole basis of market incentive. Consequently, the training activities in question would have been undertaken by the company in any event, even without aid. Training aid is not necessary in these circumstances. It does not motivate the company to undertake 'additional' training activities beyond those already carried out just on the basis of market forces. The aid would cover an operational cost normally borne by the company, and would therefore constitute distortive operating aid."

"In addition, the introduction of a single platform in the Genk plant is likely to lead to more efficient production of the new models. The company will therefore benefit directly from the single platform. Market forces alone are thus sufficient to push the company to undertake this restructuring of production and to bear the cost of the correlated training activities. In view of this, the aid is not necessary, as it would cover normal reorganisation costs of the company."

The Commission concluded that EUR $6,039,000$ of the state aid which Belgium was planning to accord a training project at Ford Genk was incompatible with the common market. Therefore that part of the aid could 
The Balancing Test and Incentive Effect:Is State Aid Necessary when Investment Is Unnecessary?

not be implemented. The remaining EUR 6,241,000 of the aid was compatible with the common market.

\section{Opening of formal investigations C 23/2007 on Vauxhall Ellesmere Port (UK) and C 35/2007 on Volvo Gent (Belgium)}

Both cases concerned proposed training aid to car manufacturers. In both cases the Commission expressed doubts and proceeded to open investigations because it thought that the training would be undertaken by the companies anyway. Once the companies had decided to make their respective investments, they would also have to undertake the training. This is because, in the Commission's view, the investments could not be completed without appropriately trained personnel.

\section{Opening of formal investigation C 18/2007 on DHL (Germany)}

The measure concerned the granting of training aid to DHL which was building a new delivery and airfreight centre in Leipzig-Halle, Germany. The training programme included both classroom and practical (on-the-job) training for certain jobs such as ground handling of airfreight, security agents and pre-flight and ramp mechanics. The programme consisted mostly of general training measures and some specific training measures. One of the objectives of the general training was to enable participating staff to obtain certain qualifications and certificates that were required by law.

The Commission was not convinced that the aid was necessary for the following reasons. First, in order to begin operations, DHL has to hire new staff. Specialized employee training is necessary to operate the logistics centre.

Second, certain staff have to acquire legally required qualifications in order to function (e.g. safety, aircraft handling). Training to obtain formal certification must be done even in the absence of aid.

Third, Commission doubted that DHL would be in the position to hire a work force with the required capabilities on the local or the European job market. In any case, it cannot be dismissed that there are no qualified personnel on the local job market. Moreover, it appears that employees are 


\section{Chapter 9}

not willing to move to the new federal states. Again the training had to be done even without aid.

\subsubsection{State aid for the switch to digital tv and development of broadband networks}

\section{Commission Decision 2006/513 on DVB-T in Berlin-Brandenburg (Germany)}

The aid in question is for the switch of terrestrial television transmission from analogue signal to digital signal in the Berlin-Brandenburg area. This switch can improve the quality of the broadcast and accommodate more channels.

The Commission recognized that the digital switch-over may be delayed if the process is left entirely to market forces; hence it had no objection of principle to public intervention in this field. Public authorities have various means of facilitating and encouraging digital switch-over, for example, regulatory means, financial support or information campaigns.

In order to decide whether the aid was necessary and proportionate, the Commission tried to identify the possible presence of market failures. Several types of market failure were examined: the coordination problem between market players; the positive externalities caused by the switch-over; the presence of market power; and the existence of uncertainty about market demand.

With respect to the coordination problem between market players, the Commission recognised that it could, in principle, represent a "market failure". However, it concluded that state aid was not the appropriate instrument for addressing this problem. The broadcasters do not own the frequency spectrum but operate on the basis of licences. The licences are awarded for a limited period. Accordingly, the authorities could resolve the coordination problem by setting a common expiry date for all analogue licenses.

With respect to the positive externalities, the Commission considered that Germany did not provide any reasoning or calculations showing that the aid represented the minimum necessary for broadcasters to switch to digital tv. 
With respect to the aim of strengthening of competition between transmission platforms, Germany did not provide convincing evidence that broadcasting transmission in Berlin-Brandenburg was characterised by a structural competition problem or that aid could help in resolving certain market rigidities. The market appeared capable of supporting various platforms, and therefore the use of state aid to steer the market in a certain direction was not needed.

In addition, the question as to whether and to what extent aid was need to develop a terrestrial network could have been determined via an open tender procedure for the award of the network licences. Accordingly, the Commission rejected the view that state aid to broadcasters was an appropriate means of stimulating competition between transmission platforms.

With respect to the risk for the network operator, the switch-over in BerlinBrandenburg was the first in Europe and its success was therefore particularly uncertain. However, there was no particular reason to believe that the market could not cope with that type of risk. In other areas digital tv was launched without public support.

The Commission concluded that the measure did not concern a clearly superior technological solution, nor was there any market failure. On the contrary, the technical and economic conditions in Berlin-Brandenburg could accommodate various and competing market-based solutions. In those circumstances, public support represented an unjustified departure from the principle of technological neutrality. The aid was not an appropriate, necessary and proportionate instrument to remedy a market failure.

\section{Commission Decision 2007/374 on digital decoders (Italy)}

The measure concerned aid to consumers to buy digital decoders so as to speed up the switch from analogue terrestrial broadcasting to digital broadcasting.

The Commission examined first whether the aid addressed market failure. 


\section{Chapter 9}

With respect to the coordination problem, the Commission considered that the measure was not the appropriate instrument for targeting such a market failure. Indeed, the existence of a mandatory deadline for switch-over was sufficient to help broadcasters plan a coordinated transition to the new platform and consumers to adapt to the new transmission technology.

With respect to the compensation for consumers, the Commission accepted that consumers could receive aid to help them update their analogue equipment, but the need to compensate them did not justify the discrimination between the terrestrial and the satellite platforms because it was not essential to guide consumers towards one digital platform.

With respect to the strengthening of competition between the different distribution platforms, the Commission noted that aid was not an appropriate instrument to target lack of competition.

With respect to the existence of externalities, the Commission accepted that state aid could help broadcasters cope with the costs of the switchover. However, given the particular situation of strong vertical integration of the Italian tv market, the Commission was not convinced that terrestrial broadcasters faced significant risks.

With respect to promoting innovation, the Commission did not think that there were any valid reasons for excluding the satellite mode from the measure. By excluding, a priori, satellite decoders, the measure probably hampered the diffusion of high-quality satellite decoders.

\section{Commission Decision 2007/175 on broadband network in Appingedam (The Netherlands)}

The measure concerned the proposed granting of state aid to stimulate the supply of advanced broadband services to companies and households by supporting the deployment of a glass fibre access network.

The Commission did not believe that there was a market failure. On the contrary, the high level of broadband coverage in the Netherlands showed that public intervention risked crowding-out private initiative. In other cases of state support for broadband, the Commission considered that state aid for wholesale networks could be an appropriate and proportionate instrument for 
The Balancing Test and Incentive Effect:Is State Aid Necessary when Investment Is Unnecessary?

tackling elements of market failure and/or equity problems. However, in those cases, the market did not support a competitive supply of broadband services or there were structural impediments to the roll-out of broadband.

\section{Opening of formal investigation $\mathrm{C34/2006}$ on digital terrestrial television in North-Rhine Westphalen (Germany)}

The measure in question concerned financial support for DVB-T (Förderreichtlinie DVB-T) related to the broadcasters' transmission fees in the DVB-T network for a five-year period. In the first year of operation, the assistance amounts to $40 \%$ of the fees and it is subsequently reduced every year by five percent to reach $20 \%$ in the fifth year. The assistance is reduced by the amount which broadcasters save from the switch-off of their analogue transmissions. The financial assistance will be granted in the form of nonrepayable grants.

The German authorities argued that the measure contributed to the development of the broadcasting sector, firstly, since DVB-T ensured media plurality and a balanced broadcasting landscape including regional and local programmes. The authorities maintained that cable and satellite were not suitable to transmit local and regional programmes in the same manner as the terrestrial platform because terrestrial transmissions could be better targeted to the relevant audience and were needed to feed local and regional programmes into the respective cable networks. Moreover, the German authorities claimed that satellite and cable were insufficient to ensure universal TV coverage of all households.

Secondly, the German authorities argued that the measure contributed to the development of the broadcasting sector since it promoted the development of new services such as interactive television services or mobile and portable reception via DVB-T.

Thirdly, the authorities maintained that the measure fosters competition between the various modes of digital transmission.

The Commission had doubts as to whether the arguments of the German authorities could justify the aid to within the meaning of Article 87(3)(c). 


\section{Chapter 9}

Channel variety could barely justify an aid that favoured DVB-T over competing platforms that offered even greater variety. Moreover, the channels in DVB-T had been allocated in such a way that incumbent broadcasters had been privileged while market entry had been marginal.

The Commission also had doubts as to whether the terrestrial platform was more suitable to ensure pluralism and to transmit local and regional programmes than cable or satellite and whether, in this context, the measure remedied a market failure. In fact, both alternative platforms provided for local and regional programmes. Local TV channels transmitted via cable existed in NRW in numerous areas, while there were no local TV channels transmitted via the digital terrestrial platform. With respect to the argument of universal coverage, the German authorities had not provided any data specifying the share of households not able to receive TV via cable or satellite. Instead, the authorities conceded that, from a technical point of view, practically every building could receive television via satellite.

The Commission noted that in NRW neither the capacity allocation nor the public funding was focused on any innovative media or telecom services in particular. With respect to capacity, it was unclear which frequencies were allocated to new media services. With respect to the public funding, only the transmission of television channels was subsidised.

Finally, the Commission had doubts as to whether the measure could be justified to strengthen competition between the different distribution platforms. The German authorities did not provide convincing evidence that broadcasting transmission in NRW was characterised by a structural competition problem or that DVB-T could help in resolving certain market rigidities. Even leaving aside terrestrial transmission, cable and satellite offered a large range of free-to-air television channels and were generally available. There was also competition among different cable operators for the connection to households. More competition was emerging from television via broadband (e.g. DSL), which was about to establish itself as an additional platform for broadcasting transmission.

Finally, the Commission had no indication that the notified measure would be appropriate or necessary to overcome any other type of market failure which may hamper the switchover to digital television. On the contrary, the necessity of the measure appeared doubtful because the commercial 
The Balancing Test and Incentive Effect:Is State Aid Necessary when Investment Is Unnecessary?

broadcasters had found it worthwhile launching DVB-T and transmitting for more than two years without any guarantee of financial assistance.

\section{Cases on broadband networks where the outcome balancing test was positive}

In many cases concerning the construction and operation of broadband networks, the Commission found that the aid had an incentive effect. Examples of such cases are the following: N 57/2005: regional innovative broadband support in Wales (UK); N 282/2003: Cumbria broadband (UK); N 307/2004: broadband in Scotland - remote and rural areas (UK); N 199/2004: broadband business fund (UK); N 267/2005: rural broadband access project (UK); N 126/2004: broadband for SMEs in Lincolnshire (UK); N 284/2005: metropolitan area networks (Ireland).

In these cases the Commission accepted that aid had an incentive effect for the following reasons:

- Telecoms companies would not realise any profit by incurring large costs to expand networks and provide services in rural or sparsely populated areas where demand was low.

- Regulation was not an appropriate instrument because it could not force providers to offer their services at low prices [possibly below cost] so that broadband access would be attractive enough to end users.

- State aid was an appropriate instrument to remedy market failure and to strengthen territorial cohesion.

For the sake of completeness, it is worth noting that in most cases the aid was found to be proportional because public authorities relied on competitive tendering to award contracts.

Lastly, aid did not cause a disproportionate negative effect because it was only stimulating competition in the regions which were under-provided with broadband services.

\subsubsection{State aid for $R \& D$}

The cases reviewed here have been assessed or are currently being investigated by the Commission on the basis of the 2006 Framework on state aid to R\&D and Innovation [OJ C 323, 30/12/2006]. Most state aid for R\&D 


\section{Chapter 9}

is approved on the basis of Article 87(3)(c). For this type of aid, the Framework defines three categories of requirements and three levels of assessment. The most important criterion for assessing the compatibility of state aid is the existence or not of an incentive effect.

The requirements of the Framework are laid down in three chapters:

- Chapter 5 defines requirements concerning the eligible R\&D\&I activities, the recipients of the aid, eligible costs and aid ceilings. All aid measures have to comply with the requirements in this chapter.

- Chapter 6 defines requirements concerning the identification of the incentive effect and necessity of aid. The necessity of aid must be shown only for some state aid measures.

- Chapter 7 defines requirements concerning the detailed assessment [i.e. the balancing test] that should be carried out for certain aided activities. Only very large amounts of state aid are subject to detailed assessment.

The Framework also provides for three levels of assessment of notified measures:

- Level 1 (incentive effect presumed): The R\&D\&I activities specified at this level are presumed to be compatible with Article 87(3)(c) and the incentive effect of aid is also presumed to exist, provided that work on R\&D\&I does not start before the aid application.

- Level 2 (incentive effect to be demonstrated): The R\&D\&I activities specified at this level are presumed to be compatible with Article 87(3)(c) provided member states can demonstrate that the aid has a incentive effect.

- Level 3 (detailed assessment): The R\&D\&I activities specified at this level must be individually notified to the European Commission and are subject to detailed assessment on the basis of the balancing test. Member states have to submit more information to justify the granting of aid in these cases. The Commission may or may not open a formal investigation.

Commission Decision on measure $N$ 674/2006 concerning aid to Siemens \& Lohr for metro trains [France] and Commission Decision on measure N 854/2006 concerning aid to Alcatel-Lucent for unlimited mobile tv [France] 
The Balancing Test and Incentive Effect:Is State Aid Necessary when Investment Is Unnecessary?

Unlike most of the cases reviewed above, the Commission concluded in these two cases that France, the member state concerned, had succeeded to demonstrate that aid had an incentive effect and therefore was necessary.

The Commission accepted that the aid had an incentive effect primarily because of three factors:

- The projects had a long time duration.

- The risk of failure was high.

- The envisaged rate of return would have been either too low or negative without aid.

It is worth noting for the sake of completeness that when the Commission examined the potential distortive effect of the aid, it concluded that it would not be excessive because:

- It was unlikely that state aid would crowd out private investment. The amount of aid was small relative to the normal $R \& D$ expenditure in those sectors.

- There were other strong competitors who were unlikely to be excessively affected by the state aid.

- The sectors were growing and there were competing technologies so the aid was unlikely to maintain an inefficient market structure.

\section{Opening of formal investigation on R\&D aid to Peugeot-Citroën (France), N 530/2007 [IP/07/1679]}

France plans to grant EUR 96 million aid to Peugeot-Citroën and 16 partners in the form of grants and repayable advances for the development of various parts of a hybrid diesel car. The total R\&D costs of the project are EUR 470 million out of which EUR 271 million would constitute costs eligible for aid. The programme is within the framework of the French Industrial Innovation Agency aid scheme, which was authorised by the Commission on 19 July 2006 (VHD).

The Commission thinks it is likely that Peugeot-Citroën, the second largest automobile manufacturer in Europe, would have undertaken this project anyway, even in the absence of a state subsidy. 


\section{Chapter 9}

The automobile sector is one of the most R\&D intensive in the European economy and similar pro-environment projects have been announced by competitors. Therefore, the Commission has doubts that a market failure exists in this field. Aid where there is no market failure would give an unfair advantage to Peugeot-Citroën and its partners. The Commission also doubts whether the aid to be granted via the VHD programme would not simply help to finance R\&D that the beneficiaries would have carried out in any event, even without aid.

\subsection{Evaluation}

Aid must be necessary in order to be exempted. On the basis of the cases reviewed in the previous sections, aid is not necessary in the following ten situations:

1. Aid is used to support operations or activities that must be carried out by the recipient in order to remain in business [e.g. launch of new model, GM and Ford].

2. Aid is used to cover costs of production rationalisation and implementation of changes which are necessary for the recipient to become more efficient [e.g. restructuring and training on new production methods, Ford; new production methods, Volvo and Vauxhall].

3. Aid is used to support the acquisition of legally required permits and/or certificates [e.g. handling new operations, DHL].

4. Aid is used to shift operations or activities from one plant to another or one subsidiary to another but which would still have to be carried out by the group as a whole. This may be a legitimate consideration for obtaining regional aid but not other kinds of aid [e.g. allocation of operations to a particular plant, GM, Ford and Volvo].

5. Aid is used to support products and/or services which are already provided by the market [e.g. digital tv, Berlin-Brandenburg; digital tv, NRW; Italian decoders; broadband network, Appingedam].

6. Aid is used to support products and/or services without any evidence that the costs of development/production cannot be fully borne by companies [e.g. switch to digital tv, Berlin-Brandenburg; digital tv, NRW].

7. Aid is used to reduce the risk associated with new products when the market appears capable of bearing such risk [e.g. digital tv, BerlinBrandenburg; digital tv, NRW; Italian decoders]. 


\section{The Balancing Test and Incentive Effect:Is State Aid Necessary when}

Investment Is Unnecessary?

8. Aid is used to encourage services which could be made available through imposition of regulatory obligations [e.g. switch to digital tv, Berlin-Brandenburg; Italian decoders].

9. Aid is used to stimulate competition when there is sufficient competition in the market or other policy instruments could be more effective [e.g. digital tv, Berlin-Brandenburg; digital tv, NRW; Italian decoders].

10. Aid is used to favour a particular technology when there is no legitimate reason for discriminating against other technologies [e.g. digital tv, Berlin-Brandenburg; digital tv, NRW; Italian decoders].

By contrast the most typical reason for which aid is found to be necessary is when the project is high-risk and counterfactual analysis shows that the profitability of the project is low or negative.

It is clear from the above ten situations that when an undertaking would have to carry out an activity either because the market forces it or the law obliges it to do so, aid lacks any incentive effect.

It is also clear that when public authorities try to steer undertakings towards particular technologies without any proper justification, aid may be capable of inducing undertakings to behave differently, but the aid would still be unnecessary given the fact that the policy objective is unjustified.

Although the Commission is right to oppose aid that is unnecessary, its assessment of the existence or not of incentive effect can be criticised in two cases.

The first case concerns the aid granted to Ford Genk. Here the Commission was probably too lenient on the aid that was allocated to the costs of the training department. Article 4(7)(e) of Regulation 68/2001 provides the following:

"7. The eligible costs of a training aid project shall be:

(e) cost of guidance and counselling services with regard to the training project".

Belgium claimed that the costs of the training department were covered by Article 4(7)(e) of Regulation 68/2001, that the employees in question had been seconded to the programme for three years and that the result was extra 


\section{Chapter 9}

staffing costs over that period. It also claimed that those costs had to be accounted for as general training.

The Commission thought that it could not discriminate against large companies that have their own training departments. So it accepted the costs of the training department as eligible costs and only adjusted them so as to reflect the share of general and specific training in the overall project.

This immediately raises the question, what the staff of the training department would be doing had they not been involved in that particular training project. The most likely answer is that they would be involved in training anyway. That was their job. It follows that aid to cover their costs lacked incentive effect.

Belgium claimed that staff were seconded to that particular project and that that raised costs. However, it did not explain whether the seconded staff had been removed from other projects [e.g. "normal" training activities] and whether the extra staffing costs were simply the additional costs for the project from more people assigned to it or for the training department that had to hire additional staff. In the absence of such explanations, the costs of a training department should not normally be regarded as eligible to receive training aid, irrespective of whether the company is large or small. This is because the company in question, by its own decision, has established a department to provide continuous training. Only aid for purely additional costs would have an incentive effect.

The second case concerns the construction and operation of a new centre by DHL. Here the Commission was probably too strict. It is questionable whether the Commission should prohibit the granting of aid that makes new investment projects viable. The Commission expressed doubt that the training aid promised by Germany would have any incentive effect because DHL would not be able to operate its new centre without properly trained and qualified personnel.

The Commission is certainly right in finding that DHL could not operate without properly trained personnel. This, however, cannot automatically lead to the conclusion that the aid lacked incentive effect. Without the aid, the overall investment costs would be higher making the return on that 


\section{The Balancing Test and Incentive Effect:Is State Aid Necessary when}

Investment Is Unnecessary?

investment to fall below whatever benchmark of commercial viability was used by DHL as a criterion for deciding whether to invest or not.

This is not the same as the GM case. Although both cases concerned training aid, the aid that was to be offered to GM was for the launch of a new model. GM had to launch new models in order to remain in business. This consideration of survivability or of sustaining viable operations does not appear to be the issue in the case of DHL. The publicly available information suggests that the context of the DHL investment was different. It was not about sustaining existing operations either in Leipzig or in Europe but in deciding whether and where to establish a new logistics centre.

Presumably DHL had to decide, first, whether the market could bear investment in a new centre and, second, where to locate it. Either decision was reversible. If the return on the envisaged investment was low or negative, DHL could decide not to undertake it without any apparent impact on its ability to remain in business. For either decision, the overall cost of the investment depended on the amount of training aid it could obtain from the relevant national authorities. Naturally, once the centre is established, training aid linked to the vital operations of the centre is unnecessary. But before the centre was established, DHL was deciding to do something extra. In this context, aid could genuinely have an incentive effect to influence its behaviour on whether or not to carry out the investment. The aid for training was decisive for the decision on the overall investment, not just the training activities themselves. Therefore, determining the right context of the analysis is crucial for finding out whether aid is necessary or not.

Lastly, a word of caution. The above reasoning should not be interpreted as leading to the conclusion that any investment that follows a previous investment that was found to be necessary is also necessary. Assume that the decision for the logistics centre was reversible. That is, DHL could decide not to build it. Therefore, the aid was necessary. The necessity of the aid for the initial investment does not mean that, say, training that is undertaken five years later in compliance with new, stricter regulations is also necessary. The subsequent training is not indivisibly linked to the initial project. For aid to be necessary must be granted only to activities which are indivisibly linked to the investment project at the moment the decision to carry out the investment is taken. 


\section{Chapter 9}

\subsection{Conclusion}

This paper has reviewed a number of recent Commission decisions concerning state aid that was found to be unnecessary or to lack incentive effect. On the basis of this review, the paper has identified the various situations in which aid is deemed to be unnecessary.

The paper also argues that the context of the assessment of aid is important for determining the existence or not of incentive effect. There is no incentive effect only when an undertaking is already committed to a particular course of action or must undertake a particular activity for reasons of legal compliance or business survival. But aid may indeed have an incentive effect before the undertaking makes or has to make that commitment. 
The Balancing Test and Incentive Effect:Is State Aid Necessary when Investment Is Unnecessary?

\section{Annex: Application of Balancing Test}

Table 9.1

\begin{tabular}{|c|c|c|c|}
\hline $\begin{array}{c}\text { Case } \\
(+ \text { or - outcome })\end{array}$ & $\begin{array}{l}\text { Appropriate } \\
\text { instrument }\end{array}$ & $\begin{array}{c}\text { Incentive effect } \\
\text { \& necessity }\end{array}$ & $\begin{array}{c}\text { Distortionary } \\
\text { effect }\end{array}$ \\
\hline $\begin{array}{l}\text { (-) Training aid } \\
\text { - GM [2007/612] } \\
\text { - Ford Genk } \\
\text { [2006/938] } \\
\text { - Vauxhall Ellesmere } \\
\text { Port [C23/2007] } \\
\text { - Volvo Gent } \\
\text { [C35/2007] } \\
\text { - DHL [C18/2007] }\end{array}$ & & $\begin{array}{l}\text { No: training } \\
\text { necessary } \\
\text { - to launch of new } \\
\text { model } \\
\text { - to adopt efficient } \\
\text { production method } \\
\text { - for operation of new } \\
\text { centre (DHL) } \\
\text { - for acquisition of } \\
\text { legally required } \\
\text { certificates (DHL) }\end{array}$ & \\
\hline $\begin{array}{l}\text { (-) Switch to digital tv } \\
\text { - Berlin-Brandenburg } \\
\text { [2006/513] } \\
\text { - North-Rhine } \\
\text { Westphalia [C34/2006] } \\
\text { - digital decoders (I) } \\
\text { [2007/374] }\end{array}$ & $\begin{array}{l}\text { No: } \\
\text { - regulation more } \\
\text { effective to bring } \\
\text { about switch } \\
\text { - there is enough } \\
\text { competition, no } \\
\text { need for state aid to } \\
\text { stimulate it }\end{array}$ & $\begin{array}{l}\text { No: } \\
\text { - market provides } \\
\text { similar services } \\
\text { - firms can bear cost } \\
\text { - firms can bear risk }\end{array}$ & $\begin{array}{l}\text { Yes: } \\
\text { discrimination } \\
\text { against other } \\
\text { platforms }\end{array}$ \\
\hline $\begin{array}{l}\text { (-) Broadband } \\
\text { networks } \\
\text { - Appingedam (NL) } \\
{[2007 / 175]}\end{array}$ & & $\begin{array}{l}\text { No: market provides } \\
\text { similar services }\end{array}$ & \\
\hline $\begin{array}{l}\text { (+) Broadband } \\
\text { networks } \\
\text { - Cumbria [N } \\
282 / 2003], \text { Wales [N } \\
57 / 2005], \text { Scotland [N } \\
307 / 2004], \text { Ireland [N } \\
284 / 2005]\end{array}$ & $\begin{array}{l}\text { Yes: } \\
\text { - regulation cannot } \\
\text { reduce costs \& } \\
\text { price } \\
\text { - state aid } \\
\text { strengthens } \\
\text { territorial cohesion }\end{array}$ & $\begin{array}{l}\text { Yes: } \\
\text { - market } \\
\text { underprovides in rural } \\
\text { areas } \\
\text { - zero profit without } \\
\text { aid }\end{array}$ & $\begin{array}{l}\text { Little: strengthens } \\
\text { competition in } \\
\text { rural areas }\end{array}$ \\
\hline $\begin{array}{l}\text { (-) R\&D } \\
\text { - Peugeot-Citroën (F) } \\
\text { [N 530/2007] }\end{array}$ & & $\begin{array}{l}\text { No: competitors } \\
\text { already make similar } \\
\text { models }\end{array}$ & \\
\hline $\begin{array}{l}\text { (+) R\&D } \\
\text { - Siemens \& Lohr (F) } \\
\text { [N 674/2006] } \\
\text { - Alcatel-Lucent (F) [N } \\
\text { 854/2006] }\end{array}$ & $\begin{array}{l}\text { Yes: market } \\
\text { underprovides } \\
\text { R\&D }\end{array}$ & $\begin{array}{l}\text { Yes: } \\
\text { - high-risk projects } \\
\text { - long gestation } \\
\text { periods } \\
\text { - zero profit without } \\
\text { aid }\end{array}$ & $\begin{array}{l}\text { Little: } \\
\text { - no crowding out } \\
\text { of private } \\
\text { investment } \\
\text { - there are strong } \\
\text { competitors } \\
\text { - sector is growing }\end{array}$ \\
\hline
\end{tabular}




\title{
Part III: Assessing the Rules
}

\author{
Chapter 10 \\ The Concept of Undertaking in Education and Public Health Systems
}

\subsection{Introduction}

Member states finance public universities or research establishments and hospitals. Since public measures only constitute state aid when the recipient is classified as an undertaking, the question whether the above-mentioned establishments are covered by the concept of an undertaking is crucial for the application of Article 87 (1) EC.

At a first glance, the answer to this question seems to be simple. One just has to apply the definition of the concept of an undertaking and determine whether the activities carried out by a university or hospital can be considered to be "economic".

The purpose of this short chapter is to explain under which conditions a university, a research organisation or a hospital is an undertaking and under which conditions it is not. Like other areas of competition policy there is a dividing line which is not always clear and which shifts from time to time following rulings of the courts of the European Union.

Our main finding is that, with the exception of activities belonging to the exclusive competence of the state, activities are non-economic not because of inherent characteristics but because of the terms on which they are provided. These terms preclude remuneration or "consideration" that would generate profit or cover the costs of supply and therefore make it impossible for a market to exist in which they can be voluntarily offered. 


\subsection{The concept of an undertaking in the case law of the Court of Justice}

The landmark case on the concept of an undertaking in competition law is the Klaus Höfner case ${ }^{136}$ where the ECJ defined an undertaking as "every entity engaged in an economic activity, regardless of the legal status of the entity and the way in which it is financed". From this definition it is clear, that the only decisive factor in determining whether an entity is an undertaken is the entity's engagement in an "economic activity". It is irrelevant that it may concern a private or public ${ }^{137}$ entity, a non-profit or profit entity, or even only one individual who is engaged in the activity in question.

According to settled case law an "economic activity" is "any activity consisting in offering goods and services on a given market". ${ }^{138}$ An economic activity presupposes the assumption of risk for the purpose for remuneration. ${ }^{139}$ Remuneration constitutes consideration "normally agreed upon between the provider and the recipient" ${ }^{140}$ (It is worth noting that Article 49 of the EC Treaty refers to freedom to provide services and Article 50 stipulates that these services are those for "remuneration").

This suggests that an economic activity is the voluntary offer of goods and services under conditions that generate profit or return or at least cover the costs of the goods and services in question. ${ }^{141}$

For some activities there cannot be a market because they belong to the sphere of exclusive competence of the state, such as the issuing of passports

\footnotetext{
${ }^{136}$ Case C-41/90, Klaus Höfner, [1991] ECR, I-01979, Para.21.

${ }^{137}$ In Commission v Italy (Case C-118/85, [1987] ECR, I-02599, Para.7], the ECJ held that the state can also engage in economic activities.

${ }^{138}$ Case C-35/96, Commission v Italy, [1998] ECR, I-03851, Para.36. See also, Case C-180/98 to C-184/98, Pavel Pavlov and Others, [2000] ECR, I-6451, Para.75; Case C-222/-4, Ministerio dell'Economica e delle Finanze, Judgement of 10 January 2006, Para.108.

139 Case C-184/98, Pavel Pavlov and Others, [2000] ECR, I-6451; C475/99,Ambulanz Glöckner, [2001] ECR, I-09089

${ }^{140}$ Case C-263/86, Humbel and Edel, [1988] ECR, I-05365, Para. 17.

${ }^{141}$ Joined Cases C-159/91 and C-160/91, Poucet and Pistre, [1993] ECR, I-00637
} 


\section{Chapter 10}

or birth certificates, irrespective of the fact that normally one has to pay to obtain such documents. Moreover, only the state has the prerogative to impose regulatory requirements such as broadcasting or banking licensing. Not only are these activities reserved for the state, one cannot obtain certificates or licences unless one qualifies by satisfying certain legal criteria or fiduciary requirements. ${ }^{142}$

It follows that an activity is non-economic when there can be no market for comparable goods \& services either because there is no voluntary participation or interaction or transactions by sellers and buyers (because costs cannot be covered) or because the state has reserved it for itself. ${ }^{143}$

Therefore, with the exception of the activities that are reserved for the state, the decisive issue is not any inherent quality of the activity but whether there can be a market for it where the provision of a product covers its costs so that sellers or investors would have an incentive to supply it. This is not a question of whether the price is high enough or not, but whether the buyer, consumer or beneficiary pays at all a price that constitutes remuneration or consideration by covering the cost of the product or corresponding to the value of the product.

In conclusion, many similar activities can be both economic and noneconomic depending on the terms on which they are provided, as for example, education (private tuition $\mathrm{v}$ public schooling), health care (private clinics $\mathrm{v}$ public hospitals), pensions (private schemes $\mathrm{v}$ compulsory social insurance), rescue and emergency services (privately arranged $v$ publicly and freely provided) or research funding (in the form of investment $v$ granted to worthy or promising projects).

${ }^{142}$ Case C-30/87, Bodson, [1988] ECR, I-2479; Case C-364/92, Eurocontrol, [1994] ECR, I-43; Case C-96/94, Centro Servizi Spediporto, [1995] ECR, I-2883.

${ }^{143}$ Commission Decision of 6 April 2005, N 244/2003, United Kingdom - Credit Union Provision of Access to Basic Financial Services - Scotland. 


\subsection{The non-economic nature of public education}

In Humbel and $\mathrm{Edel}^{144}$ the ECJ held that the establishment and maintenance of a public education system belongs to the duties of the State towards its citizens and that the State in fulfilling this duty is "not seeking to engage in gainful activity". The fact that sometimes enrolment fees have to be paid does not change the nature of these activities. It follows, that activities within the public education system, especially if it is compulsory or open to all, can not be classified as "economic activities".

Conversely, education which does not fall within the scope of the public education system is of an economic nature.

\subsection{The economic nature of public education}

In 2002 the Dutch authorities granted a subsidy to a consortium (OEC) of several universities which aims at the development and implementation of an electronic learning environment and the development of on-line teaching material for education establishments and business. ${ }^{145}$ In analysing the state aid, the Commission examined whether the OEC engaged in economic activities. It first referred to the case law of the Court of Justice establishing that activities carried out by the state in fulfilling its duties under the public education system are not considered to constitute economic activities. It then concluded that the consortium was operating within the framework of this system because of the fact that it assisted the state in carrying out its responsibilities, that it was a non-profit foundation established under public law and that all participating establishments were covered by the "Wet Hoger Onderwijs" (Higher education Act).

This decision suggests that a public entity is not engaging in an economic activity as long as it operates within the framework of the public education system.

${ }^{144}$ Case C-263/86, Humbel and Edel, [1988] ECR, I-05365, Para.18.

${ }^{145}$ Commission Decision of 15 January 2002, NN 152/2001, Netherlands - Digitale Universiteit. 
A more recent Commission decision concerning an Italian aid measure, however, seems at first glance to question the non-economic nature of activities carried out in the framework of the public education system. The decision concerned an Italian aid scheme which was implemented for the reform of training institutions. The Commission reiterated the case-law concerning public education systems, but also pointed out that "the concept of economic activity is an evolving concept", and if a member state decides to transfer certain tasks which usually fall within its sovereign powers to undertakings and decides to create a new market for a product or service, activities which previously were not considered to be "economic activities" would now be covered by this concept.

The Commission concluded that the fact that an activity is carried out within the framework of the national education system does not necessarily mean that it cannot be qualified as an economic activity.

We agree with this conclusion for the reasons we explained in section 2 . What matters is not any inherent quality or the activity or who carries out the activity or the context in which it is carried out but whether there can in principle be a market for it where the product can be offered for "consideration".

\subsection{Research and development}

Most Commission decisions on education establishments or research institutions concern research and development activities and are assessed on the basis of the Community Framework for state aid for research and development ${ }^{146} \cdot{ }^{147}$ Point 2.4 of the Framework excludes from the scope of Article 87(1) aid measures for R\&D activities carried out by "public nonprofit-making higher-education or research establishments". Nevertheless, in

${ }^{146}$ OJ C 045, 17.02.1996, pp.5-16.

${ }^{147}$ See for example: Commission Decision of 9 December 2004, N 200/2004, Netherlands - Ultimate Chiral Technology Project; Commission Decision of 2 October 2001, N 364/2001, Germany - Bauforschung und -technik für eine nachhaltige Stadt- und Raumentwicklung; Commission Decision of 5 July 2001, N 140/2001, United Kingdom, $R \& D$ for renewables and sustainable energy. 
cases where the such establishments make their R\&D results available to the industry, this must happen on a non-discriminatory basis, and when the R\&D is carried out on behalf of or in collaboration with the industry, "state aid within the meaning of Article 87(1) of the EC Treaty is not involved either:

(a) where the public non-profit-making higher-education or research establishments contribute to research projects as a commercial firm would, e.g. in return for payment at the market rate for the services they provide;

(b) or

- where the industrial participants in the research bear the full costs of the project, or

- where the results which do not give rise to intellectual property right may be widely disseminated and any intellectual property rights to the $\mathrm{R} \& \mathrm{D}$ results are fully allocated to the public non-profit-making establishments, or

- where the public non-profit-making establishments receive from the industrial participants compensation equivalent to the market price for the intellectual property rights which result from the research project and which are held by those industrial participants, and where the results which do not give rise to intellectual property right may be widely disseminated to interested third parties." 148

Because of the existence of point 2.4 the Commission can simply refer to this point in all R\&D cases involving the above-mentioned establishments, and the question whether they are undertakings is not directly answered. Of course, one might argue that the reasoning behind point 2.4 is the same as the one applied to the concept of an undertaking - the economic nature of the activity being the decisive factor - and, from this one might conclude that the Commission does not qualify the public non-profit making establishments in question as undertakings.

But this approach immediately raises the question why the R\&D Framework only refers to "public non-profit making" establishments and not other research organisations that may not be undertakings even if they are private. Unfortunately, the Commission is not very clear in its decisions either

\footnotetext{
${ }^{148}$ Point 2.4. (a) and (b) of the Community Framework for state aid for research and development.
} 


\section{Chapter 10}

whether private higher education or research establishments can also be covered by point 2.4 of the R\&D Framework.

In a decision concerning a Danish aid scheme ${ }^{149}$ under which subsidies were granted to private contract research and technology organisations, the Commission argued that they were comparable to public non-profit research establishments. The crucial factors were the special status of the organisations, their duty to work for the benefit of the society as a whole and the fact that they were not governed by private special interests. But, in cases where the private entity does not have these characteristics, the Commission is not ready to assimilate private higher-education or research establishments with public non-profit making establishments for the purpose of the R\&D Framework. ${ }^{150}$

This ambiguous state of affairs may change in the future. On 20 April 2006 the European Commission published the preliminary draft of the new Community Framework for state aid for research and development and innovation ${ }^{151}$ which now brings both public and private non-profit research institutes and universities under the same heading. It furthermore provides that in cases where an entity carries out economic as well as non-economic activities, public funding will not be considered to be state aid if:

- the non-economic activities can be clearly separated from the economic activities;

- the funding of the non-economic activities can be clearly separated from the funding of the economic activities; and

${ }^{149}$ Commission Decision of 19 February 2003, NN 76/02, Denmark - Contract Research and Technology Organisations; see also, Commission Decision of 13 March 2004, N 605/03, Spain - Plan Nacional de Investigación Científica, Desarrollo e Innovación Tecnológica (2004 - 2007).

${ }^{150}$ Commission Decision of 24 March 2002, N 856/2001, United Kingdom - LINK Collaborative Research Scheme; Commission Decision of 19 March 2003, Netherlands - Nationaal programma gebruikersondersteuning; Commission Decision of 12 January 2002, N 694/2001, Germany - Rahmenprogramm der Bundesrepublik Deutschland für Forschung und Entwicklung im Bereich der optischen Technologien".

http://europa.eu.int/comm/competition/state_aid/others/action_plan/rdi_frame_en.pd f 
- the entity is able to allocate costs to either one of the activities and no cross-subsidization of the economic activity will take place.

\subsection{Public health systems}

As outlined by the European Commission in its green paper on services of general interest ${ }^{152}$, economic and non-economic services can co-exist within the same sector and sometimes even be provided by the same organisation.

The case law of the Court of Justice and Commission decisions seem to suggest that this is certainly the case in the public health sector.

In the landmark cases Poucet and Pistre ${ }^{153}$ the ECJ did not consider a compulsory old-age insurance scheme and a compulsory sickness and maternity insurance scheme for self-employed persons to be undertakings since they were "fulfilling an exclusively social function, (...) their activity was based on the principle of national solidarity and, (...) they were nonprofit-making, the benefits paid out being statutory benefits that bore no relation to the level of contributions".

This "test" was subsequently applied by the Court of First Instance in Fenin ${ }^{154}$. The case concerned three Spanish ministries running the Spanish national health system which purchased medical goods from FENIN (an association of undertakings which markets these goods), and which were accused by FENIN of having abused their dominant position. The Commission dismissed the complaint because it did not consider these ministries to be undertakings. The Court of First Instance agreed with the Commission on the grounds that the same characteristics applied to the Spanish national health system as the ones mentioned in Poucet and Pistre, and it, therefore, held that the ministries in question did not act as undertakings "in managing the SNS".

FENIN filed an appeal arguing that the Court of First Instance's view that purchasing activities could not be seen separately from the activity for which

\footnotetext{
${ }^{152}$ Green Paper on Services of General Interest, 21.05.2003.

153 Joined Cases C-159/91 and C-160/91, Poucet and Pistre, [1993] ECR, I-00637.

${ }^{154}$ Case T-319/99, FENIN, Judgement of 4 March 2003, Paras. 38-39.
} 


\section{Chapter 10}

they are purchased did not hold. According to them the purchasing activity is an "economic activity" and "dissociable" from its subsequent use. ${ }^{155}$ The Court of Justice recently ${ }^{156}$ dismissed this appeal by confirming the Court of First Instance's ruling.

On the basis of these cases we conclude that a public hospital that fulfils a social function (the implementation of a public health system belongs to an obligation which the state has towards its citizen) can not be considered to be an undertaking because its operation is based on the principle of solidarity (everybody has access to the hospital services) and operates on a non-profit basis. However, we must be very careful not to over-generalise here because the case law is still evolving.

Unlike the public education system where the Court has held that activities within this system cannot be classified as economic activities, the public health system has not, prima facie, been excluded from the scope of this concept. In Smits/Stichting Ziekenfonds the Court rejected the argument that hospital services could not constitute economic activities. It pointed out that medical services are covered by Article $60 \mathrm{EC}$ and that there was no difference "between care provided in a hospital environment and care provided outside such an environment". ${ }^{157}$

Furthermore, in Ambulanz Glöckner ${ }^{158}$ a German provider of emergency transport services was regarded as an undertaking because in Germany this activity - the transport of patients - is a remunerated activity which is offered by various operators. Although the provider in question operated on a non-profit basis it was held that that did not affect the Court's conclusion. While in Henning Veedfald ${ }^{159}$ it was held that "the fact that products are manufactured for a specific medical service for which the patient does not pay directly but which if financed from public funds maintained out of

\footnotetext{
${ }^{155}$ See also, Bettercare II case 1006/2/1/01, Judgement of the CCAT of 1 August 2002.

${ }^{156}$ Case C-205/03 P, FENIN, Judgement of 11 July 2006, Paras. 25-28.

${ }^{157}$ Case C-157/99, Smits and Others, [2001] ECR, I-5473, Paras.52 -53. See also, Case C-368/98, Abdon Vanbraekel, [2001] ECR, I-5363, and Case C-475/99, Ambulanz Glöckner, [2001] ECR, I-09089, Paras.19-22.

${ }^{158}$ C-475/99, Ambulanz Glöckner, [2001] ECR, I-09089, Paras.19-22.

${ }^{159}$ Case C-203/99, Veedfald, [2001] ECR, I-3569.
} 
taxpayers' contributions cannot detract from the economic and business character of that manufacture".

It follows, that for determining whether an activity is an economic activity, it is not enough to simply classify it as a public health activity. Nevertheless, applying the Poucet and Pistre case might be very helpful.

In any case, the fact that an entity operates within the public health system does not automatically imply that it can never be considered to be an undertaking.

This is also confirmed by a Commission decision on capital allowances for hospitals in Ireland. ${ }^{160}$ It concerned an Irish system under which capital allowances were granted to investors in certain hospitals. Although the measure was aimed at investors, the Commission argued that the measure was also likely to benefit the hospitals concerned. And, even though it did not assess the nature of the hospitals in detail, it stated that hospitals can be considered as undertakings, especially when they are offering private health care as well as public.

\subsection{Conclusion}

Although, the definition of an undertaking in the case law is very straightforward, Commission decisions dealing with public assistance to universities and hospitals reveal that there is a large grey area.

The case law as well as the Commission decisions demonstrates that entities which operate within the public education and public health system are normally not considered to be undertakings. Nevertheless, a member state

\footnotetext{
${ }^{160}$ Commission Decision of 27 February 2002, N 543/2001, Ireland - Captial Allowances for Hospitals. Further reading on this chapter: Enhancing Beneficial Competition in the Health Professions. OECD Journal of Competition Law \& Policy, 2006, Vol. 8 Issue 3, p69-69, 1p; (AN 24818990), Competition in the Provision of Hospital Services. OECD Journal of Competition Law \& Policy, 2006, Vol. 8 Issue 3, p153-153, 1p; (AN 24818995), M. Kleis and P. Nicolaides, The concept of undertaking in Education and Public Health Systems, European State Aid law Quarterly, Volume 5 No. 32006.
} 


\section{Chapter 10}

can create a market for activities which traditionally fall within the boundaries of these systems thereby transforming them into "economic" activities.

Moreover, the fact that an entity is not considered to be an undertaking because it is engaged in public health or public education activities does not imply that it cannot be classified as undertaking with respect to activities falling outside the boundaries of public education and public health. Likewise, private entities having all the characteristics of public universities or public health providers are not always regarded as undertakings.

Where a public university or hospital or private research organisation is not certain whether an activity is economic or not, it is advisable that they separate in financial and accounting terms the activities which are clearly non-economic so as to protect them from the application of Article 87(1). Naturally, where there is doubt, it is always advisable to notify the relevant measures to the European Commission. Only an explicit decision of the Commission can provide certainty. 
Where Is the Advantage? The Case of Public Funding of Infrastructure \& Broadband Networks

\section{Chapter 11}

Where Is the Advantage?

The Case of Public Funding of Infrastructure \& Broadband Networks

\subsection{Introduction}

Public funding of "general infrastructure" is not state aid and, therefore, is in principle not prohibited by Article 87(1) of the EC Treaty. The reason is that this kind of public funding does not confer an advantage to any specific undertaking.

By contrast, public funding of "user-specific infrastructure" does confer an advantage to certain undertakings and is normally regarded to be a form of state aid.

However, in practice it may not be easy to distinguish between general and user-specific infrastructure, especially when the former is embedded in the latter. Moreover, infrastructure is increasingly built in the form of publicprivate partnerships or under arrangements where the state retains ownership of the infrastructure but assigns its management to undertakings. These issues create policy uncertainty because it is difficult to determine whether and how state aid rules may apply.

Since, in this type of cases, the decisive factor concerning the existence or not of state aid is whether state measures create advantages for specific undertakings, the purpose of this chapter is to examine the circumstances under which advantage is thought to be conferred when the state is involved in the construction and/or operation of infrastructure.

We first analyse the concept of advantage in the meaning of Article 87(1). We argue that the effect of a public subsidy depends on its effect on the performance of the beneficiary in comparison to its competitors. 


\section{Chapter 11}

We then examine the Commission's practice with regard to infrastructure cases in general and broadband infrastructure cases in particular. Infrastructure cases very often involve tender procedures and the Commission, in principle, considers conformity of tender procedures with EC rules on public procurement as proof that no advantage is conferred. Our assessment of the broadband cases shows, however, that the Commission seems to take a different approach in this area. We will explain why, in our view, this approach does not appear to be based on correct understanding of the meaning of advantage.

\subsection{Meaning of advantage}

There are many Court rulings that have shed light on the meaning of advantage in the context of Article 87(1). State intervention through subsidies or equivalent measures creates an advantage when undertakings receive gratuitous benefits they would not otherwise receive under normal market conditions [SFEI, C-39/94; Linde, T-98/00].

The benefits which are crucial in this context are those that provide relief from costs that should normally be borne by the undertakings themselves. These are the costs which are "inherent" in their economic activities [GEMO, C-126/01] and which exclude aid but include outlays caused by compliance with laws, regulations and contractual obligations [see Commission Decision 2004/125 on Berlin development funds].

Alleviation of "abnormal" costs caused by the state itself is not state aid. As explained by the CFI in the Combus case [T-157/01], "Article 87(1) merely prohibits advantages for certain undertakings and the concept of aid covers only measures which lighten burdens normally assumed in an undertaking's budget and which are to be regarded as an economic advantage that recipient undertaking would not have obtained under normal market conditions."

The state can reduce the normal costs of undertakings not only by outright subsidies or grants that offset partly or fully those costs but also by failing to receive fully what is owed to it by undertakings. The latter occurs when the state forgoes fully or partially dividends [WestLB v Commission, T-228/99], taxes [Ladbroke $\mathrm{v}$ Commission, T-67/94], revenue from fees, prices or rents 
Where Is the Advantage? The Case of Public Funding of Infrastructure \& Broadband Networks

on goods, services and other assets it sells or leases to undertakings [van der Kooy v Commission, C-70/85].

Public assistance directly to clients or employees may also confer an indirect advantage to undertakings if indirectly it reduces the normal costs of those undertakings by, for example, lowering the gross salaries paid to employees [Belgium v Commission, C-5/01].

The state may also confer an advantage not just by reducing the normal costs of undertakings but by allowing them to cover those costs with revenue that exceeds the rate or proportion that would be possible under market conditions [see case C-64/98 concerning contracts between the Italian state and the Instituto Poligrafico e Zecca dello Stato which provided for remuneration above normal market rates]. Revenue is also raised artificially when public subsidies boost demand for the product of a particular undertaking [see Commission Decision 2005/351 on Spanish aid to Intermed Aerea].

In other words, there are two possible ways that the state enables undertakings to escape the discipline imposed by the market. It either reduces their costs or raises their revenue beyond what is possible under free market conditions.

In the context of the second possibility, the state confers an advantage when it purchases goods or services at prices higher than their true value, as given by market prices, or at volume that does not reflect its true needs so it artificially boosts demand for a product [BAI v Commission, T-14/96; P\&O v Commission, T-116/01].

The table below summarises the possible ways through which the state confers an advantage in the meaning of Article 87(1). 


\section{Chapter 11}

able 11.1: How the state confers advantage

\begin{tabular}{|c|c|c|}
\hline \multirow[t]{2}{*}{ Roles of the state } & \multicolumn{2}{|c|}{$\begin{array}{c}\text { Form of action by the state and its primary } \\
\text { impact on beneficiary undertakings }\end{array}$} \\
\hline & Cost side & Revenue side \\
\hline Regulator or tax authority & $\begin{array}{l}\text { Lower levies, charges or } \\
\text { taxes }\end{array}$ & \\
\hline $\begin{array}{l}\text { Provider of subsidies to } \\
\text { induce undertakings to } \\
\text { modify their behaviour }\end{array}$ & $\begin{array}{l}\text { Lower operating or } \\
\text { investment costs }\end{array}$ & \\
\hline $\begin{array}{c}\text { Provider of share capital or } \\
\text { debt finance }\end{array}$ & $\begin{array}{c}\text { Lower dividends or debt } \\
\text { repayment }\end{array}$ & \\
\hline $\begin{array}{c}\text { Provider of goods and } \\
\text { services }\end{array}$ & $\begin{array}{l}\text { Lower outlays on purchased } \\
\text { goods and services }\end{array}$ & \\
\hline $\begin{array}{c}\text { Owner of assets used by } \\
\text { undertakings }\end{array}$ & $\begin{array}{c}\text { Lower rents or access } \\
\text { charges }\end{array}$ & \\
\hline $\begin{array}{l}\text { User of goods and services } \\
\text { provided by undertakings }\end{array}$ & & $\begin{array}{l}\text { Higher prices or demand } \\
\text { leading to higher gross } \\
\text { revenue }\end{array}$ \\
\hline
\end{tabular}

It follows from the above analysis that in determining whether the state confers an advantage it is necessary to establish what the costs or revenue may be under normal market conditions. In some cases it is sufficient to determine the level in the absence of state intervention [we understand "intervention" here to mean both a decision to act (e.g. offer a subsidy) and a decision not to act (e.g. not collect a fee)]. If there is no subsidy, for example, investment costs would be $20 \%$ or $30 \%$ higher. But the market conditions in the absence of state intervention cannot serve as a benchmark in all cases. This is for the simple reason that not every act of state intervention confers an advantage. The state may be acting like a private investor. What is, therefore, the decisive difference between the acts of the state in its policymaking role and the acts of the state in its private investor role?

As is well established in the case law, the state behaves as a private investor when it pursues profit and ignores other public policy issues [Italy $\mathrm{v}$ Commission, C-303/88, Italy v Commission, C-305/89; Spain v Commission, C-278/92; Air France v Commission, T-358/94]. When the state behaves like a private investor the undertaking that receives public funds does not enjoy any benefit that would not be obtained on the market or from other market participants. So the decisive factor is not the state intervention as such but 
Where Is the Advantage? The Case of Public Funding of Infrastructure \& Broadband Networks

that through that intervention some undertaking is relieved partially or fully from the constraints imposed by the market.

The constraints imposed by market competition ensure that firms do not charge prices higher than those of their competitors. Under these conditions, and other things being equal, the most efficient firm prevails because it has the lowest costs or charges the lowest price. This is the reason that, as shown later on, payments by public authorities do not constitute state aid if they are made on terms that replicate market conditions with undistorted competition.

Undistorted competition or market competition is an inclusive concept. It means that no undertaking faces any obstruction to its intention to offer its product. Since any undertaking may offer its product with no hindrance, the market provides a mechanism which compares all related products and creates a benchmark against which to judge whether the costs or prices of an undertaking are high or low. After all, as Community courts have ruled in numerous competition cases, the (relevant) market comprises all those products which are deemed by consumers to be substitutable [United Brands, C-27/76; Hoffmann-La Roche, C-85/76]. Competition emerges when there is at least one firm that can offer a product that can be a substitute for the product of another firm. It follows that, if any undertaking can enter a given market, the undertaking that succeeds to sell its product is the one with the lowest price and therefore the lowest possible costs, for any given level of quality.

In economic terms, the test of whether an advantage is conferred has to answer three questions.

The first is whether state intervention reduces the costs or raises the revenue of an undertaking. If the answer is no, then there is no state aid.

However, if the answer is yes, the second question is whether the costs are abnormally high and caused by the action of the state. If the answer is yes and the purpose of the aid is merely to compensate the undertaking for the damage caused by the state then there is no state aid. If the answer is no [i.e. costs are not abnormally high because of damage caused by the state], there is state aid only if a third question can be answered in the affirmative. 


\section{Chapter 11}

The third question is whether there is any other undertaking that would be capable of offering the same product or carrying out the same project for lower revenue or at lower cost, respectively. Normally, this information is given by the market or market-like processes such as open and nondiscriminatory tendering or procurement procedures.

Table11.2: Three-step test of advantage

\begin{tabular}{|l|c|c|}
\hline \multicolumn{1}{|c|}{ Question } & Answer & Result \\
\hline $\begin{array}{l}\text { Question 1: } \\
\text { Does state intervention reduce costs or raises } \\
\text { revenue? }\end{array}$ & $\begin{array}{c}\text { No }=> \\
\text { Yes }=>\end{array}$ & $\begin{array}{c}\text { There is no advantage } \\
\text { Go to question 2 }\end{array}$ \\
\hline $\begin{array}{l}\text { Question 2: } \\
\begin{array}{l}\text { Are costs abnormally high and caused by state action } \\
\text { [e.g. damage]? }\end{array}\end{array}$ & $\begin{array}{l}\text { Yes }=> \\
\text { No }=>\end{array}$ & $\begin{array}{c}\text { There is no advantage } \\
\text { Go to question 3 }\end{array}$ \\
\hline $\begin{array}{l}\text { Question 3: } \\
\text { Is there any other undertaking capable of offering the } \\
\text { same product at lower price or carrying out the same } \\
\text { project at lower costs? }\end{array}$ & $\begin{array}{c}\text { No }=> \\
\text { Yes }=>\end{array}$ & $\begin{array}{c}\text { There is no advantage } \\
\text { There is advantage }\end{array}$ \\
\hline
\end{tabular}

The analysis above can be formalised in a few simple equations. The aim of any firm [or any private investor] is to make profit [or earn a return on its investment]. Profit is the difference between revenue and costs under normal market conditions and it is given by the following equation

(1) $\pi^{*}=\mathrm{R}-\mathrm{C}=\mathrm{R}-(\mathrm{Cop}+\mathrm{Cin})$, where Cop is operating cost and Cin is investment cost.

If a firm receives a subsidy that reduces its investment costs, then its profit will be

(2) $\quad \pi^{\prime}=\mathrm{R}-(\mathrm{Cop}+$ Cin')

Since Cin $>$ Cin', it follows that

(3) $\pi^{\prime}>\pi^{*}$

The same happens when the subsidy results in an increase of revenue, as, for example, in the case of a subsidy to the users of a product. Since R' $>$ R, then again

(3a) $\quad \pi^{\prime}>\pi^{*}$

The recipient of a subsidy obtains an unfair advantage because it can raise its profitability and, perhaps, attract investors and capital not because of superior efficiency but because of the assistance it receives from the state. 
Where Is the Advantage? The Case of Public Funding of Infrastructure \& Broadband Networks

Even worse, an inefficient recipient of subsidies may be able to sell its product at lower prices without any impact on its profitability simply because its higher costs are offset by state aid.

An example can illuminate how this analysis may be applied in practice. Suppose that there are two competing undertakings, A and B. Also assume that firm A is more efficient than firm B because the costs of the former are lower than the costs of the latter. Due to capacity constraints, the more efficient firm cannot entirely displace the less efficient firm from the market and, as a consequence, both of them sell their product on the market, but at different rates of profitability.

Assume that the government wants to establish a network of sophisticated meteorological stations across the country. Firms A and B are the only ones that have the technological capacity to construct that network. Firm A, however, will charge a lower price because its costs are lower than those of firm B. Therefore if the government awards the contract to firm A to carry out the project, it will not confer to it an advantage in relation to its competitors.

In fact firm A can even make an amount of profit which, for the sake of argument, may exceed what other firms make on average. This is because the price that will be quoted by firm $A$ is just slightly below the price quoted by firm B. If the price quoted by firm B is equal to its cost plus, say, a rate of profit of $10 \%$, firm A can charge a slightly lower price, because its costs are lower and still make a profit that exceeds $10 \%$. The government project has enabled firm A to earn higher profits than its competitors. But exactly the same situation would have prevailed in the market had any one else asked for the construction of a similar project.

So, the decisive factor is not whether a firm earns revenue due to a state measure but whether the same revenue or costs would be obtainable under market conditions. As long as there is competition between firms for the same project, then the answer must be in the affirmative.

\section{Example where the Commission found no advantage}

In case N 657/1999 concerning business infrastructure development in the UK, the Welsh Development Agency bought land, developed it and then 


\section{Chapter 11}

sold it to businesses. The reason for state intervention was the low supply of land suitable for businesses needs.

On the basis of the above analysis we proceed to examine the application of state aid rules to the construction and operation of infrastructure and identify the conditions under which an advantage may be conferred by the state to undertakings that build, manage or use infrastructure.

The Commission observed in its decision that "no special advantage accrues to the end user [of the re-developed land] if the final price is not lower than the market value and the sale or lease is achieved through a competitive process or subject to independent valuation. The acts of acquiring and developing land and buildings for non-specified end users are of a public nature, similar to the construction of infrastructure. They can be considered not to confer specific advantages to the end users in so far as these pay the market price for the land and buildings acquired thereafter. " [p. 5]

\subsection{General v user-specific infrastructure ${ }^{161}$}

In general, public funding of infrastructure does not fall within the ambit of Article 87 (1) if it is "open to all potential users on equal and nondiscriminatory terms". ${ }^{162}$ There is also no state aid if infrastructure which is open to all potential users in a non-discriminatory way is managed by the state. The Commission recognises that in this situation no advantage is conferred to an undertaking in the sense of Article 87(1), competing with other undertakings. ${ }^{163}$

${ }^{161}$ For more detailed analyses of the application of state aid rules to infrastructure see Christian Keonig and Andreas Haratsch, The Logic of Infrastructure Funding under EC State Aid Control, European State Aid Law Quarterly, 2004, no. 3, pp. 393-398; Christian Koenig and Susanne Kiefer, Public Funding of Infrastructure Projects under EC State Aid Law, European State Aid Law Quarterly, 2005, no. 3, pp. 415-424; Leigh Hancher et al, Selectivity and Infrastructural Aid, in EC State Aids, (London: Sweet \& Maxwell, 2006), pp. 62-69.

${ }^{162}$ See for example State aid N 478/2004 of 7 June 2006, Ireland - State guarantee for capital borrowings by Coràs Iompair Eirann (CIE) for infrastructure investment. ${ }^{163}$ Commission Decision N 649/2001 on freight facilities grant in the UK. 
Where Is the Advantage? The Case of Public Funding of Infrastructure \& Broadband Networks

It is after all the responsibility of the state to fund and operate such infrastructure because it falls within its public duties and because this is the quintessential public good that has to be collectively financed given that no one can be excluded from using it [see XXVth Annual Report on Competition Policy 1995, point 175; and Commission Decision 2007/385 on an ethylene pipeline in Bavaria].

Most land transport infrastructure financing (e.g. roads constructed and maintained by the public authorities, inland waterway channels) takes the form of this kind of investment. This approach may also apply to maritime ports. The Commission has reflected this in its communication on "Reinforcing Quality Service in Sea Ports: A key for European Transport", that attempts to define "public (general)" infrastructure which in principle triggers no state aid considerations, once it is open to all users on a nondiscriminatory basis.

In its decision on infrastructure works in Flemish ports [case N-520/2003], the Commission explained that "public investments in maritime access routes $\ldots$ and other maritime infrastructure that benefit the maritime community as a whole do not normally raise any State aid issues, as such measures are considered as being expenditures incurred by the State in the framework of its responsibilities for planning and developing a maritime transport system in the interest of the general public and does hence not normally benefit a particular undertaking."

If infrastructure is put at the disposal of only some undertakings, then the users derive an advantage and the funding for the construction and/or maintenance of the infrastructure is state aid [Commission Decision $2005 / 170$ on a propylene pipeline from Rotterdam to the Ruhr. See also Commission Decision 2007/385 on an ethylene pipeline in Bavaria]. In this situation there is no state aid only if the users pay a market price to the state, as is normally the case with renting of business premises built and operated by public authorities.

The principle of open access holds even if the infrastructure is built in response to or in anticipation of private investments. The case of "Terra Mitica" highlights the importance of this point. It concerned the 


\section{Chapter 11}

establishment of a theme park in the region of Valencia. ${ }^{164}$ The Regional Authority bore the costs of the infrastructure outside Terra Mitica such as access routes, motorway links, etc. representing infrastructure without which Terra Mitica could not function.

According to the Commission, public funding of an infrastructure is not state aid as long as the infrastructure is in the interest of the local community as a whole. Then it does not matter for which reasons the infrastructure is constructed. In this case it was not relevant that the public infrastructure plan was adopted solely in connection with private plans to build Terra Mitica.

However, it was necessary to establish "which construction projects or infrastructure are of benefit to the community as a whole and which are of use to the park only." The state could not fund those which were only of use to the park.

\subsection{Public infrastructure embedded within private infrastructure}

As explained above, the general principle for determining whether certain works represent public infrastructure is whether there is unrestricted access by the public. Occasionally, public and private infrastructure is joined, as in the case of roads. This represents no major problem because it is relatively easy to draw a dividing line between them. For example, a road leading to a privately-owned port would normally be public infrastructure funded by the state, while the roads within the port would be private infrastructure funded by the owners or owners of the port.

It is considerably more difficult to distinguish between the two types of infrastructure when one is embedded in the other. For example, certain operations within ports or airports are considered to be the duty of the state and, therefore, can be funded by the state without raising state aid issues. This is the case of security, navigation safety or air traffic control, police and customs. Even though the activities of ports or airports are normally economic in nature and therefore fall within the scope of Article 87(1) [see

${ }^{164}$ Commission Decision 2003/227/EC of 2 August 2002 on various measures and the state aid invested by Spain in 'Terra Mitica SA', a theme park near Benidorm (Alicante), OJ L 91, 08.04.2003, p.23. 
Where Is the Advantage? The Case of Public Funding of Infrastructure \& Broadband Networks

Enirisorse, C-237/04; Aeroports de Paris, T-128/98], the official activities of the state are not economic.

It follows, then, that public funding of the facilities used for official activities does not constitute state aid. Indeed the Commission concluded in case N 353/2006 on Irish regional airports that "the practice of the Commission is that in relation to functions falling within the public policy remit, the financing of these functions or of infrastructure directly related to these functions does not constitute State aid." A similar conclusion was reached in the Flemish ports case [N 520/2003] where "public land transport facilities within the port area ... are considered as [funded] by the state in the framework of its responsibilities ... in the interest of the general public ...". See also Commission Decision NN 21/2006 concerning the City of Derry airport.

\subsection{Owner, manager and user of infrastructure}

When the state constructs a public road or bridge, the state normally owns and manages the infrastructure. There is no state aid if it is open to all users [Commission Decision N 649/01 on freight facilities in the UK; Commission Decision N 356/02 on the UK's Network Rail].

The fact that the owner of a certain infrastructure is the state is irrelevant in the characterisation of the management of that infrastructure as being an economic activity. The operation of airport, for example, is an economic activity irrespective of whether the owner is a public authority [see Commission Decision in case NN 21/2006 concerning the City of Derry airport].

However, publicly owned infrastructure may be managed and maintained by an undertaking. This is often the case with toll roads, railways, seaports and airports. Management or maintenance is a service. The question that arises is whether there is any state aid problem if the award of the contract for such a service follows a competitive tender. This question is very important and is examined in more detail in the following section.

The situation is more complicated when the manager is also the constructor of the infrastructure. This arrangement is the core feature of PPP projects. 


\section{Chapter 11}

An undertaking is chosen to build the infrastructure and operate it for a specified period of time. After the period expires, the infrastructure reverts back to the state. The state is the owner of the infrastructure irrespective of whether it contributes part of the finance for the construction of that infrastructure.

The problem in this situation lies in the fact that a state asset is put at the disposal of an undertaking. The undertaking has to remunerate the state for the use of that asset. The remuneration should correspond to the discounted value of the residual worth of the infrastructure when it is turned over to the state. It is difficult to determine a market benchmark for such arrangements. As explained in more detailed below, the Commission and the Courts regard the use of competitive and unconditional tenders as a means for ensuring that no state aid is granted.

Lastly, there is also the possibility that state aid may be indirectly granted to users of infrastructure even if all public funding goes to the constructor and/or manager of the infrastructure. The reason is that users benefit from the fact that the state has made possible the construction and/or operation of an asset that provides services to them at prices that are lower than what they would have been without public funding.

\subsection{Selection of beneficiary through open, transparent and non- discriminatory tender}

When a contract is awarded on the basis of an open and competitive procedure, in principle, there should be no state aid to the winning constructor because the competitive procedure eliminates any advantage to the winner. This is because the winning constructor does not obtain an advantage that would not be available under free market conditions.

Indeed this is the conclusion of the Commission in a number of cases. "If such an infrastructure manager is chosen by an open and non-discriminatory procedure, the State support granted to it for construction and maintenance of transport infrastructure represents the market price to achieve the desired result, financing is also not considered to fall under Article 87(1) EC Treaty." [Commission Decision on case N 649/2001, Freight Facilities Grant (UK)] 
The principle that competitive tendering eliminates advantage has been confirmed by the Court of First Instance. The case concerned an agreement between the Regional Council of Vizcaya and the Ministry of Trade and Tourism of the Basque Government on the one hand and P\&O European Ferries on the other hand. The agreement provided for the purchase of a certain amount of travel vouchers by the public authorities which signed the agreement [see P\&O European Ferries, T-116/01].

When it examined whether an advantage had been conferred to P\&O Ferries, the CFI referred to the fact that P\&O Ferries had not been selected on the basis of a "sufficiently advertised open tender procedure". It went on to explain that it was "all the more necessary for a Member State to demonstrate that its purchase of goods or services constitutes a normal commercial transaction" in this case since "[i]n accordance with the Commission's settled practice, the fact that such a tender procedure is conducted before a Member State makes a purchase is normally considered sufficient for the possibility that the Member State is seeking to grant an advantage to a given undertaking to be ruled out".

More broadly, competitive tendering eliminates advantage. In the landmark GEMO case [C-126/01], the French government implemented a scheme which provided for firms that were chosen through open tendering to collect and dispose free of charge animal carcasses from farmers and slaughter houses. One of the questions dealt with by the Advocate-General in his opinion was whether the remuneration of the undertakings selected to dispose carcasses was state aid. He concluded that "the payments made by the State to carcass disposal undertakings for the operation of the public carcass disposal service will thus constitute State aid within the meaning of Article 87(1) EC only if and to the extent that they exceed an appropriate remuneration* for providing that service." [* footnote: "In cases where the State purchases general interest services on the market the appropriate point of reference is not the costs of the measure but the remuneration they would receive on a normally functioning market."] The implication being that an appropriate remuneration does not confer an advantage.

On the basis of the principle laid down in the P\&O case, it follows that if infrastructure is owned by a public authority but managed or used by an undertaking, categorising the infrastructure as open to all on non- 


\section{Chapter 11}

discriminatory terms is not sufficient to establish that the funding of this infrastructure does not amount to state aid. In such cases it must be established that the manager or user pays a price that reflects the value of the asset. The safest way to ensure that that price contains no advantage is to carry out a competitive tender which can guarantee that the price corresponds to the rate that would have to be paid in the market. Otherwise it can not be excluded that the beneficiary receives an advantage. ${ }^{165}$

In a case concerning the construction of a train line between Belgium and the Netherlands the Commission concluded that there was no advantage because the public funding was granted on the basis of an open, transparent and nondiscriminatory tender. ${ }^{166}$ This means that the granting authority must have complied with EC public procurement rules.

Another example is the Commission's decision on the London Underground. It concerned public funding for the modernisation of the London Underground through a Public Private Partnership (PPP). ${ }^{167}$ The measure involved the division of London Underground into a publicly-owned operating company and three infrastructure companies (Infracos) to be transferred to the private sector and be responsible for the maintenance, improvement and upgrading of the Underground's infrastructure. Shares of the Infracos could be acquired by the private sector. Three consortia were selected for the Infracos according to a negotiated tender process.

In its assessment of the PPP arrangements, the Commission observed that "when these types of infrastructure arrangements are concluded after the observance of an open, transparent and non-discriminatory procedure, it is, in principle, presumed that the level of any public sector support can be regarded as representing the market price for the execution of a project".

${ }^{165}$ State aid N649/2001 of 20 December 2001, United Kingdom - Freight facilities Grant (FFG); State aid N 208/2000 of 14 September 2000, The Netherlands "Subsidieregeling voor openbare inland terminals (SOIT)"; State Aid N 355/2004 of 20 April 2005, Belgium - "Publiek-private samenwerking voor de ondertunneling van de Krijgsbaan te Deurne, en de ontwikkeling van bedrijventerreinen en de exploitatie van de luchthaven van Antwerpen".

166 State Aid N 390/200, Belgium - "De bouw van overslagfaciliteiten op de spoorlijn Lanaken - Maastricht".

${ }^{167}$ State Aid N 264/2002, United Kingdom - London Underground Public Private Partnership. 
It then went on to assess whether such a procedure had been followed. It first found, that "the choice of a negotiated procedure is in line with the requirements laid down in EC public procurement legislation. It then observed that "various periodic indicative notices (...) were published in order to ensure that the market had as much time as possible to prepare for participation" and that "the notices published by the London Underground were sufficient for the purposes of an open tendering process". It also noticed that the principle of transparency and equality of treatment had been respected "because the proposed contracts were duly advertised in the Official Journal of the European Communities and any modification or new elements introduced during negotiations respect the parameters of the notices and contract documents, as defined by the United Kingdom." It therefore concluded that no advantage had been granted and that there was no state aid.

Even, the fact that the contract terms were modified after the selection of the preferred bidders did not matter in this case since they were only few, "the principle of changes being made was known to all tenderers in advance" and their introduction "was operated in an objective way".

This decision appears to indicate that a procedure will be regarded as open, transparent and non-discriminatory if the public authorities complied with the public procurement directives. Moreover, it demonstrates that it does not matter, in principle, whether an open, restrictive of negotiated procedure has been followed as long as this was foreseen by public procurement rules. ${ }^{168}$

\section{Examples where the Commission found no advantage}

In its decision on the Welsh business infrastructure development [N 657/1999], the Commission explained that "the acquisition and development of land and buildings is addressed in part by the EC public procurement directives, which, if satisfied, generally eliminate State aid from the transactions." [p. 4]

In the case N 520/2003 concerning infrastructure works in Flemish ports, the Commission found that public funding of the task of maintaining maritime access routes did not involve state aid. In the words of the Commission, "as

\footnotetext{
${ }^{168}$ See, Sue Arrowsmith, The Law of Public and Utilities Procurement, Sweet \& Maxwell, 2005, p. 224.
} 


\section{Chapter 11}

this task is normally procured by the public authorities through an open and non-discriminatory tender it can be assumed that the successful bidder does not receive more that the market price for carrying out the necessary works. Hence, neither the ports in question nor the contractors receive State aid within the meaning of Article 87(1)."

In a case concerning German aid for the development of municipal infrastructure and the construction of business, technology and incubator centres the Commission examined whether there was state aid to three categories of entities: municipalities and other public bodies that funded the infrastructure and incubator centres, the operators of the centres and the users of the centres. In its decision [2005/782], the Commission found that public funds granted to municipalities and bodies controlled by them did not constitute state aid because, in the first place, the municipalities were not undertakings and that, more importantly, even if there were any doubts as to the status of municipalities and the other bodies, they only served as channels for passing on public funds to third parties. No advantage was obtained by the municipalities and other public bodies.

With respect to the operators of the centres, there was also no state aid because they were selected through a competitive procedure. The fact that they would operate publicly funded infrastructure was not sufficient to lead to a finding of state aid because the infrastructure would be returned to municipalities after a period of 15 years, the centres would be used exclusively as incubators and any excess profits would be siphoned off.

The Commission concluded that there as state aid only for the intended users of the centres which were only SMEs and for this reason aid could be exempted under the SME Regulation.

In the very recent case on the Welsh public sector network scheme [N 46/2007], the Commission found that there was no state aid either for the users of the network, because they were public authorities, or for the provider of the services. The latter obtained no advantage because of the following:

The contract was awarded according to public procurement procedures.

The state was procuring services that were intended to address its own needs. Arrangements were introduced to siphon off any excess profits in the future due to unforeseen market developments. 
Where Is the Advantage? The Case of Public Funding of Infrastructure \& Broadband Networks

The operator would not be required to build any substantial extension of the network so that the network could not be used for any commercial purposes.

\subsection{The economics of eliminating advantage}

In economic terms, a properly designed competitive tendering procedure would eliminate any advantage. To see why, assume that the cost of an infrastructure is higher than the revenue it can generate in its lifetime. The project will not be undertaken by the market without state intervention. In this situation, the aim of a competitive tender organised by the state is to award the contract for the construction and operation of the infrastructure to the firm that will be willing to accept the lowest subsidy.

Suppose that a potential bidder, say firm A, is willing to make an offer which is indicated by $\mathrm{S}_{\mathrm{A}}$. It is the amount of subsidy requested by that firm. The amount of subsidy requested by its competitor, firm $B$, is $S_{B}$. Either firm is willing to carry out the project only if $\pi(=\mathrm{R}+\mathrm{S}-\mathrm{C})>0$.

Also suppose firm A wins the project. Then it must be that the subsidy it requests is smaller than that requested by its competitor or $\mathrm{S}_{\mathrm{A}}<\mathrm{S}_{\mathrm{B}}$. This can happen only if $C_{A}<C_{B}$ or if $R_{A}>R_{B}$. In the first case, firm $A$ is more efficient than firm $\mathrm{B}$. In the second case firm $\mathrm{A}$ has a better plan and it believes it can generate more revenue from the project. In either case, $\pi_{\mathrm{A}}>$ $\pi_{\mathrm{B}}$. Because there is competition between firm A and firm B, firm A is not earning a larger profit than it would have earned had the project been carried out for a private client.

The important point to note here is that even though the project would not have happened without state intervention, firm $\mathrm{A}$ is not displacing a more profitable firm and is not obtaining an unfair advantage in relation to its competitors.

The Commission, in its communication on state aid elements in sales of land and buildings by public authorities [97/C 209/03], observes the following: "A sale of land and buildings following a sufficiently well-publicized, open and unconditional bidding procedure, comparable to an auction, accepting the best or only bid is by definition at market value and consequently does not contain State aid." 


\section{Chapter 11}

In the same communication the Commission makes clear that certain conditions imposed on buyers do not affect the openness of the auction. "Restrictions may be imposed for the prevention of public nuisance, for reasons of environmental protection or to avoid purely speculative bids. Urban and regional planning restrictions imposed on the owner pursuant to domestic law on the use of the land and buildings do not affect the unconditional nature of an offer. If it is a condition of the sale that the future owner is to assume special obligations - other than those arising from general domestic law or decision of the planning authorities or those relating to the general protection and conservation of the environment and to public health - for the benefit of the public authorities or in the general public interest, the offer is to be regarded as 'unconditional' within the meaning of the above definition only if all potential buyers would have to, and be able to, meet that obligation ..."

Lastly, we do not claim that the winner of a bidding competition or tender does not make more profit than the average rate of profitability that prevails in any particular industry. We only claim that a tender only ensures that the winner does not earn more than the next most efficient supplier. And this outcome is indistinguishable from the outcome of normal market competition. After all this is the benchmark of advantage in the meaning of Article 87(1).

In a recent analysis of the Altmark judgement and in particular the fourth criterion of that judgement, two DG Competition officials make the following observation:

"In view of the asymmetry between providers, a tender procedure would not necessarily drive the winning offer down to the least possible cost. The incumbent, in fact, can limit its offer to just below what can be afforded by its competitors. This observation begs the question of what is intended by the wording 'least cost to the community'. Does it refer to the cost of the most efficient producer or to the best offer available on the market? The two are not necessarily equal and a tender procedure would only ensure the achievement of the latter." ${ }^{169} \mathrm{We}$ agree with their conclusion. But this is

${ }^{169}$ Sandro Santamato and Nicola Pesaresi, Compensation for Services of General Economic Interest: Some Thoughts on the Altmark Ruling, Competition Policy Newsletter, Spring 2004, no. 1, pp. 17-21. 
Where Is the Advantage? The Case of Public Funding of Infrastructure \& Broadband Networks

enough to remove abnormal advantage that falls within the scope of Article $87(1)$.

A comparison with another but pertinent area of Commission practice will illuminate further our argument. In its so-called English partnership decision, the Commission explained its policy towards a whole category of cases concerning rehabilitation of polluted or derelict land and buildings [see Commission Decision 2000/389 and also related cases N 680/01 and N 239/02]. In these cases, UK authorities offered "gap funding" to land developers. The amount of public funding was the "gap" or difference between the cost of land rehabilitation and the price that the developed land could obtain on the open market. The UK authorities insisted that gap funding did not constitute state aid because the development costs were benchmarked against market prices, any profit was limited to the average in the sector and because work was contracted out through tendering to ensure that no excess profit was realized. On this basis they argued that there was no advantage and therefore no state aid in gap funding. The Commission disagreed. We believe the Commission was right.

For sure there was no aid for the company that was chosen to carry out the clearing and remediation work. However, the situation for the owner of the land is different. Even though the owner of the land that was rehabilitated did not earn any excessive profit, he was able to dispose of an asset that often had marginal or even negative value due to contamination or debris. More importantly, the amount of the state aid was solely dependent on the costs of rehabilitating his land. The authorities did not limit the amount of the subsidy to the corresponding costs for the rehabilitation of other sites. The gap funding concept only ensured that no excess profits were made on top of the costs for each site. These costs were determined individually. State intervention gave land owners an advantage that was unavailable under normal market conditions. By contrast, the operator of a broadband network has to make an offer that is constrained by what other potential providers are willing to offer.

\subsection{Counter-arguments}

We need to address a number of counter-arguments to the conclusion we reach above. We embed these counter-arguments in the context of the cases 


\section{Chapter 11}

concerning construction of broadband networks. The facts of these cases and the corresponding Commission decisions are examined in more detail below. The reason we use these cases is to show how the general aspects of our analysis also apply to the specific features of typical cases.

\section{i. Public policy aims}

The first counter-argument is that the state pursues a public policy aim which is to make internet services more widely available. This is correct and we do not deny it. But it is an irrelevant argument because public measures are classified as state aid on the basis of their effects, not the aims of the public authorities that implement such measures [Italy v Commission, C173/73].

The only thing that this counter-argument is saying is that the state is not acting as a private investor. This is also correct because no private investor would expend resources of its own for the benefit of society in general.

\section{ii. The state does not procure services for its own needs}

The second counter-argument is that in most broadband cases public authorities subsidized the construction of networks and the provision of services to third parties. As with the first counter-argument above, the intentions of the public authorities and form of the public measure are not relevant issues.

There is no doubt that users of the subsidized services obtain a benefit they would not otherwise be able to enjoy in the absence of state intervention. But the salient issue here is whether the service providers themselves obtained an advantage. As we have argued, this requires an assessment of whether they derived a benefit which exceeded the benefit that would be available to them under market conditions.

In a case concerning exemption of dredging sludge from a waste tax in the Netherlands [N 574/2004], the Commission had to consider two issues: whether there was aid to those depositing tax exempt sludge in landfill sites and whether there was aid to those that had sludge dredged from their canals and harbours.

The Commission found that the tax exemption was selective. However, it was also within the nature and logic of the system. The objective of the tax 
Where Is the Advantage? The Case of Public Funding of Infrastructure \& Broadband Networks

was to reduce waste deposited at landfill sites to prevent further environmental deterioration. Dredging improved the environment. Public policy on dredging was to increase the amount of sludge extracted from waterways. No other product had similar characteristics as there was no public policy to increase the supply of any other type of waste. Therefore, the exemption for dredging sludge was within the nature and logic of the tax.

The Commission also examined who would benefit from the tax exemption had it been state aid. The main beneficiaries were port operators. Since dredging was a task subsumed within the overall responsibility of the state to provide public infrastructure, the Commission concluded that there was no state aid for the port operators.

More interestingly for the purpose of this chapter, the Commission went on to assess whether there was state aid for the dredging companies. According to the Commission,

"because of market forces and in particular because of the tender procedures followed by the public authorities, the Commission considers that the advantage of the tax exemption is fully passed on to the public and private parties that are procuring the dredging services. They receive these services at prices that otherwise would have been significantly higher. The landfill sites and dredging companies must be considered as intermediaries, just passing on to the bodies procuring the dredging services, the advantage that is created by not levying the tax at the landfill." [paragraph 14]

Here is a case where the state intervenes in the market and, according to the Commission's own admission, manages to reduce prices of a service that would otherwise be much higher. Nevertheless, the undertakings that provide these services obtain no advantage because they pass on to the port authorities the advantage created by state intervention. The mechanism that ensures this elimination of advantage at the level of the service providers is the use of competitive tendering.

\footnotetext{
iii. Infrastructure used for commercial purposes and residual advantages

The third counter-argument is advanced by the Commission in its decisions on broadband. According to the Commission, the state puts to the disposal of undertaking assets or resources which are not available under free market conditions. Moreover, undertakings that win contracts to run these assets or
} 


\section{Chapter 11}

infrastructure exploit them later on for other commercial purposes. So there a "residual advantage" which is not priced in the contracts awarded by the public. $^{170}$

It is true that the state puts assets to the disposal of undertakings. It is also true that the state is not acting as a private investor seeking to obtain a return on its investment. Somebody benefits from the intervention of the state in the market and enjoys an advantage in the meaning of Article 87(1). However, it does not follow that those who benefit are the undertakings that are selected through a competitive tender to carry out the project. The market-like competition in bidding eliminates any abnormal advantage.

If the tender is open and unconditional, any firm can enter the market and bid for the subsidy. The subsidy can be thought of as a kind of prize. Let's denote the net costs of carrying out the project as NC. The amount of NC depends partly on costs incurred at the beginning of the project and partly on expected future revenues and other commercial benefits stemming from the project. Any firm that expects to enjoy any residual benefit after the end of the project will take that into account too. By doing that, it reduces the size of NC and, correspondingly, the amount of subsidy it needs and increases its chances of winning the project. It is in the interest of any participating firm not to ignore any benefits because by ignoring any benefits it reduces its chances of winning the bidding process. Under these conditions, the winner will be the firm with the lowest NC.

It would be irrational for any firm to ignore any residual benefits because they can always borrow money to undertake the necessary investment. Of course, this argument does not mean that all firms have the same competitive advantages and the same capacity. Not at all. Some firms are more efficient or more innovative than others and some firms have lower borrowing costs and easier access to capital markets. These differences imply that not all firms have the same chances of success by participating in the tender. However, it is important to understand that such competitive differences and variations in their capacities exist also in the absence of any state intervention in the economy. The point we are making here is that a welldesigned tender does not eliminate them. On the contrary, it enables the firm

\footnotetext{
${ }^{170}$ State aid N 57/2005, United Kingdom - Regional Innovative Broadband Support in Wales.
} 


\section{Where Is the Advantage? The Case of Public Funding of Infrastructure \& Broadband Networks}

with the strongest competitive advantage and capacity to be chosen. Again, the subsidy makes it possible for firms to enter unprofitable markets but does not confer an advantage to the winner in relation to its competitors.

This does not mean, however, that the users of the infrastructure do not receive hidden state aid. In fact, users are more likely to receive state aid if the state also imposes a ceiling on the price charged by the winning operator. The state may legitimately want to impose a price ceiling in order to prevent the winner from earning excess profits at the expense of users. This is particular concern in the case of infrastructure that is essential facility. Nonetheless, for users, the intervention of the state creates an advantage in terms of lower access costs that would not have been possible under normal market conditions. Moreover, the same advantage is not available to their competitors which are not using the same infrastructure.

\section{iv. Competition for subsidies}

The fourth counter-argument is that undertakings are actually competing for subsidies, which is something different from normal competition on the market. The final award is still a subsidy, albeit smaller than otherwise.

It is true that there is an increasing tendency among public authorities to rely on competitive procedures when awarding state aid. This method minimises the amount of subsidies granted, for example, to support R\&D. In this connection, projects selected to receive public funding are those that fulfil the criteria of the Community Framework on state aid to R\&D, additional scientific criteria defined by the award-granting authority and also request a "reasonable" amount of subsidy that may fall below what is in principle allowed by EC rules. This conforms with the principle of proportionality for aid that is compatible with the common market.

But there is a fundamental difference between competitive procedures for the award of state aid, say for $\mathrm{R} \& \mathrm{D}$, and for selecting the most efficient firm to carry out an infrastructure project. There is no market-like competition between the projects in the first category. All projects that comply with the state aid rules on R\&D are in principle eligible. Such projects are not necessarily substitutable and therefore do not compete against each other. The ones that are chosen to receive public subsidies are those that satisfy certain scientific quality criteria and make "reasonable" requests for public money [because they demonstrate that they are managed prudently in 


\section{Chapter 11}

financial terms]. The beneficiary companies are not necessarily the most efficient in carrying out the particular research for which they applied for public money. They still obtain an advantage over those of their competitors that would have the capacity to submit equivalent projects.

In the case of the second category, that of competition for the execution of an infrastructure project, the government in effect creates a market. It defines a single project over which there is more than one firm that is willing to compete for the right to execute it. It is irrelevant that the winner may enjoy residual benefits after the project is completed. The value of the benefits will be incorporated in the bids that are submitted. It is also irrelevant that users of the infrastructure will also derive benefits from gaining access to cheaper services. The constructors or operators of the infrastructure that have to compete against each other do not obtain an advantage that would be unavailable to them had they carried out the same project for a private client.

The table below summarises the various possibilities that use or not use of competitive tendering eliminates or confers state aid. 
Where Is the Advantage? The Case of Public Funding of Infrastructure \& Broadband Networks

Table 11.3: Existence of state aid when infrastructure is publicly funded but it is operated (managed) by undertakings and/or used by undertakings

\begin{tabular}{|c|c|c|c|}
\hline Situation & Beneficiary & $\begin{array}{l}\text { Existence } \\
\text { of state } \\
\text { aid } \\
\end{array}$ & Examples \\
\hline $\begin{array}{c}\text { State owner \& operator } \\
\text { Open access } \\
\text { Restricted access }\end{array}$ & $\begin{array}{l}\text { User } \\
\text { User }\end{array}$ & $\begin{array}{c}\text { No } \\
\text { Nes, if user } \\
\text { does not pay } \\
\text { fee that } \\
\text { reflects value } \\
\text { of } \\
\text { infrastructure }\end{array}$ & $\begin{array}{c}\text { Road } \\
\text { Business park }\end{array}$ \\
\hline $\begin{array}{l}\text { State owner } \\
\text { Private operator } \\
\text { chosen through } \\
\text { competitive process } \\
\text { Open access } \\
\text { Restricted } \\
\text { access }\end{array}$ & $\begin{array}{c}\text { Operator } \\
\text { User } \\
\text { User }\end{array}$ & $\begin{array}{c}\text { No } \\
\\
\text { No } \\
\text { Yes, if user } \\
\text { does not pay } \\
\text { fee that } \\
\text { reflects value } \\
\text { of } \\
\text { infrastructure }\end{array}$ & $\begin{array}{l}\text { Car park } \\
\text { Bus depot }\end{array}$ \\
\hline $\begin{array}{l}\text { State owner } \\
\begin{array}{l}\text { Private operator given } \\
\text { direct award }\end{array} \\
\\
\text { Open access } \\
\text { Restricted } \\
\text { access }\end{array}$ & $\begin{array}{c}\text { Operator } \\
\text { User } \\
\text { User }\end{array}$ & $\begin{array}{c}-- \\
\text { Yes [provided } \\
\text { Altmark } \\
\text { criteria do not } \\
\text { apply] } \\
\text { No } \\
\text { Yes, if user } \\
\text { does not pay } \\
\text { fee that } \\
\text { reflects value } \\
\text { of } \\
\text { infrastructure }\end{array}$ & $\begin{array}{c}\text { Seaport } \\
\text { Oil terminal }\end{array}$ \\
\hline
\end{tabular}




\section{Chapter 11}

\begin{tabular}{|c|c|c|c|}
\hline $\begin{array}{l}\text { Restricted } \\
\text { access }\end{array}$ & $\begin{array}{c}\text { Owner/ } \\
\text { operator } \\
\text { User }\end{array}$ & $\begin{array}{l}\text { Yes [provided } \\
\text { Altmark } \\
\text { criteria do not } \\
\text { apply] } \\
\text { Yes, if user } \\
\text { does not pay } \\
\text { fee that } \\
\text { reflects value } \\
\text { of } \\
\text { infrastructure }\end{array}$ & Telecoms network \\
\hline
\end{tabular}

The next section applies this method of analysis to the public funding of broadband networks and examines the various Commission decisions.

\subsection{Broadband networks ${ }^{171}$}

\section{When a network is not general infrastructure}

The ATLAS case concerned a project "aimed at lowering prices of broadband services for commercial users located in business parks (...) it [intended] to utilise existing fibre telecom infrastructure wherever practicable." 172 Existing fibre owners who already had fibre on the parks were given the opportunity to supply dark fibre. The United Kingdom argued that the measure should be seen as one of the tasks of a public authority consisting in providing general infrastructure.

The Commission was not prepared to accept this argument. In its view "the dark fibre does not supply a service to end users, but provides an input to businesses offering broadband services (...). [T] his type of infrastructure can and is actually deployed by market operators who intend to provide the final

${ }^{171}$ Two recent articles by Commission officials provide extensive reviews of the Commission practice in the analysis of state aid to broadband projects. See Monika Hencsey et al, State Aid Rules and Public Funding of Broadband, Competition Policy Newsletter, 2005, no. 1, pp. 8-15; Lambros Papadias et al, Public Funding for Broadband Networks - Recent Developments, Competition Policy Newsletter, 2006, no. 3, pp. 13-18.

${ }^{172}$ State Aid N 213/2003 of 20 July 2004, United Kingdom - Project ATLAS; broadband infrastructure scheme for business parks. 


\section{Where Is the Advantage? The Case of Public Funding of Infrastructure \& Broadband Networks}

service. Broadband services are actually offered in the concerned business parks also in the absence of State intervention, although, possibly, at a higher price. The type of service provided by the Asset Manager of the ATLAS project not only is an economically viable one, but is also targeted only at the commercial customers in the business parks and does not serve the interest of the general public. Accordingly, the Commission considers that the ATLAS project must be seen as a dedicated facility for undertakings, which is within the scope of State aid control, rather than a general infrastructure."

A similar conclusion was reached in the MANs case (See Annex II). ${ }^{173}$ The Metropolitan Area Networks ("MANs") programme was notified by Ireland and aimed at supporting "the construction of an open carrier-neutral wholesale infrastructure (optical fibre rings) to enable the provision of ducts, dark fibre, collocation space and wholesale high-speed electronic communications services to operators in town of Ireland where such an open neutral wholesale infrastructure is not available. The measure aims at facilitating the provision of retail broadband services and competition, thereby also contributing to a range of policy and strategic objectives for Ireland, supporting the economic, social and rural development of Ireland."

In response to the Irish arguments that the measure involved the provision of general infrastructure the Commission stated that "this would be the case of an infrastructure which is needed to provide a service that is considered as falling within the responsibility of the State towards the general public and is limited to meeting the requirements of that service. Moreover it should be a facility that is unlikely to be provided by the market because not economically viable and the way it is operated should not selectively favour any specific undertaking."

The Commission concluded that the MANs project was no general infrastructure since "contrary (...) to certain infrastructures in the transport sector, which are open to all potential users on equal and non-discriminatory terms and which are not provided (constructed and/or managed) by the market on purely commercial terms, this type of infrastructure is actually

173 State Aid N 284/2005 of 8 March 2006, Ireland - Regional Broadband Programme: Metropolitan Area Networks ("MANs"), phases II and III". 


\section{Chapter 11}

deployed by market operators who intend to provide telecommunications services".

The Commission's reasoning in these cases is in line with its reasoning in cases concerning general transport infrastructure. It is prepared to qualify broadband infrastructure as general infrastructure if it can be defined as open to all, and as provided on non-discriminatory terms, and if the market cannot provide for the service in question.

\section{market \\ Service of general economic interest and under-provision by the}

The market does not always provide all services which are deemed important by the state or society at large. This is because undertakings supply a service only if the price consumers are willing to pay can cover their costs. Similarly, the reason that the state is normally responsible for infrastructure is simply due to the fact that the market does not provide it.

Naturally, this justification alone is not capable of removing infrastructure from the ambit of Article 87(1) as long as all the criteria defined in that Article are satisfied. After all, a measure is classified as state aid on the basis of its effects, not the intentions or motives of the state.

Services of general economic interest are those that have special importance to every day life but cannot be adequately provided by the market. They may also merit state intervention to ensure their uninterrupted and widespread supply at affordable prices.

So, general infrastructure and SGEI have a common characteristic. They are under-supplied under free market conditions.

In 2004 France notified a project to the Commission concerning the granting of aid for the building of a broadband infrastructure in the department Pyrénées-Atlantiques. ${ }^{174}$ According to the French authorities the measure

${ }^{174}$ State Aid N 381/2004 of 16 November 2004, France - "Projet de réseau de télécommunication haut débit des Pyrénées-Atlantiques". See also State Aid N 382/2004 of 3 May 2005, France - "Mise en place d'une infrastructure haut débit sur le territoire de la région Limousin (DORSAL)". 


\section{Where Is the Advantage? The Case of Public Funding of Infrastructure \& Broadband Networks}

was to be carried out in the context of a public service and in the light of the need to establish an information society for everybody.

The Commission applied the Altmark criteria and came to the conclusion that the measure did not constitute a state aid since all the criteria were fulfilled. For the purpose of the analysis of the Commission's policy in broadband cases the assessment of this measure in the light of the first criterion is worth mentioning.

It first recalled that while, in the absence of Community measures, member states have a wide discretion with respect to the nature of a service which is susceptible to be qualified as a service of general economic interest, the respective service must be of a "general economic interest exhibiting special characteristics as compared with the general economic interest of other economic activities". Moreover, the undertaking in question must have been entrusted by a member state with the operation of a service of general economic interest.

In the telecommunication sector, Community legislation harmonises the principles applicable to the universal service obligation, which consist in the supply of a set of basic services to all end-users regardless of their geographic location and for an affordable price. According to the Commission, broadband services differ from services which are included in the universal service obligation because the latter concern well-established basic services. The challenge with respect to broadband services, on the other hand, consists in acquiring equitable access to technologically advanced services in geographical zones where, due to economical reasons, the offer of these services is either non-existent or insufficient.

The Commission then referred to Directive 2002/22 which specifies that member states may take measures to ensure the supply of specific services other than those already covered by the universal service concept. In this context it recognised the need for intervention by public authorities in order to ensure a more rapid expansion of supply in under-provided areas and concluded that the French authorities were justified to qualify this service as service of general economic interest.

Moreover, the Commission accepted that the service would contribute to the economic development of the department and offer access to education 


\section{Chapter 11}

establishments. The market did not offer the service in question in a complete and satisfactory manner within the respective territory due to high costs. The Commission specified, however, that this was only true for the investment in the network and not for end-user services.

After having established that the French authorities had clearly defined the public service obligation it concluded that the first Atmark criterion had been fulfilled.

\section{Existence of advantage}

The assets of the ATLAS project were owned by Scottish Enterprise and managed by an Asset Manager who was to lease capacity to whole-sale operators and/or service providers. The Manager was selected through a tender procedure which was carried out in accordance with EC public procurement rules.

According to the Commission, the application of this tender procedure "would rule out any unnecessary advantage to the Asset Manager". Yet, it went on to say that it was "doubtful that the infrastructure will be built on the same terms as a private investment", and that the fact that prices could not be freely determined by the Asset Manager suggested that "the prices for the dark fibre will be lower than the normal market price would have been, giving rise to an economic advantage for the telecom operators and the service providers, which can, at least partially, translate into an economic advantage for the enterprises in the business parks that are the ultimate customers of the broadband services".

So in this case, the competitive selection procedure eliminated any advantage for the Manager of the network but accentuated advantages for the operators and users of the network because the service was provided at even lower cost. In other words, the elimination of state aid upstream generated more aid downstream.

In the MANs case the infrastructure concerned was to be "managed, activated and commercialised within the framework of a public-privatepartnership by a private-sector management service entity (MSE)" which had "to offer wholesale services and infrastructure to operators". As in the ATLAS case, the MSE was selected on the basis of a tender procedure. 


\section{Where Is the Advantage? The Case of Public Funding of Infrastructure \& Broadband Networks}

The Commission acknowledged that the MSE had been selected on the basis of an open, transparent and non-discriminatory and that it was "generally accepted that an open tender for the management and marketing of an infrastructure such as the MANs tends to minimise a potential advantage to the winning bidder, in terms of excessive returns". It, nevertheless, argued that the MSE received an advantage because it would "be able to establish its business based on the government-funded MAN infrastructure and enter the market for wholesale services on conditions not otherwise available on the market".

This reasoning is faulty. It confuses two issues: the impact of state intervention on the market and whether such intervention is capable of creating a selective advantage. There is no doubt that the Irish authorities altered the conditions on the market. But it does not necessarily follow from that observation that anyone firm had obtained an advantage in relation to its rivals.

This reasoning is repeated in other Commission decisions. In 2005 the United Kingdom notified a planned Regional Innovative Broadband Support aid scheme to the Commission. ${ }^{175}$ The measure aimed at "supporting the provision of first generation broadband services, at conditions and prices similar to urban areas (...) which are currently not served and where there are no plans for coverage in the near future". The direct beneficiaries of the aid were electronic communication services providers. Indirect beneficiaries were end-users and third party providers.

According to the description of the measure, the direct beneficiaries were selected on the basis of a negotiated tender procedure conducted in accordance with EC public procurement rules. It was advertised in the EU's Official Journal and the grant was awarded to the economically most advantageous tender, following a number of well-defined outlined criteria".

In its assessment, the Commission argued that, while "a tender tends to minimise potential advantages to the service provider in terms of excessive returns" it nevertheless received "financial support which provides the possibility of entering the market and establishing its business on conditions

\footnotetext{
${ }^{175}$ State Aid N 57/2005 of 1 June 2005, United Kingdom - Regional innovative broadband support in Wales.
} 


\section{Chapter 11}

not otherwise available on the market." It went on to say that "in addition, the subsidy will allow the service provider to offer the services at lower prices than it would have been able to offer had it had to bear all the costs itself and, as a consequence, such a service provider will be able to attract more customers than under normal conditions."

A number of similar measures were notified to the Commission. ${ }^{176}$ The primary beneficiaries in these cases were all selected through a tender which was applied in conformity with EC public procurement rules. In all cases the Commission reached the same conclusion as in the Regional Innovative Broadband Support case.

The "Connecting Rural Businesses" project in Lincolnshire subsidised service providers who were to provide affordable advanced broadband services to SMEs in Lincolnshire. ${ }^{177}$ Selection of the service providers was, according to the description of the measure, conducted in accordance with the EU procurement rules.

Like in the other cases, the Commission found that the existence of an advantage could not be excluded because of the possibility to enter the market and establishing its business. But, it also based this finding on the fact "that the procurement procedure followed included a negotiation phase and has involved qualitative elements".

\subsection{An assessment}

In its 2003 Annual Report on Competition Policy, the Commission briefly dealt with state aid issues in broadband infrastructure cases, and it outlined a

\footnotetext{
${ }^{176}$ State Aid N 131/2005 of 22 February 2006, United Kingdom - Fibre speed broadband project Wales; State Aid N 583/2004 of 6 April 2005, Spain - "Banda ancha en zonas rurales y aisladas"; State Aid N 267/2005 of 5 October 2005, United Kingdom - Rural Broadband Access Project; State Aid N 307/2004 of 16 November 2004, United Kingdom - Broadband in Scotland - remote and rural areas; State Aid N 263/2005 of 20 October 2005, Austria - "Breitband Kärnten";

${ }^{177}$ State Aid N 126/2004 of 14 December 2004, United Kingdom - Broadband for SMEs in Lincolnshire-Connecting Rural Business". See also: State Aid N 199/2004 of 16 November 2004, United Kingdom - Broadband business fund.
} 


\section{Where Is the Advantage? The Case of Public Funding of Infrastructure \& Broadband Networks}

policy which is rather similar to the one in applied in transport infrastructure cases (see Annex I). Like in the case of the transport infrastructure, it seems that the funding of broadband infrastructure does not constitute state aid where an open, transparent and non-discriminatory procedure is applied.

However, with the exception of the ATLAS case, the policy of the Commission in examining whether an advantage was granted to beneficiaries selected through a tender procedure seems to divert from its general policy as outlined in the Annual Report and as applied in transport infrastructure cases.

The ATLAS case upholds the general principle that an open, transparent and non-discriminatory tender rules out the existence of an advantage. Therefore, an advantage did not exist with respect to the Asset Manager who had been selected on the basis of this procedure but only with respect to other beneficiaries who were not selected through the application of a tender procedure.

On the other hand, in the MANs decision, as well as the other decisions mentioned above, the Commission established that an advantage had been granted to the beneficiary which had been selected through a tender procedure carried out according to EC public procurement rules.

In all cases the Commission seemingly bases this finding on what it defines as a "residual" advantage which apparently can not be ruled out through the application of EC public procurement rules. While this advantage in MANs consists in the beneficiaries ability "to establish its business based on the government-funded MAN infrastructure and enter the market for wholesale services on conditions not otherwise available on the market", the advantage in the other cases lies in the fact that the selected beneficiary receives "financial support which provides the possibility of entering the market and establishing its business on conditions not otherwise available on the market", and "will allow the service provider to offer the services at lower prices than it would have been able to offer had it had to bear all the costs itself and, as a consequence, such a service provider will be able to attract more customers than under normal conditions."

Assume that the "residual" advantage that the Commission detects is the experience and the knowledge of the market that an operator gains when it 


\section{Chapter 11}

completes a project. It is puzzling why the Commission detects such an advantage in broadband cases and not in other cases where the state awards contracts for the execution of infrastructural projects [e.g. the London Underground]. In principle any additional project any company carries out adds to its experience and therefore strengthens its competitive advantage in relation to its rivals. Taken to its logical conclusion, the theory of residual advantage would bring any purchase by the state or the award of any contract by the state within the ambit of Article 87(1).

Given the fact that the Commission does not further motivate this reasoning it is very difficult to follow its line of thought. It might be true that the beneficiaries are able to enter the market on more favourable conditions and may, possibly, offer lower prices to potential customers. It is also true, however, that a tender which is applied in conformity with EC public procurement rules, generally, assures that everyone who is interested and, in case of a restricted tender, fulfils the conditions for participating in the tender can participate in the tender. In addition, the correct application of the procurement rules normally assures that the selected bidder is the qualitative and economically most advantageous one. ${ }^{178}$

178 Sue Arrowsmith, The Law of Public and Utilities Procurement, Sweet \& Maxwell, p.222. Further reading on this chapter: P. Dias and A. Antoniadis, Increased transparency and efficiency in public service broadcasting: Recent cases in Spain and Germany, Competition policy newsletter: $n r .2$ 2007, L. Papadias, A. Riedl and J.G. Westerhof, Public funding for broadband networks - recent developments, Competition policy newsletter: $n r .3$ 2007, P. Dias and J.G. Westerhof, State aid in the broadcasting sector: two decisions regarding ad hoc aid to public service broadcasters in Portugal and the Netherlands, Competition policy newsletter: $n r .3$ 2007, C. Schoser, Commission rules subsidy for digital terrestrial television (DVB-T) in Berlin-Brandenburg illegal, Competition policy newsletter: $n r$. 1 2006, M. Hencsey, I. Reymond, A. Riedl, S. Santamato and J.G. Westerhof, State aid rules and public funding of broadband, Competition policy newsletter: $n r .12005$, J. Lucking, Presumed margin squeeze for broadband access in Germany: settlement with Deutsche Telekom, Competition policy newsletter: $n r .3$ 2004, S. Depupere, J. Broche and N. Tigchelaar, State aid and broadcasting: state of play, Competition policy newsletter: $n r .1$ 2004, N. Sumarada and N. Nohlen, Control of State Aid for Public Service Broadcasting: Analysis of the European Commission's recent Policy, European State Aid law - Quarterly, Volume 4 No. 4 2005, K. Nordlander and H. Melin, Switching to action: commission applies State aid action plan to digital switchover, European State Aid law-Quarterly, Volume 5 No. 22006. 
If we presume that in all cases open, transparent and non-discriminatory tenders have been applied and that the procedures followed were in line with the EC procurement rules the Commission's reasoning might be that broadband projects involve competition issues which are so different from other subject areas that an application of the general rules is not possible. Since it concerns, however, a rule which is applied in general to state aid decisions covering a whole range of subject areas, non-applicability of it to one subject calls for some kind of explicit motivation. It should be clearly stated why broadband requires tighter rules and why a tender which complies with the EC public procurement rules and which is "open, transparent and non-discriminatory" does not constitute sufficient proof that the aid equals the market rate.

\subsection{Conclusions}

Since assessing the existence of an advantage means comparing the situation in which the state intervened with the situation in which such an intervention is absent a vital question is the behaviour of market competition. No intervention means that the most efficient undertaking will always prevail. Therefore, measures by public authorities which result in the most efficient undertaking getting a subsidy do not confer an advantage and, therefore, do not constitute state aid. This result can be assured through the application of a tender procedure which is in conformity with EU public procurement rules.

In infrastructure cases, the Commission decisions are in line with the "general infrastructure" rule, the Altmark-criteria and its treatment of undertakings selected according to public procurement procedures. However, while the "general infrastructure" rule and the Altmark-criteria are equally applied in broadband decisions, the Commission seems to take a different approach with respect to tenders. Recent decisions in this area seem to imply that following an open, transparent and non-discriminatory tender might simply not be enough to eliminate a so-called "residual advantage". Unfortunately, the decisions do not give an indication as to why this change in approach has taken place.

We have explained why this approach appears to ignore the fact that a competitive tendering procedure would eliminate any abnormal advantage. 


\section{Chapter 11}

\section{Annex I: Excerpts from the XXXIIIrd Annual Competition Report, 2003 (pp.81-82)}

\section{Infrastructure owned by public authorities}

394. The funding of broadband infrastructure owned by a public authority does not constitute the granting of State aid within the meaning of Article 87(1). The procurement of the works for the creation of such infrastructure must comply with the appropriate Community legislation on the subject. However, when the infrastructure is made available to undertakings, this should be done on non-discriminatory terms and upon payment of appropriate fees. Such fees are not expected to cover the entire cost of the investment - in cases where the market is not capable of providing equivalent services - but should not allow the users of the infrastructure to make extra profits.

395. If a service equivalent to that provided by the infrastructure is already supplied by the market, then the infrastructure should be rented out for fees allowing coverage of costs and a fair return on investment. If the management of the facility is entrusted to a third party, it should be conceded for a limited amount of time following an open, transparent and non-discriminatory procedure, preferably determined through a competitive process and leading to a market compensation paid by the concession holder. As a general rule, this should be organised at the appropriate level (national, regional or local) under the supervision of the competent authority, which should ensure compliance with the relevant legislation and consistency with national and regional IS policies. The manager of the infrastructure should be subject to operating requirements that preserve the nature of the infrastructure as a facility open to all operators providing electronic communication networks and services under non-discriminatory conditions.

\section{Infrastructure owned by undertakings}

396. In the case of the (co-)funding of a facility which is owned by an undertaking, the State financial contribution would have to be made conditional on the acceptance of operating requirements which would preserve the nature of the infrastructure as a facility open to all operators 
Where Is the Advantage? The Case of Public Funding of Infrastructure \& Broadband Networks

providing electronic communication networks and services under nondiscriminatory conditions.

397. There should be evidence that the amount of State funding was the minimum necessary to allow the project to proceed, so as to ensure that the operator using the facility does not receive more than a normal market return for its activity. To this end, State funding should be awarded through open calls for tenders. As a general rule, this should be organised at the appropriate level (national, regional or local) under the supervision of the competent authority, which should ensure compliance with the relevant legislation and consistency with national and regional IS policies. Competitors would be invited to submit their technical and financial offer. The contract will need to be awarded to the operator(s) providing electronic communication networks which fulfil the minimum specified requirements for the service (in terms of quality of service, future improvements, etc.) at the lowest cost.

\section{The case of non-open infrastructure projects}

398. Direct financing of installations and equipment which are not open to all but are dedicated to one or more operators, for example installations reserved to a specific operator as a result of an agreement with the regulatory authority, does not qualify as funding of an 'open infrastructure' project.

399. Funding of installations and equipment dedicated to a specific final user may constitute State aid where such user is an undertaking. Depending on the particular circumstances, such funding may not constitute State aid or may be found compatible where it is necessary for the provision of a 'service of general economic interest' (SGEI). Where it constitutes State aid, it may be compatible under the rules governing aid to small and medium-sized enterprises, regional aid or de minimis aid.

400. The provision of the service should respect the principles of transparency, non-discrimination, proportionality and least market distortion. If the service is not awarded following an open, transparent and nondiscriminatory procedure, the operator is required to hold a separate accounting system for the service in question which makes it possible to establish the amount of public compensation or tariffs applicable for use of the service. 


\section{Annex II: Identification of Advantage in Commission Decisions on Broadband}

\section{N57/2005: Regional innovative broadband support in Wales (UK)}

Procurement procedure: Negotiated procedure

Service providers: "A tender tends to minimise potential advantages to the service provider in terms of excessive returns. However, even if a service provider would not receive an excessive return on its overall investment, it receives financial support which provides the possibility of entering the market and establishing its business on conditions not otherwise available on the market. In addition, the subsidy will allow the service provider to offer the services at lower prices than it would have been able to offer had it had to bear all the costs itself and, as a consequence, such a service provider will be able to attract more customers than under normal conditions.

As a result of the State contribution, the selected providers are likely to build or upgrade new or additional infrastructure and communications equipment necessary to offer the services. The providers will be in a position to exploit this infrastructure and equipment as well as customer relationships partly acquired with State funds even after the lifetime of the project. Hence, it may benefit from continuing residual advantages from the project." [emphasis added]

Resellers: Third party providers "will be customers of the service provider, in this case of a wholesale service. In some of the areas covered by the project, there is no broadband infrastructure and therefore no wholesale offer at all, preventing market entry of third parties such as resellers without their own infrastructure".

End users: “(...) businesses in the targeted geography will benefit from service coverage beyond and prices below what would be provided purely on a commercial basis (...)." 
Where Is the Advantage? The Case of Public Funding of Infrastructure \& Broadband Networks

N 381/2004: Projet de resequ de telecommunication haut debit des Pyrenees-Atlantiques (France)

Procurement Procedure: Open tender

\section{Service of General Economic Interest}

The Commission applied the Altmark-criteria and came to the conclusion that the measure did not constitute a state aid since all criteria were fulfilled.

\section{N 117/2005: Aggregated public sector procurement of broadband in Scotland (UK)}

Procurement procedure: Negotiated procedure

Final beneficiaries: The Commission does not regard theses beneficiaries (public authorities) as exercising an economic activity. They are, thus, no undertakings.

Service providers: "An open tender procedure as employed in the case under consideration tends to minimize potential advantages to the service providers and thus possible elements of state aid." With regard to the possible elements of state aid, the Commission applied Article 87(3)(c) and came to the conclusion that the measure was compatible with the common market.

\section{N 282/2003: Cumbria broadband (UK)}

Procurement procedure: Open tender, followed by negotiations

Service providers: "In order to provide the required services within the region covered by the Broadband Service Agreement, the UK authorities have stated that there will be a need for significant investment in technical infrastructure (...) by the successful service provider. The service provider will, via the fees charged to the public and to the residential private customers, be compensated for the costs of the initial investment in the technical infrastructure. This infrastructure will, however, remain in the ownership of the service provider upon termination of the [agreement] and the service provider will hence be able to exploit it commercially. 


\section{Chapter 11}

Moreover, by being selected to provide broadband services to a broad range of local public authorities and institutions over the whole duration of the [agreement], a certain aggregated level of demand for broadband services will be confined to the service provider and will hence not be available to potential competitors.

This conclusion is, in the light of the conditions set out by the Court of Justice in its Altmark judgment, not altered by the fact that the service provider will be selected through a tendering procedure. First, it should be noted that the UK authorities intend to use a negotiated procedure, so that the terms of the eventual agreement will the service provider are not clear yet. Therefore, the second condition of the Altmark judgment (...) is not fulfilled in the present case (...). Second, given that the infrastructure will be in the ownership of the service provider after termination of the agreement, it cannot be excluded that the compensation awarded eventually exceeds what is necessary to cover all or part of the costs that the service provider will incur in discharging itself of its obligations."

Residential and business end-users: "The enterprises will enjoy access to broadband services more rapidly and to conditions that they would not have enjoyed under normal market conditions. This is demonstrated by the fact that under the Broadband Services Agreement, the service provider will always charge prices not exceeding those in "wired-up" urban areas (...). As demand for broadband services in such "wired-up" urban areas will regularly exceed the demand in rural and remote areas (...), it follows that the price for such services would have to be significantly higher in the remote areas. Enterprises under the present scheme are thus only charged prices of highly populated urban areas. Consequently, the difference between these two prices is borne by the public and hence constitutes an advantage for the user enterprises (...), in particular with respect to enterprises located in other remote areas that do not benefit from a similar scheme".

\section{N 307/2004: Broadband in Scotland - remote and rural areas (UK)}

Procurement procedure: Negotiated procedure 


\section{Where Is the Advantage? The Case of Public Funding of Infrastructure \&}

Broadband Networks

Service provider: "An open tender procedure tends to minimise potential advantages to the service provider in terms of excessive returns. However, it should be noted that the procurement procedure followed included a negotiation phase and has involved qualitative elements. Moreover, even if the Service Provider would not receive an excessive return on its overall investment, it receives a financial support that gives it the possibility of entering the market and establishing its business. The subsidy will allow the Service Provider to offer lower prices than it would have been able to offer had it to bear all costs by itself and, as a consequence, the Service Provider will be able to attract more customers than under normal conditions."

The Commission is not satisfied by the measures which will be taken by the Authorities to avoid over-compensation since "even if eventually all public funds are repaid, payment of interest is not foreseen and their availability upfront is comparable to an interest-free loan. The absence of interest might imply a reduction in the net present value of the repayment."

With regard to the infrastructure the Commission notices that "the selected bidder is likely to acquire ownership of part of the infrastructure necessary to provide the services", and that he "will be in a position to exploit this infrastructure, as well as other tangible and intangible assets acquired with State funds (...) even after the lifetime of the project and hence enjoy continuing benefits."

End-users: "With the intervention of the authorities, broadband will be available at affordable prices (...) hence citizens and businesses in rural and remote Scotland will benefit from service coverage beyond and priced below what is provided purely on a commercial basis. In addition, they will enjoy an advantage in comparison to businesses located in other underserved regions of the United Kingdom."

Resellers: "While the prices of these wholesale products are not predetermined, given the fact that a subsidy is given, the project is aiming at a minimum coverage to be achieved via retail or wholesale services and affordability is one of the requirements, one would expect the wholesale prices to be lower than what would be offered under normal market conditions in these remote and rural areas without State intervention." 


\section{Chapter 11}

\section{N 199/2004: Broadband business fund (UK)}

Procurement procedure: Restricted procedure

Service providers: "An open tender procedure tends to minimise potential advantages to the service provider in terms of excessive returns. However, it should be noted that the procurement procedure followed included a negotiation phase and has involved qualitative elements. Moreover, even if the service provider would not receive an excessive return on its overall investment, it receives financial support which provides the possibility of entering the market and establishing its business as a "first mover". Moreover, the subsidy will allow the service provider to offer the services at lower prices than it would have been able to offer had it had to bear all the costs itself and, as a consequence, such a service provider will be able to attract more customers than under normal conditions.

The Commission is not satisfied by the measures which will be taken by the Authorities to avoid over-compensation since "even if eventually all public funds are repaid, payment of interest is not foreseen and their availability upfront is comparable to an interest-free loan. The absence of interest might imply a reduction in the net present value of the repayment."

With regard to the infrastructure the Commission notices that "the selected bidder is likely to acquire ownership of part of the infrastructure necessary to provide the services", and that he "will be in a position to exploit this infrastructure, as well as other tangible and intangible assets acquired with State funds (...) even after the lifetime of the project and hence enjoy continuing benefits."

End-users: "With the intervention of the authorities, broadband will be available at affordable prices (...) hence citizens and businesses in rural and remote Scotland will benefit from service coverage beyond and priced below what is provided purely on a commercial basis. In addition, they will enjoy an advantage in comparison to businesses located in other underserved regions of the United Kingdom."

Resellers: "In the areas covered by the project, there is currently no broadband infrastructure and therefore no wholesale offer at all, preventing market entry of third parties such as resellers without own infrastructure." 
Where Is the Advantage? The Case of Public Funding of Infrastructure \& Broadband Networks

\section{N 267/2005: Rural broadband access project (UK)}

Procurement procedure: Tender

Service providers: "A tender tends to minimise potential advantages to the service provider in terms of excessive return. However, even if a service provider would not receive an excessive return on its overall investment, it receives financial support which provides the possibility of entering the market for wholesale broadband services and establishing its business on conditions not otherwise available on the market."

Resellers: "In some of the areas covered by the project, there is no broadband infrastructure and therefore no wholesale offer at all, preventing market entry of third parties such as resellers without their own infrastructures.

End users: "Businesses in the targeted geography will benefit from service coverage beyond and prices below what would be provided purely on a commercial basis like."

\section{N 126/2004: Broadband for SMEs in Lincolnshire (UK)}

Procurement procedure: tender

Selected providers: "An open tender procedure tends to minimise potential advantages to the service provider in terms of excessive returns. However, it should be noted, that the procurement procedure followed included a negotiation phase and has involved qualitative elements. Moreover, even if the service provider would not receive an excessive return on its overall investment, it receives financial support providing the possibility of entering the market and establishing its business. The subsidy will (...) allow the service provider to offer lower prices than it would have been able to offer had it had to bear all the costs by itself and, as a consequence, the service provider will be able to attract more customers than under normal conditions. The fact that the subsidised market entry will coincide with a series of State supported initiatives to stimulate demand for business broadband services 


\section{Chapter 11}

under the (...) programme, will further help customer acquisition and contribute to a "first mover" advantage for the service provider in the areas which currently have no advanced broadband services."

The Commission is not satisfied by the measures which will be taken by the Authorities to avoid over-compensation since "even if eventually all public funds are repaid, payment of interest is not foreseen and their availability upfront is comparable to an interest-free loan. The absence of interest might imply a reduction in the net present value of the repayment."

End-users: With the intervention of the authorities, broadband will be available at affordable prices (...) hence citizens and businesses in Lincolnshire will benefit from service coverage beyond and priced below what is provided purely on a commercial basis. In addition, they will enjoy an advantage in comparison to businesses located in other underserved regions of the United Kingdom."

Resellers: "In large areas covered by the project there is currently no broadband infrastructure and hence no wholesale offer at all, precluding market entry of third parties such as resellers without any infrastructure." In other areas the wholesale product offered is not as advanced, high-speed, etc. as the one offered by the service provider. Since the project is "aiming at minimum coverage to be achieved via retail or wholesale services, and affordability is one of the scoring requirements, one would expect the wholesale prices to be lower than those that would be offered under normal market conditions without State intervention..

\section{N 284/2005: Regional broadband programme: metropolitan area networks ("MANs"), (Ireland)}

Procurement procedure: Open tender conducted in accordance with EU rules

First-layer:

MAN Infrastructure: "The mere construction of the MAN infrastructure, which is owned by the public authorities, does not provide an economic advantage to an undertaking as long as market compensation is paid for its construction. In this respect, it is noted that the public authorities have 


\section{Where Is the Advantage? The Case of Public Funding of Infrastructure \& Broadband Networks}

tendered out the construction of the passive networks to civil engineering companies in accordance with open and competitive tendering procedures. It can therefore be excluded that state aid is present at the level of the construction of these facilities. A possible state aid issue can arise at a following stage when the public authorities make these facilities available to undertakings.

\section{Second layer:}

MSE: "It is generally accepted that an open tender for the management and marketing of an infrastructure such as the MANs tends to minimise a potential advantage to the winning bidder, in terms of excessive returns. In particular, the Commission considers that when a concession under a publicprivate-partnership is tendered out following an open, transparent and nondiscriminatory procedure, it is, in principle, presumed that he level of any public sector support can be regarded as representing the minimum necessary for the execution of a project. The principles of openness, transparency and equality of treatment will be respected because the proposed contract concerning the MSE will be duly advertised in the Official Journal of the European Communities and any modifications or new elements introduced during negotiations respect the parameters of the notices and contract documents, as defined by the Irish authorities.

However, although as a result of the tender, the MSE would not obtain an excessive return from the project it would, nevertheless, - as outlined above - be able to establish its business based on the government-funded MAN infrastructure and enter the market for wholesale services on conditions not otherwise available on the market. The intervention on the State therefore confers an economic advantage to the MSE."

Third party operators: The MSE for phases II and III will (...) make its services available at transparent price conditions, which, for some services, will be benchmarked against the prices of similar services in Dublin. The roll out of the MANs built in phase I enabled telecoms operators (...) to avoid significant capital investment by using the government-funded infrastructure and puts them at a advantage vis-à-vis an operator which has invested in own infrastructure. Hence, operators using the MSE's wholesale network will be granted indirectly an economic advantage since they have access to infrastructure and services made possible by State funding and at prices which would not be available without State support. 


\section{Chapter 11}

End users: “(...) businesses in the targeted geography might benefit from service coverage beyond and at prices below what would be provided on a purely commercial basis like, in some areas, currently offered leased lines or satellite connections.

\section{General Infrastructure}

"Contrary (...) to certain infrastructures in the transport sector, which are open to all potential users on equal and non-discriminatory terms and which are not provided (constructed and/or managed) by the market on purely commercial terms, this type of infrastructure is actually deployed by market operators who intend to provide telecommunications services, although not necessarily on the conditions that will apply to the MANs. Accordingly, phases II and III of the MANs programme can potentially distort competition by competing with existing private infrastructures or by discouraging future private investment in similar facilities. The absence of distortion of competition is not an inherent feature of this type of facilities, but rather ahs to be verified on a case by case basis."

\section{Service of general economic interest}

"The contractual relationship between the MSE and the Irish government reflects rather a classical private-public-partnership than the entrustment and implementation of a Service of General Economic Interest. (...) Unlike Pyrénées-Atlantiques, the MSE has no clear SGEI mandate to enable broadband access to the general public, citizens and businesses, in rural and remote areas. (...) In the notified measure, although residential users may benefit from the measure, the wholesale services provided by the MSE are high-bandwidth services, dark fibre or sub-ducts which are targeted not at the general public and citizens, but are offered to operators of electronic communications services to provide, first of all, high speed services to businesses. 


\section{Chapter 12}

\section{Puzzles of State Aid: Structural Funds, Cumulation and De Minimis}

\subsection{Introduction}

The compliance of the member states with the rules of the European Community depends on several factors one of which is the clarity of those rules. ${ }^{179}$ This is especially pertinent in the field of state aid where the Commission issues guidelines and notices for the express purpose of helping the member states understand the rules and comply with them in timely fashion. Ambiguity can weaken the system of state aid control. More seriously, ambiguity can be grounds for annulment of the rules by the European Court of Justice. ${ }^{180}$

In view of the importance of clarity, the purpose of this short chapter is threefold. First it identifies four issues which are currently causing problems of interpretation for national authorities which grant state aid. Second, and more significantly, it explains how these interpretation problems may be resolved. Third, it proposes a simplification of procedural rules that can ameliorate both interpretation and application difficulties.

The issues dealt in this chapter can be posed in terms of the following questions:

1. Can de minimis aid be used for any purpose and especially for "topping up" approved state aid without infringing cumulation rules?

\footnotetext{
${ }^{179}$ On the factors that determine compliance, see, for example, P. Nicolaides, From Graphite to Diamond: The Importance of Institutional Structure in Establishing Capacity for Effective and Credible Application of EU Rules, (Maastricht, NL: European Institute of Public Administration, 2002).

${ }^{180} \mathrm{See}$, in this respect, the recent judgement of the Court of Justice dismissing a request by Belgium for annulment of the Commission Regulation 2204/2002 on employment aid; Belgium v Commission, C- C-110/03.
} 


\section{Chapter 12}

2. Must de minimis aid be limited to EUR 100,000 per legally separate entity or independent enterprise?

3. Must aid from the EC structural funds comply with state aid rules, given the fact that it is granted through national authorities?

4. Must aid from the EC structural funds be included in de minimis aid?

\subsection{Issue 1: Use of de minimis aid}

Article 2(1) of Regulation 69/2001 defines de minimis aid as aid that does not fall within Article 87(1) if certain conditions hold and primarily if the total amount does not exceed EUR 100,000 over a three-year period per recipient undertaking.

This means that public funds that otherwise meet the criteria laid down in Article 87(1) are not regarded as state aid if they remain below the threshold of EUR 100,000.

Since the de minimis Regulation prohibits de minimis aid only when it is granted to promote exports or when it is linked to the use of domestic products, it follows that it can be given for any other purpose. National authorities are free to grant de minimis even to cover operating costs. Normally operating aid is not allowed in the EC. In addition, the Regulation allows de minimis aid to be granted to any sector, except in agriculture, fisheries and transport.

What is not clear from the Regulation is whether de minimis aid may be given to top up approved state aid. However, it should be possible for a number of reasons which are elaborated below.

First, recital 5 of the Regulation says: "The de minimis rule is without prejudice to the possibility that enterprises receive, also for the same project, State aid authorised by the Commission or covered by a group exemption Regulation." [emphasis added]

Second, the maximum allowable amounts of aid are laid down in the various rules of cumulation of aid. The rules of cumulation in the block exemption Regulations and the main guidelines [the relevant texts are quoted in Annex I], with the exception of the regional guidelines, refer explicitly to aid that 
falls within the meaning of Article 87(1). Since Article 2(1) of the de minimis Regulation defines de minimis as aid that does not satisfy all the requirements of Article 87(1), it is not state aid and therefore it is not bound by the rules of cumulation. Consequently, it should be possible to use it to top up approved aid.

It is true that the cumulation rule in the regional guidelines [point 4.18] does not allow us to infer unequivocally that de minimis cannot be used for topping up purposes. But that is because it is ambiguous. It simply refers to aid from "all sources". It is theoretically possible that the word "aid" could include funds that emanate from a public source but do not otherwise fall within Article 87(1). However, this potential explanation is not plausible because it is unlikely that the concept of cumulation would vary unexplainably across guidelines or regulations. On the contrary, there are indeed cases of public funds which are given to undertakings and which do not fall within the scope of Article 87(1). These are the cases of funds given in remuneration for goods and services purchased by public bodies and the cases of injection of public capital in undertakings according the basis of the private investor principle. Such public funds are never taken into account for cumulation purposes simply because they are not state aid.

Third, the de minimis Regulation does not explicitly forbid the use of de minimis aid to top up approved state aid. By contrast, the other Regulations and guidelines both prohibit the use of aid from other sources for the same underlying costs when intensity ceilings are exceeded and permit topping up of aid up to the allowable ceilings.

Fourth, the practice of the Commission itself suggests so. In its decisions on problematic cases of state aid [mostly non-notified aid or aid that is only partly covered by existing Regulations or guidelines], the Commission routinely exempts the part of aid that falls within Regulations and guidelines and the part of aid that can be covered by the de minimis rule without stipulating that topping up is prohibited. See, for example, Commission Decision 2000/128 [upheld by the ECJ] on employment aid granted by Italy, recitals $115 \& 119$. In this Decision, the Commission refers explicitly to eligible costs that can be aided both under the guidelines and de minimis.

Fifth, if topping up were prohibited, it would have been impossible to enforce such a prohibition. Suppose a company proposes to undertake a 


\section{Chapter 12}

project costing EUR 1,000,000 and applies for a grant of EUR 300,000 because it would not be commercially viable for it to commit more than EUR 700,000 of its own resources. Also suppose that the allowable ceiling of aid intensity is $20 \%$. In this case the member state concerned could simply do the following. It could grant aid up to the allowable ceiling and then give de minimis aid with no explicit topping up aim [so the Commission would never be able to detect any illegal topping up], but on the condition that the recipient company commits an additional EUR 100,000 of its own resources. Naturally, the company will divert resources from its operating expenses to the project. Since money is fungible, the de minimis aid that is given, say to cover operating expenses, will in essence be used to cover the difference between EUR 200,000 and EUR 300,000. The end result is the same as if state aid were explicitly topped up and no court would find any fault in a national procedure that requires recipient firms to commit more of their own money to aided projects.

\subsection{Issue 2: De minimis aid per legal entity or independent enterprise?}

Art 2(2) of the de minimis Regulation refers to "the total de minimis aid granted to any one enterprise ..." It does not refer either to "independent" or "autonomous" enterprise or "undertaking" which may include distinct legal entities that do not have freedom to make independent economic decisions [see Intermills v Commission, C-323/82, for the definition of undertakings as single economic units].

The absence of any reference to independence or undertakings suggests that the term "enterprise" in the Regulation means separate legal entity.

Indeed, if the Regulation meant independent enterprise, it would have said so explicitly. It is worth noting that the now defunct proposals on "Lesser Amount of State Aid" and "Limited Effect on Trade", which attempted to introduce concepts similar to de minimis, referred explicitly to "independent enterprises".

Moreover, if the Regulation meant independent enterprise, it would have imposed a disproportionate burden on national authorities which would have to check the status of any recipient of public funds even in cases where those funds would be very small. 
Public authorities, however, should be careful that, in cases of related enterprises, there is no spillover or leakage of aid from one to another in a way that would breach the threshold of aid received by any one of them. State aid rules apply both to primary and secondary beneficiaries. It is probably not easy for public authorities to check that, but if they suspect that aid flows from one enterprise to another they need to investigate and take measures to prevent cumulation above the threshold. As the landmark case of the Dutch petrol stations shows, once aid flows from one company to another, it is not so easy to recover it [see Commission Decision 1999/705 upheld by the Court in case C-382/99].

\subsection{Issue 3: Status of EC structural funds under state aid rules}

In general, when EC structural funds are combined with state aid, the member state concerned has to comply also with the relevant state aid rules if a state aid situation arises. This is explicitly stipulated in Articles 12, 29(3) and 34(1) of Regulation 1260/99 [the basic Regulation for structural funds]. There is a state aid situation when structural funds are combined with national money in situations where the national money falls within the meaning of Article 87(1). In this case, even if the EC funds are not state aid, under the relevant rules of cumulation [see Annex I] they must also be counted together with state aid for the purpose of compliance with the allowable rates of aid intensity.

Indeed the latest available Annual Competition Report by the Commission makes this point clear. It says that "with respect to competition rules, it should be noted that Community support does not represent State aid within the meaning of Article 87(1), but it must follow the same rules and must be taken into account - where it concurs with Member State funding - for the purpose of determining the compatible amount of aid." [XXXIII Competition Report, 2003, paragraph 393] [emphasis added].

The standard structural fund requirement for national co-financing does not create a state aid situation in three cases. First, a project can be funded solely by EC and private funds without any public funds from a national source. This means that the national co-financing obligation laid down in Article 29 of Regulation 1260/99 is fulfilled by private contributions [but see further 


\section{Chapter 12}

below on whether the granting of only EC money can escape being caught by Article 87(1)].

Second, the national co-financing may fall below the de minimis level which means that it is not classified as state aid and as a consequence no state aid situation arises [but see also next section which considers whether EC money should be included in the de minimis amount].

Third, the national co-financing may exceed the de minimis level without, however, satisfying all the criteria in Article 87(1). This prevents it from being classified as state aid. This is the situation where the recipient of the combined EC and state funds is not an undertaking as is the case with infrastructural projects and aid that goes directly to individuals such as unemployed persons.

The implications of this reasoning are that, first, where there is no state aid situation [e.g. the only funds are EC and private], the "aid intensity" of EC grants may exceed those laid down in the various state aid Regulations and guidelines. Second, EC aid may be used for purposes not allowed by state aid rules but permitted by structural fund rules such as to promote investment by firms located in Objective 2 regions which are not designated as Article 87(3)(c) areas [e.g. projects funded wholly by EC and private sources].

Since these are significant implications, how certain can we be that structural funds are not state aid?

Article 9 of the structural funds Regulation, which defines the various terms used in the Regulation, stipulates in paragraph $\mathrm{j}$ that a measure is a state aid measure when it satisfies the criteria of Article 87(1). This implies that other funds that fall within the scope of the Regulation, but which do not satisfy the criteria of Article 87(1), are not state aid. Those other funds are either Community funds or private funds.

More importantly, the relevant case law concerning Article 87(1) defines what funds fall within its scope. These are funds that come directly from the state or are controlled by the state and because they are controlled by the state they become "state resources". The Community is not a state and EC funds do not come from the state. But because they are channelled through 
public bodies [i.e. the Managing and Paying Authorities set up under Regulation 1260/99], perhaps they come under the control of the state. What then is the meaning of state resources?

At a general level, the Court has said that EC resources are not state resources without, however, considering issues of control over resources flowing though institutions set up and managed by the state [Nordeutsches Fleischkontor, C-213/81]. Could this definition be changed if issues of control are taken into account?

Let's consider first why, in general, EC resources are not state resources. It is not just that the Community is not a state. It is because the Community's money belongs to it even if it is contributed by the member states. That is the reason that the relevant Council Decision [the Own-Resources Decision $2000 / 597]^{181}$ is unanimously agreed by the member states and ratified by national parliaments. Member states may not refuse to make their contributions.

On the expenditure side, resources are, first, committed and, then, paid after a Community decision, not member state decision. In the case of the allocation of structural funds, there is first a unanimous agreement at the highest political level, i.e. the European Council, then unanimous agreement in the Council after it receives the assent of the European Parliament, as stipulated by Article 161/EC, and finally a Commission decision authorising the disbursement of structural funds after member states submit the requisite single programming documents or operational programmes.

We see, therefore, that neither on the revenue, nor on the expenditure side of the EU budget can individual member states either refuse to contribute resources or use them for purposes other than those approved by the Council or the Commission. More broadly, it would be inconceivable that the EC would lose control over its own resources, especially agricultural and structural funds, simply by the fact that these resources reach their final beneficiaries in the member states through channels managed by public entities established by member states.

${ }^{181}$ OJ L253, 7/10/2000. 


\section{Chapter 12}

If the mere channelling of EC funds through public entities would be sufficient to categorise them as state funds, then any EC aid exceeding EUR 100,000 would be caught by Article 87(1) whenever it was granted to undertakings and even if no other state resources were committed at the same time and for the same purpose. But then it would also be possible for member states to escape being caught by Article 87(1) simply by assigning the task of disbursing structural funds to a private company and allowing it to choose between different proposals and projects not on the basis of policy objectives determined by the state, but, say, on the basis of value-for-money, or cost-benefit analysis, etc. Certainly Article 9 of Regulation 1260/99 does allow this possibility. However, as the Court has said in many cases, the internal administrative arrangements of member states may not attenuate the application of Community law. ${ }^{182}$

Admittedly, however, these are general arguments based on general principles. We still need to ask whether it is conceivable that in channelling EC funds through public entities, member states exercise a degree of control which is sufficient to create a state aid situation. There appears to be no specific case law on this point so we need to derive an answer from similar cases.

In this respect, the case law distinguishes between resources from the budgets of state-owned or controlled entities such as public undertakings and state-controlled funds such as money raised and distributed by stateorganised lotteries.

As the Court has said, "for advantages to be capable of being categorised as aid within the meaning of Article 87(1) of the Treaty, they must, first, be granted directly or indirectly through State resources and, second, be imputable to the State" [Pearle, C-345/02, paragraph 35] [See also Italy v Commission, C-303/88; GEMO, C-126/01].

Attribution to the state is especially necessary in the case of public undertakings [see France v Commission (Stardust Marine), C-482/99]. The granting of specific grants must be imputed to an act or decision of the state

182 See, for example, Commission vs. Belgium, C-227/85; Balsamo, C-380/87; Costanzo, C-103/88; Commission v Italy, C-33/90; Konle, C-302/97; Larsy, C$118 / 00$. 
for the simple reason that undertakings have both an obligation to carry out commercial activities and discretion when doing so. Their spending decisions are motivated by commercial objectives rather than public policy aims. It is for this reason that for a particular transfer of funds to be considered as involving state aid it is necessary to impute it to the state in the form, for example, of instructions issued by the relevant minister to the management of the public undertaking concerned.

Although it is well recognised that a public entity can be considered to be an undertaking under competition rules [see Hoefner, C-41/90; Assurances Générales de France, C-159/91; Pavlov, C-180/98; Ambulanz Glockner, C475/99], in our case Managing Authorities and Paying Agencies responsible for structural funds are not acting as undertakings when they disburse those funds. Moreover, the money is not theirs in the sense that it does not come from their budget since the origin of the funds is the EC, nor is it raised by themselves through revenue-generating activities or tax measures.

This leaves us with the second possibility that structural funds could be regarded as resources over which the state exercises control even if strictly speaking the funds do not belong to the member state concerned.

In the case France v Ladbroke and Commission [C-83/98P], the Court said in paragraph 50 that "Article $87(1)$ of the Treaty covers all the financial means by which the public sector may actually support undertakings, irrespective of whether or not those means are permanent assets of the public sector. Consequently, even though the sums ... are not permanently held by the Treasury, the fact that they constantly remain under public control, and therefore available to the competent national authorities, is sufficient for them to be categorised as State aid and for the measure to fall within Article 87(1) of the Treaty." [emphasis added] Are structural funds under the constant control of the member states? It seems not, given the fact that the allocation of structural funds per member state and the eventual release of those funds are determined by the Council and the Commission, respectively.

In the earlier Sloman Neptun case [C-72/91], the Court concluded that the advantages granted to German shipowners were not state aid because the measures in question did not create an "additional burden" for the state [paragraph 21]. 


\section{Chapter 12}

In the more recent Pearle case [C-345/02], the Court said again that "... the Board's action did not tend to create an advantage which would constitute an additional burden for the State or that body." [paragraph 36] [emphasis added].

If follows then that even if we could still find a residual degree of control by the state when it disburses structural funds, that is not a sufficient criterion because structural funds do not come out of public budgets creating in the process an additional burden for the state.

At this point one may retort that a principle of structural funds is that of national co-financing. Member states must contribute money of their own in order to draw down the structural funds provisionally allocated to them. That could be regarded as an additional burden for the state. Although this is true, it refers to the member states' share of financing of projects, not the structural funds themselves. Moreover, one could also argue the opposite. That since member states must co-finance projects, this co-financing is not a decision that can be imputed to the state. In the case law, imputation means that the state is also free not to provide funds. The implication is that acts of member states which are mandated by the EC cannot be imputed to the state. Since national co-financing is mandated by the EC, it appears that even the national contribution should not be classified as state aid. ${ }^{183}$ But perhaps this is too strong of an argument if one considers that member states may have the option not to use structural funds. Although this is an interesting possibility, it is not decisive for the purposes of this chapter so we do not investigate it further.

Finally, if structural funds could be characterised as state resources we would have in some cases a contradictory situation, already mentioned earlier, where the Council [through Regulation 1260/99] would allow aid to investments in large firms located in Objective 2 regions while the Commission [through the regional guidelines] would prohibit such investments whenever those firms are located outside Article 87(3)(c) areas. Such contradiction disappears if structural funds are not regarded as state aid.

${ }^{183}$ In this context, please note, for example, that Article 15 of Council Regulation 2369/2002 amends Article 19 of Regulation 2792/1999 on structural assistance to fisheries by stipulating that Articles 87-89 "shall not apply to mandatory financial contributions by Member States to measures co-financed by the Community ..." 


\subsection{Issue 4: Inclusion of EC structural funds in the de minimis amount}

Since EC funds do not come from the state, irrespective of whether they are channelled through national authorities, they can not satisfy the criteria of Article 87(1). This means that EC funds would not be classified as state aid even if they exceeded the de minimis threshold. As explained above, Article 2 of Regulation 69/2001 defines de minimis aid as that aid that would otherwise be caught by Article 87(1) if it would exceed the threshold of EUR 100,000 .

Moreover, Article 3 of the de minimis Regulation, which lays down the rules on cumulation of de minimis aid, stipulates that member states may not grant de minimis aid that exceeds the level set out in Article 2(2). But since any excess amount over that level cannot include EC funds, it follows that EC funds cannot be counted together with other public funds whose combined total remains below or reaches above the de minimis threshold.

In addition, there is no such thing as de minimis EC funds.

\subsection{Recommendations on procedural simplification}

Many national authorities treat structural funds as state aid. In most cases, this makes no practical difference because, once EC funds are combined with state resources, the sum total has to remain below the stipulated maximum rates of aid intensity. In this sense, it is irrelevant whether structural funds are classified as state aid or not. But, as shown above, there are cases where it does make a difference as when, for example, a project if financed wholly by Community and private funds.

The misunderstanding about the nature of structural funds stems partly from the state aid rules that stipulate cumulation of EC with national resources and partly from the practice of the Commission that requires national authorities to obtain from the Commission two authorisations for projects combining structural funds with state resources that are classified as state aid. One approval is granted by DG Regional Policy and covers structural funds 


\section{Chapter 12}

and another is granted by DG Competition and covers the state aid that is used to co-finance projects.

At present both the rules on structural funds and the guidelines on regional state aid are being revised. This presents an excellent opportunity to simplify the rules on projects combining funds from Community and national sources.

Naturally, national officials find this system of double authorisation too bureaucratic. When Commission officials from DG Competition are asked why they must also check projects already approved by DG Regional Policy, they answer that national authorities have discretion which they may use to distort competition.

This answer creates a problem of policy transparency because the perceived implications of national control in this context have never been made explicit in any meaningful detail. Indeed it would be interesting to learn whether the Commission understands member state discretion to be different from control over the disbursement of structural funds and how this presumed discretion is compatible with the official position of the Commission that EC funds are not state resources.

At any rate, it would make sense to continue with the present system of double authorisation only in those cases where the addition of state aid to structural funds brings the total aid intensity above the thresholds of aid provided in the structural fund Regulation and for which DG regional Policy has already granted its approval.

For example, Article 29 of Regulation 1260/99 limits EC funding to only $15 \%$ of total investment costs of firms located in Objective 2 regions. If the same region is eligible for state aid under Article 87(3)(c), and the maximum permissible aid intensity [for aid from both EC and national sources] is equal to or less than $15 \%$, then no additional authorisation should be necessary. This is because the distortion of competition is the same irrespective of whether the aid is fully from the EC or fully from the member state. The recipient firm reacts in the same way and has the same impact on the market, unless EC money and national money target different costs. But in the case of productive investments the eligible costs are the same. 
The situation is different where the allowable state aid intensity exceeds the rate of the Community contribution or the eligible costs are different. For example, if the maximum allowable state aid intensity is $20 \%$ of investment costs, while the Community contribution is limited to $15 \%$ of those costs, it means that state aid may be used to top up Community assistance by 5 percentage points. Now there can be an extra distortion of competition and a second authorisation from DG Competition is necessary. ${ }^{184}$

It follows that there are situations where the procedures for notification and approval of state aid that is combined with Community funds can be simplified and shortened.

\subsection{Conclusions}

The purpose of this short chapter has been to clarify four issues that are apparently perplexing national authorities involved in the granting of state aid or in disbursing EC structural funds.

The answers given to the four questions posed at the beginning of the chapter are that de minimis aid may be used to top up other approved aid schemes, that EC structural funds are not state aid, that EC funds need not be included in de minimis amounts of aid and that the de minimis threshold applies per legal entity rather than independent enterprise.

In addition the chapter has suggested simplification of the present system of double approval for projects financed by Community and national public funds. Where the aid thresholds laid down for Community funds do not exceed those stipulated by state aid rules, a single approval should be sufficient.

\footnotetext{
${ }^{184}$ This is a situation similar to that envisaged by the amended Regulation $2792 / 1999$ [see previous footnote] which continues to apply state aid rules to "public financing exceeding the provisions of this regulation ..." [emphasis added]. Further reading on this chapter: $M$. Berghofer, The new de minimis regulation: enlarging the sword of Damocles? European State Aid law-Quarterly, Volume 6 No. 12007. M. Herm and P. Rossi, Commission requests phasing out of Spain's export related tax incentives, Competition policy newsletter: $n$ r. 22006.
} 


\section{Annex I: Cumulation Rules}

\section{Regulation 69/2001 on De Minimis Aid (OJ L10, 13/1/2001)}

Article 2

De minimis aid

1. Aid measures shall be deemed not to meet all the criteria of Article 87(1) of the Treaty and shall therefore not fall under the notification requirement of Article 88(3) of the Treaty, if they fulfil the conditions laid down in paragraphs 2 and 3 .

2. The total de minimis aid granted to any one enterprise shall not exceed EUR 100000 over any period of three years. This ceiling shall apply irrespective of the form of the aid or the objective pursued.

\section{Article 3}

Cumulation and monitoring

1. Where a Member State grants de minimis aid to an enterprise, it shall inform the enterprise about the de minimis character of the aid and obtain from the enterprise concerned full information about other de minimis aid received during the previous three years. The Member State may only grant the new de minimis aid after having checked that this will not raise the total amount of de minimis aid received during the relevant period of three years to a level above the ceiling set out in Article 2(2).

\section{Regulation 70/2001 on aid to SMEs (OJ L10, 13/1/2001)}

Article 8

Cumulation

1. The aid ceilings fixed in Articles 4,5 and 6 shall apply regardless of whether the support for the aided project is financed entirely from State resources or is partly financed by the Community.

2. Aid exempted by this Regulation shall not be cumulated with any other State aid within the meaning of Article 87(1) of the Treaty, or with other Community funding, in relation to the same eligible costs, if such cumulation would result in an aid intensity exceeding that fixed by this Regulation.

Regulation 68/2001 on Aid to Training (OJ L10, 13/1/2001)

Article 6

Cumulation 
1. The aid ceilings fixed in Articles 4 and 5 shall apply regardless of whether the support for the project is financed entirely from State resources or is partly financed by the Community.

2. Aid exempted by this Regulation shall not be cumulated with any other State aid within the meaning of Article 87(1) of the Treaty, or with other Community funding, in relation to the same eligible costs, if such cumulation would result in an aid intensity exceeding that fixed by this Regulation.

\section{Regulation 2204/2002 on Aid to Employment (OJ L337, 13/12/2002)}

Article 8

Cumulation

1. The aid ceilings fixed in Articles 4, 5 and 6 shall apply regardless of whether the support for the aided employment or recruitment is financed entirely from State resources or is partly financed by the Community.

2. Aid under schemes exempted by Article 4 of this Regulation shall not be cumulated with any other State aid within the meaning of Article 87(1) of the Treaty, or with other Community funding, in relation to the same wage costs, if such cumulation would result in an aid intensity exceeding that fixed by this Regulation.

3. Aid under schemes exempted by Article 4 of this Regulation shall not be cumulated:

(a) with any other State aid within the meaning of Article 87(1) of the Treaty, or with other Community funding, in relation to costs of any investment to which the created employment is linked and which has not yet been completed at the time the employment is created, or which was completed in the three years before the employment is created; or

(b) with any such aid or funding in relation to the same wage costs or to other employment linked to the same investment, if such cumulation would result in an aid intensity exceeding the relevant ceiling of regional investment aid determined in the guidelines on national regional aid and in the map approved by the Commission for each Member State or the ceiling in Regulation (EC) No 70/2001. Where the relevant ceiling has been adapted in a particular case, in particular by the application of State aid rules applying in a particular sector, or by an instrument applying to large investment projects, such as the applicable multisectoral framework for regional aid for large investment projects, the adapted ceiling shall apply for the purposes of this paragraph. 


\section{Chapter 12}

4. By way of derogation from paragraphs 2 and 3, aid under schemes exempted by Articles 5 and 6 of this Regulation may be cumulated with other State aid within the meaning of Article 87(1) of the Treaty, or with other Community funding, in relation to the same costs, including with aid under schemes exempted by Article 4 of this Regulation which complies with paragraphs 2 and 3, provided that such cumulation does not result in a gross aid intensity exceeding $100 \%$ of the wage costs over any period for which the worker or workers are employed. The first subparagraph shall be without prejudice to any lower limits on aid intensity that may have been set pursuant to the Community framework for State aid for research and development(16).

\section{Regional Guidelines (OJ C74, 10/3/1998)}

4.18. The aid intensity ceilings laid down in accordance with the criteria set out at points 4.8 and 4.9 , apply to the total aid:

- where assistance is granted concurrently under several regional schemes, - whether the aid comes from local, regional, national or Community sources. 4.19. The job creation aid described in points 4.11 to 4.14 and the investment aid described in points 4.4 to 4.10 may be combined, subject to the intensity ceiling laid down for the region.

4.20. Where the expenditure eligible for regional aid is eligible in whole or in part for aid for other purposes, the common portion will be subject to the most favourable ceiling under the schemes in question.

4.21. Where the Member State lays down that State aid under one scheme may be combined with aid under other schemes, it must specify, for each scheme, the method by which it will ensure compliance with the conditions listed above.

\section{R\&D Framework (OJ C45, 17/2/1996)}

5.12. The ceilings laid down above in respect of R\& D aid apply to State aid. However, when examining $\mathrm{R} \& \mathrm{D}$ aid, the Commission must take into account the effect on competition and trade of a combination of State aid with Community financing.

Where Community financing and State aid are combined, total official support may not exceed $75 \%$ in the case of industrial research and $50 \%$ in the case of pre-competitive development activities. 


\section{Environmental Guidelines (OJ C373, 3/2/2001)}

74. The aid ceilings stipulated in these guidelines are applicable irrespective of whether the aid in question is financed wholly or in part from State resources or from Community resources. Aid authorised under these guidelines may not be combined with other forms of State aid within the meaning of Article 87(1) of the Treaty or with other forms of Community financing if such overlapping produces an aid intensity higher than that laid down in these guidelines

In the case of aid serving different purposes and involving the same eligible costs, the most favourable aid ceiling will apply. 


\section{Chapter 13}

\section{Markets and Words: The Distortive Effect of Government Pronouncements}

\subsection{Introduction}

It is said that "words are cheap" because if they are not backed up with deeds they are ineffective. Apparently, not so in the games governments play with state aid. The European Commission is indeed concerned about the impact of public statements on markets. In its recent investigation of state aid for France Telecom, the Commission referred to government statements that "created expectations and confidence on the financial markets and France Telecom's investment rating. If the statements had not been made, no reasonable investor would have offered a shareholder's advance in these circumstances and assumed alone a very large financial risk." 185

Politicians, by expressing support for a particular company that happens to be in financial trouble, seek to shape the perceptions of its banks and shareholders and induce them to provide it with new finance. Perhaps creditors are assured that in case the condition of the company deteriorates further, the government will be ready to step in to shore it up.

If indeed politicians can influence market outcomes through their statements, then certainly the lucky companies obtain an advantage they would not have obtained under normal market conditions. Two questions arise in this context: Do the markets actually believe them and could such statements be considered to be a form of state aid?

Assuming that the companies that have the support of the government derive some kind of benefit, as is well known, there can be no state aid as long as there is no transfer of state resources. But could the expression of intent to

${ }^{185}$ Press Release, 20 July 2004, IP/04/981. 
inject public money be regarded as a commitment to a future transfer of state funds? What happens when the public statements simply refer to the strong wish of the government to see the company continue its activities?

The point is that if the Commission starts treating public statements of support as a form of a commitment to effect a future transfer of state resources, then there is hardly any doubt that politicians will learn to make pronouncements that hide that intent so as to be compatible with state aid rules.

But before we even need to consider how politicians are likely to react and how their statements may evolve, we need to resolve something more fundamental. It is far from clear how precisely such statements can influence company decisions and eventually affect market outcomes.

This is the purpose of this short chapter. It examines, first, whether markets are likely to be swayed by public statements. Then it considers the nature of the advantage that is conferred through such statements. It shows that the impact of government pronouncements is wider. Through a simple case, it demonstrates not just how the willingness for intervention raises the chances of survival of a company but also how it affects the market entry of its rivals. Therefore, public statements can have an impact both on the entry as well as the exit of a company from the market. Reputation matters and in this sense words are certainly not cheap.

\subsection{Investor rationality and public statements}

Words are indeed cheap if they are not backed up with deeds. Just like the proverbial shepherd who cried wolf too many times, the government that talks without acting will eventually fail to be believed by the market. That does not mean that governments do not renege on their commitments. It only means that if they do, very soon they lose their credibility. So if investors are rational they will take into account the discounted value of the future amount of any state aid that is "promised" by the government. The present value of future aid will also be discounted by the probability of reneging.

But public statements are by their very nature available to anyone on the market, including the Commission. Investors, therefore, will take into 


\section{Chapter 13}

account only the maximum amount of aid that is likely to be authorised by the Commission. Investors will not believe the government that promises aid in excess of what may be allowed by the Commission or of a kind that is not permitted under state aid rules.

Public statements do influence markets but they are unlikely to influence them to an extent not allowable by the prevailing state aid rules. If there is uncertainty about the outcome of an eventual Commission investigation, rational investors would take that into account too!

If we believe in investor rationality, it seems that there is nothing unfair or illegal about public pronouncements. They do not generate outcomes that are unobtainable from the granting of aid that is compatible with the common market. Perhaps the only two things which are unfair in this context are, first, that the governments of some countries appear more willing to intervene to prop up ailing companies and, second, that governments have discretion to grant ad-hoc aid. This means that not all companies are treated equally. But the point is that despite their unfairness, neither is prohibited by the state aid rules of the European Community.

This reasoning suggests that public statements do not confer an advantage that the company concerned would not have obtained from legal state aid. So perhaps the European Commission should not worry too much about them.

By contrast, the Commission should worry about the distortive effect of government intervention which is less visible. The next section demonstrates what may happen when public authorities are too eager to forgive debts on the grounds that full debt repayment may precipitate the collapse of companies that owe them money. This debt forgiveness encourages riskier investments by the debtor companies and discourages market entry by their competitors.

\subsection{A game of market entry and exit with public funds}

This section develops a case to illustrate how access to public funds may distort competition even when public loans are granted at market rates of interest. What makes this case more interesting is that such loans do not 
satisfy any of the formal criteria of Article 87(1). Therefore, they cannot be regarded as state aid.

Under the conditions explained below, the distortion arises from the possibility that public authorities may be more willing to reschedule loans whenever debtors find themselves in financial difficulty. Since, when public authorities act as "public creditors" they have considerable discretion, this action of rescheduling or even writing-off debt may also escape being caught by Article $87(1) .{ }^{186}$

Suppose two otherwise similar firms, A and B, are about to launch rival products of comparable quality. Assume that the market can successfully sustain only one product. The cost of the project is 100 for either firm and is financed through one-year loans. If the project succeeds it will generate revenue estimated at $320 \%$ of the cost of investment. The possibility of success for each firm is $50 \%$, but in case they succeed they gain whole market while the loser gains nothing. Therefore the expected return for either firm is the sum of the revenue they make in case they succeed and the revenue they make in case they fail, or $E=[(100 \times 3.2) \times 0.5]+[0 \times 0.5]=$ 160. This means that the net return is $60(=160-100)$, corresponding to a profit rate of $60 \%$ before financial charges.

Since the project is very risky and the firms do not have sufficient security to offer, their banks charge them a rate of interest that reflects the high risk of the investment. If the market rate is, say, $5 \%$, and the risk premium is $50 \%$ (reflecting the chances of success), the overall rate of interest charged is 55\%. This means that after deducting financial charges, the net profit rate for each firm, in case their projects succeed, is 5\%. Therefore, each firm may make a small profit but the risk is very high.

The question is whether they should make the investment. Each firm makes a profit of $165(=320-155)$ if the other firm stays out of the market and a profit of $5(=160-155)$ if the other firm also enters the market. Their payoff matrix is as follows.

\section{Payoffs for A / B $B$ enters B stays out}

${ }^{186}$ See the landmark cases of C-342/96, Spain v Commission (Tubacex), 1999 ECR I-2459 and C-256/97, DM Transport, 1999 ECR I-3913. 

A enters
5,5
165,0
A stays out
0,165
0,0

As can be seen, despite the very high risk of the project, the dominant strategy of each firm is to enter the market, irrespective of what the other firm does [the shaded box indicates the dominant option]. The Nash equilibrium entails success of one firm and failure of the other.

Suppose that firm A adopts an aggressive policy and commits an additional 35 from its own resources and succeeds in the process to raise its chances of success. To make matter worse for firm A, assume that this aggressive policy does not generate more revenue, but only extra costs. The possibility of success is now $60 \%$ and the expected return $\mathrm{E}=[(320) \times 0.6]+[(0 \times 0.4)]$ $=192$. The net return will be $192-100-55-35=2$. For firm $\mathrm{B}$, the commitment of additional resources by firm $\mathrm{A}$ has reduced the chances of its success and the net expected return is now $[(320) \times 0.4]+[(0 \times 0.6)]-155=$ -27 .

If firm A enters alone, it gains $130(=320-155-35)$. If it enters together with firm B, it gains 2 . If firm B enters alone, it gains 165 and if it enters with $\mathrm{A}$ it loses -27 . The payoff matrix changes as follows.

$\begin{array}{ccc}\text { Payoffs for A / B } & \text { B enters } & \text { B stays out } \\ \text { A enters } & 2,-27 & 130,0 \\ \text { A stays out } & 0,165 & 0,0\end{array}$

The adoption of an aggressive strategy by firm A has improved its situation because it has destroyed the symmetry between the two companies. It will enter irrespective of what B chooses to do. For B the right option depends on what A decides to do. Since entry is the dominant option for A, B will stay out.

But what happens if the commitment of additional resources has a different outcome? Assume, for example, that the increase of the probability of success from $50 \%$ to $60 \%$ requires not 35 units of resources but 40 . Now the net return of firm A becomes $192-100-55-40=-3$. If firm A enters alone, it gains $125(=320-155-40)$. If it enters together with firm $\mathrm{B}$, it loses -3 . If firm B enters alone, it gains 165 and if it enters with A it loses 27 . The payoff matrix changes significantly. 


$\begin{array}{ccc}\text { Payoffs for A / B } & \text { B enters } & \text { B stays out } \\ \text { A enters } & -3,-27 & 125,0 \\ \text { A stays out } & 0,165 & 0,0\end{array}$

There is no dominant strategy anymore. Each firm enters only if the other stays out and vice versa. The outcome is now indeterminate.

But firm A can still do something else to change the outcome in its favour. Suppose that firm A has access to government finance and applies for a government loan instead of a commercial loan. The possibility for firm A to obtain public funds can influence the strategy of the rival firm B and deter it from entering the market. This is another way trough which firm A can destroy the symmetry between itself and its rival and change the outcome to its favour.

Normally firm A would not commit additional resources if the return were negative. But it knows form assurances it has received that in case the project fails the government would not call in the loan because it would precipitate the collapse of the company or would be willing to renegotiate repayment of the loan. Now, in case it fails it will lose only its own money. This means that the net expected return for firm $A$ is $(0.6 \times(320-195))+$ $(0.4 \times(0-40))=+59$.

The options for the two firms change significantly. If firm A enters the market alone, it gains $125(=320-155-40)$. If firm B also enters the market, then firm A still stands to gain 59. If firm B enters alone it will gain 165 , but if firm A also enters, firm B will lose 27 . The payoff matrix is now as indicated below.
Payoffs for A / B
$B$ enters
A enters
$59,-27$
A stays out
0,165
B stays out
125,0
0,0

For firm A the dominant strategy is to enter, irrespective of what B chooses to do. By contrast, firm B enters the market only if firm A stays out. Since firm A will certainly enter the market, firm B will choose to stay out. The presence of government finance and the possibility that the government may be more forgiving than a commercial bank have the potential to affect the 


\section{Chapter 13}

calculations of the rival firms and significantly distort competition between them.

It follows, therefore, that access to public funds, even at market rates of interest, coupled with the possibility that the government may not be as demanding as commercial banks in recovering its money may confer an advantage that distorts competition by discouraging rival firms from competing against the recipients of public funds on risky projects.

What can be done to remedy this situation? Nicolaides and Kekelekis ${ }^{187}$ have proposed that public authorities should not be allowed to negotiate directly with debtors. These negotiations should be left to independent professional negotiators whose fee should be proportional to the debt they recover. They would then have a strong motive to behave as private creditors trying to maximise the recovery of their own money. Public authorities cannot be presumed to be acting as private creditors because of the obvious conflict of interest and because their employees who negotiate repayments are not trying to maximise the amount of their own money they get back.

\subsection{Conclusion}

This short chapter has shown how the reputation of a government for intervention may influence market outcomes in favour of certain firms. However, there are two distinct categories of intervention. In the first category, under conditions of investor rationality, public statements are unlikely to influence the market to a greater extent than that caused by the actual granting of legal aid.

In the second category, the possibility of debt forgiveness discourages market entry by rivals firms. Their entry decision is determined, among other things, by the ability of the aid recipients and their competitors, respectively, to avoid exiting the market. If public creditors make it easier for a firm to remain in the market by reducing any debt it may incur, its rivals will have to think twice before they invest in that market. So reputation may be decisive and public words are not necessarily cheap.

${ }^{187}$ P. Nicolaides and M. Kekelekis, When Do Firms in Trouble Escape from State Aid Rules?, European State Aid Law Quarterly, 2005. 


\section{Chapter 14}

\section{Re-introducing the Market in the "Market Economy Investor" Principle}

\subsection{A necessary but imperfect principle}

The European Commission invented the principle of the "market economy investor" almost twenty years ago in order to deal with injections of public capital in both state-owned and private enterprises. Since public investment in enterprises cannot be prohibited by virtue of Article 295, it is necessary, in the context of the legal framework of the European Union, to have a criterion with which to determine whether public investments contain state aid. The principle is also used to assess the rescheduling or recovery of public loans to undertakings and the sale or renting of public assets, goods and services.

The Commission's practice and the case law have come a long way since then. In the short space available to me I want to make three observations: that the term "market economy investor" is a misnomer, that ex-post assessment of a private investor's actions may undermine the principle itself and that it is necessary to "re-introduce" the market in the assessment of public investments and other financial deals.

\subsection{From market economy investor to private investor}

Why is the "market economy investor" principle a misnomer? The reason is simple. In judging whether public investment contains state aid, the Commission compares the actions of the public authority concerned with those of a "typical" private investor in a similar situation in terms of the size, risk and terms of the investment [see the landmark cases of C-234/84, Belgium v Commission; C-40/85, Belgium v Commission; C-305/89, Italy v Commission; C-278/92, Spain v Commission; T-228/99, WestLB v Commission]. 


\section{Chapter 14}

This is a reasonable approach. The problem, however, is that it is not always possible to identify a "typical" investor. This has become clear in recent cases concerning recovery of debt, rescheduling of debt or closure of factories [see, for example, T-152/99, Molina v Commission; C-334/99, Germany v Commission; C-342/96, Spain v Commission; C-256/97, DMT]. To cope with this situation, the European Court of Justice has invented a new principle: The "private creditor". The corresponding "public creditor" is expected to do as a private creditor would do in a similar situation.

But in these conditions there are no comparable market benchmarks. That is why the term "market economy investor" is a misnomer. We are no longer looking at the market for guidance. Every debt rescheduling, every bankruptcy and every factory closure is different. How much debt may be recovered or what kind of financial restructuring may be arranged or what closure terms may be agreed between the different parties [shareholders, creditors, management and staff] very much depend on the negotiating skills and tenacity of each side and the offer that is presented by each side. It is not a case of comparing agreed rates with market rates. The terms and timehorizon of agreed arrangements are also decisive. Creativity and ingenuity are as important as toughness and persistence in negotiations. There are no market benchmarks for these factors. That is why successful corporate bankers command huge salaries. Since public authorities are not known for their foresight and investment skills, it is hard to believe that when it comes to debt recovery, debt rescheduling or sale of public assets, public officials can negotiate as well as private investors.

Admittedly, we may question the skills of public officials but that does not solve the problem facing the Commission and the Court. They still need to have some kind of benchmark in order to detect state aid. Since they cannot turn to the market for guidance, they ask instead how a private investor would behave in that situation. But I do not think that they have found the right benchmark because it is not enough to hypothesise what private investors could potentially do. Since opinions and skills vary significantly, it is important to establish what an investor can actually do. I will come back to the issue of the right benchmark later on. 


\subsection{The investment horizon and time-frame of analysis}

The second problem with the market economy investor or, more appropriately as I have argued above, the private investor principle is that it has recently been applied in an ex-post manner that defeats the principle. As the landmark WestLB judgement clarifies, a private investor will demand a return on his investment that reflects all the benefits obtained by the recipient of his funds and will take into account all foreseeable future contingencies.

In its judgement on the case T-98/00, Linde $\mathrm{v}$ Commission, the Court of First Instance confirmed that a public authority may be justified to make payments to an undertaking in order to reduce much larger losses it would otherwise incur. The Court said that this is how a private investor would behave. What is strange about this judgement is that the Court did not examine whether a private investor would have voluntarily assumed obligations that would have resulted in similar losses. In that case, German authorities had sold off a chemical company. Under the terms of the sale, they assumed the obligation to provide the privatised company with a certain chemical product for a period of ten years at market prices. A couple of years later they realised that it was too costly to continue supplying that chemical because the plant they used was out-dated and because there was no alternative supply source in the area.

Although the judgement of the Court seems reasonable at first sight, it ceases to be so when one takes into account the overall context of the case. Why would a private investor agree to supply that chemical product for a ten year period at market prices when the plant was out-dated and inefficient and when there was no alternative source of supply in the area. The German authorities argued that when the agreement was made it was hoped that a second user of that chemical would build a plan in the area so that demand and, thus, output would increase, allowing the supplier to gain from economies of scale. But how reasonable was that expectation? No proof was provided for that claim.

It seems to me that the Court ignored vital issues in reaching its judgement. If the financial mess was not caused by the sloppy decision of the German authorities to enter into the supply agreement in the first place, then the 


\section{Chapter 14}

Court was right to say that it was rational to expend some public funds in order to save a larger amount of such funds. But if the public authorities were responsible for that financial mess, then the judgement is faulty because it has arbitrarily ignored issues that a private investor would never have ignored. The Court has arbitrarily narrowed the investment horizon of a private investor by neglecting to assess the events that took place at the time of the signing of the ten-year supply agreement. This is the fundamental problem with the ex-post application of the private investor principle. How far back should the Commission and the Court go?

It is true that a private investor always looks forward. He does not consider the size of past investments and expectations. He asks, instead, how much can be earned in the future on what ever of the past investment is still available. In economics and business "bygones are bygones". But the task of the Court was not to determine the economics of the deal. Its task was to establish whether the German authorities had acted as a private investor. It seems to me that they did not. Public authorities may not create costs for themselves and then claim that the payments they make to reduce those costs are not state aid.

A similar conclusion has been reached by the Court of Justice in case C334/99, Germany v Commission, concerning aid granted in the process of privatising the steel company Gröditzer Stahlwerke. Germany argued that it acted as a private investor would do because the aid that made privatisation possible was smaller than the cost of closing down the company. The ECJ correctly observed that Germany had included in the cost of closure the repayment of state aid that had been granted earlier. The German authorities could not grant state aid and then claim that the cost of closing down the company had to take into account previous state aid. First, the state aid that was granted earlier did not have to be repaid. Second, and most importantly, if the aid would create problems later on why was it granted in the first place? It follows that public authorities may not create costs for themselves which can justify the granting of additional state aid later on. The only difference between this case and the Linde case is that here the German authorities did not claim that they acted as a private investor when they granted the first state aid award. This, however, is not a decisive difference because I do not think that in the Linde case the authorities acted as a private investor would. There was hidden state aid in that case too. 
In cases of debt recovery or sale of assets, there is always prior state involvement [in providing credit or in acquiring assets]. This immediately raises the question of how far back in time should one go in investigating the existence of state aid? And which state decisions should be included in a state aid investigation? It seems to me that a properly framed investigation should cover all the related state decisions that involve transfer of public resources or create state liabilities. But the problem is that it may not be possible to identify ex post all related state decisions.

\subsection{Remedies: Re-introducing the market}

Since it is easy to be critical, one also has to ask whether there are any solutions to these problems? This brings me to my third point on how to reintroduce the market in the market economy investor principle. To understand the solution I will propose, it is necessary first to ask what makes public investments so special? Apparently, if one believes the case law, there must be no difference between public and private investments. If there is any difference or if the public investments are made at more favourable terms then the recipients derive an advantage they would not otherwise obtain under normal market conditions. This would turn public investment into state aid. So if public and private investments are indistinguishable, why do certain companies ask for injections of public money? Alternatively, why can they not find private money?

I think the answer is that in reality private money is not the same as public money. Even when the initial terms of investment are identical, there are still significant differences in the subsequent management of the investments. This is reflected in the fact that a private investor would be less willing to tolerate new or additional losses later on, would be less patient and, therefore, more willing to pull out of a loss-making investment, would be more knowledgeable and consequently exercise closer scrutiny on the managers of the company and finally would apply much more pressure on those managers.

Since, as I said earlier, we have no market benchmark for inventiveness and tenacity, it is inevitable that public investments will have an element of state aid. This bias in favour of public investments can be corrected in three different ways. The first and least onerous way is to presume that all 


\section{Chapter 14}

injections or write-offs of public funds involve state aid, unless the authorities concerned can obtain an assessment of the prospects of the investment by an independent investment advisor confirming the terms under which a private investor would make the proposed investment or write-off.

The second corrective method is to ask public authorities not to negotiate directly the terms of any investment or write off. That is, they should always use a private intermediary whose fee should be inversely linked to the amount of capital injection or debt reduction.

The third and most drastic corrective method is to presume that public authorities are always less demanding than a private investor and adjust upwards the return that should be earned on investments of public capital. That is, the rate of return demanded on public investments should be a certain percentage higher than the comparable market return to reflect the less demanding manner with which the state manages its investments.

All three corrective methods impose a penalty on public investment. Is this not a discrimination that is prohibited by Article 295 of the EC Treaty? I do not think so. As the Court of Justice has observed on numerous occasions, there is discrimination only when like are not treated the same. But a public investment is not the same as private investment by the mere fact that the officials in charge of the investment are not dealing with their own money. Due diligence in handling public money is not the same as continuously seeking the highest return on one's own money. As long as public officials do not stay awake during the night worrying about public investments, I would think that public investment is different from private investment.

\subsection{Conclusion}

The market economy investor principle is a necessary instrument for assessing public investments in undertakings. However, the principle has evolved into that of merely the private investor. The market has dropped out. Once the market drops out it is difficult to identify any hidden state aid in public investment or debt recovery. The solution is to re-introduce the market. I have proposed above three different methods of re-introducing market benchmarks and therefore market discipline. All three methods are 
justified by two facts. First, at minimum public authorities should always provide proof of the terms and return that the market would demand before any investment is made or debt recovery is attempted. Second, it is more artificial to assume equality of public and private investment than to presume that they are qualitatively different and treat them accordingly. 


\title{
Part IV: The Challenge of National Tax Autonomy
}

\author{
Chapter 15
}

Developments in Fiscal Aid:

New Interpretations and New Problems with the Concept of Selectivity

\subsection{Introduction}

Policy and practice on state aid in the form of tax advantages is evolving rapidly. This kind of state aid, also known as fiscal aid, lies on the boundary of the division of competences between the European Community and member states.

I have analysed policy developments and the case law for the period 1997 2005 in a number of other papers. ${ }^{188}$ In this short chapter I focus on three

${ }^{188}$ See The Boundaries of Tax Autonomy: Comments on the Opinion of A-G Geelhoed on Case C-88/03, Portuguese Republic v. European Commission, European State Aid Law, 2006; State Aid and Sub-national Taxation, European State Aid Law Quarterly, 2005; Fiscal State Aid in the EU: The Boundaries of Tax Autonomy, World Competition, 2004; Operating Aid and Fiscal Aid in the EC: A Critical Review of Current Practice, World Competition, 2001. Further reading on this chapter: M. Herm and P. Rossi, Commission requests phasing out of Spain's export related tax incentives, Competition policy newsletter: $n r .2$ 2006, R. Horacek, Commission's suspension injunction against illegal tax exempt fund in Greece, Competition policy newsletter: $n r .1$ 2006, A. T. Seinen and C. Guillemaut, Exemptions from the fuel excise tax for alumina production, Competition policy newsletter: $n r .1$ 2006, P. Rossi, The Italian tax premium in favour of newly listed companies and the notion of material selectivity relative to direct business taxation, Competition policy newsletter: $n r .3$ 2005, R. Horacek, Commission's proposal to phase out tax benefits for exempt companies in Gibraltar: Strict limits on existing as well as new beneficiaries, Competition policy newsletter: $n r .2$ 2005, R. Horacek, Commission's negative decision on Gibraltar corporation tax reform: findings on regional and material selectivity, Competition policy newsletter: $n r .22004$, I. 
Developments in Fiscal Aid:New Interpretations and New Problems with the Concept of Selectivity

recent cases that seem to be breaking new ground and therefore deserve particular attention: (i) C-88/03, Portuguese Republic (Azores) v European Commission; (ii) C-526/04, Laboratoires Boiron v ACOSS ; (iii) T-210/02, British Aggregates Association v European Commission.

These cases deal with the perennial problem of fiscal aid: selectivity. The Azores case addresses the issue of regional selectivity. The Boiron case is about taxes that are used to neutralise a selective disadvantage caused by other forms of government intervention (the imposition of a public service obligation). The British Aggregates case concerns selectivity that may arise out of taxes that are applied on specific products.

The chapter argues that while these three cases clarify certain aspects of fiscal aid, they also raise a number of new issues which create new ambiguities and even contradictions.

\subsection{Portuguese Republic v European Commission, C-88/03: The issue of regional selectivity}

Portugal sought the annulment of Commission Decision 2003/442 which found that the system of taxation in the Azores was a form of state aid that was incompatible with the common market. The European Court of Justice found in favour of the Commission and dismissed the appeal.

The Azores enjoys a degree of tax autonomy. The issue was whether that degree of autonomy was sufficient to characterise the tax system of the

\footnotetext{
Atanasiu, EC State Aid policy with respect to soft budgetary constraints: tax and social security contribution payment arrears, European State Aid law - Quarterly, Volume 4 No. 4 2005, P. Rossi-Maccancio, Commentary of State Aid Review of multinational tax regimes, European State Aid law - Quarterly, Volume 6 No. 1 2007, P. Nicolaides, Developments in fiscal aid: new interpretations and new problems with the concept of selectivity, European State Aid law-Quarterly, Volume 6 No. 1 2007, P. Rossi-Maccanico, State aid review of business tax measures - proposals for State aid control of direct business tax measures, European State Aid law-Quarterly, Volume 6 No. 2 2007, J. Mehta, Tax harmonisation and state aid - a warning for the future?, European State Aid law-Quarterly, Volume 6 No. 22007.
} 


\section{Chapter 15}

Azores as a general system or whether its autonomy was more limited so that, as a consequence, its system was a mere derogation from the national Portuguese system. Derogation of this kind would signify that the system was selective.

The Commission had argued in its Decision that "in so far as the element of selectivity in the concept of aid is based on a comparison between two groups in the same reference framework (those which benefit from the scheme and those which do not), it can only be established in relation to taxation defined as normal." [paragraph 26]. In its view, the fact that the regional government of the Azores had obtained the permission of the Portuguese government to reduce the rates of corporate taxation applicable in the Azores proved that the normal system of taxation was that which applied to the rest of the country and was determined by the Portuguese government.

The Court explained that "the concept of State aid does not refer to State measures which differentiate between undertakings and which are, therefore, prima facie selective where that differentiation arises from the nature or the overall structure of the system of charges of which they are part." [paragraph 52]

It went on to agree with the Commission that "as regards the assessment of the condition of selectivity, which is a constituent factor in the concept of State aid, it is clear from settled case-law that Article 87(1) EC requires assessment of whether, under a particular statutory scheme, a State measure is such as to 'favour certain undertakings or the production of certain goods' in comparison with other undertakings which are in a legal and factual situation that is comparable in the light of the objective pursued by the measure in question." [paragraph 54] "In order to determine whether the measure at issue is selective it is appropriate to examine whether, within the context of a particular legal system, that measure constitutes an advantage for certain undertakings in comparison with others which are in a comparable legal and factual situation. The determination of the reference framework has a particular importance in the case of tax measures, since the very existence of an advantage may be established only when compared with 'normal' taxation. The 'normal' tax rate is the rate in force in the geographical area constituting the reference framework." [paragraph 56] Therefore, the question turned out to be whether the normal rate was that 
prevailing in the rest of Portugal or whether the area of responsibility of the regional government could constitute the reference framework.

The Court stated that "it is possible that an infra-State body enjoys a legal and factual status which makes it sufficiently autonomous in relation to the central government of a Member State, with the result that, by the measures it adopts, it is that body and not the central government which plays a fundamental role in the definition of the political and economic environment in which undertakings operate. In such a case it is the area in which the infra-State body responsible for the measure exercises its powers, and not the country as a whole, that constitutes the relevant context for the assessment of whether a measure adopted by such a body favours certain undertakings in comparison with others in a comparable legal and factual situation, having regard to the objective pursued by the measure or the legal system concerned." [paragraph 58]

The Court then rejected one of the arguments of the Commission "that such an analysis is rendered inadmissible by the wording of the Treaty and the well-established case-law in that field cannot be accepted." [paragraph 59] This is because "it cannot be inferred ... that a measure is selective, for the purposes of Article 87(1) EC, on the sole ground that it is applicable only in a limited geographical area of a Member State." [paragraph 60]

For the Court the decisive criterion was whether the regional government had sufficient autonomy to set its own tax rates. It said that "in order to determine the selectivity of a measure adopted by an infra-State body which, like the measure at issue, seeks to establish in one part of the territory of a Member State a tax rate which is lower than the rate in force in the rest of that State it is appropriate ... to examine whether that measure was adopted by that body in the exercise of powers sufficiently autonomous vis-à-vis the central power and, if appropriate, to examine whether that measure indeed applies to all the undertakings established in or all production of goods on the territory coming within the competence of that body." [paragraph 62]

The Court then elaborated three conditions that had to hold in order to determine whether the autonomy of the regional government was sufficient or not. "In order that a decision taken in such circumstances can be regarded as having been adopted in the exercise of sufficiently autonomous powers, that decision must, first of all, have been taken by a regional or local 


\section{Chapter 15}

authority which has, from a constitutional point of view, a political and administrative status separate from that of the central government. Next, it must have been adopted without the central government being able to directly intervene as regards its content. Finally, the financial consequences of a reduction of the national tax rate for undertakings in the region must not be offset by aid or subsidies from other regions or central government." [paragraph 67]

So, the Court has for the first time defined that a sub-national body can levy taxes which deviate from those applied in the rest of the country, provided it is, first, politically separate from central government; second, the central government has not interfered in the decision of the sub-national body; and third, the central government does not make up any short-fall in tax revenue as a result of lower local taxes.

On the basis of these three criteria, the Court concluded that the Azores system was a deviation from the national Portuguese system because the revenue short-fall was made good by the Portuguese government.

In essence, what the Court has said is that for a sub-national system to be regarded as the relevant framework of reference, it must be able to act independently and must not depend on the national system. In the case of the Azores, its constitution requires that the regional government obtains the permission of the central government before it implements a tax reduction. Moreover, any reduction may not exceed a certain ceiling. One wonders whether it would make any substantive difference to the ability of the Azores to lower taxes had the constitution not imposed that requirement and had it set a pre-determined level of budgetary transfers, as it happens in the case of the Basque Country in Spain. A pre-determined level of transfers necessarily implies that it is the regional government that bears the consequences of any revenue short-fall.

Certainly, the three criteria expounded by the Court will be tested in future cases as member states seek to adjust their domestic constitutional arrangements to confer advantages to specific regions without falling foul of state aid rules. It is likely that they will attempt to do it by eliminating from their constitutional arrangements any clauses that stipulate that tax decisions are subject to the approval of the central government and by making transfers automatic rather than discretionary. 
A last issue of note that was examined by the Court was whether the policy objective of solidarity and reduction of regional disparities could be regarded as a legitimate tax objective and therefore fall outside the scope of Article $87(1)$.

The Court reiterated that "a measure which creates an exception to the application of the general tax system may be justified by the nature and overall structure of the tax system if the Member State concerned can show that that measure results directly from the basic or guiding principles of its tax system. In that connection, a distinction must be made between, on the one hand, the objectives attributed to a particular tax scheme which are extrinsic to it and, on the other, the mechanisms inherent in the tax system itself which are necessary for the achievement of such objectives. Measures such as those at issue, which apply to all economic operators without any distinction as to their financial circumstances, cannot be regarded as ensuring that for the purpose of redistribution the criterion of ability to pay is observed. Although it is true that the disadvantages related to the insularity of the Azores might, in principle, be suffered by all economic operators regardless of their financial circumstances, the mere fact that the regional tax system is conceived in such a way as to ensure the correction of such inequalities does not allow the conclusion to be drawn that every tax advantage granted by the authorities of the autonomous region concerned is justified by the nature and overall structure of the national tax system. The fact of acting on the basis of a regional development or social cohesion policy is not sufficient in itself to justify a measure adopted within the framework of that policy." [paragraphs 81-82]

In other words, solidarity and the differentiation of tax rates may be justified by the nature of the tax system, but it cannot be presumed that every tax payer in a poor region is automatically poor and therefore eligible for the lower tax rates. Regional or cohesion objectives are not inherent in tax systems.

\subsection{Laboratoires Boiron v ACOSS, C-526/04}

This case was a reference for preliminary ruling in relation to French proceedings brought by Laboratoires Boiron SA ("Boiron") seeking 


\section{Chapter 15}

repayment of the sum which it had paid to the Agence Centrale des Organismes de Sécurité Sociale (Central Agency for Social Security Bodies) ("ACOSS") by way of a tax on direct sales of medicines. Distributors of pharmaceutical products are exempted from this tax. Boiron essentially argued that exempting wholesale distributors from the disputed tax amounted to unlawful state aid within the meaning of Article $87 \mathrm{EC}$.

In its ruling, the Court first reiterated the principle that "those liable to pay a charge cannot rely on the argument that the exemption enjoyed by other businesses constitutes State aid in order to avoid payment of that charge or to obtain reimbursement." [paragraph 30]

The Court then went on to make a very important distinction. In the earlier cases which established that principle, the exemption concerned relief of certain operators from a tax of general application. By contrast, the present case did not concern a taxation scheme, but rather a charge for which only one of two categories of competing operators, namely pharmaceutical producers, was liable. The other category comprised pharmaceutical distributors. Since there was unequal liability, the aid derived from the fact that producers were in direct competition with distributors who were exempted. The absence of liability was a deliberate objective of the tax on direct sales.

This is because the aim of the tax on direct sales was "to restore the balance of competition between the two distribution channels for medicines which ... is distorted by the imposition of public service obligations on wholesale distributors alone.” [paragraph 36]

Once the Court identified the issue of liability as being of critical importance, it went on to rule that "if it were shown that the absence of liability to the tax on direct sales leads to an overcompensation of the wholesale distributors, to the extent that the advantage in not being liable exceeds the additional costs that they bear in discharging the public service obligations imposed on them, the liability of a pharmaceutical laboratory such as Boiron to such a charge would constitute an act giving effect to an aid measure." [paragraph 37] "In this case, the measure alleged to constitute an aid is the tax on direct sales itself and not some exemption which is separable from that tax. In such a case, it should be accepted that an economic operator such as Boiron may plead that the charge on direct sales is unlawful, for the purposes of applying 
for reimbursement, on the ground that it amounts to an aid measure." [paragraphs 39-40]

This interpretation is significant because it adds a second situation where a tax measure, rather than a tax exemption, is subject to the rules on state aid. The first situation is when an aid measure, of which the tax which finances it is an integral part, is implemented without prior notification to the European Commission. In this situation, the ECJ has said in Van Calster (C-261/01, paragraph 54), that national courts must in principle order reimbursement of taxes, charges or contributions levied specifically for the purpose of financing that aid. A tax is regarded as forming an integral part of an aid measure when it is "hypothecated" to the aid measure, in the sense that the revenue from the tax is necessarily allocated for the financing of the aid (see, in particular, Air Liquide, C-393/04).

The second situation arises in the present case of a tax on direct sales. A special feature of this tax measure is the tax itself and the aid measure "constitute two elements of one and the same" tax measure which are inseparable. The tax and the aid are "more closely linked than in the case of a parafiscal charge" whose revenue is hypothecated to an aid measure as in Van Calster.

In Ferring C-53/00, an earlier and very similar case, the Court found that a tax imposed on producers of pharmaceutical products was state aid "to wholesale distributors only to the extent that the advantage in not being assessed to the tax on direct sales of medicines exceeds the additional costs that they bear in discharging the public service obligations imposed on them by national law." [paragraph 29] This means that to avoid granting illegal aid, the relevant tax authorities have to ensure that the reduction in the tax liabilities of wholesale distributors do not exceed their own extra costs from fulfilling the public service obligations imposed on them. It is not clear how these extra costs are to be determined, but at least in theory they must be determined in relation to the costs borne by those undertakings when they carry out their public service obligation.

But in the Boiron case the Court added that payers of the tax could claim reimbursement from the relevant authorities. However "such reimbursement can be granted only if it is shown that those sums or, at the very least, the part of those sums for which reimbursement is claimed, amount to an 


\section{Chapter 15}

overcompensation of wholesale distributors and thus, by this measure, confer an economic advantage on the latter, if, in addition, the other conditions referred to in Article 87(1) EC for a measure to be classed as State aid are also fulfilled." [paragraph 47]

This is a virtually impossible condition. It differs from the normal situation where firms complain against aid to their competitors in that it is not sufficient in this case for the complainants to know that un-notified aid has been granted. It is also necessary for them to know the costs of their competitors. How can a tax-paying producer of medicines know the extent to which the tax advantage granted to distributors of medicines exceeds the extra costs of the public service obligations imposed on them? Not only must the producers know the normal costs of the distributors but they must be in a position to calculate the extra costs. The latter is a task that is difficult for the distributors themselves, let alone competitors such as the producers of medicines.

Indeed the referring national court raised precisely this issue in its request for preliminary ruling. The ECJ was forced to face the question of how its ruling could be enforced. In the end it circumvented it by passing responsibility to the national court. The ECJ stipulated that "in order to ensure compliance ...if the national court finds that the fact of requiring a pharmaceutical laboratory such as Boiron to prove that wholesale distributors are overcompensated, and thus that the tax on direct sales amounts to State aid, is likely to make it impossible or excessively difficult for such evidence to be produced, since inter alia that evidence relates to data which such a laboratory will not have, the national court is required to use all procedures available to it under national law, including that of ordering the necessary measures of inquiry, in particular the production by one of the parties or a third party of a particular document." [paragraph 55]

This is not a satisfactory answer. In order for a national court to order an inquiry, a complainant must first persuade the court that it has grounds for its complaint How will the complainant prove that in the absence of the needed information?

The extent of possible reimbursement is also likely to be a vexing issue. It is not clear from the judgement whether the amount that can be claimed for reimbursement is the amount by which the savings from not paying tax 
Developments in Fiscal Aid:New Interpretations and New Problems with the Concept of Selectivity

exceed the extra costs of public service obligation [i.e. to be determined by comparing costs and tax liabilities of non-tax-payers] or whether in case there is an overcompensation, the tax payers can claim reimbursement of all of their own tax payments.

Moreover, this judgement suffers from the same fundamental problem as the Ferring judgement. It is easier to understand the nature of this problem by reference to the criteria for compensation laid down in the Altmark case [C280/00]. In Ferring, as in Boiron, the relevant cost is the cost of the beneficiary undertakings. By contrast to Ferring, Altmark's fourth criterion stipulates that the undertaking which receives compensation should not have costs higher than those of the "typical" undertaking in the same sector. In other words, Altmark requires that the recipient of aid is reasonably efficient. This means that when public authorities grant aid to undertakings regardless of their ability and efficiency to fulfil the public service obligation imposed on them, these public authorities can no longer claim that there is no state aid involved. This makes sense because (such) inefficient undertakings would not survive in the market without public subsidies. The public service obligation that appears to impose a burden on them, in fact allows public authorities to keep them artificially alive.

As shown more rigorously in the Annex, a similar situation may develop in the present case of compensation through taxes imposed on competing undertakings. The tax seeks to eliminate the extra burden of the public service obligation imposed on distributors by handicapping the producers who are their competitors. If those who are exempt are inefficient, the handicap imposed on the competitors must correspondingly be more severe. This deviates from the logic of the Altmark case and it cannot be presumed, as the Court does in the present case, that the tax "restores the balance of competition".

\subsection{British Aggregates Association v European Commission, T-210/02}

British Aggregates Association appealed against Commission Decision C(2002) 1478 final concerning state aid case N 863/01. British Aggregates Association comprises small independent quarrying companies in the United Kingdom. 


\section{Chapter 15}

Aggregates are chemically inert granular materials used in construction. Aggregates can be produced from quarrying of rock or sand or from byproducts of other processes such as china making. The UK imposes a levy on aggregates extracted from nature, so-called virgin aggregates, while it exempts aggregates resulting from spoils or waste generated by other processes. The objective of the levy is to reduce environmental damage. In order to prevent distortions to trade, the UK also makes available a tax credit to operators whenever taxable aggregate is exported from the UK.

In its Decision, the Commission found that the levy did not comprise any elements of state aid within the meaning of Article 87(1), inasmuch as its scope was justified by the logic and nature of the tax system. The dispute in this case related to the application of the criterion of selectivity by the Commission.

The Court of First Instance began its analysis by stating settled case-law that when reviewing the selective nature of a measure, it is necessary to consider whether "the differentiation between undertakings, as regards advantages or burdens, introduced by the measure in question, arises from the nature or the general system of the overall scheme which applies. Where such a differentiation is based on objectives other than those pursued by the overall scheme, the measure in question will, in principle, be considered as satisfying the condition of selectivity laid down under Article 87(1) EC." [paragraph 107]

The CFI explained that "a levy may be described as an environmental levy where 'the taxable base of the levy has a clear negative effect on the environment', as the Commission stated in its Notice of 26 March 1997 on environmental taxes and charges in the single market (COM (97) 9 final, point 11). An environmental levy is thus an autonomous fiscal measure which is characterised by its environmental objective and its specific tax base. It seeks to tax certain goods or services so that the environmental costs may be included in their price and/or so that recycled products are rendered more competitive and producers and consumers are oriented towards activities which better respect the environment." [paragraph 114]

According to the CFI, "it is open to the Member States, which, in the current state of Community law, retain, in the absence of coordination in that field, their powers in relation to environmental policy, to introduce sectoral 
environmental levies in order to attain [certain] environmental objectives... In particular, the Member States are free, in balancing the various interests involved, to set their priorities as regards the protection of the environment and, as a result, to determine which goods or services they are to decide to subject to an environmental levy. It follows that, in principle, the mere fact that an environmental levy constitutes a specific measure, which extends to certain designated goods or services, and cannot be seen as part of an overall system of taxation which applies to all similar activities which have a comparable impact on the environment, does not mean that similar activities, which are not subject to the levy, benefit from a selective advantage." [paragraph 115] [emphasis added]

The CFI is making two different statements here. First, member states are free to choose the activities or products on which to impose environmental taxes. Member states are not required to tax all products that harm the environment or tax more heavily those products that harm the environment more than others. In other words, member states do not have to carry out a general assessment of environmental impact or devise a general scheme that applies to all products whose manufacturing has the same impact on the environment.This is a statement about the boundaries of the discretion of member states in tax matters and therefore one accepts that Community courts may set those boundaries in perhaps an axiomatic manner.

However, the second point made by the CFI is based on logical inference and as such it can be more critically assessed. The second point is that, because member states have discretion to choose which products to tax, similar products that escape from taxation do not obtain a selective benefit. As a statement of fact, it is wrong because it is too broad. Similar products would not benefit only if they are not competing with products which are subject to taxation. It is the foundation of competition analysis that competing products are those which are interchangeable in the eyes of consumers. Therefore, if one product becomes more expensive as a result of a tax, consumers will substitute it with a similar product which is cheaper because it is not taxed.

Moreover, the objective of the tax in this particular case was to "promote" and "encourage" the use of aggregates that did not harm the environment. This is precisely the purpose of a selective measure. 


\section{Chapter 15}

However, to be fair to the CFI, it is possible that the word "similar" can be interpreted in a different way. A "similar" product need not be one which is interchangeable in terms of use but has a similar effect on the environment even though it is not used by consumers for the same purpose. For example, the use of insecticides in the production of apples and potatoes may have the same effect on the environment, even though consumers would not substitute apples for potatoes. By taxing the production of apples, the state does not confer a selective benefit to the production of potatoes. If this is how the CFI understood the meaning of "similar", it should have stated so.

The CFI also considered whether the exemption from the aggregates levy could be regarded to be of the same quality or same nature as other tax exemptions which had been found in other cases to constitute state aid [e.g. Spain v Commission, C-409/00; CETM v Commission, T-55/99; Diputación Foral de Álava v Commission, T-127/99]. Most fiscal state aid is in the form of exemption from normal taxation. The CFI rejected this comparison on the grounds that "unlike an environmental levy, which can be distinguished precisely by its particular scope and purpose, and thus cannot in principle be related to any overall system, ... measures of tax relief ... were an exception to the system of burdens normally imposed on undertakings." [paragraph $116]$.

So, it is clear that when a measure is an exemption from a tax that has wider application, that exemption is likely to qualify as state aid, provided all the other conditions in Article 87(1) apply. Although the CFI does not say so explicitly, this is precisely the reason why the aggregates levy did not confer a selective advantage. Virgin aggregates are not in the same situation as waste aggregates. The former cause environmental degradation while the latter do not. They are similar products in terms of use but dissimilar products in terms of impact on the environment. The tax sought to remedy the latter effect.

That this must be the interpretation of the CFI's ruling is reinforced by the fact that the CFI contrasted the present case with the landmark Adria-Wien case [C-143/99] where at issue was an exemption from an environmental tax levied on consumption of electricity. In that case the ECJ held that there was no justification, based on the nature or general scheme of the tax in question, for the exemption of manufacturing from that tax, given the fact that service companies could have similar rates of electricity consumption as 
Developments in Fiscal Aid:New Interpretations and New Problems with the Concept of Selectivity

manufacturing companies. In the case of aggregates, virgin aggregates have different effect on the environment than waste aggregates.

Lastly, the CFI examined the exemption of exports from the aggregates levy. The levy applies to the use or commercial exploitation of virgin aggregates in the UK. Virgin aggregates are subject to a levy on importation and the exportation of those materials is exempt in order to ensure equality between virgin aggregate produced in the UK and that produced in other member states. The Commission justified that exemption in its Decision by the fact that the UK authorities had no control over the use of aggregates outside their jurisdiction.

The CFI concluded that "it is clear from case-law that a specific tax measure which is justified by the internal logic of the tax system is not subject to the application of Article 87(1) EC. In the present case, the exemption for exports cannot therefore be considered to confer a selective advantage on exporters since it is justified by the nature of the aggregates levy as an indirect tax. It was open to the Member State concerned to grant priority to considerations linked to the structure of the tax scheme concerned over the environmental objectives pursued. The applicant's assertion that other Member States take a different approach is irrelevant." [paragraphs 152-153]

It appears that at this point the CFI performed a leap in its reasoning. The internal logic of this particular tax is environmental protection. The exemption for exports undermines that logic because it allows virgin aggregates, whose extraction damages the environment, to be produced and sold abroad. Undoubtedly, the exemption levels the playing field between UK producers and producers based in other member states where similar taxes may not exist. But this must not be an issue of concern for a tax whose objective is not to ensure fair competition but rather to penalise environmentally damaging activities.

\subsection{Conclusion}

This chapter has reviewed three very recent rulings dealing with fiscal state aid. The Azores case has clarified that regional authorities must have considerable autonomy and must bear the consequences of their tax 


\section{Chapter 15}

decisions if their tax measures are not to be regarded as deviations from the national systems.

The Boiron case has shown that, contrary to the general principle in the case law, taxes themselves can, under certain circumstances, be a form of state aid. However, it has defined very difficult standards of proof.

Lastly, the British Aggregates case has shed light on the meaning of the internal logic of tax systems. It has also made clear that member states have considerable discretion in levying specific taxes, especially for environmental protection purposes. However, the extension of the internal logic to exports seems to go beyond the objective of environmental protection.

We will have to wait for new cases to deal with the issues that have been left unclear.

\section{Annex: The Effect of Taxes on Competing Products}

In order to understand the problems with the reasoning of the Court in the Boiron case, it is necessary to analyse the economic effect of taxes on competing products and see whether there is any straight forward relationship between taxes paid by producers of one group of producers and the gains enjoyed by another group who do not pay such taxes.

Figure 15.1 shows such a case. Line DD indicates the demand for pharmaceutical products which are sold by producers, group $\mathbf{j}$, and distributors, group i. Assume that the costs of these two groups are the same and that they act as price-takers so that they have identical supply lines, indicated by $\mathbf{S i}, \mathbf{j}$. Their joint supply or market supply is given by $\mathbf{S}$ [which is $\mathbf{S i}, \mathbf{j}$ added to itself]. $\mathbf{S}$ intersects the demand line at point $\mathbf{a}$ and therefore, before any tax is levied, the market price is $\mathbf{f}$ and market output and consumption are shown by $\mathbf{x}$. At price $\mathbf{f}$, each group produces at point $\mathbf{n}$ of their supply lines and the sales of each group are given by point $\mathbf{q}$.

Assume now that the government imposes a public service obligation that raises the costs of group $\mathbf{i}$ so that its supply line shifts to $\mathbf{S i}$ '. If nothing else happens group $\mathbf{i}$ will produce at point $\mathbf{z}$, group $\mathbf{j}$ at point $\mathbf{m}$ and their 
Developments in Fiscal Aid:New Interpretations and New Problems with the Concept of Selectivity

combined sales will be $\mathbf{v}$. Consumption declines from $\mathbf{x}$ to $\mathbf{v}$ and price rises from $\mathbf{f}$ to $\mathbf{e}$.

The government addresses this competitive imbalance by imposing a tax on group $\mathbf{j}$. The tax shifts its supply line to $\mathbf{S j t}$ and the total output is now $\mathbf{u}$, while market price rises even higher to point $\mathbf{d}$. This situation is equivalent to a tax levied on both groups. If a tax at the rate of $\mathbf{b w}$ is levied on the sales of both groups, they produce at point $\mathbf{k}$, price increases to $\mathbf{d}$ and sales and consumption decline to $\mathbf{u}$.

Note that using a tax levied on just one group to restore fair competition between the two groups is a very inefficient policy because it harms consumers who are supposed to be served by the public service obligation. Consumption declines and price increases. Society would be better off without the tax. The optimum policy here would be a subsidy to the group that bears the extra costs of the public service obligation.

The tax collected by the government per unit of sale is kt, which means that the total tax revenue from the sales of group $\mathbf{j}$ is given by the rectangle ktgd. The extra costs of group $\mathbf{i}$ are shown by the triangle kth. Note that the area ktgd may or may not be equal to the area kth. A tax that attempts to impose the same handicap as an increase in costs may or may not result in an equivalent amount of taxes paid on the sale of the taxed product.

But for the sake of argument assume that rectangle ktgd is smaller than triangle kth. There is no possibility of over-compensation. Figure 15.1 also shows the case of inefficient companies where the public service obligation results in much higher costs. The supply line in this case is shown by Si', and the extra costs are indicated by the area kthy. Tax revenue, shown by ktgd, is definitely smaller than kthy. This means that to use a tax to restore competitive balance between the two groups, the government must raise the tax.

This case illustrates the fundamental problem in using taxes to restore the "balance of competition". Because the distributors of medicines are less efficient than the producers of medicines in complying with the public service obligation imposed on them, the tax eliminates the competitive advantage of the latter. Without any knowledge of the efficiency of the two 


\section{Chapter 15}

groups, it cannot be presumed that, in general, a tax of this kind restores competition. In fact, it may do precisely the opposite. 
Developments in Fiscal Aid:New Interpretations and New Problems with the Concept of Selectivity

Figure 15.1: Effects of taxes on competing products

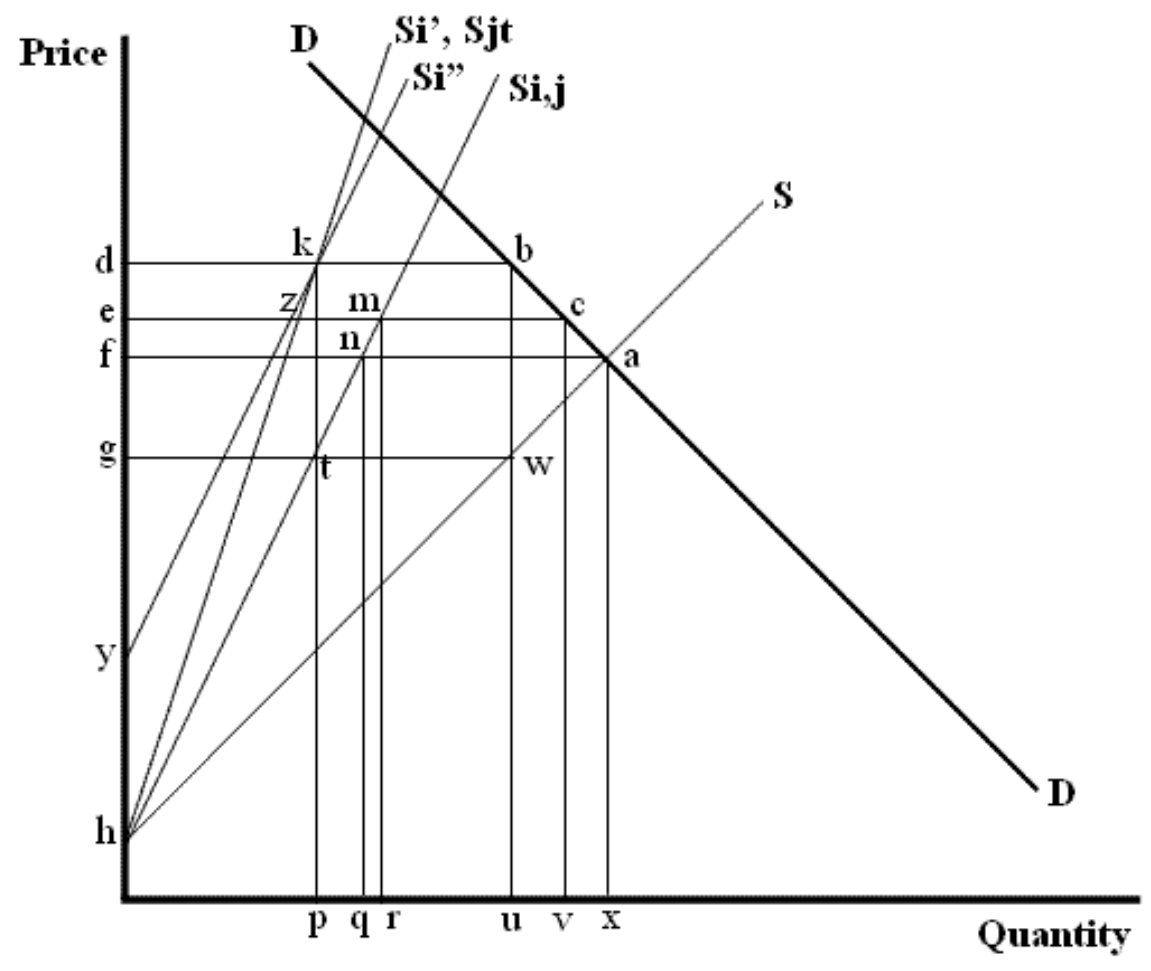




\section{Chapter 16}

\section{State Aid and Taxation by Sub-National Authorities}

\subsection{Introduction}

During the past couple of years, the Commission and the Courts have had several opportunities to examine state aid schemes involving tax rates and systems. Through these cases a firm pattern of practice has emerged and many aspects of the relationship between taxes and state aid have been clarified. Nonetheless, a number of contentious issues remain. These issues concern mostly the extent of objective differentiation between products and activities subject to different tax rates, the regional coverage of tax measures and the extent to which the tax autonomy of regional authorities may cause state aid problems.

The purpose of this chapter is to analyse and assess the position taken by the Commission concerning taxation by sub-national authorities. Community Courts have not yet ruled explicitly and directly on tax measures adopted by sub-national authorities whenever such measures also exist at the national level. Most, if not all, EU member states have regions with varying degree of tax autonomy. Recent developments in state aid policy have, therefore, serious implications for such regions.

The main issues that arise from recent cases in relation to the applicability of state aid rules can be summarised as follows:

i. Any differentiation between undertakings, products or activities in terms of tax rates, methods of calculating tax liability or treatment is likely to be a form of state aid, unless it can be shown that undertakings, products or activities are at objectively different situations.

ii. The desire of public authorities to promote certain regions or activities is not a reason that can objectively differentiate between undertakings or their products. 
iii. However, public policy aims may determine the extent of tax liability for certain products or activities (e.g. for causing pollution or noise) and, by implication, the extent of justifiable tax exemption (e.g. for not causing pollution or noise).

iv. State aid rules apply to the tax measures of public authorities at all levels of government.

v. Sub-national authorities [at regional or local level] may set the rates of regional/local taxes at any level they wish without infringing state aid rules, provided these taxes apply uniformly to all undertakings or activities in the area of their jurisdiction.

vi. Reduction by regional/local authorities of rates of nationally applicable taxes is likely to be viewed by the Commission as a form of state aid, even if these authorities have legal power or constitutional autonomy to do so.

The chapter begins with a review of the main principles that have emerged from recent cases and then focuses extensively on two cases where the Commission has spelled out its views with respect to the tax autonomy of sub-national authorities and the implications for state aid. The chapter concludes with a critical assessment of these views.

The main aspect of that critique is that the Commission's extensive argumentation still has a weak point. When taxation powers are devolved to regional authorities, it is not obvious how the state forgoes resources or assumes additional liabilities - which is a fundamental criterion in order for Article 87(1) to apply. On the one hand, the Appendix at the end of the chapter shows that at a macroeconomic level, devolution of taxation may increase tax revenue, obviating the need for inter-regional transfers that would increase the liabilities of the central government. On the other, any selectivity in favour of undertakings operating within the region with the autonomous taxing powers may be justified by the logic and/or nature of the tax system. 


\subsection{A review of the main principles that have emerged from recent $\operatorname{cases}^{189}$}

\section{Applicability of Article 87(1)}

It is now amply clear that although the base and rates of direct taxation are not harmonised in the EU, the tax measures of member states must comply with the rules of the EC Treaty. ${ }^{190}$ This means in particular that:

i. the state aid aspects of tax measures fall within Article 87(1), while

ii. other aspects of tax measures may fall within Articles 96 \& 97 that apply to distortions caused by general differences between national laws, regulations, administrative practices, etc. [Streekgewest Westelijk Noord Brabant, C-174/02].

Article 87(1) applies to state aid included in tax measures. Their fiscal (or social) nature is not sufficient to remove them from the ambit of Article $87(1)$. This is because any public measure that contains state aid is assessed on the basis of its effects, not intentions [Italy v Commission, C-173/73].

Although a tax (i.e. charge) is not in itself aid [Banks, C-390/98], Article 87 does apply to tax exemptions or reductions and any other form of favourable treatment that reduces the tax burden normally borne by undertakings. Nevertheless, Article 87 can still apply to taxes themselves in so far as there is a direct link between the tax revenue they generate and aid measures that

${ }^{189}$ More extensive analyses can be found in P. Nicolaides, Fiscal State Aid in the EU: The Limits of Tax Autonomy, World Competition, 2004, vol. 27(3), pp. 365396; P. Nicolaides, Fiscal Aid in the EC: A Critical Review of Current Practice, World Competition, 2001, vol. 24(3), pp. 319-342; R. Luja, Assessment and Recovery of Tax Incentives in the EC and the WTO: A View on State Aids, Trade Subsidies and Direct Taxation, (Antwerp: Intersentia, 2003).

${ }^{190}$ See Commission Notice on the Application of the State Aid Rules to Measures Relating to Direct Business Taxation, OJ C384, 10/12/1998, p.3. Further reading on this chapter: I. Atanasiu, EC State Aid policy with respect to soft budgetary constraints: tax and social security contribution payment areas, European State Aid law-Quarterly, Volume 4 No. 4 2005, P. Rossi-Maccanico, Commentary of State Aid Review of multinational tax regimes, European State Aid law-Quarterly, Volume 6 No. 1 2007, P. Rossi-Maccanico, State aid review of business tax measures - proposals for State aid control of direct business tax measures, European State Aid law-Quarterly, Volume 6 No. 22007. 
are financed by that revenue [Streekgewest Westelijk Noord Brabant, C$174 / 02]$.

The obligation to comply with state aid rules concerns the tax measures of all public authorities at all levels of government [Germany v Commission, C-248/84; Daewoo v Commission, T-127/99].

Article 87(1) applies irrespective of the status of the beneficiary [see, for example, the Commission Decision concerning a French exemption from a specific tax concerning insurance contracts concluded by mutual \& provident societies in France (not published yet, IP/05/243)].

The typical kind of state aid granted through tax measures is the favourable treatment of beneficiary undertakings in relation to other undertakings in similar situations [Italy v Commission, C-6/97]. Favourable treatment is effected through such things as

i. reduction of the tax base;

ii. reduction of the rate of tax;

iii. deferment, cancellation or rescheduling of tax debt;

iv. reduction of employers' social insurance contributions;

v. application of different methods of taxation that reduce tax liability [Commission Decisions 2003/438 (OJ L153, 20/6/2003) and 2003/501 (OJ L170, 9/7/2003) on finance companies and coordination centres, respectively, in Luxembourg].

Delay in collecting taxes may also be state aid unless it is justified by the private-creditor principle [DMT, C-256/97].

Since in most cases, the state aid element is found in tax reductions or exemptions, a question that arose recently is whether higher taxes on some products or undertakings imply state aid for those not subject to the higher rates. Naturally if the answer is "yes", then not being taxed is a form of state aid. AG Tizzano in Ferring [C-53/00] answered that the existence or not of state aid depended on the competitive relationship between undertakings, the reason for the tax and its effects. He did not elaborate further. In the more recent GIL Insurance case [C-308/01], AG Geelhoed argued that the answer must be "no" because:

i. otherwise Article 87 would impinge on Articles 96-97 that apply to general, not specific, distortions between member states; and 


\section{Chapter 16}

ii. public authorities would be forced to impose taxes [i.e. a burden] on products that are not related to the particular policy aim at hand, as for example in the taxation of polluting activities. That is, non-taxation of nonpolluting products or activities should not be regarded as state aid in their favour.

It seems to me that this answer is correct. The existence of state aid depends on the scope of application of the tax in question. Where, for example, a tax aims to curtail pollution, it is true that a polluting product that is not taxed does receive state aid. The problem is that it is not so easy to detect the policy aim(s) of every single tax. For example, certain products such as jewellery are taxed for being "luxury" items while certain other products such as aircraft are taxed because they cause "noise". Why are other luxuries or noisy products not taxed and what is the limit of luxury or noise pollution?

\section{Unacceptable arguments}

It is evident from recent practice that member states use a variety of arguments to justify their tax measures. It is however clear that the Commission hardly accepts anyone of them [see Commission Decision 2004/339 on state aid to RAI (I), OJ L119, 23/4/2004; Commission Decision 2003/601 on Irish foreign income, OJ L204, 13/8/2003; Commission Decisions 2002/540, 2002/806 \& 2002/820 on investment aid in the Spanish regions of Guipuzcoa, Vizcaya and Alava, respectively; Commission Decision 2005/77 on taxation of qualifying companies in Gibraltar, OJ L29, $2 / 2 / 2005]$.

The Commission has rejected typical arguments such as:

i. "The same tax exemptions have applied in other cases" - irrelevant, each case is examined on its own merits;

ii. "The firms in question have obtained no real financial advantage" irrelevant, the tax exemption still places those undertakings in a more advantageous position in relation to their competitors;

iii. "The tax exemption is intended to compensate undertakings for the burden imposed on them by compliance with public regulation" [other than a public service obligation] - irrelevant, state aid is an objective concept and does not depend on intent.

iv. "The measure encourages repatriation of profits and that in the case of no repatriation there would be no tax liability" - irrelevant, member states may not use lower taxes to attract income from abroad; 
v. "The measure was not banned by the Code of Conduct Group"191 irrelevant, the Code does not replace Article 87.

vi. "The measure aimed to generate tax revenue by stimulating investment" - irrelevant, a measure is not assessed by its macroeconomic effects but by the selective advantages it confers to some companies in relation to others in similar situations.

vii. "The measure is designed to operate in an international context" irrelevant, the selectivity is determined in relation to differential treatment within the country.

viii. "The Commission was aware of the scheme" - irrelevant, long tolerance of the scheme by the Commission does not establish legitimate expectations.

\section{Selectivity or specificity}

For a tax measure to be found to contain state aid, all conditions in Article 87 (1) must be satisfied. Normally it is relatively easy to find that a tax reduction or exemption fulfils all the criteria of Article 87(1). The criterion which is particularly relevant to tax measures is that of selectivity because in most cases state aid in tax measures is in the form of a reduction or exemption for certain products, economic activities or types of undertakings.

Selectivity means different treatment of goods or services which are in a comparable legal \& factual situation [Heiser, C-172/03]. It follows that different treatment is justified only when the legal and factual situations vary.

An otherwise general measure may become specific by the fact that secondary beneficiaries are specific [e.g. tax incentives are open to all investors, but eligible companies in which they can invest must be located in a specific region or industry][Germany v Commission, C-156/98].

In the case of a complex measure it is sufficient to find a single selective feature to make the whole measure selective [Commission Decisions 2002/540, 2002/806 \& 2002/820 on investment aid in the Spanish regions of Guipuzcoa, Vizcaya and Alava, respectively; confirmed in cases T-127/99, T-269/99, T-346/99 \& T-92/00].

${ }^{191}$ The Code of Conduct on Business Taxation was established in December 1997 by the member states for the purpose of combating "unfair tax competition". See OJ C2, 6/1/1988, p.1. 


\section{Chapter 16}

Selectivity may also be found in the actual functioning of a tax system. In the case of the Irish system for avoiding double taxation, the foreign-source income of Irish companies was exempted from Irish corporate tax to avoid double taxation but only when they would generate employment in Ireland. The Commission found that that exemption was a form of state aid whenever the applicable foreign tax was lower than the Irish tax liability [note that in a credit system as opposed to an exemption system there would be no aid] and because some companies could not qualify if they did not generate employment [Commission Decision 2003/601 on Irish foreign income, OJ L204, 13/8/2003].

A measure cannot escape being classified as selective simply because it i. applies on the basis of quantitative criteria;

ii. applies to many undertakings;

iii. applies to many sectors;

iv. aims to increase tax revenue [what matters is not the overall effect of tax but the reduced rate that benefits certain firms];

v. promotes investment

[Commission Decision on taxation in the Spanish region of Guipuzcoa, 2002/540].

An example of a non-selective tax measure is the favourable treatment of certain insurance products in France. The Commission found in November 2001 [see IP/01/1575], that in France, insurance contracts concluded by mutual societies governed by the code on mutual societies and provident societies were not subject to the tax on insurance contracts. The Commission considered that that exemption constituted state aid because it conferred an advantage on mutual and provident societies not enjoyed by other French and foreign insurance companies with which they were in competition. In response to a request by the Commission to put an end to the exemption of mutual and provident societies from the tax on insurance contracts concerning health insurance risks, France replaced the specific exemption for mutual and provident societies with an exemption for so-called "solidarity" health insurance contracts, i.e., contracts concluded without a prior medical examination, irrespective of the status of the body providing the cover. The latter exemption was considered by the Commission not to constitute state aid. 


\section{The logic or general scheme of tax measures}

Occasionally, the application of the criterion of selectivity is tricky and requires assessment of the objectives of the broader tax framework or system in which a tax exemption/reduction is embedded. This is because an otherwise selective measure may be justified by the logic, nature or general scheme of the tax system and, because of that, it may not constitute state aid.

The Court of First Instance has ruled that: "A measure which is justified ... does not fulfil the condition of selectivity, even if it confers an advantage on its recipients" [Guipuzcoa, Alava, Vizcaya v Commission, T-269/99] [emphasis added].

An example of a measure that has been found to be justified by the logic of the system is the exemption of dual-use energy products from the UK climate change levy. Dual-use products are used as inputs [i.e. as non-fuel] in industrial process [e.g. manufacturing of steel or chemicals]. The Commission found the exception to confer a selective advantage but still to be within the logic of the system because the exempted energy products did not contribute to harmful emissions against which the tax was levied [Commission Decision 2002/676, OJ L229, 27/8/2002].

Another recent measure that has been found to be within the logic or nature of the tax system was a Dutch exemption from a waste tax for dredging sludge. In order to provide incentives to reduce waste, the Netherlands imposes a tax on waste deposited in landfill sites. The Commission concluded that the exemption for dredging sludge was not state aid because while the tax aimed to discourage waste, dredging removes waste from rivers \& canals. In this case the "polluter-pays" principle could not be applied because it was not possible to identify the causes of sludge [Commission Decision on case N574/2004 of 2/2/2005].

\subsection{Contentious issues: Regional tax measures}

It is clear that a national measure [i.e. adopted by the central government] is selective when it applies only to part of the territory of a country. It is also clear that when sub-national governments levy taxes, they too are bound by Treaty rules including those on state aid [Germany v Commission, C-248/84; 


\section{Chapter 16}

Commission Decision 93/337 on taxation in the Basque country, OJ L 134, 3/6/1993].

The recent cases involving measures adopted by regional authorities, including all the Spanish schemes cited above, concerned taxes that were selective within the regions themselves. That is, they favoured certain types of companies or activities located or taking place within those regions. The Commission, therefore, was correct to find "material selectivity" or intraregional selectivity or specificity.

However, two cases stand out because the Commission based its finding of "regional selectivity" or inter-regional specificity on a series of novel arguments. In the case concerning Azores, the Commission deduced that the tax measures were selective despite the fact that they applied equally to all undertakings in that region. In the case concerning Gibraltar the interregional specificity was predicated on the argument that despite the tax autonomy of the Gibraltar authorities the reference system was the UK national system.

It is necessary to point out at the outset that the measures in Gibraltar were indeed selective because they discriminated between different types of undertakings established within Gibraltar. However, this case is interesting because of the views of the Commission on the tax autonomy of regional authorities. The rest of this chapter examines in detail the features of the tax measures and arguments employed in the two cases.

\section{Reduced corporate taxation in the Azores}

According to the text of the Commission Decision [no. 2003/442, OJ L150, 18/6/2003], "under the Constitution of the Portuguese Republic, the Azores and Madeira are autonomous regions which have administrative and financial autonomy. By Law No 13/98 of 24 February 1998 on the finances of the autonomous regions, the Portuguese State precisely defined the conditions of the financial autonomy [of Azores]. The Law sets out the principles and objectives of regional financial autonomy, provides for the finances of the autonomous regions to be coordinated with central government finances, and establishes the principle of national solidarity and the obligation for the central government and the autonomous regions to cooperate. The Law lays down in particular that personal income tax and corporation tax constitute revenue of the autonomous regions, under the 
conditions it determines itself. Under Article 37 of the Law, the regional legislative assemblies are authorised to reduce the rates of income and corporation tax applicable there up to a maximum of $30 \%$ of those laid down by national legislation." [para. 7] [emphasis added]

The Commission found that "in this case the abovementioned tax reductions do in fact favour firms taxed in the Azores, in comparison with all other Portuguese firms." [para. 24]

As explained above, a measure is selective [discriminatory] only when it treats differently [the same] undertakings which are in the same [different] position. It is not enough to observe that tax rates differ between two groups of companies. It is also necessary to determine whether the different tax rates can in principle be applicable to the two groups. Since regional measures cannot be applicable outside the geographic boundaries of the region, it follows that companies outside the region are not in the same position as companies within the region.

However, the Commission deduced that the reduced corporate taxation of the Azores was selective because it was of the opinion that both companies based in the Azores and companies based in mainland Portugal were liable to the same tax - the national corporate tax. Indeed, the Decision states that "the element of selectivity in the concept of aid is based on a comparison between the advantageous treatment granted to certain firms and the treatment that applies to other firms in the same reference framework." [para. 26] [emphasis added]

It was irrelevant that the reduced rate was non-selective within the Azores. The fact that the regional government was "authorised" to reduce the rate of corporation tax up to $30 \%$, led the Commission to the conclusion that the tax in the Azores was a deviation from the national tax and therefore interregionally selective or specific. On the basis of that authorisation "the regional legislator then actually introduced the reductions. This mechanism produces the same effects as if the benefits were granted directly by the national authorities, as was already the case in the past with other aid schemes in favour of firms in the Azores." [para. 28] And, "the case in point involves a reduction applicable solely in the Azores in the rate of tax established by national legislation and applicable on the mainland of Portugal. Under the circumstances, the measure adopted by the regional 


\section{Chapter 16}

authorities clearly constitutes a derogation from the national tax system." [para. 31]

I think there is little doubt that if indeed the whole scheme hinged on the authorisation granted by the Portuguese government to the regional government to introduce lower taxes, then the scheme could be attributed to the Portuguese government. However, there are two weak points in this line of reasoning.

First, it is not clear that the Portuguese state, by authorising the tax reduction, had to forgo any state resources or incur any extra liabilities or "additional burden". The loss of resources or the assumption an additional burden is an indispensable feature of any measure that is classified as state aid [see Sloman Neptun, C-72/91; Pearle, C-345/02]. The relevant Portuguese law apparently also provides that "personal income tax and corporation tax constitute revenue of the autonomous regions". This suggests that the Portuguese state gives up no resources of its own through the tax reduction.

Although the Decision is not explicit on this point, it tries to demonstrate indirectly that the tax reduction will result in increased liabilities for the Portuguese state. The Commission argues that the relevant reference framework is the national system, because "it follows from the fundamental role the central authorities of the Member States play in defining the political and economic environment in which firms operate, thanks to the measures they adopt, the services they provide and possibly the financial transfers they make, that the framework in which such a comparison should be made is the economy of the Member State." [para. 26] [emphasis added] While these points may apply in general to any member state, the Commission does not actually show how they impinged on this particular case and whether indeed the Portuguese state assumed more liabilities in the process.

Second, the Commission does not examine in any detail the nature of the authorisation by the Portuguese government. Was the authorisation fully in the discretion of the government or was it a mere formality? Since the government was obliged to "cooperate", could it refuse to grant authorisation? And, was the authorisation about the extent of the tax reduction rather than the reduction itself? For example, if the authorities in the Azores could alter the relevant rate of corporate tax levied in their territory without prior formal 
approval by the Portuguese government, would it still be viewed as a deviation from the national system?

While the Decision does not analyse the nature of the authorisation, it clearly puts forth the view that regional autonomy is not a decisive factor. It states that if "Member States whose internal administrative organization allowed certain regional authorities below State level to make changes to the general tax system in the form of tax benefits applicable to firms that operated in the respective regions would escape the rules on aid in relation to those regions and measures." [para. 29] And, "the application of the rules on aid to regional tax benefits should be based on objective criteria and cannot depend on a purely institutional factor such as the application at a particular time of more or less extensive tax autonomy in favour of an infra-State authority of more or less broad territorial scope. If this technique were generalised it would undermine equality in applying the rules on State aid and therefore render them ineffective." [para. 30]

This raises the question under which conditions autonomous and nonselective measures adopted by regional authorities could escape being classified as state aid? The Decision suggests that that would be possible when "all local authorities of a particular level (regions, districts or others) introduce and levy local taxes with no reference at all to national taxation." [para. 31]

This appears to mean that regionally imposed taxes are not caught by Article 87(1) only when

i. they are levied by all authorities at the same level of government, and ii. they are local in nature [e.g. property tax, garbage collection tax, local services tax].

By implication, it appears that a member state cannot voluntarily limit the territorial application of its tax powers so as to grant autonomy to selected regions to determine their own rate of taxes which are also levied at the national level. It seems that if an autonomous authority also wants to levy, say a corporation tax or a personal income tax, it has to do so on top of taxes applicable nation-wide.

In conclusion, the Decision concerning taxation in the Azores reveals that if a regional measure is a deviation from a national measure, it will be found to 


\section{Chapter 16}

be inter-regionally selective, even if it is not intra-regionally selective. Tax autonomy that empowers regional authorities to vary nationally applicable tax measures is not a sufficient factor to remove regional taxes from the scope of Article 87(1). Such autonomy escapes from the scope of Article $87(1)$ only in relation to non-selective local taxes.

\section{Reduced corporate taxation in Gibraltar}

Having rehearsed the issue of inter-regional selectivity in its Azores Decision, the reasoning of the Commission in its Decision concerning reform of the corporate tax system in Gibraltar is more sophisticated [Commission Decision 2005/261 on corporate taxation in Gibraltar, OJ L85, $2 / 4 / 2005]$. This Decision is very important because it is the first time that the Commission assessed a whole tax system.

This Decision was preceded by two other Decisions and a court challenge by the government of Gibraltar against the Commission for opening the investigation procedure under Article 88(2) concerning "exempt" and "qualifying" companies.

The Court of First Instance, in its ruling in joined cases T-195/01 and T207/01, accepted the arguments of Gibraltar that the tax treatment of "exempt companies" was existing aid, while it rejected the same arguments with respect to the treatment of "qualifying companies". The Commission then continued with its investigation and concluded with Decision 2005/77 [OJ L29, 2/2/2005] finding the regime for qualifying companies to be incompatible with the common market.

Exempt companies are registered in Gibraltar but have no activities there. They are not subject to any corporation tax. Qualifying companies are registered in Gibraltar, have presence there and are subject to a negotiated tax rate of between $2 \%$ and $10 \%$. The normal rate is $35 \%$. Both types of companies may be owned only by non-residents of Gibraltar. The legislation for these companies predated the UK's entry into the EU in 1973. It was regarded by the UK to be existing aid. However, because the legislation for qualifying companies was altered after the UK accession, the CFI concluded that as far as qualifying companies were concerned, their preferential tax treatment constituted illegal state aid. 
With respect to exempt companies, the Commission proposed abolition of the regime and the appropriate measures were accepted by the UK in January 2005 on the following conditions:

i. there would be no new entrants after 2006;

ii. the total number of beneficiaries was capped at 8464; and that

iii. existing beneficiaries would retain their privileges only until 31/12/2010 [see Commission Decision C(2004)2687 of 19/1/2005 concerning scheme no. E 7/2002].

With respect to qualifying companies, the Commission [Decision 2005/77] had little difficulty to show the selectivity of the system, despite its ringfencing. The Gibraltar authorities claimed that ring-fencing, which normally precludes eligible companies - also known as offshore companies - from operating within the territory of the taxing authority, makes a measure general instead of selective by virtue of the fact that all local residents or companies are prohibited from owning offshore companies. It is now clear that ring-fencing is selective even if offshore companies can be established in any sector of the economy. The selective factor rests in the exclusion of local residents or the prohibition of carrying out local activities. The fact that such exclusions discriminate against local residents is not enough to remove their selectivity since they are by their very nature discriminatory.

As mentioned earlier, for the purposes of this chapter, the most interesting Decision is that which concerns the reform of the Gibraltar corporation tax. This is because the Gibraltar and UK authorities designed the system in such a way so as to make it compatible with state aid rules. Apparently, they did not succeed in this objective.

The main features of the notified scheme were as follows:

i. there was no corporation tax; instead companies had to pay a fixed amount of $£ 3000 /$ employee/year plus property tax;

ii. only financial companies had to pay a top-up tax of $4-6 \%$ on profits;

iii. total tax liability was capped at $15 \%$ of profits or $£ 0.5$ million; this applied to companies in any sector, except utility companies.

The Commission had no difficulty demonstrating that financial companies with no presence in Gibraltar would pay no payroll or property taxes which were the main tax instruments. Therefore, the system would persistently exclude from its scope companies that were registered in Gibraltar but were 


\section{Chapter 16}

active somewhere else. The capping of total tax liability at $15 \%$ of profits would mean that companies with small profits but with larger liability for payroll/property tax would pay less tax. In addition, it would mean that otherwise profitable companies but with smaller liability for payroll/property tax would also pay less tax. These selective features turned the proposed tax system into a state aid scheme that was by its very nature incompatible with the common market.

However, what is interesting about this case is not its intra-regional selectivity, which undoubtedly existed, but its inter-regional selectivity and the arguments used by the Commission to prove it. Since the Commission could strike down the system solely on the basis of its intra-regional selectivity, the fact that it chose to elaborate at length the inter-regional selectivity of the system reveals that the Commission wanted to establish firmly the principle that autonomous regions may not deviate from national rates in respect to national taxes. The main inter-regionally selective feature of the system was that the $15 \%$ limit was a derogation from the UK system where corporate profits were taxed at $30 \%$.

The UK and Gibraltar authorities did not deny that the level of taxation in Gibraltar was lower than that of the UK. They rejected, however, that the system in Gibraltar represented a derogation from the system in the UK. They made a distinction between intra-regional and inter-regional specificity and claimed that the proposed tax system contained no intra-regionally specific elements [as seen above, that was not true]. Their claim about the absence of inter-regional specificity rested on the argument that the system in question was the act of the autonomous authorities of Gibraltar and, for this reason, it could not be regarded as a derogation from the UK system.

The Commission began its assessment by stating that "the element of selectivity in the concept of aid is based on a comparison between the advantageous treatment granted to certain firms and the treatment that applies to other firms in the same reference framework. ... It follows ... from the fundamental role the central authorities of the Member States play in defining the political and economic environment in which firms operate, thanks to the measures they adopt, the services they provide and possibly the financial transfers they make, that the framework in which such a comparison should be made is the economy of the Member State." [para. 104] [emphasis added] 
In connection to any financial transfers between the UK and Gibraltar, the Commission is of the view that "the fact that the budget of a given territory is self-sufficient is not immediately relevant for the assessment under State aid rules of the measures adopted by the authorities of that territory. Such an assessment must be based on the effects of the measures for the benefiting undertakings and not on the situation of the granting authority. In particular, a small territory like Gibraltar may well become self-sufficient precisely as a result of its ability to apply lower taxes and to attract business, in particular off-shore activities. In any event, it is common ground that Gibraltar depends on the United Kingdom, inter alia, for its foreign policy, including membership of the European Union, for its defence and for its monetary policy. It thus benefits from a number of services provided by the United Kingdom." [para. 125]

There is a contradiction in the line of reasoning pursued by the Commission in this paragraph. On the one hand, the Commission contends that the financial autonomy of the regional authority is irrelevant. On the other hand, it goes on to refer to the dependency of Gibraltar on the UK, implying that Gibraltar receives certain services and benefits for which it does not have to pay. But if financial autonomy is not relevant, why is financial dependency relevant?

The Commission then goes on to assert that "it is clear that if the reference context for assessing the territorial selectivity of a measure is the territory in which it applies, measures that benefit all the firms in the territory would by definition become general measures. The settled practice of the Commission, confirmed by the Court of Justice, on the contrary consists of classifying as aid tax schemes applicable in particular regions or territories which are favourable in comparison to the general scheme of a Member State." [para. 104]

While this statement is correct as far as national measures are concerned, it is certainly not true that the Court has explicitly endorsed the view that measures adopted by sub-national authorities are a form of state aid if they are more favourable in relation to the corresponding national measure. All the cases which are cited in relation to this paragraph concern either selective measures adopted by national authorities or selective measures 


\section{Chapter 16}

adopted by sub-national authorities. However, the issue at hand is the status of non-selective measures adopted by sub-national authorities.

In this connection, the Commission argues that "a distinction based solely on the body that decides the measure would remove all effectiveness from Article 87 of the Treaty ... Such aid therefore cannot be treated differently from measures which have the same objectives, use the same resources and have the same effects on trade and competition, according only to the formal criterion of the degree of autonomy of the infra-State authority that establishes it." [para. 105] [emphasis added] And, "if the United Kingdom's argument were accepted, Member States whose internal administrative organisation allowed certain regional authorities below State level to make changes to the general tax system in the form of tax benefits applicable to firms that operated in the respective regions would escape the rules on regional aid in relation to those regions and measures." [para. 106] [emphasis added] And finally, the applicability of Article 87(1) "cannot depend on a purely institutional factor such as the application at a particular time of more or less extensive tax autonomy in favour of an infra-State authority of more or less broad territorial scope. If this technique were generalised it would undermine equality in applying the rules on State aid and therefore render them ineffective." [para. 107]

It is now amply clear that for the Commission internal constitutional arrangements in the member states and division of powers are irrelevant. "Whenever a central government decides to give up its power to establish a uniform taxation framework for enterprises and allows a sub-national entity to reduce the tax rate or to introduce another taxation system that is more advantageous, the result of this decentralisation of power is a derogation from a common system of reference. De facto, providing directly for a reduction of the tax rate, or granting to a territory the possibility to reduce a common tax rate, or exempting a territory from a common system and granting to it a power to establish a more advantageous taxation system comes to the same result; it allows companies in a certain region to pay lower taxes while State resources are foregone." [para. 114] [emphasis added]

The only source from which the Commission draws authority for its views on inter-regional selectivity are the conclusions of Advocate General Saggio in joined cases C-400/97, C-401/97 and C-402/97. According to the AG Saggio "'the fact that the measures at issue were adopted by regional 
authorities with exclusive competence under national law is (...) merely a matter of form, which is not sufficient to justify the preferential treatment reserved to companies which fall under the provincial laws. If this were not the case, the State could easily avoid the application, in part of its own territory, of provisions of Community law on State aid simply by making changes to the internal allocation of competence on certain matters, thus raising the general nature, for that territory, of the measure in question"”. [para. 105]

The Commission has made extensive use of this quotation from AG Saggio's opinion in many different tax cases. One has to bear in mind, however, that that opinion was delivered on cases which also had strong intra-regional selectivity and that it was never tested before the Court as the cases were closed before the Court delivered its judgement.

So far these arguments are similar to those made in the Azores case. But in response to novel comments by the UK and Gibraltar, the Commission dismissed them for being "formalistic". According to the Commission, "to suggest that State aid is only present if State resources are used through a tax foregone and that in the Gibraltar case, no tax is foregone as there is no United Kingdom rate of tax for an activity which would also apply in Gibraltar is also an argument about the form of the measure. Equally formalistic, in the sense of Advocate General Saggio, is the argument to the effect that even if the alleged aid measure were abolished, the United Kingdom standard or normal rate would not apply and that therefore any comparison where the tax system is devised locally is not meaningful for the purposes of State aid. ... It is necessary to compare the measure at hand with other measures which apply to similar situations, in this case company taxation in the United Kingdom." [para. 112]

The Commission goes on also to reject "the United Kingdom suggestion that a tax jurisdiction not covering the whole Member State would be prevented from adopting any tax rate except the one applicable in the other tax jurisdiction in the State. As mentioned above, the key to any State aid analysis of tax measures is to establish the common system applicable, in this case, the United Kingdom tax system. In this context it should be noted that the present decision does not concern a mechanism that would allow all local authorities of a particular level (regions, territories or others) to introduce and levy local taxes." [para. 115] However, "where tax powers are 


\section{Chapter 16}

devolved but a central reference system remains, Member States must ensure that reductions in tax, insofar as they constitute aid, are compatible with the common market." [para. 121]

\subsection{A critical assessment}

Most if not all EU member states have regions with varying degree of tax autonomy. ${ }^{192}$ The cases that have been reviewed have serious implications for such regions. The principle that can be drawn from the Azores and Gibraltar cases is that autonomous regions may levy either local taxes at any rate they choose or taxes similar to national taxes but only at equal or higher rates. This is fairly simple. The important question, however, is whether it can indeed be inferred from the criteria laid down in Article 87(1) and the related case law.

The Commission has in essence claimed that authorisation of regional authorities to adopt their own tax rates and/or the granting of autonomous taxing powers can both be attributed to the state or the central government. The precise nature of the authorisation and the extent of autonomy are merely formalistic differences and therefore irrelevant issues. They both come down to the same thing: the state limits the scope of its taxes and forgoes state resources.

But how does the state forgo resources? There are two mechanisms at play: Either the central state incurs increased liabilities in terms of larger interregional transfers in favour of the autonomous regions or the central state loses tax revenue directly from tax payers. The rest of this section examines these two mechanisms.

The first mechanism creates an uncomfortable possibility. The tax revenue of the autonomous region may increase, reducing in this way the liabilities of the central state. The Commission glossed over this issue in the Azores case by implying that the national tax was in principle applicable there and that the Portuguese state had to forgo resources either because it did not apply its

${ }^{192}$ See OECD, Fiscal_Decentralisation in EU Applicant States and Selected EU Member States, (Paris, September 2002). It can be accessed at: http://www.oecd.org/dataoecd/10/47/2765013.pdf 
own tax or because indirectly it had to bear the costs of extra transfers to the Azores to finance public services there. The latter point was asserted rather than proven. The Commission also ignored the fact that the relevant Portuguese law laid down the principle that the tax revenue was for the regional government rather than the central government. The latter would appear to forgo no revenue by any lower tax.

In the Gibraltar case, the UK could not apply its own tax in the territory of Gibraltar. Here the Commission could not counter-argue that the national tax could in principle apply. Instead it relied on the indirect link between lower tax revenue in Gibraltar and the presumed extra cost borne by the UK in providing certain services to Gibraltar. But the cost of these services such as diplomatic representation would not increase as a result of the introduction of a lower corporate tax in Gibraltar. The UK would assume no extra burden. The fact that a state bears some costs on behalf of an autonomous region cannot lead to the conclusion that the exercise of tax autonomy by that region necessarily or potentially raises the liability of the central government towards that region. While in the case of the Azores there could be a potential link between the exercise of regional tax autonomy and potential future liability for the central state, no actual or potential link seems to exist in the case of Gibraltar.

The Commission argues at a macroeconomic level that there is a transfer of state resources. But at a macroeconomic level and even in the case of the Azores this assertion may not be correct. The Appendix demonstrates that under certain conditions, tax autonomy may reduce the liabilities of the central state rather than increase them precisely because it may raise the revenue raised through lower taxes by the autonomous region.

We now turn to the second mechanism through which state resources may be forgone. This occurs when the state loses the tax revenue it would have obtained from the undertakings that are subject to lower taxation. It is very important to analyse this point because the position of the Commission appears to be based on the axiom, which is untested before the Courts, that sub-national authorities may not levy lower taxes than corresponding national taxes because even when such measures are general within the region in question, they are selective at the national level. 


\section{Chapter 16}

If the relevant benchmark is the national rate, then the Commission would be right. But there is also the possibility that the preferential treatment is the outcome of the logic or the scheme of the system. Taxes are not only means for raising revenue for the government. They are also, on the one hand, an instrument of solidarity and income redistribution and, on the other, a manifestation of sovereignty.

A central government may voluntarily assign powers of taxation to regions which enjoy political autonomy precisely because such powers underpin that autonomy. In this context, the central government would have no other option but to exclude from the application of its tax measures those regions. The limitation of the area of application of national taxes is within the logic of the system because it is the natural consequence of tax autonomy.

The Commission argues that autonomous regions can exercise their autonomy only by raising taxes above national levels. This, however, would undermine their autonomy. In addition, the fact that the central and regional governments have to negotiate the level of the regional tax rates may simply indicate the fact that regional governments are autonomous rather than independent. The acts of the autonomous authorities have repercussions on the rest of the country which have to be taken into account by the central government. The Commission has interpreted such negotiations to signify "delegation" of the responsibility of the central government which can be reversed by a unilateral decision of the delegating authority. However, within the logic of the system, those negotiations may instead signify "devolution" of taxing powers which cannot be reclaimed by a unilateral decision of the central government.

Therefore, at a macroeconomic level the Commission has not proven the loss of state resources, while at a microeconomic level it has ignored to examine whether the selectivity of the regionally-determined tax measures and the direct loss of state resources can be explained by the logic or scheme of tax systems as instruments for the exercise of sovereignty and the devolution of taxing powers. 


\subsection{Conclusion}

There is no doubt anymore that the state aid rules of the European Community apply to all aspects of tax systems and tax measures.

The only remaining doubt is whether regional authorities can deviate from the rates set at the national level. This chapter has examined two landmark decisions and has found that the line of argumentation of the Commission is not fully convincing. There is, therefore, urgent need for clarification by the Courts.

Until that clarification is provided, the conclusion which is of relevance to sub-national authorities is the following. Regional authorities, autonomous or otherwise, can safely levy local taxes and choose the rate of such taxes, provided such taxes apply equally to all liable undertaking, activities or products. There is no need for harmonisation across the country. However, where they levy taxes for which a national rate exists, they must be careful that their rate is equal or exceeds the national rate. If their rate falls below the national rate, there is state aid that must be notified and comply with the current block exemption regulations and guidelines.

\section{Appendix: Tax autonomy and inter-regional transfers}

The simple model that is developed below shows that, under certain conditions, tax autonomy may raise the tax revenue of both the central state and the autonomous region. This outcome reduces the need for transfers from the central government to the autonomous region. Therefore, it cannot be asserted that at a macroeconomic level, tax autonomy necessarily increases the liability of the central government.

Assume that a country is made up of two regions: the autonomous region, $\mathbf{1}$, and the rest of the country, 2. Assume also that in the first instance, there is no national tax and each region levies its own independently determined rate of tax. If the aim of the tax authorities is to maximise tax revenue and if the decision of one region does not affect the other [i.e. firms do not move from 


\section{Chapter 16}

one region to another to exploit tax differences] so that tax revenue can be represented by a function that increases at a decreasing rate [i.e. it is a convex], the tax revenue for each region is given by the following convex function:

$\mathbf{R}_{\mathbf{1}}=\mathbf{a T}-\mathbf{b} \mathbf{T}^{\mathbf{2}}$, and $\mathbf{R}_{\mathbf{2}}=\mathbf{f} \mathbf{T}-\mathbf{g} \mathbf{T}^{\mathbf{2}}$

where $\mathbf{a}, \mathbf{b}, \mathbf{f}$ and $\mathbf{g}$ are parameters which for a convex function the following conditions must hold

$\mathbf{a}, \mathbf{b}>\mathbf{1}$ and $\mathbf{f}, \mathbf{g}<\mathbf{1}$.

The optimum rate of taxation for the two regions is given by the value of $\mathbf{T}$ which sets the derivative $\mathbf{d R / \mathbf { d T }}$ equal to zero. Therefore, for each region it is

$\mathbf{T}_{1} *=(\mathbf{a} / \mathbf{2 b})$, and $\mathbf{T}_{2} *=(\mathbf{f} / \mathbf{2 g})$

If the parameters differ, it follows that the two rates will also differ. The total amounts of tax revenue for each region can be calculated by substituting the values of $\mathbf{T}_{1} *$ and $\mathbf{T}_{2} *$ in the revenue equations, so that $\mathbf{R}_{1} *=\mathbf{a}^{2} / \mathbf{4 b}$, and $\mathbf{R}_{2} *=\mathbf{f}^{2} / 4 \mathrm{~g}$

Suppose now that the central government can levy taxes throughout the territory of the country. If it also seeks to maximise tax revenue, its optimum rate of taxation will be given by the derivative of the sum of the two functions [given the assumption of independence between them] and it will be

$T^{*}=(\mathbf{a}+\mathbf{f}) / 2(\mathbf{b}+\mathbf{g})$

By substituting this value of $\mathbf{T}^{*}$ into the sum of $\mathbf{R}_{\mathbf{1}}$ and $\mathbf{R}_{\mathbf{2}}$, we obtain the maximum amount of revenue for the country as a whole, which is $R *=(a+f)^{2} / 4(b+g)$

A comparison of the results reveals that if $\mathbf{a}, \mathbf{b}>\mathbf{2}$ then $\mathbf{R}_{\mathbf{1}} *+\mathbf{R}_{\mathbf{2}} *>\mathbf{R} *$

This is very important because under certain conditions independently determined taxes result in greater tax revenue than when there is a single tax for the whole country. This means the granting of tax autonomy need not result in automatic loss of resources for the central government or for the regional government. If the revenue of the regional government increases, 
there will also be less need for compensatory transfers from the central government.

Admittedly, this strong result is the outcome of the assumption that there is no tax competition between the two regions. This means that a more realistic conclusion should be that the lower the intensity of tax competition between different regions declines, the lower the impact of tax autonomy on tax revenues and the lower the likelihood of any loss in tax revenues either for the central or the regional authorities. 


\title{
Chapter 17
}

\section{The Boundaries of Tax Autonomy:}

\section{An Assessment of the Opinion of Advocate-General Geelhoed on Case}

\author{
C-88/03, Portuguese Republic v European Commission
}

\subsection{A landmark case}

On 20 October 2005, Advocate-General Leendert Geelhoed delivered his opinion on case C-88/03, Portuguese Republic $\mathrm{v}$ European Commission, concerning a reduction in tax rates for the revenue of legal and natural persons resident in the Azores. The Portuguese Republic sought the annulment of Commission Decision 2003/442 of 11 December 2002 which found that the tax measures adopted by the autonomous region of the Azores constituted state aid.

This is a landmark case for two reasons. First, it examines the discretion of autonomous regions to vary their tax rates from those of the central government. Second, it tests a theory that the Commission has developed recently, which distinguishes between "material selectivity" and "regional selectivity". Material selectivity exists when a measure favours certain sectors or economic activities. Regional selectivity exists when a measure favours enterprises based in certain geographic areas even when there is no distinction made between the sectors or economic activities within each particular area. The Azores measures were non-discriminatory in relation to sectors or type of economic activity but they applied only to undertakings based in the Azores. They were regionally selective.

The issue at hand was whether an autonomous authority that had legal powers to levy taxes and had a constitutional right to vary its tax rates from those of the central government could be found to grant state aid even when its measures applied with no discrimination with respect to sectors or type of 
The Boundaries of Tax Autonomy:An Assessment of the Opinion of AdvocateGeneral Geelhoed on CaseC-88/03, Portuguese Republic v European Commission economic activity. The answer of the Commission in its Decision 2003/442 was in the affirmative.

\subsection{Commission views}

The Commission position was based on a number of arguments which, however, can be grouped in three categories. First, if member states could escape from the scope of Article 87(1) by assigning taxation tasks to lowerlevel public authorities, the prohibition of Article 87(1) would become meaningless. The Commission regarded delegation of taxation as merely formalistic. Second, the authorities in the Azores had to obtain the permission of central government before they adopted the measures in question. Moreover, the rates of tax could not vary more than a certain percentage. The Commission regarded both the need for authorisation and the limit imposed on the maximum allowed tax difference as evidence that the measures could be attributed to the central government. Third, the Azores remained financially dependent on the Portuguese state for a certain proportion of its budget and for provision of other services such as defence and diplomatic representation. The Commission considered this dependency as evidence that the Azores were not capable of covering the true costs of the provision of public services and that instead of lowering their tax rate they should have increased it. They were able to reduce it only because they were "subsidised" by the central government. For these reasons, therefore, it concluded that the measure could be attributed to the central government, that the "reference" rate was the rate determined by the central government and that it constituted state aid because it was lower than the reference rate and satisfied all the conditions in Article 87(1).

This Commission Decision is also important because it clarifies the extent to which sub-national authorities at regional or local level can exercise their tax powers. Under certain conditions, some types of regionally-based tax differences are not state aid. This would be the case where local authorities have autonomy to levy locally-based taxes such as property tax or wastecollection tax. In this case, they are free to choose the rate of tax as long as there is no material selectivity. The fact that there is regional selectivity is not important because there is no national reference rate. For taxes where 


\section{Chapter 17}

there is a national reference rate, local authorities may only levy higher taxes rather than lower.

\subsection{Critique}

In another article published in this Journal I explain why I disagree with the general conclusion of the Commission. ${ }^{193}$ With respect to the formalism in the delegation of tax responsibility, I believe that the relevant factor is not whether tax responsibility is assigned to a lower authority but how it is assigned and whether it is reversible or not. If the assignment can be reversed, then I would agree with the Commission that it is formalistic. If, by contrast, a central government gives away powers that it cannot regain, then the delegation permanently changes the allocation of tax powers in a country. What matters is not whether the lower-level authority has to obtain permission in the first place but whether the central government can withdraw such permission afterwards. These are issues that the Commission did not examine in its Decision.

With respect to the financial dependency of the Azores on the central government, the Commission merely asserted it without actually proving it or even providing any indicative numbers. I would agree with the Commission in case the reduction of tax rates in the Azores was accompanied by an increase in financial transfers from the central government. That would prove that the tax reduction was unsustainable. However, I show in the article mentioned above that it is possible that a tax

\footnotetext{
${ }^{193}$ Phedon Nicolaides, State Aid and Taxation by Sub-National Authorities, special issue on New Development in European State Aid Law, May 2005. Further reading on this chapter: C. Arhold, The case law of the European Court of Justice and the Court of First Instance on State Aids in 2004/2005, European State Aid lawQuarterly, Volume 4 No. 2 2005, C. Arhold, The case law of the European Court of Justice and the Court of First Instance on State Aids in 2005/2006 (Part 1), European State Aid law - Quarterly, Volume 5 No. 2 2006, C. Arhold, The case law of the European Court of Justice and the Court of First Instance on State Aids in 2005/2006 (Part 2), European State Aid law-Quarterly, Volume 5 No. 3 2006, C. Arhold, The case law of the European Court of Justice and the Court of First Instance on state aids in 2006/2007 (part 1), European State Aid law-Quarterly, Volume 6 No. 22007.
} 
The Boundaries of Tax Autonomy:An Assessment of the Opinion of AdvocateGeneral Geelhoed on CaseC-88/03, Portuguese Republic v European Commission reduction may raise tax revenue. This would be equivalent to a general tax measure that would not normally be caught by Article 87(1).

\subsection{The opinion: Three criteria}

In his opinion, AG Geelhoed regards autonomy as a decisive factor. Therefore, he proposes three criteria for determining whether a sub-national authority is autonomous from the central government [paragraph 54]:

Institutional autonomy: "The decision must be taken by a local authority with its own constitutional, political and administrative status separate from that of the central government."

Procedural autonomy: "The decision must be taken by the local authority pursuant to a procedure where the central government does not have any power to intervene directly in the procedure of setting the tax rate, and without any obligation on the part of the local authority to take the interest of the central State into account in setting the tax rate."

Economic autonomy: "The lower tax rate applicable within the region must not be cross-subsidised or financed by central government, so that the economic consequences of these reductions are borne by the region itself."

Mr Geelhoed concludes that "if all of these senses of autonomy exist when a local authority decides to institute a tax rate lower than the national rate, this decision cannot be classed as 'selective' for Article 87(1) EC purposes." [paragraph 55]

He then applies the three criteria to the Azores case. He finds that the Azores are institutionally autonomous with power to exercise fiscal competence. However, he also finds that they do not have procedural autonomy with respect to tax matters and that they lack economic autonomy.

He does not believe that there is real procedural autonomy because the regional and central government have to cooperate in the spirit of national solidarity in setting the regional tax rates.

He also does not believe that the Azores are economically autonomous because the principle of national solidarity requires budgetary transfers from the central government and because the Portuguese government has not 


\section{Chapter 17}

attempted to show that the Azores receives no countervailing funding from the central government to compensate for the lower tax revenue.

With respect to procedural autonomy, as I explained above, in my mind the decisive factor is whether the decision is irreversible rather than whether it requires cooperation between the two levels of government in the first place. It is natural for authorities which cannot exercise sovereignty to cooperate with central government. Therefore, we should not be implicitly using as a benchmark national governments which are not accountable to any other government. I regard as unavoidable some degree of consultation and cooperation between regional and national governments when setting tax rates in the first place. Once they are set, however, the test of true autonomy is whether the central government can intervene to alter such tax rates.

With respect to economic autonomy, again, the implicit benchmark should not be whether there are budgetary transfers from the central government. It is unavoidable that sub-national governments either have to rely on central government for certain services such as defence and diplomatic representation or have to be partly subsidised in order to be able to provide services to their residents that are equivalent to those provided in the rest of the country. The decisive factor here is whether the central government makes up any shortfall in the tax revenue. Mr Geelhoed does not investigate this further because the Portuguese government did not provide any evidence.

While I agree with the three criteria proposed by Mr Geelhoed, I believe that he should have modified them appropriately to reflect the reality of autonomous regions within sovereign countries. This is because, in essence, autonomy is not independence, so some kind of financial and administrative cooperation and dependency between regional and central authorities is unavoidable.

\subsection{Consequences}

If the Court adopts the Advocate-General's opinion, the Commission will win the case against Portugal. However, it will be a pyrrhic victory because it will have its theory of regional selectivity and the formalism of delegation of tax powers severely constrained. If the ruling follows Mr Geelhoed's 
The Boundaries of Tax Autonomy:An Assessment of the Opinion of AdvocateGeneral Geelhoed on CaseC-88/03, Portuguese Republic v European

Commission

logic, it will confirm that under certain conditions regional authorities can indeed deviate from the rates of taxation set by the national government.

Perhaps more importantly, it signifies that the Commission is bound to lose another landmark case involving, for the first time, the whole tax system of an autonomous region. This is the case concerning Gibraltar. The Commission in its Decision 2005/261 concludes that the new corporate tax system in Gibraltar constitutes state aid for practically the same reasons as those in the Azores case. If the Court follows the opinion of the AdvocateGeneral and adopts his three criteria, then there is little doubt that it will find that the system in Gibraltar is not state aid on the grounds of its institutional, procedural and financial independence from the government in London. 


\section{Chapter 18}

Fiscal State Aid in the EU: The Limits of Tax Autonomy

\subsection{Introduction}

Until 1997 direct taxes had largely escaped scrutiny under the European Community's state aid rules. Then the Code of Conduct Group on Business Taxation, made up of officials from finance ministries, began examining whether national tax measures competed "unfairly". ${ }^{194}$ A year later, the European Commission issued its communication on the kind of tax measures that could be caught by Article 87(1) of the EC Treaty. ${ }^{195}$ This is the Article that lays down the principle that state aid measures, in any form, are incompatible with the common market.

Of the several hundred or so national measures that were examined by the Code of Conduct Group, 270 were identified as being potentially harmful. Eventually 65 measures were found to fall within the scope of the Code. ${ }^{196}$ The member states concerned were supposed to remove those measures, although there was no legal obligation to do so.

The Commission raised the stakes in July 2001 when it launched investigations concerning fifteen national measures in twelve member states. The investigations, which were concluded in 2003, all resulted in negative decisions.

In the meantime, between 1999 and 2003, the Commission examined a number of tax measures in Spain and in Gibraltar in a series of cases some of

\footnotetext{
${ }^{194}$ See the Code on Business Taxation in OJ C2, 6.1.1998.

195 Commission Notice on the Application of the State Aid Rules to Measures Relating to Direct Business Taxation, OJ C 384, 10/12/98.

${ }^{196}$ European Parliament, Tax Coordination in the EU: The Latest Position, Working Paper ECON 128, March 2002, (Brussels).
} 
which were appealed to the Court of First Instance. ${ }^{197}$ In all cases the Commission found the national tax measures to be contrary to Article 87(1). In all cases but one, the CFI upheld the Commission decisions. Even where the Court partly found against the Commission it was for a reason that had nothing to do with the question of whether Article 87 applied. ${ }^{198}$

In just a few years the landscape of direct taxation has changed dramatically. It is now firmly recognised that state aid rules apply to tax measures, that member states, despite their tax autonomy, have to comply with those rules and that the Commission can exercise its normal powers in assessing whether national tax measures contain elements of state aid. ${ }^{199}$

The purpose of this chapter is twofold. First, it extends and updates the analysis I carried out in an earlier paper. ${ }^{200}$ That paper attempted a comprehensive review of state aid policy on taxation but was completed before the Commission launched its landmark investigations in 2001. It is now time to take stock of the evolution of state aid policy regarding taxation during the past couple of years.

Second, and more importantly, recent cases do not only confirm that state aid rules apply to direct taxation but they also reveal that those rules constrain the tax autonomy of member states in unexpected and significant ways. In addition to stock-taking, this chapter intends to evaluate these policy innovations and consider whether the Commission is justified in

\footnotetext{
${ }^{197}$ See Commission, Report on the Implementation of the Commission Notice on the Application of the State Aid Rules to Measures Relating to Direct Business Taxation, 26.11.2003. The Report can be accessed at:

"http://europa.eu.int/comm/competition/state_aid/legislation/business/rapportaidesfi scales_en.pdf”.

${ }^{198}$ See case T-127/99, "Daewoo" which partly annulled Commission Decision $1999 / 18$ on the grounds that the Commission had not assessed properly the application of the guidelines on regional aid.

${ }^{199}$ See cases T-269/99, T-271/99 and T-272/99 Territorio Histórico de Guipúzcoa Diputación Foral de Guipúzcoa, Territorio Histórico de Álava - Diputación Foral de Álava and Territorio Histórico de Vizcaya - Diputación Foral de Vizcaya v Commission.

${ }^{200}$ See P. Nicolaides, Fiscal Aid in the EC: A Critical Review of Current Practice, World Competition, 2001, vol. 24(3), pp. 319-342.
} 


\section{Chapter 18}

stretching the scope of application of Article 87 to issues such as tax decentralisation.

The chapter begins with an explanation of how tax measures can be caught by Article 87 and especially under which conditions tax measures can be found to constitute selective treatment of certain undertakings. Then it reviews the principal cases of the past few years and identifies the policy innovations, especially with respect to taxes levied by autonomous regional authorities. Particular attention is paid to the case of the autonomous Portuguese region of Azores. The rest of the chapter evaluates these innovations on the basis of a simple model that disaggregates the effects of tax decentralisation. It concludes that the Commission was justified in finding against those regional measures, but only under specific circumstances.

\subsection{Applicability of state aid rules to fiscal measures}

The rules of state aid of the European Community apply to all public measures, even those for which no explicit or precise provisions exist in the Treaty. This means that direct taxation falls within the scope of state aid rules, although the EC lacks any general competence to regulate national tax measures that concern individuals or corporations. ${ }^{201,202}$

In numerous decisions, the European Court of Justice has clarified that member states cannot exercise their reserved powers by adopting measures that are prohibited by the Treaty [see, for example, Commission v France, C6/69; Italy v Commission, C-173/73; CIRFS v Commission, C-313/90]. This is because the concept of aid is wider than that of a subsidy and includes all

\footnotetext{
${ }^{201}$ Please note, however, that the EC has adopted a few measures in the form of directives on avoidance of double taxation on the remittances of subsidiaries and royalties, on taxation of withholding taxes for savings and on cooperation between tax authorities.

${ }^{202}$ For a detailed review of EC law relating to taxation, both direct and indirect, see R. Luja, Assessment and Recovery of Tax incentives in the EC and the WTO: A View on State Aid, Trade Subsidies and Direct Taxation, (Antwerp: Intersentia, 2003).
} 
measures that mitigate charges normally borne by firms such as taxes [see Banco Exterior de Espana, C-387/92; Belgium v Commission, C-75/97].

As is well known, for a public measure to be classified as state aid it must satisfy all conditions which are laid down in Article 87(1). Once a measure satisfies all of those conditions it is automatically incompatible with the common market, unless it can benefit from the exceptions specified in Article $87(2$ or 3$)$.

There are five conditions in Article 87(1):

- aid must be granted by a public authority and must benefit an undertaking in the sense that it transfers public resources to that undertaking (an undertaking is an enterprise or, more broadly, a natural or legal person engaged in economic activities);

- aid must confer an advantage to the recipient in the sense that it reduces its normal costs of operation that should be borne in its budget;

- the measure in question must be selective in the sense that it does not apply to all other similar undertakings or undertakings in similar economic situation;

- it must affect intra-EU trade in the sense that there is reasonable expectation that it can disturb the pattern of trade;

- and lastly, it must distort competition in the sense that the competitors of the undertaking (that may be located in other member states) do not obtain the same advantage.

In assessing the applicability of Article $87(1)$ to tax measures there is normally no doubt that they involve transfers of public funds [because, for example, tax reductions result in loss of tax revenue], that they confer an advantage [because they reduce liabilities that are normally covered by the revenue of the beneficiary undertakings] and that they affect trade and distort competition [because the concept of trade is very wide and once trade is affected it is very easy to show that some firms in other member states are harmed by the extra competition from lower taxes].

Therefore, the core issue in most cases is whether a tax measure is selective or not; i.e. whether it relieves from taxes only certain undertakings instead of all undertakings that are normally liable to that tax. Since, however, tax systems are not uniform [i.e. they apply different rates of taxation to 


\section{Chapter 18}

different sources of income] and since they apply to so many diverse activities, it is not so easy to determine the whether a tax measure is selective. This is of particular relevance to the recent cases in which the Commission has found that previously uncontested measures are now regarded as state aid because they apply to certain groups of companies, certain of their activities or certain geographic areas. All these are manifestations of selectivity.

It follows that to evaluate these recent cases and determine whether this extension by the Commission of the application of state aid rules raises any novel policy questions, we need to understand why Article 87 requires that, inter alia, a measure must be selective in order to be classified as state aid and be regarded in principle as incompatible with the common market.

Surprisingly, legal textbooks offer hardly any explanation. Most of them suggest that if state aid were left unchecked it would distort competition in the internal market and would lead to a spiral of subsidies. This may indeed be a likely outcome. After all, for any measure to have a negative effect on the internal market it must be capable of affecting trade by conferring an advantage to some firms. But it is not obvious why a general measure, as opposed to a selective measure, is not capable of distorting competition. Legal texts do not offer any plausible explanation. I turn therefore to economics.

\subsection{The economic logic of control of selective measures}

Economics suggests that government intervention in the economy is in general warranted only in the presence of market imperfections. ${ }^{203}$ When markets do not function efficiently, government intervention in the form of inducements such as state aid or regulations may raise economic welfare. However, it is important to note that even when markets are imperfect it does not follow that any inducement or regulatory intervention improves welfare. This is because there is also the problem of government failure.

${ }^{203}$ For reviews of the economics of state aid see R. Meiklejohn, The Economics of State Aid, European Economy, 1999, no.3, pp. 25-31; P. Nicolaides \& S. Bilal, An Appraisal of the State Aid Rules of the European Community: Do they Promote Efficiency?', Journal of World Trade, 1999, vol. 33(2), pp. 97-124. 
That is, the government may not have all the necessary information it needs or the intervention itself is too costly or the government is motivated by narrow interests.

Assuming therefore that the government is acting benevolently, that it has sufficient information and that its intervention is not excessively costly, the purpose of state aid is to improve economic efficiency - to allocate resources to their highest value. But under these assumptions, why do we need any kind of supranational control?

The reason is that even well-meaning intervention may generate spillovers that harm other countries. For example, if all countries in the EU attempt to attract investors to their backward regions, they will end up undermining each others' efforts. So some form of coordination becomes necessary. In addition, supranational control ensures uniform application of the principles enshrined in the EC Treaty. These principles are fairly general and need to be interpreted and applied according to the specificities of each case.

Naturally, we cannot assume that governments will act benevolently all the time or at all. Like in many other instances of international agreements, not only does supranational control of state aid aim to prevent intentionally predatory or beggar-thy-neighbour policies, but also measures which are harmful to the country itself because public policy is captured by specialinterest groups. Supranational control, then, functions as an instrument for committing governments not to pursue policies which are harmful either to others or to themselves. How often, for example, have member state governments not blamed Brussels for unpopular measures they had to adopt internally in an attempt to shift blame and political cost away from themselves?

These arguments provide a justification both for the granting of state aid under certain conditions and for the control of state aid at a supranational level. The question that was raised in the previous section is whether there is any justification for the inclusion of selectivity as one of the criteria for categorising public measures as state aid. The answer is yes. There are at least two justifications: one based on the principle of comparative advantage and another based on political economy considerations. 


\section{Chapter 18}

The economic argument runs as follows. Elementary trade theory shows that what fuels trade is differences in relative prices across countries. These indicate the opportunity costs of producing different goods and services in terms of how much other goods and services have to be "sacrificed" or given up in order to produce one extra unit of another good or service. This is the essence of the principle of comparative advantage and it suggests that government intervention that does not disturb relative prices will not influence the comparative advantage of the country and therefore will not distort trade. The country may become more efficient but this will not change the pattern of trade because the principle of comparative advantage shows that the pattern of trade is determined by relative rather than absolute advantage. Moreover, government intervention that raises efficiency makes the trading system as a whole better off.

Other countries should not complain when a country uses general policy measures. On the one hand, the pattern of trade is not disturbed. On the other, a prohibition of general measures would be too excessive because it would prevent countries from improving their efficiency across the board.

The political economy argument suggests that what matters in predatory or beggar-thy-neighbour policies is the ability of a country to sustain such policies. For several reasons, predatory general measures are less likely to be sustained than selective measures. They are also less likely to be effective. First, a general measure [i.e. one which is open to all sectors and firms with no discrimination] would be much more expensive than an equivalent selective measure [in terms of the rate of aid] and therefore less likely to be maintained for too long. Second, it would be more visible and subject to scrutiny and critical assessment. Most studies, for example, that investigate why governments prefer border restrictions to less distortionary subsidies conclude that border restrictions are less visible [not subject to budgetary scrutiny] and therefore are opposed to a lesser degree. Third, general measures are more exploitable by foreign firms. This defeats the purpose of pursuing a predatory policy. Fourth, and more importantly, general measures dilute the benefits they confer to any one industry or sector because, for example, a general tax reduction would lead all firms to bid up the prices of inputs across the board. This would eliminate any advantage to any single industry or sector. And fifth, precisely for this reason, general measures are not effective political tools. They are not useful to governments which may want to promote particular sectors in order to elicit their political support. 
All these considerations lead to the conclusion that the Treaty correctly proscribes selective measures rather than general measures. ${ }^{204}$ The latter are less likely to distort the pattern of trade because they do not channel public resources into any particular industry of sector. In the model I develop later on in this chapter I demonstrate that the mere act of tax decentralisation has no effect on tax rates and, by implication, on the pattern of trade, ceteris paribus. Moreover, decentralisation itself does not require or result in channelling of resources to any particular region. Certain conditions must hold in order for tax rates to change or for more public resources to flow into a region after tax decentralisation. But, both of these effects may be justified by the "logic of the tax system".

However, before we analyse the economic effects of decentralisation and the logic of tax systems, we first have to understand how the EU determines the selectivity of tax measures. This is because tax systems are not uniform so it is not so easy to identify what has general application and what does not. Over the years, the EC has developed an extensive practice on how to distinguish selective from general measures. Therefore, the next section reviews this practice and the section after that examines how the criterion of selectivity has applied to tax measures.

\subsection{Selective $v$ general measures}

A measure is selective when it does not have general applicability. This means that its coverage is restricted with respect to such things as regions, sectors, type of economic activity, size of companies or size of project. It is now well-established in the EC case law that it is not necessary for a policy to be selective in all its features in order for it to be classified as selective. In other words, when a few or even one firm is excluded from a policy, that policy is selective. This is especially pertinent in the case of a complex measure, where it would be sufficient to find a single selective feature to

${ }^{204}$ In the field of taxation general measures may also be harmful to other countries. On the broader issue of whether national tax measures cause harmful competition see K. Marsden, Is Tax Competition Harmful? (London: European Policy Forum, 1998) and European Commission, Company Taxation in the Internal Market, $\operatorname{COM}(2001) 582$ final (Luxembourg: OOPEC, 2002). 


\section{Chapter 18}

make the whole measure selective [see Commission Decision 2002/820 on investment aid in Alava, OJ L296, 30/10/2002]. Neither the large number of beneficiaries, nor the diversity of the sectors in which they are located is capable of rendering a measure as general when it has one or more selective features [see Belgium v Commission, C-75/97; "Adria-Wien Pipeline", C409/00].

Selectivity may also emerge in the application of an otherwise general measure. Its application may have a persistent bias in favour or against certain sectors. This was the case, for example, in the reduction of social insurance contributions for female workers [C-203/82] where the Court found that female workers were more likely to be employed in certain sectors and, therefore, the measure was in practice more favourable to those sectors which employed primarily female workers.

More broadly, the application of an otherwise general measure would result in selectivity where the benefits from the measure disproportionally benefit only certain undertakings. For example, infrastructural projects which are in theory open to all firms may in practice be selective if the responsible authority intentionally undertook them in order to support certain firms and, if in doing so, it deviated from its normal infrastructural development activities. So, a measure may be selective when it is foreseeable that its outcome would favour only certain firms. However, especially with respect to infrastructural projects, it is important to determine whether the authority concerned does something outside its normal development remit. If the projects are within its remit they would be regarded as general measures even if they favour certain firms because, for example, they result in wider roads or improved telephone services or faster transport links [see Commission Decision 2003/227 on a Spanish theme park, OJ L91, 8/4/03].

A general measure may also become selective when the secondary beneficiaries are specific companies. For example, Germany granted tax incentives for investment in the new Laender plus Berlin. These incentives were open to any investor irrespective of nationality. For this reason Germany argued that the measure was general. However, the Commission and the ECJ rejected this reasoning because investors could obtain the tax credit only if they would invest in a certain location. Therefore, there was an identified class of secondary beneficiaries which was geographically restricted [see Germany v Commission, C-156/98]. 
The application of an otherwise general measure also turns it into a selective measure where the relevant authorities have discretion to change important features of the measure or to determine which firm may qualify for support [see DM Transport, C-256/97; France v Commission, "Kimberly Clark", C241/94]. Certainly any eligibility conditions that are attached to a general measure may make it specific; e.g. thresholds for qualified investment [see the case below concerning tax credits in Spain].

Recently, however, the Commission has taken decisions that have limited this broad interpretation of what is a general measure; i.e. a measure which in intention or practice does not favour any sector or type of economic activity. In the 4th Maribel case concerning credits for the employment of manual workers the Commission did not classify the relevant Belgian measure as state aid because it accepted the non-discriminatory selection criteria. In addition, the authorities had no decision-making discretion and the measure itself had no sectoral or regional exclusion.

It seems that the Commission now is making a distinction between "statutory" selectivity and "material" selectivity, although this distinction has not been confirmed by EU Courts. In this context statutory selectivity means intentional favour of a region, sector, industry, firm or activity, whereas material selectivity means the de facto favour of one or more firms in the application of a measure. But such a measure must not result in a predictable and systematic bias in favour of some firms because, as was explained above, it would become selective.

Some recent example of measures approved by the Commission because they were found to be general: ${ }^{205}$

- Dutch tax breaks for R\&D which are open to all sectors [case N 291/2002].

- A Dutch system for the disposal of car wrecks on basis of payment of a levy by all car manufacturers \& importers with the proceeds used to fund disposal of car wrecks [Commission Decision 2002/204, OJ L68, $12 / 3 / 2002]$.

\footnotetext{
${ }^{205}$ The text of the Commission decisions in the relevant national language for the year concerned can be found on the Secretariat-General's special internet site at "http://europa.eu.int/comm/secretariat_general/sgb/droit_com/index_en.htm\#aides"
} 


\section{Chapter 18}

- Reduction of Italian tax and social security rates to encourage "regularisation" of underground employees throughout Italy and sectors [N 674/2001].

- Reduction of Belgian social security rates for firms that introduce shorter working hours [case N 232/2001].

- Exemption from German corporate tax of reserves for contingent liabilities which was open to all sectors [case NN 137/2001].

These examples suggest that it is possible to support certain economic activities without necessarily granting them state aid in the meaning of Article 87(1). For example, lower taxation of computer companies would be selective in intent whereas incentives for wider use of computers granted to all firms and individuals would be a general measure. Also lower taxation of companies using specific energy technologies would be selective in application [as it would benefit the producers of that technology and certain users] whereas incentives to convert to energy saving equipment open to all firms and households with no restriction on the type of equipment would be a general measure.

We can conclude, therefore, that selectivity is determined in the following way. First the Commission and the EU Courts ask whether a measure intends to favour certain firms or classes of firms or whether there is administrative discretion in its implementation. If yes, the measure is selective. If not, then the question is whether the results of that measure are likely, with a high degree of probability, to favour certain firms more than others. If not, the measure is not selective. If yes, the final question is whether the measure is open to all firms on equal terms and without any overt or covert discrimination. If yes, the measure is not selective. On the basis of these questions the following four-stage decision-making sequence can be constructed for the purpose of determining whether a measure is selective. 
Table 18.1: Determination of selectivity

\begin{tabular}{|c|l|l|}
\hline Stage & \multicolumn{1}{|c|}{ Questions } & \multicolumn{1}{c|}{ Outcome } \\
\hline I & $\begin{array}{l}\text { Does the measure intend to favour certain } \\
\text { firms or class of firms? }\end{array}$ & $\begin{array}{l}\text { Yes }=>\text { selective } \\
\text { No }=>\text { go to stage II }\end{array}$ \\
\hline II & $\begin{array}{l}\text { Is there administrative discretion in its } \\
\text { application? }\end{array}$ & $\begin{array}{l}\text { Yes }=>\text { selective } \\
\text { No }=>\text { go to stage III }\end{array}$ \\
\hline III & $\begin{array}{l}\text { Are the results likely to favour in practice } \\
\text { certain firms or class of firms? }\end{array}$ & $\begin{array}{l}\text { Yes => go to state IV } \\
\text { No }=>\text { not selective }\end{array}$ \\
\hline IV & $\begin{array}{l}\text { Is the measure open to all firms without } \\
\text { any discrimination? }\end{array}$ & $\begin{array}{l}\text { Yes }=>\text { not selective } \\
\text { No }=>\text { selective }\end{array}$ \\
\hline
\end{tabular}

\subsection{Selective v objectively justified tax measures}

When a tax measure is selective, there is hardly any doubt as to whether it provides state aid. In view, however, of the fact that tax systems are not uniform, it is not always so easy to determine the selectivity of a tax measure, especially when its applicability is limited to certain activities or products. It may be the case, for example, that different activities or sources of income are subject to different tax rates because they are inherently different. This would be compatible with EC rules because a general principle of EC law is that of objective differentiation: similar things have to be treated the same different things have to be treated differently (e.g. workers v capital) [see Finsider v Commission, C-250/83; "Schumacker", C-279/93].

Indeed the issue of discrimination is very important in this context. EC rules regarding equal treatment prohibit not only overt discrimination as, for example, by reason of the nationality or the location of the registered office of a company, but also all covert forms of discrimination which by the application of other criteria of differentiation lead to the same result, unless there is an objective reason for doing so [see Germany v Commission, C156/98]. All levels of government, irrespective of their tax autonomy, are bound by the rule on non-discrimination [opinion of Advocate-General Saggio in case C-400/97, "Guipúzcoa"]. Moreover, discriminatory measures may not be exempted under Article $87(2$ or 3$)$ and any regional restrictions may make a measure incompatible with Articles 43, 48 and 49 of the EC Treaty [Commission Decision 93/337 on the Basque tax exemptions, OJ 


\section{Chapter 18}

L134, 3/6/1993; and C-400/97, "Guipúzcoa"]. ${ }^{206}$ So the question that needs to be answered in relation to any tax measure is when a taxable activity is objectively different and when it is not.

This is a question that the EC Courts have had to grapple with in landmark cases of fiscal state aid. There is still no satisfactory answer. In the case Belgium v Commission, "maribel" [C-75/97], the Advocate General concluded that a measure is general when it aims to achieve equality between businesses, it applies to all undertakings to which it is capable of being applied and it provides no arbitrary benefits to any class of undertakings. In the case Italy v Commission concerning tax credits to road hauliers [C-6/97], the Advocate-General proposed that a measure is general when it follows from the logic or is compatible with the internal logic of the tax system. In the earlier case of "Sloman Neptun" [C-72/91], the AdvocateGeneral defined a measure as not being general when it constituted a derogation from the scheme of the general tax system.

The problem with theses definitions is that they do not explain how the scheme or the logic of the system is to be identified, nor do they provide guidance on how to determine whether a tax measure falls within that logic. Recent cases have demonstrated how easy it is to fail to persuade the Commission or the Courts that a measure falls within the logic of the system. For example, in the case concerning preferential tax treatment in the Spanish region of Guipuzcoa, the Commission in its Decision 2002/540 [OJ L174, 4/7/2002] rejected all the claims put forth by the Spanish authorities to justify their measures. In particular, the Commission found that it was not sufficient for tax measures to be applied on the basis of quantitative criteria;

${ }^{206}$ But note, however, that according to the European Court of Justice: “A measure to support investment adopted by a public authority can by definition apply only in respect of the territory for which it is responsible and the authority cannot be criticised for not extending the benefit of the measure to undertakings not established in its territory ... it does not, however, mean that such a measure of support cannot be classified as aid if it fulfils the conditions laid down by Article 87(1)" [Spain V Commission, C-351/98, concerning the replacement of old commercial vehicles]. In this case, the Commission had argued that foreign firms were discriminated against because they had to find Spanish firms to withdraw some of their own cars so as to be able to transfer to the foreign firms the fiscal advantage that was provided by the Spanish authorities in relation to Spanish-registered vehicles. 
to apply to many undertakings; to apply in many different sectors; to aim to collect revenue; or to aim to promote investment (by reducing the tax base or rates for large undertakings).

Indeed, procedures which are intended to reduce administrative burden or make a tax measure more efficient, by targeting it more narrowly, or prevent fraud can themselves become selective measures caught by Article 87(1). They may even be ineligible for exception under Article 87(3) on the grounds that they contravene other Treaty provisions. For example, the following two schemes would be state aid: (i) calculation of aid on the basis of the average costs of recipients in order to make the granting of aid easier and less bureaucratic [e.g. aid granted by the Netherlands that was based on the average cost of disposal of car wrecks]; (ii) limiting aid to certain large, well identified, projects to prevent dilution of aid when granted to anyone making investments [e.g. tax incentives granted by Basque authorities to large investment projects].

In another recent case involving Spain and which concerned a scheme to encourage replacement of old vehicles, ECJ found that the targeting of aid on economic grounds was not a consequence of the nature or general scheme of the system and therefore the scheme involved state aid [Spain $\mathrm{v}$ Commission, C-351/98]. The scheme in question was open only to SMEs because the Spanish authorities considered that large companies replace their cars more often and therefore did not need an tax incentives.

So, arguments that would appear as natural to tax authorities because they raise the efficiency of a tax measure by focusing or targeting it or by simplifying its application, would be rejected by the Commission on the grounds that they make the measure selective and that they do not follow from the logic of the system.

In my previous paper, I proposed a two-stage test for determining whether a tax measure follows from the logic or general scheme of the system. ${ }^{207}$ The test sought to identify, first, the implicit policy aim of the actual tax measure and, then, to derive from that aim all the measure(s) that could achieve that policy aim. If all the firms that were subject to the actual measure coincided with the firms that would fall within the scope of the derived measures, then

${ }^{207}$ See Nicolaides (2001), op. cit. 


\section{Chapter 18}

the measure in question was general. The rationale of this test has since then received indirect support from a recent Court ruling.

The Court of First Instance in Alava v Commission [T-92/00], rejected Spanish claims that the tax measures in question were general and that they aimed to encourage investment in Alava in order to increase future tax receipts. The Court based its rejection on the following reasoning: (i) no evidence was adduced that the explicit aim of the measure was to increase tax revenue; (ii) it was difficult to reconcile tax exemptions with the aim of raising tax revenue; and (iii) the same policy objective could be achieved by general measures. It is as if the Court were saying that the true scope of a measure that was intended to raise tax revenue would have been wider and would not limit itself to certain firms. Alternatively, it would not exclude all the firms that the actual measure was excluding.

On subsequent reflection, my two-stage test was perhaps too broad for tax measures. Although I still think it applies to any policy measure, it can be refined for the purposes of detecting fiscal state aid. All tax measures have one or two of the following three aims: to raise revenue, to discourage/penalise certain activities or to encourage certain other activities. Since all tax measures by definition impose a burden or cost, fiscal state aid is always in the form of an exception from that burden or a reduction of that burden [even tax credits may be understood to mean not an increase of benefits but a reduction of taxes]. The question, therefore, is whether the exception or reduction is justified. The more elaborate test which is proposed below seeks to answer that.

Some times, however, a tax measure may not be defined as an exception or reduction but as an autonomous or distinct measure. For example, a national tax code may stipulate that "All income is taxed. Income earned from domestic activities is taxed at $30 \%$. Income earned from foreign activities is tax at $10 \%$." It is not obvious now which is the exception or reduction. Is the $10 \%$ the reduction in relation to a benchmark rate of $30 \%$ or is the $30 \%$ rate an increase over the benchmark rate of $10 \%$ ? To give a proper answer we need to ask whether domestic activities are penalised or conversely whether foreign activities are being encouraged. In either case it is necessary to prove that they are objectively different so as to warrant different treatment. 
When we ask the question whether the consumption of cigarettes is penalised by higher taxes or whether all other products benefit from a reduction, it is easy to give the correct answer. This is because tax codes define a standard rate of sales tax, because additional excise taxes are imposed only on a few products and because cigarettes are addictive and harmful.

Similarly, to determine whether the reduction of landing charges for aircraft confers state aid, it is useless to ask whether landing charges are lower than other taxes. This is because landing charges apply only to air transport and only aircraft are liable to that tax. In this case there is state aid only if the reduction applies only to some airports or some airlines and not to others.

I call all these measures which appear to be different and not within any other tax measure as "self-standing". The core of the problem is to decide whether these apparently "self-standing" measures do indeed apply to substantially or objectively different products and activities or whether they are disguised exceptions that fall within some other measure.

Therefore, the key to a robust test of determining whether a tax rate constitutes a selective measure is to identify a benchmark rate. Such benchmark rate applies to all similar entities, products or activities [i.e. entities, products or activities that are not objectively different]. Only then are we able to deduce whether a particular measure follows from the logic of the system. Indeed the "logic" of tax systems is determine or group together similar entities, products and activities to which the derived benchmark rate applies.

On the basis of these considerations a more natural and refined test to detect state aid in tax measures is the following. 
Table 18.2: Determination of whether a measure follows from the logic of the system

\begin{tabular}{|l|l|l|}
\hline Stage & Question & Outcome \\
\hline I & $\begin{array}{l}\text { Is the tax measure self-standing? [i.e. } \\
\text { the relevant benchmark rate is itself] }\end{array}$ & $\begin{array}{l}\text { Yes }=>\text { go to stage III } \\
\text { No }=>\text { go to stage II }\end{array}$ \\
\hline II & $\begin{array}{l}\text { If the measure is not self-standing, it } \\
\text { must be a reduction or exception from a } \\
\text { benchmark rate. Is it justified on } \\
\text { objective grounds? }\end{array}$ & $\begin{array}{l}\text { Yes }=>\text { measure follows from logic of } \\
\text { system }\end{array}$ \\
$\mathbf{N o}=>$ measure is selective \\
\hline III & $\begin{array}{l}\text { If the measure is self-standing, does it } \\
\text { apply to entities, products or activities } \\
\text { which are objectively different from } \\
\text { those subject to other benchmark rates? }\end{array}$ & $\begin{array}{l}\text { Yes }=>\text { go to stage IV } \\
\mathbf{N o}=>\text { measure is selective }\end{array}$ \\
\hline IV & $\begin{array}{l}\text { Does that measure apply uniformly? } \\
\text { [i.e. it does not have any internal } \\
\text { discriminatory features] }\end{array}$ & $\begin{array}{l}\text { Yes }=>\text { measure is general } \\
\mathbf{N o}=>\text { measure is selective }\end{array}$ \\
\hline
\end{tabular}

Here are examples of measures that have been found not to constitute objective fiscal differentiation:

- Lower discount rate for exports in all sectors [France v Commission, C6/69].

- No tax on export earnings in all sectors [Greece, Commission Decision 1989/659].

- Accelerated depreciation rates in air transport [Germany, Commission Decision 1996/369, OJ L146, 20/6/1996].

- Reduction of family allowances for employers in textiles sector [Italy $\mathrm{v}$ Commission, C-173/73].

- Reduction of social insurance contributions for female employees [Italy v Commission, C-203/82].

- Reduction of tax for re-organisation of companies [it appeared in practice to benefit only one firm [Italy, Commission Decision 1992/389].

- Reduction of the tax base of newly established firms; tax credits for firms investing above certain amounts [Spain, Commission Decisions (Ramondin) 2000/795, OJ L318, 16/12/2000; (Daewoo), 1999/718, OJ L292, 13/11/1999].

- Exception of companies investing in more than a certain number of countries [The Netherlands, Commission Decision 2003/515, OJ L180, 18/7/2003]. 
- Exception of companies involved in certain economic activities (selfinsurance) [Finland, Commission Decision 2002/977, OJ L329, $5 / 12 / 2002]$.

And here are some examples of objectively differentiated tax measures:

- Zero profit tax when no profits are supposed to be made.

- Different rules on asset valuation of banks, liabilities of insurance companies, etc.

- Different rates of taxation of different factors of production.

- Zero tax on income already taxed [avoidance of double taxation].

- Technical rules [depreciation, loss carry-over, etc].

- General incentives for job creation or R\&D.

- Measures to ease the administrative burden of SMEs.

- Measures to give breathing space to companies in bankruptcy proceedings.

- Exception of agricultural land from standard land tax due to the specific role of land in agricultural production [cases N20/2000 (Netherlands) and N53/99 (Denmark)]. ${ }^{208}$

I have now shown that the principle that emerges from EC case law and practice for determining both the selectivity of a measure, in general, and also whether it follows from the logic or general scheme of the system, in particular, is to define the relevant benchmark or the scope of the underlying policy that encompasses the measure under examination. I now turn to the recent Commission decisions on various aspects of national tax systems which until just a couple of years ago were regarded as falling outside state aid rules. $^{209}$

\footnotetext{
${ }^{208}$ They can be accessed at

"http://europa.eu.int/comm/secretariat_general/sgb/state_aids".

${ }^{209}$ The Commission itself has proposed the following test: "To determine whether a tax scheme derogating from the normal system may constitute state aid, it must be established whether the resulting tax burden is lower than that which would have resulted from application of the relevant Member State's normal taxation method." [See reference in footnote 4, at page 4.] I explain later on why this test is not sufficient.
} 


\section{Chapter 18}

\subsection{A review of recent cases of fiscal state aid}

During the past three years there have been many Commission decisions and Court rulings on tax issues. The main cases are the following.

Commission investigations on incompatible tax schemes [investigations launched in July 2001]:

- Germany: coordination centres of foreign companies;

- Spain: Basque coordination centres;

- France: (i) headquarters and logistics centres, (ii) central treasuries;

- Ireland: exemption of foreign income;

- Luxembourg: (i) coordination centres, (ii) finance companies;

- Netherlands: international financing activities;

- Finland: Åland captive insurance;

- UK: Gibraltar offshore companies.

Commission proposals for appropriate measures [existing aid, or aid found in the past to be compatible with the common market]:

- Belgium: coordination centres;

- Greece: offices of foreign companies;

- Italy: Trieste financial services centre;

- Sweden: foreign insurance companies.

In addition, the Commission investigated separately the corporate tax measures of several Spanish autonomous regions [these decisions were appealed and all were upheld by the Court of First Instance]:

- Commission Decision 1999/18 [Daewoo] => T-127/99, partly annulled for reasons not related to taxation.

- Commission Decision 2000/795 [Ramondin] => T-92/00, upheld.

- Commission Decision 2002/540, [investment aid for new firms in Guipuzcoa] $=>$ banned.

- Commission Decision 2002/806 [investment aid for new firms in Vizcaya] $=>$ banned.

- Commission Decision 2002/820 [aid for new investment in Alava] => banned.

- T-269/99, Guipuzcoa, Alava, Vizcaya v Commission [45\% tax credit] $=>$ dismissed. 
- T-346/99, Alava, Guipuzcoa, Vizcaya v Commission [reduced tax base] $=>$ dismissed.

Belgium: Coordination centres: In 1984, the Commission decided that there was no aid. In July 2001, the Commission proposed appropriate measures. Belgium did not accept them and the Commission opened an investigation in February 2002. Belgium law required that coordination centres had to be part of a multinational group in at least four countries, having own capital of BEF 1 billion and turnover of BEF 10 billion. They also had to employ at minimum 10 staff. Financial firms were not eligible. Coordination centres were taxed at a flat rate of $8 \%$ on the basis of their operating costs [minus staff costs]. The Commission [Decision 2003/755, OJ L282, 30/10/03] found the measure selective because it applied only to large groups and because it excluded certain costs. It has to be phased out by 31 December 2010. No aid recovery was ordered because firms had legitimate expectations on the basis of the 1984 Commission decision. ${ }^{210}$

Germany: Control \& coordination centres of foreign companies. Their profit was calculated by a cost-plus principle with a mark-up varying between $5 \% \& 10 \%$. The exact rate of mark-up was chosen by the control and coordination centres themselves but the authorities never imposed a rate that was higher than $10 \%$. The Commission [Decision 2003/512, OJ L177, $16 / 7 / 03$ ] found that accepting $10 \%$ as ceiling could confer aid. In this situation it is normal to have case-by-case assessment. It also found that it was irrelevant that the measure served to ease administrative burden on authorities and create legal certainty for companies. Certainty could be requested in relation to items that were to be taxed not on the outcome of taxation. The measure was selective even though it was open to all sectors because it excluded German resident companies

Spain: Vizcaya coordination centres: In this case profit was calculated either by the traditional method or by applying a rate of $25 \%$ to all expenditure ["cost plus" method] except financial expenditure. There was also qualifying thresholds in terms of capital and turnover. The Commission [Decision 2003/81, OJ L31, 6/2/03] found that the second method could

${ }^{210} \mathrm{R}$. Luja also comments on this case and the subsequent use of Article 88(2) by Belgium. See his Harmful Tax Policy: When Political Objectives Interfere with State Aid Rules, Intertax, 2003, vol. 31(12), pp. 484-488. 


\section{Chapter 18}

confer aid because it was no indication how the differential method could be justified by the nature or general scheme of the system. It was banned but no recovery was ordered because of legitimate expectations. Apparently, the scheme was modelled on the approved Belgian scheme of 1984.

France: Coordination \& logistics centres: Corporate profit was calculated by applying a fixed rate to operating expenditure. This expenditure did not include occasional and incidental outgoings reimbursed to the centres. It also excluded subcontracted activities. The centres were subject only to the first bracket of the tax rate because they were regarded as not to generate any turnover. The Commission [Decision 2004/76, OJ L23, 28/1/04] found that the alternative method could confer aid in relation to the cost-plus method that takes into account all costs. In addition, the use of the first tax bracket could also lower taxation.

France: Central corporate treasuries: The relevant fiscal law imposed a limit on the deductibility of interest paid to shareholders on sums they left at the disposal of the qualifying company. The fiscal authorities could, however, authorise derogations from that limit under certain conditions. The Commission [Decision 2003/883, OJ L330, 18/12/03] found that any failure to limit deductibility made it possible to reduce the tax base.

Finland: Åland Islands captive insurance: The schemes was introduced in 1993 before Finland acceded to the EU. In principle it would be regarded as existing aid. But because it was modified after accession in October 1995, the Commission considered it to be a notifiable scheme and that Finland had breached its obligation to notify it to the Commission and have it authorised before it came into effect. The scheme granted tax reduction of $10 \%$ points to captive insurance activities. Captive insurance was defined as an entity with $100 \%$ of the shares owned by a single foreign company, the only client was the owner, and that it had to be a limited company licensed by the Province of Åland. The Commission [Decision 2002/977, OJ L329, 5/12/02] found that the scheme granted operating aid that could not be exempted under the current state aid rules.

Italy: Trieste Financial services \& insurance centre: Banking and insurance firms located in Trieste and providing services in central \& eastern Europe could benefit from a tax reduction on their corporate profits. This scheme was approved by the Commission in 1995. Apparently it had never 
been applied. Therefore, the Commission decided to propose appropriate measures to Italy requiring the abolition of the scheme [Decision 2003/230, OJ L91, 8/4/03].

Ireland: Foreign income: Income from "foreign trade" subsidiaries was exempted from corporation tax if the parents would submit an application and obtain approval by the Ministry of Finance for a plan aimed to maintain or increase jobs in Ireland. The Irish authorities claimed that the scheme intended to prevent double taxation and encourage repatriation of foreign income. The Commission [Decision 2003/601, OJ L204, 13/8/2003] found the scheme to operate on ambiguous criteria and therefore was not within the logic of the tax system to grant relief from double taxation on the basis of those ambiguous criteria. The exemption was a form of state aid whenever foreign taxes were lower than Irish taxes [a credit system would not have been aid]. In addition, it was restricted only to those who applied for certificates. There were no procedures to safeguard the proportionality of the tax exemption in relation to the number of jobs created or maintained. It was irrelevant that the scheme encouraged repatriation of profits and that in case of no repatriation the companies concerned would face no tax liability. A member state may not use lower taxes to attract income. It was also irrelevant that the scheme was not banned by the Code of Conduct Group. In the end the Commission banned it because it was operating aid with regard to job maintenance, but it asked for no aid recovery because the scheme resembled Belgium's approved scheme of 1984.

Luxembourg: Coordination centres: The profit of these centres was calculated by a cost-plus pricing method. However, if expenditure did not exceed LUF 30 million, profit was fixed at LUF 1.5 million. Alternatively, if a centre was involved in the payment of invoices, its profit was presumed to be equal to $1 \%$ of the value of invoices, adjusted for risk. The Commission [Decision 2003/501, OJ L170, 9/7/03] found that the second and third method could confer aid because the objective of alternative methods taxation must be to arrive at equal or comparable taxation to what would otherwise be the case under the traditional method. The scheme was banned but no recovery was requested because the scheme was modelled on the approved Belgian scheme.

Luxembourg: Finance companies: A qualifying finance company was an entity that was set up to grant loans to intra-group companies based abroad 


\section{Chapter 18}

and which had minimum assets of $€ 185$ million. Tax liability was determined on the basis of a minimum rate of acceptable profit that was fixed at $0.25 \%$ of the amount of loans it granted. Municipal tax was assessed on the basis of operating capital. The Commission [Decision 2003/438, OJ L153, 20/6/03] regarded that the purpose of using alternative methods of taxation is to arrive at comparable taxation where profit is the difference between revenue and costs. The Commission found that it was unclear how and why authorities in Luxembourg set the rate of $0.25 \%$ or why a different method was used for municipal tax. In addition, the measure was selective because it was limited to large MNCs. It was banned but no recovery was requested because the measure was modelled on the approved Belgian scheme.

The Netherlands: International financing activities: In order to counter a tendency by Dutch firms to establish finance companies in tax havens, the Netherlands allowed companies operating in more than four countries to set up risk reserves. They could then deposit in these reserves up to $80 \%$ of the profits from the group's financing activities without paying any tax. Any remaining profit was taxed at the standard rate of $35 \%$. The Commission [Decision 2003/515, OJ L180, 18/7/03] found that the $80 \%$ deduction of profit could reduce tax burden more than on the basis of the standard method of taxation. Moreover, withdrawals from the reserves that would normally be taxed at $35 \%$ were taxed at $10 \%$ or not taxed at all if they were used for certain purposes such as acquisition of companies. The measure was selective both in terms of intent and in terms of its application because it was restricted to certain financial functions and undertakings operating in more than four countries. The Commission banned it but did not ask for recovery because it resembled the approved Belgian scheme.

Portugal: Reduction of corporation tax for firms in Azores: Portugal allowed the autonomous region of Azores to reduce the rates of income and corporation tax by up to $30 \%$ of those laid down by national legislation. The Commission [Decision 2003/442, OJ L150, 18/6/03] found that the reduction was a selective measure that was not justified by the nature or scheme of the tax system. The Azores taxation was deemed to be a derogation from the national tax system because if member states could limit the regional application of their taxes through institutional arrangements that conferred autonomy to certain regions, then state aid control would be ineffective. The tax deductions constituted operating aid which was partially permitted by the 
Commission on the grounds that Azores was an outermost region as defined by Article 299. Operating aid is exceptionally allowed when it is intended to reduce the extra costs of economic activities caused by the remoteness of these regions. For this reason, the Commission banned this kind of aid to financial services firms for which remoteness (distance) does not represent a handicap.

UK: Gibraltar offshore companies: At issue in this case was whether rules on "exempt" \& "qualifying" companies were existing or new schemes. Exempt companies were registered in Gibraltar but had no activities there and therefore were not subject to tax. Qualifying companies were registered in Gibraltar, had presence there but they were subject to a negotiated tax rate of between $2 \%$ and $10 \%$. The Commission decided in July 2001 that because of adjustments to the tax legislation of Gibraltar, the rules on exempt and qualifying companies were new aid that was incompatible with the common market. On appeal, the Court of First Instance [T-195/01 \& T-207/01] ruled that (i) notification to the Code of Conduct Group was not notification in the meaning of Article 88(3), (ii) legislation on exempt companies predated the UK's entry into the EU and therefore was "existing" aid (Commission Decision annulled), (iii) legislation on qualifying companies also predated UK entry but was subsequently amended making it new aid. The favourable tax treatment of qualifying companies could not be exempted under Article 87(3). It was irrelevant that the number of qualifying companies was small and that Gibraltar was also small in relation to EU market. It was also irrelevant that by having to withdraw these tax privileges Gibraltar risked irreparable harm to its standing as international financial centre. The long tolerance of the scheme by the Commission did not establish any legitimate expectations for beneficiaries.

\subsection{New criteria: (i) Similar tax burden and (ii) boundaries of fiscal autonomy}

The review of the recent cases above reveals that the Commission indeed seeks a benchmark in order to determine whether a tax measure contains state aid. Some of these cases, however, are more important because the Commission has introduced two novel criteria in order to determine the existence of state aid. 


\section{Chapter 18}

The first criterion is that any alternative system for calculating tax liability should result in the "same tax burden". This was one of the main faults found by the Commission in the cases concerning the Belgian coordination centres, control and coordination centres of foreign companies in Germany, coordination centres in Luxembourg, Luxembourg finance companies, coordination centres in Vizcaya, Spain, and headquarters and logistics centres in France.

A typical alternative tax method used in these cases is the "cost-plus" method which is recognised by the OECD. ${ }^{211}$ This method takes the costs incurred by the supplier of goods or services in a transaction between associated companies and then adds to those costs a cost-plus mark-up to obtain an appropriate profit in the light of the functions performed, assets used, risks assumed and market conditions.

The criterion of "same tax burden" is as yet untested before EC Courts. Although at first sight it seems reasonable, it raises a question to which the Commission has not provided any satisfactory answer. If it were possible to determine the tax burden under different taxation methods, then it would be feasible to apply the normal method of taxing the difference between revenue and costs. So, if that were feasible why was it not applied? If, however, it were not feasible to apply the normal method, then it would be impossible to know what the tax burden would be under the normal method and, consequently, it would also be impossible to compare the tax burden under different methods. Hence, this idea that alternative tax methods should arrive at the same tax burden, which seems to be so reasonable, is in fact based on contradictory assumptions.

It is indeed revealing that although the Commission introduced this criterion in several of its recent decisions on fiscal state aid, it proved the selectivity of the measures in question by relying exclusively on the existence of restrictions on taxable costs or taxable profit [e.g. some measures excluded certain cost items from the tax base while some others fixed the taxable income at a predetermined level]. All these are arbitrary limitations of tax liability without any foundation that may derive from the logic of the tax system. So, the Commission was correct to find that the measures in

\footnotetext{
${ }^{211}$ See in particular the Transfer Pricing Guidelines for Multinational Enterprises and Tax Administrations, (Paris: 1995).
} 
question were a form of state aid, but it did not attempt to measure the tax burden ensuing from alternative methods of taxation. The only thing it did was to point out that under certain conditions, certain firms could be more favourable treated without any objective reason.

As the Commission itself puts it, "although the [cost-plus] method as such is not caught by Article 87(1) of the EC Treaty, it can give rise to an advantage where the tax arrangements applied do not take proper account of the economic reality of the transactions and thereby result in a lower rate of taxation than if the standard tax method had been applied." 212 This is not, however, the same as measuring the equivalence of tax burdens. Moreover, the Commission did not seek to estimate the resulting taxation had the standard method applied. Once more, close reading of the Decisions above reveals that what in fact the Commission did was to identify arbitrary limitations of tax liability.

The second criterion appeared in the Commission Decision 2003/442 [OJ L $150,18 / 6 / 2003$ ] concerning reduced rates of corporate tax in the autonomous region of Azores. The Commission argued that the regional government was able to lower the rate of corporate tax because it was compensated by a transfer from the central government. This is a beguilingly simple argument where in fact the underlying economics of the case is much more complex. It is first necessary to understand the economic impact of regional transfers to be in a position to assess whether the Azores region was able to obtain an advantage that allowed it to reduce its taxation. I, therefore, examine below the economic issues which are relevant to this case.

\subsection{A simple model of regional tax autonomy}

Suppose the tasks of the government are two: to provide a public good and to raise revenue to pay for the public good through taxation of capital. If there were no taxation and capital markets functioned perfectly, the return on

\footnotetext{
${ }^{212}$ Report on the Implementation of the Commission Notice on the Application of the State Aid Rules to Measures Relating to Direct Business Taxation, p. 3, paragraph 10. It can be accessed at "http://europa.eu.int/comm/competition/state_aid/legislation/business/rapportaidesfi scales_en.pdf"
} 


\section{Chapter 18}

capital would be fixed at the rate where the supply of capital would equal the demand for capital. Assume that demand and supply are linear functions given by the following equations:

Demand for capital, D: $\mathbf{r}_{\mathbf{d}}=\mathbf{a}-\mathbf{b K}$

Supply for capital, $\mathbf{S}: \mathbf{r}_{\mathbf{s}}=\mathbf{c}$

where, $\mathbf{r}_{\mathbf{d}}$ is the rate of return offered by those who demand capital, $\mathbf{r}_{\mathbf{s}}$ is the rate of return requested by those who supply capital, $\mathbf{K}$ is the amount of capital demanded and supplied and $\mathbf{c}$ is the fixed rate of return at which there is an infinite supply of capital. These conditions simply mean that the country in question is small in relation to capital markets.

Before tax, the amount of capital demanded and supplied at the equilibrium rate of return is

$$
\mathbf{K}=(\mathbf{a}-\mathbf{c}) / \mathbf{b}
$$

The constants, $\mathbf{a}$ and $\mathbf{b}$, are exogenously given and they are determined by the conditions of the economy.

\section{The effect of taxation}

A tax, $\mathbf{t}$, injects a wedge so that at equilibrium the return offered, $\mathbf{r}_{\mathbf{d}}$, is equal to the return requested, $\mathbf{r}_{\mathbf{s}}$, plus tax, or

$$
\mathbf{r}_{\mathbf{d}}=\mathbf{r}_{\mathrm{s}}+\mathbf{t} \text { or } \mathbf{r}=\mathbf{c}+\mathbf{t}
$$

The revenue raised from this tax is

$$
\mathbf{R}=\mathbf{t K}
$$

This revenue is used to supply a public good, G. Assume that the amount of public good is a function of the collected revenue so that

$$
\mathbf{G}=\mathbf{f}(\mathbf{R})
$$

Assume for simplicity that

$$
\mathbf{G}=\mathbf{e R}
$$

where $\mathbf{e}$ is a factor indicating efficiency of converting revenue into that public good. Further assume that this society must consume a certain amount of that public good, given by $\mathbf{G}^{*}$.

It follows that in this very simple society, the minimum necessary rate of taxation is

$$
\mathbf{G}^{*}=\mathbf{e R}=\mathbf{e t K} \Rightarrow \mathbf{t}^{*}=\left(\mathrm{G}^{*} / \mathrm{eK}\right)
$$

where "“*” indicates the required values of $\mathbf{G}$ and $\mathbf{t}$.

If we make the necessary substitutions, the rate of taxation is given by

$$
\left[(\mathbf{e a}-\mathbf{e c}) \mathrm{t}-\mathrm{et}^{2}\right] / \mathbf{b}=\mathbf{G}^{*}
$$


This quadratic equation shows that there are two values of taxation that can generate the required revenue: a low rate and a high rate. Naturally, the country in question should choose the low rate.

Please note that the rate of taxation that generates the maximum amount of revenue $\mathbf{R}$ and consequently the maximum amount of the public good is obtained by differentiating $\mathbf{G}$ with respect to $\mathbf{t}$

$$
\mathrm{dR} / \mathrm{dt}=[(\mathbf{a}-\mathrm{c}) / \mathrm{b}-\mathbf{2 t}] / \mathrm{b} \text { or } \mathbf{d G} * / \mathbf{d t}=[\mathrm{e}(\mathrm{a}-\mathrm{c})-2 \mathrm{et}] / \mathrm{b}
$$

By setting either derivative equal to zero we find the value of $\mathbf{t}$ that maximises revenue

$$
\mathbf{t}=(\mathbf{a}-\mathbf{c}) / \mathbf{2}
$$

The second-order derivative is

$$
\mathrm{d}^{2} \mathrm{R} / \mathrm{dt}^{2}=-2 / \mathrm{b}<0, \text { or } \mathrm{d}^{2} \mathrm{G} / \mathrm{dt}^{2}=-2 \mathrm{e} / \mathrm{b}<0
$$

This means that if the rate of taxation is

$$
0<\mathrm{t}<(\mathrm{a}-\mathrm{c}) / 2
$$

Both $\mathbf{R}$ and $\mathbf{G}$ increase at a decreasing rate.

\section{Tax decentralisation}

Assume now that this country is divided into two equal regions in which capital can flow freely. If everything else remains the same, nothing will change in the rate of return on capital or the rate of taxation. This is because

$$
\mathbf{G}=\mathbf{G}_{\mathbf{1}}+\mathbf{G}_{\mathbf{2}}, \mathbf{D}=\mathbf{D}_{\mathbf{1}}+\mathbf{D}_{\mathbf{2}} \text { and } \mathbf{S}=\mathbf{S}_{\mathbf{1}}+\mathbf{S}_{\mathbf{2}}
$$

where the subscripts indicate the two regions.

There is another way to explain why the act of tax decentralisation itself has no effect on tax rates, cateris paribus. If the two regions are identical, their demands for capital would be

$$
D_{1}=D_{2}=>r_{d 1,2}=a-2 b K
$$

This shows that their demands will be twice as steep as the demand of the whole country. The tax rate that maximises revenue in each region is $\mathbf{t}=\mathbf{( a -}$ $\mathbf{r}) \mathbf{2}$. It does not depend on the slope of the demand which is given by $\mathbf{b}$ [for the whole country] or $\mathbf{2 b}$ [for each region]. So the same rate applies to both the whole country and each of the regions.

The amount of revenue raised by the two regions will be exactly half of the amount that is raised by the central government. This can be proven by solving the equation for $\mathbf{R}$. For example, the maximum amount of revenue that can be raised by the central government is

$$
\mathbf{R}^{*}=(\mathbf{a}-\mathbf{c})^{2} / \mathbf{4 b}
$$




\section{Chapter 18}

while the maximum amount of revenue that can be raised by each region is

$$
\mathbf{R}_{\mathbf{1}} *=\mathbf{R}_{\mathbf{2}} *=(\mathbf{a}-\mathbf{c})^{\mathbf{2}} / \mathbf{8 b}
$$

But suppose that one region is more efficient than the other in producing that public good. Whereas before the split the central government provided the public good in conditions that reflected the average efficiency of the country, the provision of the public good by each region after the split necessarily reflects their own efficiency. The efficiency factors are

$$
\mathbf{e}_{1}>\mathbf{e}_{\mathrm{n}}>\mathbf{e}_{2}
$$

where subscript $\mathbf{n}$ indicates the average national efficiency. These inequalities indicate that region 1 is more efficient than region 2.

It follows that region 1 will need less revenue to produce the same amount of public good as region 2. This means that if

$$
\mathbf{G}_{\mathbf{1}}{ }^{*}=\mathbf{G}_{\mathbf{2}}{ }^{*} \text { and } \mathbf{e}_{\mathbf{1}}>\mathbf{e}_{\mathbf{2}} \text {, then it must be that } \mathbf{R}_{\mathbf{1}}<\mathbf{R}_{\mathbf{2}}
$$

If each region is also granted tax autonomy, then region 1 will need a lower rate of tax than region 2 in order to raise the necessary amount of revenue to pay for its public good. But if

$$
\mathbf{t}_{\mathbf{1}}<\mathbf{t}_{\mathbf{2}} \text {, it follows that } \mathbf{K}_{\mathbf{1}}>\mathbf{K}_{\mathbf{2}}
$$

because the higher the net rate of return [i.e. the after-tax rate of return], the larger the amount of capital that is supplied. The reverse process occurs in region 2. Consequently, capital will flow from region 2 to region 1. Each region, therefore, levies a rate of tax that corresponds to its relative efficiency in producing that public good.

So we can derive the following preliminary conclusions. First, if regions are identical, tax decentralisation has no effect on the rate of taxation. And second, if regions vary in their productive efficiencies, the rates of regional taxation will reflect those efficiency differences.

\section{Regional transfers}

If the capital outflow is harmful to region 2, it would want to reverse it. It cannot lower its tax because it will have a shortfall in the revenue that it needs to finance the public good. The only way that this outflow can be reversed is for the central government to subsidise the production of the public good in region 2 . The amount of the required subsidy, $\mathbf{S}$, must be

$$
S+e_{2} t_{2} K_{2}=e_{1} t_{1} K_{1}=>S=e_{1} t_{1} K_{1}-e_{2} t_{2} K_{2}
$$

If region 2 uses the subsidy to reduce its own tax to the level of the tax in region 1 so that 


$$
\mathbf{t}_{\mathbf{1}}=\mathbf{t}_{\mathbf{2}}=\mathbf{t} \text {, it follows that } \mathbf{K}_{\mathbf{1}}=\mathbf{K}_{\mathbf{2}}=\mathbf{K}
$$

[otherwise capital will not flow back into region 2]. Under these conditions

$$
S=\mathbf{e}_{1} \mathbf{t K}-\mathbf{e}_{2} \mathbf{t K}=\left(\mathbf{e}_{1}-\mathbf{e}_{2}\right) \mathbf{t K}
$$

So, the subsidy is a function of the relative efficiencies in the two regions and the larger the difference, the larger the amount of subsidy that will be needed to reverse capital flows.

Note, however, two important features of this transfer of resources to region 2. First, in this case it is the high-tax region that receives the subsidy. Second, the rate of tax that prevails after the split into two tax regions is lower than before. This is because region 2 lowers its tax to the level of the tax in region 1 , which is lower than before since its efficiency factor, $\mathbf{e}_{\mathbf{1}}$, in producing the public good is higher than the national average, $\mathbf{e}_{\mathbf{n}}$.

This general lowering of regional taxes need not make the whole country better off. On the one hand, there is a beneficial effect due to the reduction in the distortion in capital markets caused by the tax to pay the public good. On the other hand, the central government has to raise a subsidy from somewhere. In this simple and partial-equilibrium model we do not know the magnitude of the inefficiency which is introduced somewhere else by a tax whose purpose is to raise revenue to pay for the subsidy to region 2 .

But aside from whether economic efficiency rises or declines, the point here is that tax autonomy results in some rates being lower than the rate of a previous uniform tax. This has nothing to do with "tax competition" as such. It is the natural result of variation in regional efficiencies. ${ }^{213}$ In political terms, however, this "natural" result may be objectionable in the sense that it makes more difficult or costly the provision of public good in region 2. It is conceivable that some form of subsidy from the central government may be deemed necessary to compensate region 2 for the higher cost it faces after the split. If this subsidy is seen later on in isolation, it may be construed as a selective measure. But if it is seen in the overall context of an inter-regional agreement with the central government that makes possible decentralisation of tax responsibility, then it may be regarded as a compensatory measure which is within the logic of a decentralised tax system. It is within the logic of the system in two ways: it is a form of regional solidarity [all tax systems

\footnotetext{
${ }^{213}$ In fact, the assumption for constant returns to capital, means that the regions do not compete for capital.
} 


\section{Chapter 18}

are based on solidarity] and it compensates region 2 so that decentralisation does not leave it worse off.

We can also ask what may happen when the central government provides subsidies to both regions. In the context of the simple model in this chapter, there is no reason for the central government to give subsidies to all regions. But such subsidies or transfers are typical arrangements in most if not all federal countries and countries with autonomous regions. How do these transfers affect regional taxes?

Since we derived earlier that tax revenue increases at a decreasing rate with the rate of taxation, it follows that when the central government gives exactly the same amount of subsidy to the two regions, the subsidy to the high-tax region will result in a larger reduction of its rate of tax than the equivalent subsidy to the low-tax region. Even if the tax rate of region 2 remains above the rate of region 1, an equivalent subsidy enables region 2 to achieve a larger tax decrease. Conversely, if the central government wants to achieve equal reductions of regional taxes, it must give a larger subsidy to the low tax region [or a smaller subsidy to the high-tax region]! On the other hand, if it wants the two regions to have the same level of taxation, it must give a larger subsidy to the high-tax region. Irrespective of whether the objective is to achieve uniform tax reductions or the same level of tax rates, the subsidies granted by the central government cannot be uniform.

\section{Dissimilar regions}

So far the analysis of the various possible situations has been based on the assumption that regions were either identical or different in only one respect: their efficiency of producing the local public good. If we drop these assumptions, it is possible that after the regional split, a region, say region 1 , may want to reduce its rate of taxation for the simple reason that the rate of national tax, $\mathbf{t}_{\mathbf{n}}$, that prevailed before the split exceeds its revenuemaximising rate [as given by the specific demand for capital in that region], or

$$
t_{1} *=\left(a_{1}-c_{1}\right) / 2<t_{n}
$$

By reducing its tax rate, it raises revenue to pay for the public good. The outcome may be

$$
t_{1} *<\left(a_{1}-c_{1}\right) / 2<t_{n}
$$

So the reduction may be necessitated by the fact that in a devolved political system, region 1 has responsibility to pay for public goods. 
The political agreement that made the split possible may have also imposed limits on the extent of any tax reduction in order to prevent too much tax competition. If region 1 abides by that restriction, it may not generate enough revenue to pay for the public good. In this case it may be necessary for the central government to make up the shortfall through transfers. So now we have a possibility whereby, the tax rate of region 1 may be lower than that of region 2 and still receive some subsidy from the central government.

\section{Conclusions}

The model has derived a number of results which are relevant for the purposes of this chapter. First, tax decentralisation may result in regional tax differences reflecting the variations in the efficiency of each region in producing local public goods. Second, transfers from the central government may be an integral part of the decentralisation in the sense that they compensate those regions for which the production of the local public good is too expensive. This is part of the solidarity [inter-regional in this case] that is inherent in tax systems.

It is therefore insufficient to just check whether subsidies to regions are equivalent [as their actual impact differs across regions] or whether subsidies have a neutral effect on the ranking of regional taxes [as the high-tax regions may still be able to achieve a larger percentage reduction than the low-tax regions] or whether the subsidy goes to the low-tax region [as that region may still not be able to raise on its own all the tax revenue it needs to pay for public goods].

Admittedly, the model developed here is very simple and cannot capture the richness and complexity of real tax systems. But if in this simple framework there are so many different effects and variations, there must be considerably more in the real world. We should not, therefore, presume that there is a straight forward relationship between regional transfers and regional taxes.

\subsection{Assessment of the Azores case}

Before assessing this landmark case it is necessary to identify the points which are of relevance for the purposes of this chapter. The main issue 


\section{Chapter 18}

addressed in the Commission Decision was whether taxation in the Azores was selective or not. The Commission accepted that only measures "whose scope extends to the entire territory of the State escape the specificity criterion laid down in Article 87(1)". Although the Azores measures applied to all operators liable for tax in the Azores, they did "favour firms taxed in the Azores, in comparison with all other Portuguese firms." [p. 57, paragraph 24].

The Commission specifically rejected the argument of the Portuguese government that the measures were general on the grounds that they applied with no distinction to all operators within the jurisdiction of the regional authority. According to the Commission, if a measure would be classified as state aid on the basis of the autonomy or regional level of the authority that adopts them, then Article 87 would lose its effectiveness. Member states would avoid compliance with Article 87 simply by "changing the internal allocation of fiscal competences" [paragraph 29]. Moreover, it was the national legislator who authorised the regional legislator to introduce tax reductions.

The Commission also expounded the general principle that selectivity is "based on a comparison between the advantageous treatment granted to certain firms and the treatment that applies to other firms in the same reference framework". It then went on to say that "the very existence of an advantage can only be established in relation to taxation defined as normal" and that "the framework in which such comparison should be made is the economy of the Member State.” [p. 58, paragraph 26]

Accordingly, the tax reductions could not be "justified by the nature or the general scheme of the Portuguese tax system, nor that, because of their economic rationality, they are necessary or functional in relation to the effectiveness of that system. In so far as these reductions do not derive from applying principles such as proportionality or progressive taxation, since on the contrary they favour firms in a specific region regardless of their financial situation, the objectives of regional development attributed to them cannot be considered to be inherent in the Portuguese tax system." [p. 60, paragraph 31]

On the basis of this reasoning, the Commission concluded that the measures in question involved "a reduction applicable solely in the Azores in the rate 
of tax established by national legislation and applicable on the mainland of Portugal. Under the circumstances, the measure adopted by the regional authorities clearly constitutes a derogation from the national tax system." [p. 59, paragraph 31].

Since the Commission acknowledged that it did not call into question the tax autonomy of the Portuguese regions, presumably if all the regions were free to determine their own rate of tax or if there were no national tax rate established by the central authorities, then there would be no question of state aid.

As explained earlier, this is a landmark Decision because it is the first time that the Commission finds a tax levied by an autonomous regional authority and which has no selective elements in itself to be in fact a selective measure. The selectivity in this case has been deduced from the apparent derogation of the tax from the national norm. In this regard, the Decision confirms that to be able to judge the selectivity of a measure, it is first necessary to define the norm from which the measure or scheme in question may constitute a derogation or an exception.

Therefore, the issue that arises now is whether the lower regional tax of the kind levied in the Azores can derive from the logic, nature or general scheme of the Portuguese tax system or, in other words, whether it can be inherent in that tax system.

The model developed in the previous section shows that when regions have tax autonomy it is possible that the regions with higher efficiency in producing local public goods may need less tax revenue and may, consequently, levy lower taxes. In this framework, variations in tax rates reflect differences in the costs of producing those public goods.

Moreover, transfers from the central government may be an integral part of the tax autonomy whenever such transfers are needed to compensate regions for their low efficiency in producing public goods [caused perhaps by diseconomies of scale]. Even though taxes levied by the autonomous regions may be lower than those in the rest of the country, they may still be at the revenue-maximising rates. Any higher taxes would generate even less revenue, so it would be illogical to raise them. 


\section{Chapter 18}

The Decision of the Commission does not refer to any transfers of resources from the central government in Portugal to the regional government of the Azores. Nor does it examine whether any such transfers more than compensate the region in order to enable it to maintain a lower tax rate than otherwise.

Therefore, it is possible in this case that the tax rate in the Azores reflected the natural efficiency of the region, even though it was lower than the national Portuguese rate. Conversely, that rate could be the revenuemaximising level of taxation. Both of these outcomes are inherent consequences of tax autonomy. And as the Commission acknowledged in its Decision, the tax autonomy itself was not at issue.

Naturally, these are only possibilities whose actual validity has to be confirmed empirically. Nevertheless, they suggest that no general case can be built against taxes levied by regional authorities on the mere grounds that they are lower than national rates or that there are transfers from the central to the regional governments.

By contrast, had the Commission found that the rate of taxation in the Azores was set at a lower than the revenue-maximising level or that the central government subsidised public goods and other public expenditure in the Azores for the purpose of enabling the regional government to maintain a lower than otherwise rate of tax, then there would hardly be any doubt that the allocation of tax competences to the region was intended to circumvent Community state aid rules.

Like the Commission, I do not base my argument on any axiomatic statement of whether tax autonomy is or is not compatible with Article 87(1). My argument rests solely on the possibility (but not the necessity) that tax autonomy may under certain conditions naturally result in lower regional taxes. This is an outcome that is inherent in the logic of devolving tax responsibility.

Before concluding this section, it is also worth examining whether the case law provides any support for the interpretation of the Commission. The only support I have been able to find is an opinion by Advocate-General Saggio in cases C-400-2/97 that concerned the tax measures in the Spanish autonomous regions outlined above. Unfortunately, those cases were 
dismissed without the Court having an opportunity to rule on them. Nonetheless, the case-law referred to by the Commission and the Advocate General concern either regionally-selective application of national measures [e.g. Germany v Commission, C-248/84] or selective application within a certain region of measures adopted by the authorities of that region [e.g. Commission v Italy, C-130/83; Germany v Commission, C-248/84; Wallonia v Commission, C-62/87]. I completely agree that in these situations there is state aid. But the Azores case is different.

Although, it is amply clear that all levels of government are subject to state aid rules [C-248/84], I have not been able to identify a statement from the CFI or the ECJ that non-selective measures adopted by regional authorities may be selective in comparison with similar national measures. In my view, the selectivity of a tax measure is determined by asking the question who is liable to that measure and who can objectively be excluded. Any arbitrary (non-objective or not resulting from the logic of the system) limitation would make it selective. But a measure adopted by a regional authority is not selective by the mere fact that it has a limited regional application for the simple reason that firms outside this region would not be liable to it or would be objectively excluded [e.g. they generate no income in that region].

A recent ruling of the ECJ seems to confirm my view. In Spain v Commission [C-351/98] that concerned aid to firms to replace their old vehicles, the Court ruled that "it is settled case-law that discrimination consists in particular in treating like cases differently, involving a disadvantage for some operators in relation to others, without that difference in treatment being justified by the existence of substantial objective differences ... A measure to support investment adopted by a public authority can by definition apply only in respect of the territory for which it is responsible and the authority cannot be criticised for not extending the benefit of the measure to undertakings not established in its territory, since such undertakings are in a wholly different position vis-à-vis the authority from undertakings established within the territory. That statement does not, however, mean that such a measure of support cannot be classified as "aid" within the meaning of Article 87(1) of the Treaty if it fulfils the conditions laid down by that provision." [paragraph 57]

It seems to me that this pronouncement of the Court is very much relevant to the subject matter of this chapter because it implies the following. A measure 


\section{Chapter 18}

is selective or discriminatory if, without objective justification, it does not apply uniformly to all firms it can potentially apply. Since a measure adopted by a regional authority has, by definition, limited regional scope, it can be selective only if it applies partially to firms within the region in question.

In the Azores case, the Commission used the national tax rate as the relevant benchmark. I think the relevant benchmark should have been the uniformity or not of the tax measure within the Azores region. In fact, the Commission did something extra. It indirectly attributed the measure to the central government on the grounds that the Azores regional authorities could adopt that measure only after authorisation by the central government and within the boundaries set by the central government. I think this is an irrelevant argument. Autonomy need not be absolute. It may be modulated by many different constraints. What matters here is that the regional authorities could deviate from the national rates. But they could not be compelled to do so. Therefore, they had discretion on whether to lower their rates or not.

The part of the ruling from case C-351/98 that I have quoted above ends with the sentence "that statement does not, however, mean that such a measure of support cannot be classified as "aid" within the meaning of Article 87(1) of the Treaty if it fulfils the conditions laid down by that provision." Could it mean that it invalidates the interpretation I have presented above? I don't think so. It seems to me that the Court is repeating the general principle that a measure is classified as state aid if and only if it satisfies the conditions laid down in Article 87(1), irrespective of whether or not it applies to undertakings outside the region of the authority granting the aid in question. By contrast, the mere fact that a measure does not apply to undertakings outside that region is not in itself sufficient to categorise a measure as discriminatory and therefore as selective in the meaning of Article 87(1). Indeed it is natural for measures that are adopted by subnational authorities to have a geographic scope of application which is narrower than the territory of the country and the scope of application of the measures adopted by the national government. This limited geographic scope cannot in itself be a form of selectivity for sub-national measures.

\section{And Gibraltar}

After the completion of this chapter in March 2004, the Commission announced that it had ended its investigation into the reform of the tax 
system in Gibraltar with a negative decision [see IP/04/4004 of 30 March 2004]. The decision on Gibraltar has many similarities with the decision on the Azores. In both cases the Commission found that the tax systems were derogations from the national systems, despite the tax autonomy of the two regions. In the context of this chapter I can only comment briefly on the Commission decision. ${ }^{214}$

The case concerned the planned reform of Gibraltar's company taxation laws. It is also worth noting that that was the first time a whole tax system was notified to the Commission for prior authorisation. The reform aimed at abolishing the $35 \%$ corporate tax rate and replacing it with a payroll tax and a business property occupation tax. Companies domiciled in Gibraltar would be subject to a yearly payroll tax of $£ 3,000$ per employee and to a business property occupation tax (BPOT). Total tax liability (payroll + BPOT) would be capped at $15 \%$ of profit. In addition to the payroll and property taxes, financial services companies would be charged a top-up tax fixed at a rate between $4 \%$ and $6 \%$ of profits from their financial service activities. The total taxation of financial services companies (payroll + BPOT + top-up) would also be capped at $15 \%$ of profit.

${ }^{214}$ For a brief and, necessarily preliminary, commentary on this case see also Raymond Luja, State Aid: The Gibraltar Corporation Tax Reform, mimeo, University of Maastricht, 2004 and forthcoming in EC Tax Review. Further reading on this chapter: M. Herm and P. Rossi, Commission requests phasing out of Spain's export related tax incentive, Competition policy newsletter: $n r .2$ 2006, R. Horacek, Commission's suspension injunction against illegal tax exempt fund in Greece, Competition policy newsletter: $n r .1$ 2006, A. T. Seinen and C. Guillemaut, Exemptions from the fuel excise tax for alumina production, Competition policy newsletter: $n r .1$ 2006, R. Horacek, Commission's proposal to phase out tax benefits for exempt companies in Gibraltar: Strict limits on existing as well as new beneficiaries, Competition policy newsletter: $n r .2$ 2005, R. Horacek, Commission's negative decision on Gibraltar corporation tax reform: findings on regional and material selectivity, Competition policy newsletter: $n r .2$ 2004, P. Rossi-Maccanico, Commentary of State Aid Review of multinational tax regimes, European State Aid law - Quarterly, Volume 6 No. 1 2007, P. Rossi-Maccanico, State aid review of business tax measures - proposals for State aid control of direct business tax measures, European State Aid law - Quarterly, Volume 6 No. 2 2007, J. Mehta, Tax harmonisation and state aid - a warning for the future?, European State Aid law Quarterly, Volume 6 No. 22007. 


\section{Chapter 18}

The Commission decided that the planned reform of corporate taxation in Gibraltar would give companies domiciled in Gibraltar an unfair tax advantage because of the following two reasons. First, the new tax system would limit tax liability to $15 \%$ while the normal rate of corporate tax in the United Kingdom is $30 \%$ of profit. Second, the planned reform was designed in such a way that despite the fact that advantages appeared in law to be applicable equally to all companies in Gibraltar only a defined number of companies would benefit de facto form the favourable tax rates. This was true for offshore companies that did not have a physical presence in Gibraltar. These companies would neither be subject to payroll tax because they had no employees, nor to BPOT, because they had no premises.

Since the measure only aimed at reducing the tax liabilities of companies located in Gibraltar and the offshore sector in particular, and did not aim at promoting any Community objective (regional development, employment, etc.), the Commission considered that the notified system could not be deemed compatible with the common market. The Commission also stressed that its finding did not put in question the autonomy of Gibraltar in fiscal matters. It only confirmed the line taken by the Commission in its decision concerning reductions in the rates of income and corporation tax limited to the autonomous region of the Azores.

There are three issues here worthy of comment. First, the indirect favourable treatment of offshore companies is probably a form of state aid. Second, the capping of overall tax liability and the fixing of the payroll tax per employee also provide indirect favourable treatment of companies when they make large profits or when they are capital intensive. Third, the lower rate of tax in Gibraltar as compared to that of the UK raises the same question as with the Azores case in relation to the regional scope of the tax. From the press release it is impossible to infer whether the UK government determines tax rates in Gibraltar or whether Gibraltar authorities have any tax autonomy. In both cases we will have to wait for the Court to determine whether measures adopted by sub-national authorities can be a form of state aid when they have general application within the area of jurisdiction of those authorities but differ from the benchmark national rate. 


\subsection{Conclusions: New trends in fiscal state aid}

It is now very clear that the Community state aid rules apply to many different aspects of direct taxation. Recent practice indicates that the Commission will not hesitate to attack any measure that falls within the scope of Article 87(1).

Whenever a tax measure is selective or discriminates directly or indirectly in favour of a certain class of companies or activities, there is little doubt that it involves state aid. However, the issue of selectivity is likely to remain contentious. Differentiated treatment of certain classes of companies or activities may be justified by the logic or general scheme of the tax system. One of the purposes of this chapter has been to derive simple tests for determining the existence or not of selectivity and whether it may be justified or not.

Another purpose of this chapter has been to explain why in at least one recent case the Commission has stretched the meaning of selectivity too far. Since the ultimate arbiters on the correct interpretation of state aid rules are the Community Courts, we will have to wait to see where they will draw the boundaries of regional tax autonomy.

One thing is certain, however. Member states will have to be very careful in how they devolve tax autonomy to lower levels of government. As long as there exist corresponding national tax measures, geographically-restricted derogations may be construed by the Commission to be a form of state aid that is contrary to the EC Treaty. 


\section{Chapter 19}

Fiscal Aid in the EC: A Critical Review of Current Practice

\subsection{Introduction}

National tax (or fiscal) measures are currently under the scrutiny of the European Commission which seeks to identify any hidden elements of state aid. In parallel to the Commission investigations, there is the process of the Code of Conduct for Unfair Business Practices, which was initiated several years ago but not yet concluded with any tangible results. Both of these developments reflect concerns in the European Union that national tax systems contain covert subsidies to firms.

Direct taxation, as opposed to indirect taxation, is one of the few areas of economic and social policy that have been left virtually untouched by the process of integration within the EU. This does not mean, however, that the member states of the EU have discretion to construct whatever system of corporate and personal taxation they wish. They are still bound by the general principles of the Treaty that require no discrimination against the nationals and capital of other member states, no impediments of fiscal nature to the provision of goods and services and no favourable treatment of national companies through the provision of state aid.

The purpose of this chapter is threefold. First, it reviews Community policy on operating aid. Fiscal aid is a form of operating aid. While for many other forms of aid the Commission has issued over the years guidelines, frameworks and notices that explain the rules, highlight practice and clarify ambiguous points, there is no such explicit policy statement on operating aid. Current policy has emerged from jurisprudence and for this reason it is not very transparent. One cannot understand many of the competition problems caused by fiscal aid unless one understands the nature and the issues raised by operating aid. So the first objective of this chapter is to identify the main 
policy features with respect to operating aid and explain why it is normally not permitted.

The second objective is to carry out a similar review of fiscal aid. The chapter confines itself to direct taxation [i.e. taxation of companies and persons; not consumption taxes]. Annex I summarises many prominent cases of fiscal aid. In general, tax provisions that discriminate in favour or treat in a different manner certain companies may be regarded as a form of state aid. The problem, however, is that tax systems are not uniform. Immediately there is a problem of what type of differentiation is acceptable and what type is state aid and therefore incompatible with the common market. The chapter evaluates the various tests of "objective differentiation" that have been proposed in the literature.

The third and most important objective of the chapter is to propose an economically meaningful method of distinguishing between tax provisions that are a hidden form of state aid and those that are not. Because tax measures may favour certain companies or activities even when they are not overtly discriminatory, the proposed method involves a multi-stage test.

The plan of the chapter is as follows. The next section defines the concept of operating aid, the reasons why it is not normally allowed in the EU and identifies the very few situations in which it may be allowed. In view of the fact that operating aid is in general banned, state aid of fiscal nature causes particular problems. This is because fiscal aid is invariably found to be operating aid.

The chapter then proceeds to consider the various definitions of state aid. Given that tax systems are never uniform, the question arises as to when differential tax treatment is a form of state aid. The chapter reviews the various tests that have been developed to distinguish between differentiation which is state aid and differentiation which is not.

Having done that, it will be argued that all of the tests have weaknesses. An alternative, two-stage, will then be presented. This test is robust in the sense that it complies with EC state aid rules, it incorporates a procedure for officials to use when they apply the test, and it is likely to preserve an efficient allocation of resources. 


\section{Chapter 19}

Finally, to help the reader obtain a better understanding of the practice of the Commission with respect to fiscal aid, Annex I of the chapter summarises the main issues of prominent cases of fiscal aid.

\subsection{Operating aid - definition}

Article 87(1) of the EC Treaty declares any form of state aid to be incompatible with the common market. The second and third paragraph of that Article define a number of exceptions. In particular, Article 87(2) identifies three types of aid that are always compatible with the common market and hence permitted. Article 87(3) identifies another five types of aid that may be compatible with the common market, provided certain conditions hold and the Commission grants authorisation.

More precisely, Article 87(1) provides that "save as otherwise provided in this Treaty, any aid granted by a Member State or through State resources in any form whatsoever which distorts or threatens to distort competition by favouring certain undertakings or the production of certain goods shall, in so far as it affects trade between Member States, be incompatible with the common market."

It follows that not all measures of public support are measures that constitute state aid in the meaning of Article 87(1). To constitute state aid, a measure or scheme of similar kinds of aid or one-off grant must satisfy cumulatively all of the following conditions: ${ }^{215}$

- the measure provides "aid" or a benefit that reduces the expenses normally borne in the accounts of the recipient companies;

- it is granted by the "state" or through "state resources" (i.e. companies or undertakings owned or controlled by the state or other agencies of the state);

\footnotetext{
${ }^{215}$ For a review of the principles of EC state aid policy see S. Bilal and P. Nicolaides (eds.), Understanding State Aid Policy in the European Community, (Maastricht: EIPA, 1999). See also the various documents on the website of the DirectorateGeneral for Competition of the European Commission ("europa.eu.int/comm/competition/state_aid/legislation/") and the background information on state aid at EIPA's website ("www.eipa.nl").
} 
- the recipient is an "undertaking" (i.e. a legal or natural entity that engages in economic transactions);

- it confers a "favour" or an advantage (i.e. it is not given to offset liabilities of the state);

- it is granted to "certain" undertakings or activities (i.e. it is selective in nature);

- the aid potentially affects intra-EU "trade" and distorts "competition".

The Commission as a rule refuses to authorise aid for promotion of exports and for reduction of operating expenses because these two kinds of aid are considered to be extremely distorting to intra-EU trade without having any redeeming economic effects [e.g. contribution to regional development]. However, rarely and under certain conditions operating aid may be approved.

Operating aid is defined as aid that has directly alleviates production costs and subsidises selling prices without being associated with investment or job creation and without requiring the recipient to provide anything in return such as increased $R \& D$ activities or new jobs.

The European Court of Justice has also defined it as aid which is granted without any specific condition and solely by reference to quantities of the aided product or service. Operating aid seeks to relieve expenses normally borne in the daily operation (e.g. the marketing or distribution of products) of recipient firms and without requiring any change in company action or development of other activities [Siemens v Commission, C-278/95].

In practice, the Commission regards any aid which is granted with no obligations on the part of the beneficiary as operating aid, irrespective of the use to which the beneficiary finally puts the aid. In addition, aid which is granted with specific obligations attached may also be considered to be operating aid if the costs it offsets are those that would normally be borne by the recipient in order to remain a viable concern.

A question which often arises is what kind of expenses would a firm expect to incur in order to remain in the market? The answer, of course, depends on the prevailing market conditions and the specific features of the economic sector in question. For instance, advertising on national television or buying the latest word-processing software would be real investments for a small 


\section{Chapter 19}

neighbourhood grocery shop, while it would be normal expenses for a perfume maker or a publishing house, respectively.

Examples of aid that has been found to be operating aid are the following:

- aid for routine equipment replacement and aid for R\&D that would have been undertaken anyway;

- aid for investment in normal equipment modernisation (that has to be done anyway) may also be considered as operational aid [see Commission Decision $86 / 509$ on aid granted to a polyester yarn producer in Bavaria];

- aid granted in the form of regional assistance that finances all investment including routine replacement of capital goods and for unlimited period.

Operating aid is, as a rule, banned because it allows firms to continue uncompetitive activities without restructuring and without achieving a durable level of development. Operating aid, therefore, is unlikely to render the recipients commercially viable without aid and does not by its very nature contribute to the objectives of Article 87(3)(a to d) [see Commission Decision $79 / 496$ on aid to UK offshore supply industry and Commission Decision $72 / 253$ on aid to Dutch fodder plant producers]. However, operating aid for rescue and restructuring may include aid for equipment modernisation [Commission Decision 99/197 on aid to Air France]. This is considered to be an exceptional form of aid.

In other words, operating aid is not normally authorised because when aid is withdrawn or discontinued the recipient is likely to return to its uncompetitive situation, leaving no lasting benefit to the rest of the economy. In the meantime, aid has distorted the competitive process and reduced incentives for investment by competitors in the product or geographic market in which the beneficiary operates.

Another reason for not normally authorising operating aid is that it is difficult to quantify its amount if it is fiscal in nature and even more difficult to assess its proportionality to the subsidised costs before the aid is granted. That kind of assessment requires information on the final output of the recipients. In the case of fiscal aid the assessment will depend on the ex post revenue of the beneficiary firms. 
As mentioned earlier, export aid is completely banned even in circumstances where operating aid may be allowed. For a recent restatement of the Commission's position on this issue see its Notice on aid to SMEs by Greece for establishment of networks abroad [OJ C54, 25/2/99] and in particular the new Regulations 69/2001 on de minimis aid and 70/2001 on aid to SMEs [OJ L10, 13/1/2001].

\subsection{Exceptions to the general ban on operating aid}

Even though operating is not normally authorised, exceptionally and under strict conditions it may be allowed. Operating aid has been allowed in the following situations:

- offsetting of operating costs, exceptionally and temporarily, in "87(3)(a) regions" suffering from severe regional handicaps [see Guidelines on National Regional Aid, OJ C74, 10/3/98];

- offsetting of additional transport costs incurred due to locational factors in outermost regions or regions with low population density (i.e. ex objective 6 regions);

- compensation for the extra costs imposed by taxes for environmental protection in waste management and for offsetting costs of developing renewable resources [see Guidelines on Environmental Aid, OJ C72, 10/3/94 and the revised Guidelines, OJ C37, 3/2/01];

- certain sectors which are widely exposed to international competition that is extensively shaped by subsidies; these sectors are shipbuilding [see Council Regulation 1540/98] and maritime transport [see Guidelines on State Aid to Maritime Transport, OJ C205, 5/7/97].

Operating aid (e.g. tax concessions) for regional development purposes must be granted solely to companies in the specified region, the amount of aid must be decreasing over time, it must be subject to time limits and must not be open to sensitive industries which are subject to their own aid rules [see Commission Decision 98/476 banning tax concessions on investment in companies in Berlin and Eastern Länder; see also the Court ruling in case Germany v Commission, C-156/98, that upheld the Commission Decision].

As already mentioned, the prevailing general policy is that operating aid must be limited in time. In the last couple of years the Commission has taken 


\section{Chapter 19}

several decisions to enforce the temporary nature of operating aid [see, for example, the cases included in Annex I concerning the Irish International Financial Services Centre (Dublin) and the objections transmitted to Portugal on the offshore tax regime of Madeira].

In the field of transportation, the Commission has also taken action to impose strict time limits. For example, the Commission in July 1998 permitted the continuation of an existing aid scheme for the benefit of Volvo (Sweden) on the condition that it would last only for a total time length of seven years (1996-2002) and that aid intensity, in terms of overall transport costs, would decline from 35\% in 1996 to 5\% in 2002.

However, following the coming into force of the Treaty of Amsterdam $(1 / 5 / 99)$ with the new emphasis on the need for support for the outermost regions [Article 299(2)], the Commission adopted in the Spring of 2000 a new Notice which signals an apparent shift in policy.

There is now an exception to the conditions of time limitation and degressivity that apply to the exception for operating aid. The exception to the exception applies to transport in remote regions, the maritime sector and the Article 299(2) outermost regions of French overseas departments, the Azores, Madeira and Canary Isles [OJ C285, 9/9/2000].

In conclusion, operating aid is not normally allowed in the European Union. State aid of fiscal nature causes particular problems because such aid would invariably be found to be operating aid and, hence, rarely compatible with the common market. Can tax systems that raise the costs of companies and persons also grant aid? The answer is yes. Tax systems do not only take away income from companies and persons, they also grant credits or exemptions. When are such credits, exemptions, reduced rates of taxation and any other form of differential tax treatment a form of state aid? We begin by examining the conditions under which fiscal measures can be state aid.

\subsection{When is taxation a form of aid?}

Although direct taxation remains virtually within the exclusive competence of member states, as far as the tax base and rates are concerned, in exercising 
their taxing powers they still have to comply with the provisions of the Treaty. A member state's tax system normally has general application and for this reason it falls outside the scope of Article 87(1). It does not satisfy the criterion of selectivity.

However, tax exemptions, granted on a sectoral or regional basis, are not considered to be general measures and they are invariably found to constitute state aid [see Commission v Germany, C-70/72]. A general reduction in the rate of taxation may also constitute aid if the reduction is confined to products defined by regional, sectoral or other criteria.

A distinction must be drawn between the sectoral elements of taxation and the sectoral incidence of general taxation. Favourable treatment granted to a given sector within the scope of general taxation will normally be regarded as state aid. For example, a provision granting accelerated capital allowances to the textiles industry is aid under Article 87(1). By contrast, capital allowances for unrestricted forms of investment in non-congested rural areas for the purpose of spatial planning may in practice favour agricultural firms, for example, but would not be regarded as state aid, provided the scheme is open to all firms and there is no intention to disguise sectoral aid as general incentives.

The case brought by the Commission against Germany [C-70/72] in respect of the latter's assistance to coalmining, established from the very early stages of the Community that tax measures which have territorial or sectoral application constitute aid. In the late 1960s, Germany obtained approval from the Commission to reduce taxes on new investments undertaken by coalmining companies. Later on, however, Germany modified the aid scheme so that the same tax benefits for new investments were nonselectively available to all companies investing in the regions affected by the coalmining crisis. The reasoning of the German authorities was that such tax incentives would assist in the regeneration of industry in those regions and would compensate for the decline of coalmining. This reasoning was rejected by the Court. The non-sectorally selective but regionally concentrated incentives were still found to constitute state aid.

The fixing of different rates of corporate tax (linked to levels of income) and subsequent amendments across the board are measures of general fiscal policy, which fall within the sovereignty of the member states and which do 


\section{Chapter 19}

not constitute state aid. Arguably this is so even when rates are lowered with the intention to benefit those subject to the tax. As long as the rates are lowered across the board, they would be classified as an adjustment of general fiscal policy.

However, general measures in whose application the relevant authorities have discretion may be found to have an element of specificity and, therefore, to fall within the scope of Article 87(1) [see, for example, France v Commission, C-241/94, concerning state contributions to legally mandatory social plans of companies intended to provide alternative employment opportunities to workers who would otherwise be laid off. Public authorities had discretion in approving the details of those plans and, therefore, the amount of contribution to be made by the state].

The easiest and simplest criterion for establishing whether a tax measure is a form of state aid is to ask whether the government or the taxing authority (e.g. local authority) loses or forgoes revenue. Examples of tax measures that have been found to be state aid and all involve some loss of tax revenue are the following:

- reduced rate of corporate tax [Commission Communication 1/94 concerning tax relief granted to mushroom growers in Ireland];

- exemption from taxation [Commission Decision 70/304 concerning a ten-year exemption from tax on profits from approved investments in the context of a reorganisation of textiles industry in Italy];

- reduced tax on profits [Commission Decision 95/452 on a financial services centre in Triest, Italy];

- reduced tax base for newly established companies [Commission Decision 2000/795 on a scheme by the Basque Country to encourage the establishment of new companies; the scheme was restricted to large companies];

- relief from social charges [Commission Decision 91/500 on enterprises in the Venezia region];

- suspension of interest on debts [Ecotrade v AFS; C-200/97].

However, loss of tax revenue by public authorities does not necessarily imply that a certain measure is a form of state aid. First, as already mentioned, it may be a general measure and, therefore, fall outside the scope of Article 87(1). Second, it may be the tax consequence of a regulatory 
measure. Regulatory measures also fall outside the scope of Article 87(1). The case law refers to them as the consequence of inherent features of statutory obligations within the tax system [see, for example, Ecotrade $\mathrm{v}$ AFS, C-200/97; Sloman Neptune, C-72/91; Belgium v Commission (Maribel), C-75/97; PreussenElektra v Schleswag, C-379/98].

As will be argued later on, while is easy to understand and identify loss of revenue, it is not so easy either to understand or identify the meaning of "inherent features of statutory obligations". It is therefore imperative to be able to distinguish between specific (selective) and general tax measures and to determine whether any detected specificity can be justified or not. The following section examines in more detail the concept of justifiable or objective differentiation.

\subsection{Objectively justified differentiation}

Most industries are subject to corporation tax on their profits in accordance with general rules. Occasionally, however, special rules apply to individual sectors such as banks and insurance companies, reflecting the peculiarities that objectively differentiate their operations from those in other sectors. For example, whereas in most industries taxable revenue is net of operating costs and other expenses, in the banking sector it may be net of provisions on bad or doubtful loans, even before legal bankruptcy proceedings declare a borrower to be insolvent.

However, not all claimed special rules can be justified. For example, in the UK oil production was in the past subject to separate tax legislation (petroleum revenue tax) that took into account the various costs and risks involved in oil exploration. Despite the fact that this tax applied only to a particular sector, it was regarded to form part of the general system of corporate taxation in the sense that different rules applied to objectively different activities. Nevertheless, it is not obvious how those risks were substantially different or significantly larger than say the risks borne by companies with heavy research commitments such as pharmaceutical or semiconductor manufacturers or risks borne by companies in rapidly evolving markets (e.g. telecommunications) or highly fluctuating markets (e.g. music production). 


\section{Chapter 19}

The factor that may justify differential tax treatment need not always be found in the operations or the business environment of the undertakings concerned but in their own nature or objectives. For example, a non-profit organisation that is established under a different set of rules than "normal" companies and is supposed not to make any profits may reasonably be exempted from the obligation to pay tax on profits [Ladbroke $\mathrm{v}$ Commission, T-67/94].

On the other hand, it is important to stress that unless the tax system is completely uniform, variations in the treatment of companies may be found to infringe the Treaty even if there is no sectoral or territorial differentiation or distinction. National tax provisions can be contrary to the obligations of free movement and free establishment (Articles $39 \& 43$ [ex 48 \& 52]), unless they can be justified on "objective grounds".

In the landmark "avoir fiscal" case, French tax regulations which applied across the board were, nonetheless, ruled by the Court to be incompatible with ex Article 52 because they discriminated against non-resident companies [Commission v France, C-270/83]. There was no objective reason for that differentiation and nationality has never been accepted as an objective justification.

So, the Commission may find that Article 87 applies by virtue of infringement of another Treaty provision. This works in the following way. If one of the fundamental freedoms is restricted, say the right of establishment, then some EU companies are being treated less favourably than others. It follows from this that some companies are treated more favourably than others and this conclusion may be sufficient for the selectivity criterion of Article 87(1) to apply.

In the case of the tax concessions in the Basque Country the Commission in effect argued that certain companies were favoured because certain other companies were disadvantaged as a result of not being eligible to benefit from the available tax concessions whenever they chose to carry out business in the Basque Country through the medium of branches or agencies. Only subsidiaries were eligible for those concessions and that restriction constituted an obstruction of their freedom to establish business presence because it prevented companies from choosing the form of representation which was economically most beneficial to them. Annex I provides more 
information on the Basque Country case as well as other prominent cases concerning fiscal aid.

A more recent case has also confirmed that a tax measure may be found to be a form of state aid by virtue of the fact that it infringes some other provision of the Treaty and, therefore, not only discriminates against some undertakings (this is sufficient to classify the measure in question as selective), but more importantly it deprives that measure from the possibility of obtaining any exception under Article 87(3). This is because the exceptions in Article 87(3) cannot benefit a measure that violates other provisions of the Treaty [see the case of Germany v Commission, C-156/98, where the Court found that tax incentives for companies established in Berlin and the new Länder was contrary to Article 43 [ex 52] even though they applied in a non-discriminatory manner to all companies irrespective of nationality; the reason was that they in fact favoured companies established there while companies operating through branches or representative offices were not eligible].

In the case concerning tax credits to Italian road hauliers [see Commission Decision 93/496 of 9/6/93], the Italian government contented that those credits were part of the general tax system. In other words it maintained that the aid scheme in question was not really aid but a fiscal measure designed to alleviate the high tax burden on diesel vehicles. The Commission's response to that argument deserves to be quoted at length:

"As regards the taxation and national sovereignty in this domain, it should be pointed out that the rules governing state aid and those governing taxation have different objectives. This means that a national measures may comply with taxation rules but conflict with other provisions such as Articles 87 and 88 of the Treaty. Furthermore, Article 87 does not distinguish between the measure of state intervention concerned by reference to their causes or aims but defines them in relation to their effects. The effect of the scheme is a direct net cash flow increase in favour of the undertakings of a particular economic sector only ... The cash flow which results from the measure thus clearly leads to a distortion of competition in favour of those benefiting from the measure. Consequently the alleged fiscal nature or social aim of the measure cannot suffice of itself to shield it from application of Article 87. For this reason tax exemptions granted on a sectoral or regional basis have consistently been treated as constituting state aid."

According to the Fifteenth Annual Report Monitoring the Application of Community Law (1997) [COM(1998) 317 final, OJ C250, 10/8/98], "there is no significant harmonisation in direct taxation ... Consequently, the principle, 


\section{Chapter 19}

of non-discrimination, the most frequently used yardstick, applies to cases of tax treatment by one and the same tax system. The difference in taxation, for natural persons and for businesses, between non-residents and residents in all Member States, [is] in principle accepted by the Court where it reflects the difference in the situations of these two categories of taxpayers ...".

It is worth noting observed, however, that a certain type of treatment of nonresidents has subsequently been considered by the Commission in its Notice on Fiscal Aid to be a form of state aid (see Annex II for a brief summary of the main points in the Notice). Policy is evolving in this respect and for this reason the rest of the chapter will examine established principles, rather than speculate about the future evolution of policy.

On the basis of the analysis so far, we can conclude that overt or covert discrimination is sufficient to turn a fiscal measure into a state aid measure. It is well understood that the principle of equal treatment in the EU prohibits not only overt discrimination by reason of nationality or the place of the registered office, but all covert forms of discrimination, which by application of other criteria of differentiation lead to the same result. Furthermore, discrimination can arise not only through the application of different rules to comparable situations but also through the application of the same rules to different situations. For example, and notwithstanding the Commission Notice on Fiscal Aid mentioned above, taxation of residents and nonresidents is different because their situation is not comparable [see Germany v Commission, C-156/98].

\subsection{Equalisation of tax burden?}

In view of the conclusion above, the question arises as to what kind of equality has to be respected by the fiscal measures of the member states. There is a kind of equality that is of particular relevance to fiscal measures; that of equalisation of tax burden. Can a government, for example, treat the same persons or companies differently so as to equalise their overall tax burden?

In the application of Article 87 (and of other Treaty provisions) neither the Treaty, nor the Court nor the Commission, have required equality of 
"effective tax burden". Effective tax burden is the proportion of gross income which a company or individual pays out after all taxes and allowances are taken into account. The tax burden may be higher or lower than the marginal (highest) tax rate.

In the "avoir fiscal" case, the French government argued in its defence that the discrimination against non-resident companies (which did not benefit from certain tax credits on shares in other companies) was more than compensated by other tax regulations which conferred on them advantages not available to companies fully resident in France. In other words, the French government contended that the net tax burden on non-resident companies was lower. This argument was rejected by the Court because what mattered was not the ex post effect but the ex ante treatment accorded to different classes of companies [France v Commission, C-270/83].

It is not difficult to understand why the Court did not endorse the line of reasoning of the French government. The actual magnitude of the tax burden depends on the particular circumstances of a company. It is very difficult to estimate the tax burden of an ex ante measure that applies across the board. This means that a policy aiming to equalise tax burdens can only operate ex post and retroactively. This is contrary to basic principles of policy transparency and legal certainty. Moreover, if governments want to compensate for a disadvantage they have caused, they should eliminate that disadvantage directly (most of which are prohibited by the Treaty, anyway) rather than try to redress the problem indirectly through some form of aid.

What happens, however, when the disadvantage imposed by the government is not in the form of fiscal measures but in the form of obligations of service and/or price? Can preferential tax treatment be justified in this case? The next section looks briefly at this issue.

\subsection{Tax concessions as compensation}

Indeed on those rare occasions that the Commission allows aid as a form of compensation for certain disadvantages imposed on companies, it insists that the monetary value of such disadvantages is measured and that aid never exceeds what is strictly necessary to offset them. More significantly, it appears not to have ever authorised aid for the purpose of compensating a 


\section{Chapter 19}

tax disadvantage imposed by the government. But certain other disadvantages may be offset through state aid.

In a recent case involving tax concessions granted to the French Post Office in order to compensate it for the extra costs of the legally required universal letter delivery service, the Court of First Instance ruled in February 1997 that even though the tax concession was state aid it was, nevertheless, justified because its purpose was to offset the extra costs incurred by the Post Office in performing the tasks assigned to it by the state [Federation Francaise des Societes d'Assurances v Commission, T-106/95].

More broadly, Article 86(2) may under certain conditions exempt fiscal (and other forms) of state aid granted to providers of services of general economic interest. These conditions are:

- the recipient must be mandated by law to provide services of general economic interest;

- absence of aid must make it impossible for the recipient to carry out its public service asks;

- the amount of aid must be strictly proportional to the extra costs of providing those services;

- the distortion to competition must not be contrary to the common interest.

Even though aid may be granted within the context of Article 86(2), member state governments are still under obligation to notify it to the Commission and obtain its prior authorisation, as required by both Article 88(3) and the new procedural Regulation 659/99. Moreover, it is an established policy principle that only the Commission can carry out the assessment of whether granted aid is compatible with the common interest, as required by Article 86(2).

To conclude on the subject of this section, it appears that there has never been any authorisation of fiscal aid intended to compensate for other taxes. But fiscal aid may be used to compensate undertakings that cannot cover the costs of providing legally required services of general economic interest.

Now that we have clarified what taxation may or may not do, we return to the issue of how to distinguish a specific fiscal measure from a general fiscal 
measure. The former is state aid while the latter is not. Previous sections explained that a fiscal measure can have limited applicability as long as there is an objective justification. But what is objective justification? This is the task of the next section.

\subsection{Tests to distinguish between general and specific tax measures}

As already mentioned above, tax systems are never uniform. Some tax measures have limited scope or applicability. Does that make them selective and, as a consequence, state aid in the meaning of Article 87(1)? The answer is "not necessarily" because they can be objectively justified. If they can be objectively justified, they are not discriminatory. But the problem is that it is not easy to ascertain "objective justification".

To identify discrimination, it is first necessary to identify the relevant common features and on the basis of that commonality conclude that treatment is unequal. This raises two issues. First, it is not obvious what features are common and what features are different among the various companies, factors of production, regions and sectors of the economy. Since there may be many common and distinct features, it is necessary to identify those that are relevant. But what may seem relevant to one observer, may seem irrelevant to another. Second, any policy system, and tax system in particular contain arbitrary definitions. That is, economic activities are classified together or separately without any prior definition of their similarities or differences. Hence, we need to find a method to identify selective measures that allows us to cope with the ambiguities and arbitrariness of tax systems.

In this respect, the Court has ruled on several occasions that the only acceptable type of selectivity is that which emanates from the "scheme or general system" of taxation [Belgium v Commission, C-75/97].

But how does one know the scheme or general system of taxation? Tax laws and systems do not normally contain such statements. Even worse, tax laws include many objectives some of which are arbitrary but of no lesser economic or social value. For example, the arts are usually assisted through public subsidies, but it is not so easy to justify why, in the commercial age we live, arts should receive public assistance while pioneering work on 


\section{Chapter 19}

financial instruments with no immediate applications should not. If the logic of taxation is to correct market imperfections, as well as to re-distribute income and raise revenue for the functions of government, the public funding for artistic innovation and at the same time the exclusion of financial innovation are not as self-evident as many may presume. While a piece of art can be signed, financial innovation cannot be secured by its inventors. Moreover, public subsidies often benefit both established artists (with long client lists) and unknown artists (needy/deserving?).

Several tests have been proposed for the purpose of distinguishing between general and specific tax measures. These tests have been put forth by advocates-general in their opinions on landmark state aid cases. Although all three tests that are identified below advance our understanding, they also suffer from a number of conceptual weaknesses. Because of these weaknesses, an alternative test is suggested later on.

The first test was fully spelled out in the Sloman Neptun case [C-72/91], even though it partly appeared in previous cases as well. The advocategeneral, after considering the case law and various legal opinions until that point in time, argued that a measure is not general (hence, it is specific) when it constitutes a derogation from the scheme of the general system. This is the definition that has been used by the Court to identify specific tax measures.

Once more we encounter the problem that it is presumed that the scheme of the general system is somehow known. Another complication is that preferential measures that are specific are not always expressed as derogations. As often explained by the Court, what matters is not the intention or the way a measure is defined but its effect. The fact that it is not always possible to identify a certain measure as a derogation does not mean that it is not a form of state aid. But the problem is that if a measure is not formulated as derogation, how can we see through its disguise? Selective but objectively justified measures are also formulated in the same terms and would have the same restricted effects.

The second test was proposed in the case of Italy v Commission concerning tax credits to road hauliers [C-6/97]. The advocate general contended that a measure is general when it follows from or is compatible with the internal logic of the tax system. This test suffers from the same weakness as the one 
in the previous paragraph. Most tax systems have ad-hoc (arbitrary) elements which are not all compatible with each other or with the overall logic of the tax system itself. Nonetheless, their ad-hoc nature or arbitrariness does not make them state aid in the meaning of Article 87(1) for the simple reason that they can be arbitrary without being specific. For example, the granting of tax credits for the installation of anti-burglary devices may have nothing to do with the internal logic of the system and in terms of that system they may be regarded as arbitrary. But the general availability of such credits stops them from being specific. As will be proposed in the next section, the task at hand is to be able to determine whether a measure is selective or not without having to establish the logic of the tax system.

The third test appeared in the case of Belgium $\mathrm{v}$ Commission concerning the "maribel" scheme of tax incentives for the employment of manual labour [C75/97]. The advocate general said that a measure is general when it aims to achieve equality between businesses and it should apply to all undertakings to which it is capable of being applied. The first part of this test immediately raises the question about the nature of "equality" between businesses. Would it be equality of treatment, equality of opportunity or equality of results? The measures that would achieve these three kinds of equality could be very different indeed. For example, equality of treatment would imply the application of the same measures to all, equality of opportunity would adjust treatment to take into account the capability or circumstances of the beneficiaries while equality of results would definitely require unequal treatment, depending on the conditions and achievements of each business. Therefore, the first part of the test is ambiguous.

The second part, however, is more promising. It says in essence that a measure is specific if it excludes undertakings that are potentially eligible for the same treatment. Although it is not clear how eligibility in this context is to be established, one may imagine a series of questions which seek to identify the precise objective or policy target of the measures in question and then examine whether other undertakings which are formally excluded could in fact be eligible for support because they possess those characteristics or features which are aided by those measures. This is the logic behind the alternative test which is explained immediately below.

Another conclusion that can be drawn so far is that the fundamental weakness of the tests that have appeared in the case law is that they assume 


\section{Chapter 19}

that a benchmark can be established by examining the tax system and that policy measures can be classified as being a derogation or not from that benchmark.

\subsection{An alternative two-stage test}

In searching for methods to identify fiscal aid, it is first necessary to delineate the boundaries of that search. Since what constitutes state aid depends on its effects rather than the intentions of the granting authority, the boundaries must be defined in terms of effects. After even a cursory examination of measures that have been found by the Commission and the Court to constitute general measures [e.g. Sloman Neptune, C-72/91], soon one realises that there is no public measure (of financial nature) that affects all companies in all sectors in the same way, defined either in absolute amounts or relative to eligible costs. ${ }^{216}$

This realisation does not mean that we have to conclude that all measures of economic policy are forms of state aid. The measures that are state aid are those that, among other things, support certain undertakings. The purpose of state aid control in the EU is precisely to prevent national authorities from discriminating, intentionally or unintentionally, in favour of specific groups of companies which can be identified by the sector in which they operate, the region in which they are located, or the nature of the activities in which they engage. Its purpose, contrary to what was argued in the other tests examined earlier or what is normally thought, is not to force member states to treat all companies equally. As shown above, that is impossible because the value of any benefit granted by the state very much depends on the circumstances of the recipient. So, equal treatment is a meaningless concept in this context. Equality of value of the benefits granted by the state could require the granting of unequal amounts of aid, which would entail right from the outset unequal treatment. State aid rules have never been meant to

\footnotetext{
${ }^{216}$ Yet, it is worth noting that the Commission tends to raise no objections to those fiscal measures it finds to be of general nature whenever they do not intend to discriminate against any company or sector. This observation does not mean that the Commission follows a wrong approach. It just shows how difficult it is to run a system of state aid control by examining the effects rather than the objectives of the various national policies.
} 
impose on member states such complicated obligations (whose correct implementation is also exceedingly difficult to ascertain).

As also argued above, it is very difficult, perhaps, impossible, to define the general logic of any tax system. Tax systems include arbitrary objectives which do not all exist in unison, nor do they all emanate from the same basic principles. So, looking at the intentions of policy makers and the internal logic of the system may also be futile.

Consider the example of taxation of alcoholic beverages. Usually, higher taxes are levied on beverages with higher content of alcohol. Indeed, the most common method by which the Commission discovers whether member states discriminate against competing imported drinks is to correlate tax rates with alcohol content. But in the context of the present chapter, why should we accept that there is unassailable logic (reasonableness?) in the levying of lower taxes on beer and higher taxes on spirits? How is that justified by the internal logic of tax systems? Why should there be a (rough) correspondence between alcohol content and tax? If the aim of the tax is to discourage consumption, then one could very well argue that higher taxes should be imposed on the cheaper products (e.g. beer) simply because more people can afford them. These products may be those that have lower alcohol content.

Our starting position then must be that the aim of state aid control is to prevent member states from favouring certain undertakings or activities in a systematic manner. "Certain" here must mean that any benefits go or are confined to one or more undertakings or activities which can be identified beforehand with a reasonable degree of precision; i.e. in a systematic manner. If it is possible for other undertakings or activities, in different sectors or of different nature, to benefit as well, then the benefits are not confined to just certain undertakings or activities and we must conclude that they are of general nature.

It follows that economic policy measures are general as long as any undertaking in any sector can, at least in theory, claim eligibility (provided, of course, that it can satisfy the other, possibly technical, conditions of eligibility). In effect, this is an "entry" criterion which, admittedly, has not yet been defined as such by the Courts, although they have come close to it. In other words, the eligibility or entry criterion must be distinct from regional, sectoral or activity characteristics of the recipients. 


\section{Chapter 19}

We can now apply such entry criteria to fiscal measures in a two-stage test. The first stage concerns identification of what may be called the "revealed potential targets" of the fiscal measures concerned. The second stage concerns identification of what may be called their "revealed potential scope".

The revealed potential targets are those companies, regions, or economic activities that could in principle benefit from the aid which is granted through the measure under examination. They may be "revealed" rather than explicitly stated in so far as the potential beneficiaries are deduced from the various particular actions sponsored by the measure or the instruments used by the measure. The revealed potential scope of the policy measure in question is the ideal coverage or extent that its objectives should have.

We can now define a fiscal measure to be a general measure when both its revealed targets and revealed scope do not preclude the entry of any firm from any sector, region or type of activity that is potentially eligible. An example would help to clarify this two-stage test.

Suppose the government adopts a new policy of encouraging the use of environmentally friendly technologies and as part of that policy it offers tax incentives to companies for the purchase of new, less polluting, heavy trucks and buses. The incentives are open to all companies, from any sector, in any region. Is this a general or specific measure? The first stage of the test asks what are the revealed targets in the granting of incentives to the purchase of trucks and buses? Assume the answer is that these vehicles produce a certain chemical that has a particularly damaging effect on the environment. The next question is to ask whether other means of transport or other machinery that also generate the same chemical, should also be eligible for the same incentives; in other words, whether the scope of application or the revealed targets actually coincide with the beneficiary companies. For example, light vans may also generate that chemical and therefore should also be targeted by those measures. The non-eligibility of, say, a courier company using light vans for inner-city deliveries would make that measure specific rather than general. Assume, however, for the sake of argument, that no other type of vehicle or machinery produces that chemical and that on the basis of the first stage of the test we conclude that it is general - no one that could benefit 
from it is excluded, or to put it differently, all the potential targets are covered.

That is not the end of the story for the simple reason that governments can always come up with arbitrary measures that are applied in an apparently non-discriminatory way, yet they are defined so narrowly as to have effects identical to state aid. How can we know that that fiscal measure is not a cleverly disguised subsidy to transport companies rather than to protect the environment? The second stage, therefore, seeks to identify the revealed "potential scope" of the measure in question in order to ensure that it is not too narrow. In our example, the second stage of the test in effect it asks what is the reason for granting incentives for the reduction of that particular chemical instead of other chemicals? If the reason is that they have a certain impact on the environment but there are other chemicals with the same effects and the companies who produce those chemicals receive no incentives to reduce them, then the measure is specific because its scope is too narrow. On the contrary, if they are also eligible for assistance because those chemicals are also covered by the measure, then it is general.

In summary, the first stage which establishes the revealed potential targets asks whether any undertaking is favoured without objective justification while the second stage which establishes the revealed potential scope asks whether the technical criteria used to determine eligibility may also favour certain undertakings by limiting arbitrarily the extent of their application.

One may retort at this point that this line of reasoning has no end. Why stop at that level? Why not also ask what is the reason for remedying that kind of environmental damage over other kinds of damage (e.g. from waste material)? An answer could be that indeed we would enter into a potentially interminable process of queries. But a better answer is that the aim of state aid control is not to establish whether public policies are reasonable, consistent, efficient or well designed. The aim is to prevent them from favouring certain undertakings or activities in a systematic and, therefore, ex ante predictable manner. Hence, any analysis must stop at the first level where the policy loses its ability to favour certain undertakings or activities. The proposed two-stages exhaust those possibilities. If systematic discrimination is not possible at the first or second stage then we must conclude that the measure in question is not state aid even if it is otherwise 


\section{Chapter 19}

arbitrary or even if it does not follow from the scheme, general nature or internal logic of the tax system.

Lastly, a comment needs to be made about a counter-argument that is likely to be raised against the proposed test. The counter-argument would run as follows: Governments may decide to limit the scope of application of the fiscal incentives they offer because they would not want to lose too much revenue or because they could not control the use of those incentives for the purpose of preventing tax evasion. Surely, these are legitimate reasons for restricting the applicability of fiscal measures.

One may accept or reject the legitimacy of such policy aims. But this chapter has not developed instruments for judging their legitimacy (indeed, legitimacy with respect to what?). In the context of this chapter and within the logic of Article 87(1) they can still be found to be state aid. If there are any legitimate reasons that justify limitations to the scope of application of tax incentives, they should be notified to the Commission for authorisation under the exceptions which are possible to the general incompatibility of state aid with the common market.

\subsection{Robustness and efficiency}

Is the proposed two-stage test robust in the sense that it cannot be exploited by public authorities to grant hidden subsidies? I think the answer to this question must be in the affirmative. The proposed test forces public authorities, first, to open up their policies to any undertaking which is eligible on the basis of technical and objective criteria and, second, to design their policies so as to avoid discriminating inadvertently and indirectly in favour of some undertakings by limiting the scope or number of the objective criteria they employ.

Does the test promote efficient use of resources within the economy? A fundamental tenet of public finance theory is that taxation should be as neutral as possible in order to distort consumption and production decisions as little as possible. ${ }^{217}$ This means that tax rates must be such so that the

\footnotetext{
${ }^{217}$ See, for example, the classic textbook by Richard and Peggy Musgrave, Public Finance in Theory and Practice, (New York: McGraw-Hill, 1973).
} 
marginal rates of production or consumption after tax should be equalised across goods and services. ${ }^{218}$ Although it is not possible to prove beyond any

${ }^{218}$ To illustrate that an optimal tax or subsidy policy should aim to equalise marginal rates of production and consumption across the economy, assume that there are " $n$ " goods (and services), denoted by "Xi", in a society of "m" persons. If the utility functions of these persons are $\mathrm{U} 1(\mathrm{X} 1, \ldots, \mathrm{Xn}), \ldots, \mathrm{Um}(\mathrm{X} 1, \ldots, \mathrm{Xn})$, maximisation of those utilities (assumed to be additive) subject to their income constraint, $\Sigma \mathrm{I}=\Sigma(\mathrm{P} 1 \mathrm{X} 1+\ldots+\mathrm{PnXn})$, would give the following Lagrangean function:

$\mathrm{L}=\mathrm{U} 1(\mathrm{X} 1, \ldots, \mathrm{Xn})+\ldots+\mathrm{Um}(\mathrm{X} 1, \ldots, \mathrm{Xn})+\lambda[\Sigma \mathrm{I}-(\mathrm{P} 1 \mathrm{X} 1+\ldots+\mathrm{P} 2 \mathrm{Xn})]$

Differentiation with respect to $\mathrm{X}$ gives the following first-order conditions for maximisation of L:

$[(\partial \mathrm{U} 1 / \partial \mathrm{X} 1)+(\partial \mathrm{U} 2 / \partial \mathrm{X} 1)+\ldots+(\partial \mathrm{Um} / \partial \mathrm{X} 1)] /[(\partial \mathrm{U} 1 / \partial \mathrm{X} 2)+(\partial \mathrm{U} 2 / \partial \mathrm{X} 2)$

$+\ldots+(\partial \mathrm{Um} / \partial \mathrm{X} 2)]=\mathrm{P} 1 / \mathrm{P} 2$

and so on for each pair of goods across the $\mathrm{m}$ persons.

If now the there is a government, acting as a benevolent despot, who knows those utilities and imposes the minimum necessary taxes (in this illustrative example, on the consumption of some or all goods), it would maximise social utility subject to an adjusted income constraint as follows:

$\Sigma \mathrm{I}=\Sigma(\mathrm{P} 1 \mathrm{X} 1+\ldots+\mathrm{PnXn}-\alpha \mathrm{P} 1 \mathrm{X} 1-\beta \mathrm{P} 2 \mathrm{X} 2-\ldots-\varphi \mathrm{PnXn})$ or

$\Sigma \mathrm{I}=\Sigma((1-\alpha) \mathrm{P} 1 \mathrm{X} 1+(1-\beta) \mathrm{P} 2 \mathrm{X} 2+\ldots+(1-\varphi) \mathrm{PnXn})$

where the parameters $\alpha, \beta, \ldots, \varphi$, represent the rates of taxation imposed on different goods.

The first-order conditions would now become:

$[(\partial \mathrm{U} 1 / \partial \mathrm{X} 1)+(\partial \mathrm{U} 2 / \partial \mathrm{X} 1)+\ldots+(\partial \mathrm{Um} / \partial \mathrm{X} 1)] /[(\partial \mathrm{U} 1 / \partial \mathrm{X} 2)+(\partial \mathrm{U} 2 / \partial \mathrm{X} 2)$

$+\ldots+(\partial \mathrm{Um} / \partial \mathrm{X} 2)]=(1-\alpha) \mathrm{P} 1 /(1-\beta) \mathrm{P} 2$

and so on for each pair of goods across the $\mathrm{m}$ persons.

In both cases, with and without taxation, optimality (i.e. efficient distribution of resources) requires that rates of consumption are equalised (before taxation in the first case and after taxation in the second case). Although not shown here, it is fairly easy to demonstrate that the rates of production must also be equalised. The same applies to the case of subsidies. The only difference would be that the income constraint would be $\Sigma \mathrm{I}=\Sigma(\mathrm{P} 1 \mathrm{X} 1+\ldots+\mathrm{PnXn}+\alpha \mathrm{P} 1 \mathrm{X} 1+\beta \mathrm{P} 2 \mathrm{X} 2+\ldots+\varphi \mathrm{PnXn})$.

Assume now that there are market imperfections in the economy, which discourage production of certain goods, and that the best policy response is the provision of subsidies to their producers. For ease of exposition assume that the economy has only two goods both of which are affected by those imperfections. Had there been no distortion, the optimum rate of production would be given by the following condition:

$$
[(\partial \mathrm{B} 1 / \partial \mathrm{X} 1) /(\partial \mathrm{B} 2 / \partial \mathrm{X} 2)]=[(\partial \mathrm{C} 1 / \partial \mathrm{X} 1) /(\partial \mathrm{C} 2 / \partial \mathrm{X} 2)]
$$




\section{Chapter 19}

doubt that the proposed test respects that equality (because, potentially, there is an infinite number of distinct policy measures that can be adopted by public authorities), the test, by forcing public authorities to generalise as widely as necessary the measures they adopt, provides a sort of a guarantee that no industry or sector of the economy will receive more relative benefits than others that operate in similar conditions and face similar problems.

\subsection{Conclusions}

The Commission normally prohibits any state aid scheme that provides operating or fiscal assistance, that is unnecessary for the achievement of the

where $\mathrm{B}$ is the social benefit from consumption (as indicated by market demand) and $\mathrm{C}$ is the social cost of production.

The imperfections mentioned above introduce a wedge between the private cost, $\mathrm{Cp}$, and the social cost, $\mathrm{C}$, so that $\mathrm{Cp} 1,2>\mathrm{C} 1,2$. This means that $(\partial \mathrm{B} 1 / \partial \mathrm{X} 1)>$ $(\partial \mathrm{C} 1 / \partial \mathrm{X} 1)$ and $(\partial \mathrm{B} 2 / \partial \mathrm{X} 2)>(\partial \mathrm{C} 2 / \partial \mathrm{X} 2)$. A production subsidy, $\mathrm{S} 1$, to the production of good 1 will restore the equality between $\partial \mathrm{B} 1 / \partial \mathrm{X} 1$ and $\partial \mathrm{C} 1 / \partial \mathrm{X} 1$ (which is equal to $((\partial \mathrm{Cp} 1 / \partial \mathrm{X} 1)-\mathrm{S} 1)$ but would not restore the equality of the ratios between the two goods (in fact, it could make it worse). An optimum policy response using subsidies requires intervention in the markets of both goods. Further reading on this chapter: $\mathrm{M}$. Herm and P. Rossi, Commission requests phasing out of Spain's export related tax incentives, Competition policy newsletter: $n r .2$ 2006, R. Horacek, Commission's suspension injunction against illegal tax exempt fund in Greece, Competition policy newsletter: $n r .1$ 2006, A. T. Seinen and C. Guillemaut, Exemptions from the fuel excise tax for alumina production, Competition policy newsletter: $n r .12006$,

R. Horacek, Commission's proposal to phase out tax benefits for exempt companies in Gibraltar: Strict limits on existing as well as new beneficiaries, Competition policy newsletter: $n r .2$ 2005, R. Horacek, Commission's negative decision on Gibraltar corporation tax reform: findings on regional and material selectivity, Competition policy newsletter: $n r .2$ 2004, C. Arhold, Recovery of unlawful state aid by the Member States - the new German approach, European State Aid law Quarterly, Volume 5 No. 1 2006, P. Rossi-Maccanico, Commentary of State Aid Review of multinational tax regimes, European State Aid law - Quarterly, Volume 6 No. 1 2007, P. Rossi-Maccanico, State aid review of business tax measures proposals for State aid control of direct business tax measures, European State Aid law - Quarterly, Volume 6 No. 2 2007, J. Mehta, Tax harmonisation and state aid a warning for the future?, European State Aid law-Quarterly, Volume 6 No. 22007. 
objectives defined in Article 87(3) (i.e. market forces are sufficient), that does not impose requirements on recipient undertakings to modify their behaviour to achieve the objectives of Article 87(3), that goes beyond what is necessary in terms of intensity and that distorts competition to an extent which is contrary to Community interest.

Although the objectives and procedures of Community policy on the treatment of fiscal aid are fairly clear, the same cannot be said for the criteria used to distinguish between general tax measures and specific tax measures. This chapter, in addition to reviewing that policy, has also sought to put forth a robust and efficient test for identifying specific tax measures.

The test in essence requires, first, that no company that could potentially benefit is excluded and, second, that public policy measures are not defined so narrowly as to assist selected groups of companies. Policy measures should be generalised to the point where they lose their ability to systematically favour particular companies.

\section{Annex I: Main Cases on Fiscal Aid}

[highlighting Commission practice]

\section{Summary of Community policy on fiscal aid}

Schemes involving fiscal aid (including tax concessions, reduction of social security contributions and parafiscal charges) are not normally authorised by the European Commission. The reason is that in most cases fiscal aid is found to be operating aid [this does not hold all the times because fiscal aid has occasionally been used to stimulate investment and job creation].

Any measure that deviates from the general rules of a tax system, without objective justification, is normally regarded as state aid [Commission Decision on German depreciation facility for airlines, OJ L 146, 20/6/96]. Objective justification results from differences in physical characteristics or the conditions of use on the market.

The Commission prohibits operating aid because it alleviates only temporarily costs and other running expenses without having a lasting effect either on the company concerned or the region in which the company 


\section{Chapter 19}

operates. Operating aid can only indirectly remove those factors or conditions that prevent markets from functioning properly or bring about a result that can not be otherwise achieved by the markets.

Operating aid of fiscal nature is also prohibited because it is virtually impossible to measure its intensity and ensure that it is proportional to the effect sought. For example, a reduction of corporate tax, say, by $50 \%$ may be extremely valuable to a company that happens to make profits. By contrast, it may be worthless to a company that has suffered losses. The intensity operating aid can only be measured ex post, rather than ex ante, and therefore there can be no guarantee that the principle of proportionality can be respected.

In addition to operating aid, certain other forms of aid are also normally prohibited. These kinds of aid are (a) export subsidies and other forms of indirect assistance to exports, (b) aid that infringes fundamental Community principles such as non-discrimination, the right to move and the right of establishment, (c) aid that does not fall within any of the exceptions provided by Article 87(3) either because it has different aims than those allowed by the exceptions or because it is unnecessary (those aims could be achieved by the free play of the market) and (d) aid that does not comply with the intensity (ceilings), forms and objectives stipulated in the various guidelines and frameworks defined by the Commission.

\section{Tax aid scheme for Canary Islands}

(18 January 2000)

Decision: The scheme whose purpose is to promote economic development and diversify the structure of production in the Canary Islands through corporate tax reductions was approved by the Commission which also imposed the conditions that there must be a minimum productive investment of $€ 100000$ and net creation of at least five jobs, in specified types of business activity.

Reasoning: The scheme was approved in the light of the guidelines on national regional aid and the notice on the application of the state aid rules to measures relating to direct business taxation. The Canary Islands are eligible for the exemption provided in Article 87(3)(a), the tax aid and the targeted objectives are consistent with the regional rules on operating aid, it is proportional, it is limited in time and degressive, and it is ring fenced. Operating aid in the form of tax aid was needed so as to attract firms to the 
Canary Islands and thus help to offset the handicaps imposed by the high rate of unemployment and lack of diversification in the local economy (based essentially on tourism).

\section{Tax concessions to investment in companies in Berlin and Eastern}

\section{Länder}

(Commission Decision 98/476, 21/1/98; upheld in C-156/98)

Decision: The aid scheme was prohibited because it discriminated in favour of companies in Berlin and Eastern Länder.

Reasoning: None of the exceptions of Article 87(3) could be used because Berlin did not qualify under Article 87(3)(a) [operating aid is not allowed under Article 87(3)(c)], there were no restrictions preventing companies in other regions from benefiting, there was no time limit, there were no restrictions preventing sensitive industries from benefiting and limitation of incentives to companies established in Berlin and new Länder was contrary to Article 43 [ex 52] even though it applied in nondiscriminatory way to all German and non-German companies.

\section{Special depreciation and investment allowance schemes in West Berlin} (Commission Decision, [IP/97/117], February 1997)

Decision: The Commission decided that the extension of the German special depreciation and investment allowance schemes to include West Berlin was, in principle, compatible with the common market, in so far as the schemes did not apply to the processing and marketing of agricultural products.

Reasoning: The authorisation was subject to the following conditions: (1) replacement investment would be excluded from both schemes which would have to apply only to initial investment, (2) were the investment was outside an assisted area the investment allowances would be confined to "small" enterprises as defined in the guidelines on state aid for SMEs and (3) aid under these schemes could be combined with other forms of public assistance only up to the certain ceilings: $15 \%$ gross for SMEs outside assisted areas, and inside assisted areas 35\% gross for large enterprises and $45 \%$ gross for SMEs.

\section{Low-interest loans to shipping companies in Sardinia}

(Commission Decision 97/95, 21/10/97)

Decision: The aid scheme which was unnotified was prohibited because it discriminated on the basis of nationality (required employment of Sardinians), conflicted with the right of establishment (open only to 


\section{Chapter 19}

companies with head offices in Sardinia), encouraged investment in ships (contrary to Community rules).

Reasoning: None of the exceptions under article 87(3) could be utilised because Article 87(3)(a) did not apply even though Sardinia was eligible because the aid scheme had no regional objectives as it was confined only to shipping companies, Article 87(3)(b) did not apply as it was not an important project of common interest, Article 87(3)(c) did not apply because the aid scheme would affect trading conditions to an extent contrary to the common interest as it did no comply with the guidelines on aid to shipping (1989) or maritime transport (1997).

\section{Free zone in Corsica}

(Commission Decision, , October 1996)

Decision: The scheme which was approved provided a five-year exemption from business tax chiefly for small enterprises. The aid was available in most economic sectors, with the main exceptions being financial services, and betting activities. Companies in Corsica would benefit from the scheme either under the de minimis rule (maximum allowable aid of ECU 100,000 per company over three years) or if they were small and operated in the local market sector.

Reasoning: In view of the size of the firms concerned, the nature of their activities and the fact that Corsica is an island, the Commission did not consider that the aid in question was likely to affect trade between member states. This is the reason why financial services and distributive trade companies belonging to major French groups, were not eligible for aid. The scheme was approved on the grounds that unemployment in Corsica was $156 \%$ of the French average. In addition, the economy of Corsica relied heavily on tourism (20\% of GDP), construction and wholesaling/retailing. The island's GDP was $79 \%$ of the EU average and $71 \%$ of the national average, being the lowest in France.

\section{Tax credit to Italian road hauliers}

(Commission Decision 93/496, 9/6/93)

Decision: The aid scheme which was unnotified was prohibited because it provided operating aid, it was open to all hauliers, it was not linked to restructuring, it would preserve the status quo and would only delay adjustment.

Reasoning: None of the exceptions under 87(3) could apply because Article 87(3)(a) and (c) did not apply as there were no regional development 
elements, Article 87(3)(b) did not apply as there was no major European interest or serious economic disturbance, Article 87(3)(c) did not apply as the aid scheme was not intended to facilitate the development of certain economic activities, while the specific provisions on transport did not allow that kind of state aid.

\section{Tax concessions for investment in the Basque Country of Spain} (Commission Decision 93/337 of May 1993)

Decision: The scheme offered tax reductions to companies that would invest in specified sectors of the economy of the Basque Country on the condition that they would carry out their activities exclusively within the Basque Country. They were prohibited because they infringed Article 43 [ex 52].

Reasoning: There was distortion of competition because the scheme discriminated against firms from other member states, which intended to open branches or agencies in the Basque Country. If these firms wished to continue carrying out business with clients outside the province they would cease to be eligible for the tax concessions. The aid in question did not qualify for the exemption in Article 87(3)(a) because the per capita GDP of the Basque Country was $89 \%$ of the EU average. It did not qualify for exemption under Article 87(3)(c) because it did not seek to promote certain economic activities, it was not confined to certain areas with regional problems, nor did it meet the conditions for aid to SMEs.

\section{Parafiscal charge collected by the French Horticultural Committee} (Commission Decision 91/255, 1/12/90)

Decision: A notified scheme concerning a charge on sales and imports of flowers for the purpose of funding research undertaken by the national Horticultural Committee was prohibited because it was a state aid scheme as it was financed by a compulsory charge.

Reasoning: The possible exception of Article 87(3)(c) could not apply because the aid in question was financed by charges on imports and therefore directly discriminated against imports, which was contrary to the common interest, even if the research was available to all interested parties.

\section{Special single tax on Greek undertakings}

(Commission Decision 89/659, 3/5/89) 
Decision: The notified tax scheme which would exclude export profits from the taxable profits was prohibited because it was aid to exports liable to affect trade between member states.

Reasoning: None of the exceptions under Article 87(3) could apply because it was not shown that market forces were insufficient to guide recipients towards actions that would serve one of the objectives of the exceptions, although Greece qualified for aid under Article 87(3)(a) the aid was not intended for investment or expansion or restructuring, the aid did not promote a major European project as required by Article 87(3)(b), while the aid was contrary to the Community interest under Article 87(3)(c) because it promoted exports without being intended to promote the development of certain regions or certain activities.

\section{Parafiscal charges in facour of the French textile and clothing industry} (Commission Decision 85/380, 5/6/85)

Decision: The aid scheme which involved charges on sales of textiles and clothing was prohibited because the compulsory parafiscal charges were aid liable to distort trade and competition within the common market.

Reasoning: None of the exceptions under Article 87(3) could apply because of the character and purpose of the proposed aid. Neither Article 87(3)(a) nor (c) could apply because France was not eligible for aid for regional development, nor was the aid scheme intended to promote certain regions as it was restricted to a single sector and at the same time it was open to all textile firms irrespective of their location, aid in favour of that sector was not suited to remedy the kind of situation described in Article 87(3)(b), while the aid scheme did not facilitate the development of a certain activity under Article 87(3)(c) because it did not comply with the guidelines for the textile sector. It was a palliative measure that would transfer structural problems to other member states, it required no restructuring or new investment, it was not selective enough, it had no quantitative objectives and it was virtually impossible to measure its intensity.

\section{Annex II: Commission Notice on Fiscal Aid}

[adopted by the Commission on 11 November 1998; OJ C 384, 10/12/98]

It is a follow-up to the Code of Conduct on Business Taxation [1 December 1997]. It signals the intention of Commission to examine all tax systems. 
It makes a distinction between general tax measures and specific measures. It also explains when a general measure may justifiably have a specific effect, i.e. benefit certain sector or factor of production more than others as a result of the functioning of the general tax system or because of objective differentiation [e.g. measures to reduce labour costs will benefit more labour-intensive industries; yet they are not state aid].

Sectoral or regional measures are specific and therefore constitute state aid. General measures that are applied at the discretion of the tax authorities are also state aid.

The Notice provides examples of fiscal aid such as reduction of rates and accelerated depreciation allowance. In addition, it identifies measures that appear to be difficult to be justified by logic of tax system such as favourable treatment of non-residents, head-offices, and intra-group financial services. 
Part V: Services of General Economic Interest

\section{Chapter 20}

\section{The Economics of Services of General Economic Interest}

\subsection{Introduction}

Services of general economic interest (hereinafter 'SGEI') are deemed to have 'special characteristics' in relation to other economic activities. ${ }^{219}$ However, from an economic point of view the decisive factor is that these services have a 'non-profitable' segment. This is what discourages market operators from voluntarily supplying the services in question.

In the context of EC law some services are not 'economic' and therefore are not covered by the rules of competition of the EC Treaty. Non-economic services are not economic or marketable because in principle they cannot be placed on the market - either transactions between sellers and buyers for remuneration are impossible (e.g. compulsory social insurance where everyone has rights and obligations, but the benefits are not proportional to contributions) or competition between sellers is impossible (e.g. issuing of passports and other official documents).

The case of SGEI is different. Market transactions can in principle take place. The market does not provide them because either the cost of services is too high for the prevailing level of demand or, conversely, demand is too low for the prevailing (or most efficient) level of cost. ${ }^{220}$ Therefore, the definition of

\footnotetext{
219 See, for example, the judgments in Case 127/73 BRT [1974] ECR 313; and Case C-266/96 Corsica Ferries [1998] ECR I-3949.

220 I ignore here special cases where a dominant enterprise, for example, with relatively high fixed costs refuses to supply the market segment with high-elasticity of demand (i.e. with low market price) unless it can price discriminate. Since price discrimination is an abusive practice under Article $82 \mathrm{EC}$, the dominant firm has to charge a uniform price and, therefore, does not sell any services on the low-price
} 
a SGEI or public service task is inextricably linked to the capacity of the market to provide the service in question rather than the nature of the service itself. In fact, if the service is of economic nature, the market will in principle provide it. This was made very clear by the Court in its judgment in Ambulanz Glöckner. ${ }^{221}$ The Court held:

"Public service obligations may, of course, render the service provided by a given medical aid organisation less competitive than comparable services rendered by other operators not bound by such obligations, but that fact cannot prevent the activities in question from being regarded as economic activities." 222

Therefore, when dealing with SGEI, the important questions for public authorities are, first, how much aid they should offer to providers of SGEI, given that some services can be supplied by the market and, second, in what form to offer that aid so that it causes the least distortion in the market.

The purpose of this Chapter is to analyse these two questions and examine what kind of distortions may be caused by aid to SGEI providers.

Despite the fact that legally, SGEI have 'special characteristics', economically they do not differ from other services or economic activities apart from the fact that some of them may be natural monopolies as is the case of electricity, telecommunications or transport networks. Therefore, to understand the special economic aspects of SGEI we need first to establish the reason why governments feel they need to intervene to confer special or exclusive rights or to grant State aid. As already mentioned, the principal reason is that the market does not voluntarily provide such services at the desired quantity or level of price and quality or geographic coverage. Again, this is because costs are too high at the prevailing demand or, conversely, demand is insufficient to cover costs.

This chapter is developed as follows: The next section lays the foundations by identifying the generic problems of granting aid. The section after that considers how costs and revenues may be assigned to different services

segment. See D. Carlton \& J. Perloff, Modern Industrial Organization (Reading, MA: Addison-Wesley, 2000).

221 Case C-475/99 Ambulanz Glöckner [2001] ECR I-8089.

222 Case C-475/99 Ambulanz Glöckner [2001] ECR I-8089, paragraph 21. 


\section{Chapter 20}

within a 'multi-service firm'. Then there is an analysis of the effects of aid awarded directly and through cross-subsidies. The problem of spillovers into other markets is then taken up. The chapter concludes with some recommendations on the least distortionary method of subsidising SGEI. The chapter also refers to the various criteria laid down in the landmark Altmark case $^{223}$ and evaluates them on the basis of the findings of the analysis that follows.

\subsection{The economic problem of subsidy-granting}

Governments grant subsidies for many reasons: economic, social, political, strategic. ${ }^{224}$ The main economic reason for granting subsidies is to correct market failure. However, public subsidies are almost always a second-best solution for market correction because they introduce their own distortions in the market, even if they are relatively small. The first-best solution is to remove the distortion directly.

Assume that the first-best solution is unobtainable. An authority that wants to offer subsidies will face the following problems:

Necessity: It needs to be determined whether subsidies are necessary to induce firms to do something they would not otherwise do under normal market conditions. This has three aspects: First, the presumed market failure has to be proven. Second, even in the presence of market failure it does not mean that firms will not, for example, invest or hire staff or undertake R\&D. They may only do less than what is socially optimum. This means that the

223 Case C-280/00 Altmark Trans [2003] ECR I-7747. Concerning this judgment, see also supra Chapter 4.

${ }^{224}$ On the general problem of granting State aid, see: S. Lehner, R. Meiklejohn \& A. Louw, Fair Competition in the Internal Market: Community State Aid Policy (Luxembourg: OOPEC, 1991); R. Meiklejohn, The Economics of State Aid, in: European Economy, 1999, no. 3, pages 25 to 31; D. Neven, The Political Economy of State Aids in the European Community: Some Econometric Evidence, in: Cahiers de Recherches Économique, 1994, no. 9402, University of Lausanne; P. Nicolaides $\&$ S. Bilal, An Appraisal of the State Aid Rules of the European Community: Do they Promote Efficiency?', in: Journal of World Trade, 1999, vol. 33(2), pages 97 to 124; Public Subsidies, Office of Fair Trading, London, November, 2004. 
subsidy has to be the minimum necessary - which is the issue of proportionality that is examined below. Third, even in the presence of a general market failure it still does not follow that each firm suffers from that failure. For example, a firm may manufacture a very specialised product so that it faces no risk of imitation by competitors. This firm would not need any public incentive to engage in $R \& D$ or to retain its technological leadership. For the same reason, in industries where R\&D is indispensable for the survival of each firm, subsidies would not be necessary to induce them to undertake research. This is in essence the fundamental problem of every subsidy-granting authority. It can never know what the subsidy recipients truly intended to do in case they would obtain no subsidy.

Proportionality: Even if the need for subsidies is established in principle, the next problem is to determine the minimum amount necessary. This has two aspects. First, the granting authority has to calculate the amount of subsidy that will induce the recipient firms to carry out the socially-optimum investment, training, $R \& D$, etc. Second, the authority has to identify the true costs of the recipients. Every subsidy recipient has a strong incentive to exaggerate its relevant costs. In principle, if each Euro of the subsidy fully captures the cost to society for granting that subsidy, ${ }^{225}$ then the subsidy is proportional (and, therefore, at its optimum level) when the last Euro granted is equal to the extra benefit derived by society (or the marginal cost of the subsidy is equal its marginal benefit).

Impact on competition in the same and other markets: But subsidies also create costs in terms of the distortions they cause. This is because subsidy recipients obtain an advantage that is not normally available to their competitors. Even if society obtains some benefits from more investment or $\mathrm{R} \& \mathrm{D}$, it may also experience negative effects by the fact that the recipients capture market share at the expense of potentially more efficient competitors. Not only national authorities do not normally worry about any negative impact on foreign competitors, sometimes they intentionally seek to distort international competition by supporting their national 'champions'. In any case, consumers lose out from not having access to cheaper or better products. In addition, there is the potential of distortion in adjacent markets. Government subsidies in one market may stimulate demand for inputs from

\footnotetext{
225 That is, the subsidy is neither a pure transfer, so it has zero costs, nor does it generate other costs.
} 


\section{Chapter 20}

other markets, distorting competition in favour of the suppliers that happen to have access to the subsidy-receiving firms.

Administrative costs: The granting of subsidies is costly for both the authority that provides them and the firms that obtain them. The former has to maintain the necessary administrative infrastructure to process applications and to ensure compliance with the relevant rules. The latter have to expend resources to apply for subsidies and to report later on how they have used them. It has been estimated that such administrative costs account for about 10 per cent of subsidies granted ( 5 per cent for the granting authorities and 5 per cent for the recipient firms). ${ }^{226}$

Other costs: Subsidies have to be raised through taxation which is itself an economic distortion. In addition, there is the possibility that subsidies generate spillovers that worsen distortions in other markets or create new distortions in the same market. For example, subsidies to farmers stimulate demand for fertilisers produced through polluting processes in other markets. At the same time overproduction of agricultural products results in excessive use of fertilisers worsening soil degradation of farmland.

It is very doubtful that aid that is compatible with EC rules is strictly necessary and proportional, causes no other distortions and keeps any other costs to the minimum necessary.

\subsection{What costs and how much profit?}

In order to ensure that subsidies to SGEI are proportional, the granting authorities need to have a pretty accurate picture of the relevant costs. The case $\mathrm{aww}^{227}$ and the recent Commission Decision ${ }^{228}$ and Framework ${ }^{229}$ on aid

\footnotetext{
226 National Audit Office, Regional Grants in England (London: Stationery Office, 2003).

227 See for example: Case C-280/00 Altmark Trans, cited supra, footnote 6.

228 Commission Decision of 28 November 2005 on the application of Article 86(2) of the Treaty to State aid in the form of public service compensation granted to certain undertakings entrusted with operational services of general economic interest, OJ 2005 L 312, page 67.
} 
to compensate for public service obligations also allow that a 'reasonable' rate of profit is added to eligible costs. ${ }^{230}$

It is also important for granting authorities to know the relevant costs because the provision of SGEI often takes place in conditions of weak competition. When there is strong competition, it is not so essential that costs are known. This is because the market itself reveals who is the most efficient producer and how low firms must price their products in order to remain in the market. In the absence of such market signals, the aid-granting authorities have to identify them through other means. What, then, are the eligible costs and what is reasonable profit?

The eligible costs are those that emanate directly from the provision of the SGEI. These are the variable costs of the SGEI. In addition, EC law allows for an appropriate share of fixed costs to be included in the total costs of the SGEI. We can show this with the following notation:

\section{(1) $\mathrm{TC}=\mathrm{VC}+\mathrm{kFC}$}

where TC is the total cost, $\mathbf{V C}$ is the variable cost, $\mathbf{F C}$ is the fixed cost and $\mathbf{k}$ is a parameter that determines how much of the fixed costs are assigned to the SGEI operations.

Although the concept of variable cost is straightforward, it is not always easy to calculate it in practice. This is because the variability of any cost depends on the time frame of investigation. In the long-term, everything is variable. This is particularly important in the case of those SGEI which are delivered through networks. The network at any point in time is fixed, but networks always expand even marginally. Such extensions of the network should be considered, if not as variable costs, at least as incremental to the new services that are made available.

229 Community framework for State aid in the form of public service compensation, OJ 2005 C 297, page 4.

230 Both texts can be accessed at:

http://europa.eu.int/comm/competition/state_aid/others/action_plan/sgei_art86_en.p df

http://europa.eu.int/comm/competition/state_aid/others/action_plan/sgei_encadreme nt_en.pdf 


\section{Chapter 20}

With respect to fixed costs, as is well known, there is no established method in economics for determining $\mathbf{k}$. It can be calculated as a proportion of costs, or sales, or number of workers, etc. EC rules only require that the allocation or apportioning of fixed costs follows some acceptable accounting convention and that whichever method is chosen, it is determined in advance and not adjusted in response to changes in market conditions. Given the discretion that companies have in allocating fixed costs, it is doubtful that these rules constrain too much.

It is also difficult to determine $\mathbf{F C}$ itself, especially when it concerns a durable asset. This is because of the difference between the purchase (historic) cost of the asset and its economic cost. The latter changes constantly for two reasons. Other things being equal, it depreciates with usage. Also at any point in time the true economic cost (or value) of an asset depends on its possible alternative functions or 'rental' value. A firm that receives a subsidy based on the historic cost of its assets derives an advantage over its competitors whenever the latter employ technologically superior assets. In such a situation, the firm using the obsolete technology would have been driven out of the market in the absence of subsidies.

Before concluding this section, let's consider briefly the issue of the 'reasonable' rate of profit. In competitive markets, the rate of economic profit is zero. Even though accounting profit may be above zero, investment in a sector or industry will continue until no additional profit can be earned in relation to other potential investments of comparable risk. Since any investor could simply leave his money in the bank and earn the going rate of interest for virtually no risk, some profit must necessarily be allowed in the provision of SGEI if firms will voluntarily enter the sector. The question, therefore, is how much profit above the riskless rate of the bank or government bonds?

The answer in principle is given in the following equation of profit:

\section{d) $\cdot$ Capital}

$$
\pi=\text { Revenue }- \text { Labour Costs }- \text { Material Costs }-(r+
$$

where $\mathbf{r}$ is the (rental) rate of return on capital invested and $\mathbf{d}$ is the rate of depreciation. The competitive rate of return is derived by setting equation (2) equal to zero, so that

$$
\text { r* }=\text { (Revenue }- \text { Labour Costs }- \text { Material Costs - }
$$

\section{d.Capital)/Capital}


By contrast the answer given in Community case law or Commission practice is different. First, note, however, that the word 'answer' here is a euphemism. The closest they have come to a kind of an answer is that 'reasonable' rate of profit is that which allows the recipient of the subsidy to operate at "economically acceptable conditions ${ }^{\text {,231 }}$ or to achieve "economic equilibrium ${ }^{, 232}$ or to reach a level of profit which is similar to the industry average. These conditions are too generous. To see why they are too favourable to aid recipients consider again the relationship between profit and costs. Since by definition revenue falls short of costs and a subsidy must be granted to stimulate the supply of the SGEI, the rate of return is calculated as follows:

$$
\begin{aligned}
& \mathbf{r}^{\mathbf{s}}=(\mathbf{s}+\text { Revenue - Labour Costs - Material Costs - } \\
& \text { d.Capital }) / \text { Capital }
\end{aligned}
$$

where $\mathbf{s}$ is the amount of subsidy.

Whereas the assumption for the calculation of the competitive rate of return on capital is that $\boldsymbol{\pi}=\mathbf{0}$, now the amount of subsidy $\mathbf{s}$ is such that [s (Revenue - Costs)] $>0$.

One may think that this criticism is too harsh as normally the amount of subsidy is calculated on the basis of accounting data and, as explained above, the accounting rate of profit is normally higher than the economic rate of profit.

Even if an allowance is made for this difference in accounting and economic measures of profit, there is still a problem. Whereas the competitive rate of return is based on the economic value of the capital of the aid recipient, the amount of subsidy is based on measures of profitability derived from other companies that may be more efficient. This establishes a favourable benchmark against which to determine the reasonable profit for aid recipients. In fact, it neutralises the competitiveness of rival firms.

The recent Commission Decision of November $2005^{233}$ exempting certain forms of public service compensation from prior notification specifies that the rate of return on own capital should be adjusted for the risk assumed by

\footnotetext{
231 Case C-320/91 Corbeau [1993] ECR I-2533.

232 Case T-106/95 FFSA [1997] ECR II-229.

233 See supra footnote 11.
} 


\section{Chapter 20}

the beneficiary and should not exceed the industry or sector average. This goes in the right direction but it does not remedy the problem that the beneficiary is automatically entitled to whatever profitability is achieved by its competitors.

\subsection{Direct aid to SGEI and the Altmark criteria}

Assume that a government has decided that its citizens deserve to consume more of a certain service because it is a SGEI. Further assume that the market for this service is characterised by monopolistic competition which means that each provider has some market power; i.e. each provider sells a differentiated product and faces a downward sloping demand. This means that there is entry into that market until firms just cover their costs. Firms do not produce at the lowest point or most efficient point of their cost curve. That is, they have spare capacity. The situation is depicted infra in Figure 20.1 .

The government gives a subsidy of ' $\mathbf{s}$ ' per unit of output to firm A. Its average cost curve is shown by $\mathbf{A C}_{\mathbf{A}}$. The recipient firm expands its output from $\mathbf{Q}_{1}$ to $\mathbf{Q}_{2}$. The government justifies the granting of the subsidy to firm A because it appears to be the most efficient firm before the aid is made available.

This is important because it would satisfy the fourth Altmark criterion. ${ }^{234}$ However, as indicated infra by Figure 20.1, this conclusion may be false. The reason is that another firm which at the pre-subsidy output, $\mathbf{Q}_{1}$, has higher costs, may have lower costs at the post-subsidy output, $\mathbf{Q}_{2}$. This is shown by its average cost curve $\mathbf{A C}_{\mathbf{B}}$. The subsidy that firm $\mathrm{B}$ would require is consequently lower as well. The point here is that, as many telecoms and electricity regulators know, pricing should be determined on the basis of the forward-looking costs or expected future costs of the most efficient entrant using the latest available technology rather than past or historic costs.

The fourth condition of Altmark states:

"... where the undertaking which is to discharge public service obligations, in a specific case, is not chosen pursuant to a public

234 Case C-280/00 Altmark Trans, cited supra, footnote 6. See also supra Chapter 3. 


\begin{abstract}
procurement procedure which would allow for the selection of the tenderer capable of providing those services at the least cost to the community, the level of compensation needed must be determined on the basis of an analysis of the costs which a typical undertaking, well run and adequately provided with means of transport so as to be able to meet the necessary public service requirements, would have incurred in discharging those obligations, taking into account the relevant receipts and a reasonable profit for discharging the obligations. $" 235$
\end{abstract}

It does not specify whether the comparison of costs is done before or after the granting of aid. It is also very doubtful that national authorities in practice seek to identify the potential provider with the lowest forwardlooking costs.

If aid is not given directly but it is granted instead through an auctioning process, the competitors themselves would place their bids according to their expected future costs rather than historic costs. So, unlike direct awards of aid, a competitive process would avoid this problem. Since technology constantly evolves and costs change, the granting of direct aid to a firm not chosen via a competitive process that is repeated at regular intervals is an inferior method of subsidising SGEI and the fourth Altmark criterion is defective because it does not impose such an obligation on Member States.

\title{
20.5 Direct aid and potential spillovers
}

As mentioned earlier, eligible costs are those that are caused directly by the provision of SGEI. As also mentioned, the relevant rules allow aid to cover those costs plus a proportion of fixed costs plus an amount of reasonable profit minus any revenue earned from selling the SGEI. Since previous sections have examined how fixed costs may be apportioned and how reasonable profit may be determined, this section examines what may happen when the SGEI provider also operates in another market where competition is open.

Suppose the SGEI provider has the following cost structure:

235 Case C-280/00 Altmark Trans, paragraph 93, cited supra, footnote 6. 
(5) $\quad \mathrm{TC}=\mathrm{VC}_{1}+\mathrm{VC}_{2}+\mathrm{FC}$

where $\mathbf{T C}$ is the total cost, $\mathbf{V C}_{\mathbf{1}}$ is the variable cost of the SGEI, $\mathbf{V C}_{\mathbf{2}}$ is the variable cost of the competitive service and $\mathbf{F C}$ is the fixed cost or overheads.

The allowable subsidy, $\mathbf{s}$, is determined as follows:

(6) $\quad \mathrm{s}=\mathrm{VC}_{1}-\mathrm{R} 1+\mathrm{FC}\left(\mathrm{VC}_{1} /\left(\mathrm{VC}_{1}+\mathrm{VC}_{2}\right)\right)+\pi$

where $\mathbf{R} 1$ is the revenue from the SGEI, $\mathbf{V C}_{\mathbf{1}} /\left(\mathbf{V C}_{\mathbf{1}}+\mathbf{V \mathbf { C } _ { 2 } )}\right.$ is the share of the fixed costs assigned to the SGEI and $\boldsymbol{\pi}$ is the reasonable amount of profit. In this case, the fixed cost is assumed to be divided according to the relative size of the variable costs of the SGEI and the competitive activity, respectively.

The SGEI provider has a strong incentive to exaggerate its eligible costs for two reasons. First, it obtains a larger subsidy. Second, it can derive an advantage in the other market. This is because the larger the share of the fixed costs it assigns to the SGEI, the lower the share it assigns to the competitive service. This means that it can charge a lower price than an equally efficient competitor in that other market by the mere fact that it receives aid for the SGEI.

In the short-term, fixed costs are irrelevant. Prices are determined on the basis of variable costs. However, in the longer-term, firms have to cover all costs in order to remain in business. Even if we assume that before the subsidy was granted the identical firm in the other market incurred exactly the same amount of variable and fixed costs as the SGEI provider, the situation will change against it after the granting of the subsidy to the SGEI provider. The price charged by the SGEI provider in that other market will be lower because the allocated fixed costs will be lower.

The November 2005 amendment to Commission Directive 80/723/EEC ${ }^{236}$ requires account separation whenever the SGEI providers also 'carry on activities outside the scope of the SGEI'. This is because 'it is only by maintaining separate accounts that the costs imputable to the SGEI can be identified and the correct amount of compensation calculated.' This is

236 Commission Directive 2005/81/EC of 28 November 2005 amending Directive $80 / 723 /$ EEC on the transparency of financial relations between Member States and public undertakings as well as on financial transparency within certain undertakings, OJ 2005 L 312, page 47. 
correct as far as the amount of the subsidy is concerned. But competition spillovers of the kind described here are not avoided by account separation.

Again, the solution to this problem is to introduce competition in the provision of the SGEI, possibly through tender procedures, so that each contestant has an incentive to keep costs as low as possible. Direct assignment of SGEI tasks without a competitive process confers an indirect advantage to any SGEI provider who operates on other markets as well. Once more, the Altmark criteria prove to be insufficient.

This is not the only kind of spillovers into other markets. They can manifest themselves in different ways. For example, assume that a provider of SGEI acquires an asset that is used in both the SGEI market and in the other markets where it operates. To purchase that asset the firm obtains a loan. The rate of interest that the lender would charge on the loan would depend on how risky the business of the borrower is. In this case, the direct award of aid removes most, if not all, external - i.e. market - risk facing the SGEI provider. The subsidy covers all revenue shortfall and allows for a predetermined rate of profit. This is compatible with the second Altmark condition which requires that the terms of compensation are determined in advance and the third Altmark condition that restricts compensation to net extra costs plus profit. Although there is still some ambiguity as to how the second condition can exactly be applied, presumably it does not cover any internal cost increases, excessive investments or unreasonable rates of profit.

But the important point to note here is that the direct award of aid reduces the risk facing both the SGEI provider and its creditors. As a consequence it can raise cheaper capital or it can borrow at lower rates and can therefore buy assets and operate its business at more favourable terms. All these are advantages that can skew competition in other markets in its favour.

As already mentioned, the Commission Decision of 28 November $2005^{237}$ exempting certain forms of PSC from prior notification specifies that the rate of return on own capital should be adjusted for the risk assumed by the beneficiary and should not exceed the industry or sector average. It is obvious that these restrictions do not address the problems identified in this

237 See supra footnote 11. 


\section{Chapter 20}

section, especially the less costly access to financial markets due to the lower inherent risk in the provision of the SGEI.

\subsection{Cross-subsidisation}

Another method that is often used to compensate SGEI providers is to allow them or even request them to cross-subsidise one service with another. Naturally, in order for them to be able to carry out this cross-subsidisation, they must be able to earn above normal profits in at least one market. Crosssubsidisation solves one problem - that of increasing the supply of the SGEI - by creating another - that of introducing a distortion in the profitable market.

Figure 20.2 infra shows two markets, $\mathbf{M}_{\mathbf{1}}$ and $\mathbf{M}_{\mathbf{2}}$, with demand curves $\mathbf{D}_{\mathbf{1}}$ and $\mathbf{D}_{\mathbf{2}}$ where $\mathbf{M}_{\mathbf{1}}$ is the low-price market and $\mathbf{M}_{\mathbf{2}}$ is the high-price market. The government wants to expand output in the second market so that consumers there can purchase the SGEI at a more affordable price. Assume that there is a single provider. This provider, being a monopoly, is regulated and required to charge prices equal to the marginal cost, $\mathbf{m}$ and $\mathbf{n}$, of providing the SGEI in each market. For ease of exposition, fixed costs are zero. Also assume that the two cost functions are independent so production in one market does not affect costs in the other. This means that before the government subsidy we have a situation of optimum allocation of resources.

The government allows the SGEI provider to raise its price in $\mathbf{M}_{\mathbf{1}}$ to $\mathbf{P}_{\mathbf{2}}$ so as to earn extra revenue that can be used to subsidise sales at lower prices in $\mathbf{M}_{2}$. The prices in the two markets are identical because this is the typical condition imposed by governments in universal service obligations. Prices must be both affordable and uniform. At $\mathbf{P}_{2}, \boldsymbol{\pi}_{1}$ and $\boldsymbol{\pi}_{2}$, i.e. profits (or losses) in each market are equal; $\boldsymbol{\pi}_{1}=\mathbf{P}_{2}-\mathbf{m}$ and $\boldsymbol{\pi}_{2}=\mathbf{n}-\mathbf{P}_{2}$. Formally, $\boldsymbol{\pi}_{1}=-\boldsymbol{\pi}_{2}$.

It can also be seen infra in Figure 20.2 that society experiences a net loss in efficiency. This is shown by the shaded areas in the two markets which are indicated with $\mathbf{L}_{\mathbf{1}}$ and $\mathbf{L}_{\mathbf{2}}$. This is the deadweight loss or the 'price' society has to pay for distorting resource allocation in order to achieve its social objective of affordable and uniform prices. 
In most political discussions of this issue this is where the debate ends. However, this is not the end of the story as far as efficiency is concerned. For society as a whole the second-best intervention may be different. Assuming that the policy constraint is that prices must be the same in the two market, the second-best is determined by that price at which the sum of $\mathbf{L}_{1}$ and $\mathbf{L}_{\mathbf{2}}$ is minimised. That price is indicated by $\mathbf{P}_{1}$ in Figure 20.2 infra. But now we have another problem because at $\mathbf{P}_{1}$ the SGEI provider cannot cover its losses in $\mathbf{M}_{\mathbf{2}}$ since $\boldsymbol{\pi}_{\mathbf{1}}<-\boldsymbol{\pi}_{\mathbf{2}}$. The second-best solution may require both a cross-subsidy and a direct subsidy to make up for the shortfall in revenue!

There is also another possibility. The price that minimises deadweight loss may exceed $\mathbf{P}_{2}$. This is shown by $\mathbf{P}_{3}$. At that price, however, $\boldsymbol{\pi}_{\mathbf{1}}>-\boldsymbol{\pi}_{\mathbf{2}}$. Now, the second-best solution requires instead of a direct subsidy, a tax to extract the excess profits earned by the SGEI provider in $\mathbf{M}_{\mathbf{1}}$.

It is only by coincidence that cross-subsidisation will be both sufficient and an optimum method of intervention to make the SGEI available at affordable prices to consumers across markets. The optimum policy would require a mixture of tools that in some cases would involve additional taxes!

\subsection{Conclusions and recommendations}

Public subsidisation of firms may be justified as a second-best response to market failure. Whenever subsidies are given for political, social, regional or strategic reasons they are likely to be third-best policy tools.

This brief analysis of subsidies for the provision of SGEI has identified four major problems:

1. The difficulty of identifying relevant costs and the appropriate rate of profit.

2. The possible differences in costs before and after awards of aid between aid recipients and competitors.

3. Negative spillovers into other markets and distortion of competition in those markets.

4. The need to combine cross-subsidies with direct subsidies or taxation. 


\section{Chapter 20}

Cross-subsidies are unlikely to be in themselves a second-best optimum policy. Almost always they need to be combined with either direct subsidies or, surprisingly, taxes.

In addition, this analysis of the economics of compensation for public service obligations suggests that the Altmark criteria are neither clear, nor sufficient in preventing aid beneficiaries from obtaining an unfair advantage over their competitors.

To put it starkly, the way subsidies are calculated in practice is likely to create conditions that favour the subsidy recipient either because they allow it to earn profit at rates achieved by more efficient firms or because they enable it to price its products in adjacent markets at lower levels.

Distortions may be minimised by the use of tender procedures and avoidance of direct awards of aid. Competitive bids induce firms to minimise the amount of subsidy they request and weaken their ability to exploit the subsidy to strengthen their position in other markets. In this way taxpayers gain as subsidies are lower than otherwise. Moreover and more importantly, the SGEI would be provided by the least costly firm which presumably would supply it at lower prices. Consumers gain too.

To recapitulate, a competitive process has three major advantages: It minimises subsidies (to the advantage of taxpayers), it minimises spillovers (to the advantage of competitors), it lowers prices (to the advantage of consumers).

Please note that a competitive process is not a first-best option because it does not eliminate all problems caused by subsidies and especially the fact that any subsidy introduces distortions of its own. Since a competitive process may create novel distortions and may have its own defects, its three advantages identified above should only lead us to the tentative conclusion that it should be preferred over direct awards of aid.

Commission Decision 2005/285 on public service compensation ${ }^{238}$ states that

238 See supra footnote 11. 


\section{The Economics of Services of General Economic Interest}

"... the PSO must be clearly set out in a formal act of the competent public authorities. The form of the instrument may vary from one member state to another but it should specify the precise nature, scope and duration of the public service obligations imposed and the identity of undertakings concerned, and the costs to be borne by the undertaking concerned."

It should be clear by now that this is not enough. Costs may creep upwards. If competitive processes are not used by Member State authorities, at least the amount of the subsidy should be fixed, rather than the costs. By fixing the subsidy, beneficiary undertakings are forced to bear the risk of cost increases and have a strong incentive to keep costs down. Since there can be no overcompensation, any cost reductions that result in excess aid would be clawed back by the granting authority.

Therefore, a second-best approach is competitive bidding, pre-fixing of the amount of aid is third-best, while the pre-fixing of eligible costs is fourthbest. 
Chapter 20

Figure 20.1

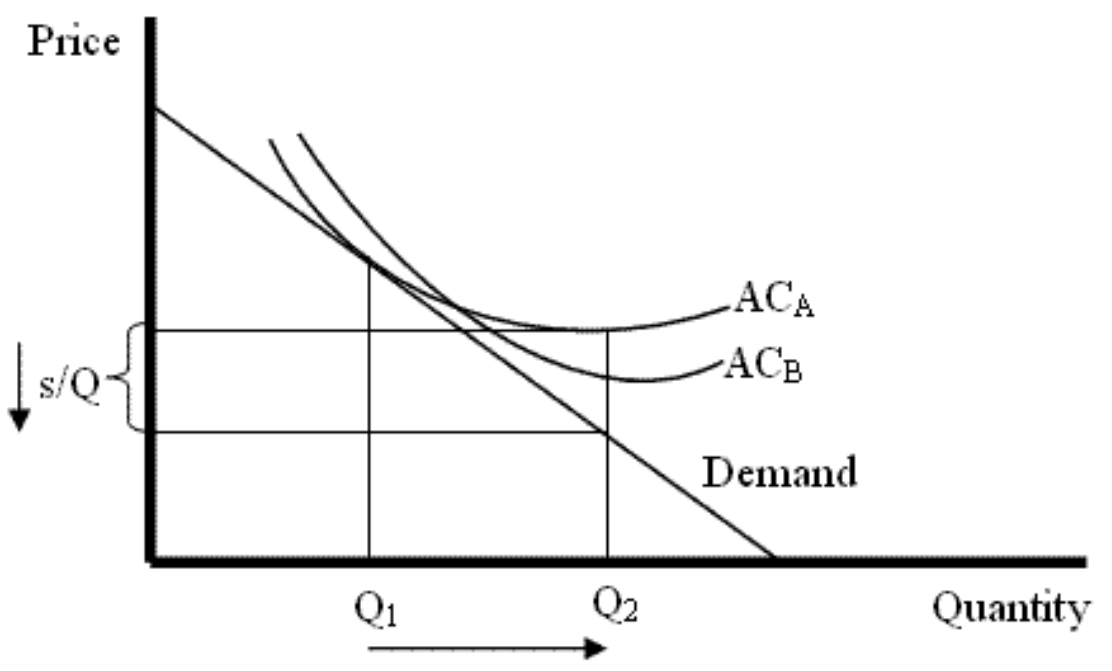

Figure 20.2

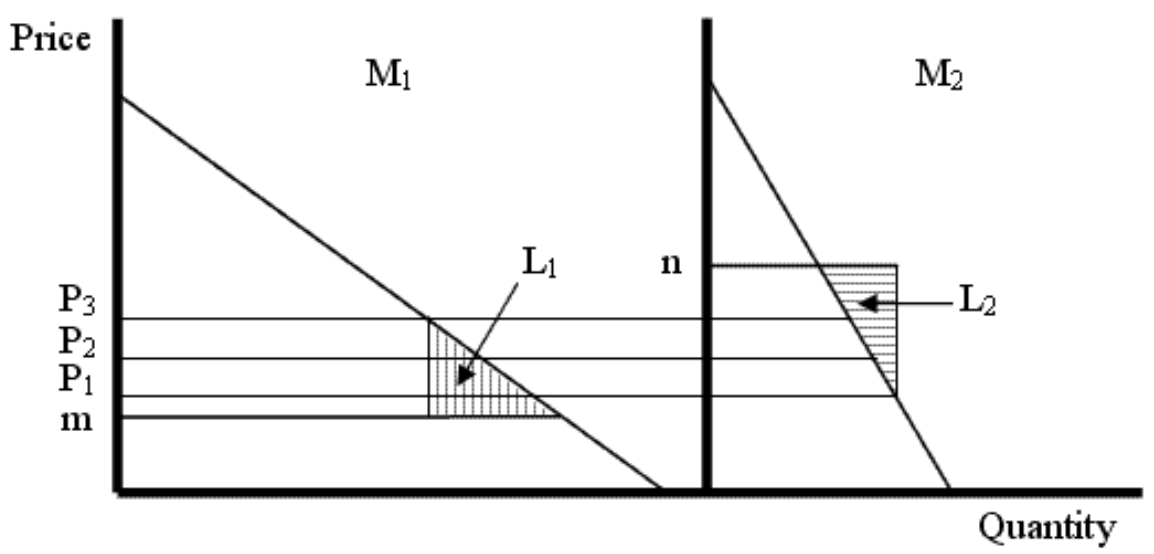




\section{Chapter 21}

\section{Compensation for Public Service Obligations: The Floodgates of State Aid?}

\subsection{Introduction: Why the floodgates have been flung open?}

The European Court of Justice has ruled that, under certain conditions, providers of services of general economic interest (SGEI) may receive aid as a form of compensation for the extra costs they incur in supplying those services. ${ }^{239}$ The Court concluded that this kind of aid is not covered by the definition of state aid in Article 87(1) of the EC Treaty! Therefore, it does not need to be notified to the Commission for prior authorisation. The consequence is that it falls completely outside the Community system for control of state aid. Normally, any public measure granting state aid must first be notified to the Commission, unless it is explicitly exempted by Commission Regulations.

Traditionally, providers of SGEI could obtain exemption from state aid and anti-trust rules by virtue of Article 86(2). The most significant weakness of this exemption is that it applies irrespective of the efficiency of the enterprise that benefits from it. ${ }^{240}$ Now, the potential distortion to competition is wider. Public assistance may not even be regarded as state aid to the extent that it has a compensatory role and as long as it does not exceed the extra costs of the public service obligation.

The purpose of this chapter is twofold. First, it argues that this new treatment of "compensatory aid" has in essence opened the floodgates of state aid because many other requirements imposed by law on business can also be

239 "Ferring", C-53/00.

${ }^{240}$ See P. Nicolaides (2002), The New Frontier in State Aid Control: An Economic Assessment of Measures that Compensate Enterprises, Intereconomics, vol. 37, pp. 190-199; and P. Nicolaides (2002), The Distortive Effects of Compensatory Aid Measures: A Note on the Economics of the "Ferring" Judgement, European Competition Law Review, vol. 23, pp. 313-319. 


\section{Chapter 21}

regarded as public service obligations. Public authorities, then, may attempt to exploit the loophole created by the Court to justify their granting of state aid on the grounds that they have imposed costly obligations on enterprises.

Second, the chapter explains that compensation for the extra cost of public service obligations in many cases confers an advantage to recipient enterprises. This is paradoxical because the Court has presumed that public service obligations put these enterprises at a disadvantage.

The chapter is organised as follows. Section 2 reviews the relevant Court rulings and related opinions of Advocates General. Section 3 identifies a number of weaknesses in the proposals for solving the problem of compensatory aid to SGEI providers. Sections 4 and 5 analyse the competition issues involved. Section 6 outlines a less distortionary approach to the treatment of SGEI. Finally, section 7 summarises the main arguments developed in this chapter.

\subsection{Application of EC state aid rules to SGEI}

Under Article 87 of the EC Treaty a state measure must be judged on the basis of its effects on competition. The Court of Justice has held that Article 87 does not make any distinction according to the causes or aims of the aid in question but defines them in relation to their effects [C-173/73, Italy $\mathrm{v}$ Commission]. That is, whether the measure confers an advantage to certain undertakings in relation to their competitors.

Nonetheless, in one of its earliest pronouncements on the issue of compensation of providers of SGEI, the Court of Justice veered away from examining compensation in terms of its effects. In a ruling handed down in 1985 in a case concerning the extra costs generated by the obligation imposed by France on certain undertakings to dispose of waste oils, the Court stated that those "indemnities do not constitute aid within the meaning of Article [87] of the Treaty, but rather consideration for the services performed by the collection or disposal undertakings." Public authorities in France paid to the collecting companies indemnities not exceeding their actual annual costs as a form of compensation [C-240/83, ADBHU]. 
In line with the ADBHU ruling, the Commission held for a long time the view that financial benefits granted by member states to compensate for the additional burden of extra public service duties do not constitute state aid. For example, in the "Community guidelines on state aid to maritime transport" [OJ 1997 C 205], it is stated that "the Commission's practice in assessing contracts relating to PSOs [public service obligations] is generally to consider the reimbursement of operating losses incurred as a direct result of fulfilling certain public service obligations is not State aid within the meaning of Article 87(1) of the Treaty".

The Commission's practice was contradicted in the mid-1990s by rulings of the Court of First Instance, starting with the judgement in FFSA [T-106/95], which concerned a Commission decision that certain tax concessions granted to the French postal service in order to offset its public service obligations were not state aid. In that decision, the CFI took the opposite approach to the Commission and concluded that the measures in question did constitute state aid, even though they could be deemed compatible with the common market under Article 86(2) of the Treaty.

The CFI adopted the same position in its subsequent judgement in SIC [T46/97] which concerned the financing of public television in Portugal. There the Court held that "the fact that a financial advantage is granted to an undertaking by the public authorities in order to offset the cost of public service obligations which that undertaking is claimed to have assumed has no bearing on the classification of that measure as aid within the meaning of Article 87(1)".

That ruling by the CFI was based, in particular, on the consideration that "Article 87(1) of the Treaty does not distinguish between measures of State intervention by reference to their causes or aims but defines them in relation to their effects" with the result that "the concept of aid is an objective one, the test being whether a State measure confers an advantage on one or more particular undertakings". According to that case-law, therefore, the fact that certain financial advantages are granted to offset extra public service obligations merely represents the purpose or aim of the measure in question, but does not impinge on its effects and, for that reason, has no bearing on its objective status as aid. 


\section{Chapter 21}

And then came the ECJ ruling on "Ferring" [C-53/00] which reversed the case law generated by the CFI and which until that moment held that compensation for extra costs was state aid. That case concerned the preferential tax treatment of wholesale distributors of medicines in France. France argued, successfully, that the preferential tax treatment in the form of tax exemptions was justified on the grounds that public service obligations imposed extra costs on the wholesalers. State aid compensated them for being obliged to deliver medicines within 24 hours of receiving a request and for maintaining a full range of stocks.

In its opinion on the Ferring case, Advocate General Tizzano was in favour of "not classifying as aid public measures intended exclusively to offset the additional net cost arising from the performance of a service of general economic interest. In particular, the fact that such measures do not confer any real advantage on an undertaking entrusted with a service of general interest and therefore are not likely to alter the conditions of competition appears a decisive argument to me." [emphasis added]

He went on to elaborate that "if the State imposes certain public service obligations on an undertaking, then covering the additional costs arising from the performance of those obligations confers no advantage on the undertaking in question, but serves, if anything, to ensure that it is not unjustly disadvantaged vis-à-vis its competitors. In other words the imposition of the obligation and the provision of compensation cannot be considered as separate matters as they are two sides of the same public measure which is intended, as a whole, to guarantee that public interests of primary importance are satisfied. If that is the correct analysis, the conclusion that must be drawn in the situation under consideration is that the measure taken by the public authorities ends up having an economically neutral effect on the undertaking concerned, which derives from it neither advantage nor disadvantage ... Accordingly, normal conditions of competition will only be altered where any compensation exceeds the additional net costs attributable to the performance of public service obligations. In such a case, State intervention will contain an element of aid equal to the surplus over and above the additional cost of the public service obligations, in so far as it confers an unwarranted advantage on the undertaking concerned and may thus distort competition in the market where the public service constraints apply or, where there are cross-subsidies, in other markets in which the undertaking operates." [emphasis added] 
The Court adopted the Advocate General's views. It said that "the French regulation requires only wholesale distributors to have at their disposal a permanent range of medicinal products sufficient to meet the requirements of a specific geographical area and to deliver requested supplies within a very short time over the whole of that area, in such a way that the population as a whole can be guaranteed an adequate supply of medicines at all times. Discharging those obligations entails additional costs for wholesale distributors which pharmaceutical laboratories do not have to bear. In like manner, provided that the tax on direct sales imposed on pharmaceutical laboratories corresponds to the additional costs actually incurred by wholesale distributors in discharging their public service obligations, not assessing wholesale distributors to the tax may be regarded as compensation for the services they provide and hence not State aid within the meaning of Article 87 of the Treaty. Moreover, provided there is the necessary equivalence between the exemption and the additional costs incurred, wholesale distributors will not be enjoying any real advantage for the purposes of Article 87(1) of the Treaty because the only effect of the tax will be to put distributors and laboratories on an equal competitive footing." [emphasis added]

Although Ferring appeared to simplify things, it has in fact complicated them. In his opinion in Altmark Trans [C-280/00], Advocate General Léger proposed that the compensation approach adopted in Ferring should be abandoned. Altmark Trans concerned a case of state aid to providers of public transport services in the region of Altmark in Germany. AG Léger advanced three arguments against the logic of Ferring or the "compensation approach".

He argued, first, that state aid is an objective concept. That is, it is not defined in terms of the intentions or motives of the granting authorities, but in terms of its effects and whether it confers a selective advantage that is capable of distorting competition and affecting intra-EU trade. He criticised the approach followed in Ferring because, in his view, it confused two distinct legal questions, namely the classification of a measure as aid and the justification of that measure. A measure may be found to be state aid but still benefit from exemption. 


\section{Chapter 21}

Second, he thought that the compensation approach was liable to deprive Article 86(2) of its effect, because the provision would no longer apply to cases where the compensation granted did not exceed the costs of the public service obligations (in other cases, this provision could not apply anyway, since any over-compensation which constituted aid could not be necessary within the meaning of Article 86(2)).

Third, he pointed out that the compensation approach diminished the Commission's surveillance role in reviewing measures for financing public services. Member states have a general obligation to notify all state aid schemes to the Commission and to obtain its authorisation before they put them into effect. The Court has not yet ruled on Altmark Trans.

A second, but different, view against Ferring was put forth by Advocate General Jacobs in his opinion in GEMO [C-126/01]. Although the Court has also not yet ruled on GEMO, it is worth considering AG Jacobs's reasons for disagreeing with the logic expounded in Ferring, but also with the position of AG Leger. GEMO concerns the exemption from a special tax of small butchers and farmers in France. The tax is levied on meat retailers for the purpose of financing the mandatory collection and disposal of animal carcasses. The proceeds of the tax are used to pay undertakings which collect and dispose carcasses.

AG Jacobs began by making the following distinction:

"Under Articles 87(1) and 86(2) there are basically two possible ways to analyse state funding of services of general interest. Under the first approach, or 'the state aid approach', state funding granted to an undertaking for the performance of general interest obligations constitutes state aid within the meaning of Article 87(1) which may however be justified under Article 86(2) if the conditions of that derogation are fulfilled and, in particular, if the funding complies with the principle of proportionality."

"Under the second approach, or 'the compensation approach', the term 'compensation' is intended to cover an appropriate remuneration for the services provided or the costs of providing those services. Under that approach, state funding of services of general interest amounts to state aid within the meaning of Article 87 (1) only if and to the extent that the economic advantage which it provides exceeds such an appropriate remuneration or such additional costs. At first sight it seems that the Community Courts' case-law on the correct approach is inconsistent." 
He observed that initially, the Court followed the compensation approach. In subsequent cases, however, the EU Courts followed expressly or implicitly the state aid approach. By contrast, in its recent judgement in Ferring, the Court applied the compensation approach.

Although under both approaches the most important substantive question is essentially whether the state funding exceeds what is necessary to provide for an appropriate remuneration for or to offset the extra costs caused by the general interest obligations, the two approaches, according to AG Jacobs, have very different implications. Where, on the basis of the compensation approach, a given financing measure does not constitute state aid, the measure falls outside the scope of the state aid rules and need not be notified to the Commission. Under the state aid approach the same measure would constitute state aid which must be notified in advance to the Commission.

He then identified certain arguments against a generalised application of the state aid approach in all cases. First, the concept of state aid in Article 87(1) applies only to measures which provide an economic advantage and which distort or threaten to distort competition. In his view, there are no obvious reasons why those two requirements should not apply where state funding of services of general interest is involved. Second, where the state purchases goods (e.g. computers) or services (e.g. room cleaning services) on the markets, there will be state aid only if and only to the extent that the remuneration paid exceeds what is appropriate. Again he can detect no obvious reasons why the analysis should be different where the state purchases services which are to be provided to the collectivity (e.g. waste disposal services).

According to AG Jacobs, the main arguments against a generalised application of the compensation approach are the following. Article 86(2) and the conditions which it imposes would be deprived of any role in the control of state aid. Where state financing does not exceed what is necessary to offset the extra costs of the services provided, there would be no state aid within the meaning of Article 87(1) and thus no need to examine the compatibility of the measure with Article 86(2). In so far as the financing exceeds what is necessary the measure could not be justified under Article 86(2) because it would infringe the principle of proportionality. There would thus be no cases in which the Commission or a national court would be able to control 


\section{Chapter 21}

- whether the services in question in fact constitute services of general economic interest,

- whether the services in question have in fact been entrusted to the undertaking(s) concerned,

- whether the financing in question affects the development of trade to an extent contrary to the interests of the Community (last sentence of Article 86(2)).

AG Jacobs then concluded that: "the key to the correct analysis under Articles 87(1) and 86(2) of state financing of services of general interest might in my view be a distinction between two different categories of cases which is based (i) on the nature of the link between the financing granted and the general interest duties imposed and (ii) on how clearly those duties are defined. In accordance with the proposed distinction the first category would comprise cases where the financing measures are clearly intended as a quid pro quo for clearly defined general interest obligations, or in other words where the link between, on the one hand, the state financing granted and, on the other hand, clearly defined general interest obligations imposed is direct and manifest. The clearest example of such a direct and manifest link between state financing and clearly defined obligations are public service contracts awarded after public procurement procedures: one and the same contract defines the obligations of the undertakings entrusted with the services of general interest in question and the remuneration which they will receive in return. Cases falling into that category should in my view be analysed according to the compensation approach." [emphasis added]

"The second category consists of cases where it is not clear from the outset that the state funding is intended as a quid pro quo for clearly defined general interest obligations. In those cases the link between state funding and the general interest obligations imposed is either not direct or not manifest or the general interest obligations are not clearly defined. A good example of that category is Banco Exterior de España in which a Spanish law exempted all public banks from the payment of taxes. The law did not indicate that that advantage was intended as a quid pro quo for the fulfilment of general interest obligations nor did it define exactly any such obligations. Only before the Court did the Spanish government allege that the exemption was necessary for the fulfilment by public banks of their function of 'administering the public provision of credit.' Cases in the second category should in my view be analysed according to the state aid approach." 
More recently a third voice has been added on the issue of compensation of extra costs with the opinion of Advocate General Stix-Hackl on cases C34/01 to C-38/01 [Enirisorse SpA v Ministero delle Finanze]. These cases concern an Italian law that entrusts the management of stevedoring equipment, warehouses, depots and other port property to certain undertakings in Italian ports. In order to perform their statutory tasks, these undertakings have available to them, among other things, two thirds of port charges levied on goods passing through those ports.

AG Stix-Hackl began her analysis by "noting that if one proceeds on the basis that the determination of whether a measure constitutes state aid requires an investigation into whether the recipient undertaking receives an economic advantage which it would not have obtained under normal market conditions [SFEI, C-39/94], then it must be examined whether the recipient undertaking supplies a service which is normally supplied in return for consideration and whether the consideration actually given was reasonably proportionate to that service." [emphasis added] She seems to imply that state aid in these circumstances could be considered as payment for services normally procured by public authorities. The only difference is that the SGEI provider supplies the services to consumers instead of the authorities and on behalf of those authorities.

But then she goes on to note that "the compensation approach taken in Ferring may be adopted only where the service and the consideration are clearly identifiable. However, as regards services of general economic interest, it is to be observed that it is difficult to find a standard for assessing the proportionality of the compensation, since services of general economic interest are supplied usually where market forces alone do not result in a satisfactory provision of services." Indeed, how can that compensation be considered as normal procurement of services when public authorities offer compensation without having first selected the most efficient provider as they would normally do under public procurement procedures.

She also admits that "where the general interest duties have not been clearly defined, it is not possible to adopt the compensation approach. This is because in such cases it is ex hypothesi impossible to calculate the burdens (i.e. the costs) resulting from them with sufficient precision. In such cases, it 


\section{Chapter 21}

is impossible to find the direct and manifest link to the obligations undertaken which Advocate General Jacobs required."

AG Stix-Hackl appears, therefore, to be siding with AG Jacobs favouring a differentiated compensation approach, provided that there is a clear link between the costs of the SGEI and the obligations imposed on the recipient of public funds. She also notes that where SGEI are provided in the absence of competition or where the provider is obliged to supply services no one else supplies voluntarily it would be difficult to determine the proportionality of aid. In practice this would mean that the SGEI provider may receive subsidies for costs which are not directly linked to the SGEI itself.

In conclusion, we see in all opinions quoted above a fleeting and implicit recognition of the need for having a benchmark for determining the proportionality of aid granted to compensate providers of SGEI. This proportionality is to be determined according to the costs borne by the providers in relation to the costs they would incur under normal market conditions. We also see that there is the impression that compensation for imposed extra costs somehow restores fair competition.

In fact I will argue in the rest of this chapter that it is impossible to obtain an objective benchmark when ignoring the costs of other potential providers of similar services. More importantly, mere compensation does not restore fair competition. On the contrary, it may distort it even more and in less transparent manner. The only objective benchmark is that which is obtained from open and competitive selection procedures that allow all potential providers to submit bids.

I believe that the case law itself justifies the approach of this chapter. In the case BAI v Commission [T-14/96] concerning the mass purchase of ferry tickets by the Basque authorities for the purpose of distributing them to certain groups of people, the CFI ruled that even though the tickets were purchased at apparently market prices, the company which sold the tickets still obtained an advantage. The reason was that the Basque authorities purchased a very large amount of tickets for which there was no apparent demand. The CFI found that that was not a normal commercial transaction. 
Similarly, I will argue that, since public measures are assessed on the basis of their effects, we need to examine whether the providers of SGEI who are compensated for the extra costs derive an advantage they would not otherwise obtain under normal market conditions. The advantage may be conferred by the fact that the compensation is not offered through open, competitive procedures. In the market, the purchasers of goods seek to buy them from the cheapest source so as to minimise their outlay. I will show that by not seeking to minimise the amount of aid they grant to SGEI providers, public authorities grant a larger subsidy or indirectly enable the recipient to become more competitive in adjacent markets. Either possibility distorts competition. This happens even if the amount of aid does not exceed the apparent accounting cost of the SGEI.

\subsection{A critique of the proposed solution of distinguishing between a "compensation" and a "state aid" approach}

Before explaining how the distortion to competition arises, it is instructive to understand why the differentiated approach preferred by Advocates General will not provide a satisfactory solution to the problem of compensatory state aid. It suffers from at least three weaknesses.

First, it is not easy to make a distinction between obligations imposed on certain undertakings and obligations imposed on undertakings in general. I do not refer here to the issue of insufficiently clear obligations. This has been dealt by the case law concerning Article 86(2) and it is well understood that a SGEI provider can benefit from the dispensation provided by Article 86(2) only when the public service obligation defines precise tasks. A general obligation to "serve the public" or "promote public interests" will simply not do. But the question I raise here is different. It is not about the specificity of the obligation but about the specificity of the undertakings under the obligation.

Since the reason why the specificity of the undertakings under the public service obligation is to determine whether those undertakings can avoid it or not, it seems to me that that specificity is an admissible grounds for exemption only when it names particular undertakings. For example, assume that a public authority in a Mediterranean member state imposes an obligation on all taxi companies during summer months to provide inner-city 


\section{Chapter 21}

air-conditioned rides at specified temperatures. Use of air-conditioning raises fuel consumption and, hence, operating costs. This is claimed by the public authority concerned to constitute grounds for compensating taxi companies for the cost of the extra fuel that is consumed. The obligation is very explicit and clear. It goes beyond the general obligation to transport passengers in safety and comfort. The obligation is also specific: it applies only to taxi companies that provide inner-city rides. Ignore for the time being the fact that the some or even all taxi companies could voluntarily offered airconditioned rides simply because in the summer months customers would be willing to pay a reasonable extra fare.

The obligation is really binding only on those who cannot avoid it by leaving the market. It follows, therefore, that only when the law or regulation that defines the public service obligation names particular undertakings can we conclude that both the obligation and associated costs are unavoidable. In all other cases, such an obligation should be regarded just as another government regulation that affects business. Firms will take into account those regulations when making a decision to enter the market or undertake new investments after they establish in the market or exit the market. However, even if the obligation names the firms to which it applies, I will explain in the following section that competition may still be distorted.

The second weakness of the compensation approach follows from the argument above. Why should state aid rules make a distinction between the extra costs of public service obligations and the costs of other regulations on business? Perhaps one may believe that the difference is that normal business regulations assure product quality or safety while public service obligations concern services offered directly to consumers. This is indeed the case with some regulations such as those concerning safety. No business "sells" unsafe products or dangerous working environments. But one cannot generalise from this example that this distinction holds for all regulations.

For instance, insurance salesmen are under obligation in the UK to allow for a "cooling off" period before contracts become binding. This is because regulators want to protect the public from high-pressure sales techniques. This regulation raises the costs of selling insurance cover. The same customer has to be contacted twice. But is this not a service to the public? While it is realistic to say that there is no market for dangerous working environments or carcinogenic food stuffs, it is conceivable that consumers 
would be willing to "buy" a cooling-off period as a form of insurance against their own rash decisions. At present when you buy a holiday package most travel agents also ask whether you need travel insurance. The two products are separated. The government, however, could have regulated that a minimum travel insurance is part of the package in the way they have done with airline delays.

It is difficult, perhaps impossible, to make a general case supporting a meaningful distinction between business regulations and public service obligations. Business regulations do contain obligations towards the public and some of these obligations are nothing else but services. Once the artificial nature of the distinction between regulations and public service obligations is recognised, then it become even more difficult to understand why state aid rules may allow compensation for the latter but not the former.

Even more worrisome for the integrity of state aid control in the EU is the likelihood that once member states realise that they can stretch the meaning of compensatory aid to cover other kinds of obligations imposed on undertakings, the floodgates of state aid will be thrown wide open. For example, under present rules, public funding of training within firms is a form of state aid. What would happen if a member state passed a law obliging firms in selected sectors to train their employees and offered compensation at the same time? Would it still be regarded as state aid?

The member state could argue that by forcing companies to train these employees, it pre-empts social disruption from long periods of unemployment in the even they are laid off. Well trained workers can presumably find another job more easily. If the pending court cases mentioned earlier uphold Ferring, I will indeed be surprised if national authorities do not attempt to exploit this ambiguity. I also think that it will be very difficult for national courts to rule on cases brought before them concerning compensatory aid.

The third weakness of the compensatory approach is about the meaning of compensation itself. The case law refers to the "extra costs" of obligations. It does not stipulate that related revenue must be subtracted from any state aid granted. The Commission, however, in its practice does take related revenue into account [see, for example, Commission Decision 2001/156 on aid granted to Trasmed, OJ L57, 27/2/2001]. I want to show with a numerical 


\section{Chapter 21}

example that even when there is no identifiable revenue from the public service obligation, the undertakings under the obligation may actually benefit from it. Not only does state aid have no incentive effect, but it is misleading to consider only the extra costs without taking into account other benefits because consumers perceive a product of different quality.

Following the example of the taxi companies above, assume that the typical urban taxi in that Mediterranean member state performs 30 rides per day [assume that these are standard rides of say 5 or 10 kilometres]. Fares are regulated and each ride generates revenue of eur 5 so that total revenue is eur $150 /$ day. The costs of the taxi are eur 20/day for the depreciation of the car, the road tax, the taxi licence and the air-conditioning unit, eur 60 for the wages of the driver and eur 55 for fuel. Total costs are eur 135, leading to profit of eur 15. The use of air-conditioning raises the cost per ride by eur 0.33 . This means that for the 30 rides, each taxi incurs eur 10 [ $=30 \times 0.33$ ] of extra costs. Should this company receive compensatory state aid?

There is no doubt that air-conditioned taxis offer an added service to their customers. Is this a public service for which taxi companies should be compensated? Well, it depends on how the member state in question justifies the imposition of the public service obligation. The Ferring case and all the other pending cases also involve services whose relationship with the concept of SGEI is dubious. ${ }^{241}$ But for the sake of argument assume that it is a SGEI. The point I want to make here is that the legal obligation to install air-conditioning in taxis may actually boost demand for their services.

Assume that before the obligation was imposed, the typical taxi would supply only 20 rides per day. Therefore, total revenue was eur 100 . The operating costs were eur 5 for depreciating costs plus, eur 60 for wages and eur 30 for fuel. In total, costs amounted to eur 95, with profits of eur 5. This means that after the obligation is imposed profits increase because the quality of the service improves.

Although this is an artificial example, the essential point is that in the absence of information on how the market would value the service without

\footnotetext{
${ }^{241}$ For various definitions of the concept of SGEI, see Commission Communication on SGEI in Europe, COM(2000), 580 final, OJ C17, 19/1/2001; and the very recent Green Paper on Service of General Interest, COM(2003), 270 final, 21/5/2003.
} 
the public service obligation, it is impossible to know whether undertakings would leave the market. Taxi companies in this example would argue that costs have increased while fares remain the same. But even when there is no identifiable related revenue, undertakings may still obtain a hidden benefit. The market here is the ultimate test. As long as undertakings have the option of leaving the market but instead choose to remain in it after the obligation is imposed, we must conclude that there is no need for state aid. In the penultimate section I will explain what a public authority should do when the public service obligation raises operating costs of undertakings and as a result reduces the supply of the SGEI to consumers.

In the following section I examine the distortions to competition caused by the granting of compensatory aid.

\subsection{The distortions to competition caused by compensatory state aid}

Consider the case of a firm that receives subsidies to provide a SGEI in market M. Also assume that the revenue it earns plus the subsidy it receives just cover its costs, including variable and fixed costs. The same firm also intends to provide a related product in another market called $\mathbf{C}$. The second market is open to competition so other firms also operate in that market. The price in market $\mathbf{M}$ is fixed by public authorities, while the price in market $\mathbf{C}$ is determined by the competitive interaction between different firms.

If the firm supplies only market $\mathbf{M}$, it receives a subsidy which is equal to the difference between sales or revenue, $\mathbf{R}$, and costs, $\mathbf{C}$, in that market. That is, $\mathbf{S}=\mathbf{C}-\mathbf{R}$, where $\mathbf{S}$ is the amount of state aid. The cost component, $\mathbf{C}$, includes both variable and fixed costs. Assume that the subsidy is half the amount of the firm's fixed costs. The other half of the fixed costs plus all the variable costs are covered by the revenue it earns in market $\mathbf{M}$.

Assume now that the firm enters market $\mathbf{C}$. To facilitate the presentation of the problem, also assume that the variable costs of the firm in question in each market, after it enters market $\mathbf{C}$, are of equal size. Under the conditions described above, it can sell its product in market $\mathbf{C}$ and make a profit as long as the price that prevails after its entry more than covers its variable costs. This is because its fixed costs are covered by revenue it earns in market $\mathbf{M}$ and the subsidy it receives. 


\section{Chapter 21}

If the firm maintains the price it charges in market $\mathbf{C}$ at the level where it just covers its variable costs, other firms in that market will naturally claim that this is unfair competition because the firm charges no fixed costs to the product it sells in market $\mathbf{C}$. Please note that in economic theory there is no general prescription of how fixed costs should be allocated. A widely quoted rule, the so-called "Ramsey" rule, only says that prices of multi-product firms should be inversely proportional to the elasticity of demand facing each of those products. This entails that a proportionately larger share of fixed costs is borne by products whose price is inelastic. See the classic analysis by Baumol and Bradford (1970).

If the firm allocates its fixed costs in proportion to the size of its variable costs in each market, then it will have to attribute half of its fixed costs to sales in market $\mathbf{C}$. If the total cost in market $\mathbf{C}$ is then higher than the postentry market price, it will not be able to compete and will have to withdraw.

But the firm in question can avoid this problem by allocating fewer fixed costs to market $\mathbf{C}$. To understand how this can happen suppose the variable costs of the firm in market $\mathbf{M}$ increase by $10 \%$. This means that the new total costs (variable plus fix cost) in that market will rise to $(1.1 \mathbf{V m}+\mathbf{F})$. If the revenue in that market stays constant, the subsidy will have to increase to cover the extra costs. If we assume that fixed costs, $\mathbf{F}$, are allocated between the two markets in proportion to the size of the operations of the firm in the two markets and that size is given by its variable costs, then the allocation of fixed costs to market $\mathbf{M}$ will be

$\mathbf{F m}_{1}=\mathbf{F} \times(1.1 \mathbf{V m} /(1.1 \mathbf{V m}+\mathbf{V c}))$, where subscript 1 indicates the costs after the increase.

It follows that

$$
\begin{aligned}
& \mathbf{F} \mathbf{m}_{1}>\mathbf{F m}, \quad \text { because } \mathbf{F} \times(1.1 \mathbf{V m} /(1.1 \mathbf{V m}+\mathbf{V c}))>[\mathbf{F} \mathrm{x} \\
& (\mathbf{V m} /(\mathbf{V m}+\mathbf{V} \mathbf{c}))]
\end{aligned}
$$

This firm, by doing nothing, just allowing its inefficiency to rise in the market where it receives a subsidy, all of a sudden becomes more competitive in market $\mathbf{C}$ which is open to competition. This result holds even if the firm is forced to allocate its fixed costs proportionately between the two markets. We now arrive at the paradoxical result that inefficiency is rewarded by public policy! In two other papers I analyse related cases which also generate such paradoxical outcomes. See Nicolaides (2002a and 2002b). 
We should note that when the firm holds a dominant position in the EU market, cross-subsidisation of a competitive activity by an activity which is closed to competition would constitute abuse of dominance and would be contrary to Article 82. A firm that has a legal monopoly that extends across the territory of a member state would normally be found to be dominant in the common market. But under the conditions described above where the price charged in market $\mathbf{C}$ exceeds variable costs plus an appropriate portion of fixed costs it would not be regarded as abusive. It would, therefore, escape the prohibition of Article 82. Competition policy is incapable of preventing this kind of distortion to competition caused indirectly by subsidies to providers of SGEI. Not only do they escape the net of competition policy through an explicit exception, they escape its reach for a second time when subsidies allow them to use increases in the costs of providing the SFEI to reduce the portion of fixed costs they allocate to competitive services.

Perhaps the reader may think that I am exaggerating my point. Well, the Commission itself in its Communication on Aid to Public Service Broadcasting [OJ C320, p.5 15/11/01] states in paragraph 53 that it will take action against broadcasters who, while receiving state aid in order to carry out a public mission, also supply other services at a price which falls below their "stand-alone" cost. The stand-alone cost includes all fixed costs necessary for the production of a particular product. The Commission justifies its attitude on the grounds that state aid confers to the recipient an advantage that may be exploited for the purpose of expanding its share in the market of related services.

The standard defined by the Commission, i.e. the stand-alone cost, is admittedly stricter than the standard I have used in my analysis. This is because the stand-alone cost of a product is higher than a proportional allocation of fixed costs to all products provided by a certain firm. But if the Commission is worried about prices below such higher level, then the risk of distortion of competition is certainly greater when prices fall below the lower level defined by proportionally allocated fixed costs.

Had the public authority concerned chosen the provider of the SGEI through an open and competitive procedure, the amount of subsidy would have been fixed at the outset to the minimum possible level. The chosen firm would not have been able subsequently to exploit any rise in its costs of the SGEI. As 


\section{Chapter 21}

the subsidy would have been capped the firm would suffer losses. This is precisely the reason why economics has no rules on the allocation of fixed costs. In order to gain an advantage in one market simply by reallocating costs, a multi-product firm must apportion a bigger share of those fixed costs to another market. But then it becomes vulnerable to entry by competitors. The threat of or actual entry is the disciplining factor that ensures that only truly efficient firms survive. This discipline is absent when providers of SGEI are shielded from competition through compensatory state aid.

In section 6, I come back to the issue of allocation of aid through competitive procedures. I examine whether it is legally possible under the present EU rules to oblige public authorities in the member states to use auctions or other competitive procedures [e.g. tenders] to select the providers of SGEI and limit the amount of state aid granted to them. Before examining this issue, the next section considers the case of fiscal state aid to SGEI providers.

\subsection{The special case of tax incentives}

The public aid which has been granted to compensate providers of SGEI has taken mainly two forms: either direct subsidies [grants] or reductions of tax liability. So far this chapter has looked at direct subsidies. This was, for example, how Spain compensated a company that provided maritime transport services between the mainland and some islands [see Commission Decision 2001/156 on aid granted to Trasmed, OJ L57, 27/2/2001]. For the sake of completeness we also need to have a closer look at tax reductions.

There are two kinds of tax reductions: exemption from profit or income tax and exemption from sales tax. Consider first the exemption from profit tax. This kind of tax applies only when a firm makes profit. That is, its revenue must exceed its costs. But if the firm still makes profit after the public service obligation raises the operating costs, aid is unnecessary. Aid will simply make it even more profitable. In this case the distortion to competition will come about for the same reason as that explained in the previous section: state aid enables the firm strengthen its position in or enter adjacent markets by having part of its fixed costs covered by the subsidy. If the firm already operated in the market before the public service obligation was imposed, if it would not cover the variable costs of the service in 
question it would not sell it. When it receives aid to sell it, it can also charge part of its fixed costs which, without the aid, would have to be fully apportioned to other products or services.

In the opposite instance where its costs exceed its revenue, it will make no profit. But now relief from profit tax is useless because it does not have to pay any tax. So we see that when profits are positive, exemption from profit tax is unnecessary and when profits are negative, exemption from profit tax is ineffective. I will examine in the following section what a public authority may do when the increase in operating costs due to the public service obligation forces the firm to suffer losses and leave the market.

Consider now reductions of sales tax. That was the situation in Ferring. Manufacturers of pharmaceutical products had to pay a special sales tax. This means their profits before income tax were:

$\boldsymbol{\pi}=\mathbf{R}-\mathbf{R t}-\mathbf{C}$, where $\mathbf{t}$ is the tax rate and $\mathbf{R t}$ is the amount of tax that has to be paid

Wholesale distributors were exempted from the sales tax. The Court concluded that as long as the amount of the sales tax was less than the extra costs incurred due to the public service mission [i.e. $\mathbf{R t}<\mathbf{C}$ ], then there was no state aid. To simplify things, assume that the firm provides only one product, that subject to the public service obligation, so that all of its costs are extra costs.

On the face of it, relief from sales tax appears to be different from relief from profit tax. This is because, as long as revenue exceeded costs, the profit tax was irrelevant to the decision of a firm whether to enter the market or not. It still made a profit in an economic sense [i.e. costs include the opportunity cost of capital]. By contrast, the firm has to take into account the amount of the sales tax because it reduces directly its revenue.

Even under these conditions, note again, that public authorities do not know whether a firm would make profit even after paying the sales tax and, therefore, would voluntarily enter the market without asking for any state aid. If $(\mathbf{R}-\mathbf{R t}-\mathbf{C})>\mathbf{0}$, the aid is unnecessary. It follows that the necessary amount of aid is not that which compensates the firm for all its extra costs but that which merely returns it to profitability. To see the difference assume that

$$
(\mathbf{R}-\mathbf{C})>\mathbf{0} \text {, but }(\mathbf{R}-\mathbf{R t}-\mathbf{C})<\mathbf{0} \text {, }
$$




\section{Chapter 21}

while the condition imposed by the Court holds, i.e. $\mathbf{R t}<\mathbf{C}$

Since the tax amount is less than the extra cost, the European Court of Justice would count the whole of the tax amount, Rt, as not being state aid. But this may be too much. The tax reduction which is truly necessary is only that which returns the firm to profitability [i.e. $\mathbf{R}=\mathbf{C}$ ]. It follows that the amount of the required subsidy, $\mathbf{S}$, is

$\mathbf{S}=\mathbf{R t} \mathbf{-}(\mathbf{R}-\mathbf{C})$, which is less than $\mathbf{R t}$

Once more we see that compensation of firms without regard as to whether they would voluntarily serve the market or not, in fact results in over compensation. This must distort competition between firms and give an advantage to those firms that need state aid less than others! Our conclusion, therefore, must be that this form of aid is state aid within the meaning of Article 87(1) for the reason that public authorities do not know whether they grant an unnecessary advantage.

But suppose that the tax liability of the firm exceeds its extra cost, i.e. Rt $>$ C. There is still a problem. The amount of subsidy, $\mathbf{S}$, that can be claimed by the firm is now equal to $\mathbf{C}$. This means that between two firms that have equal tax liability because they have the same amount of sales and generate exactly the same amount of revenue, the less efficient firm with the higher costs will receive a larger subsidy. The competitive advantage of the more efficient firm is reversed! The total expenses of either firm is the sum of the operating costs and tax liability; i.e. $(\mathbf{R t}+\mathbf{C})$. Since they obtain a subsidy which is equal to the costs of providing the SGEI, the net expenses are $\left(\mathbf{R}_{\mathbf{1}} \mathbf{t}\right.$ $\left.\mathbf{C}_{1}\right)$ for the first firm which is assumed to be more efficient and $\left(\mathbf{R}_{\mathbf{2}} \mathbf{t}-\mathbf{C}_{\mathbf{2}}\right)$ for the second firm. Since $\left(\mathbf{C}_{\mathbf{1}}<\mathbf{C}_{2}\right)$, the more efficient firm will end up paying a larger amount of tax.

The situation gets worse if these firms also provide other services not subject to public service obligations. Like before, if the costs which we considered above also include a share of the fixed costs to be borne by the SGEI, it means that the less efficient firm will be able to have a larger proportion of its fixed costs subsidised by including them in the extra costs of the SGEI. In the process it strengthens its competitive advantage in an adjacent market. State aid for one service distorts competition in the market for related services. Since this kind of state aid cannot be presumed to restore competitive advantage, it must fall within the scope of application of Article $87(1)$. 
The remedy to these problems is to auction the obligation (or contract) to provide the SGEI in question together with the minimum required amount of subsidy. Firms would have an incentive to ask for the lowest amount of subsidy. At present they ask for the maximum permitted by law. The minimum which is economically necessary is certainly not the same as the maximum which is legally allowable.

\subsection{Re-interpreting Article 87}

Under the prevailing interpretation and application of Article 87 on state aid, subsidies or other aid to compensate undertakings for the extra costs imposed on them by public authorities are not regarded as state aid, regardless of the efficiency of the beneficiaries in relation to their competitors.

But as explained above, the problem with this approach is that it weakness the incentives to firms to keep costs low. It weakens the discipline imposed by the market on firms to keep their costs at least as low as those of their competitors. Even worse, this kind of state aid may enable firms to expand into adjacent markets without being caught by any of competition rules and gives an advantage to less efficient firms.

Advocates General of the European Court of Justice have tried to grapple with this problem by creating more narrow definitions of the kind of subsidies that may escape being classified as state aid. In section 3, I identified three weaknesses in this approach. It is doubtful whether it will solve the legal problem. Certainly, it will not solve the economic problem. There will still be a distortion to competition irrespective of whether the compensation falls outside Article 87(1) and irrespective of whether the compensation is found to be state aid but then exempted under Article 86(2).

The only solution to the economic problem of minimising the distortion to competition caused by compensatory state aid is to minimise the amount of state aid that is eventually granted, by relying on auctions or open procedures. 


\section{Chapter 21}

Before examining how such open procedures may be used to minimise the amount of state aid necessary, I want to explain why the prevailing interpretation of the application of state aid rules to compensation for the extra costs of SGEI is faulty. Remember that the Court in Ferring and the opinions of the Advocates General implied that this kind of compensation merely eliminates competitive disadvantage. For a public measure to be classified as state aid, it must, among other things, confer an advantage to certain undertakings that they could not obtain under normal market conditions. But as shown in the previous two sections, far from restoring a level playing field, compensation as currently done strengthens anticompetitive advantages.

The first fault is that, unless the public service obligation is imposed on a certain firm explicitly, any disadvantage may be avoidable. The firm concerned may choose not to supply the SGEI in question. But how do public authorities know that such unwillingness would prevail in each and every case? They do not. So, they may be subsidising something that firms may do voluntarily. Even if the total costs allocated to the SGEI through accounting methods exceed the revenue from the SGEI, how do public authorities know that beneficiary firms have not simply re-allocated fixed costs so that the accounting costs of the SGEI exceed its true incremental costs? Again, they do not.

More importantly for legal purposes, what is the difference between the extra costs of public service obligations and other costs imposed by the normal regulation of businesses, such as the obligation of lenders or insurers to have a cooling off period during which borrowers or clients can break off contracts without penalty, the obligation of food manufacturers to list the nutritional value of the ingredients they use, the obligation of airlines to compensate passengers for cancelled flights or the obligation of employers not to fire under-performing workers without first giving them one or more warnings. All these regulations add to the costs of doing business. Yet, firms voluntarily enter regulated markets and industries without obtaining state aid. It is not clear to me at all why classification of an obligation as a public service mission justifies granting of public aid which is not state aid while public aid to relieve costs imposed by other regulations is regarded as state aid. 
The second fault is the opposite of the first. The problem above is that firms by allocating their fixed costs to the subsidised activity they can justify receipt of aid to cover seemingly higher costs. There is a problem, when by shifting fixed costs, firms can artificially reduce the costs of other activities. Beneficiary firms, even when they cannot avoid the public service obligation, can turn the seeming disadvantage into a surreptitious advantage in supplying related services. Since state aid rules do not prohibit a firm receiving state aid from engaging in other activities, subsidised suppliers of SGEI can always expand into related but apparently non-subsidised activities. Current enforcement of Article 87 cannot prevent these problems because firms have much discretion in how they allocate their fixed costs among their various activities. There are several credible accounting methods for doing so.

These problems are compounded by the fact that the amount of compensation allowed under state aid rules is open-ended, as long as it remains below the amount of the extra costs of the public service obligation. The way to avoid these problems is to impose a ceiling on permissible state aid.

Can auctions or other open procedures minimise the amount of state aid? I think the answer is yes. When firms bid for the right to provide a SGEI and obtain the related subsidy they can win only by asking for as small a subsidy as possible. They have a strong incentive to minimise both the variable and fixed costs of the SGEI. This means that they will be allocating fixed costs to other activities, rather than shifting them to the subsidised operations as was the case above!!

Another important advantage of open procedures is that once a contract is won, the amount of the subsidy is fixed. Firms may be able to raise their profits by reducing their costs by a greater degree than the authorities expected. But this is not so bad because it would mean that those firms become more productive and use resources more efficiently. If, by contrast, their costs rise faster than they expected, their share holders will have to bear the losses and would naturally take measures against the management of the firms. In either case it is unlikely that the firms that receive the subsidy would be able to use it to cross-subsidise adjacent operations and gain an unfair advantage over their competitors. 


\section{Chapter 21}

Can the use of open procedures be demanded from the member states? Again, I think the answer is yes, even without revising the present state aid rules. The Commission should only re-interpret it as I am suggesting here. The justification is that any direct allocation of aid cannot be presumed not to distort competition and confer a selective advantage to the recipient firm. This is also what the Court of First Instance said in SIC [T-46/97]. One must examine whether the granting of direct aid, even if it compensates for extra costs, confers other kinds of advantage. I have shown in this chapter that it does. Moreover, the solution I propose respects the neutrality between private and public undertakings, demanded by Article 295.

If the direct granting of aid or through closed procedures is state aid, does it mean that the granting of public assistance via open and competitive procedures is not state aid? I believe the answer must be yes because there is no distortion of competition among actual or potential suppliers of SGEI. However, if the services are not supplied to the general public, as in the case of GEMO, then there may be an indirect granting of state aid due to the distortion of competition among the users of the services in question. ${ }^{242}$ This solution deals both with the legal and the economic problem of compensation for the extra costs imposed by public service obligations.

\subsection{Conclusions and recommendations}

The providers of services of general economic interest are, under certain conditions, exempted from the competition rules of the EU that normally apply to all enterprises regardless of economic sector. This exception appears to have widened as a result of a recent decision of the European Court of Justice.

There is now intense political debate in the EU on how SGEI should be treated in the future, whether they should receive public funds, whether they should continue to be subject in principle to the rules of competition and whether they should be exempted more explicitly and widely than at present.

\footnotetext{
${ }^{242}$ To understand this distinction between primary and secondary beneficiaries and between direct and indirect granting of aid see Commission Decision 2000/389 on English partnerships, OJ L145, 20/6/2000, and the Commission Communication on Risk Capital, OJ C235, 21/8/2001.
} 
The chapter has examined how state aid rules impact on the provision of SGEI and proposes a different interpretation of Article 87 so that public policy objectives can be achieved as efficiently as possible. In order to remedy the weaknesses it has identified in the current practice on SGEI, the chapter proposes a different approach to treating SGEI providers under state aid rules. This approach leads to a more efficient allocation of resources, given the constraint that the public policy objective of reaching citizens is preserved.

The proposal is rather simple. Both competition rules and public policies aim to raise the availability of SGEI. This aim can be more effectively achieved by enabling the most efficient operators to enter the market. Auctions or open selection procedures distort competition less than the granting of direct subsidies to certain enterprises.

Compensation for the extra costs of public service obligations is unnecessary unless the obligation has a negative effect on market supply. Compensation would then be justified to induce undertakings to increase their supply. To ensure that only the minimum aid is offered, auctioning is an efficient policy tool. This kind of compensation would not normally be regarded state aid, but the users of the SGEI, in case they are undertakings, may still receive indirect aid.

\section{Epilogue: The implications of the Altmark judgement}

The research and the drafting of this chapter were completed in April 2003. It was accepted for publication in June 2003. On 24 July 2003, the European Court of Justice issued its judgement on the Altmark case (C-280/00). Here I examine the main aspects of the judgement and consider how they relate to the thesis of this chapter.

On the issue of whether compensation of the costs of public service obligations constitutes state aid, the Court ruled as follows:

"87. ... "where a State measure must be regarded as compensation for the services provided by the recipient undertakings in order to discharge public service obligations, so that those undertakings do not enjoy a real financial 


\section{Chapter 21}

advantage and the measure thus does not have the effect of putting them in a more favourable competitive position than the undertakings competing with them, such a measure is not caught by Article 87(1) of the Treaty.

88. However, for such compensation to escape classification as State aid in a particular case, a number of conditions must be satisfied.

89. First, the recipient undertaking must actually have public service obligations to discharge, and the obligations must be clearly defined. In the main proceedings, the national court will therefore have to examine whether the public service obligations which were imposed on Altmark Trans are clear from the national legislation and/or the licences at issue in the main proceedings.

90. Second, the parameters on the basis of which the compensation is calculated must be established in advance in an objective and transparent manner, to avoid it conferring an economic advantage which may favour the recipient undertaking over competing undertakings.

91. Payment by a Member State of compensation for the loss incurred by an undertaking without the parameters of such compensation having been established beforehand, where it turns out after the event that the operation of certain services in connection with the discharge of public service obligations was not economically viable, therefore constitutes a financial measure which falls within the concept of State aid within the meaning of Article 92(1) of the Treaty.

92. Third, the compensation cannot exceed what is necessary to cover all or part of the costs incurred in the discharge of public service obligations, taking into account the relevant receipts and a reasonable profit for discharging those obligations. Compliance with such a condition is essential to ensure that the recipient undertaking is not given any advantage which distorts or threatens to distort competition by strengthening that undertaking's competitive position.

93. Fourth, where the undertaking which is to discharge public service obligations, in a specific case, is not chosen pursuant to a public procurement procedure which would allow for the selection of the tenderer capable of providing those services at the least cost to the community, the 
level of compensation needed must be determined on the basis of an analysis of the costs which a typical undertaking, well run and adequately provided with means of transport so as to be able to meet the necessary public service requirements, would have incurred in discharging those obligations, taking into account the relevant receipts and a reasonable profit for discharging the obligations.

94. It follows from the above considerations that, where public subsidies granted to undertakings expressly required to discharge public service obligations in order to compensate for the costs incurred in discharging those obligations comply with the conditions set out in paragraphs 89 to 93 above, such subsidies do not fall within Article 92(1) of the Treaty. Conversely, a State measure which does not comply with one or more of those conditions must be regarded as State aid within the meaning of that provision."

Although this judgement is a step in the right direction, it has not solved all problems related to the issue of compensation of public service obligations. In some respects that are explained below this judgement has opened up new points of uncertainty.

The judgement will make it more difficult for public authorities to grant state aid to any undertaking on which they have imposed public service obligations. The judgement reiterates the established point of law that compensation must not exceed the extra costs of public services obligations and goes on to stipulate that compensation must be clearly linked to an explicit public service obligation.

More significantly, the judgement adds two novel conditions. First, it requires that the terms of compensation must be set before hand in an objective and transparent manner. This condition can only strengthen competition because it will force beneficiary undertakings to assume at least part of the risk of their operations. One of the sources of distortion to competition identified in this chapter was that compensatory aid shields operators of public services from their own inefficiencies. They can let their costs to creep up in the knowledge that the state will compensate them. This gives them an unfair advantage over potential competitors. The requirement that the conditions of compensation, which presumably should also include the amount of compensation, must be determined ex ante should prevent 


\section{Chapter 21}

beneficiary operators from passing all of their commercial risk to the state and at the expense of competitors.

The second novel condition is the recognition that compensation is not supposed to cover any costs claimed to be "extra" by the beneficiary undertakings. The Court implicitly favours the use of public procurement procedures which is exactly what has been advocated in this chapter. But the Court stops short of actually imposing this as a requirement on member states.

However, the Court in essence stipulates that recipients of aid must be at least as efficient as the "typical undertaking". This is because the level of compensation is to be set with reference to the costs of the "typical undertaking". I believe that this must be the first ever case where such requirement is elaborated. If I am not wrong, this condition goes against recent trends in the case law on Article 86(2), where providers of SGEI appear to be treated more favourably and, as a result, protected from more efficient competitors [see, for example, Albany International BV v Stichting Bedrijfspensioenfonds Textielindustrie, C-67/96; TNT Traco v Poste Italiane, C-340/99]. This, however, is not the place for a comparison between Article 87 and $86(2)$.

What is important is that public authorities may not grant unlimited amounts of aid without regard for the efficiency of the recipient undertaking relative to its competitors. Although this appears to be a considerable boost to competition, I wonder how useful it will prove to be in practice. What is this "typical undertaking" which is "well run and adequately provided" with the necessary means to carry out its tasks? There is so much room for interpretation of these few words, especially when bearing in mind that in network industries the competitors are usually not more than a handful.

Moreover, what happens when the costs of the beneficiary undertaking are in some years lower and in some years higher than those of potential competitors? It will become necessary to establish a benchmark time period. But, how long should that period be? What happens when during the benchmark period a firm has relatively higher costs, but then undertakes restructuring to reduce its costs and upgrade its services? Should it be excluded from compensation? These questions suggest that the benchmark defined by the Court is essentially "backward-looking" whereas tender and 
other open selection procedures are "forward-looking". The latter method of selecting undertakings is based on firmer economic foundations because what matters is the expected future costs of delivering a service.

On the basis of this brief examination, which at this stage must be regarded only as preliminary, I conclude that the Altmark judgement is a step in the right direction. It will make it more difficult for member states to grant unlimited amounts of aid and to cover the costs of certain firms irrespective of the efficiency of excluded competitors. But the ambiguity of the benchmark defined by the Court in terms of a "typical undertaking" which is "well run and adequately provided" will not necessarily force public authorities to deviate significantly from current practices. 


\title{
Chapter 22
}

\section{Competition and Services of General Economic Interest in the EU:}

\author{
Reconciling Economics and Law
}

\subsection{Introduction: What is the problem?}

A new conflict is fermenting within the European Union. It concerns one of the last vestiges of the "old" form of state interventionism in the economy. This is how the Financial Times reported the news on 1 April 2003:

"Public services such as electricity, post and telecommunications could be given greater protection against competition and state aid rules under plans being considered by European regulators. The European Commission is studying proposals that could prevent antitrust and single market regulators from acting against companies involved in services of general interest. Brussels authorities are also considering whether to launch new regulations to clarify the role of public services such as railways, energy, telecoms and health. The plans are at an early stage but could attract criticism that European governments are seeking to protect state-owned enterprises such as Electricité de France and Deutsche Post. Both companies have been attacked by the Commission for using government protection and subsidies to harm rivals in the private sector. An early draft of a consultative document, due to be finalised by the summer, says the Commission could present an EU-wide law on public services. The text, seen by the Financial Times, says the 'law could specify the conditions under which the provision of services of general interest is exempted from ... the internal market and competition rules'. Critics of the Commission's proposals fear that a new law would widen the scope for exemptions and make it easier for companies to escape punishment from Brussels. Such a law has been championed by the French government, which made it a condition for the partial opening of its electricity market - currently dominated by EdF - at last year's Barcelona summit. The French government and other supporters of the law argue that without protection from regulators, companies would not have the incentives to provide vital services such as post and healthcare to remote or poorer regions."

At the heart of the problem is the special treatment accorded to services of general economic interest by the EC Treaty. Article 16 of the Treaty stipulates, among other things, that the Community and the member states "shall take care that services of general economic interest operate on the 
Competition and Services of General Economic Interest in the EU: Reconciling Economics and Law

basis of principles and conditions which enable them to fulfil their missions". Even though this Article was inserted several years ago by the Treaty of Amsterdam, there is no consensus as to how it may be interpreted and applied in practice. In fact it appears not to have played any significant role in Commission decisions or Court rulings since the coming into force of the Treaty of Amsterdam on 1 May 1999.

The Commission has recently published several documents on the meaning of services of general economic interest (SGEI) and how they should be treated under EC competition rules. The views expressed in these documents do not indicate any significant departure from the traditional position of the Commission that SGEI should be subject to competition rules unless it is demonstrated that there is a need to grant a specific exemption. With regard to state aid, the Commission is currently considering whether to issue a "block exemption" regulation that would provide automatic authorisation for certain forms and intensities of aid.

From a competition perspective, the views of the Commission are not so problematic as those of the Court. The Commission has always favoured a broad and strict application of competition rules to SGEI. By contrast, the Court has ruled that, under certain conditions, restrictions of competition may be tolerated in order to enable providers of SGEI to break even; i.e. to supply SGEI without suffering financial losses. With respect to state aid, the exception defined by the Court seems to be even wider. Providers of SGEI may receive aid as a form of compensation for the extra costs they incur in supplying those services. This kind of aid is not covered by the definition of state aid in Article 87(1) of the Treaty! Therefore, it does not need to be notified to the Commission for prior authorisation. The consequence is that it falls completely outside the Community system for control of state aid. Normally, any public measure granting state aid must first be notified to the Commission, unless it is explicitly exempted by Commission Regulations.

The prevailing public positions on SGEI range from those held by Community institutions [according to which SGEI may be exempted from competition rules under certain conditions] to those held by the industry itself [exceptions are indispensable for the uninterrupted provision of sufficient and high-quality services]. 


\section{Chapter 22}

The prevailing situation in the EU raises two fundamental policy questions. First, what is that which makes SGEI so important and why does it justify exception from competition rules? After all, if SGEI are thought to be essential for consumers, competition policy should be seen as their natural ally, given the fact that its main aim is to raise welfare by preventing companies from behaving anti-competitively, most notably by raising prices and reducing output. Second, if the exception afforded to providers of SGEI is retained, how can the distortion to competition be minimised?

The most significant weakness of EU policy on SGEI, as it stands today, is that it makes no distinction between efficient and inefficient providers, nor does it oblige member states to ensure the efficiency of providers of SGEI who benefit from derogations from competition rules. The providers of such services in Europe are naturally hostile to any requirement that would make the state aid they receive or any other exception conditional on their level of efficiency in relation to potential competitors.

But protecting inefficient enterprises contradicts the purpose of treating SEGI preferentially. If the reason for such preferential treatment is that they are important to consumers, why then are governments not seeking to ensure that they are supplied by the most efficient providers? As is explained in this chapter, the presumed social significance of SGEI establishes no general case in favour of restrictions of competition and prevention of market entry by more efficient providers.

The reason why restrictions of competition and state aid are allowed under certain conditions is that providers need to subsidise unprofitable services with profitable ones. Cross-subsidisation is, therefore, at the heart of the economic problem of SGEI. However, once it is recognised that crosssubsidisation is the common feature in cases involving restrictions on competition, the following conundrum emerges. Article 86(2), applying the competition rules of the EU to SGEI, requires that any restriction or distortion of competition is necessary and proportional. How, then, can exclusion of more efficient enterprises be justified?

The purpose of this chapter is to explore the limits of the exception of SGEI, identify cases where it may be justified and show that, in general, the exception of SGEI from competition rules has been too generous. It cannot 
Competition and Services of General Economic Interest in the EU: Reconciling Economics and Law

be justified either by the logic of the system of competition itself or by the economic effects it generates.

The chapter is organised as follows. Section 2 reviews the various definitions of SGEI and considers whether the special features of SGEI may justify public ownership of providers of SGEI. Section 3 examines the treatment of SGEI under EC competition rules. Section 4 analyses the competition issues involved. Section 5 proposes a stricter approach to the treatment of SGEI. Finally, section 6 summarises the main arguments of the chapter.

\subsection{SGEI in the EC framework}

\section{Treaty provisions and the political context}

In order to understand why SGEI are accorded special treatment in the economies of member state and within the EC Treaty, we need first to know what they are and how they are defined.

Paradoxically, the EC Treaty does not define the meaning of SGEI. Article 16EC states:

"Without prejudice to Articles 73 [transport services], 86 [competition] and 87 [state aid], and given the place occupied by services of general economic interest in the shared values of the Union as well as their role in promoting social and territorial cohesion, the Community and the Member States, each within their respective powers and within the scope of application of this Treaty, shall take care that such services operate on the basis of principles and conditions which enable them to fulfil their missions."

Article 16 does not say which services are of general economic interest but indirectly identifies an essential characteristic of SGEI: they promote social and territorial cohesion. On its own, this statement does not really clarify the concept of SGEI. But as it will be seen below, social and economic cohesion means that SGEI, for political and social reasons, are made available to all citizens in all regions of each member state. Section 4 will examine whether the market is incapable of providing these services to all citizens across the regions of member states, but suffice it for the time being to note this perceived special contribution of SGEI to social and territorial cohesion. 


\section{Chapter 22}

Article 16 was inserted in the EC Treaty by the Treaty of Amsterdam. In this context, it is worth noting that in the final stages of the negotiations on 18 June 1997 to conclude the Treaty of Amsterdam, the European Council adopted the following Declaration on public credit institutions in Germany:

"The Conference notes the Commission's opinion to the effect that the Community's existing competition rules allow services of general economic interest provided by public credit institutions existing in Germany and the facilities granted to them to compensate for the costs connected with such services to be taken into account in full. In this context, the way in which Germany enables local authorities to carry out their task of making available in their regions a comprehensive and efficient financial infrastructure is a matter for the organisation of that Member State. Such facilities may not adversely affect the conditions of competition to an extent beyond that required in order to perform these particular tasks and which is contrary to the interests of the Community."

Austria and Luxembourg subsequently added the own Declaration:

"Austria and Luxembourg consider that the Declaration on public credit institutions in Germany also applies to credit institutions in Austria and Luxembourg with a comparable organisational structure."

Once more we see that, at least in the case of banking services, member states believe that complete territorial coverage necessitates deviation from the rules of competition. Once more this raises the question of how deviation from competition rules can result in "efficient financial structure". As already mentioned, section 4 will ask whether provision of services, such as financial services, through market mechanisms creates inefficiencies that can be remedied by derogations from competition rules.

The Treaty of Amsterdam also added a Protocol on the system of public broadcasting in the Member States. It states that:

"The provisions of the Treaty establishing the European Community shall be without prejudice to the competence of Member States to provide for the funding of public service broadcasting insofar as such funding is granted to broadcasting organisations for the fulfilment of the public service remit as conferred, defined and organised by each Member State, and insofar as such funding does not affect trading conditions and competition in the Community to an extent which would be contrary to the common interest, while the realisation of the remit of that public service shall be taken into account."

Also in the case of broadcasting, which appears to have been given a more generous exemption from competition rules than for public credit institutions, the EU does not tolerate an unconditional distortion to competition. Funding arrangements (i.e. state aid) must not be contrary to the common interest. 
Competition and Services of General Economic Interest in the EU: Reconciling Economics and Law

This was later re-affirmed by the Council Resolution of 25 January 1999 [see OJ C30, 5/2/1999]. Later on I will argue that current arrangements distort competition to a disproportional degree.

The other explicit mention of SGEI in the EC Treaty is in Article 86(2)EC which provides the exception from competition rules. It stipulates that:

"Undertakings entrusted with the operation of services of general economic interest or having the character of a revenue-producing monopoly shall be subject to the rules contained in this Treaty, in particular to the rules on competition, in so far as the application of such rules does not obstruct the performance, in law or in fact, of the particular tasks assigned to them. The development of trade must not be affected to such an extent as would be contrary to the interests of the Community."

We see that Article 86 does not define SGEI either. It only lays down conditions for exemption from competition rules. The European Court of Justice, however, in interpreting the meaning of his exception has defined the following conditions that must all be satisfied in order for Article 86(2) to apply:

- The service in question must be a service of general economic interest and must be accurately defined as such by the member state concerned [explicit definition of SGEI].

- The undertaking in question must be specifically entrusted through law by the member state with the provision of such a service [explicit allocation of tasks].

- The application of the competition rules of the treaty must obstruct the performance of the particular tasks assigned to undertakings entrusted with the operation of services of general economic interest [necessity].

- The exception should be limited to what is necessary [proportionality].

- The exception must not affect the development of trade within the Union to an extent that would be contrary to the Community's interest. It is in the Community's interest that the distortion of competition is kept to a minimum [concordance with the EU's interest].

Section 3 will review in more detail the relevant case law and the treatment accorded to SEGI under the competition rules of the EU. Then section 4 will consider whether allowable restrictions are indeed limited to the minimum necessary economically while section 5 will examine how they can be limited even further. If this proves possible, then distortions can also be reduced further. 


\section{Chapter 22}

Since the Amsterdam European Council [June 1997], discussion about the treatment of SGEI has taken place at the highest political level in the EU. The Laeken European Council [December 2001] "welcomed the Council's conclusions and the joint Council and Commission report concerning services of general interest, which will be the subject of an assessment, at Community level, as to their performance and their effects on competition. The European Council encouraged the Commission to set up a policy framework for State aid to undertakings entrusted with the provision of services of general interest."

The Barcelona European Council [March 2002] went further by noting the following:

"The integration of European networks and the opening of utility markets should take full account of the importance of quality public services. In this regard, the European Council underlines the importance for citizens, and for territorial and social cohesion, of access to services of general economic interest. In this context, the European Council asks the Commission to:

- present its communication on evaluation methodology at the May Council and report to the Seville European Council on the state of work on the guidelines for State aids and if necessary propose a block exemption regulation in this area;

- continue its examination with a view to consolidating and specifying the principles on services of general economic interest, which underlie Article 16 of the Treaty, in a proposal for a framework directive, while respecting the specificities of the different sectors involved and taking into account the provisions of Article 86 of the Treaty. The Commission will present a report by the end of the year." [emphasis added]

The recent European Council that took place in Brussels in March 2003 made a more explicit reference to the issues surrounding SGEI. Paragraph 26 of the Presidency Conclusions provides that

"regarding services of general interest, [the European Council] invites the Council (Competitiveness) to take the necessary procedural decisions for future work in order to safeguard their supply and funding, while ensuring that the provision of public services is compatible with EU state aid and competition rules and that the application of this aid and these rules do not endanger the provision of public services and equally that Member States' financing arrangements do not distort the market for tradable services; it confirms the conclusions of the European Council in 
Competition and Services of General Economic Interest in the EU: Reconciling Economics and Law

its Barcelona meeting on this issue and invites the Council to examine the forthcoming Commission Green Paper following the request of the Barcelona European Council regarding a proposal for a framework Directive."

It is obvious that a thorough analysis of the relationship between competition rules and SGEI is both significant and timely. It is significant because those services constitute a significant economic sector which benefits from special treatment and may deviate from competition rules. It is timely because the EU intends to adopt new measures in this field. Since both the proposed block exemption regulation and the framework directive intend to elaborate the application of competition rules, it is imperative to assess the problems caused by the derogation from competition rules and to identify means of narrowing this loop hole. This is indeed the purpose of this chapter.

\section{Definitions of SGEI in Community policies and the case law}

The Commission (2002c, pp.5-6) makes a distinction between "services of general interest", "services of general economic interest", "universal service" and "public services":

Services of general interest are market and non-market services that the public authorities classify as being of general interest and may therefore be subject to specific public service obligations.

Services of general economic interest are market services that discharge general interest tasks and are therefore subject to specific public service obligations imposed by the Member States. The term universal service is an evolving concept developed by the Community institutions and designates a set of general interest requirements which should be met by undertakings operating in certain sectors such as the postal service and telecommunications. The resulting obligations are intended to ensure that everyone everywhere has access to certain essential services of specified quality at an affordable price. They may be imposed on one undertaking or on all the undertakings in a given sector of activity.

The Commission is of the view that the term public service is an ambiguous term since it may refer either to the actual body providing the service or to the general interest role assigned to the body concerned. It is with a view to promoting or facilitating the performance of the general interest role that specific public service obligations may be imposed by the public authorities 


\section{Chapter 22}

on the body rendering the service, for instance in the matter of inland, air or rail transport and energy. These obligations can be applied at national or regional level. There is often confusion between the term public service and the term public sector, which relates to the legal status of those providing the service in terms of who owns the services.

Yet, Faull \& Nikpay (1999, p.313) believe that SGEI are "a Community law concept that more or less corresponds with the notion of "public services' that exists in some Member States."

The position of the Court expressed in the many rulings it has handed down concerning SEGI is somehow surprising. The Court has made it clear that

"in the absence of Community rules governing the matter, the Commission has no power to take a position on the organisation and scale of the public service tasks or on the expediency of political choices made in this regard by the competent national authorities, provided that the [state] aid in question does not benefit the activities pursued in competitive sectors or exceed what is necessary to enable the undertaking concerned to perform the particular task assigned to it" [T-106/95, FFSA].

By contrast, where the conditions governing the imposition of public service obligations are laid down in a Community instrument, the member states may not derogate from them [see, for example, the early Regulation 1191/69 on action by member states concerning obligations inherent in the concept of a public service in transport by rail, road and inland waterway (OJ L 156, 28/6/1969)]. The Commission's task is to ensure that these provisions are applied with no manifest error.

In its judgement in BRT v SABAM [C-127/73], the Court emphasised that the concept of service in the general economic interest within the meaning of Article 86 of the Treaty means, among other things, that member states assign specific tasks to particular undertakings. According to the Court, "that is not the position in the case of an undertaking to which the State has not assigned any task and which manages private interests, including intellectual property rights protected by law" [paragraph 23].

The Court in its judgement in GVL [C-7/82] elaborated on the specificity of the assigned SGEI tasks. The case concerned a law on the management of copyright and related rights which stipulated inter alia that a management company had to be authorised by the public authorities, that it was subject to 
Competition and Services of General Economic Interest in the EU: Reconciling Economics and Law

monitoring by the patents office and that it was obliged to conclude certain management contracts. The Court took the view that the legislation in question

"does not confer the management of copyright and related rights on specific undertakings but defines in a general manner the rules applying to the activities of companies which intend to undertake the collective exploitation of such rights. Even if it is true that the monitoring of the activities of such companies as provided for by that law goes further than the public supervision of many other undertakings, that is, however, not sufficient for those companies to be included in the category of undertakings referred to in Article 86(2) of the Treaty." [paragraphs 31 and 32].

Similarly, the Court considered that the loading, unloading, transhipment, storage and general movement of goods or material of any kind within a port are not necessarily of a general economic interest exhibiting special characteristics as compared with the general economic interest of other economic activities [C-179/90, Porto di Genova; C-242/95, GT-Link].

By contrast, it took the view that

"mooring operations are of general economic interest, such interest having special characteristics, in relation to those of other economic activities, which is capable of bringing them within the scope of Article 86(2) of the Treaty. Mooring groups are obliged to provide at any time and to any user a universal mooring service, for reasons of safety in port waters." [C-266/96, Corsica Ferries]

The Court applied the same reasoning in the area of postal services, finding that
"it cannot be disputed that the Régie des Postes [Belgian post office] is entrusted with a service of general economic interest consisting in the obligation to collect, carry and distribute mail on behalf of all users throughout the territory of the Member State concerned, at uniform tariffs and on similar quality conditions, irrespective of the specific situations or the degree of economic profitability of each individual operation" [C-320/91, Corbeau].

However, it should be pointed out that, in the same judgement, the Court made a distinction in that specific services which meet the special needs of economic operators and call for certain additional services not offered by the traditional postal service are dissociable from the service of general interest. 


\title{
Chapter 22
}

In the electricity sector, the Court considered that the concept of service in the general economic interest covers the activity of an undertaking which

"must ensure that throughout the territory in respect of which the concession is granted, all consumers, whether local distributors or end-users, receive uninterrupted supplies of electricity in sufficient quantities to meet demand at any given time, at uniform tariff rates and on terms which may not vary save in accordance with objective criteria applicable to all customers" [C-393/92, Municipality of Almelo].

The Court has also ruled that the concept of service in the general economic interest may cover maintenance of the navigability of an important river [C10/71, Muller] the distribution of water [C-96/82, IAZ], the supply of services in the telecommunications field [C-41/83, Italy v Commission], or television broadcasting [C-155/73, Sacchi].

Advocate-General Stix-Hackl's opinion on cases C-34/01 to C-38/01 [Enirisorse v Ministero delle Finanze], which are not yet decided, clarifies that

\begin{abstract}
"what is decisive in determining whether a service is of general economic interest is whether the service concerned is of general economic interest exhibiting special characteristics compared with that of other economic activities [C-242/95, GTLink]. In Corsica Ferries [C-266/96], the special characteristic was that for safety reasons the services were required to be available at all times to all persons using the port. In GT-Link, the Court did not preclude the possibility that, 'the mere provision of the port infrastructure' could be classified as a service of general economic interest. Finally, in SIOT [C-266/81], the Court recognised the more general benefits derived from the use of harbour waters or installations for the navigability and maintenance of which the public authorities are responsible. The criteria laid down in the case-law are the offer of services to everyone, at any given time, at uniform tariff rates and on terms which may not vary save in accordance with objective criteria [see C-393/92, Almelo; C-320/91, Corbeau]."
\end{abstract}

Although the perceived special features of SGEI set them apart from other economic services, operators of SGEI are undertakings which engage in economic activities. They are, therefore, in principle subject to competition rules. The Commission's 1996 and 2000 communications on services of general interest in Europe as well as the Commission's report to the Laeken European Council contain statements on the concept of economic activity. As a general rule, Community law classifies as an undertaking any entity engaged in an economic activity, regardless of its legal status and the way in which it is financed [C-41/90, Höfner]. The fact that an entity is non-profitmaking is not relevant. The concept of economic activity encompasses "an 
Competition and Services of General Economic Interest in the EU: Reconciling Economics and Law

activity which consists in offering goods or services on a given market and which could, at least in principle, be carried out by a private actor in order to make profits" [Opinion of Advocate-General Jacobs on C-218/00, Cisal di Battistello Venanzio].

Advocate-General Stix-Hackl, in her opinion on the same cases quoted above, observed that

"recent case law also shows that the concept of economic activity is an evolving concept linked in part to the political choices of each member state. Member states may decide to transfer to undertakings certain tasks traditionally regarded as falling within the sovereign powers of states. Member states may also create the conditions necessary to ensure the existence of a market for a product or service that would otherwise not exist. The result of such state intervention is that the activities in question become economic and fall within the scope of the competition rules."

It should be noted that an entity carrying out primarily non-economic activities may be engaged in secondary activities of an economic nature. In such cases, classification as an undertaking within the meaning of the competition rules will be confined to the economic activities involved.

On the basis of the statements and examples analysed above it is safe to reach the following conclusions:

- The EC does not define SGEI.

- Member states are free to designate services as being in the general economic interest.

- Member states also have discretion in which services they designate as being in the general economic interest.

- SGEI fall within the scope of EC competition rules precisely because they are economic in nature. Member states also have the right to turn into economic certain services which may not be economic in other member states [e.g. provision of supplementary pensions].

- However, the Court, which is the ultimate authority for interpreting the meaning and assessing the application of EC rules, has identified certain characteristics that justify a service to be regarded as being in the general economic interest. Such services

- must be important to consumers,

- must be open to all consumers,

- must be provided at uniform terms and predetermined quantity, price and regularity. 


\section{Chapter 22}

- Services that are designated as being in the general economic interest are not necessarily public goods that are under-supplied or not supplied by the market because users cannot be charged or cannot be excluded from consuming them. SGEI are services that member states want them to be supplied under specific terms and prices.

- It follows that if SGEI are, to put it simply, services to be supplied at lower prices or higher quality than what enterprises are prepared to provide them for under prevailing market (demand and supply) conditions, the problem of competition is not about allocating property rights [as in the case of public goods], nor is it about regulating providers who may be natural monopolies due to economies of scale [as in the case of most utilities]. It is about ensuring that providers of SGEI generate enough revenue to cover their costs.

Indeed, the heart of the problem is the inability of providers to cover their costs because of the conditions imposed on them by the member states. This was explicitly acknowledged in one of the earliest regulations dealing with public transport. Regulation 1191 of 1969 defined "public service obligations" to mean "obligations which the transport undertaking in question, if it were considering its own commercial interests, would not assume or would not assume to the same extent or under the same conditions" [Article 2]. Similar wording has been used in more recent regulations such as Regulation 2408/92 concerning public service obligations in air transport and Regulation 3577/92 concerning public service obligations in shipping.

For example, in air transport, "public service obligation means any obligation imposed upon an air carrier to take, in respect of any route which it is licensed to operate by a Member State, all necessary measures to ensure the provision of a service satisfying fixed standards of continuity, regularity, capacity and pricing, which standards the air carrier would not assume if it were solely considering its commercial interest."

It is very important to note, however, that these regulations make no mention of the efficiency of the designated undertakings in relation to their competitors. From the perspective of the European Community that has to ensure the effective application of its competition rules, the freedom of member states to assign SGEI obligations without regard for the efficiency of the providers of SGEI makes this problem worse. 
The Advocate-General Tizzano in his opinion on Ferring [C-53/00] put the issue succinctly. He stated that

"it is for the Member States to define the services of general economic interest that they intend to entrust to certain public or private undertakings. It is clear from caselaw that, in the absence of any harmonised rules governing the matter, the Community institutions are not entitled to rule on the basis of the public service tasks assigned to the public operator, such as the level of costs linked to that service, or the expediency of the political choices made in this regard by the national authorities or ... [the] economic efficiency of the undertaking [T-106/95 FFSA]."

This is the economic problem to which we return in section 4 .

Since AG Tizzano refers to public or private undertakings, it is worth noting at this point that in all the definitions and statements quoted above there is no reference to any perceived need for public ownership of SGEI providers. There are two reasons for the absence of any apparent concern over public ownership. First, the Treaty itself is neutral as to private or public ownership of enterprises. Article 295 states explicitly that "this Treaty shall in no way prejudice the rules in Member States governing the system of property ownership." This means that the EU cannot prevent public authorities from owning enterprises, nor can it prevent state-owned companies from competing on the market. At the same time, the Treaty and the EU cannot treat state-owned or state-controlled enterprises more favourably than private enterprises, nor can it give preference to private firms. So, Article 295 requires the EU to treat all undertakings equally and prevents the EU and member states from granting any special favours to any undertaking on the grounds of its legal status.

This neutrality of treatment has significant competition implications. The status, special legal privileges or any close links with the government can not be used by any undertaking to gain an unfair advantage over its competitors. As will be explained in the following section, the only available exception from competition rules is for designated providers of SGEI. But this exception applies irrespective of legal status or public ownership.

In fact, publicly-owned enterprises often claim that their status is more of a handicap than an advantage in relation to private enterprises. This is because the latter have more flexibility in hiring and firing workers, in accessing private capital and other financial resources and in forging alliances with national and foreign companies. Irrespective of whether such claims are true 


\section{Chapter 22}

or not, the fact remains that public ownership alone does not shield companies from EC competition rules.

The second reason why public ownership has not played any significant role in the discussions on SGEI is that the central competition issue with SGEI is not the status of the provider or the perceived importance of the services themselves but the delivery of sufficient and affordable services to consumers. Since state-owned enterprises have the same standing in competition law as private enterprises, any extra costs they may bear because of state ownership cannot in principle be subsidised by the state or through other restrictions of competition. State aid is in principle prohibited [but see the section below] and, under certain conditions, restrictions of competition are allowed only for providers of SGEI [also see the section below]. Hence, what matters is the nature of the services provided rather than the nature of the owner of the provider.

In conclusion, the review of the various definitions of SGEI reveals that there is no established list of what is to be regarded as SGEI. Moreover, there are apparently two approaches to defining SGEI. The first is what may be called an "axiomatic" or top-down definition and basically consists of what member states or the EU courts designate as such. Since in the absence of any definition in the Treaty or secondary legislation it is the courts that have the last word on what is a SGEI, so far we know that certain telecommunications services, postal services, electricity services, water distribution and navigation services have been recognised as being SGEI.

The second approach may be called "essential requirements" or bottom-up. Irrespective of which particular service is classified as SGEI, its provision must be subject to certain requirements such as continuity, regularity, affordable and uniform pricing and terms of supply.

Both approaches raise the fundamental question why it is necessary for the state to designate certain services as SGEI or impose those conditions on the provision of such services. The answer, at least in the context of competition policy which is the subject matter of this dissertation, is that the market does not provide them at the required price, area of supply or terms of supply. But this creates a puzzle. If it is necessary to designate certain services as SGEI because the market under-provides them or charges too high prices, why then would restrictions to competition even become indispensable? 
Competition and Services of General Economic Interest in the EU: Reconciling Economics and Law

Competition means that supply increases and prices decrease. Restriction of competition appears to be contrary to the purpose and underlying rationale of SGEI. The next section examines what kind of exceptions from competition rules are allowed for SGEI. Section 4 analyses in more detail the economic effects of such restrictions. Finally section 5 will propose appropriate policy responses to these problems so that public measures do not contradict the purpose of SGEI.

\section{Should public authorities be supporting the provision of SGEI?}

Before examining the application of competition rules to SGEI, it is worth considering for a moment whether governments and other public authorities should be regulating the supply of SGEI. As is well understood in economics, the government should intervene in the economy primarily to correct market failure. However, even in the case of market failure, intervention may not be warranted whenever government action itself causes additional and excessive distortions of its own. This possibility is the so called "government failure".

The various definitions of SGEI reviewed earlier refer to the presumed importance of SGEI but do not make any explicit reference to market failure. Rather, the main concern appears to be with uninterrupted and sufficient supply of SGEI. Since the market normally provides any good or service for which consumers are willing to pay the price asked by the suppliers, the concern about interrupted or insufficient supply of SGEI is in reality a concern about the ability of consumers to pay for such services.

The government should worry about the ability of consumers to pay for certain goods and services whenever consumption or the use of these goods and services generates positive externalities for the rest of society. For example, it is thought that education has a "socialising" effect that makes people "better citizens". Even if people would pay a price that included all the costs of the education they obtained, there could still be unpriced positive externalities in the sense that schooling makes them respect other peoples' property or that they develop a sense of loyalty to their country. These externalities would justify some public subsidies to general education. It is, however, a different issue whether current amounts of subsidies and subsidies to post-graduate university education can be justified on these grounds. 


\section{Chapter 22}

Goods and services such as education are also called "merit goods". These are the goods that some people in society claim that all citizens should be entitled to because they have "acquired" rights over them or because they make them "better" persons. These are arguments which are different from the alleged existence of externalities. It is outside the scope of this chapter to examine whether people should have the "right" to consume telecommunications or transport services or whether they become "better" persons by being able to communicate and travel are cheap rates.

We can ask instead how society may provide such goods and services with the lowest possible efficiency loss. Again, it is well established in economics that, if society must ensure that certain goods such as merit goods must be made available to all citizens, the optimum way of doing so is to provide direct income subsidies to those who obtain these goods. If the government believes that income subsidies may be used for other purposes, then the next best option is provision of coupons that can be redeemed for lessons, visits to museums, etc.

But even such schemes such as income subsidies and coupons are a secondbest option because they have their own drawbacks. First, they are normally financed through general income taxation. This distorts economic incentives and penalises indirectly non-subsidised goods and services. Second, income subsidies and coupons are also offered to persons who would otherwise be willing to pay for the purchase of the goods and services in question. So they derive an additional benefit in receiving an unnecessary subsidy. See Südekum (2002).

As we will see in section 4, currently adopted policy measures for the support of SGEI are in fact third-best if not fourth-best measures. This is because they subsidise firms some of which may not be efficient and because they implicitly penalise certain groups of consumers so as to favour other groups of consumers.

In conclusion, there appears to be no overwhelming argument in favour of public support of SGEI. Market failure is not pervasive. Whether such services are merit goods that must be available to all citizens is an issue that falls outside the scope of this chapter. What must be noted, however, is that the fact that the EU Treaty allows member states to define their SGEI does not automatically convert them into merit goods. Just because member states 
Competition and Services of General Economic Interest in the EU: Reconciling Economics and Law

have that kind of discretion does not follow that every time they use it the services concerned are true merit goods.

Moreover, economics suggests that there are other, less distortionary means of making such services available to citizens. As I will show later on, current arrangements are in fact contrary to the avowed objective of public policy to increase the supply of SGEI. These arrangements do not increase supply as much as they could otherwise do because they subsidise inefficient companies.

\subsection{Application of EC competition rules to SGEI}

\section{Enforcement of Article 86(2): Necessity and proportionality}

Article 86 applies the rules of competition, and of the Treaty in general, to those enterprises or undertakings to which the member states confer special or exclusive rights. The special status or the special missions of these undertakings does not justify any anti-competitive behaviour on their part or on the part of the public authority that has conferred those rights.

Whereas Article 82 applies "only to anti-competitive conduct engaged in by undertakings on their own initiative, not to measures adopted by States" [C320/91, Corbeau], the aim of Article 86(1) is "to specify in particular the conditions for the application of the competition rules laid down by Articles 81 and 82 to public undertakings, to undertakings granted special or exclusive rights by the Member States and to undertakings entrusted with the operation of services in the general economic interest" [C-30/87, Bodson]. Accordingly, Article 86(1) enables the competition rules to apply to anticompetitive practices which could not otherwise be attributed to the undertaking concerned.

It may sound surprising but as the Treaty stands, creating a dominant position through the granting of special or exclusive rights by the state is not, in itself, incompatible with Article 82. However, a member state breaches the prohibitions laid down by Article 86(1) in conjunction with Article 82 if it adopts any law, regulation or administrative provision that creates a situation in which an undertaking on which it has conferred special or exclusive rights cannot avoid abusing its dominant position [C-340/99, TNT Traco]. 


\section{Chapter 22}

There is abuse, for example, where the dominant undertaking has made use of the opportunities arising out of its dominant position in such a way as to reap trading benefits which it would not have reaped if there had been normal and sufficiently effective competition [United Brands]. In particular, an undertaking abuses its dominant position where it charges for its services fees which are unfair or disproportionate to the economic value of the service provided [TNT Traco, Crespelle]. This implies that crosssubsidisation by undertakings that hold dominant positions by virtue of rights conferred to them by the state infringes Article 82 in conjunction with Article 86(1). The infringement is caused by the fact that with crosssubsidisation some prices must necessarily be higher than others. As a consequence, there is both price discrimination [illegal under Article 82] and charging of prices which are disproportionate in respect to their underlying costs at least for certain consumers.

However, the second paragraph of Article 86 offers the possibility for exception. A member state may rely upon Article 86(2) to justify the granting, to an undertaking entrusted with the operation of services of general economic interest, of exclusive rights which are contrary to Article 82 , to the extent to which performance of the particular task assigned to that undertaking can be assured only through the granting of such rights and provided that the development of trade is not affected to such an extent as would be contrary to the interests of the Community.

The application of Article 86(2) is conditional on the member state defining the content of the obligations and duties imposed in entrusting the particular task, and on these obligations being specific to the particular undertaking and its business, being linked to the subject-matter of the service of general economic interest in question and being designed to make a direct contribution to satisfying that interest [Commission v France, C-159/94].

More specifically, the exception in Article 86(2) applies only when restrictions to competition are necessary and proportional to the intended result. Two conditions need to be satisfied in order to prove necessity and proportionality:

1. The execution of the tasks of SGEI cannot be carried out without restricting competition; this also means that there is no alternative, less restrictive, option for the designated operator to supply the market. 
Competition and Services of General Economic Interest in the EU: Reconciling Economics and Law

2. The restriction is the minimum or smallest possible.

In addition, the Commission checks whether a third condition is satisfied, namely, that the restriction is not contrary to the common European interest by obstructing intra-Community trade to an unwarranted degree.

Not surprisingly, much of the case law that has clarified how Article 86(2) may be enforced refers to utilities such as telecommunications, postal services, electricity distribution, etc. In this connection, the ECJ has acknowledged that the exception of Article 86(2) may be invoked for the purpose of maintaining the "economic equilibrium" of the undertakings entrusted with the supply of SGEI [C-320/91, Corbeau; C-393/92, Almelo].

Providers of universal services are typically obliged by law to supply these services at affordable or, in most cases, uniform prices to all citizens throughout the territory of a particular country or throughout the designated supply area. Offering the same service at affordable or uniform prices to all consumer groups or to consumers in all areas may mean that consumers in low-cost regions have to subsidise consumers in high-cost regions. This would certainly be true if the price of the service in question is regulated and fixed at the same level for all consumers in all regions.

Under these conditions, competing providers would have a strong incentive to enter the profitable segments of the market (i.e. those with the low-cost consumers) and "skim" the profits of the supplier with the SGEI tasks. When this kind of market entry takes place, the SGEI provider may not be able to cover its losses in the high-cost areas. The ECJ has recognised that restrictions can then be justified as a means of enabling the SGEI provider to break even or to achieve "economic equilibrium". The same logic would apply in the case of a single group of consumers or area of supply. Here, the SGEI provider would simply have to cover its costs rather than crosssubsidise between different groups of consumers or regions.

It is important to note, once more, that in either case, the efficiency or productivity of the SGEI provider is not a relevant issue. It is immaterial whether competitors are more efficient and can supply the service in question at a lower cost and, therefore, lower price. What matters, in the eyes of EC competition law, is whether the undertaking on which the state has imposed the obligation to provide SGEI can do so without being prevented 


\section{Chapter 22}

by competition. As soon as competition becomes an obstacle to the execution of the SGEI tasks, Article 86(2) may be invoked.

In more recent cases, the ECJ appears to have relaxed even more the conditions imposed by Article 86(2). In the case concerning compulsory pension contributions to an entity to which the Netherlands had conferred the obligation to collect premiums and subsequently pay out pensions [Albany International BV $\mathrm{v}$ Stichting Bedrijfspensioenfonds Textielindustrie, C67/96], the Court ruled that "it is not necessary, in order for the conditions for the application of Article 86(2) of the Treaty to be fulfilled, that the financial balance or economic viability of the undertaking entrusted with the operation of a service of general economic interest should be threatened. It is sufficient that, in the absence of the rights at issue, it would not be possible for the undertaking to perform the particular tasks entrusted to it, defined by reference to the obligations and constraints to which it is subject or that maintenance of those rights is necessary to enable the holder of them to perform tasks of general economic interest which have been assigned to it under economically acceptable conditions" (emphasis added).

It is not clear what the Court meant by the reference to "economically acceptable conditions". But by making a distinction between a threat to the viability of the SGEI and economically acceptable conditions, it probably meant that the SGEI provider ought to be able to make some profit, not just break even, or that it should be able to supply the services in question without having to cross-subsidise them, thereby reducing the profitability of its other operations. At any rate, it seems reasonable to assume that that distinction signified that economically acceptable conditions were a laxer criterion than economic equilibrium.

Virtually the same reasoning was repeated by the Court in the case of TNT Traco v Poste Italiane [C-340/99] concerning fees imposed by the Italian postal operator on TNT Traco, an express delivery company. After quoting the text from the Albany judgement mentioned above, the Court went further and stated that in order for the SGEI operator to perform its tasks under economically acceptable conditions "it may prove necessary not only to permit the undertaking entrusted with the task, in the general interest, of operating the universal service to offset profitable sectors against less profitable sectors, but also to require suppliers of postal services not forming part of the universal service to contribute, by paying postal dues to the 
Competition and Services of General Economic Interest in the EU: Reconciling Economics and Law

financing of the universal service and in that way to enable the undertaking entrusted with that task to perform it in conditions of economic stability."

We now have the possibility that the law does not only protect an inefficient provider of SGEI, but even more seriously, that the law confers a right to that provider to demand from its competitors in market segments open to competition to subsidise its own costs in the monopolised segment of the market!

The problem with this, apparently wider, interpretation of the necessity and proportionality criteria embedded in Article 86(2) is that restriction of competition to enable an undertaking to cross-subsidise is neither necessary, nor proportional. I will argue in section 5 that the SGEI provider can always procure the services of the more efficient competitors or allow the undertakings in question to supply the services on its behalf. Moreover, in the absence of any significant economies of scale, the government may allow competition where competition is feasible and subsidise only the highcost operations of the SGEI provider (for more detailed analysis of the economics of cross-subsidisation see section 4 below).

Indeed the latter option has been chosen by secondary EU legislation as a means of liberalising important sectors such as telecommunications. The Universal Service Directive 2002/22 requires member states to finance the costs of universal telecommunications services either through direct subsidisation of any extra costs or to set up a universal service fund to which all operators are required to make a contribution. In this way, consumers reap both the benefits from universal service and the benefits from competition because entry of new providers is no longer prohibited. It is worth noting that as of 2003 only two member states have established universal service funds (France and Italy). This suggests either that the universal telecoms providers do not incur prohibitively high costs or that they are capable of making enough profit in the more competitive segments of the market to subsidise the higher-cost segments.

By contrast to the Court of Justice, the Court of First Instance has favoured a more narrow approach to Article 86(2). In case T-260/94 concerning the refusal of the French authorities to grant permission to TAT European Airlines to compete against Air Inter on domestic routes for which Air Inter had an exclusive right, the CFI stressed that 


\section{Chapter 22}

"as Article 86(2) is a provision which thus permits, in certain circumstances, derogation from the rules of the Treaty, it must be strictly interpreted and its application is not left to the discretion of the Member State which has entrusted an undertaking with the operation of a service of general economic interest ... The application of [competition rules] could, however, be excluded only in as much as they 'obstructed' performance of the tasks entrusted to the applicant. Since that condition must be interpreted strictly, it was not sufficient for such performance to be simply hindered or made more difficult. Furthermore, it was for the applicant to establish any obstruction of its task."

"In that regard, the applicant merely asserts that the organisation of domestic air transport was based on a system of cross-subsidy between profitable routes and unprofitable routes and that the exclusivity which had been granted to it on the Orly-Marseille and Orly-Toulouse routes was justified by its obligation to operate the unprofitable routes regularly and at tariffs that were not prohibitive, in order to contribute to regional development. It does not put a figure on the probable loss of revenue if other air carriers are allowed to compete with it on the two routes in question. Nor has it shown that that loss of income will be so great that it will be forced to abandon certain routes forming part of its network."

"In any event, the domestic air network system combined with the internal crosssubsidy system to which the applicant refers in support of its case did not constitute an aim in themselves, but were the means chosen by the French public authorities for developing the French regions. The applicant has not argued and still less established that ... there was no appropriate alternative system capable of ensuring regional development and in particular of ensuring that loss-making routes continue to be financed".

As we will see later on in state aid cases, the CFI has demanded a similar quantification and inclusion of possible advantages emanating from the operation of exclusive rights. It is also interesting that in the Air Inter case, the CFI rejected the application of Article 86(2) to exclusive rights in the air transport sector because it was not satisfied that internal flights to regional destinations were SGEI, that they were directly linked to regional development and that regional development could not be achieved without internal flights supplied through a restrictive regime. In essence, it asked not only for evidence of the contribution of air transport but also of the indispensability of air transport to regional development.

\section{Enforcement of Article 87 on state aid: Compensation for extra}

\section{costs}

Under Article 87 of the EC Treaty a state measure must be judged on the basis of its effects on competition. The Court of Justice has held that Article 87 does not make any distinction according to the causes or aims of the aid 
Competition and Services of General Economic Interest in the EU: Reconciling Economics and Law

in question but defines them in relation to their effects in [C-173/73, Italy $\mathrm{v}$ Commission]. That is, whether the measure confers an advantage to certain undertakings in relation to their competitors.

Nonetheless, in one of its earliest pronouncements on the issue of compensation of providers of SGEI, the Court of Justice veered away from examining compensation in terms of its effects. In a ruling handed down in 1985 in a case concerning the extra costs generated by the obligation imposed by France on certain undertakings to dispose of waste oils, the Court stated that those "indemnities do not constitute aid within the meaning of Articles 87 of the Treaty, but rather consideration for the services performed by the collection or disposal undertakings." Public authorities in France paid to the collecting companies indemnities not exceeding their actual annual costs as a form of compensation [C-240/83, ADBHU].

In line with the ADBHU ruling, the Commission held for a long time the view that financial benefits granted by member states to compensate for the additional burden of extra public service duties do not constitute state aid. For example, in the "Community guidelines on state aid to maritime transport" [OJ 1997 C 205], it is stated that "the Commission's practice in assessing contracts relating to PSOs [public service obligations] is generally to consider the reimbursement of operating losses incurred as a direct result of fulfilling certain public service obligations is not State aid within the meaning of Article 87(1) of the Treaty".

The Commission's practice has been contradicted by recent rulings of the Court of First Instance, starting with the judgement in FFSA [T-106/95], which concerned a Commission decision that certain tax concessions granted to the French postal service in order to offset its public service obligations were not State aid. In that decision the Court of First Instance took the opposite approach to the Commission and concluded that the measures in question did constitute State aid, even though they could be deemed compatible with the common market under Article 86(2) of the Treaty.

The Court of First Instance adopted the same position in its subsequent judgement in SIC [T-46/97] which concerned the financing of public television in Portugal. There the Court held that

"the fact that a financial advantage is granted to an undertaking by the public authorities in order to offset the cost of public service obligations which that 


\section{Chapter 22}

undertaking is claimed to have assumed has no bearing on the classification of that measure as aid within the meaning of Article 87(1)".

That ruling by the CFI was based, in particular, on the consideration that "Article 87(1) of the Treaty does not distinguish between measures of State intervention by reference to their causes or aims but defines them in relation to their effects" with the result that "the concept of aid is an objective one, the test being whether a State measure confers an advantage on one or more particular undertakings". According to that case-law, therefore, the fact that certain financial advantages are granted to offset extra public service obligations merely represents the purpose or aim of the measure in question, but does not impinge on its effects and, for that reason, has no bearing on its objective status as aid.

And then came the ECJ ruling on "Ferring" [C-53/00] which reversed the case law generated by the CFI and which until that moment held that compensation for extra costs was state aid. That case concerned the preferential tax treatment of wholesale distributors of medicines in France. France argued, successfully, that the preferential tax treatment in the form of tax exemptions was justified on the grounds that public service obligations imposed extra costs on the wholesalers. State aid compensated them for being obliged to deliver medicines within 24 hours of receiving a request and for maintaining a full range of stocks.

In its opinion on the Ferring case, Advocate General Tizzano was in favour of

"not classifying as aid public measures intended exclusively to offset the additional net cost arising from the performance of a service of general economic interest. In particular, the fact that such measures do not confer any real advantage on an undertaking entrusted with a service of general interest and therefore are not likely to alter the conditions of competition appears a decisive argument to me."

He went on to elaborate that

"if the State imposes certain public service obligations on an undertaking, then covering the additional costs arising from the performance of those obligations confers no advantage on the undertaking in question, but serves, if anything, to ensure that it is not unjustly disadvantaged vis-à-vis its competitors. In other words the imposition of the obligation and the provision of compensation cannot be considered as separate matters as they are two sides of the same public measure which is intended, as a whole, to guarantee that public interests of primary importance are satisfied. If that is the correct analysis, the conclusion that must be drawn in the situation under consideration is that the measure taken by the public 

Economics and Law

authorities ends up having an economically neutral effect on the undertaking concerned, which derives from it neither advantage nor disadvantage ... Accordingly, normal conditions of competition will only be altered where any compensation exceeds the additional net costs attributable to the performance of public service obligations. In such a case, State intervention will contain an element of aid equal to the surplus over and above the additional cost of the public service obligations, in so far as it confers an unwarranted advantage on the undertaking concerned and may thus distort competition in the market where the public service constraints apply or, where there are cross-subsidies, in other markets in which the undertaking operates." [emphasis added]

\section{The Court adopted the Advocate-General's views. It said that}

"the French regulation requires only wholesale distributors to have at their disposal a permanent range of medicinal products sufficient to meet the requirements of a specific geographical area and to deliver requested supplies within a very short time over the whole of that area, in such a way that the population as a whole can be guaranteed an adequate supply of medicines at all times. Discharging those obligations entails additional costs for wholesale distributors which pharmaceutical laboratories do not have to bear. In like manner, provided that the tax on direct sales imposed on pharmaceutical laboratories corresponds to the additional costs actually incurred by wholesale distributors in discharging their public service obligations, not assessing wholesale distributors to the tax may be regarded as compensation for the services they provide and hence not State aid within the meaning of Article 87 of the Treaty. Moreover, provided there is the necessary equivalence between the exemption and the additional costs incurred, wholesale distributors will not be enjoying any real advantage for the purposes of Article 87(1) of the Treaty because the only effect of the tax will be to put distributors and laboratories on an equal competitive footing." [emphasis added]

Although Ferring appeared to simplify things, it has in fact complicated them. In his opinion in Altmark Trans [C-280/00], Advocate-General Léger proposed that the compensation approach adopted in Ferring should be abandoned. Altmark Trans concerned a case of state aid to providers of public transport services in Germany. AG Léger advanced three arguments against the logic of Ferring or the "compensation approach".

He argued, first, that state aid is an objective concept. That is, it is not defined in terms of the intentions or motives of the granting authorities, but in terms of its effects and whether it confers a selective advantage that is capable of distorting competition and affecting intra-EU trade. He criticised the approach followed in Ferring because, in his view, it confused two distinct legal questions, namely the classification of a measure as aid and the 


\section{Chapter 22}

justification of that measure. A measure may be found to be state aid but still benefit from exemption.

Second, he thought that the compensation approach was liable to deprive Article 86(2) of its effect, because the provision would no longer apply to cases where the compensation granted did not exceed the costs of the public service obligations (in other cases, this provision could not apply anyway, since any over-compensation which constituted aid could not be necessary within the meaning of Article 86(2)).

Third, he pointed out that the compensation approach diminished the Commission's surveillance role in reviewing measures for financing public services. Member states have a general obligation to notify all state aid schemes to the Commission and to obtain its authorisation before they put them into effect. The Court has not yet ruled on Altmark Trans.

A second, but different, view against Ferring was put forth by AdvocateGeneral Jacobs in his opinion on case C-126/01, [GEMO]. Although the Court has also not yet ruled on GEMO, it is worth considering AG Jacob's reasons for disagreeing with the logic expounded in Ferring, but also with the position of AG Leger. GEMO concerns the exemption from a special tax of small butchers and farmers levied on the mandatory collection and disposal of animal carcasses. The proceeds of the tax are used to pay undertakings which collect and dispose carcasses.

AG Jacobs began by making the following distinction.

"Under Articles 87(1) and 86(2) there are basically two possible ways to analyse state funding of services of general interest. Under the first approach, or 'the state aid approach', state funding granted to an undertaking for the performance of general interest obligations constitutes state aid within the meaning of Article 87(1) which may however be justified under Article 86(2) if the conditions of that derogation are fulfilled and, in particular, if the funding complies with the principle of proportionality."

"Under the second approach, or 'the compensation approach', the term 'compensation' is intended to cover an appropriate remuneration for the services provided or the costs of providing those services. Under that approach, state funding of services of general interest amounts to state aid within the meaning of Article $87(1)$ only if and to the extent that the economic advantage which it provides exceeds such an appropriate remuneration or such additional costs. At first sight it seems that the Community Courts' case-law on the correct approach is inconsistent." 
He observed that initially, the Court followed the compensation approach. In subsequent cases, however, the EU Courts followed expressly or implicitly the state aid approach. By contrast, in its recent judgement in Ferring, the Court applied the compensation approach.

Although under both approaches the most important substantive question is essentially whether the state funding exceeds what is necessary to provide for an appropriate remuneration for or to offset the extra costs caused by the general interest obligations, the two approaches, according to AG Jacobs, have very different implications. Where, on the basis of the compensation approach, a given financing measure does not constitute state aid, the measure falls outside the scope of the state aid rules and need not be notified to the Commission. Under the state aid approach the same measure would constitute state aid which must be notified in advance to the Commission.

He then identified certain arguments against a generalised application of the state aid approach in all cases. First, the concept of state aid in Article 87(1) applies only to measures which provide an economic advantage and which distort or threaten to distort competition. In his view, there are no obvious reasons why those two requirements should not apply where state funding of services of general interest is involved. Second, where the state purchases goods (e.g. computers) or services (e.g. room cleaning services) on the markets, there will be state aid only if and only to the extent that the remuneration paid exceeds what is appropriate. Again he can detect no obvious reasons why the analysis should be different where the state purchases services which are to be provided to the collectivity (e.g. waste disposal services).

According to AG Jacobs, the main arguments against a generalised application of the compensation approach are the following. Article 86(2) and the conditions which it imposes would be deprived of any role in the control of state aid. Where state financing does not exceed what is necessary to offset the extra costs of the services provided, there would be no state aid within the meaning of Article 87(1) and thus no need to examine the compatibility of the measure with Article 86(2). In so far as the financing exceeds what is necessary the measure could not be justified under Article $86(2)$ because it would infringe the principle of proportionality. There would 


\section{Chapter 22}

thus be no cases in which the Commission or a national court would be able to control

- whether the services in question in fact constitute services of general economic interest,

- whether the services in question have in fact been entrusted to the undertaking(s) concerned,

- whether the financing in question affects the development of trade to an extent contrary to the interests of the Community (last sentence of Article 86(2).

\section{AG Jacobs then concluded that}

"the key to the correct analysis under Articles 87(1) and 86(2) of state financing of services of general interest might in my view be a distinction between two different categories of cases which is based (i) on the nature of the link between the financing granted and the general interest duties imposed and (ii) on how clearly those duties are defined. In accordance with the proposed distinction the first category would comprise cases where the financing measures are clearly intended as a quid pro quo for clearly defined general interest obligations, or in other words where the link between, on the one hand, the state financing granted and, on the other hand, clearly defined general interest obligations imposed is direct and manifest. The clearest example of such a direct and manifest link between state financing and clearly defined obligations are public service contracts awarded after public procurement procedures: one and the same contract defines the obligations of the undertakings entrusted with the services of general interest in question and the remuneration which they will receive in return. Cases falling into that category should in my view be analysed according to the compensation approach." [emphasis added]

"The second category consists of cases where it is not clear from the outset that the state funding is intended as a quid pro quo for clearly defined general interest obligations. In those cases the link between state funding and the general interest obligations imposed is either not direct or not manifest or the general interest obligations are not clearly defined. A good example of that category is Banco Exterior de España in which a Spanish law exempted all public banks from the payment of taxes. The law did not indicate that that advantage was intended as a quid pro quo for the fulfilment of general interest obligations nor did it define exactly any such obligations. Only before the Court did the Spanish government allege that the exemption was necessary for the fulfilment by public banks of their function of 'administering the public provision of credit.' Cases in the second category should in my view be analysed according to the state aid approach."

More recently a third voice has been added on the issue of compensation of extra costs with the opinion of Advocate-General Stix-Hackl on cases C34/01 to C-38/01 [Enirisorse SpA v Ministero delle Finanze]. These cases concern an Italian law that entrusts the management of stevedoring 

Economics and Law

equipment, warehouses, depots and other port property to certain undertakings in Italian ports. In order to perform their statutory tasks, these undertakings have available to them, among other things, two thirds of port charges levied on goods passing through those ports.

\section{AG Stix-Hackl began her analysis by}

"noting that if one proceeds on the basis that the determination of whether a measure constitutes state aid requires an investigation into whether the recipient undertaking receives an economic advantage which it would not have obtained under normal market conditions [SFEI, C-39/94], then it must be examined whether the recipient undertaking supplies a service which is normally supplied in return for consideration and whether the consideration actually given was reasonably proportionate to that service."

She seems to imply that state aid in these circumstances could be considered as payment for services normally procured by public authorities. The only difference is that the SGEI provider supplies the services to consumers instead of the authorities and on behalf of those authorities.

But then she goes to note that

"the compensation approach taken in Ferring may be adopted only where the service and the consideration are clearly identifiable. However, as regards services of general economic interest, it is to be observed that it is difficult to find a standard for assessing the proportionality of the compensation, since services of general economic interest are supplied usually where market forces alone do not result in a satisfactory provision of services."

Indeed, how can that compensation be considered as normal procurement of services when public authorities offer compensation without having first selected the most efficient provider as they would normally do under public procurement procedures.

She also admits that

"where the general interest duties have not been clearly defined, it is not possible to adopt the compensation approach. This is because in such cases it is ex hypothesi impossible to calculate the burdens (i.e. the costs) resulting from them with sufficient precision. In such cases, it is impossible to find the direct and manifest link to the obligations undertaken which Advocate General Jacobs required."

AG Stix-Hackl appears, therefore, to be siding with AG Jacobs favouring a differentiated compensation approach, provided that there is a clear link between the costs of the SGEI and the obligations imposed on the recipient of public funds. She also notes that where SGEI are provided in the absence of competition or where the provider is obliged to supply services no one 


\section{Chapter 22}

else supplies voluntarily it would be difficult to determine the proportionality of aid. In practice this would mean that all the costs of the SGEI provider are subsidised even if they are not directly linked to the SGEI itself.

In conclusion, we see in all opinions quoted above a fleeting and implicit recognition of the need for having a benchmark for determining the proportionality of aid granted to compensate providers of SGEI. This proportionality is to be determined according to the costs incurred by the providers. We also see that there is the impression that compensation for imposed extra costs somehow restore fair competition.

In fact I will argue in the next two sections that it is impossible to obtain an objective benchmark when ignoring the costs of other potential providers of similar services. More importantly, mere compensation does not restore fair competition. On the contrary, it may distort it even more and in less transparent manner. The only objective benchmark is that which is obtained from open and competitive selection procedures that allow all potential providers to submit bids.

I believe that the case law itself justifies the approach of this chapter. In the case BAI v Commission [T-14/96] concerning the mass purchase of ferry tickets by the Basque authorities for the purpose of distributing them to certain groups of people, the CFI ruled that even though the tickets were purchased at apparently market prices, the company which sold the tickets still obtained an advantage. The reason was that the Basque authorities purchased a very large amount of tickets for which there was no apparent demand. The CFI found that that was not a normal commercial transaction.

Similarly, I will argue that, since public measures are assessed on the basis of their effects, we need to examine whether the beneficiary undertakings derive an advantage they would not otherwise obtain under normal market conditions. In the market, the purchasers of goods seek to buy them from the cheapest source so as to minimise their outlay. I will show that by not minimising the amount of aid they grant to SGEI providers, public authorities either grant a larger subsidy or indirectly enable the recipient to become more competitive in adjacent markets. Either possibility distorts competition. 
Competition and Services of General Economic Interest in the EU: Reconciling Economics and Law

\subsection{An assessment of the competition problems caused by the special treatment of SGEI}

"Regulation and competition are rhetorical friends and deadly enemies: over the doorway of every regulatory agency ... should be carved: Competition Not Admitted." 243

The competition problems caused by the special treatment of SGEI have their root in the broader problem of regulation and administrative control of market processes. To gain a better understanding of the competition problems, it is instructive to begin by reviewing briefly why regulation and regulators have difficulty mimicking market solutions.

\section{Competition and the problem of regulation in public utilities and natural monopolies}

Certain industries such as energy, telecommunications and transportation, while differing in a number of respects, share certain common features. They each combine natural monopoly segments with potentially competitive activities. In the case of gas and electricity, production and supply are potentially competitive while transmission and distribution constitute natural monopolies. In telecommunications competition is feasible in the case of long distance and international services. Rival networks need to interconnect with each other in order that their customers can communicate with subscribers of other networks. Similarly, transportation by road of passengers and goods can be undertaken by many different companies while in rail transport the minimum efficient scale of operation would require a single national network while allowing several regional ones.

Historically in many European countries the public utility industries operated as state-owned or state-controlled monopolies. This was because the government response to the natural monopoly problem was to extend the monopoly into the upstream production and downstream supply markets thereby establishing vertically integrated monopoly public utility firms. In the United States private ownership of such industries was the norm with the potential for abuse of market power, due to natural monopoly, being dealt

${ }^{243}$ George Stigler, "First Lecture", in M.F. Cohen and G.J. Stigler, Can Regulatory Agencies Protect Consumers?, (Washington, DC: American Enterprise Institute, 1971). 


\section{Chapter 22}

with by regulation. The past decade has seen the introduction of competition in public utility industries throughout the world.

The case for a regulatory regime in public utility industries arises because the incumbent firm:

- may refuse access to the transmission and distribution network to rival firms or set prices for access so as to hinder or prevent entry;

- may abuse its market power by charging excessively high prices for its output;

- may abuse its market power by imposing conditions of supply which are unrelated to the value of the service offered to consumers.

When the network operator is part of a vertically integrated firm which is also competing in the provision of services over the network it has obvious incentives to deny access to the network to its rivals or to provide it on less favourable terms than those it applies to its parent. Correspondingly new entrants will naturally seek to gain access at as low a price as possible. Disputes about access charges frequently arise when utility industries are opened to competition. In telecommunications, regulation of access pricing may be necessary even when there are competing local networks because firms may agree high access charges to interconnect with each other's network as a means of facilitating collusion.

Various alternative mechanisms have been employed for setting access charges. All access-pricing rules involve difficult and detailed economic analysis. The regulator requires highly detailed information about the operations of the incumbent firm and must be prepared to undertake extensive monitoring of its activities.

An interesting approach to tackling the problems involved in setting access prices has recently been adopted in some EU countries. The parties are allowed a specified maximum period (e.g. four months) to agree terms. If they fail to agree, the regulator chooses between the parties' final offers. This provides the parties with an incentive for truthful revelation and it is in each party's interest to reach a negotiated agreement.

By contrast, an independent network operator has no incentive to discriminate against new entrants. Vertical separation of the natural monopoly elements from the potentially competitive segments can therefore 
Competition and Services of General Economic Interest in the EU: Reconciling Economics and Law

greatly simplify the task of regulating access charges. The issue is whether economies of scope resulting from vertical integration outweigh the possible gains from separation.

Regulating output prices is also complicated by the fact that the regulated firm has more information than the regulator. Price-cap regulation (the CPI $\mathrm{X}$ formula) is designed to overcome this by offering incentives to regulated firms to provide information to regulators. The regulator sets a price cap for the firm's output. The firm can increase its profits by cutting costs. However, this provides the regulator with information on the scope for efficiency gains which can be incorporated into subsequent price reviews. Price capping has proved far more complex than originally envisaged.

Regulation has traditionally been justified on the grounds of "market failure". However, the potential for "regulatory failure" is now widely recognised. Regulatory agencies are prone to capture by regulated firms and the state bureaucracy. Information asymmetries mean that regulators are heavily reliant on regulated firms for information. Thus, over time there is a risk that regulators tend to identify with the regulated industry and end up defending it rather than policing it. Similarly once established, regulatory bodies tend to perpetuate and enlarge their activities and this may also give rise to regulatory failure. In order to ensure that customers of public utility industries enjoy the benefits which competition can produce, it is necessary to take measures to limit the possibility for regulatory failure.

International experience shows that although regulation is superior to monopoly it is not a substitute for, and will not deliver the benefits which can accrue from competition. In fact, certain forms of regulation may even hinder the development of competition. In those circumstances the objective should be to allow competition to as great an extent as possible which, of itself will reduce the need for specific forms of regulation.

\section{Why is competition distorted in the case of SGEI?}

We have seen above that even in the case of natural monopolies it may be possible to separate them into distinct sub-services some of which can be provided by the market under competitive conditions. We have also seen that the regulation of pure natural monopolies is not an easy task. Regulation is a second-best option. It tries to address the issue of competition through cost or price control. As is well known, this introduces fresh problems of its own 


\section{Chapter 22}

-- primarily how the regulator can obtain true information and how to fix prices at the level that offer enough incentives to the regulated firm to invest and innovate so as to reduce costs and expand the range and quality of its services. If the regulators have such problems in dealing with a single firm, one can imagine the magnitude of the problems when they regulate the prices of more firms.

But irrespective of all these problems the aim of regulation is to introduce more competition by mimicking market mechanisms. While in the case of natural monopolies it is perhaps easier to understand the logic of government intervention and regulation, this is not so easy in the case of SGEI. Why are restrictions of competition necessary? Let's therefore examine in which situations provision of SGEI necessitates restriction of competition.

There are two possibilities: When there is a single market and when there are two or more market segments or geographic markets. We begin with the case of a single market.

As our starting point we must assume that the market provides a certain service at a quantity which is regarded as too low or charges a price that is regarded as too high. This happens only when the cost of provision under free market conditions exceeds a certain level. This situation is shown diagramatically in Figure 22.1. Assume initially that there is a single provider who charges the economically optimum price which is equal to marginal cost. For ease of presentation, marginal cost is assumed to be equal to average cost. In Figure 22.1, " $\mathbf{P}_{\mathbf{2}}$ " is the market price and " $\mathbf{Q}$ " is the quantity supplied before state aid. " $\mathbf{P}_{\mathbf{0}}$ " is the level of price that is considered by the state to be "affordable" by citizens. Naturally, at a lower price level, the quantity demanded is larger and more people can afford to buy this particular service. The only way to increase supply on the market is to offer a subsidy to the provider of that service. The amount of subsidy that can induce output to expand to $\mathbf{Q}_{2}$ is equal to the two shaded rectangles.

What are the distortions to competition in this case? If there is a single provider, there is no direct distortion to competition, but there is a misallocation of resources. Society wastes part of its resources represented by the segment of the rectangle which lies to the right of the demand curve [because if the marginal cost shows the true social cost of resources, then the opportunity cost or forgone value of resources diverted from other activities 
Competition and Services of General Economic Interest in the EU: Reconciling Economics and Law

is indicated by $\mathbf{P}_{\mathbf{2}}=\mathbf{M} \mathbf{C}_{2}$ ] plus the cost of raising the subsidy. In real life no subsidy represents a pure transfer, i.e. it is raised by distortion-free taxes. The taxes that raise the revenue for the subsidy also cause their own distortions.

Perhaps one could argue that this is the "price" to be paid for expanding the supply of a product that society considers as too important. On the other hand, however, if that product is important why are consumers not willing to pay for it? The typical reply to this question is that consumers or citizens cannot afford to pay for the important things in life. The proponents of this view would claim that market prices do not reflect true need, they only reflect ability to pay.

It is essential to note that irrespective of whether one espouses these views or not, society wastes more resources than what is strictly necessary whenever there is more than one provider and the subsidy does not go to the most efficient one. This possibility is also shown in Figure 22.1. If the more efficient firm were allowed to provide the service in question, market price would fall to $\mathbf{P}_{\mathbf{1}}$. Since this firm is capable of providing that service at a lower price because its marginal cost, indicated by $\mathbf{M C}_{\mathbf{1}}$, is correspondingly lower, society ends up granting a larger subsidy than what is necessary by subsidising the less efficient firm. Consequently, other firms that happen to be more efficient are forced to exit the market.

There is now a distortion to competition which makes more difficult the achievement of the public policy objective of providing cheap SGEI. Subsidisation of the less efficient provider generates more costs to society. This means that if society would grant an equivalent subsidy to the more efficient provider, prices would decline even more, supply would expand more and consumers would be able to afford larger quantities of that product. There may also be other distortions in the longer term caused by possible lower rate of investment and innovation by the firm that receives the subsidy. For a fuller analysis of the various possible effects of subsidies see Bhaskar (1990).

Our conclusion must be, first, that subsidisation of anyone else apart from the most efficient provider of the service in question is contrary to the avowed policy objective of offering certain services which are deemed to be important and must, therefore, be offered at affordable prices and sufficient 


\section{Chapter 22}

quantities to citizens. Second, there is no need to legally exclude competitors from the market. They are excluded by the mere fact that one firm receives a direct subsidy.

Let's now consider the case of two or more market segments. The problem is virtually the same as earlier but, as we will see, the result is different. I assume that the costs of supply in market $\mathbf{A}$ are separate and lower than the costs in market $\mathbf{B}$. I further assume, as is normally the practice, that services in both markets are supplied at the same price. This means that the incumbent will have to make profits in one geographic market, $\mathbf{A}$, to cover losses made in the other geographic market, $\mathbf{B}$. It is important to note that there would be no problem if market $\mathbf{B}$ could be supplied at higher prices. The problem is caused by the fact that prices have to be uniform when costs differ. In Figure 22.2 this is shown by $\mathbf{P}_{\mathbf{m}}$. Price uniformity is the typical requirement imposed on providers of SGEI. So the problem is caused partly by the regional differences in costs and partly by the uniformity of prices.

The problem for the firm is to earn profits in market $\mathbf{A}$ to cover its losses in market $\mathbf{B}$. If the firm in question receives no subsidy and if it sets its price at the level where it just breaks even, then there is a unique price that generates enough profit in $\mathbf{A}$ so as to counter-balance the losses in $\mathbf{B} .{ }^{244}$ Please note that politicians cannot set whatever price they want. There is a unique price that allows the firm to balance profits and losses without making excessive profits and without receiving subsidies. But if it has to raise its price in $\mathbf{A}$ then it must exclude competitors from that market. The shaded rectangle in market $\mathbf{A}$ is equal to the similarly shaded rectangle in market $\mathbf{B}$. Any competitors that will eat away its profits in market $\mathbf{A}$ will make it impossible for the SGEI provider to continue its operations in market $\mathbf{B}$.

It is worth observing that this cross-subsidisation means that in order to serve consumers in market $\mathbf{B}$, public policy introduces a distortion in market $\mathbf{A}$ with the result that the quantity supplied in market $\mathbf{A}$ is smaller than otherwise and the price charged is higher than otherwise. So, public policy that aims to make it possible for certain consumers to obtain a SGEI at affordable prices in fact must always make such services less affordable than

${ }^{244}$ The problem of the firm can be expressed as follows: $\mathbf{P}_{\mathbf{1}} \mathbf{Q}_{\mathbf{1}}-\mathbf{A} \mathbf{C}_{\mathbf{1}} \mathbf{Q}_{\mathbf{1}}=\mathbf{A} \mathbf{C}_{\mathbf{2}} \mathbf{Q}_{\mathbf{2}}$ $\mathbf{P}_{\mathbf{2}} \mathbf{Q}_{\mathbf{2}}$; i.e. profits in $\mathrm{A}=$ losses in $\mathrm{B}$. The solution is $\mathbf{P}=\mathbf{P}_{\mathbf{1}}=\mathbf{P}_{\mathbf{2}}=\left(\mathbf{A C}_{\mathbf{1}} \mathbf{Q}_{\mathbf{1}}+\right.$ $\left.\mathrm{AC}_{2} \mathbf{Q}_{2}\right) /\left(\mathbf{Q}_{1}+\mathbf{Q}_{2}\right)$. 
Competition and Services of General Economic Interest in the EU: Reconciling Economics and Law

otherwise for other consumers. Naturally, the proponents of government intervention for this purpose would argue that forcing those who can afford to pay a bit more in order to increase the consumption of those who cannot otherwise afford them is a well worth trade-off.

\section{A comparison of the two cases}

We have seen that both in the case of a single market and in the case of geographically separated markets [or separated groups of consumers], public policy introduces distortions to achieve its objectives.

In either case, the public policy objective of increasing the supply of the SGEI requires that someone pays for it. In the first case, taxpayers bear the cost. In the second case, one group of consumers pays for another. In fact, the higher price in market $\mathbf{A}$ functions just like a tax whose revenue is transferred to the consumers in market $\mathbf{B}$. There is always a form of subsidy, overt in the first case and covert in the second.

The next section examines how the distortions of competition may be reduced. The natural solution is to consider how the amount of the required subsidy or cross-subsidy may be minimised.

\subsection{Removing competition distortions in the provision of SGEI}

The purpose of this section is twofold. First, it identifies an economic solution. Second, it examines whether this solution is legally possible under the present interpretation of Articles 86 and 87. In identifying a solution I will assume that the objective of public policy is to provide a certain amount of SGEI at certain pre-determined prices. These are the given policy constraints. Naturally, in the absence of these constraints there is no economic problem. The supply and the price of the SGEI would be set at the level where social marginal costs equal social marginal benefits as revealed by demand in each market; i.e. $\mathbf{M C}=\mathbf{P}$. Indeed, there is an economic and a legal problem because of these constraints.

The solution in the case of the single market is to offer the subsidy to the most efficient producer through a competitive tender procedure. This is in fact the solution that was proposed 35 years ago for the purpose of dealing with the problem of natural monopoly. As observed ago by Demsetz (1968), 


\section{Chapter 22}

even where a single firm can operate more efficiently in the market because of economies of scale, there is no need to tolerate monopoly prices. Auctioning the right to operate in the market would result in the selection of the firm that would be willing to do so for the lowest possible prices and, therefore, the lowest amount of profit. As shown in Figure 22.1, the required amount of subsidy would decline to the lower cross-shaded rectangle.

The same solution applies in the case of two or more market segments. This is shown diagrammatically in Figure 22.3. It reproduces Figure 22.2 with the additional element of the marginal cost, $\mathbf{M C}_{\mathbf{a}}$, of a more efficient firm. The incumbent, with $\mathbf{M C}_{\mathbf{a} 2}$, may purchase the services of the other firm and in fact make a profit in the process. This is because the incumbent needs to be able to earn as much profit as shown by the top shaded rectangle in market $\mathbf{A}$. It can then afford to pay any price that can be agreed between $\mathbf{P}_{\mathbf{1}}$ and $\mathbf{P}_{\mathbf{2}}$ to the other firm. The bottom cross-shaded rectangle represents the amount of profit that can be earned by the other firm or the amount of savings that can be achieved by the state if public authorities auction the right to provide services to the market $\mathbf{A}$. In any case, society as a whole becomes better off because it saves the resources shown by the lower shaded rectangle.

In fact the entry into the market of a more efficient provider affords another possibility to public authorities. This is because they can also set the market price, $\mathbf{P}_{\mathbf{m}}$, at a lower level due to the savings in operating costs. In order not to clutter Figure 22.3, this possibility is not shown in the diagram.

\section{Misalignment of incentives and need for regulatory intervention}

In either case there is a competition problem when a more efficient firm is excluded from the market. Since in either situation we can solve the competition problem by allowing the more efficient firm to enter the market, we need to ask whether this is a feasible solution when the incumbent firm has a legally imposed obligation to supply the market.

This is an important question for the following reason. On the one hand, if the incumbent has a legal obligation which is coupled with legal monopoly rights it may not want to enter into any agreement with a more efficient competitor. Although the incumbent may make extra profits in the shortterm, as is shown above, it may be afraid that in the longer term the government would take away its exclusive right. It seems to me that this is 
Competition and Services of General Economic Interest in the EU: Reconciling Economics and Law

one of the unspoken reasons for which this kind of arrangements are rejected by incumbent firms.

On the other hand, if the incumbent has no legal monopoly rights or no exclusive rights, no rival firm would be willing to enter into any subcontracting deal that would force it to share its profits with the less efficient incumbent firm.

We have now a mismatch of incentives so that one or both sides would be unwilling to enter into a voluntary agreement. The government, therefore, would have to step in. But in principle at least, this is no obstacle to injecting more competition in the markets for SGEI. The distortions to competition are created by the granting of state aid or by the granting of exclusive rights or by the assignment of SGEI obligations to inefficient firms. Therefore, the solution is to identify the most efficient provider of the SGEI in question. As I mention above, auctioning the right to supply the market or using some other open selection procedure [e.g. tender] is the best way to ensure that the provider who is eventually chosen is the one with the lowest operating costs.

Public authorities may also impose an obligation on the incumbent to enter into supply agreements with third firms. This is the norm now in liberalised markets such as those for telecoms and electricity distribution. Regulatory authorities intervene when firms cannot reach agreement or when the incumbent is demanding an excessively high entry fee.

Perhaps a word of caution is necessary at this point. The recent experience with the auctioning of third generation telecommunications licences suggests that firms can also make errors in their calculations about expected profits. The consequences of such costly mistakes are born by their shareholders but if these mistakes threaten the viability of large providers of SGEI the taxpayers may in the end have to bail them out through public subsidies. In this case, solving one policy problem [auctions to reduce competition distortions] creates another policy problem [bailing out large failing companies].

I think, however, that this possibility should not detract us from the conclusion that adopted policy measures should in principle aim to minimise the impact on competition. The fact that companies over-bid for telecoms 


\section{Chapter 22}

licences does not mean that we should tolerate distortions in the provision of electricity, water, transport, etc.

\section{Additional distortions from appointing SGEI providers through closed procedures}

To understand better the consequences of not using an open procedure for the selection of SGEI providers, we need to consider what may happen to the allocation of resources when a firm is given the right to supply the market at the exclusion of its competitors.

Figures 22.1 to 22.3 show the static welfare losses. It is said that the biggest benefit from a monopoly is the "quite life". This is understood in economics to mean that the monopolist is under no pressure to reduce its costs or contain their increase in the longer term. It is also under no pressure to innovate and make investments. These are the dynamic costs of monopoly, which are reflected in lower productivity and lower rate of innovation.

On the other hand, economic theory recognises that firms have to be given incentives to invest in new technologies. Indeed, this is the heart of the regulatory dilemma that I explained at the beginning of this section. The regulator has to set prices at a level where profits are not excessive but at the same time not too low because the regulated firm should have incentives to invest. No firm would invest and assume risk when it knows that any future profits will be taken away by the regulator.

Therefore, the problem that is identified below must be understood to be in addition to those caused by the regulatory process itself. My intention here is to examine one particular dynamic problem of how a firm may use its SGEIrelated activities in one market to gain an unfair advantage in another.

Consider the case of a firm that receives subsidies to provide a SGEI in market M. Also assume that the revenue it earns plus the subsidy it receives just cover its costs, including variable and fixed costs. The same firm also intends to provide a related product in another market called $\mathbf{C}$. The second market is open to competition so other firms also operate in that market. The situation is shown in Figure 22.4. The price in market $\mathbf{M}$ is fixed by public authorities, while the price in market $\mathbf{C}$ is determined by the competitive interaction between different firms. To facilitate the presentation of the problem I have made the activities of the firm in question in each market to 
Competition and Services of General Economic Interest in the EU: Reconciling Economics and Law

be of equal size. If the firm supplies only market $\mathbf{M}$, it receives a subsidy whose size is also shown in Figure 22.4. Assume that the subsidy is half the amount of the firm's fixed costs. The other half of the fixed costs plus all the variable costs are covered by the revenue it earns in market $\mathbf{M}$.

Assume now that the firm enters market $\mathbf{C}$. Under the conditions described above, it can sell its product in market $\mathbf{C}$ and make a considerable amount of profit because the price that prevails after its entry more than covers its variable costs.

The firm can also reduce the price it charges in market $\mathbf{C}$ down to the level where it just covers its variable costs. Other firms will naturally claim that this is unfair competition because the firm charges no fixed costs to the product it sells in market $\mathbf{C}$. Please note that in economic theory there is no general prescription of how fixed costs should be allocated. The "Ramsey" rule only says that prices of multi-product firms should be inversely proportional to the elasticity of demand. This entails that a proportionately larger share of fixed costs is borne by products whose price is inelastic. See the classic analysis by Baumol and Bradford (1970).

If the firm allocates its fixed costs in proportion to the size of its variable costs in each market, then it will have to attribute half of its fixed costs to sales in market $\mathbf{C}$. Since the total cost in market $\mathbf{C}$ will be higher than the post-entry market price, it will not be able to compete and will have to withdraw. But this means that prices in market $\mathbf{C}$ remain at a level higher than they would otherwise. For two reasons, this is a misallocation of society's resources. First, prices remain higher in market C. Second, if the firm is allowed to use some of the revenue it earns in market $\mathbf{C}$ to cover some of the costs in market $\mathbf{M}$, a lower subsidy would be required to support the supply of the SGEI in market $\mathbf{M}$.

I believe that this conclusion holds only in a static context. In a more dynamic context the ability of the firm in question to allocate its fixed costs to the subsidised activity in market $\mathbf{M}$ can damage competition in market $\mathbf{C}$. This is because any firm of equal efficiency will not be able to enter market C. This holds even if the incumbent is forced to allocate a proportionate share of its fixed costs to sales in market $\mathbf{C}$. Indeed, EU law does demand such a proportionate allocation of fixed costs. 


\section{Chapter 22}

To understand why this is so, suppose the variable costs of the incumbent in market $\mathbf{M}$ increase by $10 \%$. This means that the new total costs (variable plus fix cost) in that market will rise to $(1.1 \mathbf{V m}+\mathbf{F})$. If the revenue in that market stays constant, the subsidy will have to increase to cover the extra costs. If we assume that fixed costs, $\mathbf{F}$, are allocated between the two markets in proportion to the size of the operations of the firm in the two markets and that size is given by its variable costs, then the allocation of fixed costs to market $\mathbf{M}$ will be

$\mathbf{F m}_{\mathbf{1}}=\mathbf{F} \times(1.1 \mathbf{V m} /(1.1 \mathbf{V m}+\mathbf{V c}))$, where subscript 1 indicates the costs after the increase.

It follows that

$$
\mathbf{F} \mathbf{m}_{1}>\mathbf{F m} \text {, i.e. } \mathbf{F} \times(1.1 \mathbf{V m} /(1.1 \mathbf{V m}+\mathbf{V c}))>[\mathbf{F} \times(\mathbf{V m} /(\mathbf{V m}+\mathbf{V c}))]
$$

This firm, by doing nothing, just allowing its inefficiency to rise in the market where it receives a subsidy, all of a sudden becomes more competitive in market $\mathbf{C}$ which is open to competition. I repeat, this result holds even if the firm is forced to allocate its fixed costs proportionately between the two markets. We now arrive at the paradoxical result that inefficiency is rewarded by public policy! In two other papers I explain in more detail how we can arrive at such paradoxical outcome. See Nicolaides (2002a and 2002b).

We should note that when the firm holds a dominant position in the EU market, cross-subsidisation of a competitive activity by an activity which is closed to competition would constitute abuse of dominance and would be contrary to Article 82. A firm that has a legal monopoly that extends across the territory of a member state would normally be found to be dominant in the common market. But under the conditions described above where the price charged in market $\mathbf{C}$ exceeds variable costs plus an appropriate portion of fixed costs it would not be regarded as abusive. It would, therefore, escape the prohibition of Article 82. Competition policy is incapable of preventing this kind of distortion to competition caused indirectly by subsidies to providers of SGEI. Not only do they escape the net of competition policy through an explicit exception, they escape its reach for a second time when subsidies allow them to use increases in the costs of providing the SFEI to reduce the portion of fixed costs they allocate to competitive services.

Had the public authority concerned chosen the provider of the SGEI through a competitive open procedure, the amount of subsidy would have been fixed 
Competition and Services of General Economic Interest in the EU: Reconciling Economics and Law

at the outset to the minimum possible level. The chosen firm would not have been able subsequently to exploit any rise in its costs of the SGEI. As the subsidy would have been capped the firm would suffer losses. This is precisely the reason why economics has no rules on the allocation of fixed costs. In order to gain an advantage in one market simply by reallocating costs, a multi-product firm must apportion a bigger share of those fixed costs to another market. But then it would become vulnerable to entry by competitors. The threat of or actual entry is the disciplining factor that ensures that only truly efficient firms survive. This discipline is absent when providers of SGEI are shielded from competition.

In the remaining of this section I will examine whether it is legally possible under the present EU rules to oblige public authorities in the member states to use auctions or other competitive procedures [e.g. tenders] to select the providers of SGEI.

\section{Can existing competition rules require public authorities to ensure that providers of SGEI are efficient?}

In this sub-section I will argue that existing competition rules can be interpreted differently. More specifically, I believe they can be used to protect efficiency and, in the process, promote further the interests of consumers. I begin with an analysis of Article 86 and I assume that the problem is one of cross-subsidisation. I will deal with the issue of Article 87 and state aid later on.

\section{Re-interpreting Article 86}

We saw earlier in section 3 that under the current interpretation of Article 86, member states are allowed to confer special or exclusive rights. Moreover, in the case of SGEI, they are allowed to exclude competitors so as to enable the designated providers of SGEI to break even. Indeed there is some logic behind the rulings of the courts in this respect. If a firm is legally mandated to provide SGEI and suffers losses because of cream-skimming by competitors, how can it then carry out the tasks assigned to it by law?

One response could be that it should be allowed to go bankrupt. After all, that is the ultimate risk facing every other firm in the market. Why should some firms be protected from that ultimate penalty? The answer, of course, is that if it is forced to leave the market, then no one will provide services to the higher-cost segment of the market or the services that are provided to 


\section{Chapter 22}

some groups or regions will be less and more expensive than otherwise. That would be contrary to the aims of public policy.

Another response could be that the designated SGEI provider should try to be as efficient as any other firm. Indeed it can try to raise its efficiency, but it will always be lumbered with costs that no other competitor has to bear. This is because it has to serve the high-cost segment of the market.

Understandably, therefore, the judges have concluded that the only way for member states to achieve their policy objectives with respect to SGEI is to restrict competition. This, however, is the wrong conclusion. As we have seen earlier, a superior arrangement is for the incumbent to procure the services of the more efficient firm.

We also saw earlier that it is quite possible that neither the incumbent, nor the competitor may have any incentive to enter into any such voluntary agreement. Nonetheless, I do not think that this presents an insurmountable problem. Article 86 is addressed to the member states. The member states can always take away rights they confer in the first place. Or, they can require the firm using those rights to sub-contract to other firms that offer to provide services at lower prices. Regulatory authorities in the area of telecommunications, for example, routinely intervene to compel incumbent operators to grant access to their networks to rival firms.

The question that arises is whether indeed the EU has the power to ask member states to intervene in such a way. Again, I think the answer is yes. Article 86(2) exempts providers of SGEI only to the extent that the distortion to competition is necessary and only up to a point where trade is not affected to an extent that would be contrary to common European interest.

But we have seen that the distortion is not disproportional and, therefore, to a certain extent unnecessary when another firm can be sub-contracted to provide services more cheaply. In addition, trade must in such a case be necessarily affected to an unwarranted extent because entry and, consequently, supply are overly restricted. This is contrary to the requirements laid down by Article 86(2).

I have mentioned sub-contracting here because in this way the incumbent is not forced to leave the market. If that were the case it could legitimately 
Competition and Services of General Economic Interest in the EU: Reconciling Economics and Law

complain that it is not allowed to carry out legally mandated tasks, something for which it may be held liable. However, there is nothing preventing member states from using an open selection procedure in the first place, instead of assigning public service tasks only to certain firms by law or via a closed procedure.

The re-interpretation I am advancing here is not particularly novel. It has appeared in a different context, in the form of the doctrine on "essential facilities". The holder of an exclusive right to supply a certain SGEI may be thought of as operating an essential facility. All competitors need its permission in order to enter the market.

It is now well-established that access to essential facilities which are controlled by a dominant undertaking (whose dominance may have been created by an exclusive right legally conferred by the government) may not be refused or granted on less favourable terms than those that apply to the use of the facilities by the owner. This means that the owner or manager of the essential facility may charge a fee to users of the facility, who may be competitors. The fee has to reflect the costs of granting access to that facility.

Typical essential facilities that have been dealt with have covered sea ports, airports, railways, telecommunications networks, pipelines, computer reservation facilities and cross-border credit facilities.

An essential facility is not necessarily that whose use would allow entry into the market at a lower cost than otherwise, nor is it the facility which is needed by a certain firm. It is that facility whose unavailability makes access impossible or seriously uneconomic or that which is generally needed by all competitors.

Access to an essential facility may be refused only for objective reasons. The main reasons that have been recognised in the case law as being objective are potential damage to the system, unavailability of sufficient network or system capacity or exclusive exploitation of own intellectual property rights. However, even such reasons may not provide sufficient justification for exclusion if the damage which is caused to competition by exclusion is significant. In this situation the essential facility may have to be shared with competitors. 


\section{Chapter 22}

It is not an objective reason to discriminate against a user of an essential facility, who may be a rival firm, on the basis of how that firm intends to use the facility. In particular, the pricing of access (through access charges) should be done on the basis of real/actual costs rather than the nature of the intended use. But it is permissible to charge different prices for different intensities of use of the facility.

To conclude the analysis of Article 86, it seems to me that once other institutional arrangements are taken into account [such as sub-contracting], it is possible both to remove the restrictions on market entry and competition and to allow the incumbent with the legally binding public service obligation to remain in the market and break even. But, member states may also choose to assign the obligation and the rights that come with it to the most efficient provider through an open procedure.

\section{Re-interpreting Article 87}

Under the prevailing interpretation and application of Article 87 on state aid, subsidies or other aid to compensate undertakings for the extra costs imposed on them by public authorities are not regarded as state aid, regardless of the efficiency of the beneficiaries in relation to their competitors.

But as explained above, the problem with this approach is that it weakness the incentives to firms to keep costs low. It weakens the discipline imposed by the market on firms to keep their costs at least as low as those of their competitors. Even worse, this kind of state aid may enable firms to expand into adjacent markets without being caught by any of competition rules.

Advocates General of the European Court of Justice have tried to grapple with this problem by creating more narrow definitions of the kind of subsidies that may escape being classified as state aid. Such narrower definitions may solve the legal problem but will not solve the economic problem. There will still be a distortion to competition irrespective of whether the compensation falls outside Article 87(1) and irrespective of whether the compensation is found to be state aid but then exempted under Article 86(2).

Under the assumption we made earlier that state aid may be used to support supply of SGEI, the only solution to the economic problem of minimising 
Competition and Services of General Economic Interest in the EU: Reconciling Economics and Law

the distortion to competition caused by this kind of state aid is to minimise the amount of state aid that is eventually granted. As in the case of Article 86, the solution in the case of Article 87 is to rely on auctions or open procedures.

Before examining how such open procedures may be used to minimise the amount of state aid necessary, I want to explain why the prevailing interpretation of the application of state aid rules to compensation for the extra costs of SGEI is faulty. Remember that the Court in Ferring and the opinions of the Advocates General implied that this kind of compensation merely eliminates competitive disadvantage. For a public measure to be classified as state aid, it must, among other things, confer an advantage to certain undertakings that they could not obtain under normal market conditions. I will explain that far from restoring a level playing field, compensation as currently done strengthens anti-competitive advantages.

The first fault is that, unless the public service obligation is imposed on a certain firm explicitly, any disadvantage may be avoidable. The firm concerned may choose not to supply the SGEI in question. There is no difference between this situation and other instances of state aid where firms receive aid to carry out more investment, training or research. In some cases perhaps firms could be completely unwilling to provide the SGEI. But how do public authorities know that such unwillingness would prevail in each and every case? They do not. So, they may be subsidising something that firms could do voluntarily. Even if the total costs allocated to the SGEI through accounting methods exceed the revenue from the SGEI, how do public authorities know that beneficiary firms have not simply re-allocated fixed costs, as in Figure 22.4, so that the accounting costs of the SGEI exceed its true incremental costs? Again, they do not.

More importantly for legal purposes, what is the difference between the extra costs of public service obligations and other costs imposed by the normal regulation of businesses, such as the obligation of lenders or insurers to have a cooling off period during which borrowers or clients can brake off contracts without penalty, the obligation of food manufacturers to maintain high levels of hygiene, the obligation of airlines to compensate passengers for cancelled flights or the obligation of employers not to fire underperforming workers without first giving them one or more warnings. All these regulations add to the costs of doing business. Yet, firms voluntarily 


\section{Chapter 22}

enter these industries without obtaining state aid. It is not clear to me at all why classification of an obligation as a public service mission justifies granting of public aid which is not state aid while public aid to relieve costs imposed by other regulations is regarded as state aid.

The second fault is the opposite of the first. The problem above is that firms by allocating their fixed costs to the subsidised activity they can justify receipt of aid to cover seemingly higher costs. There is a problem, however, when through shifting of fixed costs, firms can artificially reduce the costs of other activities. Beneficiary firms, even when they cannot avoid the public service obligation, can turn the seeming disadvantage into a surreptitious advantage in supplying related services. Since state aid rules do not prohibit an firm receiving state aid from engaging in other activities, subsidised suppliers of SGEI can always expand into related but apparently nonsubsidised activities. Current enforcement of Article 87 cannot prevent these problems because firms have much discretion in how they allocate their fixed costs among their various activities. There are several credible accounting methods for doing so (see the explanation earlier in relation to Figure 22.4).

These problems are compounded by the fact that the amount of compensation allowed under state aid rules is open-ended, as long as it remains below the amount of the extra costs of the public service obligation. As in the case of Article 86, the way to avoid these problems is to impose a ceiling on permissible state aid.

Can auctions or other open procedures minimise the amount of state aid? I think the answer is yes. When firms bid for the right to provide a SGEI and obtain the related subsidy they can win only by asking for as small a subsidy as possible. They have a strong incentive to minimise both the variable and fixed costs of the SGEI. This means that they will be allocating fixed costs to other activities, rather than shifting them to the subsidised operations as was the case above!!

Another important advantage of open procedures is that once a contract is won, the amount of the subsidy is fixed. Firms may be able to raise their profits by reducing their costs by a greater degree than the authorities expected. But this is not so bad because it would mean that those firms become more productive and use resources more efficiently. If, by contrast, 

Economics and Law

their costs rise faster than they expected, their share holders will have to bear the losses and would naturally take measures against the management of the firms. In either case it is unlikely that the firms that receive the subsidy would be able to use it to cross-subsidise adjacent operations and gain an unfair advantage over their competitors.

Can the use of open procedures be demanded from the member states? Again, I think the answer is yes, even without revising the present state aid rules. The Commission should only re-interpret it as I am suggesting here. The reason being that any direct allocation of aid cannot be presumed not to distort competition and confer a selective advantage to the recipient firm.

\section{The special case of tax incentives}

Before concluding the analysis in this section, we need to consider the case of tax incentives. The public aid which is granted to compensate providers of SGEI takes mainly two forms: either direct subsidies [grants] or reductions of tax liability. So far we have looked at direct subsidies. This was, for example, how Spain compensated a company that provided maritime transport services between the mainland and some islands [see Commission Decision 2001/156 on aid granted to Trasmed, OJ L57, 27/2/2001]. For the sake of completeness we also need to have a closer look at tax reductions.

There are two kinds of tax reductions: exemption from profit or income tax and exemption from sales tax. Consider first the exemption from profit tax. This kind of tax applies only when a firm makes profit. That is, its revenue must exceed its costs. But in this instance, the firm in question is "compensated" before it receives aid. Even if the public service obligation raises its operating costs, it still makes a profit. Any aid, therefore, is unnecessary.

In the opposite instance where its costs exceed its revenue, it will make no profit. But now relief from profit tax is useless. So we see that when profits are positive, exemption of profit tax is unnecessary and when profits are negative, exemption from profit tax is ineffective.

Consider now reductions of sales tax. That was the situation in Ferring. Manufacturers of pharmaceutical products had to pay a special sales tax. This means their profits before income tax were:

$$
\boldsymbol{\pi}=\mathbf{R}-\mathbf{R t}-\mathbf{C}
$$




\section{Chapter 22}

Wholesale distributors were exempted from the sales tax. The Court concluded that as long as the amount of the sales tax was less than the extra costs incurred due to the public service mission [i.e. $\mathbf{R t}<\mathbf{C}$ ], then there was no state aid. On the face of it, relief from sales tax appears to be different from relief from profit tax. This is because, as long as its revenue exceeded its costs, the profit tax was irrelevant to the decision of a firm whether to enter the market or not. It still made a profit in an economic sense [i.e. costs include the opportunity cost of capital]. By contrast, the firm has to take into account the amount of the sales tax because it reduces directly its revenue.

Even under these conditions, note again, that public authorities do not know whether a firm would make profit even after paying the sales tax and, therefore, would voluntarily enter the market without asking for any state aid. If $(\mathbf{R}-\mathbf{R t}-\mathbf{C})>\mathbf{0}$, the aid is unnecessary. It follows that the necessary amount of aid is not that which compensates the firm for all its extra costs but that which merely returns it to profitability. To see the difference assume that

$$
\text { ( R - C) }>\mathbf{0} \text {, but }(\mathbf{R}-\mathbf{R t}-\mathbf{C})<\mathbf{0} \text {, }
$$

while the condition imposed by the Court holds, i.e. $\mathbf{R t}<\mathbf{C}$

Since the tax is less than the extra cost, the European Court of Justice would count the whole of the tax, Rt, as non-state aid. But this may be too much. The tax reduction which is truly necessary is only that which returns the firm to profitability [i.e. $\mathbf{R}=\mathbf{C}$ ]. It follows that the amount of the required subsidy, $\mathbf{S}$, is

$$
\mathbf{S}=\mathbf{R t} \text { - ( } \mathbf{R}-\mathbf{C}) \text {, which is less than } \mathbf{R t}
$$

Once more we see that compensation of firms without regard as to whether they would voluntarily serve the market or not, in fact results in over compensation. This must distort competition between firms and give an advantage to those firms that need state aid less than others! Our conclusion, therefore, must be that this form of aid is state aid within the meaning of Article 87(1) for the reason that public authorities do not know whether they grant an unnecessary advantage.

But suppose that the tax liability of the firm exceeds its extra cost, i.e. Rt $>$ C. There is still a problem. The amount of subsidy, $\mathbf{S}$, that can be claimed by the firm is now equal to $\mathbf{C}$. This means that between two firms that have equal tax liability because they have the same amount of sales and generate exactly the same amount of revenue, the less efficient firm with the higher 

Economics and Law

costs will receive a larger subsidy. The competitive advantage of the more efficient firm is reversed! The total expenses of either firm are the sum of the operating costs and tax liability; i.e. $(\mathbf{R t}+\mathbf{C})$. Since they obtain a subsidy which is equal to the costs of providing the SGEI, the net expenses are $\left(\mathbf{R}_{\mathbf{1}} \mathbf{t}\right.$ $\mathbf{C}_{\mathbf{1}}$ ) for the first firm which is assumed to be more efficient and $\left(\mathbf{R}_{\mathbf{2}} \mathbf{t}-\mathbf{C}_{\mathbf{2}}\right)$ for the second firm. Since $\left(\mathbf{C}_{\mathbf{1}}<\mathbf{C}_{\mathbf{2}}\right)$, the more efficient firm will end up paying a larger amount of tax.

The situation gets worse if these firms also provide other services not subject to public service obligations. If the costs which we considered above also include a share of the fixed costs to be borne by the SGEI, it means that the less efficient firm will be able to have a larger proportion of its fixed costs subsidised by including them in the extra costs of the SGEI. In the process it strengthens its competitive advantage in an adjacent market. We are now in the situation described in Figure 22.4. State aid for one service distorts competition in the market for related services. Since this kind of state aid cannot be presumed to restore competitive advantage, it must fall within the scope of application of Article 87(1).

The remedy to these problems is to auction the obligation (or contract) to provide the SGEI in question together with the minimum required amount of subsidy. Firms would have an incentive to ask for the lowest amount of subsidy. At present they ask for the maximum permitted by law. The minimum which is economically necessary is certainly not the same as the maximum which is legally allowable.

\subsection{Conclusions and recommendations}

This chapter has shown that services of general economic interest occupy a special position in the economies of the member states of the European Union and in the framework of the EU itself. These services are extensively regulated and governments take measures to ensure their uninterrupted availability to citizens at affordable terms and prices.

The providers of services of general economic interest may also, under certain conditions, be exempted from the competition rules of the EU that normally apply to all enterprises regardless of economic sector. This exception appears to have widened as a result of recent decisions of the European Court of Justice. 


\section{Chapter 22}

There is now intense political debate in the EU on how SGEI should be treated in the future, whether they should receive public funds, whether they should continue to be subject in principle to the rules of competition and whether they should be exempted more explicitly and widely than at present. Certain member states and most operators of SGEI believe that the application of competition rules is not as clear as it should be and that compliance with those rules hampers the provision of SGEI. Others support a more rigorous enforcement of competition rules. The European Commission has not yet clarified its own position but it appears to favour the definition of a more transparent exception.

The chapter has examined how competition rules impact on the provision of SGEI and proposes a different interpretation of Articles 86 and 87 so that public policy objectives can be achieved as efficiently as possible.

The chapter began with a review of the various definitions of SGEI and the reasons why they are perceived to be so important in modern societies. It then investigated how competition rules may affect the ability of SGEI providers to reach citizens. In this connection, it also reviewed extensively relevant Commission decisions and Court rulings.

In view of the weaknesses it has identified in the current practice on SGEI, the chapter proposes a different approach to treating SGEI providers under competition rules. This approach leads to a more efficient allocation of resources, given the constraint that the public policy objective of reaching citizens is preserved.

The proposal is rather simple. Both competition rules and public policies aim to raise the availability of SGEI. This aim can be most effectively achieved by enabling the most efficient and productive operators to enter the market, rather than exclude them through the granting of exclusive rights or subsidies to less efficient operators. The chapter has explained why auction or open selection procedures are much more appropriate in selecting efficient operators than conferring exclusive rights or direct subsidies to certain enterprises. 
Competition and Services of General Economic Interest in the EU: Reconciling Economics and Law

Figure 22.1: Subsidisation of the provision of services

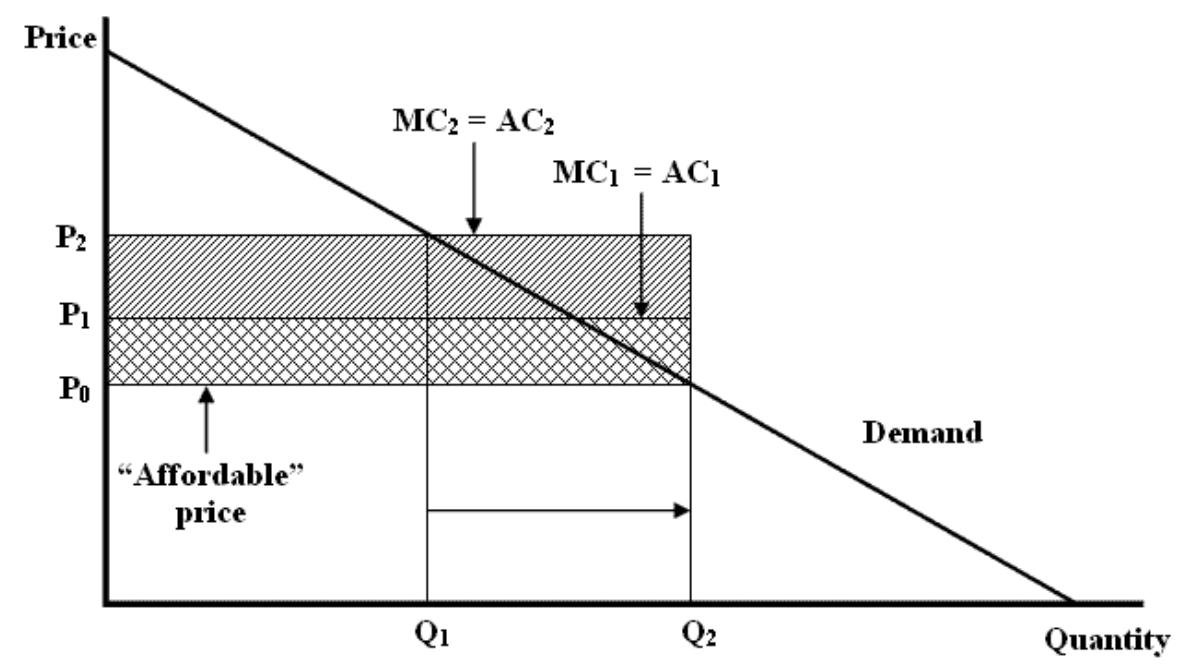

Figure 22.2: Provision of services in two market segments

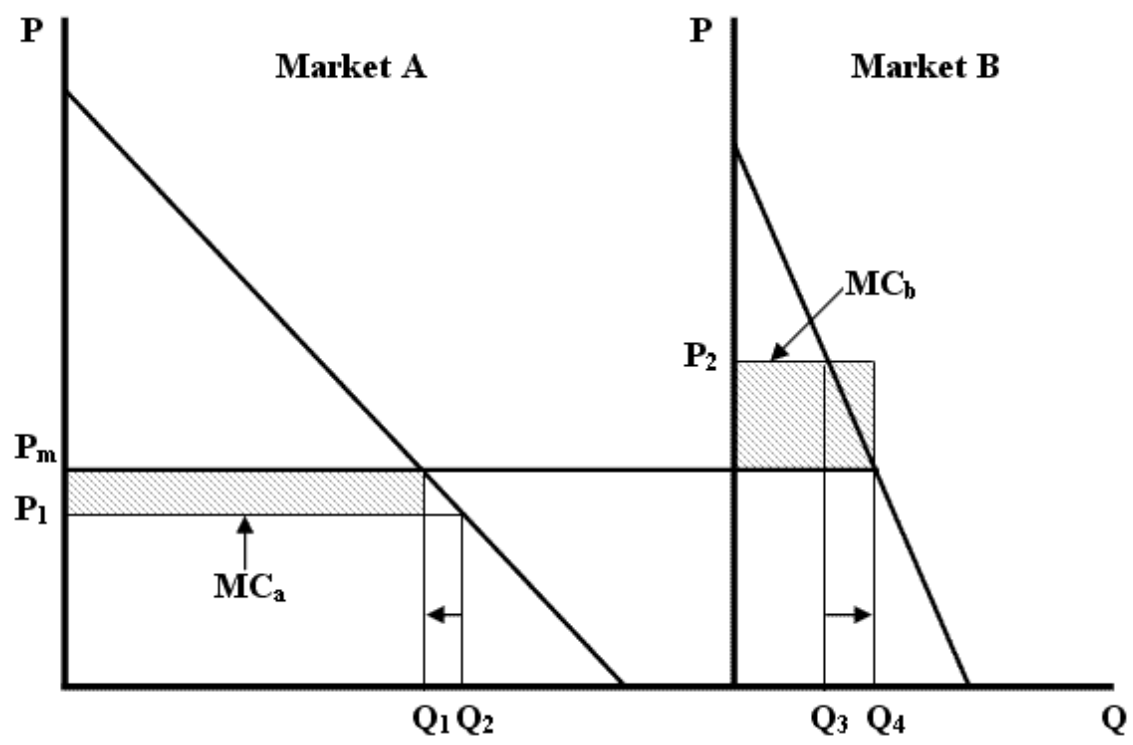




\section{Chapter 22}

Figure 22.3: Choosing the most efficient service provider

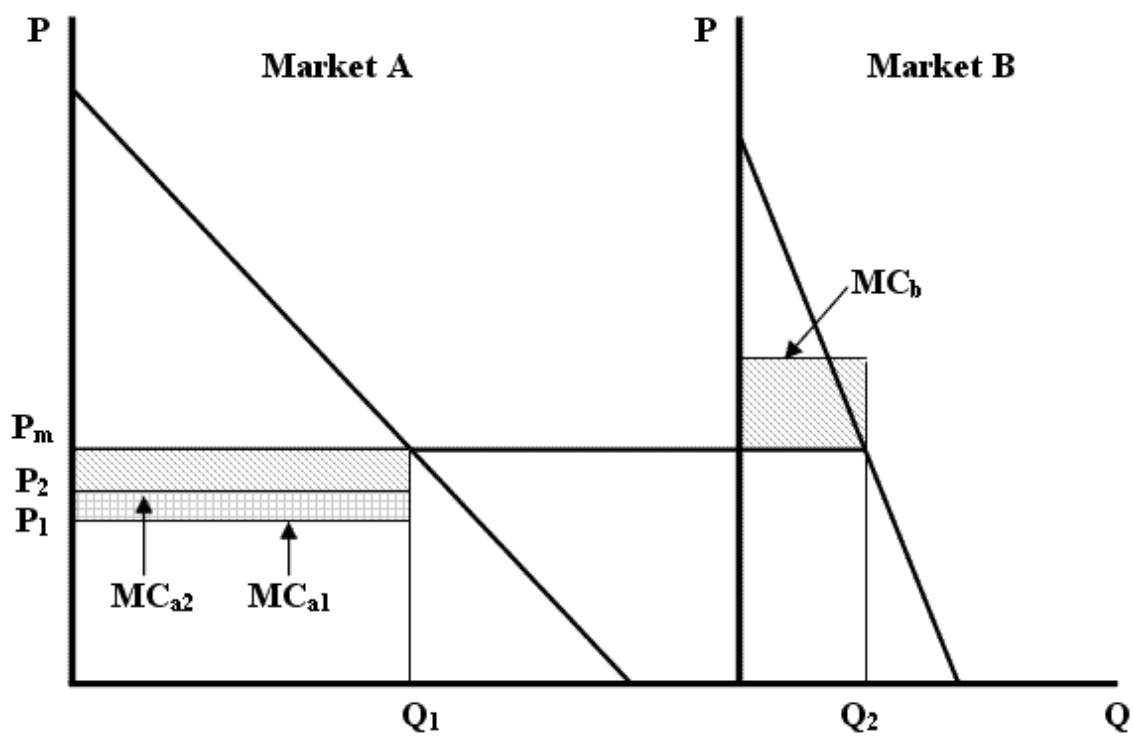

Figure 22.4: Cross-subsidisation

Market M

Market C

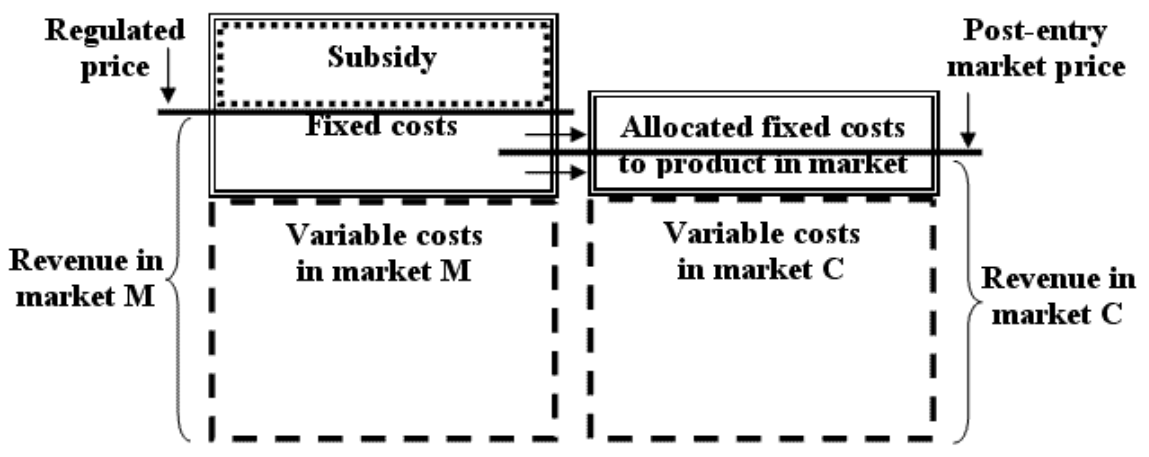


Competition and Services of General Economic Interest in the EU: Reconciling Economics and Law

\section{References and official documents}

W. Baumol and D. Bradford (1970), Optimal Departures from Marginal Cost Pricing, American Economic Review, vol. 60, pp. 265-283.

K. Bhaskar (1990), The Effect of Different State Aid Measures on IntraCommunity Competition, study prepared for the European Commission, (Luxembourg: Office of Official EC Publications).

H. Demsetz (1968), Why Regulate Utilities? Journal of Law and Economics, vol. 11, pp. 55-65.

J. Faull and A. Nikpay, The EC Law of Competition, (Oxford: Oxford university Press, 1999)

P. Nicolaides (2002a), The New Frontier in State Aid Control: An Economic Assessment of Measures that Compensate Enterprises, Intereconomics, vol. 37, pp. 190-199.

P. Nicolaides (2002b), The Distortive Effects of Compensatory Aid Measures: A Note on the Economics of the "Ferring" Judgement, European Competition Law Review, vol. 23, pp. 313-319.

J. Südekum (2002), Subsidising Education in the Economic Periphery, HWWA Discussion Paper 209, (Hamburg).

\section{EC documents}

Commission (1996), Services of General Interest in Europe, OJ C 281, 26/09/96.

Commission (1998a), Notice on the Application of the Competition Rules to the Postal Sector and on the Assessment of Certain State Measures Relating to Postal Services, OJ C39, 6/2/98.

Commission (1998b), Report to the Council of Ministers on Services of General Economic Interest in the Banking Sector, 23/11/98.

Commission (2001a), Services of General Interest, OJ C17, 19/1/01. 


\section{Chapter 22}

Commission (2001b), Services of General Interest: Report to the Laeken European Council, COM(2001)598 final, 17/10/01.

Commission (2002a), Report to the Seville European Council on the Status of Work on the Guidelines for State Aid and Services of General Economic Interest, June 2002.

Commission (2002b), A Methodological Note for the Horizontal Evaluation of Services of General Economic Interest, COM(2002 331 final, 18/6/2002.

Commission (2002c), Discussion Paper: Services of General Economic Interest and State Aid, November 2002.

Commission (2002d), Report to the Copenhagen European Council on the State of Play in the Work on the Guidelines for State Aid and Services of General Economic Interest, December 2002. 


\title{
Chapter 23
}

The Distortive Effects of Compensatory Aid Measures:

\author{
A Note on the Economics of the "Ferring" Judgement
}

\subsection{Introduction}

In November 2001, the European Court of Justice ruled in the case "Ferring v Agence centrale des organismes de securite sociale", C-53/00, that a tax exemption granted to wholesale distributors of pharmaceutical products in France was not state aid because it merely compensated them for certain public service obligations imposed on them. The relevant French law requires that wholesalers

(a) keep a permanent stock of medicinal products comprising at least ninth tenths of all forms of medicines sold in France;

(b) they satisfy all needs of their regular customers for at least two weeks; and

(c) they guarantee delivery of every medicine sold in their distribution area within 24 hours of receipt of an order.

As compensation for these onerous obligations, wholesalers are exempted from a special tax on sales of pharmaceutical products. By contrast, pharmaceutical laboratories cannot escape the tax; hence, the case which was lodged in a national court by "Ferring", a company owned by the manufacturer of a pharmaceutical product.

In particular the Court stated in paragraph 27 of its judgement:

"Provided that the tax on direct sales imposed on pharmaceutical laboratories corresponds to the additional costs actually incurred by wholesale distributors in discharging their public service obligations, not assessing wholesale distributors to the tax may be regarded as compensation for the services they provide and hence not State aid within the meaning of Article 92 [now 87] of the Treaty. Moreover, provided there is the necessary equivalence between the exemption and the additional costs incurred, wholesale distributors will not be enjoying any real advantage for the purposes of Article 92(1) [now 87(1)] of the Treaty because the 
only effect of the tax will be to put distributors and laboratories on an equal competitive footing."

In effect the Court identified two conditions or tests that have to be satisfied in order for that kind of tax exemption not to be classified as state aid: a "necessity" test (the tax exemption corresponds to additional costs) and a "proportionality" test (the tax exemption merely compensates for the additional costs). The economic question which arises is whether under these conditions wholesalers are indeed unable to derive any other advantage, as the Court presumed. In the rest of this chapter I will argue that this is not the case because the two tests cannot be always or in general satisfied by a measure such as that in question.

\subsection{The concept of state aid and the meaning of derived advantage under EC law}

Before proceeding, it is useful to review briefly the concept of state aid and the meaning of derived advantage in the EC law. In this connection, the observations of the Advocate-General in the case Italy v Commission, C6/97, paragraph 22, are particularly pertinent:

"Since 1961, the Court of Justice has consistently interpreted the concept of aid solely by reference to its effects [Steenkolenmijnen Limburg v High Authority, C30/59]: the decisive criterion is not the form that the intervention takes, nor of course, its legal nature or the aim it pursues [Italy v Commission, C-173/73] but the result to which it leads. Any intervention which gives rise to an economic advantage, accompanied by a correlative decrease in state resources, and benefits a particular undertaking or sector of production, is in principle state aid for the purposes of Article [87] of the Treaty."

So, the concept of state aid is objective. It is independent of form or the intentions of the granting authority.

In another recent case dealing with compensation for delivery of a service of general economic interest [Syndicat francais de l'express international (SFEI) et al v La Poste et al, C-39/94, paragraphs 60 and 61], the Court ruled that:

"In order to determine whether a state measure constitutes aid, it is necessary to establish whether the recipient undertaking receives an economic advantage which it would not have obtained under normal market conditions.

In examining that question, it is for the national court to determine what is the normal remuneration for the services in question. Such determination presupposes an economic analysis taking into account all the factors which an undertaking acting 
The Distortive Effects of Compensatory Aid Measures: A Note on the Economics of the "Ferring" Judgement

under normal market conditions should have taken into consideration when fixing the remuneration of the services provided."

This means that in order to determine whether an undertaking obtains an advantage, it is necessary to examine what would have happened in the absence of the public measure in question. While the concept of aid is objective, the concept of advantage is not independent of the economic context in which the aid is granted. I shall argue below that one of the weaknesses of the "Ferring" judgement is that the Court seems to have neglected to ask whether the wholesalers would withdraw from the market if they would receive no state aid.

\subsection{The virtual impossibility of ensuring proportionality and necessity}

We should first note that the additional costs imposed by the French law in question differ from each other. The first two categories, i.e. the range and volume of medicinal products stocked by wholesalers, are likely to have significant elements of fixed costs. Maintaining a larger than otherwise volume of products means primarily having a larger warehouse. Maintaining a wider than otherwise range of products means primarily a larger initial outlay and larger or more sophisticated product-management system. Naturally, operating a larger warehouse and keeping track of larger and more varied stock also generates some recurring costs which are also called variable or avoidable costs.

In addition, the company that keeps in stock less used medicines also ties part of its capital in products that do not generate quick income. This also results in some extra and recurring costs in terms of the opportunity cost of capital tied to those products. However, with today's computerised inventory and warehouse management systems and the presence of economies of scale, the extra recurring costs are unlikely to be significant. But the relative size of recurring costs is not important to my argument.

The important point to note here is that if some of the extra costs are fixed, they can naturally or easily be added to other similar fixed costs; e.g. smaller $\mathrm{v}$ bigger warehouse, smaller $\mathrm{v}$ bigger computers, etc. A multi-product company can then allocate all or most of these fixed costs to operations that benefit from the tax exemption. 


\section{Chapter 23}

There are many accounting conventions on how to apportion fixed costs. But these are conventions, not precise rules. There is no economic theory that determines unequivocally the optimum allocation of fixed costs. However, most economists would adhere to the so-called "Ramsey" rule according to which the fixed costs of a multi-product firm should be allocated in proportion to the inverse of the elasticity of demand for each product; i.e. the products with the more inelastic demand should bear a larger share of the fixed costs. So, the proportion of the fixed costs allocated to each product depends on the strength of demand (as indicated by its elasticity) rather than the share of the particular product in the total volume of output or the volume of sales or their use of internal resources of the firm or other typical accounting methods. Naturally, the allocation changes according to shifts in demand, even if the use of internal resources, for example, remains unchanged. Indeed, one of the principal reasons for which multi-product companies exist is precisely in order to obtain flexibility in their operations by being able to shift fixed costs from one product to another as market conditions change.

I conclude, therefore, that as long as the public service obligations imposed on wholesalers of pharmaceutical products generate fixed costs and as long as such fixed costs can be subsumed into other similar fixed costs, it would be virtually impossible to determine unambiguously the exact magnitude of the costs that should be allocated to operations covered by those obligations.

To repeat, the critical issue here is whether the extra fixed costs can be clearly distinguished from other costs. This can be done only if they are "incremental" in nature. That is, the extra operations that are necessary in order to comply with the public service obligations have their own fixed costs. That would indeed be the case, for example, if a wholesaler had to establish a new warehouse just for the purpose of storing the extra medicines or special medicines (e.g. requiring refrigeration) that in the absence of the public service obligations it would normally not stock.

But what are those "normal" services that a wholesaler would prefer to provide if it were not compelled to stock sufficient quantities of virtually the complete range of products and deliver them within 24 hours? It seems to me that this another question which is also close to impossible to answer. As long as any wholesaler would make a profit representing a return on its 
capital above the opportunity cost of that capital (i.e. above zero economic profit), it would provide those services.

Suppose the extra revenue from an added service is 100 and the extra cost is 80 . The wholesaler would voluntarily and with no state aid provide the service. The compensation offered by the state through the tax exemption is wholly unnecessary. State aid would be necessary only if costs exceeded revenue. But even in cases where the extra costs exceed the extra revenue for a certain service, such extra costs may not always be "avoidable". That is, the market may demand services involving fast supply of the whole range of medicines. A wholesaler may not be able to survive in the market place when attempting to offer a different service. For example, consumers in some countries are used to having a glass of water with their coffee, but they cannot normally get the water for free without the coffee, nor can the shopkeepers offer the coffee without the water. In this example, it is easy to separate the cost of coffee from the cost of water. But it would not be sensible to talk of extra costs because in the eyes of the consumers the two products are seen as inter-linked. Admittedly, the question of what is the standard or normal service in any particular market is an empirical one. It is probably very difficult to identify a "normal" service in the French market for pharmaceutical products, which has been regulated for a very long period of time. Nonetheless, the Court could have investigated further whether any incremental costs could be calculated.

Moreover, even if a service standard could be identified, it does not follow that it applies to all firms in that market. Some wholesalers may voluntarily choose to offer the complete range of products, while others may opt to specialise. How would the national authorities know which firms would have opted for the latter option and, therefore, would need aid in compensation for deviating from their optimum business strategy?

The problem gets further compounded when we extend our inquiry from the relevant product market to the relevant geographic market. It should be noted that the French law does not require anything like universal service. It only stipulates certain conditions in transactions between wholesalers and their "regular customers". Consequently, a wholesaler may choose an urban area with concentrated and large customers (e.g. teaching hospitals) which are more likely to need larger quantities of the whole range of pharmaceutical products. It would also be easy to deliver the required 


\section{Chapter 23}

quantities within hours of receiving a request. The extra costs of this wholesaler are much lower than those of another wholesaler in a rural area. But the important point here is not just that costs differ. The important point is that what appears to be extra in the urban region does not in fact relate to an activity that the wholesaler would seek to avoid.

One may retort that these are problems and questions which are typically left for the national courts to answer. The ECJ only clarifies points of law. Even if these questions could be easily answered by national courts (something which is very doubtful), I believe that the ECJ, by ignoring the underlying economics of the case, has established a flawed legal principle which is also contrary to the principle that state aid must have an incentive effect. In this case, compensation for extra costs may not be wholly necessary.

To summarise so far, the extra costs of the public service obligations can be identified only if they are incremental in nature. But to the extent that they constitute expansion of services already supplied to regular customers, they are likely to share fixed costs with those services. In this case, a higher amount of costs may be allocated to the operations benefiting from the tax exemption. More significantly, compensation for the extra costs may result in over-compensation as some firms may voluntarily supply the services stipulated by the legal obligations imposed on them.

This is not an unusual occurrence when considering the fact that in the telecommunications market, for example, member states impose universal service obligations, yet in only a small minority of member states is there a fund to compensate telecoms providers for the extra costs of universal service. Universal service funds aim to compensate providers only for those services for which the extra costs exceed extra revenue; i.e. those services which would not be provided otherwise. In the "Ferring" case, the ECJ did not ask the referring national court to examine whether the services subject to the legally mandated obligations would not be provided otherwise.

\subsection{The inherent advantage conferred by compensatory aid}

So far I have argued that neither the necessity test, nor the proportionality test is likely to be satisfied by all beneficiary firms. The tax exemptions in question contain an element of state aid to the extent that the tax authorities 
The Distortive Effects of Compensatory Aid Measures: A Note on the Economics of the "Ferring" Judgement

do not examine each beneficiary individually to determine what it would have done otherwise. Since tax measures are usually applied on the basis of general and objective conditions, it is normally up to the potential beneficiaries to provide accounting proof of compliance with the relevant rules. But accounting methods and conventions do not necessarily correspond to the underlying economics. Moreover, accounting evidence that the tax credit has been set against actually incurred costs will not prove that the costs were avoidable in an economic sense.

The Court in its ruling also contented that as long as the tax exemption merely compensates for the extra costs, it only restores competitive equality between wholesalers and pharmaceutical laboratories. I will now explain why this is unlikely to be the case.

To understand this point, consider, first, what happens when two competing firms obtain state aid to invest, for example, in an underdeveloped region. Suppose that the cost of the investment undertaken by firm A is 100 and by firm B is 50. Also suppose for simplicity that the investment depreciates completely within one year (this means that the investment horizon is just one year and that the investment outlay is part of the operating cost of the firm for that year). The permissible aid intensity is $25 \%$. The remaining operating costs of firm A are 80 while those of firm B are 45 . It follows that the total costs that have to be covered by the end of the year are $155[=(100$ $-25)+80]$ for firm A and $82.5[=(50-12.5)+45]$ for firm B. Assume, further, that firm A produces 10 units while firm B, with the smaller plant, produces 5 units. Firm A must sell those 10 units for a minimum price of 15.5 each in order to remain in the market. Firm B, by contrast, has to sell them at 16.5 each. This example shows that even though firm A has higher absolute costs than firm B and even though both firms have received the same relative amount of aid, that aid has not affected their relative production efficiency. Firm A can produce each unit at a lower cost. This kind of aid does not distort competition among competing beneficiaries.

The same cannot be said for the tax exemptions benefiting pharmaceutical wholesalers in France. Suppose that the operating costs related to the extra costs of the public service obligations are 100 for firm A and 120 for firm B. Since both firms have to provide the full range of medicines, assume that each makes 50 extra deliveries per year. If they would obtain no tax relief, firm A would at minimum have to charge a price of 2 per delivery while firm 


\section{Chapter 23}

B would charge 2.4 per delivery. Firm B which is less efficient would have to leave the market. With the tax exemption covering all of its extra operating costs, it can remain in the market irrespective of its efficiency. To be more precise, less efficient firms can afford to have extra costs as large as their tax liabilities. This does distort competition among beneficiary firms. In fact the example which is elaborated in the footnote below shows that the tax credit may have perverse effects. It may raise the profitability of the less efficient firms! $!^{245}$

But, does it also distort competition between wholesalers and pharmaceutical laboratories? The answer is that it partly does. Laboratories, naturally, supply the medicines they manufacture themselves. In this respect, they can also try to offer to their clients sufficient amounts of medicines and fast delivery. The only thing they would not normally offer is the complete range of medicines. Under the relevant French law, laboratories do not benefit from the tax exemption concerning any extra costs from stocking larger quantities and filling orders within 24 hours.

An issue that the Court did not examine is whether the laboratories did or did not provide services comparable to those specified by the public service obligations. But it should have done it because laboratories are (partial) competitors of the wholesalers and are, consequently, part of the economic environment in which wholesalers operate. In case they offer services which partly overlap with those provided by the wholesalers, then there is no doubt that competition is distorted (at least with respect to the volume of stocks and speed of delivery). The reason is that a less efficient wholesaler could

\footnotetext{
${ }^{245}$ Assume that there are two firms, A and B, with the following cost configurations: Firm A:

Cost per unit of output $=3.75$

Extra cost per unit $=0.25$

Total cost/unit $=4.00$

Firm B:

Revenue/unit $=5.00$

Cost per unit of output $=3.75$

Extra cost per unit $=0.35$

Gross profit/unit $=1.00$

Total cost/unit $=4.10$

Revenue/unit $=5.00$

Tax rate $=50 \%$ of profits

Gross profit/unit $=0.90$

Gross tax $=0.50$

Net tax $=0.50-0.25=0.25$

Tax rate $=50 \%$ of profits

Gross tax $=0.45$

Net profit/unit $=1.00-0.25=\underline{0.75}$

Net tax $=0.45-0.35=0.10$

Net profit/unit $=0.90-0.10=\underline{0.80}$

Even though firm B is less efficient in delivering the extra services, the tax credit allows it to make more profit per unit of output!!
} 
The Distortive Effects of Compensatory Aid Measures: A Note on the Economics of the "Ferring" Judgement

offer the same services as laboratories (i.e. sufficient quantities and fast delivery) at a lower price. A laboratory would provide such services only if its efficiency would be high enough to neutralise the tax advantage of the wholesalers. To understand this point consider the following example.

Assume that a laboratory that attempts to provide to its customers sufficient quantities and fast delivery bears corresponding extra costs of 8 and 10. A wholesaler bears extra costs of 15 for the larger stock (because it also carries more medicines), 22 for faster delivery and 18 for carrying a complete range of medicines. The laboratory bears a total of 18 extra costs, while the wholesaler bears 55 of extra costs. It seems self-evident that the wholesaler suffers a disproportional cost disadvantage for which it justifiably deserves compensatory state aid. To see why this may not necessarily be the case, one has to examine what would the costs of the wholesaler be if it had to deliver equivalent medicines to those supplied by the laboratory. Perhaps, the wholesaler's costs would be 10 and 12 as opposed to the 8 and 10 of the laboratory. This inefficiency, however, is hidden by the fact that the tax exemption covers all extra costs for all medicines supplied by wholesalers.

So, the fact that laboratories do not appear to provide those services does not necessarily mean that they would indeed be unwilling to offer them. The tax exemption may simply be conferring a too high competitive advantage to wholesalers. We must conclude, therefore, that this kind of tax exemption distorts competition because it offsets all the extra costs of a particular service without considering whether the beneficiaries or non-beneficiaries would willingly offer such services. The economic crux of the issue is that public policies impose a myriad of obligations and extra costs on companies [e.g. use of safer machines]. Yet, the state does not compensate companies for such extra costs. They get absorbed in normal business expenses. There is no a priori reason for which to expect that wholesalers of medicines in France would withdraw from the market as a result of the public service obligations. Even if they did that, a more efficient way for the state to respond to that development would be to buy the services through an open tender procedure. 


\subsection{Implications for state aid policy}

I have argued in this chapter that measures such as compensatory tax exemptions are inherently distortionary. This because extra costs are not necessarily costs that affected firms would wish to avoid and because beneficiary and non-beneficiary firms may offer overlapping products or services. However, the law as it stands to date, after the ruling of the Court, is that compensatory measures are not a form of state aid. Perhaps if the Court considers the economics of such measures in a future case it will reach a different conclusion, reversing its present position. The question I wish to address briefly in this section is how the Court may revise its position and how to link Articles 87(1) and 86(2).

But first, I want to explain why the Court has inadvertently weakened significantly Article 87(1). By sheer coincidence, as this chapter was being revised, Advocate-General Philippe Léger issued his opinion on 19 March 2002 on the "Altmark Trans" case (C-280/00) which was the first case taking into account the consequences of the "Ferring" judgement. He criticises "Ferring" for basically two reasons. First, the concept of state aid is objective. The intentions of the granting authorities are irrelevant. The Advocate-General argues that the Court in "Ferring" mixed intentions (compensation) with effects (advantage). Second, as a result of "Ferring", Article 86(2) has lost its significance. He goes on to argue that the Court cannot interpret the provisions of the Treaty in a way that renders any of them ineffective or meaningless.

Although I share the views of the Advocate-General (especially with respect to Article 86(2), which I examine in more detail below), there is another, probably more important reason why there is a problem with "Ferring". It follows from the analysis of the previous sections. The reason is that there is no such thing as pure market economy in Europe or, for that matter, anywhere else in the world. All national markets are regulated, some more and some less than others. These regulations impose costs on companies and raise their operating expenses. By ruling that governments may grant aid to compensate the companies on which they impose public service obligations, the Court has rendered Article 87(1) significantly less effective because it is virtually impossible to distinguish between those obligations and the many 
other regulations that impose similar obligations and corresponding costs. How would the Court regard the regulations that require, for example, pharmacies to stay open one night per week, insurance companies to give a five-day cooling off period to those who sign insurance contracts, travel agents to take out insurance to pay for the costs of repatriating holiday makers in case they go bankrupt or banks to maintain a certain level of liquidity. Such requirements impose extra costs and have nothing to do with ensuring the competency of the providers of these services. They are not like the regulations on health and safety or the professional qualifications of doctors and lawyers whose purpose is to prevent the provision of substandard services to consumers.

Since there are regulations about everything in modern markets, an exception for compensatory aid will soon be exploited by smart public authorities. There is a danger that the prohibition of Article 87 will become meaningless. Could aid be justified, for example, if it is intended to compensate telecoms providers and energy generators for the public service obligations imposed on them? In the case of telecoms operators, member states are allowed to defray the extra costs of universal service provision through a universal service fund. So far only two member states have set up such a fund because in most countries the extra costs are covered by revenue from other sources. But according to the "Ferring" logic the fact that their extra costs are covered should be irrelevant. Those operators would still make a valid case for compensatory state aid.

There is also another problem which is caused by the risk from a wide interpretation of the "Ferring" judgement. The types of regulations I mentioned earlier are examples of activities that do not generate any costs for consumers (e.g. keeping the pharmacy open or insuring against bankruptcy is good for consumers). The "Ferring" judgement merely mentions compensation for a public service obligation. But where is the limit of the justification for such compensation? Could it also be used to justify aid to companies whose activities are regulated because they generate costs for consumers? If a government limits domestic night flights or night flights to local airports in order to reduce noise, would it be justified to grant aid either to affected domestic airlines or airlines that fly to domestic airports (which would be mostly domestic)? Is that limitation not also a form of public service? Where does this line of reasoning stop? 


\section{Chapter 23}

To repeat, if the arguments in the previous sections are correct, compensatory measures that offset operating costs and benefit more than one company must be considered as state aid because they are likely to satisfy all the conditions specified in Article 87(1). More precisely, unless proven otherwise by the notifying authority, it cannot be ruled out that they do not fall within Article 87(1), especially when some services provided by beneficiary and non-beneficiary firms overlap. Once a measure falls within the scope of Article 87(1), the question immediately arises as to whether it can benefit from any of the exceptions in Article 87(2) or (3) or Article 86(2). I do not examine here the various possibilities which are available by Article $87(2) \&$ (3) and for which the Commission has considerable discretion. The interesting issue which was raised by the "Ferring" case was the applicability of Article 86(2).

In this respect, the Court ruled in paragraph 33 of its judgement that Article 86(2):

"does not cover a tax advantage enjoyed by undertakings entrusted with the operation of a public service ... in so far as that advantage exceeds the additional costs of performing the public service."

The alternative eventuality of the advantage falling below the additional costs was not considered by the Court in connection with Article 86(2) because it had already concluded that it was not state aid and therefore did not require an exemption. It is worth observing, however, that in this way the Court created a conundrum. On the one hand, if aid falls below the extra costs, it is not state aid in the meaning of Article 87(1). On the other hand, if it exceeds the extra costs, it cannot be exempted under Article 86(2) [in fact, it can neither be exempted under any of the provisions of Article 87 because it fails the proportionality test]. So, when does Article 86(2) apply? More specifically, if compensatory measures will be found in the future to be state aid, as I argued above, can they benefit from the exception in Article 86(2)?

Article 86(2) applies only when undertakings cannot supply the public services mandated by law without receiving aid (or without abusing their dominant position in the case of Article 82). ${ }^{246}$ The Court of First Instance in

${ }^{246}$ For an extensive analysis of the case law on Article 86 see J. Faull and A. Nikpay (eds.), The EC Law of Competition, (Oxford: Oxford University Press, 1999). Further reading on this chapter: C. Arhold, The case law of the European Court of Justice and the Court of First Instance on State Aids in 2004/2005, European State Aid law-Quarterly, Volume 4 No. 2 2005, C. Arhold, The case law of the European 
The Distortive Effects of Compensatory Aid Measures: A Note on the Economics of the "Ferring" Judgement

the case "federation francaise des societe d'assurances (FFSA) et al v Commission, T-106/95, paragraph 178, put it succinctly:

"... the grant of state aid may, under Article 92(2) [now 86(2)] of the Treaty, escape the prohibition laid down in Article 92 [now 87] of that Treaty provided that the sole purpose of the aid in question is to offset the additional costs incurred in performing the particular task assigned to the undertaking entrusted with the operation of a service of general economic interest and the grant of the aid is necessary in order for the undertaking to be able to perform its public service obligations under conditions of economic equilibrium." [emphasis added]

I explained above why it cannot be presumed without verification that wholesalers would not supply the legally mandated services without aid. Some of them may very well find it profitable to maintain sufficient quantities of the complete range of medicines and deliver them within 24 hours of receiving an order. Even if they bear extra costs, the extra customers they may attract and the higher price they may charge may make this extra service profitable for them. Hence, it is not sufficient for the Community to require just that state aid compensates for the extra costs. Under these circumstances, state aid is necessary only if the extra costs exceed the extra revenue and then only by the amount that they exceed it.

Therefore, the exception of Article 86(2) would apply only if the following conditions hold: (a) the beneficiaries would not offer the services in question because extra costs exceed extra revenue and (b) the amount of aid is equal or less than the net extra costs (i.e. the amount by which extra costs exceed extra revenue).

Lastly, it is worth observing that given the difficulty of determining the right amount of the subsidy which is necessary to compensate for the public service obligations, a restricted use of Article 86(2) as prescribed in the previous paragraph would still be a third-best option. A more efficient option would be to offer the same tax treatment to all undertakings that provide the same service (e.g. delivery within 24 hours), rather than restrict it to certain

Court of Justice and the Court of First Instance on State Aids in 2005/2006 (Part 1), European State Aid law-Quarterly, Volume 5 No. 2 2006, C. Arhold, The case law of the European Court of Justice and the Court of First Instance on State Aids in 2005/2006 (Part 2), European State Aid law-Quarterly, Volume 5 No. 3 2006, C. Arhold, The case law of the European Court of Justice and the Court of First Instance on state aids in 2006/2007 (part 1), European State Aid law - Quarterly, Volume 6 No. 22007 


\section{Chapter 23}

classes of undertakings. Still an even better option would be to auction the rights to provide the services which are subject to legally mandated obligations (for which compensation is offered). If the auction procedure is efficient, the bidding among potential suppliers should eliminate any unnecessary aid from the state aid measure. Unfortunately, EC law does not yet require member states to use competitive procedures when conferring rights or obligations linked with preferential or compensatory treatment.

\subsection{Conclusions}

The "Ferring" judgement is clear. Compensatory measures are not state aid, provided they do not exceed the extra costs imposed by law on beneficiary undertakings. It leaves, however, serious economic questions unanswered. Measures which aim to offset operating costs are likely to distort competition both among beneficiary undertakings and between beneficiaries and non-beneficiaries. This is likely to be the case despite the presumption of the Court that compensatory measures restore competitive opportunity.

Competition is likely to be distorted because beneficiaries derive an advantage over their competitors due to the fact that eligible costs are completely offset irrespective of whether they would be avoided by the beneficiaries. Moreover, non-eligible undertakings that may wish to offer similar services cannot benefit from similar treatment or obtain similar aid. Even if the amount of aid is less than the extra costs imposed by law, it cannot be presumed that compensatory measures do not fall within the scope of Article 87(1). In the absence of evidence to the contrary, compensatory measures of the kind dealt with in the "Ferring" judgement must be regarded as a form of state aid.

The "Ferring" judgement also raises the question as to how the exception of Article 86(2) may apply in such circumstances. I have suggested that if compensatory measures are to be considered as a form of state aid, then it would be necessary to adopt a more restricted interpretation of Article 86(2) whereby exempted aid is just that which covers only the net extra costs (extra costs minus extra revenue) of legally mandated obligations. 


\section{Part VI: Guidelines on Aid for Rescue \& Restructuring and Regional Development}

\section{Chapter 24}

When Do "Firms in Trouble" Escape from State Aid Rules?

\subsection{Introduction}

The state can influence market outcomes in many different ways, by adopting measures that range from those that seek to maintain a levelplaying-field for firms (e.g. anti-trust rules or regulation of access to networks) to those that expressly skew the playing-field in favour of particular firms.

Of the latter measures, some provide state aid and are caught by Article 87 EC Treaty. However, it is well known that not all selective measures need contain state aid in the meaning of Article 87(1) EC. This is because some public measures may confer an advantage to specific firms without actually transferring public resources, even if they affect intra-EU trade and distort competition. ${ }^{247}$ It is also possible for selective measures that do transfer public resources to escape from being caught by Article 87(1) because they are deemed not to confer any advantage, e.g. where public authorities act as "private investors" by injecting capital in companies and obtaining a reasonable return on their investment. ${ }^{248}$

In all these cases, the beneficiary companies are normally in a good financial status. When the beneficiary is in financial trouble and receives public resources, there are only two possibilities: either there is state aid in the form of rescue and restructuring aid or there is no state aid because the state acts

${ }^{247}$ Case C-379/98, Preussen Elektra v Schleswag AG, 2001 ECR I-2099.

${ }^{248}$ Case T-296/97, Alitalia v Commission, 2000 ECR II-3871. The literature has remained sceptical on whether public investment should be compared to private investment See, for example, Nicolaides 2003, ESALQ. 


\section{Chapter 24}

as a private investor or "public creditor", i.e. the counterpart of the private creditor.

The Commission presumes that there is state aid when public authorities invest in financially sick companies, unless it can be shown that the public authorities make their investment together with private investors on comparable terms and amounts or, exceptionally, when it can be shown that there are good prospects for turning a sick company around so as to enable it to regain long-term profitability and pay a dividend that corresponds to the risk assumed by public authorities.

In this chapter we examine the application of state aid rules to transfers of public funds to firms in financial trouble. More specifically, we assess the new guidelines on rescue and restructuring and the development of the public creditor principle in recent court cases and identify instances where firms may receive an advantage from state intervention without the latter being caught by the state aid rules. Much has already been written about the new guidelines. ${ }^{249}$ Therefore, to avoid unnecessary repetition, we review briefly the main issues and focus on those aspects of the guidelines that have received less attention in the literature. Then we turn to the public creditor and identify what in our view constitute major problems in the use of that concept.

\subsection{Rescue and restructuring of firms in difficulty}

The Commission has repeatedly expressed its concerns about rescue and restructuring aid given to individual recipients on an ad-hoc basis. This kind of aid is undoubtedly distortionary as it enables inefficient companies to

${ }^{249}$ Dr Phedon Nicolaides and Dr Michael Kekelekis, “An Assessment of EC State Aid Policy on Rescue and Restructuring of Companies in Difficulty', 20049 ECLR 578; Phedon Nicolaides and Michael Kekelekis, "An Economic Analysis of EC State Guidelines on State Aid for Rescue and Restructuring of Companies in Difficulty', 20044 Interconomics 39; Paris Anestis, Stephen Mavrogenis, Stamatis Drakakakis, Rescue and Restructuring Aid - A Brief Assessment of the Principal Provisions of the Guidelines, 2004 EstAL I, p. 28; E. Valle and K. van de Casteele, Revision of the Rescue and Restructuring Guidelines: A Crackdown?, 2004 EstAL I, p. 9 . 
remain in the market. Under normal market conditions, these inefficient companies would either exit the market or go bankrupt. This is the essence of competition ${ }^{250}$ and it cannot be the norm that companies, which get into difficulties, are or should be rescued by the State. This is the philosophy underpinning the new Commission guidelines. ${ }^{251}$ The Commission adopted its first guidelines in $1994,{ }^{252}$ followed by a new version in $1999 .{ }^{253}$ The former expired on 9 October 2004. The current guidelines apply as from 10 October 2004 until 9 October 2009.

However, rescue or restructuring aid to firms in difficulty may be justified in some situations subject to certain conditions. According to the new guidelines:

"[i]t may be justified, for instance, by social or regional policy considerations, by the need to take into account the beneficial role played by small and medium-sized enterprises (SMEs) in the economy or, exceptionally, by the desirability of maintaining a competitive market structure when the demise of firms could lead to a monopoly or to a tight oligopoly situation., ,254

The guidelines also justify aid when:

"....any distortions of competition will be offset by the benefits flowing from the firm's survival (for instance, where it is clear that the net effect of redundancies resulting from the firm's going out of business, combined with the effects on its suppliers, would exacerbate employment problems or, exceptionally, where the firm's disappearance would result in a monopoly or tight oligopolistic situation) and that, in principle, there are adequate compensatory measures in favour of competitors." 255

In this section we assess the new rescue and restructuring guidelines on the basis of the Commission concerns and consider the extent to which they

${ }^{250}$ XXVIIIth Report on Competition Policy, 1998, p. 91. See also European Commission: State Aid Scoreboard, COM (2003) 636 final, 29/10/2003.

${ }^{251}$ Communication from the Commission: Community Guidelines on State Aid for Rescuing and Restructuring Firms in Difficulty, OJ C 244/2, 1/10/2004, para. 4.

${ }^{252}$ OJ C 368/12, 23/12/1994.

${ }^{253}$ OJ C 288/2, 9/10/1999.

${ }^{254}$ Cited above at no. 5 , para. 8 .

${ }^{255}$ Ibid, para. 31. 


\section{Chapter 24}

remedy those concerns. In addition, we identify a number of additional weaknesses and defects in the current guidelines. ${ }^{256}$

Aid for rescue and restructuring has given rise to some of the most controversial cases in the field of state aid. Member states have tended to exploit the loopholes and ambiguities in the old guidelines. For this reason the revised guidelines aim to tighten the rules and make it more difficult for member states to grant aid. ${ }^{257}$

In the 2003 Autumn edition ${ }^{258}$ of the state aid Scoreboard, the Commission made for the first time public its views on the issues it thought problematic in relation to rescue and restructuring aid. According to the Commission, "a first internal review of the guidelines has identified a series of problems, a selection of which are presented below:"

i. When is a company in financial difficulties? There is no Community definition of a 'firm in difficulty' and it seems very difficult to derive any definition from the practice of Member States because of differences in national insolvency laws and procedures.

ii. Groups of companies. The guidelines state that a company belonging to a group is not normally eligible, except where the difficulties are the company's own and are not the result of an arbitrary allocation of costs within the group, while the difficulties are too serious to be dealt with by the group itself. These criteria are not easily applicable and raise a number of questions. For example, where a subsidiary in one Member State is in financial difficulties but whose parent company appears unwilling to support it.

iii. Urgency. Whereas the current guidelines are based on the premise that aid is notified in advance, rescue aid often has to be granted prior to Commission approval in order to avoid the collapse of the company. However, any possible solution to this situation should comply with the notification obligation under Art. 88 (3) EC Treaty.

\footnotetext{
${ }^{256}$ For a detailed comparative analysis between the 1999 and the (at that time) draft 2004 guidelines see, Dr Phedon Nicolaides and Dr Michael Kekelekis (cited above at no. 3).

${ }^{257}$ For an account of these cases see E. Valle and K. van de Casteele (cited above at no. 3).

${ }^{258}$ Cited above at no. 4 .
} 
iv. One-time last time principle. The guidelines provide that rescue aid is a one-off operation and that repeated rescue aids should be avoided. However, there have been cases of companies which were not eligible for restructuring aid because of the 'one time, last time' principle, obtaining new rescue aid. v. Various time limits. The different time limits in the current framework are unclear and thus need to be clarified.

vi. Compensatory measures. When are the compensatory measures proposed sufficient in scope 'to mitigate the potentially distortive effects of the aid on competition'? ${ }^{259}$

The six issues identified by the Commission relate largely to the clarity of the various definitions and the ease of application of key concepts. In addition, the Commission grapples with a substantive problem, i.e. the extent of compensatory measures.

As we have noted elsewhere ${ }^{260}$, the new guidelines retain many of the provisions of the 1999 guidelines. They retain the definition of undertakings in difficulty, the case of groups of companies, the principles that restructuring aid must be the minimum necessary, that it should be accompanied by a plan to restore the recipient firm to viability within a reasonable length of time, that it should not cause undue distortion to competition and that restructuring aid may not be granted more than once [at least, not more than once every ten-year period].

The main differences between the two sets of guidelines are as follows:

i. Group of companies. The new guidelines have extended the scope of the application of this concept to cover also the subsidiaries created by the firm in difficulty. ${ }^{261}$

ii. Time length of rescue aid. This aid is granted for at most six months and has to be repaid by the end of the six-month period, otherwise it will be counted in the overall amount of restructuring aid [in the 1999 guidelines, rescue aid had to be repaid within twelve months]. In addition, in cases of non-notified aid, restructuring or liquidation plan or proof that rescue loan has been reimbursed in full and/or that the guarantee has been terminated,

\footnotetext{
${ }^{259}$ Ibid, p. 28.

${ }^{260}$ Dr Phedon Nicolaides and Dr Michael Kekelekis (cited above at no. 3)

${ }^{261}$ Cited above at no. 5, para. 13.
} 


\section{Chapter 24}

must be communicated to the Commission, no later than six months after the first implementation of the rescue aid measure. ${ }^{262}$

iii. Simplified procedures. A major innovation of the new guidelines is that rescue aid is assessed through a simplified and expedited assessment process. In addition, it is subject to "the one-time, last-time" principle. ${ }^{263}$

iv. Maximum amount of rescue aid. The maximum amount of rescue aid is determined on the basis of a formula, which is defined in an annex to the new guidelines.

v. SMEs. No restructuring plan is required to be submitted in the case of SMEs. The grant of aid must however be conditional on full implementation of a restructuring plan, which is communicated to the Commission and has been approved by the Member State concerned. ${ }^{264}$

vi. Compensatory measures. The compensatory measures may have to be as high as $100 \%$ of the beneficiary company's capacity in case that the beneficiary operates in a market with long-term structural problems, as defined in the context of the multisectoral framework on regional aid for large investments. ${ }^{265}$ The reference to "negligible" market share has been dropped, whereas the new guidelines point out that the Commission will have regard to the objective of restoring the long-term viability in determining the adequacy of the compensatory measures. In addition, compensatory measures should take place in market(s) where the beneficiary firm will have a significant market position after restructuring. ${ }^{266}$

vii. Own contribution. The money that has to be contributed by the shareholders of the beneficiary company must be at least $25 \%$ in the case of small enterprises, at least $40 \%$ in the case of medium-sized enterprises and at least $50 \%$ for large enterprises.

The concept of "firm in difficulty" has not been changed by the Commission in the new guidelines. Although it is understandable that a concrete Community definition is difficult to be drawn because of differences in national insolvency laws and procedures, some clarifications could have at least been introduced on the basis of criteria used in national jurisdictions.

\footnotetext{
262 Ibid, para. 25.

${ }^{263}$ Ibid, paras. 25 and 30.

${ }^{264}$ Ibid, paras. 57 to 59 .

${ }^{265}$ OJ C 70, 19/3/2002.

${ }^{266}$ Ibid, paras. 38 to 42 .
} 
Given that the guidelines do not exclude the possibility that rescue aid can be authorised in a "stand alone" form, without it being linked to a restructuring plan, ${ }^{267}$ the question that arises is to what extend should a firm in difficulty be treated differently for rescue aid, on the one hand, and for rescue/restructuring aid, on the other? Taking into account that the criterion for "restoration of long-term viability", as well as the requirement of compensatory measures apply only in cases of restructuring aid, is it rational or fair to set less stringent criteria for rescue aid only? Even temporary aid restricted to just six months may have a significant effect on the market and market expectations. Perhaps the guidelines implicitly expect that a firm that is in so bad state that it has to be rescued will eventually have to be restructured. If this is always the case, why then has the Commission distinguished between rescue and restructuring? Rescue aid may thus in principle permitted in a stand-alone form and allow thus the recipient to obtain a "legal" advantage from state intervention, only if competition is not distorted. Probably this is the reason why no compensatory measures are required for rescue aid.

According to the guidelines,

"[a] firm belonging to or being taken by a larger business group is not normally eligible for rescue or restructuring aid, except when it can be demonstrated that the firm's difficulties are intrinsic and are not the result of an arbitrary allocation of costs within the group, and that the difficulties are too serious to be dealt with by the group itself. Where a firm in difficulty creates a subsidiary, the subsidiary, together with the firm in difficulty controlling it, will be regarded as a group and may receive aid under the conditions laid down in this point.,"268

This whole concept of eligibility of companies belonging to a group to receive rescue or restructuring aid goes deep into the heart of, among others, the issues of subsidiary control and respective liabilities. The second

${ }^{267}$ This is inferred from para. 25(c) of the guidelines, where rescue aid " [...] must [...] be accompanied [...] by an undertaking given by the Member State concerned to communicate to the Commission [...] a restructuring plan or [emphasis added] [...] proof that the [rescue] loan has been reimbursed in full and/or that the [rescue] guarantee has been terminated;" and para. 29 of the guidelines: "[t]he approval of rescue aid does not necessarily mean that aid under a restructuring plan will subsequently be approved; such aid will have to be assessed on its own merits [emphasis added]'". See also Commission Decision of 13 November 2002 concerning the cash advance granted by France to Bull, OJ L 209/1, 19/8/2003.

${ }^{268}$ Cited above at no. 5, para. 13. 


\section{Chapter 24}

sentence of the above paragraph is an addition to the new guidelines, but it has made things more complicated rather than simpler. It appears from this paragraph that a parent company in financial difficulty will be regarded as a group with its subsidiary and will be thus eligible for aid, whereas in the case of a subsidiary in financial difficulty, that will not be eligible for aid. The Commission probably expects that all subsidiaries receive assistance from their parent companies and should not be eligible for aid. However, this is not always the case as in a number of instances subsidiaries remain independent from their parents and should thus be eligible for aid, if it can be shown that the criteria of independence listed in the SME Regulation are met. $^{269}$

What is important to be pointed out in this context is that the purpose of the parent's control over its subsidiary is to hold it accountable for performance. As long as the parent company permits the subsidiary to act independently under the direction of its board, there is little risk of the parent company of being found liable for the acts of the subsidiaries. As a result, the subsidiary should be eligible of receiving individually rescue or restructuring aid, as it can easily then be demonstrated that its financial difficulties are intrinsic. On the other hand, if the parent company exercises excessive decisive influence and control over the subsidiary's strategic decisions, through, for example a strong participation in the board of directors of the latter, then each company is affected by the liabilities of the other, as they will be regarded as being part of the same group. ${ }^{270}$

As to the issue of urgency, it may indeed be the situation that rescue or restructuring aid cannot wait the Commission's prior authorisation and be

${ }^{269}$ Commission Regulation (EC) No 70/2001 on the application of Article 87 and 88 of the EC Treaty to State aid for small and medium-sized enterprises, OJ L 10/33, 13/1/2001 and Commission Recommendation of 6 May 2003 concerning the definition of micro, small and medium-sized enterprises, OJ L 124/36, 20/5/2003.

${ }^{270}$ It has been questioned whether a subsidiary in financial difficulty could get rescue or restructuring aid, the reason being that its further financial support by the parent would jeopardise other subsidiaries (Paris Anestis, Stephen Mavrogenis, Stamatis Drakakakis, cited above at no. 3). We believe that the above should not be an issue to be taken into consideration, given that what matters is the fulfilment of the criteria of the guidelines. If the firm is considered to be one in difficulty, then it must be eligible to receive rescue or restructuring aid subject to the conditions listed in the guidelines. 
granted, in order to avoid bankruptcy or liquidation. ${ }^{271}$ Could the violation of the notification obligation under Article 88(3) of Regulation 659/99 be justified in such cases? It certainly cannot! The Procedural Regulation as stands does not provide for exceptions under Article 88(3), other that in the case of de minimis aid, aid covered by an authorised aid scheme decision and aid covered by the block exemption regulation ${ }^{272}$. According to Article 3 of the Procedural Regulation, aid notifiable shall not be put into effect before the Commission has taken, or is deemed to have taken, a decision authorising such aid. It could be argued that an amendment to the Regulation to permit the adoption in such a case of derogation decision from the suspension obligation, similar to that applied under the merger regime ${ }^{273}$, could offer a certain degree of fairness and increase the effectiveness of the proceedings.

With regard to compensatory measures and how they can be sufficient in scope to mitigate the potentially distortive effects of the aid on competition, it is indeed very difficult to determine the proportionality between compensatory measures and the distortive effects of the aid. ${ }^{274}$ Even though this concept was also in the old guidelines, we are not aware of cases where

${ }^{271}$ In Philipp Holzmann, the firm in difficulty had on 23 November 1999 filed for bankruptcy. The bankruptcy petition was withdrawn on 24 November 1999, when the creditors agreed to the restructuring plan put in place by the government. The Commission had not completed its investigation in 2000 and, therefore, substantial changes were made to the restructuring plan to address the difficulties derived from the fact that aid was not available. The Commission finally authorised the measure on 8 May 2001 (OJ L 248/46, 18/9/2001).

${ }^{272}$ Commission Regulation (EC) No 68/2001 of 12 January 2001 on the application of Article 87 and 88 of the EC Treaty to training aid, OJ L 10, 13/01/2001, Commission Regulation (EC) No 69/2001 of 12 January 2001 on the application of Article 87 and 88 of the EC Treaty to de minimis aid, OJ L 10, 13/1/2001, Commission Regulation (EC) No 70/2001 of 12 January 2001 on the application of Article 87 and 88 of the EC Treaty to State aid to small and medium-sized enterprises, OJ L 10, 13/01/2001, Commission Regulation (EC) No 2204/2002 of 12 December 2002 on the application of Article 87 and 88 of the EC Treaty to State aid for employment, OJ L337, 13/12/2002.

${ }^{273}$ Article 7 of Council Regulation 139/2004 of 20 January 2004 on the control of concentrations between undertakings, OJ L 24/1, 29/1/2004.

${ }^{274}$ E. Valle and K. van de Casteele and the case law cited there in (cited above at no. 3 , p. 12). 


\section{Chapter 24}

the "distortive effect" was actually measured in any quantitative or objective manner.

According to the new guidelines, the Commission, in determining compensatory measures, must have regard to the objective of restoring longterm viability and it should also need to impose them in market(s) where the firm in difficulty is found to hold a significant market position after restructuring. The reference to "significant market position" is new and raises important questions. First of all, how should the meaning of "significant market position" be understood? In an anti-trust sense or in a different sense?

Are the member states or the Commission now obliged to provide in their notifications and decisions respectively, extensive information on relevantmarket definition and assess companies on the basis of criteria such as those applied for dominance, i.e. market share, entry barriers etc?

State aid assessment differs for the assessment carried out for merger or antitrust cases. Where in the latter cases the Commission's endeavours focus on ensuring effective competition in the relevant market(s), state aid analysis concentrates on the justification of aid on the basis of certain criteria, mostly as defined in Article 87(3) EC. National aid, in particular that which is targeted to specific sectors or firms, will inevitably distort competition, as players are treated differently in the same markets. ${ }^{275}$ The guidelines do not provide for market definition. Although the supplementary information required by the form annexed to Regulation 794/2004 refers to formal definition of the market, market shares, capacity, etc., it does not perform a proper determination of relevant market and assessment of significant market position. ${ }^{276}$ However, the Commission Notice on the definition of the

\footnotetext{
${ }^{275}$ Article 87(1) EC stipulates that the Community state aid rules apply to an aid "[...] in so far as it affects trade between Member States". This implies that the geographic market should be defined, whereas competitors across markets that may be affected by the aid need to be indicated.

${ }^{276}$ The 'Supplementary Information Sheet on aid for rescuing firms in difficulty: Individual aid' requires the submission by the Member States of a market survey giving some information on market definition, market shares of the beneficiary and the competitors, production capacity and demand etc (Part III.8.b annexed to Commission Regulation (EC) 794/2004 of 21 April 2004 implementing Council
} 
relevant market for the purposes of Community competition law, although it is mostly used for the analysis of antitrust and merger cases, also mentions that " $[\mathrm{w}]$ hen consideration of market power and therefore of the relevant market are raised in any particular case, elements of the approach outlined here might serve as a basis for the assessment of state aid cases."277

The guidelines indicate that compensatory measures may comprise divestments of assets, reductions in capacity or market presence and reduction of entry barriers on the market(s) concerned. ${ }^{278}$ These measurements cannot be executed without a legal and economic approach to market definition. Given that time is important in cases of rescue and restructuring aid, in particular when aid is urgent to avoid bankruptcy or liquidation, the Commission should adopt its decision as quickly as possible. While the submission of sufficient information for a proper market definition to be included in the text of the decision appears to increase the burden of all parties involved, on the other hand it will provide legal certainty enabling the Commission to reach a more accurate assessment of the effects of the aid. ${ }^{279}$

In comparison to the previous guidelines, the new ones are stricter. According to the 1999 guidelines, "[w] here the size of the relevant market(s) is negligible at Community and at EEA level, or the firm's share on the relevant market(s) is negligible, it should be considered that there is no undue distortion of competition. This condition should accordingly be regarded as not normally applying to small and medium-sized enterprises, except where otherwise provided by rules on State aid in a particular sector." 280 There is no such reference of "negligible" market share in the new text. By contrast, paragraph 51 of the new guidelines states that compensatory measures, "will not normally apply to small enterprises since it can be assumed that ad-hoc aid to small enterprises does not normally distort competition to the extent contrary to the common interest".

Regulation (EC) 659/1999 laying down detailed rules for the application of Article 93 of the Treaty, OJ L 140/1, 30/4/2004).

${ }^{277}$ OJ C 372, 9/12/1997, ft. 1.

${ }^{278}$ Cited above at no. 5, para. 39.

${ }^{279}$ For a detailed account of issues of market definition in state aid control see John Fingleton, Frances Ruane and Vivienne Ryan, "Market definition and State aid control', European Economy 3, 1999.

${ }^{280}$ Cited above at no. 7 , para. 35 . 
It is clear that medium-sized enterprises may also have to offer compensatory concessions. This is good because the distortive effect of aid does not necessarily depend on the absolute size of the recipient firm [the SME definition classifies firms by their absolute size]. But, the new guidelines now refer to significant market position, which in most cases would presumably apply only to large companies. Therefore, medium-sized enterprises are entitled to receive an advantage from state intervention, if they hold no significant market position in the market, following receipt of aid.

Secondly, another problem relates to the nature of compensatory measures. According to the guidelines, rescue or restructuring aid should be allowed, "[...] if strict criteria are met, and if it is certain that any distortions of competition will be offset by the benefits flowing from the firm's survival [...] and that, in principle, there are adequate compensatory measures in favour of competitors" 281 and "[t]he Commission will have regard to the objective of restoring the long-term viability in determining the adequacy of compensatory measures". ${ }^{282}$

Distortions of competition are more likely to take place in that product or geographic market where the firm is considered to have a strong presence. But it seems to us that firstly, no compensatory measures should be imposed, if no significant market position is held in the market concerned. Secondly, that market is precisely where the benefits from the firm's survival are also likely to be. There is, thus, a potential conflict here between compensatory measures such as reduction in capacity, on the one hand, and maintenance of capacity for the purpose of maximising the positive effects from the firm's survival on employment and society, on the other.

As to the issue of viability, it still remains unclear which is the reasonable period of time within which the beneficiary company shall attain viability, as the new guidelines do not provide for a clarification. They stipulate that, "[t]he restructuring plan, the duration of which must be as short as possible, must restore the long term viability of the firm within a reasonable timescale

${ }^{281}$ Cited above at no. 5 , para. 31 .

282 Ibid, para. 38. 
and on the basis of realistic assumptions as to the future operating conditions". ${ }^{283}$

The "Supplementary Information Sheet on aid for rescuing firms in difficulty: Individual" aid requires member states to provide information on, "projected profit and loss accounts for the next five years with estimated return on capital and sensitivity study based on several scenarios". 284

From the above it might be considered that a reasonable time for return to viability is five years. ${ }^{285}$ Although this is only an indication and cannot be considered to constitute a standard practice, the longer it takes the firm to return to viability, the lower the probability that it will indeed be able to achieve it. Preliminary research undertaken by London Economics for DG Enterprise indicates that $70 \%$ of companies receiving rescue or restructuring aid cease operations within five years from receiving the aid and $50 \%$ within the first three years. This suggests to us that a good rule would have been to approve aid only if member states can show that viability can be achieved in less than five years and preferably three.

In summary, the guidelines have tightened the rules on rescue and restructuring aid. This is a welcome result. But they are still more lenient on rescue aid than restructuring aid. The guidelines appear also to signal a less stringent approach towards compensatory measures, as they seem to focus on cases of firms with significant market position.

In concluding this section, we would like to repeat an argument we have made in several of our previous papers on rescue and restructuring aid. ${ }^{286}$ If this kind of aid is exceptionally allowed when the competition, regional or social benefits from a firms' survival outweigh the distortion of competition, then the guidelines should introduce an explicit method for performing that comparison.

\footnotetext{
${ }^{283}$ Cited above at no. 5 , para. 35 .

${ }^{284}$ Cited above at no. 30.

${ }^{285}$ Needless to mention that the guidelines allow for exception of the 'one time, last time' rule in cases where "[...] new rescue and restructuring aid becomes necessary after at least five years due to unforeseeable circumstances for which the company is not responsible;' (cited above at no. 5, para. 73).

${ }^{286}$ Cited above at no. 3.
} 


\subsection{The public creditor principle}

The failure or unwillingness of a public authority to demand money owed to it is also a form of state aid. As the Community courts have repeatedly stated, the concept of aid is wider than that of a subsidy because it embraces not only positive benefits, such as the subsidies themselves, but also measures, which in various forms mitigate the normal burdens on the budget of an undertaking. ${ }^{287}$ For example, when a public authority tolerates late payment of money owed to it by undertakings, it mitigates their financial burden and places those undertakings in an advantageous position vis-à-vis their competitors. ${ }^{288}$ Public authorities, therefore, have to pursue their debtors with the same vigour as that of a private creditor. ${ }^{289}$

In our view, this concept has created a serious loophole in the system of state aid control, providing companies with possibilities to receive advantages from the state without the latter being caught by the state aid rules. When the Commission applies the private investor principle there are objective benchmarks of performance: market rates of interest, average return on investment in comparable classes of assets, etc. Where such benchmarks exist in the case of the private creditor or the public creditor created by the courts, these are not sufficient.

Objective benchmarks that may exist are not sufficient because when a public authority is involved in recovering as much of the money it is owed, it is essentially engaged in bilateral negotiations with the debtor. The outcome depends on four main factors: the prevailing legal rules (which are objective), the particular contractual obligations (which are objective), the negotiating skills of each side (which are subjective) and the assessment of each side of the financial prospects of the debtor (which is largely subjective). There is no market benchmark for the third factor and hardly any for the last factor.

\footnotetext{
${ }^{287}$ See, inter alia, Case 30/59, De Gezamenlijke Steenkolenmijnen Limburg v High Authority, 1962 ECR 1; Case C-387/92, Banco Exterior de España 1994 ECR I-877; C-256/97, DM Transport, 1999 ECR I-3913; C-5/01, Belgium v Commission, 2002 ECR I-11991.

${ }^{288}$ See DM Transport, ibid.

${ }^{289}$ See Case C-342/96, Spain v Commission (Tubacex), 1999 ECR I-2459.
} 
Even when the Commission and the courts ask the question "how a private creditor would have acted in a similar situation", which presumably takes care to some extent of the problem of assessing the financial prospects of the debtor, they are still unable to determine how anyone else would have negotiated in that particular situation.

Moreover, the assessment of the financial prospects of the debtor is not as straightforward as it may seem at first glance. Unlike injections of capital where market benchmarks of returns to investment for comparable classes of assets are likely to exist, no market benchmark exists for the survivability of any particular company. Statistics do exist, for example, on the survival rate of newly established SMEs or the success of turnaround schemes, but these are at very general level and do not provide solutions to the problems of the debtor. This is because the assessment of the financial prospects of the company critically depends on whether solutions to the problems plaguing the company can be found. Finding solutions is an outcome of one's one ingenuity. If the market could offer ready made solutions, companies would not get into trouble. Therefore, the existence of general statistics is largely irrelevant to the issue of estimating how much of one's own money could be recovered from a sick company. In support of the above, the Commission has explicitly stated that "[...] particular circumstances of debtors and creditors are likely to prove problematic for the determination of a common applicable behaviour of private creditors seeking to recover sums owing to them. Consequently, the Commission has to base its assessment on an analysis of the behaviour of private creditors on a case by case approach" ${ }^{290}$

It is not surprising, therefore, that in practice when the courts assess the application of the public creditor, they resort to the simpler criterion of trying to determine whether the public authority concerned pursued all legally possible options and whether it acted promptly. These issues are illustrated well in the two most recent cases concerning Lenzing $\mathrm{v}$ Commission $^{291}$, and Spain v Commission ${ }^{292}$, where the courts annulled the contested Commission Decisions, but on different grounds.

\footnotetext{
${ }^{290}$ Commission Decision of 20 September 2000 on aid implemented by Spain in favour of Sniace SA, OJ L 11/46, 16/1/2001, at para. 23.

${ }^{291}$ Case T-36/99, not yet reported.

${ }^{292}$ Case C-276/02, not yet reported.
} 
In Spain v Commission, the Court of Justice (ECJ) examined a Commission Decision which had found that the Spanish authorities had not acted as a private creditor. The undertaking concerned had not paid taxes and social security for three years before the Spanish authorities agreed to write-off two thirds of the debt and reschedule repayment of the rest over a ten-year period. After that agreement, the undertaking continued to fail to pay what the State owed and a year later the authorities began seizing its property. Eventually, the agreement was suspended a year afterwards.

The ECJ accepted the arguments of Spain that the authorities used all the options that were legally available to them culminating in confiscation of property and eventual closure of the company. There was also some evidence that the authorities tried to seize property earlier. It seems that these draconian measures were sufficient to persuade the ECJ that the authorities acted as a private creditor would have acted in a similar situation, and therefore it annulled the Commission Decision.

The case illustrates well the problems with the concept of public creditor. The ECJ did not examine how strong were the initial attempts at property seizure. Nor, did it question why it took the authorities three years to reach an agreement with the undertaking while in the meantime its debt accumulated. And, more importantly, there was no consideration in the judgement of the provisions of the agreement itself, as the Commission itself had never stated in its decision that those agreements gave rise to state aid. Was it reasonable for the authorities to write-off two thirds of the debt, offer a grace period of two years and accept repayment by instalments over a tenyear period?

The legally available options define a sort of a floor, not ceiling, of effort to recover debt. And even with this "floor" in place, public authorities still have discretion in deciding how long to tolerate non-repayment before they take legal action. There may be excessive tolerance even if regular reminders are sent to the company threatening more drastic action against it. The authorities certainly have discretion in fixing the amount of instalments of repaid debt and the regularity of such instalments.

In the case Lenzing v Commission, the Spanish authorities were dictated by law to fix only a statutory rate of interest on the outstanding debt. The 
statutory rate was lower than the market rate, but this difference in itself is not sufficient to prove the existence of state aid. This is because a creditor would not apply the same rate as an investor who seeks to maximise profits. A creditor may accept a lower rate so as to minimise losses. ${ }^{293}$

However, the relevant Spanish law did not stipulate the amount of repayments, the number of instalments or the length of the repayment period. In this case, the Court of First Instance (CFI) did recognise the discretion of the authorities on these matters and concluded that that discretion was sufficient to convert actions dictated by law into a form of state aid. In particular, the CFI explicitly referred to the fact that the Spanish authorities had tolerated non-payment of social security contributions for several years. In fact, the CFI rejected a Spanish argument that there was no state aid because the actions of the authorities were not arbitrary. The CFI made a distinction, significant in this context, between arbitrariness and discretion.

Then the CFI went on to state that

"[...] in order for the advantages described above to be capable of being classified as aid for the purposes of Article 87(1) EC, it must still be established that [the undertaking in question] could not have obtained them under normal market conditions [...]. More specifically, the Court must consider whether the Commission made a manifest error in concluding that the Social Security Fund and Fogasa acted in the same way as a hypothetical private creditor in so far as possible, the same situation vis-à-vis its debtor as those two bodies". 294

At the end, the CFI found that the Commission had not proven that the Spanish authorities had acted as a private creditor in allowing accumulation of debt in the first place, then in agreeing to reschedule that debt over a tenyear period and finally in allowing again the undertaking not to honour the rescheduling agreement. Consequently, it annulled the Commission Decision that had found that there was no state aid in the actions of those authorities.

This case is significant because it reveals the considerable discretion that public creditors have in matters of debt recovery and how difficult it is for the courts to prove that that discretion has not been exercised wisely, prudently or aggressively enough.

\footnotetext{
${ }^{293}$ Spain v Commission (Tubacex) (cited above at no. 43).

${ }^{294}$ Cited above at no. 25, para. 149.
} 


\section{Chapter 24}

The question that naturally arises is two-fold: under what circumstances may a company be entitled to have its debt rescheduled without that being considered as state aid and whether any rules can be devised to guide public authorities in determining the existence of state aid in these situations?

Should, additionally, public authorities be requested not to negotiate and instead "pull the plug" expediting in this way the demise of their debtors? Not necessarily. Our solution is to remove, on the one hand, the discretion of the authorities in initiating recovery procedures and to introduce a sort of a market benchmark in the negotiation of rescheduling agreements, on the other.

Most cases can be divided into two categories: the category of companies whose financial problems can be remedied by the companies themselves and the category of companies whose problems are so severe that cannot be remedied independently but require action by all their creditors. This condition of severe financial difficulty must be defined by national law, otherwise any company which owes some money to the State would seek to negotiate rescheduling. In both categories, the authorities have to take measures such as sending reminders and imposing penalties for late payment. Usually these steps are defined in the relevant national law [civil law, income tax law, VAT law, etc.]. In the absence of well-defined steps, any variation in the treatment of different companies must be presumed to involve state aid. It is important to note here that the case law has clearly established that when public authorities exercise discretion, an otherwise general measure may contain state aid. ${ }^{295}$

However, in cases of companies in real financial trouble, public authorities may come into negotiations with debtors to reschedule agreements, so as to minimise their losses, which would normally be greater had the company gone bankrupt. ${ }^{296}$ Owing to the fact that there is no common applicable

\footnotetext{
${ }^{295}$ Case C-241/94, France v Commission (Kimberly Clark), 1996 ECR I-4551.

${ }^{296}$ Needless to mention that public authorities may decide to refrain from recovering debts and thus not to enter into agreements on the rescheduling and repayment of debts, if that approach constitutes the most sensible solution from an economic aspect, for example where the value of the assets received following bankruptcy is considered to be higher than what they would have got had they entered into agreements. Further reading on this chapter: T. Kleiner and R. Reppliner-Hach, The
} 
standard of behaviour for private creditors seeking to recover sums owing to them, the debtors may end up receiving legally an advantage, which they might not have received under normal and well determined market conditions. It is therefore imperative that a common approach is established. In our view, the tolerance of late payments or non-payments of debts from companies, which are not in difficult, as determined by national law, economic and financial situation should not be examined under the prism of public creditor. Undoubtedly, such tolerance is and should always be considered as state aid that must be recovered under the normal state aid concept.

But in cases of companies in real financial trouble, when individual agreements have to be concluded, public authorities should not be allowed to negotiate directly with debtors. That would certainly maximise the possibilities of debtors in obtaining a better deal, given that public authorities cannot be presumed to be acting as private creditors, because their employees who negotiate repayments are not trying to maximise the amount of their own money they get back. These negotiations should be left to independent professional negotiators whose fee should be proportional to the debt they recover. They would then have a strong motive to behave as private creditors trying to recover their own money. This professional negotiator must not only conclude rescheduling and repayment agreements but more importantly determine detailed terms in those agreements. Having firstly established that, refraining from recovering debts that are payable constitutes the most financially advantageous solution, he must then determine in concrete fashion the repayment timetable, the amount of the debt owed, the amount and number of the instalments, the requirement of sufficient securities and guarantees before agreeing to grant payment terms and a condition that any failure of the debtor to meet its repayment commitments will entitle the public authorities to immediate enforcement action.

new community framework for state aid for research and development and innovation, Competition policy newsletter: $n r .1$ 2007, A. Rubin de Cervin and V. Zuleger, Large R\&D Projects - Commission practice under the R\&D framework from 1996 to 2006, European State Aid law-Quarterly, Volume 5 No. 1 2006, T. Kleiner, The new framework for research, development and innovation, 2007-2013, European State Aid law-Quarterly, Volume 6 No. 22007. 


\section{Chapter 24}

Something similar happens in valuations of public land sold to undertakings. When the valuation is carried out by an independent surveyor there is no presumption of hidden state aid. The only difference is that even when a public authority does not engage the services of an independent surveyor, it may still be able to prove that the sale was at market prices by comparing the price of the land it sold to prices of similar plots sold on the open market. This possibility is not available to public authorities that seek to recover money owed to them because of the one-off nature of the repayment negotiations. Objectivity can be guaranteed only when an independent thirdparty is involved.

\subsection{Conclusions}

In this chapter we have assessed the new guidelines on rescue and restructuring aid and the development of the public creditor principle by the Community courts with a view to analyse instances where a company may legally receive aid from state intervention, without the latter being caught by Community state aid rules.

The new rescue and restructuring guidelines, although they have in general tightened the rules on granting that sort of aid, still allow space for manoeuvre through the incorporation of terms such as "significant market position" or through the ambiguous interpretation of "group of companies" and the difficult application of compensatory measures.

In addition, the application or, as we would argue, the non-clarification so far of the principle of public creditor, due to the lack of a common applicable behaviour for private creditors, provides debtors in real economic and financial trouble with great possibilities to boost their hopes and achieve the most favourable solution for their interests.

We have proposed a solution to this problem. Our solution would in essence introduce the missing standard of behaviour, which is in fact market-based behaviour because it relies on the efforts of third parties. The solution is also administratively simple: Public authorities should engage independent professional negotiators. This is the only way to achieve the standard of the hypothetical private creditor. 


\section{Chapter 25}

\section{An Assessment of EC State Aid Policy on}

\section{Rescue and Restructuring of Companies in Difficulty}

\subsection{Introduction}

One of the most vexed issues in economic policy is whether the government should rescue companies that find themselves in financial trouble. Last year's problems at the French company Alstom and more recently the scandal at the Italian company Parmalat, both of which are prominent European companies in their fields, demonstrate how difficult it is for any government to resist calls to provide liquidity to avert the demise of a large company. A function of the European Community is indeed to protect governments from domestic pressure to subsidise whichever company happens to have lobbying power.

However, state aid may be justified in some situations where markets do not function properly or when the failure of a company would have damaging effects on the economy. Because a blanket prohibition of state aid would prevent national authorities from intervening when such intervention would be justified by economic or other considerations, the EC system for control of state aid has guidelines and frameworks that lay down specific rules on the kind and amount of state aid that may be granted by national authorities. These rules also include guidelines on state aid for rescuing and restructuring companies.

The current guidelines on rescue and restructuring are due to expire at the end of this year. For this reason, the European Commission has recently published draft new guidelines for the purpose of eliciting comments. ${ }^{297}$

\footnotetext{
${ }^{297}$ The draft new guidelines were published on 9 January 2004 and can be accessed on DG Competition's website at "http://europa.eu.int/comm/competition/state_aid/others/difficulty/en.pdf".
} 
In view of the potentially distortive effect of aid for rescuing or restructuring of companies and the Commission's concern about this kind of aid, it is surprising that there seems to be hardly any analysis in the literature. With a few notable exceptions cited later on, the rules on rescue and restructuring have not been subject to any critical scrutiny.

This chapter seeks to fill the gap in the literature by aiming to do three things. First, it reviews the current guidelines on the basis of the experience with their application. Second, it highlights the Commission's concerns that prompted it to propose the new draft guidelines. Third, it identifies a number of additional weaknesses and defects in the current guidelines. Fourth, it appraises the draft new guidelines and considers the extent to which they remedy the weaknesses of the current guidelines.

\subsection{The main features of the guidelines on rescue and restructuring}

The current guidelines came into force at the end of 1999 and are due to expire in October $20044^{298}$ They are applicable to all sectors except motor vehicles, air transport and shipbuilding. Special provisions exist for agricultural products. ${ }^{299}$

In this context, State aid may be granted for two purposes: rescuing and/or restructuring. Aid for rescuing should normally be in the form of a shortterm loan [normally not longer than six months] or loan guarantee at market rates of interest. The intention is that within that period the firm that receives the rescue aid should put in place a plan for restructuring that would bring it back to financial viability in the medium term [approximately in a fiveyears period]. The original rescue loan has to be repaid within twelve months.

${ }^{298}$ Community Guidelines on State Aid for Rescuing and Restructuring Firms in Difficulty, OJ C288, 9/10/1999, p. 2.; see

"http://europa.eu.int/eur-

lex/pri/en/oj/dat/1999/c_288/c_28819991009en00020018.pdf".

${ }^{299}$ For a more detailed analysis of the provisions of the guidelines see P. Anestis, S. Mavroghenis and S. Drakakakis, Rescue and Restructuring Aid, 1 - European State Aid Law Quarterly, 2004, p. 27. 
An Assessment of EC State Aid Policy onRescue and Restructuring of Companies in Difficulty

Aid for restructuring may take various forms but it is usually either a longterm loan or an injection of new share capital. Some times aid is granted in the form of tax or social security relief or loan write-off.

Since rescue or restructuring aid undermines the discipline of the market, one may justifiably wonder why the EC allows such aid. The Commission itself acknowledges that "[a]id for rescue and restructuring firms in difficulty is undoubtedly one of the most potentially distortive types of State aid. It cannot be the norm that a company which runs into difficulties is kept artificially in the market by the State. The exit of unprofitable firms is a normal part of the functioning of a market economy." 300

The guidelines provide three reasons why aid may be allowed. According to the guidelines

"[s]tate aid for rescuing firms in difficulty from bankruptcy and helping them to restructure may only be regarded as legitimate subject to certain conditions. It may be justified, for instance, by social or regional policy considerations, by the need to take into account the beneficial role played by small and medium-sized enterprises (SMEs) in the economy or, exceptionally, by the desirability of maintaining a competitive market structure when the disappearance of firms could lead to a monopoly or to a tight oligopolistic situation" [paragraph 3, at p. 2].

Towards meeting these three objectives, the Commission authorises restructuring aid only if the following conditions are all satisfied:

i. A realistic restructuring plan is put in place. The plan must identify the causes of the company's difficulties and formulate measures to address those difficulties under reasonable assumptions concerning both internal changes that the company is capable of implementing [e.g. reorganisation and rationalisation] and expected external changes in market conditions [e.g. exit from activities and projects that will continue suffering losses].

ii. Restoration of financial and commercial viability. The restructuring plan must be capable of bringing the company to viability in the sense that its expected revenue should be sufficient to cover its financial outlays and operating costs and generate an acceptable return to its shareholders.

\footnotetext{
${ }^{300}$ European Commission, State Aid Scoreboard, COM(2003) 636 final, 29/10/2003, p. 13.
} 


\section{Chapter 25}

iii. State aid must be kept at a minimum. The beneficiary company should not receive more aid than is strictly necessary to implement its restructuring plan. At the same time, the shareholders of the beneficiary company should make a substantial contribution of their own money. The company may not use the aid to expand its activities or undertake investments, which are unrelated to restructuring. Nor, may it use state aid to acquire other companies.

iv. No undue distortion of competition. The company should compensate its competitors for the aid it receives. In sectors with over-capacity, the Commission normally requires that the beneficiary company closes down capacity or sells assets to competitors or gives up market share [e.g. landing slots]. The company may also not be allowed to act as price leader or sell below cost. These restrictions are waived when the beneficiary is an SME or when it has a "negligible" market share. When the recipient is located in an assisted area, the extent of compensatory measures [e.g. reduction of capacity] that is requested by the Commission is correspondingly lower.

v. Aid is authorised "one time, last time". In principle, this means that companies cannot be rescued or restructured repeatedly. Otherwise the discipline of the market is removed. In practice, however, "one time, last time" means not more than once per ten years.

\subsection{Commission concerns}

In the 2003 Autumn edition ${ }^{301}$ of the state aid Scoreboard, the Commission made for the first time public its views on the issues it thought problematic in relation to rescue and restructuring aid. According to the Commission, "a first internal review of the guidelines has identified a series of problems, a selection of which are presented below:"

"i. When is a company in financial difficulties? There is no Community definition of a 'firm in difficulty' and it seems very difficult to derive any

${ }^{301}$ European Commission, State Aid Scoreboard, COM(2003) 636 final, 29/10/2003. 
An Assessment of EC State Aid Policy onRescue and Restructuring of Companies in Difficulty

definition from the practice of member states because of differences in national insolvency laws and procedures." ${ }^{302}$

"ii. Groups of companies. The guidelines state that a company belonging to a group is not normally eligible, except where the difficulties are the company's own and are not the result of an arbitrary allocation of costs within the group, while the difficulties are too serious to be dealt with by the group itself. These criteria are not easily applicable and raise a number of questions. For example, where a subsidiary in one member state is in financial difficulties but whose parent company appears unwilling to support it."

"iii. Urgency. Whereas the current guidelines are based on the premise that aid is notified in advance, rescue aid often has to be granted prior to Commission approval in order to avoid the collapse of the company. However, any possible solution to this situation should comply with the notification obligation under Art. 88 (3) EC Treaty."

"iv. One-time last time principle. The guidelines provide that rescue aid is a one-off operation and that repeated rescue aids should be avoided. However, there have been cases of companies which were not eligible for restructuring aid because of the 'one time, last time' principle, obtaining new rescue aid."

"v. Various time limits. The different time limits in the current framework are unclear and thus need to be clarified."

"vi. Compensatory measures. When are the compensatory measures proposed sufficient in scope 'to mitigate the potentially distortive effects of the aid on competition'?"303

The six issues identified by the Commission relate largely to the clarity of the various definitions and the ease of application of key concepts. In addition, the Commission grapples with a substantive problem - the extent

\footnotetext{
${ }^{302}$ For an account of these problems see E. Valle and K. van de Casteele, Revision of the Rescue and Restructuring Guidelines: A Crackdown?, European State Aid Law Quarterly, 2004, p. 9.

State Aid Scoreboard, p. 28.
} 


\section{Chapter 25}

of compensatory measures. We agree that the extent of such measures goes to the heart of the question of whether to grant restructuring aid and for this reason we will analyse it in more detail later on.

The guidelines, however, have more weaknesses. The section that follows identifies a number of other concepts in the guidelines, which need to be clarified further and enforced more strictly.

\subsection{Additional weaknesses and defects}

The current guidelines include concepts, stipulate requirements and provide exceptions, which are not defined to any degree of operational precision.

i. What is negligible market share? Compensatory measures may not be requested from a firm with very small market share because aid would not significantly affect its competitors. There are two problems with this approach.

First, it is not clear what is "negligible" share. In the application of Article $81 \mathrm{EC}$, the Commission regards agreements between competing companies with combined market share falling below $10 \%$ as not having an appreciable effect on competition. ${ }^{304}$ Is de minimis the same as negligible? Probably not.

Second, as the EC courts have consistently held, even very small amounts of aid can have an effect on intra-EC trade and consequently on competition. ${ }^{305}$ It is unclear how the favourable treatment of firms with "negligible market share" in this context complies with the case law. Indeed, a firm may have negligible share in the relevant EU market but it may affect significantly its competitors in neighbouring markets.

ii. What is reasonable time for achieving viability? A fundamental point of the guidelines is that the beneficiary company attains viability within a reasonable period of time. It is unclear what is reasonable. Five years have often been considered reasonable, but this is not a standard practice.

\footnotetext{
${ }^{304}$ Commission Notice on Agreements of Minor Importance, OJ C368, 22/12/2001.

${ }^{305}$ Case T-214/95, Vlaamse Gewest, 1998 ECR II-717, at para 48.
} 
An Assessment of EC State Aid Policy onRescue and Restructuring of Companies in Difficulty

One may argue that it is natural that the required length of time varies from case to case according to the particular circumstances of the company, the magnitude of its problems and the prevailing market conditions. The difficulty with an open-ended approach of this kind is that the more distant the point of achieving viability is, the more the particular circumstances of the case may change unpredictably. This makes restructuring a riskier project, ceteris paribus. Since governments should be prudent with public money, it makes sense to have a limit on the time needed for return to viability.

iii. Why no compensatory measures by SMEs? When the recipient of rescue and restructuring aid is an SME it does not have to offer compensatory measures. This is not clarified in the guidelines, apart, of course, from the implicit justification that SMEs are too small. But there is no one-to-one relationship between the size of a company and the size of its market share, especially in niche or specialised markets. Moreover, if they do not need to compensate competitors because they do not have any significant impact on the economy, why, then, should they be saved?

iv. How much less capacity reduction in assisted areas? The practice of demanding smaller sacrifice from firms located in assisted areas injects ambiguity in the proceedings. Since the guidelines do not define any explicit thresholds, neither the recipient companies, nor their competitors have any clear idea of what to expect.

One may argue that each case should be decided on its merits and the relevant market conditions. The problem with this view is that the outcome depends to a decisive extent on the persuasive skills of the national authorities and beneficiaries. Since one of the main objectives of all the state aid guidelines is to bring about equality in the treatment of state aid across the member states, explicit thresholds are necessary here as well.

v. What is a significant contribution by the beneficiary company? This is probably one of the most serious defects of the guidelines. This is because the amount of own money that the Commission requires the beneficiary to invest automatically determines the amount of state aid that the granting authority is able to provide. The primary purpose of state aid rules is to limit the amount of aid through the imposition of aid ceilings in the form of rates of aid intensity. Of all the rules on state aid, the rescue and restructuring 


\section{Chapter 25}

guidelines are unique in that they do not define any ceiling of maximum allowable aid. We have come across cases where the aid that was permitted reached $80 \%$ of the relevant costs. ${ }^{306}$ Should member states be allowed to grant so much aid? Is the restructuring of a company so much more important than, say, training, R\&D or regional development, which are subject to aid intensity ceilings?

Once more, one may argue that in restructuring situations and as long as the company returns to viability with the minimum possible disruption on competition, the amount of aid should be determined according to the facts of the case, which means the actual need of the company. As before, there are two problems with this approach.

First, the outcome is partly determined by the negotiating skills of the parties involved. This undermines the aim of state aid rules to bring about objective and equal treatment across the member states.

Second and most important, this approach is not economically sound. ${ }^{307}$ The needs of a company are not the same as the needs of the economy.

vi. Why is repaid rescue aid not state aid? The Commission is concerned that member states grant rescue aid before notification and certainly before the Commission approves it. Member states argue that the rescue of a company is something that has to be done within very tight time limits if it is to be done at all. The market does not wait for the completion of state aid procedures in Brussels.

However, we would be more concerned about something else. Under current practice, when a company repays an emergency loan within six months, the Commission does not initiate proceedings against the member state concerned because it does not regard repaid rescue aid as state aid.

\footnotetext{
${ }^{306}$ As a case in point see Commission Decision 2004/166 on French aid to SNCM, OJ L61, 27/2/2004.

${ }^{307}$ See P. Nicolaides and M. Kekelekis, An Economic Analysis of EC Guidelines on State Aid for the Rescue and Restructuring of Companies in Difficulty, forthcoming in Intereconomics, 2004.
} 
An Assessment of EC State Aid Policy onRescue and Restructuring of Companies in Difficulty

But as a general approach, this must surely be wrong. A company that requires rescuing finance must be in deep trouble. If national authorities have to step in, it likely means that the company has been unable to raise the necessary capital on the market. Private investors probably find it noncreditworthy. If this is the case, injection of public capital even at market rates is a form of state aid. This is the essence of the private investor principle. ${ }^{308}$ Repayment of any loan received under these conditions does not eliminate any state aid element, simply because the beneficiary company obtained an advantage it would not otherwise obtain under normal market conditions. The Commission, therefore, should still subject repaid rescue loans to the scrutiny of the state aid rules on basis of the private investor principle.

Surprisingly, it does, at least in theory! The guidelines in paragraph 66 refer to rescue schemes for SMEs. In that paragraph it is stated that, if there is no restructuring plan at the end of the six-month rescue period, member states should "demand reimbursement of the loan and the aid corresponding to the risk premium from the beneficiary." This is correct, but it is unclear why it is demanded only for repaid rescue aid in the context of schemes and only with regard to SMEs. Moreover, there is no "one-time, last-time" restriction for rescue aid. This could mean, for example, that national authorities can grant repeatedly short-term bridging loans to the same company.

We can now see that in the current guidelines on rescue and restructuring there are many more problems and weaknesses than those publicly acknowledged by the Commission.

\subsection{An assessment of the draft new guidelines on rescue and restructuring and recommendations}

The new guidelines retain many of the provisions of the current guidelines. They retain the definition of undertakings in difficulty, the case of groups of companies, the principles that restructuring aid must be the minimum necessary, that it should be accompanied by a plan to restore the recipient

${ }^{308}$ See P. Nicolaides, Re-Introducing the Market in the Market Economy Investor Principle, European State Aid Law Quarterly, Proceedings, 19 June 2003, at p. 3943. 


\section{Chapter 25}

firm to viability within a reasonable length of time, that it should not cause undue distortion to competition and that restructuring aid may not be granted more than once [at least, not more than once every ten-year period]. Some of the Commission's concerns thus, as above mentioned, have not been satisfied in the new guidelines.

The main differences between the two sets of guidelines are as follows:

i. Urgency aid. Rescue aid is replaced by "urgency aid". This is aid that is granted for at most six months and has to be repaid by the end of the sixmonth period, otherwise it will be counted in the overall amount of restructuring aid [in the current guidelines, rescue aid has to be repaid within twelve months].

ii. Simplified procedures. A major innovation of the new guidelines is that urgency aid is assessed through a simplified and expedited assessment process. In addition, urgency aid is subject to "the one-time, last-time" principle.

iii. Maximum amount of urgency aid. The maximum amount of urgency aid is determined on the basis of a formula, which is defined in an annex to the new guidelines.

iv. SMEs. No restructuring plan is required to be submitted in the case of SMEs. The grant of aid must however be conditional on full implementation of a restructuring plan, which is communicated to the Commission and has been approved by the member state concerned.

v. Compensatory measures. The compensatory measures may have to be as high as $100 \%$ of the beneficiary company's capacity in case that the beneficiary operates in a market with long-term structural problems. Also, the new guidelines have dropped the reference to "negligible" market share.

vi. Own contribution. The money that has to contributed by the shareholders of the beneficiary company must be at least $25 \%$ for small enterprises, $40 \%$ for medium-sized enterprises and $50 \%$ for large enterprises.

The question that arises is whether the new guidelines improve on the current ones, especially as regards the comments made above at section 4 . 
An Assessment of EC State Aid Policy onRescue and Restructuring of

Companies in Difficulty

Thus, the concept of "negligible" market share has not been clarified. On the contrary, there is no such reference in the new text. One could argue that there is an indication in paragraph 51 of the new guidelines, where it is stated that compensatory measure will not normally apply to small enterprises [emphasis added] since it can be assumed that ad hoc aid to such enterprises does not normally distort competition to the extent contrary to the common interest, except where otherwise provided by rules on State aid in a particular sector or when the beneficiary is active in a market suffering from long-term overcapacity. We agree that small enterprises, defined as being those with less than 50 employees and either an annual turnover not exceeding EUR 7 million or an annual balance-sheet total not exceeding EUR 5 million $^{309}$, do not pose a real threat on competition. This, however, implies that medium or large companies with negligible or very small market share in a market concerned will be subject to compensatory measures. We consider, in this respect, that the Commission follows a very defensive policy aiming to attach compensatory measures and avoid therefore distortions of competition by focusing on the size of the undertakings concerned rather than on their presence and effect on the market, which would certainly require a more extensive market study.

As to the issue of viability, it still remains unclear which is the reasonable period of time within which the beneficiary company shall attain viability, as the new guidelines do not provide for a clarification. This difficulty may be avoided by the imposition of a maximum threshold of risk. Since there is an inverse relationship between risk and length of time needed by the firm to return to viability, it makes more sense to lay down a risk threshold that indirectly restricts the available time to achieve viability. Such a risk threshold may be defined in terms of a risk premium over the inter-bank rate of interest. The difference between this approach of setting a risk threshold and the current one of allowing the granting authorities and recipient companies to define "reasonable" time periods is that the former is objective while allowing each case to be determined on its merits and according to the underlying conditions.

${ }^{309}$ Annex I to Commission Regulation (EC) No 70/2001 of 12 January 2001 on the application of Articles 87 and 88 of the EC Treaty to State aid to small and mediumsized enterprises, OJ 2001 L 10/33. 


\section{Chapter 25}

It is worth noting in this connection that Article 9 of the recently proposed implementing regulation on state aid procedures requires that the interest rate to be charged for recovery aid shall be calculated on the basis of the average of the five-year inter-bank swap rate plus 75 percentage points. ${ }^{310}$ Therefore, it is not unusual to define risk in this way.

An alternative solution would be for the Commission to prepare a study, on the basis of its experience gained throughout the years in cases of rescue and restructuring, related to the return of aided undertakings to viability. This study would combine the percentage of success of each project with the period took place for the return of the undertaking concerned to viability. On this basis, the Commission would be in a position to determine a minimum and maximum threshold, e.g. a period between 3 to 6 years, enabling it to deal with the risk appropriately.

The other innovations of the new guidelines seem also to be heading in opposite directions. Although most of them appear to make the conditions for granting such aid stricter, some appear to widen the exception for restructuring aid.

The rules are relaxed in the case of SMEs for which no restructuring plan will be required. By contrast, the rules are tightened with respect to the amount of restructuring money that must be contributed by beneficiary companies. In the future, they will have to inject at least a certain amount of their own funds. Moreover, companies may be asked to close down all of their productive capacity whenever they operate in sectors with long-term structural problems. There are also limits on the amount of urgency aid which is now subject to the "one-time, last-time" principle.

${ }^{310}$ See Commission proposal of 14 November 2003 for a new implementing regulation. It can be accessed at http://europa.eu.int/comm/competition/state_aid/others/procedural_rules/. Further reading on this chapter: T. Kleiner and R. Reppliner-Hach, The new community framework for state aid for research and development and innovation, Competition policy newsletter: $n r .1$ 2007, A. Rubin de Cervin and V. Zuleger, Large R\&D Projects - Commission practice under the R\&D framework from 1996 to 2006, European State Aid law - Quarterly, Volume 5 No. 1 2006, T. Kleiner, The new framework for research, development and innovation, 2007-2013, European State Aid law-Quarterly, Volume 6 No. 22007. 
An Assessment of EC State Aid Policy onRescue and Restructuring of

Companies in Difficulty

Overall, the new guidelines clarify important concepts and restrict in principle the amount of state aid that may be granted. The Commission is probably right in introducing a simplified procedure for urgency aid. Since, once member states decide to grant rescue aid they will go ahead and ignore any lengthy notification requirements, the new procedures should induce them to notify such aid. The definitional clarifications are also welcome. In this sense they do improve on the current guidelines. However, the criticisms outlined above as well as in section 4 do not appear to be acknowledged by the new guidelines. With two exceptions, no new criteria for assessing state aid are used by the proposed guidelines. These guidelines, therefore, suffer from the same fundamental weaknesses and internal contradictions as the current ones.

The two exceptions we have been able to detect concern additional information that member states are requested to submit. These appear in Annex II on urgency aid:

3.1 Will the aid under the scheme be warranted on the grounds of serious social difficulties? Please justify.

3.3 Please explain why do you think that the aid is limited to the minimum necessary (i.e. is restricted to the amount needed to keep the firm in business for the period during which the aid is authorised or for urgent structural measures such as the immediate exit from a loss-making field of activity).

And in Annex III on restructuring aid:

5. Effects on employment.

Please provide an initial appraisal of the estimated impact on employment, at local, regional or national level, of the firm's possible disappearance, as well as of the predictable employment impact of any viability restoration and/or compensatory measures.

These additional information requirements raise issues concerning the negative social impact of company closure and how it may be ameliorated by state aid. Certainly, they will force national authorities to justify state aid by taking into account the potential economic effects of their intervention. But there is no requirement for any systematic comparison of positive and negative economic effects of closure and of state aid. 


\section{Chapter 25}

\section{6 Conclusion}

This chapter has examined the current and draft new guidelines on rescue or urgency and restructuring aid. It has identified a number of weaknesses and contradictions. The proposed new guidelines improve on the current ones in several respects, the most important of which are that urgency aid will be assessed more quickly and will be capped and that shareholders will be asked to inject a minimum amount of their own money in restructuring their own companies.

However, the new guidelines do not remove the contradictions inherent in the rules on rescue and restructuring aid. Most importantly, the new rules make it easier for member states to grant aid to SMEs for which no restructuring plan will be required, notwithstanding the fact that compensatory measures are now required to be implemented by medium and large enterprises and that the principle of "one-time, last-time" also applies to them. Since $99 \%$ of companies in the EU are SMEs, the new guidelines are still too generous. 


\section{Chapter 26}

\section{Regional State Aid:}

\section{An Assessment of Community Rules and National Measures}

\subsection{Introduction}

In 2001, the member states of the European Community granted about EUR 85 billion of state aid. This was the amount recorded by the European Commission. ${ }^{311}$ Most of that state aid went to just two sectors: agriculture and transport (especially railways). During the past decade, they absorbed $60 \%-70 \%$ of all state aid per year.

Outside those two sectors, the largest category of state aid concerns aid which is granted to promote regional development. It accounted for about 25\%-30\% of aid to manufacturing, which corresponded to EUR 8 billion in 2001. Germany and Italy were responsible for almost $50 \%$ of all regional aid given in the EU.

While the EC Treaty bans state aid in principle, under certain conditions some types of state aid including regional state aid are explicitly exempted. The impending enlargement of the European Union has led the Commission to launch a process of public discussion to consider possible changes to the existing framework of Community rules on regional state aid. ${ }^{312}$ All new

\footnotetext{
${ }^{311}$ See the Commission's State Aid Scoreboard. It can be accessed at "http:/europa.eu.int/comm/competition/state_aid/scoreboard/". It contains data submitted by the member states. It does not necessarily include all state aid granted by national central and regional authorities. About $15-20 \%$ of all cases of state aid investigated by the Commission each year concern non-notified aid. This suggests that if member states fail, for whatever reason, to notify all cases of state aid, it is also likely that they fail to report the true amount of state aid granted by public authorities within their territories.

${ }^{312}$ Commission Notice in OJ C110, 8/5/2003.
} 


\section{Chapter 26}

member states, with the exception of Cyprus, have regions that are eligible for state aid at the highest rates (i.e. "Objective 1 regions" or "87(3)(a) areas").

These developments raise a number of important policy questions concerning the workability of the existing framework of Community rules and whether it can cover both existing and new member states. If reform of existing rules is contemplated then it also becomes necessary to consider the effectiveness of national state aid measures in promoting regional development. If national measures are not sufficiently effective and if this is caused by constraints imposed by Community rules, then the rules need to be adjusted.

Therefore, the purpose of this chapter is threefold: First, it examines the main provisions and application of the Community rules on regional state aid on the basis of landmark Commission decisions and Court rulings. Second, it assesses the effectiveness of national measures to channel aid to needy regions. Third, it considers likely future changes to the regional aid rules as a result of the enlargement of the European Union. It concludes with a number of recommendations.

The main findings of the chapter are as follows. First, the current Commission Guidelines on regional aid and the Multisectoral Framework that will fully come into force in January 2004 represent an improvement over previous rules. However, some of these rules are not so easily enforced. Second, available statistics do not reveal any strong correlation between regional aid and regional disparities. This suggests that aid is not effectively channeled to regions according to their need. Third, in view of the impending enlargement of the EU, rules on regional aid may be adjusted to allow member states to focus more precisely their regional aid. 


\subsection{The rationale for regional state aid $^{313,314}$}

Economic and social cohesion is one of the main aims of the European Community. Article 2EC defines cohesion as a "task" of the Community. Article 2 of the European Union Treaty also defines cohesion as one of the instruments through which the Union will achieve its objectives. So cohesion is both an instrument and an aim.

Articles 158-162EC lay down specific rules on the achievement of economic and social cohesion while Article 159 requires both the Community and the member states to conduct their policies by taking into account the need for cohesion. This means that competition policy must also accommodate cohesion. Since strengthening cohesion means in practice helping poorer regions to catch up with the richer regions, the Community and the member states intervene by favouring the poorer regions.

On the other hand, the pursuit of cohesion should not distort competition. Article 12 of Regulation 1260/99 on the management of structural funds explicitly stipulates that structural fund operations conform with the rules of competition and public procurement.

So on the one hand, the Community requires competition policy to accommodate cohesion aims but, on the other, it mandates that the pursuit of cohesion should respect competition rules. These are conflicting policy objectives. How then is the potential conflict between cohesion and competition resolved?

The underlying rationale for resolution of this conflict is that poorer regions are facing certain handicaps: low level of economic activity, lack of human

\footnotetext{
${ }^{313}$ For an analysis of the theory of regional state aid and an excellent and up to date review of regional rules and practice in the EC and see F. Wishlade, Regional State Aid and Competition Policy in the European Union, European Monographs 43, (London: Kluwer Law International, 2003).

${ }^{314}$ For a more general review of the reasons for granting state aid see P. Nicolaides \& S. Bilal, An Appraisal of the State Aid Rules of the European Community: Do they Promote Efficiency?', Journal of World Trade, 1999, vol. 33(2), pp. 97-124. ${ }^{\text {See }}$ also R. Meiklejohn, The Economics of State Aid, European Economy, 1999, no. 3, pp. 25-31
} 


\section{Chapter 26}

and financial resources, limited social services, inadequate infrastructure, etc. Community and national intervention merely help to level the playing field and to make competition fair.

Whether state intervention restores fair competition very much depends on one's reference point. If the reference point is the status quo, intervention certainly distorts competition. If the reference point is what would have happened without the perceived regional handicaps, then intervention has the potential of restoring fair competition.

The problem of course is that not only is "fair competition" a vague concept, no one really knows what economic conditions would have prevailed in the absence of regional handicaps. Even when all firms start with the same assets and facing the same handicaps, the natural process of competition would bring about differentiation as some firms would succeed and some would fail with corresponding repercussions on their regions. Not surprisingly, the Community lacks a definition of fair competition. The Commission and the Courts in their many rulings on anti-trust and state aid cases have not defined fairness in this context.

The fact that we do not have a definition by which to measure the fairness of competition reveals another problem. Even if we accept that poorer regions are handicapped, it is not so easy to determine the right instruments and the extent of intervention which is necessary to restore fairness. For example, if we assume that poor regions experience lack of highly-skilled workers, we would still not know how much training should be funded by the state. This is because labour skills are not evenly distributed across regions.

And, like in so many other policy fields, there is the question of effectiveness of state intervention. For example, public funding of training need not produce the desired improvement in labour skills simply because firms may use public subsidies for kinds of training that suits their immediate needs but not the long-term needs of the region.

The European Union has by-passed the problem of the definition of fair competition but has not escaped from the second problem of deploying effective state aid instruments. The problem of definition has been settled in a twofold manner. First, the EC Treaty allows state aid for regional development purposes. While Article 87(1) prohibits in principle any form 


\section{Measures}

of state aid, Article 87(3)(a \& c) exempts aid for regional development. The European Court of Justice in Germany v Commission, C-248/84, has ruled that the Treaty exempts that kind of aid precisely because certain areas face handicaps. The handicap of the areas that fall within the exception provided by Article 87(3)(a) is defined in relation to the standard of living and economic conditions of the Community as a whole. By contrast, the handicap of the areas that fall within the exception provided by Article $87(3)(c)$ is defined in relation to the national economic conditions.

Second, the Commission has operationalised that ruling of the Court by defining "87(3)(a) areas" as those with per capita income falling below 75\% of the EU average, measured at purchasing power standard (PPS). The definition of "87(3)(c) areas" is more flexible and allows member states considerable discretion in determining their own methodology for choosing eligible areas.

The second problem, that of the effectiveness of the state aid instruments, is still being debated. The main question which arises is whether state aid can improve regional economies, raise their rate of development and ultimately reduce the gap between the poor regions and the rich regions - the cohesion task of the EC. For this reason, this chapter will examine later on the record of the member states in deploying state aid as a policy tool for strengthening cohesion. The following section reviews the existing Community framework of rules and the practice of the EC.

\subsection{EC rules on regional state aid}

Given that the provisions of the Treaty on the types of state aid that may be exempted are very general, the Commission has issued detailed guidelines on regional state aid to help member states to design and notify regional aid schemes that can be authorised by the Commission. As is well known, guidelines of this nature are binding only on the Commission. Member states in theory may deviate from the guidelines but there has been no member state that has successfully challenged such guidelines before the Court [I will return on this point in the third part of the chapter when I consider likely future reform]. 


\section{Chapter 26}

As already mentioned above, the ECJ has accepted that certain forms of regional aid are compatible with the common market because they serve to reduce regional handicaps. This is because in the landmark case of Philip Morris v Commission, C-730/79, the Court explained that state aid may be exempted only when the advantage which is given to the regions that receive the aid outweighs the distortion to competition. So there is a balancing act to be performed here that only the Commission has the competence to do. In addition, the Court has clarified that the greater the regional handicap, the greater that the advantage which may be granted via state aid [see Spain $\mathrm{v}$ Commission, C-169/95].

In line with these judgements, the regional aid Guidelines serve primarily three functions: to identify the various categories of eligible areas, to determine the allowable instruments of state aid and to modulate the intensity of state aid that is received by different eligible areas. ${ }^{315}$

With respect to the definition of eligible areas, the intention of the Commission was to ensure as much as possible coincidence between 87(3)(a) areas and Objective 1 regions under the structural funds and between 87(3)(c) areas and Objective 2 regions. ${ }^{316}$ The total share of the EU population eligible to receive regional aid was fixed by the Commission at $42.7 \%$.

In the end, only partial coincidence could be achieved between state aid areas and structural fund regions. This has implications about the future demarcation of eligible areas which is dealt with in the third part of this chapter. The main reason for the discrepancy between the two sets of "maps" were, on the one hand, the compromise between the member states on the transitional arrangements for structural fund regions that were about to lose their eligibility (agreed at the Berlin European Council in March 1999) and, on the other, the designation of $87(3)(c)$ areas by the member states. Since member states had discretion in designating eligible areas, in most cases they included in their state aid maps areas that were outside Objective 2 regions.

The country with the largest discrepancy between the two maps was the UK (8.1 million people live in areas eligible for both state aid and structural funds, 5.7 million people live in areas eligible only for Objective 2 (i.e. a

\footnotetext{
${ }^{315}$ OJ C212, 12/8/1988.

${ }^{316}$ Commission Notice in OJ C16, 21/1/1999.
} 
Regional State Aid: An Assessment of Community Rules and National

Measures

total of 13.9 million are included in Objective 2), while 3.3 million people live in areas eligible only for state aid under 87(3)(c) (i.e. a total of 11.4 million people are covered by $87(3)(\mathrm{c})) .{ }^{317}$

Table 26.1: Eligible Population for Regional State Aid, 2000 - 2006

\begin{tabular}{|l|c|c|}
\hline Member state & $\begin{array}{c}\text { \% of eligible } \\
\text { population }\end{array}$ & Type of 87(3) area \\
\hline Belgium & 30.9 & $\mathrm{c}$ \\
Denmark & 17.1 & $\mathrm{c}$ \\
Germany & 34.9 & $\mathrm{a}+\mathrm{c}$ \\
Greece & 100 & $\mathrm{a}$ \\
Spain & 79.2 & $\mathrm{a}+\mathrm{c}$ \\
France & 36.7 & $\mathrm{a}+\mathrm{c}$ \\
Ireland & 100 & $\mathrm{a}+\mathrm{c}$ \\
Italy & 43.6 & $\mathrm{a}+\mathrm{c}$ \\
Luxembourg & 32 & $\mathrm{c}$ \\
Netherlands & 15 & $\mathrm{c}$ \\
Austria & 27.5 & $\mathrm{a}+\mathrm{c}$ \\
Portugal & 100 & $\mathrm{a}+\mathrm{c}$ \\
Finland & 42.2 & $\mathrm{a}+\mathrm{c}$ \\
Sweden & 15.9 & $\mathrm{c}$ \\
United Kingdom & 28.7 & $\mathrm{a}+\mathrm{c}$ \\
EC & $\mathbf{4 2 . 7}$ & \\
\hline
\end{tabular}

With respect to the instruments of state aid, the Guidelines permit only two instruments: investment and job creation linked to investment. They also exceptionally allow operating aid but only for 87(3)(a) areas and only when it is temporary, degressive over time and clearly linked to offsetting regional handicaps (by a separate Notice, the Commission has in the meantime allowed operating aid on a permanent basis to the outermost regions of the EU and for the partial compensation of transport costs in the low density regions; i.e. the polar regions of Finland and Sweden). ${ }^{318}$

Investment aid is restricted to initial or extension investment. Replacement investment is not allowed. Subsidised assets must also be kept by the beneficiary firm for at least five years. Aid for job creation is restricted only to jobs that are linked to either initial or extension investment. The jobs must

\footnotetext{
${ }^{317}$ Commission decision N 265/2000 on the UK regional aid map.

${ }^{318}$ Commission Notice in OJ C285, 9/9/2000.
} 


\section{Chapter 26}

be made available within three years of the investment and must also be maintained for at least five years.

It is worth noting that the recently adopted Regulation on Employment Aid $2204 / 2002$, has severed the link between investment and aid for jobs. ${ }^{319}$ Under that Regulation firms may receive aid for hiring more people as a result of expansion in their operations rather than as net addition to their asset base. Moreover, the Regulation requires beneficiary firms to keep new employees for a minimum of three years instead of five, while SMEs can keep them only for two years.

Lastly, the Guidelines set maximum ceilings for the intensity of granted aid. Intensity is measured as a percentage of aid in relation to the eligible costs. It is important to understand that while the Guidelines define maximum rates, the rates which are applicable to each region are those approved by the Commission individually and included in each member state's regional aid map. The table below shows the rates defined in the Guidelines. As can be seen, there is considerable variation across regions.

Table 26.2: Guidelines on Regional Aid: Maximum Aid Intensities (amount of aid as \% of eligible cost)

\begin{tabular}{|l|c|c|}
\hline & $\mathbf{8 7 ( 3 ) ( a )}$ area & $\mathbf{8 7 ( 3 ) ( c ) ~ a r e a ~}$ \\
\hline$\quad$ Maximum rate & 50 & 20 \\
- if regional GDP $>60 \%$ & 40 & - \\
- if GDP $>$ EU average \& unemployment $<$ & - & 10 \\
EU average & - & 20 \\
- if next to 87(3)(a) area & 65 & 30 \\
\hline$\quad$ Outermost region & 50 & - \\
- if regional GDP $>60 \%$ & - & 20 \\
- if GDP $>$ EU average \& unemployment $<$ & & 30 \\
EU average & 50 & - \\
\hline$\quad$ Low density region & 40 & 20 \\
- if regional GDP $>60 \%$ & - & +10 \\
- if GDP $>$ EU average \& unemployment $<$ & & \\
EU average & +15 & \\
\hline SME &
\end{tabular}

${ }^{319}$ OJ L337, 13/12/2002. 
Regional State Aid: An Assessment of Community Rules and National Measures

\subsection{The Multisectoral Framework}

An innovation of the Commission for the present financial perspective has been the introduction of rules of the individual notification and the reduction of aid to large projects. These rules were introduced in 1998 by the "Multisectoral Framework". A new Framework has partially come into effect since the expiry of the Treaty on the European Coal and Steal Community in July 2002. The new Framework will fully be in force as of 1 January $2004 .^{320}$

The Multisectoral Framework reduces allowable aid intensities for large projects because such projects have a bigger impact on competition, they are more likely to be undertaken by multinational companies which are less affected by regional handicaps (e.g. they have access to capital markets or cutting-edge technology) and because these companies can exert much more pressure on regional and local authorities to grant aid up to the permitted ceiling. The adjustment is made as follows

Table 26.3: Multisectoral Framework: Maximum Aid Intensities for Large Projects

\begin{tabular}{|l|l|}
\hline Eligible expenditure & \multicolumn{1}{|c|}{ Adjusted regional ceiling (R) } \\
\hline A: up to EUR 50 million & $100 \%$ of ceiling \\
B: EUR $50-100$ million & $50 \%$ of ceiling \\
C: over EUR 100 million & $34 \%$ of ceiling \\
\hline Formula for adjusting ceiling: Maximum eligible aid $=\mathbf{R}(\mathbf{A}+\mathbf{0 . 5 B}+\mathbf{0 . 3 4 C})$ \\
\hline
\end{tabular}

For example, a project costing EUR 160 million in area with a $25 \%$ ceiling can obtain aid up to EUR 23.85 million. This is equivalent to aid intensity of only $14.9 \%$.

Notification is required for every case where the amount of aid exceeds the aid that corresponds to an investment costing EUR 100 million. It follows, that notifiable projects vary from area to area depending both on the size of the project and also on the aid intensity allowed for each area.

For example, in an area with aid ceiling of $20 \%$, a factory costing EUR 250 million can benefit from aid up to a maximum of EUR 25.2 million. Since,

${ }^{320}$ OJ C70, 19/3/2002. 
however, in the same area an investment costing EUR 100 million can obtain EUR 15 million of aid, any amount of aid for that factory that exceeds EUR 15 million will have to be notified individually. In other words, that factory will have to obtain aid of less than to EUR 15 million to escape notification. This means that the intensity of that aid will have to be less than $6 \%(=$ $15 / 250$ ), even though in principle the rate is $20 \%$ for that area.

\subsection{Workability of the regional aid Guidelines}

It is very difficult to know how the Guidelines have been complied with by the member states. The information submitted by member states in their notifications and the conditions imposed by the Commission in its related decisions are one thing, while the actual implementation of national schemes is a different thing. My intention here is to make a number of observations with respect to the user-friendliness of the Guidelines. These observations are based on conversations with national officials and on my own work in advising national authorities on the application of the Guidelines.

Overall, there is no doubt that the current Guidelines represent a major improvement over the previous Guidelines and the multitude of flanking rules they replaced. The aspects of the Guidelines that appear to have caused problems to national authorities are the following:

1. The distinction between truly new investment and replacement investment: What can be classified as new investment in an existing company very much depends on the nature of the industry in which that company operates. For example, whereas a printing firm would need to update regularly its printing software, the same software would represent a genuine extension investment for a training firm that wants to start publishing its own information and other training material.

2. The difficulty of national authorities to prevent companies from receiving aid to replace old machinery: Companies can simply buy new machines and equipment which they can declare as additional assets. After they receive aid, they get rid of the old machinery and equipment because granting authorities do not keep track of assets that have not previously benefited from aid. Replacement investment is regarded by the Commission as operating aid and therefore 


\section{Measures}

exceptionally approved only in the case of 87(3)(a) areas. But when aid is exceptionally approved, the Commission normally imposes extra conditions so that aid is temporary and degressive. It also ensures that aid does not spill over into non-eligible areas. See to this effect Commission Decision 2002/780 concerning investment aid to the new German Länder and Decision 1999/678 concerning aid to the creditors of a firm that went bankrupt in Sicily.

3. Aid for new jobs, not job maintenance: As with investment, firms that receive aid for jobs must be adding new positions rather than maintaining the same number of positions. For two reasons, it is difficult for granting authorities to comply with this requirement. First, national authorities have a tendency to grant aid even if its for job maintenance when they know that firms would fire their workers unless they receive aid. Second, jobs must be linked to new investment. But if replacement investment can be disguised as new investment, it follows that the beneficiary firms may only maintain existing jobs when they subsequently close down old capacity and make redundant the workers related to the disposed machinery. This can also happen when firms hire new workers [the Guidelines require a net increase in the workforce in terms of full-time equivalent at the point in time when the aid is awarded] but then get rid of workers in other divisions of the firm.

4. The practice that investment must be new with respect to the existing assets of the company: While regional authorities can check whether a company adds new premises or equipment in the assisted area, it is difficult for them to ensure whether such things are new for the company. In other words, they cannot easily verify that the company that receives investment aid has not simply transferred operations from one area to another for the sole purpose of obtaining aid. The Commission in its Decision 2000/795 concerning the shift of the operations of the firm Ramondin from one Spanish region to another partially prohibited the aid that was granted to Ramondin because it found that the company was merely seeking to benefit from the availability of regional aid in the new region. Although in that case it was obvious that Ramondin was trying to exploit state aid (by transferring its plant to another location literally a few kilometres away) and that the Decision has since been confirmed by the Court of First Instance [in Territorio Histórico de Álava - Diputación Foral de Álava v Commission, T-92/00], it still leaves unanswered the 
very important question whether a company may not move its operations to an assisted area. After all, this is indeed the purpose of regional aid to induce companies to locate their operations in handicapped regions. The regional Guidelines do not clarify whether the aid is intended for location of new assets or re-location of existing assets.

5. The requirement that assets and hired workers have to be kept for a minimum of five years: Although national authorities routinely ask past recipients of aid to declare whether they retain the assets they bought and jobs they created with the help of state aid, it is difficult for them to carry out any systematic on-site inspections. [Apparently, the on-siteinspection powers that were conferred to the Commission by Regulation 659/99 have never been used either.]

6. Hiring from outside the assisted area: Aid for job creation is allowed by the Guidelines because it contributes directly to reducing regional unemployment and indirectly to raising the disposable income and hence prosperity of assisted areas. It is virtually impossible for granting authorities to confine the hiring of workers only to those who reside in eligible areas (perhaps in some member states it is also unconstitutional). The situation is even worse when firms intentionally move their operations from a non-eligible area to an eligible area and re-hire workers who commute from outside the assisted area. The Commission in its Decision 1999/686 prohibited a German scheme for teleworking (i.e. working from home) because some beneficiary firms employed workers who lived outside assisted areas. This of course raises two uncomfortable questions: how can granting authorities know where workers live (especially in cases involving firms located in border areas) and if the intention is to create employment in eligible areas does that not contribute to unemployment in non-eligible areas when firms shift their operations? The Guidelines do not deal with these issues.

7. Ad-hoc aid: Aid outside regional schemes is not prohibited, but the Commission is not favourably predisposed towards it. In 87(3)(c) areas such aid is assessed according to its impact on the rest of the EC so as to ensure that the distortion to competition is not contrary to the "

8. common interest". No one knows what this common interest may be. That is why it is very difficult for national authorities to grant ad-hoc for which they can be certain that it is compatible with the common market. 


\section{Measures}

Prudent authorities should notify it to the Commission otherwise they risk a negative decision by the Commission, as happened in the case of the Basque authorities a few years ago. They had granted ad-hoc aid which was eventually found by the Commission to have been in a sector suffering from over-capacity. The Commission took the view that the distortion to competition was contrary to the common interest as aid to the firm in question added to the problems of its competitors. See Commission Decision 1999/718 concerning Spanish aid to Daewoo. It was not easy for the regional authorities to know the sectors in the European market which suffered from over-capacity and for this reason they should have notified their aid in advance. Of course, they should have notified it simply because they may not grant any aid without prior Commission approval.

\subsection{Assessment of national state aid measures}

The previous section argued that there are some practical problems in ensuring compliance with the spirit and letter of the Guidelines. Perhaps some national authorities bend the rules. The question addressed in this section is not whether member states cheat. Rather the question is whether member states have been successful in working within the Guidelines to raise regional prosperity. After all, the underlying rationale for exempting regional state aid from the general prohibition of state aid is that member states target it at regions that lag behind.

As a first step, then, for understanding how the member states have been using this exemption, we can formulate the hypothesis that the amount of state aid is related to disparities in national regional income. Since we want to be able to compare member states, it is postulated that, other things being equal, more state aid should in principle be granted within member states that experience bigger divergence in the standard of living across their regions.

More precisely the proposed test can be formulated as follows:

$$
\mathrm{D}_{\mathrm{t}+1}=\mathrm{a}+\mathrm{bS}_{\mathrm{t}}+\mathrm{e} \text {, }
$$

meaning that differences in regional income in period $t+1$ are a function of state aid in period t plus an unknown error term. The independent variable is 
lagged by a year because state aid is a policy instrument that can be used proactively.

Two types of regressions are run. The first type is over time for each member state. The relevant period is 1990 to 2000. Given that the independent variable is lagged by a year, there are only ten observations per country. The second type of regression pools data from all the member states for two periods: 1999 and 2000.

The independent variable (i.e. state aid) is measured in terms of state aid per capita and state aid as a share of GDP (both expressed in real figures) to account for the fact that larger countries are more populous and have larger economies so they grant larger amounts of state aid in absolute terms.

Regional disparities are measured by the differences in regional income in terms of deviations from national average income per capita expressed in PPS.

The significant problem encountered is the discontinuities in data. For the time-series regressions, Austria, Finland and Sweden have been omitted because for them data on state aid start in the mid-1990s. Denmark, Ireland and Luxembourg are also omitted because for Ireland the data on regional disparities do not go beyond the mid-1990s while for Denmark and Luxembourg there are no data on disparities for that period. In the crosscountry regressions Denmark and Luxembourg have also been excluded again for the reason that there are no data on regional disparities.

\section{Regression results}

All the regression results on time series are shown in Table 4 and on crosscountry data in Table 5 at end of the chapter. The time series results indicate the following:

- In many cases, the sign of the slope of the independent variable is positive, implying that larger amounts of state aid go hand in hand with larger regional disparities.

- However, the coefficient of correlation (R-squared) is in many cases very low.

- Regional aid has relatively high R-squared values only in two countries, Belgium and Spain where in both countries the independent variable has a positive sign. 
The cross-country results for 1999 and 2000 indicate the following:

- In all cases the sign of the slope of the independent variable is negative, implying that larger amounts of state aid go hand in hand with smaller regional disparities!

- However, the coefficient of correlation (R-squared) is in all cases very low and lower than in the time series.

These results are not encouraging. They reveal a confusing picture across the EU. They certainly do not support the prevailing policy stance that regional aid should be targeted to the most needy regions.

How can these results be explained? It seems that the main explanation is that despite the efforts of governments, state aid is a policy that has effect only if firms respond positively to the inducements offered by public authorities. Just because a government makes money available for regional development it does not necessarily follow that firms will adjust their investments and take up that funding possibility.

Not only do firms may not respond, they may also exploit whatever subsidies they receive without generating the effects desired by the national regional policies. A recent report by the National Audit Office in the UK has found that two policy instruments in England - Regional Selective Assistance and Enterprise Grants - have not had a significant impact on regional economies partly as a result of the fact that the investment undertaken by companies and the jobs they created have not had any lasting long-term effects. ${ }^{321}$ These findings should not come as a surprise given that

${ }^{321}$ National Audit Office, Regional Grants in England, 17 June 2003, (London: The Stationery Office). Further reading on this chapter: T. Kleiner and R. RepplingerHach, The new community framework for state aid for research and development and innovation, Competition policy newsletter: $n r .1$ 200, Competition policy newsletter: $n r .1$ 2007, S. Crome and C. Dupuis, Regional investment aid to the shipbuilding industry: How to deal with capacity increases? - Experience with the Volkswerft Stralsund and Rolandwerft cases, Competition policy newsletter: $n r .1$ 2007, A. Drzewoska, J. Rojo De La Viesca and A. Tari, State aid to an electronics cluster in Poland: Assessing regional investment projects in the context of spatial agglomeration, Competition policy newsletter: $n r .1$ 2007, S. Cavallo and K. Junginger-Dittel, The Multisectoral Framework 2002: new rules on regional aid to large investment projects, Competition policy newsletter: $n r .1$ 2004, A. Rubin de 


\section{Chapter 26}

the previous section explained that firms (and national authorities) can deviate from both the intent and letter of the Guidelines.

\subsection{Reform of regional state aid rules}

If the results obtained in the previous section are credible, regional state aid rules should be changed even if the enlargement of the EU would not have taken place. In this context, the purpose of this section is to consider only those changes that may be directly necessary as a result of enlargement and more specifically the entry of relatively less prosperous countries into the EU.

Enlargement will increase the number of relatively poor regions. This means that the number of eligible regions in the existing states will decline, perhaps significantly. As there will be fewer assisted areas within the territories of existing member states, how should they target their regional state aid? In order to be able to answer this question, we need first to form a more precise view as to how the regions of existing member states may be affected.

Consider first the likely impact on Objective 1 regions or 87(3)(a) areas. At present about 75 million people live in those areas. Given that the per capita income of the EU25 will drop by about $10 \%$ points, it follows that those regions of the EU15 whose per capita income exceeds $65 \%$ of the present EU average will lose their eligibility. Since that corresponds to about $50 \%$ of the present population in Objective 1 regions, only $10 \%$ of the EU15 will remain eligible, provided of course that this outcome is politically acceptable to the governments of the EU15. This reduction is equivalent to about 37 million people. Given that almost all of the population of the ten acceding countries will be eligible for Objective 1 assistance, the total eligible population of the EU25 will be 37 million +70 million $=\mathbf{1 0 7}$ million or 24\% of the EU25 [when Bulgaria and Romania join the EU, the eligible population of the EU27 will be 107 million +30 million $=137$ million or $29 \%$ of the EU27].

Cervin and V. Zuleger, Large R\&D Projects - Commission practice under the R\&D framework from 1996 to 2006, European State Aid law-Quarterly, Volume 5 No. 1 2006, T. Kleiner, The new framework for research, development and innovation, 2007-2013, European State Aid law-Quarterly, Volume 6 No. 2007. 
Consider now the likely impact on $87(3)$ (c) areas. If the present $43 \%$ ceiling is retained and there are no transitional arrangements, then only $19 \%$ [ $=43-$ 24] of the population of the EU25 will be able to benefit from aid under $87(3)(c)$. This is equivalent to a reduction of $\mathbf{4 \%}$ points in comparison to the status quo. Since virtually all of the population of the acceding countries will have Objective 1 status, it follows that the reduction in 87(3)(c) areas will have to be absorbed by existing member states.

If the $43 \%$ ceiling is retained and there are transitional arrangements for the areas which lose their designation under 87(3)(a), which is a likely event, then the total population eligible for 87(3)(a) status will be 37 million [87(3)(a) areas in the EU15] +70 million [87(3)(a) areas in the ten new member states] +37 million [transitional areas in the EU15] $=\mathbf{1 4 4}$ million or $32 \%$ of the EU25. This means that $87(3)(c)$ areas will have only $14 \%$ of population which corresponds to a drop of $10 \%$ points in comparison to the status quo.

These calculations suggest a dramatic shrinkage of eligible population in the EU15 both in relation to 87(3)(a) and 87(3)(c) areas. They also indicate that there is a trade off between the two sets of areas for those existing member states that have both (a) and (c) areas.

Given that the statistical results from the previous section reveal that state aid does not correlate with regional disparities, which suggests that the member states should narrow the geographic spread of their state aid, the fact that many areas in the existing member states will lose their eligibility to receive state aid is not such an adverse development as it appears at first glance. Member states should be more selective in the regions that receive state aid.

The policy conclusion that naturally emerges from this analysis is that the impending enlargement of the EU offers to the member states a unique opportunity to do what has perhaps proven politically difficult for them to do: limit the availability of their state aid only to the most needy regions.

There is, however, a different kind of problem with this recommendation. As argued in the section evaluating the workability of the EC rules on regional state aid, it is perhaps easy for companies outside eligible areas to cheat in 


\section{Chapter 26}

order to obtain aid for investment or job creation. Limiting the geographic scope of regional state aid may also increase the leakage of aid to other noneligible areas. That would be counter-productive. It follows that there may be a trade off between focusing of aid and reducing its geographic coverage, on the one hand, and leakage of aid, on the other. The right size of geographic coverage is an empirical matter that cannot be answered in this chapter. It is, however, an issue that both the EU and the member states cannot avoid.

\subsection{Conclusions and summary}

This chapter has reviewed the EC rules on regional state aid and assessed their interpretation and application. Although the current Commission Guidelines on regional aid and the Multisectoral Framework that will fully come into force in January 2004 represent an improvement over previous rules, a number of ambiguities remain. Some rules are not so easily enforced. The chapter has identified the rules with which compliance appears to be a problem for national authorities.

The chapter has also examined how well targeted is regional state aid. Available statistics do not reveal any strong correlation between regional aid and regional disparities. This suggests that aid is not channeled to regions according to their need and that it does not appear to have any significant impact on disparities.

On the basis of these findings, the chapter has considered how Community rules may be adjusted in view of the impending enlargement of the EU. Since many of the currently poor regions of the EU15 will lose their eligibility in the future, it follows that existing member states should use this development to focus regional state aid to their most needy regions. 
Regional State Aid: An Assessment of Community Rules and National Measures

Table 26.4: Testing the Targeting of State Aid within Member States (1990-2000)

Income Disparity $(\mathbf{t}+\mathbf{1})=\alpha+\boldsymbol{\beta}($ State Aid $)(\mathbf{t})+\varepsilon$

The dependent variable is disparity (coefficient of variation) in per capita GDP at PPS. For each type of state aid the first row tests real state aid as \% of GDP and the second row real state aid per capita.

\begin{tabular}{|c|c|c|c|}
\hline Country & Intercept & Independent Variable & R-squared \\
\hline \multirow[t]{2}{*}{ Belgium } & 0.796 & 258.440 & 0.547 \\
\hline & 10.964 & 0.787 & 0.313 \\
\hline \multirow[t]{2}{*}{ France } & 31.384 & -29.423 & 0.207 \\
\hline & 30.718 & -0.100 & 0.149 \\
\hline \multirow{2}{*}{ Germany (1991-2000) } & 24.140 & 7.053 & 0.216 \\
\hline & 25.295 & $2.82 \mathrm{E}-02$ & 0.115 \\
\hline \multirow[t]{2}{*}{ Greece } & 6.832 & 4.312 & 0.110 \\
\hline & 5.734 & $6.80 \mathrm{E}-02$ & 0.327 \\
\hline \multirow[t]{2}{*}{ Italy } & 28.699 & -3.343 & 0.216 \\
\hline & 29.284 & -0.024 & 0.418 \\
\hline \multirow[t]{2}{*}{ Netherlands } & 14.761 & -29.531 & 0.149 \\
\hline & 14.304 & -0.109 & 0.106 \\
\hline \multirow[t]{2}{*}{ Portugal } & 17.488 & -14.780 & 0.178 \\
\hline & 15.300 & -0.0159 & 0.002 \\
\hline \multirow[t]{2}{*}{ Spain } & 11.263 & 93.673 & 0.477 \\
\hline & 11.435 & 0.672 & 0.606 \\
\hline \multirow[t]{2}{*}{ UK } & 48.925 & -212.176 & 0.371 \\
\hline & 39.259 & -0.604 & 0.241 \\
\hline
\end{tabular}


Chapter 26

Table 26.5: Testing the Targeting of State Aid Across the EU (1999, 2000)

$$
\text { Income Disparity }(\mathbf{t}+\mathbf{1})=\boldsymbol{\alpha}+\boldsymbol{\beta}(\text { State Aid })(\mathbf{t})+\varepsilon
$$

The dependent variable is disparity (coefficient of variation) in per capita GDP at PPS. For each type of state aid the first row tests real state aid as $\%$ of GDP and the second row real state aid per capita.

\begin{tabular}{|l|c|c|c|}
\hline Type of state aid & Intercept & Independent Variable & R-squared \\
\hline & & & \\
\hline $\mathbf{2 0 0 0}$ & 26.134 & -18.294 & 0.107 \\
\hline & 24.410 & -0.03 & 0.020 \\
\hline $\mathbf{1 9 9 9}$ & & & 0.059 \\
\hline & 24.946 & -9.584 & 0.006 \\
\hline
\end{tabular}




\section{Chapter 27}

\section{State Aid for Maritime Transport}

\subsection{Introduction}

Operating aid is not normally allowed in the European Union. However, operating aid in the form of reduced tax, i.e. fiscal aid, is currently available, among others, to maritime transport.

There are two primary reasons why operating aid may exceptionally be granted to shipping companies. First, this kind of aid seeks to counterbalance similar advantages enjoyed by non-EU companies. Second, it aims to encourage re-flagging of EU-owned vessels that have been registered under non-EU flags.

The motive for supporting so generously maritime transport through operating aid is that shipping and the related skills and knowledge base are thought to be essential for the European economy.

The purpose of this chapter is to examine the conditions under which fiscal state aid may be granted to shipping companies.

The chapter starts by considering how fiscal or tax measures may constitute state aid. Then it explains the problems created by operating aid and fiscal aid in particular in the context of the system for the control of state aid that has been developed by the EU. It goes on to review the Commission Guidelines on aid to maritime transport and analyse a number of recent Commission decisions to launch formal investigations in the tax schemes of several member states. It concludes with an assessment of the contentious issues of the Guidelines. An Annex provides to the interested reader 


\section{Chapter 27}

summary information on three typical schemes on the fiscal treatment of seafarers.

The main conclusion of this chapter is that the most difficult aspect of the application of the current state aid rules to maritime transport is the question of what income from ship operations is eligible to receive favourable tax treatment.

The answer depends in turn on what is regarded as legitimate shipowning and ship management in the sense of assuming sufficient responsibility for the operations of a vessel. The line between legitimate and non-legitimate shipownership and ship management is to a large extent arbitrary, especially in view of today's business practices in maritime transport, where the operations of vessels are segmented and assumed by different companies, often located in different countries.

In view of the fact that it is not really possible to identify which operations of a vessel are more valuable in terms of their contribution to the European economy and to maintenance of a strong maritime knowledge base and skills in Europe, a more efficient and less complex approach would be to allow the same tax treatment of all income derived from genuine maritime activities.

The problems encountered in ensuring compliance with the maritime guidelines also reveal another more fundamental problem in the field of state aid and, more broadly, in any government attempt to offer incentives in the form of subsidies to market operators. Market operators will adjust their behaviour to maximise their gains from the available subsidies. Just because they will do that, however, it does not necessarily follow that society also gains. This was demonstrated in the previous chapter that analysed the effects of regional aid. As argued in the chapters dealing with the theory of subsidies, the best approach is to have simple schemes and simple policies that are not easily exploited.

\subsection{When do fiscal measures constitute state aid?}

The concept of state aid is wider than that of a subsidy [C-30/59, Steenkolenmijnen Limburg v High Authority]. It includes any measure that mitigates the charges which are normally borne in the budgets of firms. A 
tax is such a charge [C-387/92, Banco Exterior de Espana; C-75/97, Belgium v Commission; C-66/02, Italy v Commission].

Therefore, Art 87(1) applies to state aid in tax measures because their fiscal (or social) nature is not sufficient to exclude them from the scope of that Article. This is because whether a measure is aid is determined on the basis of its effects and not its nature or the policy intentions of the public authority that has adopted that measure [C-173/73, Italy v Commission].

Since a tax - which is a charge - is a burden on the budgets of firms it cannot be state aid in the meaning of Art 87(1) [Banks, C-390/98]. However, Art 87 does apply to those aspects of tax systems such as tax exemptions or reductions and other forms of favourable treatment that reduce partially or fully the burden of the full tax or normal treatment.

A tax exemption or reduction places beneficiaries in a more advantageous position than their competitors [C-6/97, Italy v Commission]. Therefore, the following would normally be found to constitute state aid:

- reduction of the tax base

- reduction of the rate of tax

- deferment, cancellation or rescheduling of tax debt. Delay in collecting taxes may also be aid unless justified by the privatecreditor principle [DMT, C-256/97]

- reduction of employers or employees social insurance contribution

- advantages to shareholders [C-222/04, Fondazione Cassa di Risparmio San Miniato].

Taxes themselves are caught by Art 87(1) only when there is a direct link between the tax revenue and aid measures financed by that revenue [C174/02, Streekgewest Westelijk Noord Brabant]. This is the case with parafiscal charges which are levied on particular products. The revenue that is collected is then used for the promotion of those products.

Also it is worth noting that in a number of cases, parafiscal charges have been found to be incompatible with the common market because the charges themselves were infringing other provisions of the Treaty such as the prohibition of discrimination on the basis of national origin [Commission Decision 2000/206 on aid to the Greek Cotton Board; Commission Decision 


\section{Chapter 27}

2000/116 on Dutch ornamental plants]. In those cases both the aid and the charges were prohibited.

\subsection{The problem with fiscal aid}

A measure that is found to be state aid may be exempted from the prohibition of Art 87(1) only if it promotes the objectives defined in the various categories of exemption, and in particular the conditions laid down in Art 87(3).

Community courts have ruled in numerous cases that aid must be necessary, proportional and in the Community's interest. The sole authority that has power to determine the compatibility of aid is the European Commission. Here "by virtue of Article 87(3) EC, the Commission has a wide discretion the exercise of which involves complex economic and social assessments which must be made in a Community context." [T-348/04, SIDE v Commission, paragraph 96]. Moreover, "it is not for the Community court to substitute its economic assessment for that made by the institution which adopted the decision" (C-169/95, Spain v Commission, paragraph 34].

Unless fiscal aid is capped and the granting authority ensures that it remains below the allowable ceilings, the aid becomes operating aid. This creates two major problems. First, it is impossible to determine ex ante the amount of aid. When a firm makes large profits the tax exemption/reduction results in a large amount of aid. Conversely, when the firm makes no profit the amount of aid is zero. Since the amount of aid is directly determined by the future profitability of the firm, it is impossible to determine its gross grant equivalent at the moment it is granted. This means that the Commission cannot assess its effects and proportionality.

Second, operating aid is normally granted without any obligation on the part of the beneficiary to do something that it would not otherwise do and which would be in the general interest.

The CFI has recently reiterated that "operating aid, that is to say, aid intended to relieve an undertaking of the expenses which it would itself normally have had to bear in its day-to-day management or its usual activities, does not in principle fall within the scope of Article 87(3) EC. The 
effect of such aid is in principle to distort competition in the sectors in which it is granted, whilst nevertheless being incapable, by its very nature, of achieving any of the objectives of the abovementioned derogations" [T-348/04, SIDE v Commission, paragraph 99. See also C-301/87, France v Commission, paragraph 50; C-86/89, Italy v Commission, paragraph 18; C-278/95 P, Siemens v Commission, paragraph 37; and T-459/93, Siemens v Commission, paragraph 48].

Operating aid is not normally allowed because, state aid has to be necessary and have an incentive effect. In the same case mentioned above, the CFI referred to established case law according to which "Member States are not permitted to make payments which may improve the situation of the undertakings receiving the aid but which are not necessary for the attainment of the objectives specified in Article 87(3) EC" [see also C-730/79, Philip Morris v Commission, paragraph 17].

However, operating aid is exceptionally allowed in three cases: Investment aid for regional development in Art 87(3)(a) areas; reduction of environmental taxes; and maritime transport.

In the case of regional development, the Commission Guidelines on Regional State Aid explain that in some instances, operating aid may be necessary to kick-start the process of development. However, member states have to prove that other forms of aid are not effective and that operating aid can have a direct impact on regional growth.

In the case of environmental taxes, the rationale for allowing operating aid is to lessen the damage caused to the international competitiveness of companies which bear those taxes [see the Commission Guidelines on Environmental State Aid. They can be accessed at the website of DG Competition: http://ec.europa.eu/comm/competition]. The relief from taxes is a temporary measure until the polluting companies adjust by adopting more environmentally friendly technologies.

In the case of maritime transport, operating aid has a similar rationale as for reduction of eco-taxes. It seeks to improve the international competitiveness of European shipping and, in addition, to encourage re-flagging of EUowned vessels and raise the employment of European seafarers. 


\section{Chapter 27}

As is expressed in the current Guidelines on State Aid to Maritime Transport ${ }^{322}$, "even though as a matter of principle operating aid should be exceptional, temporary, and degressive, the Commission estimates that State aid to the European shipping industry is still justified" [p. 4].

\subsection{Fiscal aid measures permitted by the Maritime Transport Guidelines}

The Guidelines provide for three categories of aid: fiscal aid to shipping companies and seafarers, investment aid and training aid. This paper focuses only on fiscal measures.

The Guidelines require, as a general condition concerning all aid granted to shipping, that

- it should not be at the expense of other member states,

- it must not distort competition between member states to an extent contrary to the common interest,

- it must always be restricted to what is necessary to achieve its purpose, and that

- it must be transparent.

However, when later on the Guidelines raise the question of fiscal competition between member states, they observe that "there is no evidence of schemes distorting competition in trade between member states to an extent contrary to the common interest. In fact, there appears to be an increasing degree of convergence in Member States' approaches to shipping aid." This suggests two things.

First, the Commission tends to authorise fiscal aid without requiring member states to prove that indeed aid does not cause undue distortion of competition. Second, it authorises schemes which are similar to or duplicate earlier schemes. As shown by its decision to open a formal investigation $(\mathrm{C} 2 / 08)$ in an Irish scheme which is mentioned in more detail later on, it believes that fiscal competition is avoided by ensuring uniformity among the various tonnage tax regimes.

${ }^{322}$ OJ C 13, 17/1/2004, p.3. 
The following types of fiscal aid are mentioned in the Guidelines, without, however, other types of measures being excluded:

- Reduced or zero rate of corporate taxation.

- Accelerated depreciation on investment in ships.

- Non taxation of profits made on the sale of ships for a number of years.

- Tonnage tax.

The inclusion of tonnage tax in the list above may, at first glance, be surprising because, as explained in the previous section, a tax does not normally confer an advantage and therefore it is not considered to be state aid. However, special types of taxes which are applied only in particular sectors, such as tonnage tax in shipping, may also be state aid because a fixed amount of tax is paid irrespective of whether the company concerned makes high or low profits or even suffers losses. Since tonnage tax may result in lower taxes paid in years of high profits, in relation to the standard method of taxation according to the amount of profits, it must be regarded as a measure that is in principle capable of providing state aid. ${ }^{323}$

This assessment of tonnage tax is not unusual. It is in line with the position of the Commission concerning special forms of taxation. If they result in less tax being paid in relation to the normal tax on corporate profits, then they are presumed to confer state aid. See, for example, Commission Decision

${ }^{323}$ The Commission's practice is elaborated in the following cases:

Dutch tonnage tax scheme (case N 738/1995, approved on 20 March 1996 );

German tonnage tax scheme (case N 396/1998, approved on 25 November 1998);

UK tonnage tax scheme (case N 790/1999, approved on 2 August 2000);

Spanish tonnage tax scheme (case N 736/2001, approved on 27 February 2002);

Danish tonnage tax scheme (case N 563/2001, approved on 12 March 2002);

Finnish tonnage tax scheme (case N 195/2002, approved on 16 October 2002

Irish tonnage tax scheme (case N 504/2002, approved on 11 December 2002);

Belgian tonnage tax scheme (case N 433/2002, approved on 19 March 2003);

French tonnage tax scheme (case N 737/2002, approved on 13 May 2003);

Basque country tonnage tax scheme (case N 572/2002, approved on 5 February 2003);

Italian tonnage tax scheme (case N 114/2004, approved on 20 October 2004);

Lithuanian tonnage tax scheme (case N 330/2005, approved on 19 July 2006);

Polish tonnage tax scheme (case N 93/2006, approved on 10 July 2007). 


\section{Chapter 27}

2003/755 on coordination centres of foreign companies in Belgium, Commission Decision 2003/512 on control centres of foreign companies in Germany and Commission Decision 2004/76 on logistics centres of foreign companies in France. In all three cases, taxes were not derived according to realised revenue or profits but according to the number of staff, operating costs or imputed profits calculated on the basis of a predetermined formula.

\subsubsection{Conditions}

The Guidelines impose the following conditions:

1. State aid may be granted only to maritime transport, including towing at sea when more than $50 \%$ of towage per year takes place at sea and dredging when transport of extracted materials to deep sea exceeds $50 \%$ of annual operating time.

2. Account separation is required for non-qualifying activities.

3. Tax relief is primarily for shipowners and mainly for their earnings from the operations of EU-flagged vessels.

However, it may also apply exceptionally to the entire fleet of an EU-based shipowner, provided

- that the fleet is managed in the EU and all vessels satisfy relevant standards on safe operations and employment conditions,

- that EU-flagged vessels are increased or maintained, and

- that it contributes to economic activity and employment in the EU.

The evidence which is normally required to prove the contribution to EU economic activity and employment includes

- data on vessels under EU flags,

- number of EU nationals employed on vessels and onshore activities, and

- amount of investment in fixed assets.

Tax relief may also be granted to ship management companies providing both technical and crewing management and which have assumed from shipowners full responsibility for the operations of vessels. Similarly to the 
case of shipowners with vessels under non-EU flags, ship managers should have the majority of the vessels they manage under EU flags.

4. With respect to EU seafarers or any other seafarers who pay taxes and social insurance contributions in the EU, fiscal aid is also allowed for the purpose of reducing

- social insurance contributions of shipowners and seafarers, and

- rates of income tax for seafarers on board EU-flagged vessels.

\subsubsection{Shipownership v ship management}

The Guidelines and the practice of the Commission reveal that it considers maritime transport to be divided into three main functions:

- the commercial management of vessels;

- the technical management of vessels (fuelling, catering, insurance, certificates of the vessels, maintenance, etc); and

- the management of crews (employment contracts, renewal of crews, etc).

With respect to ship management, the Guidelines stipulate that "ship management companies may qualify for aid only in respect of vessels for which they have been assigned the entire crew and technical management". What this means in practice is that if a ship management company does not ensure the commercial management of vessels it must simultaneously ensure at least the two other functions.

When a vessel is chartered without crew (bare-boat charter), this is generally considered as being close to operating an owned vessel. Although the charterer does not have legal title to the vessel he assumes most if not all responsibility for the management of the vessel and/or crew.

A vessel may also be chartered with a crew (time charter). In such situations the charterer is typically not responsible for all aspects of the management. Such vessels may fall within the tonnage tax system but subject to certain restrictions. The issue of management becomes important to determine eligibility for tonnage tax treatment. In these cases, the Commission considers that, to remain eligible for tonnage tax, an undertaking need not 


\section{Chapter 27}

itself carry all three functions but it must carry out at least technical and crewing management.

Therefore, revenue derived from the management of vessels is eligible for tonnage tax where the ship management company ensures:

- either both the crew and technical management of the said vessels

- or, their commercial management.

However, these two options are open to ship managers only on condition that the tonnage of such vessels does not exceed four times the tonnage of vessels for which companies offer together the crew, technical and commercial management. This rule of practice was elaborated by the Commission in relation to chartered vessels in decision N 563/2001 on the Danish tonnage tax approved on 12 March 2002.

\subsection{Problematic issues in the Guidelines}

Most member states have adopted measures that provide fiscal incentives to their shipping industry in line with the Guidelines. However, a number of recent cases have highlighted particular problems with the interpretation and scope of application of some of the requirements of the Guidelines.

27.5.1 Ring-fencing [preventing non-maritime activities from deriving benefits from fiscal aid granted to maritime activities]: Case C 5/2007 (ex N 469/2005) [Denmark] Alleviation of information obligations imposed on maritime companies

Danish law exempts Danish maritime companies taxed under the Danish tonnage tax from the obligation to provide to the fiscal authorities all necessary information on their financial transactions with foreign companies belonging to the same group.

The Danish authorities are of the view that, where one of these companies is a Danish maritime transport company taxed under the Danish tonnage tax and where another company is a foreign based affiliate, the Danish company has no interest in exporting its benefits to its foreign affiliates by manipulating transfer prices. Therefore, where one of the affiliated 
companies is taxed under the Danish tonnage tax scheme and the other one is taxed in another country, the verification by the Danish fiscal authorities of possible abuses through transfer prices does not serve, according to the Danish authorities, the interest of the Danish treasury. This verification would not lead to the recovery of any additional revenues for the Danish treasury. This is why Denmark proposed to relieve companies under the Danish tonnage tax from administrative burdens that they see as unnecessary from their own perspective. The checks are considered by the Danish authorities to be only in the interest of other member states and of third countries.

The Commission has opened a formal investigation because the Guidelines require ring-fencing measures intended to ensure that no activities other than maritime transport, in the member state in question, or in any other member state or third country, would indirectly benefit from the regime.

All the tonnage tax regimes approved by the Commission in the past five years provide for ring-fencing measures including verification of transactions between tonnage tax entities and non-tonnage tax ones.

To that end, the Commission usually requests from member states a series of ring fencing measure such as:

- the verification of commercial transactions across the ring fence, based on the arm length's principle;

- rules on the fair sharing of the cost of capital expenditure between eligible and non eligible activities;

- rules on the fair allocation of revenues between eligible and non eligible activities;

- the all-or-nothing option for maritime groups ('all eligible entities of the group shall opt for the tonnage tax where at least one of them does').

27.5.2 Non-eligible maritime activities: Cases C 58/2007 (ex N 240/2007) [Denmark] Amendments to tonnage tax; C 2/08 (ex N 572/07) [Ireland] Modification of tonnage tax

Denmark has proposed to amend its already approved tonnage tax regime so that: 
1. profits on the sale of tonnage-taxed vessels be taxed under the tonnage tax scheme;

2. the gross tonnage from chartered vessels eligible for tonnage tax can be up to ten times greater than the gross tonnage owned by the shipping company itself;

3. income from the management of pools of vessels be taxed under the tonnage tax scheme;

4. non-tonnage-tax companies be allowed to retroactively enter tonnage tax as from 2001.

The Commission has accepted the first proposal but expressed reservations on the remaining three proposals and therefore has opened a formal investigation.

With respect to eligibility of profits on the sale of tonnage-taxed vessels the Commission first notes that in its Decision of 19 March 2003 on the Belgian tonnage tax scheme, the Commission accepted that the gains derived from the disposal of tonnage tax assets could fall under tonnage tax. A similar rule exists in the UK tonnage tax regime. [Such a rule was however not referred to in the Commission decision of 2 August 2000 approving the scheme.] According to the Commission the sale of vessels is a normal activity of shipping. It therefore accepts that the profits derived from the sale of eligible vessels fall within the scope of tonnage tax.

With respect to the minimal proportion of the owned tonnage to the chartered-in tonnage, the Commission has doubts because in its former decisions it established a rule whereby the part of the fleet not owned by eligible operators, exceeding a certain threshold, must be excluded from tonnage tax. Up to now, tonnage tax schemes have provided for that no less than $20 \%$ of the tonnage of the fleet under tonnage tax should be owned by the beneficiaries. Otherwise any additional capacities exceeding the threshold of 1:4 (one ton owned for four tons chartered in on a time or voyage basis) should be then taxed under the normal corporation tax. Denmark has proposed to raise the ratio to 1:10.

With respect to the inclusion into tonnage tax of management fees derived from the management of vessels of third parties, the Commission first notes that its decisions approving tonnage tax schemes did not mention the inclusion of pool fees as eligible revenues for tonnage tax. However, it is 
willing, for consistency reasons, to apply to revenues derived from the management of pools the same rule applicable to revenues derived from activities performed with time-chartered vessels. This rule, if applied to fees derived from the management of shipping pools, implies to limit the tonnage tax treatment to capacities not exceeding four times the tonnage of vessels directly owned (chartered without crew on a long term).

With respect to the retroactive application for tonnage tax, the Commission notes that one of the important features of tonnage tax schemes is that maritime transport companies have to choose between the normal corporation tax and a lump-sum taxation and that they must be committed to this choice for a period of at least 10 years, as is the case in all Commission decisions. The Commission further notes that none of the approved tonnage tax schemes provided for retroactive entry into tonnage tax and expresses doubts whether the retroactivity of the entry into tonnage tax, and consequently, the ex post recalculation of the tax amount to be borne by the companies concerned are compatible with the common market.

In a similar case involving Ireland [C 2/08], the Commission opened the formal investigation because Ireland proposed to delete from its tonnage tax legislation the requirement that not more than $75 \%$ of the eligible ships could be chartered in. Under Irish legislation, "chartered in" vessels are provided with a crew by the charterer. This is in contrast to bare boat chartering whereby the lessee has to man the crew.

In its decision to open the investigation, the Commission repeated that "even though the guidelines do not mention any limits for the inclusion of time chartered ships under tonnage tax schemes, in its decision making practice the Commission has authorised schemes where companies with a ratio of 1:3 or 1:4 owned to time chartered ships were eligible to tonnage tax. The exception of the 1:4 ratio as compared to the initial 1:3 ratio in Decision No 563/2001/EC concerning the initial approval of the Danish tonnage tax was justified on the basis of an in depth market analysis".

According to the market analysis referred to in the earlier decision, Denmark had chosen a respective proportion of 1:4 on the basis that its maritime industry had a long lasting tradition to operate in a more intensive way by means of chartered ships as compared to those member states which had 


\section{Chapter 27}

notified a lower proportion. For this reason the Commission concluded that there would be no fiscal competition with other members states.

On the basis of this reasoning, the Commission decided to open a formal investigation into the Irish scheme because "Ireland did not provide arguments ... that the full abolition of such time charter limits may trigger fiscal competition between more or less attractive tonnage tax schemes across the EU. In the light of the guidelines' acknowledgement that such fiscal competition needs to be taken into account, the amendments proposed by the Irish authorities under the present notification to fully remove the time charter limit may be contrary to the "common interest" expressed in Article $87(3)(c)$ of the Treaty on which the approval of tonnage taxes is based."

27.5.3 The link between maritime transport and other maritime activities: Case C 22/2007 (ex N 43/2007) [Denmark] Extension to dredging and laying cable activities of the exemption of maritime transport companies from the payment of income tax and social contributions of seafarers and case N 93/2006 [Poland] Tonnage tax in favour of international maritime transport

The Commission has initiated the formal investigation procedure with respect to the Danish scheme because it has doubts about the compatibility with the common market of the extension of the fiscal exemption to cable laying activities and to certain dredging activities, inasmuch they may constitute maritime transport within the sense of the Guidelines.

According to the Commission, the concept of maritime transport should be interpreted as covering only the straightforward carriage of goods or passengers by sea between two ports or between a port and an off-shore installation, and not services incidental or ancillary to such carriage.

This view conforms with the recent ruling of the Court of Justice in case C251/04, Greece v Commission, that transport is the carriage of goods or passengers by sea. Other services such as towing are incidental or ancillary to the provision of maritime transport services. Regulations 4055/86 and $3577 / 92$ refine this definition by adding that the carriage of passengers or goods by sea is "between a port and any other port or off-shore installation." 
Accordingly, the Commission believes that cable-laying activities do not involve the carriage of passengers or goods or even drums of cable from one port to another. For the same reason the Commission has doubts with respect to dredging of navigational channels. Nonetheless, in this case it accepts that transportation of aggregates from a port to a construction site at sea could constitute maritime transport.

This conclusion, however, appears to be at odds with the provisions of the Guidelines in section 3.1. The Guidelines state that "fiscal arrangements for companies (such as tonnage tax) may be applied to those dredgers whose activity consists in 'maritime transport' - that is, the transport at deep sea of extracted materials - for more than $50 \%$ of their annual operational time and only in respect of such transport activities." This provision suggests that dumping aggregates at deep sea can qualify as maritime transport without being necessary to carry them to an off-shore installation or another port.

In its decision to launch an investigation into the Polish scheme, the Commission has further elaborated that for both towage and dredging the relevant criterion to measure whether the $50 \%$ threshold is attained is the operational time of each tug or dredger concerned over a fiscal year, and not the revenue generated. Moreover, this threshold can only be calculated against activities that strictly correspond to the definition of maritime transport within EU law.

However, the Commission has clarified that in line with its past practice [e.g. decision N 563/2001 on the Danish tonnage tax scheme] it has no objection to the coverage by the Polish tonnage tax scheme of the following ancillary activities which are very closely linked with the provision of maritime transport services:

1. lease and use of containers;

2. loading, unloading and repair activities;

3. operation of passenger terminals;

4. sale of goods or services on board passenger ships or passengercarrying cargo ships for on-board consumption;

5. operation of bureaux de change on board passenger ships or passenger carrying cargo ships, provided that this activity is related to the principal activity;

6. transfer of goods or passengers over land or by sea;

7. multimodal transport of cargo or passengers. 
Such activities are covered by tonnage tax, if they are provided by the tonnage tax companies themselves.

27.5.4 Taxation of companies $\mathbf{v}$ taxation of persons: Case N 93/2006 [Poland] Tonnage tax in favour of international maritime transport

The Commission has expressed doubts as to the compatibility of the Polish tonnage tax scheme because one of its features is "peculiar" in that, unlike other approved tonnage tax schemes, it also covers natural persons liable for personal income tax. The Commission has stated that it has no experience of tonnage tax schemes covering natural or legal persons liable for personal income tax. The wording of the Guidelines indeed explicitly links tonnage tax to corporate tax.

27.5.5 Location of companies: Case N 93/2006 [Poland] Tonnage tax in favour of international maritime transport

The Commission considers that some provisions of the Polish tax regime would infringe the right of establishment. In determining whether the strategic management of eligible companies is based in Poland, the Polish authorities will be guided by the physical location of certain key personnel. Apparently what will be important is the location of headquarters, senior managers and the location of the board of directors and operational board which should be in Poland. In the case of commercial management, the fiscal authorities will verify that route planning, taking of bookings for passengers or cargo, provisioning and catering ships, personnel management and training, technical management of ships, including the decisions on the repair and maintenance of vessel take place in Poland. A number of other factors such as the maintenance of support facilities such as training centres, terminals, etc. in Poland and the extent to which foreign offices or branches work under the direction of personnel as well as the fact that a ship is flagged, classed, insured or financed in Poland may add further weight to the indicators set out above.

In the Commission's view, these strict conditions limit the possibility of shipping companies from another member state from having a secondary establishment in Poland and availing themselves of the benefits of the measure. Therefore, the measure in question may discourage secondary 
establishment and would to give rise to problems of de facto discrimination and to limit the freedom of establishment.

27.5.6 Deduction of social security contributions from tonnage tax liability: Case N 93/2006 [Poland] Tonnage tax in favour of international maritime transport

The Commission has also serious doubts about the compatibility of the deductibility of social security contributions and health insurance contributions from respectively the amount and the base of tonnage tax.

As tonnage tax systems are based on notional earnings arrived at on the basis of the tonnage of the vessels rather than real earnings, the shipowners who are liable to tonnage tax are not allowed to avail themselves of those deductions, (including depreciation and other tax advantages) which form part of the general tax system.

The Polish authorities argue that because any natural or legal person liable for personal income tax is entitled to such deductions within the Polish general income tax system, those who are subject to tonnage tax should be entitled to these deductions too. However, the Commission has doubts regarding this argumentation. Tonnage tax regimes are designed to replace rather than complement the normal system for taxation of shipowners. For this reason, shipowners subject to corporation tax opting for tonnage tax are no longer entitled to avail themselves of deductions which would otherwise be available to any other normally taxed company. According to the Commission, this logic should also apply if the shipowner is an individual subject to personal income tax.

27.5.7 All-or-nothing option for tonnage tax for ten years: Case $\mathrm{N}$ 93/2006 [Poland] Tonnage tax in favour of international maritime transport

The Commission notes that the tonnage tax period, that is the period during which companies which opt for tonnage tax are obliged to stay under that scheme, is limited to five years in Poland. The minimal duration of this period in the other tonnage tax schemes approved so far was ten years. The policy of the Commission is to require a high level of convergence between approved tonnage tax regimes so as to avoid inequalities of treatment as 


\section{Chapter 27}

between vessels and shipowners operating under different member state registers.

\subsection{Assessment and conclusions}

The Guidelines on State Aid to Maritime Transport aim to reduce the competitive disadvantage of EU-flagged vessels by allowing them to have access to similar tax treatment as that enjoyed by vessels registered under non-EU flags.

The intention of the Guidelines is to help shipowners [and seafarers]. But after pressure from a number of member states, the Commission has conceded to extend the coverage of fiscal aid to ship management. The boundaries between shipowning and ship management are increasingly blurred and today's ship managers exhibit many of the characteristics of shipowners.

However, the cases reviewed in the previous section reveal that it is not easy to draw a line between ship managers that act as shiponwers and the rest. Perhaps such a line is not possible at all. The Commission's distinctions are to a large degree arbitrary.

The Commission, however, does have the legal power to lay down whatever rules it deems necessary in its guidelines. This has been recently confirmed by the Court of Justice in Belgium v Commission [C-110/03]. The member states, therefore, have little chance to challenge their legality. Their only hope is to persuade the Commission by adducing evidence that currently non-eligible activities are also important to the preservation of Europe's maritime base.

A reformed approach would be to extend the same fiscal treatment to all income derived from the operation of a vessel. There are at least two advantages to such a simplified approach.

First, there is no evidence to suggest that full shipowning in the traditional sense makes a more significant contribution to the economy and employment in the EU than the activities of many ship managers each one of whom undertakes only part of the full range of the operations of a vessel. 
Second, a ship manager who carries out only part of the full range of the operations of a vessel, presumably derives only a partial share of the total revenue from that vessel. This means that the benefit from fiscal aid will be proportionally less and the resultant distortion smaller. More importantly, there will be less need for arbitrary limits to eligible shipowning and ship managing activities.

Lastly, consideration should also be given to the link between eligible fiscal benefits and EU flags. The reason why the two are currently linked is because one of the aims of the Guidelines is to encourage re-flagging of ships under EU flags. This, however, handicaps the development of shipowning and ship management activities based in Europe for the simple reason that it forces shipowners and ship managers to choose between favourable tax treatment in Europe and possible larger profits and other benefits from managing non-EU vessels. Although the primary objective of the Guidelines is to stimulate the re-flagging of ships, another equally important objective is to safeguard and encourage the growth of maritime knowledge and skills in Europe. To the extent that European companies would find it advantageous to own and/or manage non-EU vessels, the current Guidelines with their link to EU flags may actually undermine their second objective.

\section{Annex: Examples of aid for the employment of seafarers}

\section{N 749/2006 [Sweden]: Employment aid for shipping}

The aim of the notified scheme is to maintain and increase employment and training of seafarers who are tax liable in Sweden and working on board vessels registered in Sweden used for international transport and goods. The aid scheme seeks to maintain the number of vessels within the Swedish maritime register by reducing the operating costs.

It complies with the provisions of the Guidelines because section 3.2 allows systems by which shipowners are reimbursed (partially or wholly) for the employment costs instead of applying reduced rates, provided that there is a clear link to these levies, no element of overcompensation and that the system is transparent and not open to abuse. 
In case of seafarers working on board vessels (including ro-ro ferries) providing scheduled passenger services between ports of the Community, that shipping aid shall be granted only to EC/EEA citizens. This is provided for in the guidelines.

\section{N 65/2007 [Estonia]: Social aid for seafarers}

The aim of the measure is to provide social aid for EC seafarers working on board freight carrying cargo vessels used in international trade, entered in the Estonian shipping register and flying the Estonian flag.

The measure allows for reimbursement of up to $100 \%$ of social taxes paid on wages of EC seafarers working on the vessels. The grants are subject to the yearly and overall budgetary limits.

It complies with the provisions of the guidelines because the concept of Community seafarer is defined according to point 3.2. Hence, since beneficiary activities consist exclusively of freight carriage and do not consist of passenger transport, EC seafarers under the present scheme are thus constituted of all seafarers liable to taxation and/or social security contributions in a Member State, as provided by the guidelines.

Since the measure provides for a reimbursement of maximum $100 \%$ of seafarer's income tax as allowed under point 3.2 of the guidelines, and since any cumulative measure would need to meet that exact same ceiling, the aid is considered to be in line with points 3.2 and 11 of the guidelines.

Finally, since reimbursement is subject to the verification of tax paid, monthly crew lists on board, certification of registry of the vessel under the Estonian shipping register and proof of absence of bankruptcy, the measure provides a clear link to the levies, ensures the absence of any overcompensation and prevents the possibility of abuse.

\section{N 311/2005 [Ireland]: Refund of employers' social security contributions}

The aim of the measure is to refund pay-related social insurance (PRSI). The PRSI scheme pays back social security contributions to employers in respect of the employment of seafarers on certain ships. 
It complies with the guidelines because the refund mechanism will only apply to those companies which fall within the Irish PRSI net and who employ qualifying seafarers working on qualifying ships carrying on qualified activities. The employers will only be refunded in respect of those contributions for those seafarers certified as qualified by the Mercantile Marine Office and they will only be refunded contributions already collected and paid over to the State. There is therefore a clear link between the levy and the aid. The refund is provided for by the law although the shipoperating company has to apply for the refund, the system is therefore transparent. The refund is designed to reduce the employers' social contribution to zero by refunding contributions already paid and no more, therefore no over-compensation is possible. 


\title{
Part VII: The System of State Aid Control
}

\section{Chapter 28}

\section{Decentralised State Aid Control in an Enlarged European Union:}

\author{
Feasible, Necessary or Both?
}

\subsection{Introduction}

During the past few years the European Union has undertaken a reform of its competition rules. The reform is not yet completed. Part of it will involve "decentralisation" of enforcement of Article 81 of the Treaty, that prohibits collusive practices and also provides for exemption of agreements between enterprises whenever such agreements generate sufficient positive effects for the economy. ${ }^{324}$ This decentralisation is monumental in the context of the competition policy of the EU because national authorities will acquire for the first time the right to consider the exception of Article 81 together with the prohibition embodied in that Article.

In the field of state aid, new Community rules have been adopted and existing ones have been improved and simplified. Yet, there is no similar decentralisation either attempted or envisaged. The Commission appears to believe that it is not wise to allow authorities in member states to control aid granted by other authorities within the same member states. In fact member states are not required to subject the state aid they propose to grant to any internal control before they submit their plans to the Commission. Since, however, notified aid that does not comply with Community rules is not authorised by the Commission, it is in the interests of each member state to design schemes that can be approved by the Commission. Otherwise they would be wasting valuable administrative resources, let alone raising in vain the expectations of businesses. Given also the fact that member states are

\footnotetext{
${ }^{324}$ See the new Regulation $1 / 2003$ that will replace Regulation 17/1962 as of 1 May 2004.
} 
Decentralised State Aid Control in an Enlarged European Union:Feasible, Necessary or Both?

liable for all state aid granted by any of their public authorities, to achieve a high degree of acceptance by the Commission of notified aid and avoid unnecessary legal proceedings initiated by the Commission, most member states have some form of internal coordination and review procedure.

I have argued in a recent paper that despite the toughness by which the Commission enforces Community rules on state aid, the Community system does not have strong enough incentives and sanctions to induce member states to comply fully. ${ }^{325}$ The remedy which was proposed in that paper was a mixture of stricter sanctions and, at the same time, lower penalties in cases of small amounts of illegal state aid and less serious infringements of Community rules. In this chapter I intend to explore the potential role of national State Aid monitoring Authorities (SAA) in enforcing Community rules in partnership with the Commission. Such authorities already exist in the countries that have applied for membership of the EU and are scheduled to join in May 2004.

The question that arises, therefore, is whether there is any fundamental reason why control of state aid cannot be carried out by national authorities. The Commission would respond that the member states cannot be trusted to police themselves and that, if anything, experience over the past forty years has demonstrated the indispensability of control of state aid by the Community and in particular the Commission.

There are, however, three counter-arguments. First, this was the attitude of the Commission before it eventually recognised that perhaps national competition authorities could be trusted to enforce anti-trust rules as effectively as it does itself. Second, the new competition Regulation 1/2003 and the Framework Directive 2002/21 in telecommunications provide for decentralised application of Community rules by national authorities which, however, are subject to close scrutiny by the Commission to prevent any defective implementation or misinterpretation. Third, and most remarkably, the apparent success of control of state aid in the candidate countries offers the strongest evidence yet that a decentralised system of state aid control can function effectively.

${ }^{325}$ See Nicolaides (2002). 


\section{Chapter 28}

Those countries that will soon become the new members of the EU have been required to establish state aid monitoring authorities and to endow them with powers similar to those held by the Commission. The Commission which has been monitoring the performance of the SAAs has, by and large, been satisfied and the EU has, as a result, closed the chapter on competition policy in the accession negotiations. There is, admittedly, hardly any doubt that the SAAs would not have been able to reign in state aid without the implicit threat of non-admittance into the EU and the constant supervision and checking by the Commission.

Although after their entry into the EU in May 2004 the threat of nonadmittance will disappear, the Commission would have been able to maintain the same intensity of scrutiny. In principle, therefore, there appears to be no insurmountable problem to some form of decentralisation of state aid control. But what kind of decentralisation?

The purpose of this chapter is to examine the feasibility and nature of decentralised enforcement of state rules by the national authorities of member states. The chapter is divided into two sections. The first section below examines the general case for international cooperation to set common rules and explores generic problems. For this purpose it builds a simple model to identify the reasons for international cooperation, the problems of securing compliance with common rules and possible solutions to cheating or deviation from the pre-agreed rules. The second section applies the conclusions drawn from the model to the particular case of state aid control. The chapter concludes with identification of possible policy options in an enlarged European Union.

\subsection{A model of international cooperation and prevention of non- compliance}

The reasons for multilateral control of state aid are extensively analysed in the literature. See, for example, Bilal \& Nicolaides (1999), Collie (2000), Collie (2003), European Commission (1991), Ioannis \& Reiner (2001), Lehner et al. (1991). The purpose of this section is not to rehearse the reasons for international cooperation but, rather, to establish the nature of the problem with this kind of cooperation, show the inherent difficulty in securing agreement and explain why such an agreement must necessarily 
Decentralised State Aid Control in an Enlarged European Union:Feasible, Necessary or Both?

contain a degree of generality, even vagueness. It also argues that this unavoidable generality necessitates the establishment of a supranational institutional framework with responsibility for elaboration of common general rules.

Assume there are two countries, A and B, that grant state aid. When deciding in isolation, each would grant so much amount of aid as would maximise the national benefits from it. I indicate the net benefits of each country as

(1) Ga for country A, and

$\mathrm{Gb}$ for country B

The problem with deciding on state aid in isolation is that aid is granted without regard for the impact on the other country. So each country maximises $\mathrm{Ga}$ and $\mathrm{Gb}$, respectively, without considering the costs imposed on the other country. These costs are indicated as

(2) $\mathrm{Cb} / \mathrm{a}$ for the costs suffered by country A due to state aid granted by country $\mathrm{B}$, and country A

$\mathrm{Ca} / \mathrm{b}$ for the costs suffered by country $\mathrm{B}$ due to state aid granted by

In an ideal world [I will return to the issue of what could be the ideal world in this context] each country should internalise the external costs of its own policies and should maximise instead

(3) country A: $\max \mathrm{Ga}-\mathrm{Ca} / \mathrm{b}$

country $\mathrm{B}: \max \mathrm{Gb}-\mathrm{Cb} / \mathrm{a}$

It is obvious that if $\mathrm{S}$ is the amount of subsidy or state aid granted by each country and if functions $\mathrm{G}$ and $\mathrm{C}$ have the usual convex shapes with $\mathrm{G}$ increasing at a decreasing rate and $\mathrm{C}$ increasing at an increasing rate, then each country will over-subsidise. This is because

$$
\begin{aligned}
& \mathrm{Ga}(\mathrm{Sa})>\mathrm{Ga}(\mathrm{Sa})-\mathrm{Ca} / \mathrm{b}(\mathrm{Sa}), \text { and } \\
& \mathrm{Gb}(\mathrm{Sb})>\mathrm{Gb}(\mathrm{Sb})-\mathrm{Cb} / \mathrm{a}(\mathrm{Sb})
\end{aligned}
$$

In reality, the situation is a bit more complicated. So far I have assumed that the authorities of each country aim to maximise national welfare. This is not necessarily true. In fact, there is a voluminous literature on this issue, which claims that politicians authorise aid for other purposes as well, such as to raise their chances of re-election. If we denote these political gains as $\mathrm{Pa}$ and 


\section{Chapter 28}

$\mathrm{Pb}$, respectively, then the government of each country maximises $(\mathrm{G}+\mathrm{P})$, instead of $(G-C)$.

To find out whether the degree of over-subsidisation increases under these conditions, consider the following specification of those functions. Assume that each function takes the following form

(5) $\mathrm{G}=\mathrm{cS}-\mathrm{fS}^{2}$; where $\mathrm{c}>1, \mathrm{f}<1$ (implying diminishing returns from state aid)

$$
\begin{aligned}
& \mathrm{P}=\mathrm{kS} \text { (implying political gains increasing at a steady rate) } \\
& \mathrm{C}=\mathrm{tS} \text { (implying external costs increasing at a steady rate) }
\end{aligned}
$$

The optimum amount subsidy when domestic state aid creates external costs for the other country is determined by maximising the sum of function $\mathrm{G}$ and function $\mathrm{C}$ or more precisely $(\mathrm{G}-\mathrm{C})$. We therefore differentiate $(\mathrm{G}-\mathrm{C})$ with respect to $\mathrm{S}$ and set the first derivative equal to zero

$$
\mathrm{dG} / \mathrm{dS}-\mathrm{dC} / \mathrm{dS}=0=\mathrm{c}-2 \mathrm{fS}-\mathrm{t} ; \Rightarrow \mathrm{S}^{*}=(\mathrm{c}-\mathrm{t}) / 2 \mathrm{f}
$$

When no external costs are imposed on the other country or when such external costs are ignored, the optimum subsidy is

$$
\mathrm{dG} / \mathrm{dS}=0=\mathrm{c}-2 \mathrm{fS} ; \Rightarrow \mathrm{S} * *=\mathrm{c} / 2 \mathrm{f}
$$

If the government also pursues its own political gains while ignoring any external costs, then the optimum subsidy in their eyes would be

$$
\mathrm{dG} / \mathrm{dS}+\mathrm{dP} / \mathrm{dS}=0=\mathrm{c}-2 \mathrm{fS}+\mathrm{k} ; \Rightarrow \mathrm{S} * * *=(\mathrm{c}+\mathrm{k}) / 2 \mathrm{f}
$$

We can see that

$$
\mathrm{S} * * *>\mathrm{S} * *>\mathrm{S} *
$$

It follows from the inequalities at (9) that state aid granted is larger when external costs are ignored and grows even larger than that when governments obtain political gains from disbursing state aid. In the absence of any control, governments would tend to over-subsidise. The solution to this problem (apart from assuming that "enlightened" politicians get elected) is for countries to agree to be bound by international rules.

It is worth noting that international rules in this context serve two, not one, important purposes. First, they prevent countries from pursuing policies that impose costs on other countries, which is the typical motive for international cooperation. Second, they prevent national authorities from seeking to derive 
Decentralised State Aid Control in an Enlarged European Union:Feasible, Necessary or Both?

political gains through over-subsidisation. Too much state aid generates costs for the rest of the country itself.

My model does not show how these two countries agree on the common rules regarding state aid control. But it shows something else which is as important. It indicates that unless the two countries have identical economies, it is very unlikely that the same amounts of state aid will be optimum for both countries at the same time.

To achieve an optimum allocation of resources globally, each country will have to reduce its state aid by the following amount

$$
\mathrm{R}(\text { reduction })=\mathrm{S}^{* * *}-\mathrm{S}^{*}=[(\mathrm{c}+\mathrm{k}) / 2 \mathrm{f}]-[(\mathrm{c}-\mathrm{t}) / 2 \mathrm{f}]=(\mathrm{k}+\mathrm{t}) / 2 \mathrm{f}
$$

This amount will be the same for both countries only if parameters $\mathrm{k}$ and $\mathrm{t}$ are the same. In general they will differ. That difference would reflect variations in national economic conditions. So, by whichever negotiating means or techniques, the two countries try to reduce the national amounts of state aid. If they rely on proportionate reductions whereby $\mathrm{Ra}=\mathrm{Rb}$, they soon arrive at a point where further reductions are not possible because they are beneficial to one of them but detrimental to the other.

If nothing else happens, that point would be the end of the negotiations. But it would not necessarily be a globally optimum point. This is because one country could afford to compensate the other if, for example, the costs incurred by country A due to the state aid of country B exceed the costs incurred by country B due to the subsidies of country A.

But countries do not normally compensate each other directly. In reality they solve the problem of compensation through two different approaches. First, they define "package" deals. By negotiating on different issues at the same time, one country makes concessions on one issue and in return the other makes concessions on another issue.

Second, when they negotiate on single issues, the two countries can express the outcome of their negotiations not in terms of precise values but in terms of principles such as "no distortions of competition", "no export subsidies", "no operating subsidies", "no subsidies above certain amounts", etc. Such principles allow for a range of possible outcomes in practice. We conclude 


\section{Chapter 28}

that globally optimum rules require general rules or simply, "optimality requires generality".

But, there is another way to understand this kind of outcome. I just argued above that trying to defining too precise common rules would result in a suboptimal outcome. Cooperation depends on a certain degree of ambiguity. The opposite, however, may also be true. In negotiating situations it is not always possible to define outcomes that are precise enough. Some ambiguity is unavoidable not because the too much clarity is unacceptable to one or both parties but because it is not feasible for them to achieve sufficient clarity. The parties involved, then, phrase their agreement in terms of procedural principles.

Therefore, international agreements take the form of binding declarations on common principles either because disagreement between the parties prevents them from making their agreement more precise or because it is not possible to define it in sufficient detail. In either case, however, the adoption of principles or general rules, which allows negotiations to be concluded, may spell trouble later on. Ironically, the solution that allows a successful end to the negotiations may cause new problems afterwards. This is because the enforcement of general rules requires discretion which may be abused as each country has strong incentives to deviate from the letter of the agreement and attempt to interpret the rules as creatively as possible.

But, rational actors are not wilfully myopic. They try to foresee future problems and take action to avoid them. If the partner countries recognise that they will have problems later on when the time comes to enforce the common rules, they will try to find solutions in advance. Hence, the successful implementation of the deal requires some kind of policing to prevent "creative" interpretation and/or lax enforcement of the common rules. A typical solution is for the partner countries to add detail to the principles of the commonly agreed rules. The more detailed the rules, the more difficult for any partner to escape from the rules afterwards. But this solution creates two additional problems.

First, statutory details impose costs. The more detailed the rules, the less flexible they become. The less flexible the rules, the less able they are to catch future practices designed to escape from the scope of the rules. Eventually there is a trade-off between details and flexibility. That is why 
Decentralised State Aid Control in an Enlarged European Union:Feasible, Necessary or Both?

Bilal and Nicolaides (2002) argue that optimum regulations are a mixture of general principles and detailed rules. This mixture minimises the sum of enforcement costs and efficiency losses. Detailed rules can be enforced at a relatively lower cost because it is easier for the enforcing authorities to prove breach of those rules. However, they may inject inflexibility in economic policies. They are probably narrower in scope and for this reason it may be easier to circumvent them. By contrast, general rules can cover many kinds of actions but it is not so easy for the authorities to prove the link between specific actions and the general principles enshrined in regulations.

Second, it may not be possible to define the rules of the agreement [i.e. the implementing rules] in sufficient detail. What happens in this situation? One outcome is that no agreement can be concluded. But I have already argued that a negotiated agreement may indeed be possible when the partner countries resort to broad principles. Hence, reliance on broad principles must be accompanied by something else if the agreement is not to be proven useless as parties find it easy to deviate from it at the implementation stage. That something else is an institutional framework. Partner countries create institutions to enforce the agreed principles.

In the case of international integration and negotiations between countries, it has been shown that common institutions are established, among other things, to interpret, elaborate and apply the rules that the partner countries are unable to define in sufficient detail (for a theoretical analysis see, for example, Axelrod (1997)). Institutions represent a response to the difficulties of cooperation caused by information imperfections.

In conclusion, international cooperation brings about benefits for partner countries by preventing them from generating negative externalities for each other and by strengthening their commitment to optimum internal policies (i.e. not granting state aid for the purpose of obtaining narrow political gains). Such agreements, however, rely on general rules or principles that have to be interpreted. Consequently, the effective implementation of this kind of agreement requires an authority to interpret and enforce the rules. Since the governments of partner countries would also derive political gains from deviating from the agreed rules, the enforcing authorities must be able to function independently of ministerial control. 


\section{Chapter 28}

In the EU, the received view is that member states cannot be "trusted" to police themselves. Therefore, the Commission enjoys the exclusive right to vet, authorise or prohibit state aid. The following section asks whether this is the only feasible system of state aid control. And, if this control could be decentralised or if tasks could be shared with national authorities, what kind of powers and obligations should those authorities have?

\subsection{Control of state aid in the $\mathbf{E U}$}

Formally, EU member states may not grant any state aid without prior approval of the Commission. This condition, however, is not as absolute. Over the years it has been relaxed in the following ways. First, the state aid which needs to be notified to the Commission is only that which falls within the scope of Article 87(1). That is, among other things, it must distort competition and affect intra-EU trade. Second, aid must have an "appreciable" effect by exceeding an amount of EUR 100,000 over three years for each recipient enterprise. Third, aid that complies with the criteria laid down in three regulations is automatically authorised and does not need to be notified to the Commission. There are now regulations on aid to small and medium-sized enterprises and aid for training, which were issued in January 2001, and a regulation on aid for employment, which was issued in December 2002. These regulations function like the block exemption regulations with regard to Article 81(3).

All other forms of aid granted by any public authority or state-controlled enterprise have to be notified. Member states do not have much freedom for manoeuvre in this respect. The Commission has issued many guidelines, frameworks, notices and communications that explain how it treats various kinds of state aid. ${ }^{326}$ Formally, member states can legally challenge these guidelines, but it appears that no member state has successfully mounted such a challenge before the European Court of Justice. As a result, these guidelines and notices effectively codify to a large extent state aid policy in the EU. Few cases deviate from these guidelines, so the purpose of the

\footnotetext{
${ }^{326}$ A list of these documents and of the new regulations can be found on the Commission website

at "http://europa.eu.int/comm/competition/state_aid/legislation/".
} 
Decentralised State Aid Control in an Enlarged European Union:Feasible, Necessary or Both?

notifications is to enable the Commission to check that indeed member states comply.

Over the past ten years, the Commission has had to deal with about 500 notifications per year. During 2001 and 2002, the number of notifications dropped by about 130-140 cases. This decline is attributed to the fact that the 2001 regulations allow member states not to notify aid that satisfies the conditions laid down in the regulations.

It seems to me that the kind of state aid for which the Commission has to go beyond mere checking of compliance with the guidelines can be classified into three categories:

(a) aid which is in the grey zone of definitions (e.g. whether aid affects intraEU trade as, for example, in the case where Spain offered incentives for the withdrawal of old commercial vehicles and the question was whether nontransport SMEs using vehicles for their own benefit would have an effect on competition with transport enterprises from other member states [Spain $\mathrm{v}$ Commission, C-352/98]);

(b) aid for which no guidelines exist (e.g. aid to providers of services of general economic interest or aid to financial institutions). When proposed aid is not covered by any existing guidelines, normally the Commission also has to determined whether it is the EU's "common interest";

(c) aid for which it is necessary to carry out market analysis (e.g. whether an injection of public capital is undertaken under conditions that would satisfy the private investor principle or whether restructuring aid granted according to the rescue and restructuring guidelines imposes sufficient obligations on the recipient enterprise so as to distort competition to the minimum extent possible).

It is obvious that the Commission plays an important role in state aid control. It would be wrong to claim that, now that there are so many rules and so much experience and case law on state aid, its tasks can be carried out by national authorities. This conclusion would be wrong simply because the Commission's role extends beyond "checking" or "monitoring" compliance with those rules. Even if national authorities could perform the market analysis (to establish, for example, the rate of return that would be acceptable to a private investor under the conditions prevailing in a particular market), the Commission often has to re-interpret or refine the boundaries of trade-affecting aid, determine whether it is in the collective 


\section{Chapter 28}

interest and establish acceptable aid intensities for aid that may be exempted under the conditions laid down in Article 87(3). Only the Commission can carry out these tasks. This is not so much because only the Commission has the requisite knowledge or the impartiality to decide what is in the EU's common interest. I believe that it has more to do with the fact that in the end these decisions have an element of arbitrariness. There is no way of telling before hand where the line should be drawn between exemptable and nonexemptable state aid. Reasonable persons starting with the same assumptions could easily arrive at different conclusions. Hence, if the rules are to be applied uniformly across the EU it is important to have a single authority that defines the boundaries of the rules. The theoretical analysis in the previous section very much supports this conclusion.

But, a situation where the Commission checks everything is the other extreme. The main reason why block exemption regulations have been adopted in the field of state aid is precisely because checking routine cases is a waste of valuable Commission resources. This checking can be decentralised. The experience of the candidate countries is illuminating in this respect.

Control of state aid in the candidate countries has provided a unique experiment in international enforcement cooperation. They have had to create state aid monitoring authorities (SAAs). The powers and degree of independence of the SAAs have varied from country to country. Some of them are in reality departments of the national competition authorities, others are departments of ministries of finance while some others have been established as separate entities. Irrespective of their degree of autonomy, they all have to assess all state aid granted within their country and keep the Commission informed of the cases they handle. The Commission reviews submitted documents, asks for additional information and clarifications and has regular bilateral and multilateral meetings with the SAAs. According to its annual Regular Reports on the candidates countries and the Common Positions it proposed to the member states for the closure of the competition chapter in the accession negotiations, the Commission appears to be satisfied 
Decentralised State Aid Control in an Enlarged European Union:Feasible, Necessary or Both?

both with the performance of the SAAs and the cooperation it has had with them. ${ }^{327}$

The SAAs have done a good job. What lesson, then, should we draw? Just because complete decentralisation of state aid control is unwise, it does not follow that complete centralisation is the only alternative. On the contrary, the existence of a large body of rules and case law and the experience of the candidate countries suggest that a "mixed" system is a feasible alternative. ${ }^{328}$ But what should be the features of such a mixed system?

The European Regulators Group in telecommunications and the European Competition Network already provide valuable guidance. In the telecoms and anti-trust fields, national authorities have responsibility to carry out local market analysis and have a first go at enforcement of Community rules. They are required to keep the Commission and their counterparts in other member states informed of the cases they handle and the decisions they intend to make. When a case raises novel policy issues national authorities are supposed to consult the Commission. As a precaution against inconsistent application of the rules, the Commission has the power to intervene to block a decision with which it disagrees and eventually remove a case from the jurisdiction of a national authority. A similar system can apply to state aid which is, I believe, at the same time more codified and requires less economic analysis than anti-trust.

In fact, the case for partial decentralisation will be strengthened as and if state aid rules undergo the same simplification and modernisation as those which are undertaken in the field of anti-trust, such as, for example, the introduction of market share thresholds in new block exemption regulations on horizontal and vertical agreements. See, for example, Bishop (1997) for a review of how competition analysis can be extended to the field of state aid as well.

${ }^{327}$ The state of play with respect to the application of competition rules in the candidate countries can be found at "http://europa.eu.int/comm/enlargement/negotiations/chapters/chap6/index.htm".

${ }^{328}$ I ignore here any political opposition by existing member states to the establishment of SAAs. 


\section{Chapter 28}

The need to rationalise/optimise state aid has also been understood at the highest political level in the EU. The Lisbon, Stockholm and Barcelona European Councils have asked member states to reduce and re-direct their aid towards horizontal schemes and improve domestic evaluation procedures so as to minimise competition distortions.

At a seminar that was held on 20 November 2002 at the European Institute of Public Administration to assess progress towards meeting the targets set by the European Councils, it transpired that no member state or candidate country has domestic procedures for measuring the competition impact of state aid and for ensuring that only state aid that reduces market distortions is eventually granted. ${ }^{329}$ At the same seminar representatives of member states were in favour of more competition analysis. This kind of competition analysis and/or checking compliance with any rules on that kind of analysis, both of which require appraisal of local conditions, can be more easily carried out by the SAAs that can be reasonably assumed to be more familiar with those conditions than the Commission.

There is also at least one more reason in favour of partial decentralisation. It will create a sense of "ownership" of the rules and will, therefore, provide incentives for stricter compliance. Supranational control of state aid is needed because domestic politicians tend to over-subsidise. In effect, supranational control prevents them from granting politically motivated state aid and makes more credible any promise they make to pursue optimum economic policies. Supranational rules which deprive them of policy autonomy would constitute a pre-commitment to optimum policies. See Neven (1994) for a broader analysis of the political economy of state aid.

Yet, the experience of the EU with state aid control tells a slightly different story. Of the 400-550 or so cases dealt with by the Commission every year, about $15-20 \%$ concern cases which are not notified. This percentage is the annual average over the past decade so it is not a temporary aberration. There are competing explanations why member states fail to notify such a high proportion of cases. A benign explanation is that member states have difficulty in distinguishing between state aid that falls within Article 87(1) and has to be notified and aid that does not. Another explanation offered by

\footnotetext{
${ }^{329}$ A summary of the proceedings of the seminar can be found at the following internet address: "http://eipa-nl.com/public/Topics/StateAid/stateaid.htm".
} 
Decentralised State Aid Control in an Enlarged European Union:Feasible, Necessary or Both?

some national officials is that Community procedures are cumbersome and time-consuming. Occasionally state aid needs to be granted quickly (to prevent, for example, the imminent collapse of a company) leaving no time to member states to obtain the necessary Commission authorisation. A third explanation is that member states provide aid to important national industries regardless of Community rules. It is not possible to discern which of the explanations is correct or more relevant. Perhaps all of them are relevant.

What is important to understand, however, is that when national officials are asked why they consent to the granting of non-notified and, therefore, illegal state aid, they explain, first, the pressure on national authorities to take urgent action and, second, acknowledge that it is not always possible to oppose decisions taken at higher political levels. It is hard for individuals to function contrary to the prevailing "culture" of state aid. ${ }^{330}$ Under these circumstances, deviating from Community rules is not something which is penalised by domestic politics because non-compliance is usually framed as a "battle" between national and Community interests or simply "us against them". The main weakness of the Community's supranational control of state aid is that it has not made it domestically costly for national politicians to grant aid. Even when they are caught red-handed and their country is dragged before the European Court of Justice, they are seen more as "Robin Hoods" rather than as anything else.

The only way to deal with this problem is to create counter-balancing forces within member states. A requirement for national authorities to measure the economic impact of state aid they propose to grant and to demonstrate how it corrects market imperfections would go a long way to redress this situation. It would make it more difficult for politicians to claim that aid is in the national interests and would correspondingly make it easier for national

${ }^{330}$ See the proceedings of the seminar cited above. Further reading on this chapter: A. Paczkowska - Tomaszewska, K. Jaros and K. Winiarski, Monitoring State aid in Poland, , European State Aid law - Quarterly, Volume 5 No. 4 2006, C. Ehlermann and M. Goyette, The interface between EU state aid control and the WTO disciplines on subsidies, European State Aid law-Quarterly, Volume 5 No. 4 2006, B. Slocock, EC and WTO subsidy control systems - some reflections, European State Aid law - Quarterly, Volume 6 No. 2 2007, D. Hildebrand and A. Schweinsberg, Refined economic approach in European State Aid control - will it gain monumentum?, World Competition, Volume 30, No. 3 September 2007. 


\section{Chapter 28}

officials to speak out against aid that demonstrably does not raise overall national welfare. Perhaps ministries of finance would even welcome rules that would facilitate their task of ensuring that public expenditure generates "value for money". Ironically, current Community rules do not require member states to demonstrate the efficiency of their state aid.

SAAs would be in an advantageous position to assist the Commission in determining whether state aid has overall positive effects. Not only would they have a better understanding of national economies, they would also function as one of the counter-balancing forces within members states. They would become the natural advocates of more effective state aid.

To succeed in that role, however, it would be absolutely essential for SAAs to be independent. In addition, they would have to be accountable to assure the Commission and other member states that they carry out their tasks faithfully and without succumbing to domestic political pressure. Indeed, a high degree of accountability would make them less susceptible to political interference. For an analysis of the significance of accountability in effective policy implementation see Nicolaides et al. (2003).

\subsection{Counter-arguments}

No policy is perfect. The kind of decentralisation I have proposed in this chapter is not perfect either. However, for the reasons I explain below, I believe that most counter-arguments are not robust enough. Let's consider the typical counter-arguments and examine whether they stand up to closer scrutiny. They would go as follows:

First, decentralisation of state aid control would absorb too many resources. State aid would have to be controlled by 15 SAAs [or 25 in the near future] instead of just one SAA - the Commission. On the face of it, this seems to be so obviously true. The problem with this counter-argument is that it presupposes that member states do not have any interest in granting state aid that is compatible with EU rules or that is subject to even stricter standards than those of the EU. On the contrary, it is in the interest of any member state to coordinate state aid granted by different national authorities and subject it to the highest possible standards to ensure its effectiveness and the efficient use of public funds. For example, member states should voluntarily 
Decentralised State Aid Control in an Enlarged European Union:Feasible, Necessary or Both?

subject their own state aid to full economic appraisal and competition impact analysis - something which is not required by EU rules. SAAs could perform that role. Already some member states have designated authorities with the task to coordinate and evaluate state aid. For example, the Department of Trade and Industry in the UK and the Competition Authority in Denmark carry out appraisals of proposed state aid schemes. What appears at first glance to be a wasteful duplication of resources is in fact a judicious use of national resources to improve the efficiency of state aid schemes.

A second counter-argument would be that the experience of candidate countries does not prove the case for decentralisation because they had to deal with relatively easy cases, not complex issues such as rescue and restructuring or injections of public capital in enterprises with financial difficulties. Again, although this is true is not very relevant. That is why the previous section advocated that SAAs are given responsibility to examine more routine cases concerning the application of guidelines and block exemption regulations. The SAAs and the Commission would share enforcement tasks, with the SAAs checking compliance with the regulations and guidelines and the Commission dealing with cases for which no guidelines exist.

A third counter-argument would be that the forthcoming decentralisation of anti-trust enforcement cannot serve as an example for decentralisation of state aid control. In anti-trust, national competition authorities will not grant exemptions. They will only refrain from applying the prohibitive part of Article 81 whenever the conditions of Article 81(3) hold. By contrast, this counter-argument goes, SAAs would effectively grant exemptions. This, however, is a false perception. I have explained in this chapter that the main responsibility of SAAs, at least initially, should be to check compliance with existing EU rules. This is not the same as granting exemptions. The rules with respect to state aid are more codified and require less extensive analysis of economic effects and prevailing market conditions. At any rate, where the SAAs have doubts they should refer the case to the Commission. As the system evolves, as SAAs gain experience, as the Commission develops new cooperation procedures with SAAs, the SAAs could be given more tasks. In particular, they could carry out more economic appraisals. That, however, would come at a later stage. Indeed, decentralisation does not have to be effected in a single step. It can be applied gradually and initially confined to certain, less complex areas of state aid control. This, however, 


\section{Chapter 28}

does not prevent member states from requiring their SAAs to carry out impact appraisals of their state aid before it is formally notified to the Commission and after it is formally approved and implemented.

\subsection{Conclusions: Options for a decentralised system of state aid control in the $\mathbf{E U}$}

Theory and practice suggest that complete decentralisation of state aid control would be a recipe for disaster. On the other hand, as the EU enlarges, as state aid policy becomes more codified, as concepts become clarified by the Courts and as state aid rules are modernised to take into account conditions in local markets, the case for some decentralisation becomes stronger. A certain degree of decentralisation will also create incentives for fuller compliance with Community rules and reduction of state aid granted for domestic political gains. A balance must be struck. The question is how the tasks should be divided between the Commission and SAAs. ${ }^{331}$ The table below proposes such a division of tasks.

${ }^{331}$ I regard as absolutely necessary that a partially decentralised system which is applied to all member states must rely on SAAs. Existing member states will also have to create them. 
Decentralised State Aid Control in an Enlarged European Union:Feasible, Necessary or Both?

Table 28.1: Proposed division of tasks between the Commission and National State Aid Authorities

\begin{tabular}{|c|c|c|}
\hline $\begin{array}{c}\text { Policy } \\
\text { foundations }\end{array}$ & Commission tasks & SAA tasks \\
\hline $\begin{array}{lll}\text { Existing } & \text { state aid } \\
\text { rules }\end{array}$ & $\begin{array}{ll}- & \text { Elaborate state aid } \\
\text { policy } \\
\text { - } & \text { Issue regulations } \\
\text { - } & \text { Define guidelines } \\
\text { - } & \text { Deal with aid falling } \\
& \text { outside guidelines } \\
- & \text { Monitor decisions of } \\
\text { - } & \text { SAAs } \\
\text { Manage a network of } \\
\text { SAAs }\end{array}$ & $\begin{array}{ll}\text { - } & \text { Receive all state aid } \\
\text { notifications } \\
\text { - } \\
\text { Check their compliance with } \\
\text { EU rules } \\
\text { - } \quad \text { Reject non-compliant schemes } \\
\text { Forward to the Commission } \\
\text { schemes that fall outside } \\
\text { guidelines (which require } \\
\text { assessment of common } \\
\text { interest) } \\
\text { Monitor compliance with block } \\
\text { exemption \& de minimis } \\
\text { regulations }\end{array}$ \\
\hline $\begin{array}{l}\text { Modernised state aid } \\
\text { rules [relying more } \\
\text { on market analysis } \\
\text { and requiring } \\
\text { assessment of } \\
\text { economic impact of } \\
\text { state aid] }\end{array}$ & As above & $\begin{array}{l}\text { As above, plus } \\
\text { - Check market analysis and } \\
\text { assessment of economic impact }\end{array}$ \\
\hline
\end{tabular}




\section{Chapter 28}

\section{References}

Axelrod, R. (1997), The Complexity of Cooperation, (Princeton, NJ: Princeton University Press).

Bilal, S. \& P. Nicolaides (1999), Understanding State Aid Policy in the European Community: Perspectives on Rules and Practice, (The Hague: Kluwer Publishers).

Bilal, S. \& P. Nicolaides (2002), Regulatory Instruments and Enforcement in Regional Blocs, Aussenwirtschaft, vol. 57, pp. 187-220.

Bishop, S. (1997), The European Commission's Policy Towards State Aid: A Role for Rigorous Competitive Analysis, European Competition Law Review, vol. 18, pp. 84-86.

Collie, D. (2000), 'State aid in the European Union: The Prohibition of Subsidies in a Integrated Market', International Journal of Industrial Organization, vol.18, 867-884.

Collie, D. (2003), 'Prohibiting State Aid in an Integrated Market, Journal of Industry, Competition and Trade, vol. 2, pp. 215-231.

European Commission (1991), Fair Competition in the Internal Market: Community State Aid Policy, European Economy, vol. 1991, no. 48, pp. 7114.

Ioannis, G. \& M. Reiner (2001), State Aid Control in the European Union: Rationale, Stylised Facts and Determining Factors, Intereconomics, vol. 36, pp. 289-297.

Lehner, S., R. Meiklejohn \& A. Louw (1991), Fair Competition in the Internal Market: Community State Aid Policy, (Luxembourg: European Community).

Neven, D. (1994), The Political Economy of State Aids in the European Community, Cahiers de Recherches Économique, no. 9402, (Lausanne: University of Lausanne). 
Decentralised State Aid Control in an Enlarged European Union:Feasible, Necessary or Both?

Nicolaides, P. (2002), Control of State Aid in the European Union: Compliance, Sanctions and Rational Behaviour, World Competition, vol. 25, pp. 249-262.

Nicolaides, P., A. Geveke and A. den Teuling (2003), Improving Policy Implementation in an Enlarged European Union: The Case of National Regulatory Authorities, (Maastricht: European Institute of Public Administration). 


\title{
Chapter 29
}

\section{Control of State Aid in the European Union:}

\author{
Compliance, Sanctions and Rational Behaviour
}

\begin{abstract}
"The affluence of the rich excites the indignation of the poor, who are often both driven by want, and prompted by envy, to invade his possessions. It is only under the shelter of the civil magistrate that the owner of that valuable property, which is acquired by the labour of many years, or perhaps of many successive generations, can sleep a single night in security. He is at all times surrounded by unknown enemies, whom, though he never provoked, he can never appease, and from whose injustice he can be protected only by the powerful arm of the civil magistrate continually held up to chastise it. The acquisition of valuable and extensive property, therefore, necessarily requires the establishment of civil government. Where there is no property, or at least none that exceeds the value of two or three days labour, civil government is not so necessary."-Adam Smith
\end{abstract}

\subsection{Introduction}

Reduction of the amount of State aid is a declared political priority in the European Union. The Lisbon European Council in March 2000 urged Member States to "reduce the general level of State aid" and to shift "the emphasis from supporting individual companies or sectors to tackling horizontal objectives of Community interest". A year later in March 2001, the Stockholm European Council repeated that "the level of State aid in the EU must be reduced and the system made more transparent" and that Member States "should demonstrate a downward trend in State aid in relation to GDP by 2003". The Barcelona European Council (March 2002) has just pronounced that "less and better-targeted State aid is a key part of effective competition".

The Commission has also been asked to establish a publicly accessible State aid register and scoreboard to be available on-line by July 2001. In fact, the 
Control of State Aid in the European Union: Compliance, Sanctions and Rational Behaviour

Commission has progressed to a second edition of the scoreboard which was published on 20 December 2001. ${ }^{332}$

These policy statements by successive European Councils raise two issues. First, how will State aid be reduced when not all forms of State aid are prohibited in the European Union? Certain types of State aid are permitted, provided they fall within the various guidelines and frameworks and they are either notified to the Commission or are in compliance with the so-called group-exemption regulations. ${ }^{333}$ More significantly, if aid is authorised by the Commission then it must be that that aid is in the interest of the Community. I do not think that this is the case for all authorised aid, but formally authorised aid must be considered, at least in a legal sense, to be compatible with the Treaty and therefore to promote the objectives of the Community. This leaves unexplained how the position of the European Council can diverge from those objectives.

Second, if the European Council statements refer to the aid which is granted by Member States in contravention of their obligations, then it becomes necessary to ask whether the European Union has an effective deterrence system to prevent Member States from granting unlawful aid. As the quotation from Adam Smith suggests, deterrence and sanctions are indispensable components of compliance with any legal system. The purpose of this article is to examine whether the European Union has effective sanctions to buttress its system of State aid control.

About 20 percent of all cases dealt with by the European Commission over the past decade concerned instances of aid that had not been notified to it prior to its implementation by a national (central or regional) authority. ${ }^{334}$ Since notification is required by Article 88(3) of the Treaty and Regulation

${ }^{332} \operatorname{COM}(2001) 782$ final.

${ }^{333}$ Commission Regulation 68/2001 on the application of Articles 87 and 88 of the EC Treaty to training aid; Commission Regulation 69/2001 on the application of Articles 87 and 88 of the EC Treaty to de minimis aid; Commission Regulation $70 / 2001$ on the application of Articles 87 and 88 of the EC Treaty to State aid to small and medium-sized enterprises. All Regulations published in OJ L10, 13 January 2001.

${ }^{334}$ See the data in the latest Commission Scoreboard on State aid published on 22 December 2001, COM(2001)782final. 


\section{Chapter 29}

659/99, non-notified aid is automatically "unlawful". However, under current rules and case law, unlawful aid is not necessarily incompatible with the common market. The Commission must still investigate it and may in the end approve it on the grounds that it can benefit from one or more of the exceptions allowed primarily by Article 87(2) and (3) and by the provisions concerning services of general economic interest (Article 86(2)), public transport (Article 73), agriculture (Regulations on the various market organisations) and by the relevant provisions of the European Coal and Steel Community (ECSC) Treaty. ${ }^{335}$

If any aid, irrespective of whether it is notified or not, is found to be incompatible with the common market, the Commission is obliged to order recovery, where it has been implemented before the Commission's approval. In addition, when Member States recover aid they must also charge interest at the corresponding "reference rate" for each Member State.

Why do Member States grant aid which is contrary to State aid rules? A perusal of similar Commission decisions on aid found to be incompatible with the common market, suggests three possible answers.

First, Member States genuinely misunderstand or misjudge prevailing rules. Current guidelines and frameworks established by the Commission cannot possibly cover every conceivable situation of aid offered by a central or regional authority to one or more companies. These guidelines have grey areas that need to be interpreted. Public authorities may also calculate eligible costs in a different way to that of the Commission, and occasionally some public authorities are simply unaware of the rules.

Secondly, Member States may intentionally wish to test the limits of the various rules and challenge the Commission's interpretation.

Thirdly, Member States may for domestic political reasons decide to take the risk to grant aid without notifying it to the Commission. They may do this either because they cannot wait for a prior approval or because they expect a negative decision.

${ }^{335}$ Under current case law, national courts may order recovery of illegal aid before it is shown to be compatible or not with the common market. See the case of SFEI et al v. La Poste et al, C-39/94. 
The third possibility suggests that Member States may break the rules intentionally and while fully aware that their actions are illegal. In this article I explore this possibility and examine how the Community may seek to discourage such intentional flouting of the rules. Indeed, unless the European Union has a credible enforcement system, Member States will not comply with the recommendations of the European Council to reduce the amount of State aid they grant.

There is a large volume of literature on EU State aid rules, procedures and jurisprudence. ${ }^{336}$ Many books and papers have explored the kind of rules that the European Union should ideally have. ${ }^{337}$ Yet, relatively little has been written on the quality of enforcement of State aid rules. Most commentary on enforcement has tended to be critical about the European Union's willingness to curb State aid. ${ }^{338}$ Some commentators have even suspected that the European Union is more permissive than perhaps, it should be and that in certain cases State aid has been authorised for political or industrial policy purposes. The objective of this chapter is not to attribute any hidden motives to the Community or the Commission. In view of the apparent absence of an analysis of how the system of State aid control may be strengthened, I will in fact assume in this article that the European Union and the Commission truly wish to prevent Member States from granting State aid that is incompatible with the common market. The chapter examines how State aid control can be strengthened with the injection of modulated sanctions into the system, offering stronger incentives to Member States to comply with the rules.

336 See, for example, the references in S. Bilal and P. Nicolaides, (eds), Understanding State Aid Policy in the European Community, Kluwer, The Hague, 1999. See also the documents cited on a special page on the internet site of the European Institute of Public Administration. It can be accessed at the following address: $<$ http://eipanl.com/public/Topics/StateAid/stateaid.htm>.

${ }^{337}$ See, for example, T. Besley and P. Seabright, The Effects and Policy Implications of State Aids to Industry, Economic Policy, 1999, vol. 28, pp. 15-53; D. Neven, The Political Economy of State Aids in the EC, discussion paper no. 945, Centre for Economic Policy Research, 1994.

${ }^{338}$ See, for example, D. Collie, State Aid in the European Union, International Journal of Industrial Organisation, 2000, vol. 18, pp. 867-884; I. Ganoulis and R. Martin, State Aid Control in the European Union, Intereconomics, 2001, vol. 36, pp. 289-297. 


\subsection{How does the European Union seek to discourage the granting of unlawful aid?}

The European Union has three ways of discouraging Member States from granting aid contrary to the rules. ${ }^{339}$ In this context, aid contrary to the rules concerns three possibilities: failure to notify the Commission for prior approval, implementation of aid that could not be approved by the Commission (so both non-notification and non-compatible aid) and misuse of otherwise approved aid.

The first disincentive in the EU's armoury is illegality. As mentioned above, unnotified aid is unlawful aid. Although the Commission cannot order recovery without first proving the incompatibility of the aid in question, affected competing undertakings may ask a national court to order the public authority in question to suspend the granting of that aid, order recovery and, if possible under national law, adopt interim measures. ${ }^{340}$ This is because Article 88(3) requires prior notification of all State aid. Infringement of that provision has been declared by the European Court of Justice to create direct rights for individuals that are enforceable in national courts.

Where it is obvious that a public measure is a form of State aid, a national court can establish the illegality of that measure by simply checking with the Commission whether it has been notified by the public authority concerned. Therefore, where a national court has no doubt that a measure falls within Article 87(1), as with outright grants or subsidies, the provision in Article $88(3)$ must in principle have high deterrence value. Yet, surprisingly, there

${ }^{339}$ For a review of the substantive and procedural rules on state aid see European Commission, Competition Law in the European Communities, Volume IIA (Rules applicable to State aid); Volume IIB (Explanation of the rules applicable to State aid).

${ }^{340}$ As the European Court of Justice ruled in SFEI v. La Poste, as note 4 above, at paragraph 40, "National courts must offer to individuals the certain prospect that all the appropriate conclusions will be drawn from an infringement of the last sentence of Article 88(3) of the Treaty, in accordance with their national law, as regards the validity of measures giving effect to the aid, the recovery of financial support granted in disregard of that provision and possible interim measures." 

Rational Behaviour

have been very few cases of State aid dealt with by national courts. A study done on behalf of the Commission a couple of years ago documented no more than 116 cases over the previous four decades! ${ }^{341}$ Perhaps the reason is that it is not easy for national courts to establish whether a measure can be classified as State aid. Cursory examination of Commission decisions banning aid suggests that the Commission learns about unlawful aid primarily from two sources: complaints and press reports. It seems, therefore, that competitors prefer to complain to the Commission rather than resort to national courts.

Secondly, aid already granted that is later found to be incompatible with the common market has to be recovered together with interest that has to be applied from the moment aid was made available to the beneficiary undertaking. Recovery of past aid may go back up to 10 years. The interest rate charged is a form of penalty to restore competitive opportunity between the beneficiaries and non-beneficiaries. I will have more to say about the deterrent effect of this penalty later on.

Thirdly, the recent State aid register and scoreboard are softer means of "naming and shaming" Member States that grant too much aid or unlawful aid. Presumably they also make it easier for third parties to find out whether aid has been granted to any of their competitors and monitor whether that aid is implemented according to the rules. This discourages misuse of aid.

Of these three disincentives in the system of State aid control, only the second, i.e. recovery with interest, is a form of sanction. My objective in the rest of the article is to examine whether this form of sanction is efficient in the sense that it provides strong enough incentives to Member States to modify their behaviour and refrain from granting illegal aid. Before, however, I deal with this issue I review briefly in the next section the basic economics of efficient enforcement of any system of rules.

${ }^{341}$ The study entitled Report on the Application of EC State Aid Law by the Member State Courts, 4 June 1999, can be accessed on the Commission's website at the following address:

$<$ http://europa.eu.int/comm/competition/state_aid/legislation/app_by_member_states $>$. 


\section{3 "Rational" illicit activities and efficient enforcement}

Economics suggests that even those who break the law act rationally in the sense that they respond to relative gains and losses. The quotation from Adam Smith at the beginning of this article indicates that economists understood early on the "economic" nature of crime and crime prevention. If it is assumed that anyone who engages in an illegal activity does so because he expects to gain from it (not simply because it is illicit), he will naturally desist from it when the costs exceed the expected gains. In other words, breaking the law occurs only when "crime pays" and "G" (the gains from breaking the law) exceeds "S" (sanctions, fines or other form of punishment such as a prison sentence).

The economics of enforcement goes a step further by identifying an equilibrium situation. ${ }^{342} \mathrm{~A}$ criminal will break the law up to the point where the gains from an extra crime just exceed the extra sanctions from detection. If we assume, therefore, that $\mathrm{G}$ and $\mathrm{S}$ are functions of " $\mathrm{x}$ " (indicating a "unit" of an illegal activity), then a criminal will maximise his net gains:

$$
\operatorname{Max} \mathrm{G}(\mathrm{x})-\mathrm{S}(\mathrm{x})
$$

and will commit his crimes up to the point where

$$
(\partial \mathrm{G} / \partial \mathrm{x})=(\partial \mathrm{S} / \partial \mathrm{x})
$$

\footnotetext{
${ }^{342}$ For a relatively easy but lucid introduction to the economics of enforcement see the classic article by

George Stigler, The Optimum Enforcement of Laws, Journal of Political Economy, 1970, vol. 78(3), pp. 526-536.
} 


\section{Figure 29.1: Illicit activities and sanctions}

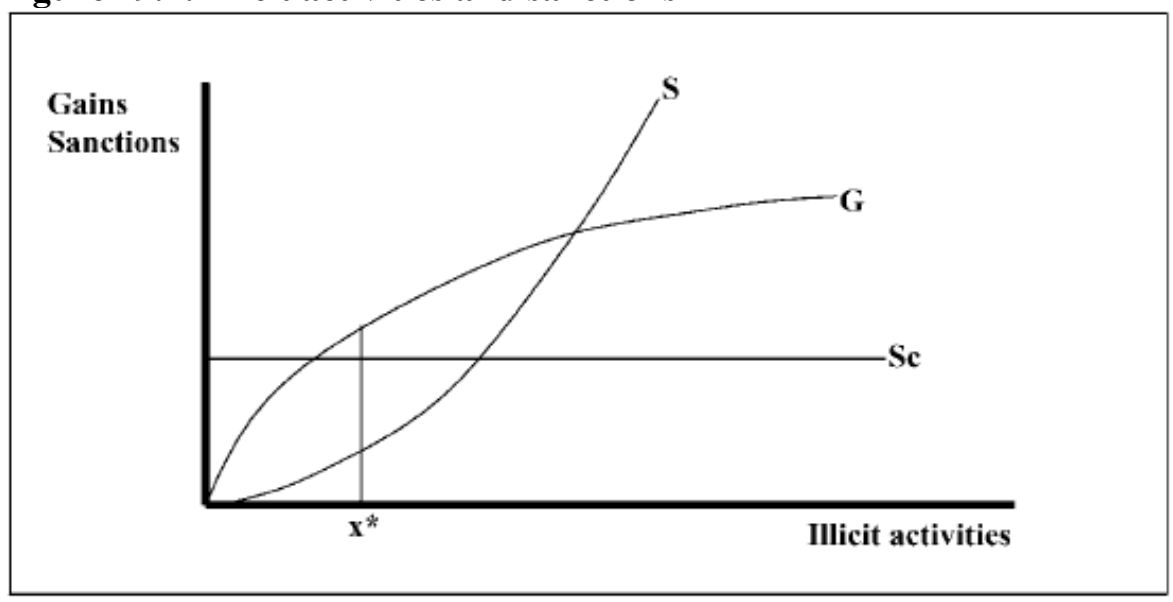

This is shown by point $x^{*}$ in Figure 29.1. Graphs $\mathrm{G}$ and $\mathrm{S}$ are indicated as being concave and convex, respectively. In principle, they can have other shapes. These two shapes, however, guarantee the existence of an equilibrium (which in the eyes of the criminal is the point of "optimum crime"). Whenever an equilibrium cannot be found, not much can be said about rational enforcement which is the subject matter of this article.

We can now add a complication. If all crimes could be detected, sanctions could be raised to such a level that it would not pay for anyone to break the law. A draconian society (in the classical meaning of the term) would be a law-abiding society. The problem, of course, is that not all crimes are detected. So rational criminals will engage in illegal activities only if the gains (assumed to be certain) exceed the "expected sanctions" which is the product of the severity of sanctions times the probability of detection, " $\beta$ " (where $0 \leq \beta \leq 1$ ). We can now modify the objective function of our criminal so that he maximises:

$$
\operatorname{Max} G(x)-\beta S(x)
$$

The solution or equilibrium condition is given by

$$
(\partial \mathrm{G} / \partial \mathrm{x})=\beta(\partial \mathrm{S} / \partial \mathrm{x})
$$

This result suggests that, if we assume a direct relationship between $\mathrm{x}$ and $\mathrm{G}$ and $\mathrm{S}$, the lower the probability of detection, the higher the value of $\mathrm{x}$ at equilibrium; i.e. the higher the number of illegal activities. 


\section{Chapter 29}

There is one additional but important complication which I will ignore in this article: crime detection is a costly activity. We need to factor into our equations the cost to society from detecting and prosecuting criminal activities. Although, in principle it is rather easy to adjust the equations (in practice it is much harder), I will not consider the costs to society because they do not affect the conclusions that I draw later on with respect to State aid in the European Union. How do societies discourage crime? They do that in basically two ways: (a) they raise sanctions and (b) they raise the probability of detection (e.g. by strengthening the capability of law enforcement agencies to apprehend criminals, by offering incentives to potential witnesses to provide relevant information, etc.).

Figure 29.1 also shows line "Sc" which may be thought of as representing a "tough" approach to punishing crime. There are high and uniform sanctions applied to all crimes irrespective of the severity or magnitude of the crime. Apparently this is an increasingly popular approach in several countries. Notwithstanding any other merits it may have, the economic problem with this approach is that, if a criminal receives the same punishment irrespective of what he does, he will have no incentive to restrict his illegal activities. Although severe punishment is meted out, in this case, paradoxically, "crime still pays". The reason is that at the margin gains exceed sanctions. The gains from one more extra illegal activity exceed the expected costs of punishment which are fixed. This holds even when there are diminishing returns from crime, as indicated in Figure 29.1.

One may think that the solution would be to make sanctions even more severe so as to raise Sc to a level above G. However, there are two major weaknesses to this approach. First, making sanctions disproportionate to the magnitude of the crime and meting out the same punishment to all irrespective of their crime may not be acceptable options in democratic societies. But this is not an economic argument per se.

This chapter is rather concerned with economic arguments. Hence the other weakness of simply raising the level of Sc across the board is that there may not be a limit to the gains from crime. If the ingenuity of criminals finds new ways of obtaining gains from illegal activities, we will simply revert to the same situation as before. They will have no incentive to limit their crimes at the margin. 

Rational Behaviour

Moreover, the level of Sc or any $\mathrm{S}$ depends partly on $\beta$ which is the probability of detection. This factor is not exogenous. It is itself partly determined by the amount of resources that society expends in law enforcement. As Nobel Laureate George Stigler pointed out in a seminal paper about 30 years ago, there is such a thing as optimum enforcement above which it is not worth expending one more euro to prevent crime costing society less than a euro.

I am very well aware that such calculations go against prevailing views concerning "zero tolerance" of crime and that there are other schools of thought advocating "non-economic" approaches to dealing with crime. But my purpose here is not to analyse an issue for which I can claim no expertise. Rather I want to illustrate the concepts of "rational infringements" and optimum enforcement and apply them to the case of State aid control in the European Union; a subject to which I turn in the next section.

\subsection{Optimum state aid control in the European Union}

The European Union has only one form of sanction to deter the granting of aid which is incompatible with the common market. That sanction is recovery with interest. If we assume that the gains of Member States from the granting of incompatible State aid are equal to the amount of aid, then a Member State would grant aid only if $\mathrm{G}(=$ aid $) \geq \mathrm{S}$.

As a matter of fact, the issue is not as simple as I am presenting it here. There may be multiplier effects in the State aid involved, making the gains larger than the amount of aid granted. Moreover, the politicians who authorise the granting of aid may derive personal gains which would induce them to grant aid irrespective of any subsequent penalties imposed on companies or their countries. However, both of these qualifications suggest that the amount of illegal aid that would be granted in practice would be larger than normal because Member States and their governments have strong incentives to evade the rules. My intention, however, is to show that the European Union has an enforcement problem even in the absence of multiplier effects or personal political gains.

Another factor which I ignore is the possibility that the Commission miscalculates the true economic effects of aid. It is presumed here that 


\section{Chapter 29}

preventing the granting of aid which does not comply with EU rules is an activity that has a net positive effect on the economic welfare of the country concerned and the European Union as a whole.

I assume, therefore, that $\mathrm{G}=$ (amount of incompatible aid) and that $\mathrm{S}=$ (recovered aid $)=(G(1+i))$, where " $i$ " is the reference rate of interest for each Member State. These are shown in Figure 29.2. 
Control of State Aid in the European Union: Compliance, Sanctions and Rational Behaviour

Figure 29.2: Sanctions against incompatible state aid in the EU

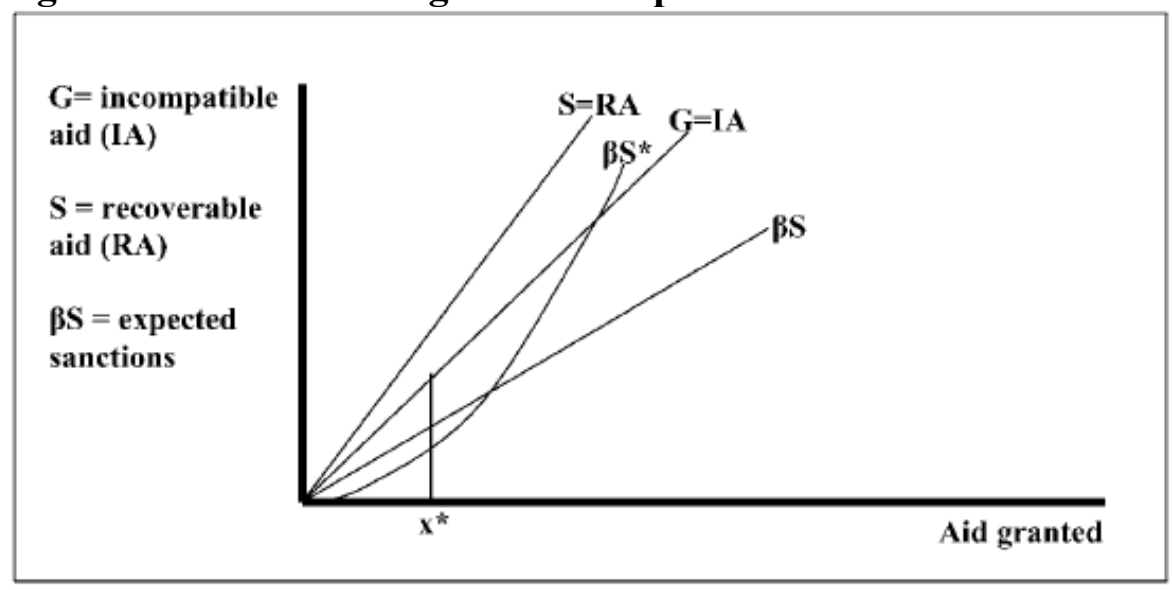

To understand the enforcement problem, first consider the following conundrum. If recoverable aid exceeds the amount of incompatible aid granted by the amount of interest, then $\mathrm{S}$ would always exceed $\mathrm{G}$ or $\mathrm{S} \geq \mathrm{G}$. In this event, no Member State would ever attempt to grant incompatible aid. Member States, therefore, must grant incompatible aid because in reality the probability of detection is less than 100 percent, making the expected sanctions fall below the gains, so that $\mathrm{G} \geq \beta \mathrm{S}$.

It is worth noting at this point that in some cases the present system of control in the European Union poses little deterrence to incompatible aid. Some recipients of State aid still come out better-off even if there is 100 percent certainty of detection and pay-back of aid together with interest. This would be the case where the recipient is in a precarious financial condition such that banks are reluctant to lend it money or that banks would lend it money only at interest rates which are higher than the going market rates. This company would presumably be happy to receive aid and then pay it back a couple of years later at the "reference rate" of interest. This reference rate is the average for the country. A company in financial trouble that could not obtain a loan at the normal rate of interest, would still derive a significant benefit - which is equal perhaps to $20-30$ percent lower interest rates than normal. 


\section{Chapter 29}

When the Commission investigates, for example, injections of public capital or the granting of loans, it uses adjusted interest rates that reflect the underlying risk of the beneficiary project and the credit worthiness of the recipient undertaking in order to calculate the true amount of aid hidden in such injections and loans. So one may think at first glance that the recipient derives no benefit. Yet, after the amount of the illegal aid is determined, the interest rate which is used for recovery purposes is the reference rate. This means, of course, that while undertakings in good financial health are penalised, those which are more risky still derive an unaccountable benefit, because for the period between the recovery order and the actual repayment it is as if they obtain a loan at normal rates that in reality is below the rate that a bank would otherwise charge for their level of risk.

Perhaps a real example will clarify this point. In the late 1980s the Greek government converted the loans that it had lent to the cement manufacturer, Heracles, into equity capital. Heracles was in financial trouble and could not service its debt. Conversion of debt into equity was naturally beneficial to Heracles because equity holders are the last group of creditors to receive payment from a company. They receive what is left after debt holders get their fixed return. So equity holders may make substantial profits but also assume considerably higher risk.

After a complaint by other cement manufacturers, including Titan, Heracles's main competitor on the Greek market, the Commission investigated that capitalisation. It decided that, in view of the brighter market prospects and the fact that the company was restructured, the Greek government acted like a private investor. On appeal, the Court of First Instance annulled that decision. The Commission had to re-open the case and after studying independent consultant reports that had been submitted by various parties, it found that Heracles was over-capitalised by about GDR 2.5 billion. It reached that conclusion by comparing the debt-equity ratio of Titan. $^{343}$

It is worth observing, first, that this is a questionable comparison. Since Titan was consistently more profitable than Heracles, investors would be more willing to commit their funds to Titan. So, the amount of its equity in

\footnotetext{
${ }^{343}$ The evolution of the case can be read in the final Commission Decision 2000/199 on aid to Heracles Cement, OJ L66, 14/3/2000.
} 

Rational Behaviour

comparison to its debt should be larger than that of Heracles which was riskier because it still had to prove that its restructuring plan would work. But the fact that the Commission appears to have relied on a more favourable measure is not the real issue here. The real issue is that recovery of the excess amount, which was regarded as State aid, was ordered about ten years after it was received by Heracles. The recovered amount had to be repaid at the reference rate used for regional projects in Greece. The end result was that Heracles obtained a ten-year loan at rates of interest that did not reflect its creditworthiness and as such were unavailable in the financial markets. Therefore, it is not unreasonable to conclude that companies like Heracles would not object very much to repaying public money, given that in some cases they obtain a hidden benefit.

Seen in this context, the enforcement problem of the European Union becomes obvious. If the $\beta S$ line in Figure 29.2 always lies below the $\mathrm{G}$ line and if they have different slopes at all points of the lines (i.e. $(\partial \mathrm{G} / \partial \mathrm{x}) \neq$ $\beta(\partial \mathrm{S} / \partial \mathrm{x})$ so that marginal losses always diverge from marginal gains), Member States have no incentive to limit the amount of incompatible aid at the margin. This is not an efficient control system. It relies completely on the ability of the Commission and injured third parties to detect illegal aid rather than using incentives for rational self-limitation of aid by the granting authorities.

Before turning to possible remedies, a comment about enforcement of international rules is in order here. Despite the criticisms made above, the European Union has the most effective system of supranational control and enforcement of any international organisation or regional bloc. The reason is that its system derives its strength from the powers vested in the Commission and the European Court of Justice. The Commission can act independently and the Court may impose fines.

By contrast, the WTO, for example, imposes sanctions by authorising retaliation by the aggrieved party. The retaliation, in the form of suspension of concessions, must be of equivalent value to the affected rights of that party. In our terms, the sanctions curve, i.e. the withdrawn concessions which the other party loses, is a straight line (see Figure 29.2). We have already seen that that is no deterrent to infringement of the rules. Even worse, by imposing sanctions through authorised retaliatory actions of its members, the WTO exposes any potential complainants to pressure from the countries 


\section{Chapter 29}

that break the rules. This is because, unlike the EU system where the Commission applies pre-determined sanctions on behalf of the European Union as a whole, WTO sanctions are linked to the amount of damages suffered by a member. This exposes potential complainants to indirect, behind-the-scenes pressure by larger countries that flout the rules. Moreover, larger countries are less likely to pay attention to retaliation by smaller countries.

This comparison allows us to highlight two important features of the EU system that make it superior to that of the WTO. They are the independence of the Commission and the Courts and the de-linking of sanctions from actual damages. These are indispensable features of any credible enforcement system. That is why the message of this article is not that the European Union needs a new system, but rather an improved system. In the next section I consider several possible means of improvement.

\subsection{Strengthening control of state aid}

Is it feasible for the European Union to inject more incentives for selfrestraint into its system of State aid control? I think the answer must be in the affirmative, but I should point out that apart from some general observations I do not examine here the legal method of doing so or the political likelihood of reforming the current system. I only consider the economic merit of such reform.

Self-restraint would be a rational reaction by the Member States only if sanctions become progressively more stringent so that, at the margin, the extra gains from the incompatible aid they grant are outweighed by the extra costs they suffer. Otherwise, the exhortations of the European Council will remain empty words. I outline below two options involving added sanctions, a third option which surprisingly involves lower sanctions for smaller amounts of incompatible aid and a fourth option that lowers the gross gains $^{344}$ that are derived by politicians who authorise illegal aid.

\footnotetext{
${ }^{344}$ These are the political gains to the government from granting aid without taking into account the costs to society from a possible recovery order later on by the Commission. The costs that society may face later on include the administrative and
} 
By way of departure, note that the amount of aid can be reduced by shifting either the G curve downwards or the S curve upwards (or both). The first three options concern shifts of the S curve while the last option concerns a shift of the G curve.

A first, and obvious by now, deterrent to the granting of incompatible aid (which also eliminates a loophole mentioned above) is, instead of the reference rate of interest, to use the rate that a private investor would use to give an equivalent loan to the recipient of the aid. The Commission has extensive experience in calculating the premium that has to be added to normal interest rates so as to account for the extra risk involved in the granting of a loan to a company in financial difficulty. This would completely remove any residual gains for the recipients of aid. Eliminating these kind of hidden gains is essential for the effectiveness of the system of State aid control because the most distorting aid is that which supports ailing companies. It is these companies which are the more likely recipients of aid with hidden benefits such as the ones described here.

A second, more drastic and more general option is to introduce punitive measures, depending on the severity of the case or infringement. The Commission has a comparable system of calculating fines in anti-trust enforcement. Naturally, under the present legal order, the Commission cannot by itself impose a punitive fine on a Member State. However, I see no tangible reason why the Commission should not petition the European Court of Justice to impose punitive fines on those who grant unlawful (i.e. unnotified) and incompatible aid.

Alternatively, the procedural Regulation 659/99 may be amended to empower the Commission to establish a system of progressive fines on Member States. In order to allay the fears of Member States, the magnitude of the fines may be subject to prior approval by a committee of the Member States. ${ }^{345}$

legal expenses of recovery procedures. Correcting bad policy decisions is wasteful because it absorbs scarce resources.

${ }^{345}$ After this article was completed and submitted to World Competition in March 2002, the Member States unanimously decided, in May 2002, to approve State aid in the form of reduced excise taxes for road transport undertakings. This form of aid is 
Unnotified aid is the Achilles' heel of the system of State aid control. At present, aid that is recovered is that which has not been notified aid and which has also been found to be incompatible with the common market. Unnotified aid is not immediately recoverable because it may be found to be compatible with State aid rules. One may ask where is the problem in this? The problem is that full inquiries to determine compatibility with Community rules on State aid take up considerable Commission resources and indirectly weaken its ability to deal with incompatible aid. It is, therefore, easier for Member States to hide incompatible aid in many non-notified measures of otherwise compatible aid. A congested enforcement system is not a credible system.

The solution to this problem is to give incentives to Member States to notify more of their aid so that valuable administrative resources at European Union level are not bogged down in investigations. If they have to pay a fine whenever they grant incompatible aid, then they will become more cautious. They will notify more of their schemes for which they are not sure whether they can be classified as State aid or not.

They may also do a better job at ensuring that autonomous regional and local authorities do not grant incompatible aid. Currently, when Member States are caught granting unnotified aid, they argue that they thought the scheme in question was not aid or that internal national procedures did not allow them to check the compatibility of aid granted by regional or local authorities. A system of fines would certainly make them think twice.

operating aid which is allowed in the EU only in very special cases and mostly for regional development purposes. The Member States used a rare procedure in Article $88(2)$. It was the first time in the history of the European Union that this procedure had been used outside the field of agriculture. Although I still think that it is worth considering the feasibility of establishing a committee of Member States to approve fines proposed by the Commission, after that development in May 2002, it is not inconceivable anymore that the Member States may be able to agree unanimously to reject any such Commission proposal. An extreme measure which was, at the time of writing this article, being considered in the Russian Federation was to make the granting of unauthorised aid a personal offence. This is equivalent to the criminal proceedings against infringements of anti-trust law in the United States where directors of companies are personally liable. Naturally, this is not a realistic option for the European Union. 
A third and probably counterintuitive option is to reduce the severity of the sanctions for small amounts of incompatible aid. At present, recovery plus interest must be ordered for any amount of aid that is found to be incompatible with the common market. But the economics of enforcement suggests that "rational infringement" of any system of rules would tend to be limited to infringements of lesser gravity because sanctions are correspondingly less severe. To put it in other words, if the European Union is to discourage the granting of large amounts of illegal aid, then it should make the granting of smaller amounts less costly to the Member States. There are many ways of doing that, e.g. fines could be linearly proportional to aid, or defined in steps or in ascending order, or larger fines may be imposed on repeat offenders. It is not my intention here to make any specific proposal, but perhaps one could consider the feasibility of reducing the interest rate for recovered amounts of aid falling below a certain threshold.

The three options presented above, in essence, concern ways of shifting the sanctions curve in Figure 29.2 to the left and upwards. Another possibility is to shift the gains curve $(\mathrm{G})$ to the right and downwards. Consequently, a fourth option is to reduce the political attractiveness of using State aid as a policy instrument. This can be achieved by making the granting of aid more difficult and at the same time economically more sensible. I have argued elsewhere that one of the weaknesses of the EU rules on State aid is that Member States are not required to assess either ex-ante or ex-post the economic effects of the aid they grant. ${ }^{346}$ If they had to carry out such an

\footnotetext{
${ }^{346}$ P. Nicolaides and S. Bilal, An Appraisal of the State Aid Rules of the EC, Journal of World Trade, 1999, vol.33(2), pp. 97-124. Further reading on this chapter: A. Paczkowska - Tomaszewska, K. Jaros and K. Winiarski, Monitoring State aid in Poland, European State Aid law - Quarterly, Volume 5 No. 4 2006, C. Ehlermann and M. Goyette, The interface between EU state aid control and the WTO disciplines on subsidies, European State Aid law-Quarterly, Volume 5 No. 4 2006, B. Slocock, EC and WTO subsidy control systems - some reflections, European State Aid law - Quarterly, Volume 6 No. 2 2007, D. Hildebrand and A. Schweinsberg, Refined economic approach in European State Aid control - will it gain monumentum?, World Competition, Volume 30, No. 3 September 2007. Further reading on this chapter: A. Paczkowska - Tomaszewska, K. Jaros and K. Winiarski, Monitoring State aid in Poland, European State Aid law - Quarterly, Volume 5 No. 4 2006, C. Ehlermann and M. Goyette, The interface between EU state aid control and the WTO disciplines on subsidies, European State Aid law-Quarterly, Volume
} 


\section{Chapter 29}

assessment and if they had to publish its results, they would be less inclined to grant inefficient aid.

An assessment would also make aid more transparent and therefore would indirectly help competitors to obtain information about aid grants or schemes that may have a negative effect on them. Politicians would be correspondingly less willing to release public funds to be used in activities of doubtful economic value. The political gains to them would be commensurately smaller because the potential political costs from the criticism they would receive from more transparent decisions would be larger.

\subsection{Conclusion}

In this chapter I have used elementary economic concepts of efficient enforcement to suggest that the European Union's goal of reducing State aid will not necessarily be achieved unless Member States have incentives to self-limit the amount of aid they grant. Once they experience these incentives they may grant only that amount of aid for which at the margin the extra costs of detection fall below the extra gains from infringement of the rules.

The current system is not efficient because it has no such incentives. As a matter of fact, apart from their own budgetary constraints, Member States have no restraint in their choice between a small amount of illegal aid and a large amount of illegal aid. Even worse, in certain cases the system has perverse incentives for aid to companies in difficulty. These companies would be willing to pay back aid plus interest irrespective of whether there is a 100 percent certainty that they would be caught.

I have also examined briefly four possible options for reform of the system: the use of variable interest rates, the use of punitive measures, depending on the severity of the infringement, the imposition of lesser penalties on smaller amounts of aid and the submission of economic impact assessments of proposed aid.

5 No. 4 2006, B. Slocock, EC and WTO subsidy control systems - some reflections, European State Aid law - Quarterly, Volume 6 No. 22007. 
Assessment and Conclusions: Will the on-going Reform of State Aid Policy

Contribute towards more Efficient Allocation of Resources?

\section{Chapter 30}

\section{Assessment and Conclusions:}

\section{Will the on-going Reform of State Aid Policy Contribute towards more Efficient Allocation of Resources?}

\section{A refined economic approach}

The papers collected in this dissertation examine the law of state aid from an economic perspective. They provide a broad review of state aid rules and the system of state aid control of the European Community.

This Community system is rather unique in the world. The only other system that comes close to it is in EFTA and that is because it is based on the EC system. Indeed only the EFTA surveillance authority has similar powers to those of the Commission.

On the whole, the Community system has been effective in restraining the propensity of member states to subsidise their firms for strategic or political reasons. In this respect it has prevented significant distortions to cross-border competition. But as the papers indicate, it is not a perfect system. Too much aid has been allowed and the granting of illegal aid is not penalised vigorously enough. There is no Community penalty for member states that grant aid without first notifying it to the European Commission. ${ }^{347}$

The situation may change in the future as the Commission applies more extensively the refined economic approach and the related balancing test. Member states reacted rather negatively when the Commission announced it

\footnotetext{
${ }^{347}$ Even action in national courts can at most achieve suspension and perhaps recovery of aid granted without authorisation by the Commission. But this does not constitute punishment for the public authority that granted the aid. Further reading on this chapter: P. Heidhues and R. Nitsche, Comments on state aid reform - some implications of an effects-based approach, European State Aid law - Quarterly, Volume 5 No. 12006.
} 


\section{Chapter 30}

in 2005 in its State Aid Action Plan. National officials complained that it would impose heavy informational requirements and would create too much policy uncertainty.

These arguments were in principle wrong and were proven to be largely unfounded. They were in principle wrong because if member states do not have the necessary information to assess the need for and effects of state aid, then they should not use instruments that distort competition without being certain that their economies derive sufficient benefits that can compensate for that distortion. Moreover, if member states cannot persuade the Commission by providing objectively verifiable data then they should ask themselves whether they are prudent with their use of public money.

They have also been proven to be largely unfounded because the Commission is not requiring that the balancing test is applied to all cases of state aid. Both the practice of the Commission and the guidelines that incorporate a balancing test create a process whereby most cases, which concern small amounts of aid, are subject to a simplified assessment. Only a small number of cases are subject to the detailed assessment of the balancing test.

The balancing test is applied to all cases where state aid is granted outside any regulations or guidelines. But these cases are only few. Where state aid falls within regulations or guidelines, its compatibility with the common market is assessed at three different levels of varying degree of detail.

The first and least demanding level applies to aid granted to SMEs and aid that falls below certain thresholds. This kind of aid is presumed to have generally positive effects and limited negative effects, provided it complies with all the requirements laid down in the regulations and guidelines. If the application for aid is made by the requesting undertaking before the project starts, then the Commission also regards the aid to be necessary and to have an incentive effect;

At the second level, member states must demonstrate explicitly the necessity of aid. Larger amounts of aid add up to certain higher thresholds and aid granted to large enterprises is subject to closer scrutiny by the Commission to determine whether the aid has an incentive effect. If the aid does not 
Assessment and Conclusions: Will the on-going Reform of State Aid Policy

Contribute towards more Efficient Allocation of Resources?

induce the recipients to go beyond their normal level of research or environmental protection, then the Commission will conclude that the aid lacks incentive effect and will not authorise it.

The third level applies the detailed assessment of the full balancing test. This detailed assessment is performed on aid that exceeds certain thresholds. For example, in the case of R\&D aid, the relevant threshold for industrial research is EUR 10 million and EUR 7.5 million for experimental development. In the case of investment in environmentally friendly technology the relevant threshold is EUR 7.5 million. In the case of risk capital invested in SMEs the relevant threshold is EUR 1.5 million per SME per year. These constitute large amounts of aid which are unlikely to be exceeded too often. The conclusion, therefore, must be that the Commission has designed such a system that will not impose an excessive administrative burden on national authorities.

If there is a criticism to be made of the balancing test it is that, first, it is not a real economic test and, second, it is not really too onerous. Despite its name, the Commission decisions concerning cases where the balancing test was performed have not revealed that the Commission is attempting to quantify and then weight the positive and negative effects of state aid. Rather the Commission appears to be developing screening criteria to identify aid with objectionable features. But this raises rather than reduces legal certainty. In this sense too, the fears of member states have proven to be unfounded.

Nor, is the balancing test too onerous. The Commission does not expect sophisticated cost-benefit analyses. Rather it wants to see proof that aid is necessary, proportional and not contrary to Community objectives by violating any of the internal market principles. The handful of negative decisions so far have been motivated by the fact that the aid concerned was either unnecessary (i.e. it lacked any incentive effect) or discriminated against certain undertakings or technologies. These decisions were not based on rigorous economic analysis.

However, as shown in the previous chapter, these few cases indicate that the Commission is breaking new ground with respect to the necessity of state aid. For large awards of aid, member states will from now on have to 


\section{Chapter 30}

provide persuasive evidence that the companies that receive the aid do indeed something they would not do without aid.

Two conclusions should be drawn with respect to the balancing test. First, the test appears to be making past practice more structured and transparent rather than introducing new quantitative tests. Second, the necessity of aid will need to be proven rather than presumed whenever it satisfied the legal criteria laid down in the various regulations and guidelines. Certainly, the practice will be streamlined in the future when the Commission will issue guidelines on the application of the balancing test.

\section{Are past criticism and recommendations still valid to date?}

Chapter 11 examined the concept of advantage in Article 87(1) and analysed a number of cases where the Commission found that despite the use of competitive selection procedures, a "residual" advantage had been conferred to the chosen providers of broadband services. Given the fact that these are very recent cases nothing has changed and the criticism that was elaborated in that chapter still holds. A properly designed competitive selection process should eliminate all known ex ante advantages. By claiming the existence of a "residual" advantage, the Commission appears to be at odds with the Courts which have accepted that contracts awarded on the basis of competitive bidding do not confer a gratuitous advantage.

Chapter 12 argued that structural funds should not be considered as state resources. At the time of writing of the paper reproduced in that chapter there was a debate on how to treat structural funds under Article 87. Since that time, however, a significant development has occurred. The rules on structural funds have changed and member states now have considerable discretion where to allocate these Community funds. The Commission, in case N 201/2006, propounded a new theory that has not yet been tested before any of the Community Courts. According to this new theory structural funds become state resources when they come under the control of the state. We do not yet know precisely what control means in this context. But if it means discretion to determine the final beneficiaries of structural funds without any further approval by the Commission, then it is reasonable to presume that in exercising that discretion the state can distort competition. 
Assessment and Conclusions: Will the on-going Reform of State Aid Policy

Contribute towards more Efficient Allocation of Resources?

So, on this subject we have gained considerable clarity although the Courts have not confirmed or rejected the Commission's new doctrine.

Chapter 13 dealt with the question whether governments can implicitly grant state aid by making public statements in favour of one or another company. There has been no case law, nor any literature on this matter, nor have my views changed. Markets should react only to the extent that the public pronouncements of the government translate into aid that the Commission would find to be compatible with the common market.

Chapter 14 criticised the market economic investor principle. If injections of public capital are truly indistinguishable from private capital, why then do companies ask for public money? The reason is that governments are undemanding shareholders and they tolerate poor management. At about the same time as when the paper was written, the CFI delivered its judgement on the WestLB case [T-228/99]. It stated that the Commission should not merely accept that the public investor should be satisfied with average return on its investment. The Commission, according to the CFI, should take into account all relevant information. The CFI did not go as far as raising the benchmark for assessing public investment but clearly questioned the assumption that public shareholders were automatically presumed to be content with average returns.

Chapters 15 to 19 analysed fiscal aid and in particular the issue of selectivity. The main innovation of those papers was to define a simple method for determining whether a specific tax measure was selective or not. This method consists of two stages. The first stage tries to infer the policy objectives which are pursued by the tax measure in question and then the second stage examines whether the measure is applied to all economic activities that fall within the scope of the inferred policy objectives. If the measure is indeed applied to all the activities that in principle fall within its scope, then it is not selective and vice versa. No Court rulings or Commission decisions since then have contradicted this method. However, on the aspect of regional selectivity my analysis was proven to be at odds with the subsequent ruling of the Court in the Azores case [C-88/03]. The views I presented at that time are therefore irrelevant to date. 


\section{Chapter 30}

Chapters 20 to 23 focused on the subsidisation of services of general economic interest. The risk of such subsidies spilling over and distorting adjacent markets is still as valid to date as it was then. Community rules attempt to prevent this kind of spill-over by requiring account separation and full allocation of the relevant variable and fixed costs to the activities under public service obligation. As the papers reproduced in those chapters explained, clever accounting can still afford providers of SGEI an advantage over their rivals. This is because Article 86(2) permits the granting of state aid irrespective of whether the recipients are efficient or not in relation to their competitors. I criticised then and I still do not see how that can be compatible with the conditions of Article 86(2) which requires that trade is not distorted to an extent contrary to the Community interest. If an inefficient provider requires a larger subsidy than a more efficient alternative provider, then trade must be disproportionally distorted. This cannot be in the common interest. The same papers also dealt very critically with the judgement of the Court in the Ferring case [C-53/00]. That that ruling was unfortunate has been proven by the fact that it was basically set aside by the judgement in the landmark Altmark case [C-280/00]. Altmark goes a long way in preventing member states from granting state aid under the pretext that they merely compensate undertakings for the extra costs of public service obligations. As long as their costs are higher than their competitors, any public subsidy they receive is regarded as state aid. However, Altmark still does not address the problem of the subsidies received by inefficient providers of SGEI under Article 86(2). So here, despite Altmark, the problem with undue distortion of competition remains.

Chapters 24 and 25 dealt with rescue and restructuring aid. The previous and current Commission guidelines declare as an overall justification of such aid that it can be useful (and therefore compatible with the common market) if it prevents closure of companies from causing significant social disruption and leading to excessive market concentration. These are legitimate policy objectives. However, my main criticism of the guidelines and Commission practice is that they do not actually require member states to indeed show that the aid they grant to rescue or restructure companies in difficulty actually prevents social disruption or excessive concentration. The guidelines and the practice focus on whether the recipients of the aid implement a reasonable restructuring plan, whether the aid is proportional to the targets of the plan and whether they make enough concessions to 
Assessment and Conclusions: Will the on-going Reform of State Aid Policy

Contribute towards more Efficient Allocation of Resources?

competitors by selling off assets or withdrawing from non-essential operations. As long as Community rules do not require that member states show that the social benefits outweigh the cost of the state aid, we will continue to have a defective system that allows too much rescue or restructuring aid.

Chapter 26 analysed the impact of regional state aid. It was based on a study I carried out for the Commission (DG Regional Policy) in the context of its review of the structural fund rules for the financial period 2007-13. I was asked to examine whether regional state aid was effective in reducing regional disparities. The Commission wanted to identify the impact of national subsidies and compare it with the impact of Community subsidies. My findings were to some extent surprising. I could not detect any statistically significant relationship between state aid and regional development. In fact there appeared a perverse relationship. Most regional aid seemed to be channelled to middle income regions, rather than the poorest and, by implication, the neediest. On reflection, there could a reasonable explanation for this phenomenon. Aid can be disbursed only if firms apply for it. Since middle-income regions are more likely to have firms capable of applying for aid, more aid goes to those regions creating a virtuous circle. It is unlikely that the situation has changed significantly since then.

Chapter 27 reviewed recent problems with the enforcement of the guidelines on maritime transport. The biggest problem is the dividing line between eligible and non-eligible activities. This is not the same as saying investment expenditure is eligible for aid while operating expenditure is not normally eligible. In the case of maritime transport, the Commission has drawn a line between the percentage of the fleet that can benefit from subsidies and the remaining share that cannot. This is not just arbitrary, it is also deprived of any compelling reason and divorced from commercial reality. Not surprisingly, member states and shipowners have been testing the boundaries of interpretation of the guidelines. Complex rules invite cheating. It is better to have simple rules that are less vulnerable to exploitation. Moreover, the problems with the maritime guidelines also reveal another issue that virtually goes unnoticed by legal practitioners because Community Courts have never accepted to judge the requirements laid down in the various Commission guidelines. Not only does the Commission have monopoly in assessing state 


\section{Chapter 30}

aid, it also has virtual free hand it determining the conditions laid down in its guidelines. On the whole this has served the EU well. But occasionally, like in the case of maritime guidelines, there are arbitrary rules that have little relationship with commercial reality.

Chapters 28 and 29 assessed the institutional system of state aid control in the European Union. They proposed that the quality of state aid measures could improve if all the member states established state aid authorities like those created in the new member states before their accession to the EU. They had an important advocacy role and they also prevented measures containing incompatible aid from being submitted to the Commission. The Commission itself complains that it cannot authorise notified aid quickly because often the quality of the notifications is poor. Procedures could be speeded up if member states notify measures that have sufficient information and are fully compliant with prevailing rules. Another issue that was dealt with in those chapters was the repeated failure of member states to notify all their aid measures. About $15 \%$ of all measures examined by the Commission every year concern non-notified aid. Currently, there is no sanction for nonnotification. This is a major weakness of the system of state aid control. My proposal was to for the Commission to either require recovery of incompatible aid at a higher rate of interest or to initiate automatic proceedings before the Court of Justice and request imposition of penalty on the member state that failed to notify aid. Of course, it is not always obvious when public measures contain state aid. In this case it could be unfair and unnecessary to penalise member states. But in many other situations it is very clear that the member state was aware that aid was granted but chose not notify it to the Commission. The Court would then have to judge whether the member state concerned could reasonably determine whether its measure contained state aid.

Finally, chapters 8 and 9 review the evolving experience with the elaboration of the balancing test in the guidelines on risk capital for SMEs, R\&D\&I aid and environmental aid and its application to cases that were assessed directly on the basis of Article 87(3)(c). The various Commission decisions so far have added clarity as to how the three stages of the balancing test are likely to be carried out. More rigour has been injected into the assessment of state aid, especially with regard to the proof that aid is necessary and has an incentive effect. This is a welcome development. 
Assessment and Conclusions: Will the on-going Reform of State Aid Policy

Contribute towards more Efficient Allocation of Resources?

\section{Conclusions}

The reform of state aid policy has resulted so far in both tougher rules but also more opportunities for granting state aid. The rules have been made stricter primarily because the ceilings for regional aid have been reduced, member states are required to provide more evidence of the necessity of aid (incentive effect) and ad-hoc and large amounts of aid are subject to more detailed scrutiny which, however, is based on a more transparent approach (the balancing test).

Nevertheless, at the same time there are new rules such as those on compensation for public service obligations and revised rules such as those on R\&D \& Innovation that have created new categories of allowable aid. The Commission has also issued a general block exemption regulation that covers more subjects than those of the regulations that it replaces. In addition, the de minimis threshold [Regulation 1998/06] and the risk capital threshold have been raised to EUR 200,000 and EUR 1.5 million, respectively.

So it is not possible to conclude that the rules in general have become stricter or laxer. The picture is complicated. The only general statement that can be made is that member states have been given more instruments to support companies but they have to justify more thoroughly the use of those instruments.

In summary, we have now in the European Community a multi-tiered system with varying degrees of scrutiny for assessing the compatibility of state aid. This is a sensible approach to the control state aid. The European Commission can focus its attention to the aid that is likely to cause the most serious distortions to cross-border trade and competition. 


\section{References}

P. Anestis, S. Mavrogenis, S. Drakakakis, Rescue and Restructuring Aid A Brief Assessment of the Principal Provisions of the Guidelines, 2004 European State Aid Law Quarterly I, p. 28.

S. Arrowsmith, The Law of Public and Utilities Procurement, Sweet \& Maxwell, 2005, p. 224.

R. Axelrod, The Complexity of Cooperation, Princeton, NJ: Princeton University Press, 1997.

W. Baumol and D. Bradford, Optimal Departures from Marginal Cost Pricing, American Economic Review, 1970, vol. 60, pp. 265-283.

T. Beasley and P. Seabright, The Effects and Policy Implications of State Aids to Industry, Economic Policy, 1999, vol. 28, pp. 15-53.

K. Bhaskar (1990), The Effect of Different State Aid Measures on IntraCommunity Competition, study prepared for the European Commission, Luxembourg: Office of Official EC Publications.

S. Bishop, The European Commission's Policy Towards State Aid: A Role for Rigorous Competitive Analysis, European Competition Law Review, 1997, vol. 18, pp. 84-86.

S. Bishop and M. Walker, The Economics of EC Competition Law, London: Sweet and Maxwell, 2002.

D. Carlton, \& J. Perloff, Modern Industrial Organization, Reading MA: Addison-Wesley, 2000.

D. Collie, 'State aid in the European Union: The Prohibition of Subsidies in an Integrated Market', International Journal of Industrial Organization, 2000, vol.18, 867-884.

D. Collie, 'Prohibiting State Aid in an Integrated Market, Journal of Industry, Competition and Trade, 2003, vol. 2, pp. 215-231. 
H. Demsetz, Why Regulate Utilities? Journal of Law and Economics, 1968, vol. 11, pp. 55-65.

European Commission, Fair Competition in the Internal Market: Community State Aid Policy, European Economy, vol. 1991, no. 48, pp. 7-114.

J. Faull and A. Nikpay (eds.), The EC Law of Competition, Oxford: Oxford University Press, 1999.

J. Fingleton, F. Ruane, and V. Ryan, Market definition and State aid control, European Economy, 1999, no. 3.

I. Ganoulis and R. Martin, State Aid Control in the European Union, Intereconomics, 2001, vol. 36, pp. 289-297.

L. Hancher et al, Selectivity and Infrastructural Aid, in EC State Aids, London: Sweet \& Maxwell, 2006, pp. 62-69.

M. Hencsey et al, State Aid Rules and Public Funding of Broadband, Competition Policy Newsletter, 2005, no. 1, pp. 8-15.

D. Hildebrand, The Role of Economic Analysis in the EC Competition Rules $\left(2^{\text {nd }}\right.$ ed.), The Hague: Kluwer Law International, 2002.

G. Ioannis and M. Reiner, State Aid Control in the European Union: Rationale, Stylised Facts and Determining Factors, Intereconomics, 2001, vol. 36, pp. 289-297.

A. Jones, \& B. Sufrin, EC Competition Law: Text, Cases and Materials, 3rd edition Oxford University Press, 2008.

C. Koenig and A. Haratsch, The Logic of Infrastructure Funding under EC State Aid Control, European State Aid Law Quarterly, 2004, no. 3, pp. 393398.

C. Koenig and S. Kiefer, Public Funding of Infrastructure Projects under EC State Aid Law, European State Aid Law Quarterly, 2005, no. 3, pp. 415-424. 
J. Langer, Tying and Bundling as a Leveraging Concern under EC Competition Law, Alphen aan den Rijn: Kluwer Law International, 2007.

S. Lehner, R. Meiklejohn \& A. Louw, Fair Competition in the Internal Market: Community State Aid Policy, Luxembourg: OOPEC, 1991.

R. Luja, Assessment and Recovery of Tax Incentives in the EC and the WTO: A View on State Aids, Trade Subsidies and Direct Taxation, Antwerp: Intersentia, 2003.

R. Luja, Assessment and Recovery of Tax Incentives in the EC and the WTO: A View on State Aids, Trade Subsidies and Direct Taxation, Antwerp: Intersentia, 2003.

R. Luja, Harmful Tax Policy: When Political Objectives Interfere with State Aid Rules, Intertax, 2003, vol. 31(12), pp. 484-488.

R. Luja, State Aid: The Gibraltar Corporation Tax Reform, mimeo, University of Maastricht, 2004.

K. Marsden, Is Tax Competition Harmful? London: European Policy Forum, 1998.

R. Meiklejohn, The Economics of State Aid, European Economy, 1999, no.3, pp. 25-31.

M. Motta, Competition Policy: Theory and Practice, Cambridge: CUP, 2004.

R. and P. Musgrave, Public Finance in Theory and Practice, New York: McGraw-Hill, 1973.

D. Neven, The Political Economy of State Aids in the European Community: Some Econometric Evidence, Cahiers de Recherches Économique, 1994, no. 9402, University of Lausanne.

OECD, Transfer Pricing Guidelines for Multinational Enterprises and Tax Administrations, Paris, 1995. 
L. Papadias et al, Public Funding for Broadband Networks - Recent Developments, Competition Policy Newsletter, 2006, no. 3, pp. 13-18.

C. Quigley \& A. M. Collins, EC State Aid Law and Policy, 2003, Hart Publishing.

S. Santamato and N. Pesaresi, Compensation for Services of General Economic Interest: Some Thoughts on the Altmark Ruling, Competition Policy Newsletter, Spring 2004, no. 1, pp. 17-21.

George Stigler, "First Lecture", in M.F. Cohen and G.J. Stigler, Can Regulatory Agencies Protect Consumers?, Washington, DC: American Enterprise Institute, 1971.

J. Südekum (2002), Subsidising Education in the Economic Periphery, HWWA Discussion Paper 209, Hamburg.

E. Valle and K. van de Casteele, Revision of the Rescue and Restructuring Guidelines: A

Crackdown?, 2004 European State Aid Law Quarterly, p. 9

R. Van den Bergh \& P. Camasasca, European Competition Law and Economics, Intersentia - Hart, 2001.

K. Viscusi, and J. Harrington, Economics of Regulation and Antitrust, 3rd ed. Cambridge, MA: MIT Press, 2001.

F. Wishlade, Regional State Aid and Competition Policy in the European Union, European Monographs 43, London: Kluwer Law International, 2003. 


\section{EC documents}

Commission VIIIth Report on Competition Policy, 1978.

Commission XXIth Report on Competition Policy, 1981.

Commission XXVIth Report on Competition Policy, 1996

Commission XXVth Report on Competition Policy, 1995.

Commission XXXth Report on Competition Policy, 2000.

Commission XXVIIIth Report on Competition Policy, 1998.

Commission (1985), Communication on the cumulation of regional aid with other aid, OJ C3, 05/01/1985.

Commission (1995), Notice on co-operation between national courts and the Commission in the State aid field, OJ C312, 23/11/1995.

Commission (1996), Services of General Interest in Europe, OJ C 281, 26/09/96.

Commission (1998), Notice on the Application of the Competition Rules to the Postal Sector and on the Assessment of Certain State Measures Relating to Postal Services, OJ C39, 6/2/98.

Commission (1998) Notice on the Application of the State Aid Rules to Measures Relating to Direct Business Taxation, OJ C384, 10/12/1998, p.3.

Commission (1998), Report to the Council of Ministers on Services of General Economic Interest in the Banking Sector, 23/11/98.

Commission (2001), Communication on Risk Capital, OJ C235, 21/8/2004.

Commission (2001), Communication on SGEI in Europe, OJ C17, 19/1/2001.

Commission (2001), Services of General Interest: Report to the Laeken European Council, $\operatorname{COM}(2001) 598$ final, 17/10/01. 
Commission (2001), Notice on Agreements of Minor Importance, OJ C368, $22 / 12 / 2001$.

Commission (2002), Report to the Seville European Council on the Status of Work on the Guidelines for State Aid and Services of General Economic Interest, June 2002.

Commission (2002), A Methodological Note for the Horizontal Evaluation of Services of General Economic Interest, COM(2002 331 final, 18/6/2002.

Commission (2002), Discussion Paper: Services of General Economic Interest and State Aid, November 2002.

Commission (2002), Report to the Copenhagen European Council on the State of Play in the Work on the Guidelines for State Aid and Services of General Economic Interest, December 2002.

European Parliament (2002e), Tax Coordination in the EU: The Latest Position, Working Paper ECON 128, March 2002, (Brussels).

Commission (2002), Company Taxation in the Internal Market, COM(2001) 582 final (Luxembourg: OOPEC, 2002).

Commission (2003), Green Paper on Service of General Interest, $\operatorname{COM}(2003), 270$ final, 21/5/2003.

Commission (2003), Report on the Implementation of the Commission Notice on the Application of the State Aid Rules to Measures Relating to Direct Business Taxation, 26.11.2003.

Commission (2004), Community guidelines on State aid to maritime sector, OJ C13, 17/01/2004.

Commission (2004), Communication: Community Guidelines on State Aid for Rescuing and Restructuring Firms in Difficulty, OJ C 244/2, 1/10/2004.

Community (2005) Framework for State aid in the form of public service compensation, OJ 2005 C 297, page 4. 
Commission (2005), State Aid Action Plan: Less and Better Targeted State Aid, $\operatorname{COM}(2005) 107$ final. 
Other documents

National Audit Office, Regional Grants in England, London: Stationery Office, 2003.

OECD, Transfer Pricing Guidelines for Multinational Enterprises and Tax Administrations, Paris: 1995.

Office of Fair Trading, Public Subsidies, London, November, 2004. 


\section{SAMENVATTING (In het Nederlands)}

Het mededingingsbeleid van de Europese Commissie heeft in het laatste decennium verrijkende hervormingen ondergaan. De mededingingsregels zijn gemoderniseerd en vereenvoudigd en de handhaving is gedecentraliseerd.

Het belangrijkste aspect van de modernisatie was de invoering van een rigoureuzere economische analyse, zowel op het gebied van antitrust als ook op het gebied van staatssteun. Het werd zelfs omschreven als de "hoeksteen van het moderniseringsproces".

Ook het Hof van Justitie van de Europese Gemeenschappen heeft blijk gegeven van een versterkte neiging om besluiten van de Commissie nietig te verklaren op grond van gebrekkige economische analyse.

De in deze collectie verzamelde verhandelingen proberen een beter inzicht te verwerven van de staatssteunregels en het controlesysteem van de Commissie door middel van economische redeneringen. Ze onderzoeken of de staatssteunregels en -procedures een efficiënte allocatie van geldmiddelen bevorderen en of nationale administraties voldoende ertoe aangezet worden om de vereisten van het staatssteunregime van de Commissie na te volgen.

Economie bestudeert hoe mensen en organisaties op impulsen reageren. Ze heeft een methodologische fundering die vorm geeft aan haar analyse. Economie biedt dus een handige methode om te onderzoeken welke invloed het recht uitoefent op het gedrag van markthandelaren alsmede die van overheidsinstanties die het recht handhaven.

Er bestaan echter wezenlijke verschillen tussen rechtsgeleerdheid en economie. Het belangrijkste verschil is het feit dat economie het nastreven van efficiëntie - de optimalisering van welvaart van het individu en de samenleving in het geheel - in het centrum van haar analyse plaatst. Dit criterium kan afwijken van het doel van het recht. Prijs discriminatie en andere vormen van discriminatie kunnen in de ogen van het recht bijvoorbeeld als verfoeilijk gezien worden terwijl dit voor economen een legitieme praktijk is mits het economische efficiëntie bevordert. Deze nadruk op efficiëntie impliceert tevens dat regels en procedures door economen 
beoordeeld worden naar gelang hun effecten in plaats van hun vorm of intentie.

Hoewel tegenwoordig het belang van kennis van onderliggende economische principes voor een correcte toepassing van mededingingsregels algemeen wordt erkend, hebben economen maar heel weinig gedaan op het gebied van staatssteun. Sommige verhandelingen in deze dissertatie, zoals bijvoorbeeld die over diensten van algemeen economisch belang, zijn vrijwel een eerste poging om de economische rationaliteit van gerelateerde staatssteunregels te beoordelen.

De meest voorkomende conclusie in de verhandelingen is dat de regels van staatssteun nog meer verbeterd kunnen worden door ze strikter te maken. Het Europese systeem van staatssteun controle laat nog steeds staatssteunbedragen toe die misschien excessief en te vrijgevig zijn. Desondanks kan de staatssteun hervorming die in gang is gezet door het Actieplan Staatssteun er misschien in slagen om de hoogte van staatssteun in lijn te brengen met de doelen van Lissabon.

De toepassing van de "verfijndere economische aanpak" van het Actieplan heeft niet tot beleidsonzekerheid geleid zoals gevreesd werd door veel commentatoren. Toegegeven, het is nog te vroeg om een definitieve conclusie over het effect en de toepassing te maken. Het kleine aantal negatieve besluiten van de Commissie suggereert echter dat zij dit instrument vooral wil gebruiken om slecht samengestelde steunmaatregelen te verbieden die overheidsgeld aan grote bedrijven verlenen zonder een ogenschijnlijke noodzaak.

In Deel I wordt het concept van staatssteun en de interpretatie daarvan in de jurisprudentie besproken. Het legt ook het systeem voor het notificeren, de autorisatie, het verbod en de terugvordering van staatssteun uit.

Deel II beschouwt waarom de EG regels voor staatssteun nodig heeft en wat het doel ervan zou moeten zijn. Het evalueert de nieuwe "verfijndere economische aanpak" en de daarmee verbonden "afweging" (balancing test). Het argumenteert dat de test in principe meer uitdrukkelijk een markt- en handelsaandeel drempel zou moeten gebruiken om gevallen te identificeren die een waarneembaar effect hebben op grensoverschrijdende mededinging. Het bestudeert ook de prestaties van de Commissie en komt tot de conclusie 
dat het er niet op lijkt, dat gegeven de weinige negatieve beslissingen die tot nog toe genomen werden, de test tot doel heeft de positieve en negatieve effecten van staatssteun te kwantificeren. Veeleer ontwikkelt het een toetsingsmethode voor het identificeren van gevallen van staatssteun met ongewenste kenmerken. In deze zin is het geen volgroeide economische kostenbaten analyse. Van een economisch perspectief is een van de ernstigste zwaktepunten van het systeem van staatssteun controle inderdaad dat de lidstaten niet verplicht zijn om een ex post beoordeling van het effect van hun staatssteun maatregel uit te voeren.

Deel III bevat een aantal verschillende onderwerpen met betrekking tot de interpretatie van verschillende aspecten van staatssteun zoals bijvoorbeeld het concept van een onderneming en de betekenis van een economische activiteit, het concept van cumulatie en de minimis steun, overheidsfinanciering van infrastructuur en breedband netwerken en het "market economy investor" principe.

Deel IV richt zich op de ontwikkeling van de jurisprudentie met betrekking tot staatssteun die zich verschuilt in vrijstelling en discriminerende toepassing van belastingen. $\mathrm{Al}$ in al stemmen de vijf hoofdstukken in dit deel in met het streven van de Commissie en het Hof om Artikel 87 streng toe te passen op belastingsmaatregelen.

Deel $\mathrm{V}$ bekijkt het probleem hoe publieke autoriteiten verleners van diensten van algemeen economisch belang kunnen ondersteunen. Onder sommige omstandigheden kunnen richtlijnen en reguleringen die door de wet zijn opgelegd efficiëntere beleidsinstrumenten zijn dan subsidies van de overheid. De vier hoofdstukken in dit deel bevatten drie punten van kritiek over de huidige praktijk. Ten eerste bestaat er op het ogenblijk geen verplichting voor overheden om aan te tonen dat de markt de dienst in kwestie niet kan aanbieden zonder oplegging van overheidsdienstverplichtingen. Ten tweede kan steun die ter compensatie van openbare diensten verleend wordt de ontvanger een concurrerende voorsprong geven over zijn rivalen op de betroffen markt. Dit kan worden verhinderd door het veilen van dienstverleningsovereenkomsten. Ten derde is de uitzondering van Artikel 86(2) te laks omdat het, het verlenen van staatssteun aan inefficiënte dienstverleners toelaat. 
Deel VI schenkt aandacht aan sectorale onderwerpen en de regels die zijn neergelegd in drie richtlijnen: die voor reddings- en herstructureringssteun voor ondernemingen in moeilijkheden, die voor steun voor regionale ontwikkeling en maritieme transport. De hoofdstukken over reddings- en herstructureringssteun bekritiseren verleden en bestaande regels voor hun inschikkelijkheid. Hoewel de meer recente regels voor reddings- en herstructureringssteun zeker strenger zijn, vraagt het bestaande regime geen belangrijke vragen zoals wat het voordeel voor de samenleving is van het verhinderen van het ineenstorten van een bedrijf. Regels voor regionale steun vermeiden het vragen van vitale vragen zoals wat de grootte van de regionale "handicap" is die gecompenseerd moet worden door publieke impulsen om de investering in benadeelde regio's te stimuleren. De regionale handicap is niet automatisch dezelfde voor iedere sector of industrie en hij is niet automatisch gelijk aan het steunplafond dat geoorloofd is door de Commissie.

Deel VII beoordeelt globaal het systeem van staatssteun controle in de Gemeenschap. Het bestudeert een "ondenkbare" stelling: de decentralisatie van staatssteun controle en het delegeren van sommige taken naar nationale overheden. Het stelt ook dat de integriteit van het systeem verzwakt wordt door lidstaten die ongestraft illegale staatssteun verlenen. De enige straf die hen opgelegd wordt is de verplichting om de steun terug te vorderen nadat die ontdekt is en als tegenstrijdig met de gemeenschappelijke markt is verklaard - een proces dat meerdere jaren kan duren.

Het laatste hoofdstuk geeft een algemene beoordeling van de nog voortdurende herziening van de regels en procedures voor staatssteun. De regels zij nu breder en geven nationale overheden meer mogelijkheden om steun te verlenen. Echter, tegelijkertijd leggen de "verfijndere economische aanpak" en de afweging strengere criteria op. Dit vooral met betrekking tot de noodzaak van steun voor grote ondernemingen.

Het Gemeenschapssysteem was, in het geheel, effectief bij het beperken van de neiging van de lidstaten om hun ondernemingen om strategische of politieke redenen te subsidiëren. Het heeft aanzienlijke verstoringen van grensoverschrijdende mededing verhinderd. Maar het is geen perfect systeem. Te veel steun werd geoorloofd en het verlenen van illegale steun wordt niet voldoende bestraft. 


\section{CURRICULUM VITAE}

Phedon Nicolaides was born in 1958 in Nicosia, Cyprus. He studied in the United States, the Netherlands and the United Kingdom where he obtained a BA (political science), an MA (economics), a Diploma (economics of the $\mathrm{EC})$, and a $\mathrm{PhD}$ (economics).

He was a Research Follow at the London Business School and Senior Research Fellow at the Royal Institute of International Affairs. For a short period he was appointed Minister Plenipotentiary in the Ministry of Foreign Affairs of Cyprus and later Secretary General at the Cyprus Shipping Council. He was also a member of the Cyprus Competition Commission. He is currently professor at the European Institute of Public Administration in Maastricht.

He has acted as consultant to several international organisations such as the OECD, the UN Food and Agricultural Organisation, the UN Centre for Transnational Corporations, the European Commission, the European Economic and Social Committee and several Ministries of the Government of Cyprus. During the accession negotiations of Cyprus, he was advisor to its Chief Negotiator. At present, he is advisor to the Cyprus Commissioner for State Aid.

He has published extensively in the fields of international trade, competition (anti-trust and state aid), regulation and EU enlargement. He is on the board of several academic journals and also lectures at Maastricht University and the College of Europe, Bruges, Belgium. 